\title{
Demokrácia-diskurzus(ok) Magyarországon az 1945 és 1949 közötti időszakban és időszakról
}

\author{
Doktori (PhD) disszertáció \\ Szegedi Tudományegyetem \\ Történelemtudományi Doktori Iskola
}

Készítette: Medgyesi Konstantin

Konzulens: Dr. Bencsik Péter 


\section{Tartalomjegyzék}

I. Bevezetés: a téma indoklása, a kutatás módszertanáról ............................................ 4

II. A korszak közéleti küzdelmeinek beszédmódja: demokrácia-viták, demokráciafogalomértelmezések a koalíciós évek közéleti küzdelmeiben.

1. A koalíciós időszak diskurzusai két fogalom hálójában: reakció és demokrácia …...... 12

2. Diszkurzív csomópontok a koalíciós évek demokrácia-diskurzusaiban 20

2.1. A kisgazdák és a kommunisták harca a demokrácia fogalom birtoklásért 1946 februárjában-márciusában, illetve 1947 májusában-júniusában 21

2.2. A parlamenti vita mint a demokrácia-diskurzus sajátos terepe 32

2.3. Fogalomértelmező viták a demokráciáról a párközi értekezleteken 43

3. A diskurzus szereplői: demokráciaértelmezők, demokrácia-hitvallók 46

3.1. Kisgazda demokráciaértelmezők 46

3.2. Kommunista demokráciaértelmezők: Révai József és Rákosi Mátyás 50

3.3. Szociáldemokrata demokráciaértelmezők 64

3.4. Parasztpárti demokráciaértelmezők: Erdei Ferenc kontra Kovács Imre 68

3.5. Ellenzéki demokráciaértelmezők: Sulyok Dezső, Moór Gyula és Barankovics István. 76

3.6. Útkereső tudósi-publicisztikai demokráciaértelmezők. 90

III. Az önéletírói beszédmód: a „demokrácia” mint narratív elem a koalíciós időszakot érintő önéletírásokban 106

1. Narratíva, diskurzus, demokrácia: elméleti megfontolások az önéletírói beszédmód kapcsán 106

2. A polgári demokrácia ethosza mellett kitartó kisgazda közéleti szereplők memoárjaiban megjelenő demokrácia-kép 109

3. A kommunisták mellett társutas szerepet vállaló kisgazdák önéletírásaiban megjelenő demokráciaértelmezési paradoxonok

4. A (népi) demokrácia mint narratíva a hithű kommunisták koalíciós évekről szóló visszaemlékezéseiben

5. A koalíciós években kommunistaként szerepet vállaló, de később a kommunista diktatúra rendszeréből kiábrándult közszereplők demokrácia-narratívája

6. Szociáldemokrata visszaemlékezők demokrácia-értelmezései

7. Parasztpárti visszaemlékezők demokrácia-narratívái.

8. A demokrácia mint választóvonal Károlyi Mihály és Mindszenty József visszaemlékezésében

9. A demokrácia mint narratíva a koalíciós években írott naplókban 162 
IV. A tudományos beszédmód - A második világháború utáni néhány esztendő magyarországi demokráciájának jelzői, fogalmi struktúrái a recepcióban.

1. Az államszocialista időszak tudományos fogalomhasználata, demokráciaértelmezése a második világháború utáni néhány évet érintően

2. Emigráns történészek koalíciós évekbeli demokrácia-értelmezései az államszocialista korszakban

3. Terminológiai diskurzusok a második világháború utáni esztendők természetéről és a demokrácia jelzőiről a rendszerváltozás utáni tudományos közéletben

4. A koalíciós évek demokráciájára vonatkozó fogalmi struktúrák angol nyelvü történettudományi és politológiai publikációkban.

V. Összegzés

Függelék

A lokális beszédmód: demokrácia-megnyilvánulások a lokális demokrácia fórumain -

A demokrácia mint fegyver a koalíciós évek makói közéleti küzdelmeiben ............. 239

1. 1944/45: A kisvárosi demokráciaépítkezés kezdetei

2. A kisvárosi demokrata ideáltípusa: Könyves-Kolonics József jogász, városvezető és publicista.....

3. A helyi demokrácia erőpróbája: a makói Pfeiffer-ügy - válság, botrány, megbélyegzés.

4. A demokrácia szó mint fegyver a helyi közéleti küzdelmekben

5. A „demokrácia-ellenes” demokrácia-megnyilvánulás: a „Mindszenty-gyülés” .... 288

6. A demokrácia mint narratíva a helyi demokrácia közszereplőinek önéletírásaiban

A kutatómunka során felhasznált források, irodalom 299

Levéltári források 299

Publikált források 299

Parlamenti naplók 300

Korabeli sajtócikkek, írások. 300

Sajtóforrások 302

Önéletírások 303

Forrásközlések 306

Szakirodalom, feldolgozások 308 


\section{Bevezetés: a téma indoklása, a kutatás módszertanáról}

A demokrácia fogalom körüli nyelvi küzdelmek a modernkori politika fontos jellemzői. A „szóvita”, a nyelvi kifejezésről szóló vita a demokrácia lényege, még akkor is, ha magáról a demokrácia fogalmáról folyik a közéleti harc. Ez a küzdelem, ez a demokráciaértelmező nyelvpolitikai harc - amely valójában politikai harc nyelvi köntösben - immáron évszázados a világ- és a magyar politikában is. Kutatásunk során egy mindössze néhány esztendős időintervallumra, vagyis a magyar koalíciós évekre vonatkozó demokrácia-diskurzusok természetét, karakterisztikáját vizsgáljuk.

„Kiindulópontunk az az általános ismeret, hogy a demokrácia szónak különböző ideológiákban különböző jelentése van" ${ }^{1}$ - írja Walther Dieckmann nyelvész, a politikai nyelv kutatója A politikai szavak tartalma címü tanulmányában. Dieckmann ugyanakkor nem tekinti a demokrácia kifejezést „elvontnak”; a kutató úgy véli, a homályosság oka „magában a nyelvben van”. 2 A nyelvészprofesszor amellett érvel, hogy a demokrácia szó különböző társadalmi formákra vonatkozik és a demokrácia fogalomról szóló örök vita „,nem egyszerüen csak szóvita, hanem ideológiai-politikai véleménykülönbségek megjelenése. [...] A fogalomhasználat vitatott, a demokrácia szó használata is, hiszen a formális jegyek tartalmilag különböző módon konkretizálódnak, és belejátszhatnak különböző elkötelezettségek is.”3 Dieckmann szerint a demokrácia fogalom történelmileg egy „érzelmileg agyonterhelt”, politikai kulcsszó. Josef Kopperschmidt diskurzuselemző elkerülhetetlennek nevezi, hogy egy demokratikus társadalomban a szavak eltérő jelentéséről viták legyenek. Kopperschmidt a modern politika jellemzőjének tekinti a különböző politikai erők részéről a „,fogalmak elfoglalásának" ${ }^{\natural 5}$ jelenségét, annak akarását. Béndek Péter politikai filozófus pedig $A$ demokrácia értelme: szóbeszéd egy banalitásról címü tanulmányában arról ír, hogy

\footnotetext{
${ }^{1}$ Walther DIECKMANN: A politikai szavak tartalma. In: Szövegváltozatok a politikára. Nyelv, szimbólum, retorika, diskurzus. Szerk.: SzABÓ Márton - KISS Balázs - BoDA Zsolt. Nemzeti Tankönyvkiadó - Universitas, Budapest, 2000. 28-52. p. /41. p./

${ }^{2}$ Uo. 33. p.

${ }^{3}$ Uo. 42-43.p.

${ }^{4}$ Uo. 50. p.

${ }^{5}$ Josef KOPPERSCHMIDT: Kell-e a szavakról vitatkozni? Történeti és rendszertani megjegyzések a politikai nyelvröl. In: SZABÓ Márton - KISS Balázs - BODA Zsolt. Nemzeti Tankönyvkiadó - Universitas, Budapest, 2000. 114-128. p.
} 
amennyiben a „népuralom” egy elvont legitimációs fogalom, akkor „a modernkori totalitarizmusok is demokráciák." 6

Reinhart Koselleck úgy véli, a történetfilozófiai gondolkodásban a demokrácia olyan „általános főfogalommá”7 vált, amely háttérbeszorított más fontos közéleti kifejezéseket, mint például a köztársaságot. A demokrácia elkerülhetetlen ,várakozási” fogalommá formálódott, s ezzel párhuzamosan a kifejezést az adott történeti korokban az új szükségleteknek megfelelően folyamatosan újjáalkotják.

Koselleck szerint a cselekvő közösségeket az is jellemzi, hogy az általános fogalmakat „,egyediekké stilizálja.”8 A csoportosulások ezáltal tudják önmagukat megfogalmazni, az ilyen típusú egyedi öndefiníciók sora pedig ezzel párhuzamosan ellenfogalmakat hoz létre. Ahogy Koselleck mondja: a „kölcsönös elhatárolódások zónáiban” artikulálódnak a fogalmi kifejeződések. Az 1945 utáni néhány esztendő demokrácia-diskurzusai megfelelően illusztrálják a jelenséget, amikor a különböző közösségek a demokrácia fogalmát kívánták egyedivé stilizálni, s ezek az egyedileg stilizált fogalmak a társadalmi párbeszéd során kitermelték a saját maguk fogalmi ellentétpárjait.

Gyáni Gábor az 1945-ös év és az azt követő néhány esztendő legfontosabb gondolatának azt tartja, hogy a demokrácia „életképesebb társadalmi konstrukció,"9 mint bármelyik modern diktatúra. Gyáni szerint a második világháborút követő évek azt a reményt hordozták, hogy a demokrácia képes leküzdeni az évszázados történelmi elmaradottságot.

A koalíciós évek a magyarországi demokrácia-tapasztalatok szempontjából a jelenkori magyar történelem egyik legtanulságosabb korszaka. Az 1944/45 és 1948 közötti évek politikai történései referenciának is tekinthetőek azáltal például, hogy az 1956-os forradalom résztvevői számára a koalíciós évek közéleti mintának számítottak. ${ }^{10}$ Az 1989/1990-ben kialakult magyar parlamentáris demokrácia szintén a koalíciós évek közjogi alapjaira építkezve kezdte meg múködését. ${ }^{11}$

\footnotetext{
6 BÉNDEK Péter: A „demokrácia” értelme: szóbeszéd egy banalitásról. In: SzABÓ Márton (szerk.): Szövegvalóság. Írások a szimbolikus és diszkurziv politikáról. Scientia Humana, Budapest, 1997. 159-169. p.

${ }^{7}$ Reinhart KoselLECK: A történeti idő szemantikája. Atlantisz Kiadó, Budapest, 2013. 133. p.

${ }^{8}$ Reinhart KOSELLECK: Az asszimetrikus ellenfogalmak történeti-politikai szemantikája. Jószöveg tankönyvek, Budapest, 1997. 7. p.

${ }^{9}$ GYÁNI Gábor: Valóban korszakhatár 1945? Levéltári közlemények, 2015. (86. évf.) 1-2. sz. 5-13. p.

${ }^{10}$ Arról, hogy a koalíciós évek demokráciája mint minta milyen szerepet játszott 1956-ban Standeisky Éva ír. (STANDEISKY Éva: Népuralom ötvenhatban. Kalligram - 1956-os Intézet, Pozsony - Budapest, 2010. $344-364$. p., 537-539. p.)

${ }^{11}$ E kérdéskörről Szücs Zoltán Gábor publikált (SzÜCS Zoltán Gábor: Az antalli pillanat. A nemzeti történelem szerepe a magyar politikai diskurzusban. 1989-1993. L’Harmattan, Budapest, 2010. 77-126. p.)
} 
Ahogy a disszertációban bemutatjuk majd, komoly történettudományi viták folynak arról, hogy az 1945 utáni koalíciós évek demokrácia-kísérlete 1947-ig, 1948-ig vagy 1949-ig tart. Már egészen korán kitetszettek ugyan az antidemokratikus jelenségek, diktatúrába hajló trendek, összességében mégis megállapíthatjuk: a háború utáni néhány év markáns korszakképző jellegzetessége a „demokrácia” mint vitatéma volt. A koalíciós évek Magyarországán - az újjáépítés, a nélkülözés, a béke és a szuverenitás kérdései mellett - az egyik legnagyobb érdeklődést kiváltó téma maga a „demokrácia” volt. A demokrácia-viták a koalíciós években nagy szenvedéllyel, indulattal zajlottak az elméleti folyóiratok hasábjain, a parlament üléstermeiben, politikai nagygyüléseken, a napi sajtóban, a társadalmi diskurzus különböző színterein és a mindennapok egyszerü kommunikációs csatornáin keresztül.

A „demokrácia” a modernkori történelemben és napjainkban is fontos kérdéskör, ugyanis a demokrácia már nem önmagában egy politikai rendszer, hanem a ,jó” társadalmi konstrukció egyfajta ideáltipikus leírása.

Megítélésünk szerint a jogállami jellegü polgári demokrácia folyamatos társadalmi próbálkozás a közösség céljainak elérése érdekében, miközben az egyéni szabadságjogok deklaráltak, alkotmányosan rögzítettek és azok érvényesülése nem hatalmi adomány, hanem a másik tiszteletén alapuló kulturális mintázatból fakad.

Kiindulópontunk szerint 1944/45 és 1948 között Magyarországon egy különleges, egyedi, jogállami jellegü, a jogosultságok kiegyensúlyozott rendszerére épülő, de végső kimenetelét tekintve reménytelen demokrácia-kísérlet zajlott, amely kísérletszerüség nem a belső társadalmi mozgások, megrázkódtatások, válságok miatt bukott el, hanem azért, mert 1946/1947 után egyre kevésbé állt a Szovjetunió érdekében a magyar polgári demokrácia léte. Úgy véljük, a koalíciós évekbeli magyar demokrácia a szuverenitáshiány miatt bukott el, de e néhány esztendő élmény- és tapasztalatanyaga mégis viszonyítási pontja lehetett a későbbi korok magyar demokráciáinak.

Meggyőződésünk, a koalíciós évek demokráciája, e demokrácia mint markáns társadalmi szándékra épülő kísérletszerüség komoly történeti kihatással bírt - közvetetten ennek a közösségi élménynek világpolitikai, világtörténelmi jelentősége volt. Az '56-os forradalom egyik alapja a koalíciós időszak „demokratizmusa” lehetett, ezért is állíthatjuk, hogy közvetetten világtörténelmi kihatása lehetett az 1945 utáni esztendők próbálkozó demokráciájának. E kísérleti jellegű demokrácia társadalmi dialógusainak elemzésére törekszünk a dolgozatban. Célunk, hogy feltárjuk a koalíciós időszak demokráciáról szóló diskurzusainak, kommunikációs paneljeit, a nyelvpolitikai küzdelmeket, amit a továbbiakban demokrácia-vita, demokrácia-diskurzus néven fogunk nevezni, illetve elemezzük e 
demokrácia-viták érvrendszerét. Azt a fajta mechanizmust, amelynek egyik jellemzője, hogy - az eltérő értelmü - demokrácia-fogalom fegyverré, mozgósító erejü tényezővé válik a politikai paletta különböző oldalán álló szereplői számára. Arra törekszünk, hogy az országos történések mögött megbúvó demokrácia-értelmezések alapelemeit, a közéleti szereplők közötti ebbéli antagonisztikus különbözőségeket a diskurzuselemzés módszerével feltárjuk.

A koalíciós évek meghatározó jellegzetessége, hogy a társadalom túlnyomó többsége a jogosultságok rendszerére építő polgári demokráciára vágyik. Az 1945 utáni időszak a demokrácia-remény korszaka. A demokrácia kifejezés tehát megkerülhetetlen fogalma vizsgált korszakunknak, ugyanakkor olyan mértékben keveredtek a fogalmak a demokráciakifejezés kontextusában, hogy a koalíciós idők szövegeit tanulmányozva azt láthatjuk: egy fogalom mögött két egymást kizáró, egymással antagonisztikus ellentétben álló világkép áll. Dolgozatunk alapvető célkitüzése az, hogy segítsen bemutatni a koalíciós korszak demokrácia-értelmezéseit, s ezáltal az értelmezési keret által az 1989 utáni Magyarország döntő súllyal bíró demokratikus tradícióját legyünk képesek tisztábban látni, értékelni és továbbvinni.

A koalíciós években zajló és a koalíciós évekről szóló demokrácia-diskurzus kutatása során az empirikus anyaggyüjtés után szöveghalmazt hoztunk létre; ezt a szöveghalmazt vetettük diskurzuselemzés alá. A szöveghalmazon belül értelmezésbeli különbségeket, okokozati és időbeli összefüggések, párhuzamosságok feltárásával különálló beszédmódokat azonosítottunk. $^{12}$ A szövegek vizsgálatakor hipotetikus jelleggel négy beszédmódot azonosítottunk $^{13}$ - ebben a szerkezetben épül fel a disszertáció. A négy beszédmód a

\footnotetext{
${ }^{12}$ A különálló beszédmódok azonosításakor Glózer Rita módszertani alapvetését használjuk. (GLÓzER Rita: Diskurzusok a civil társadalomról. Egy fogalom transzformációi a rendszerváltó évek értelmiségi közbeszédében. L'Harmattan Kiadó, Budapest, 2008. 15-31. p.) Metodológiai tekintetben is elfogadjuk Glózer pozíciókijelölését: „Az elemzés során a diskurzust mint kulturális produktumot, jelentésteli struktúrát közelítjük meg, melynek értelmezése a jelentések hálójának felfejtését jelenti. A jelentések összefüggésrendszerén belül az egyes fogalmak egymásra referálnak, intertextuális viszonyok közepette nyernek értelmet és értelmezést. Ezeket az összefüggéseket kell feltárni: az egyes fogalmak milyen más fogalmakkal, az egyes jelentések milyen más jelentésekkel kapcsolódnak össze, a diskurzuson belüli egyes beszédmódok milyen más beszédmódokkal, stratégiákkal interferálnak? Mivel a diskurzus aktorainak perspektívájából törekszünk a megértésre, az elemzés a szöveguniverzumon belül mozog." (GLÓzER Rita: A diskurzuselemzés a társadalomtudományokban. In: FEISCHMIDT Margit - KovÁCS Éva (szerk.): Kvalitatív módszerek az empirikus társadalom- és kultúrakutatásban. Digitális tankönyv, PTE - BTK Kommunikációs Tanszék, Budapest/Debrecen 2006. Elérhetö:

http://mmi.elte.hu/szabadbolcseszet/mmi.elte.hu/szabadbolcseszet/index92e1.html?option=com_tanelem\&id_tan elem $=831 \&$ tip $=0$ /A letöltés időpontja: 2016 . szeptember 3./)

13 Dell Hymes beszédmódokról szóló meghatározását viszonyítási pontnak tekintjük. Hymes szerint a beszédmódok a beszédesemények, beszédaktusok, beszédstílusok, kontextusok, nézetek, értékek, attitüdök összessége. (Dell HYMES: A nyelv és a társadalmi élet kölcsönhatásának vizsgálata. In: PLÉH Csaba-SíkLAKI István-TERESTYÉNI Tamás (szerk.): Nyelv-kommunikáció-cselekvés. 458-495. p.
} 
következő: 1. a koalíciós korszak közéleti küzdelmeinek beszédmódja; 2. az önéletírói beszédmód; 3. a tudományos beszédmód/a recepció beszédmódja; 4. a lokális beszédmód.

A disszertáció első fejezetében a korszak közéleti küzdelmeinek beszédmódját elemezzük. Áttekintjük a koalíciós időszakban megjelent korabeli tanulmányokat és a napi sajtóban publikált cikkeket. Ennek a „beszédmódnak” az áttekintése során az 1945 utáni évek fontos szereplőinek a demokrácia fogalmát érintő megszólalásait ismertetjük, s különös alapossággal tanulmányozzuk a kommunista demokrácia-értelmezés jellegzetességeit, így a formális demokráciával szembeni kommunista retorikát. A koalíciós évek kommunista demokráciaértelmezési politikai stratégiája leginkább a reakciós fogalmának kiterjesztésével összefüggésben demonstrálható, ezért arra törekszünk, hogy felvázoljuk a kommunisták részéről az ellenség megkonstruálásának mint tudatos stratégiának a folyamatát.

A disszertáció következő fejezetében az önéletírói-visszaemlékezői beszédmód áll a középpontban. Azt vizsgáljuk, hogy a korszak szereplőinek önéletírásaiban miként jelenik meg a demokrácia témája. Az önéletírások, visszaemlékezések és a naplók is sajátos „énnyomok", melyek alkalmasak arra, hogy feltárják az egyén múltbéli gondolatait, a történeti tényekhez, folyamatokhoz, jelenségekhez való viszonyulását és a személyiség létállapotait érintő fontos fogalmak és az önéletíró kapcsolatát. Dolgozatunkban a koalíciós évek különböző szereplőinek a korszakot érintő demokrácia-élményeit, demokrácia-fogalmait vizsgáljuk. S mindemellett azt a helyzetet is ábrázoljuk, ahogy a demokrácia fogalma még a visszaemlékezésekben is egyfajta harci eszköz és fegyver; más megközelítésben identitást építő narratíva-elem.

Ezután a tudományos beszédmódot kutatva áttekintjük a második világháború utáni néhány esztendő mint történeti időszak terminológiai dilemmáit. Ezáltal a történettudományi vitákból az egyes kutatók korszakra vonatkoztatott demokrácia-megközelítését igyekszünk feltárni. Ebben a fejezetben az ötvenes évek történészi álláspontjától kezdve a frissen publikált szakmai véleményekig tekintjük át, hogy miként változott a koalíciós évek demokrácia-megítéléséről szóló fogalomhasználat Az 1945 utáni esztendőkről 1955-ben jelentek meg az első publikációk. Több mint hatvan esztendő történettudományi kutatását kívánjuk körbejárni abban a tekintetben, hogy mit gondolnak az egyes szerzők a koalíciós évek demokráciájáról. A különbözö világlátású szakemberek szövegeiben közös az, hogy mindegyik szerző számára komoly dilemmát jelent a koalíciós évek vonatkozásában a demokrácia kontra diktatúra kérdéskör. Fel kívánjuk tárni a különböző magyar és angol nyelvü tudományos publikációkban a korszakról megjelenő demokrácia-fogalmak közötti 
érdemi különbségeket és hasonlóságokat, illetve a diktatúra kialakulásának mint szellemi struktúrának a megítéléséről szóló eltérő vélekedéseket.

A dolgozat függelékében egy vertikális demokrácia-kutatást végzünk. A lokális demokrácia-megnyilvánulások tekintetében Makó városa alkalmas terep lehet annak tanulmányozására, hogy az országos viták, demokrácia-értelmezések miként hatottak helyben, hogyan formálták a helyi demokráciát. E megközelítést disszertációnkban lokális beszédmódként azonosítjuk. A koalíciós évek Makójára - a maga komoly (kis)polgári demokratikus hagyományaival, létező munkásmozgalmi tradícióival - egyfajta helyi demokrácia-laborként tekinthetünk. A város az 1944 utáni bő négy esztendőben demokráciaélményeket élhetett meg, ez az időszak Makó történetében is a demokrácia-remény korszaka volt. E lokális beszédmód vizsgálata során célunk feltárni a helyi demokrácia müködési mechanizmusát, a lokális demokrácia-értelmezések unikális jellegzetességeit és azokat a helyi nyelvpolitikai küzdelmeket, amelyek a demokrácia fogalom birtoklásáért folytak.

A szövegek vizsgálatát a diskurzuselemzés módszereinek és eljárásainak segítségével végezzük el. A szövegeket azért is tartjuk kiemelten fontos forrásoknak, mert elfogadjuk Pierre Bourdieu azon tézisét, miszerint a közéleti mezőben - ahol a cselekvések célja a hatalmi pozíciók megszerzése - a politika nem „hatalmat termel, hanem jelentéseket és értelmezéséket, vagyis szövegeket." ${ }^{\text {A }}$ A bourdieu-i alapvetés szerint a politikai szövegvalóságok hatalmi helyzeteket alakítanak ki, formálnak és tartanak fenn.

„A történelem szüntelenül arra oktat minket, hogy a diskurzus nemcsak egyszerüen tolmácsolja a küzdelmeket és az uralmi rendszereket, hanem érte folyik a harc, általa dúl a küzdelem; tehát a diskurzus az a hatalom, amelyet az emberek igyekeznek megkaparintani”"15 - írja a diskurzuselmélet eszmetörténeti alapvetéseként Michel Foucault $A$ diskurzus rendje címủ tanulmányában. Terell Carver szerint a diskurzuselemzés az alábbi elven alapszik: „amikor az igazságot a nyelv segítségével megjelenítjük, akkor az igazság nem valami »eleve létező« állapot, amelyet aztán a nyelv mint semleges médium kifejez vagy visszatükröz. [...] Sokkal inkább arról van szó, hogy a nyelv az egyetlen olyan eszköz, amelyen keresztül »életformáink« kifejeződnek, amellyel megteremthetjük és kifejezhetjük szubjektivitásunkat, társadalmi tevékenységeket fejleszthetünk ki és gyakorolhatunk, hatalmi helyzeteket

\footnotetext{
${ }^{14}$ SZABÓ Márton: Politikai tudáselméletek. Szemantikai, szimbolikus, retorikai és kommunikatív-diszkurzív értelmezések a politikáról. Nemzeti Tankönyvkiadó - Universitas. Budapest, 1998. 86. p.

15 Foucault, Michel: A diskurzus rendje. Holmi, III. évf. (1991) 7. Elérhető: http://www.holmi.org/1991/07/michel-foucault-a-diskurzus-rendje-torok-gabor-forditasa (A letöltés időpontja: 2016. szeptember 2.)
} 
próbálhatunk ki és erősíthetünk meg." ${ }^{\prime 16}$ Paul Ricoeur A szöveg mint modell: a hermeneutikai megértés című tanulmányában fejti ki: „Hogy egy szerzőt jobban megérthessünk, mint ő saját magát értette, ki kell bontanunk a diskurzusaiba zárt tudati erőket, azokat, amelyek túl vannak a szerző személyes tapasztalatainak horizontján." ${ }^{\prime 17}$ Alapvetésnek tekintjük, hogy a diskurzusok hatalmi-uralmi viszonyokra utalnak, s a diskurzuselemzés az uralmi helyzetek megértéséhez segít bennünket hozzá, s mindemellett a diskurzuselemzésnek fel kell tárnia a szöveget alkotók tudati-gondolati viszonyulásait.

A diskurzuselemzés kvalitatív jellegü tartalomelemzési módszertani eszköztárat kínál. Sem a diskurzuselemzésnek, sem a narratív közpolitikai elemzésnek - ahogy Boda Zsolt fogalmaz - „nincs operacionalizálható módszere.”18 Klaus Krippendorf e témában kifejti: a „kvantitatív indikátorok rendkívül érzéketlenek és felszínesek a mélyebb politikai összefüggések láttatását illetően," ${ }^{19}$ ezért is fontos a kvalitatív jellegű tartalom- és szövegelemzés, amely képes a szövegek „felszíne alá, ${ }^{20}$ tekinteni. Dolgozatunkban a szövegek elemzésénél a következő képleteket használjuk: ki és mit mond? Milyen körülmények között, hogyan formálódnak a vélemények, az érvelési formák ${ }^{21}$ A különböző szövegek miként alakítják, alakították a politikai-kommunikációs folyamatokat? A szövegekben a kontextuális elemzés keretében keressük a vissza-visszatérő motívumokat, gondolati struktúrákat is. ${ }^{22}$ Igyekszünk feltárni a „beszédcselekvések” hogyanját, vagyis

\footnotetext{
${ }^{16}$ CARVER, Terell: Diskurzuselemzés és a „nyelvi fordulat”. Politikatudományi Szemle, XIII. évf. (2004) 4. Elérhető: http://www.poltudszemle.hu/szamok/2004_4szam/2004_4 carver.pdf (A letöltés időpontja: 2016. szeptember 2.)

${ }^{17}$ Paul RicoEUR: A szöveg mint modell: a hermeneutikai megértés. Lettre, VIII. évf. (2001) 42. sz. Elérhető: http://epa.oszk.hu/00000/00012/00026/ricoeur.htm (A letöltés időpontja: 2016. szeptember 2.)

${ }^{18}$ BODA Zsolt: Narratív közpolitika elemzés. In: SzABÓ Márton (szerk.): Szövegvalóság. Írások a szimbolikus és diszkurziv politikáról. Scientia Humana, Budapest, 1997. 113-131. p. /129. p./

${ }^{19}$ Klaus KRIPPENDORF: A tartalomelemzés módszertanának alapjai. Balassi Kiadó, Budapest, 1995. 18. p.

${ }^{20}$ Uo

${ }^{21}$ Munkánk során Szabó Mártonnak a diskurzuselemzés kutatásmódszertanáról vallott tudományos koncepcióját, nézeteit tekintjük kiindulópontnak. (SzABÓ Márton: Diszkurzív politikatudomány. Bevezetés a politika interpretatív szemléletébe és kutatásába. Osiris Kiadó, Budapest, 2016. 507-599. p.)

${ }^{22}$ A diskurzuselemzés metodológiájához felhasznált további irodalmak: SzŰCS Zoltán Gábor: A diszkurzív politikatudomány mint polittikai diskurzustörténet. Tudományszemléleti és módszertani esszé. Mühelytanulmányok 2. Digitális archívum. Miskolci Egyetem Politikatudományi Intézet, 2008. Elérhető: http://mek.oszk.hu/06200/06225/06225.pdf /A letöltés időpontja: 2016. szeptember 3./; SzÜcs Zoltán Gábor: Az antalli pillanat. A nemzeti történelem szerepe a magyar politikai diskurzusban. 1989-1993. L'Harmattan, Budapest, 2010. 21-74. p.; SíKLAKI István: A diskurzus szerepe a társadalmi befolyásolásban. In: SZABÓ Márton (szerk.): Szövegvalóság. Írások a szimbolikus és diszkurziv politikáról. Scientia Humana. Budapest, 1997. 99112. p.; CsizMADIA Ervin: Diskurzus és diktatúra. A magyar értelmiség vitái Nyugat-Európáról a késő Kádárrendszerben. Századvég Kiadó, Budapest, 2001. 135-190. p.; VIRÁG Attila: Diskurzuselemzés a politika- és vezetéstudományban. Vezetéstudomány, XLV. évf. (2014) 3. Elérhetö: http://unipub.lib.unicorvinus.hu/1491/1/vt_2014n3p30.pdf (A letöltés időpontja: 2016. szeptember 2.); FAZAKAS Gergely - MIRU György-VELKEY Ferenc (szerk.): „Politica philosophiai okoskodás” Politikai nyelvek és történeti kontextusok a középkortól a 20. századig. Debreceni Egyetem, Debrecen, 2013. Elérhető: https://www.academia.edu/11159587/_Politica_philosophiai_okoskod\%C3\%A1s_Politikai_nyelvek_\%C3\%A9s
} 
jelentéskibontást végzünk. Szabó Márton szerint a jelentéskibontás révén a kutató azt próbálja kideríteni, hogy a kommunikációs folyamatban részt vevők miként vitatják meg a közügyeket különféle fórumokon, „mit értnek ezen, s miként alakítják a szituációt.”23 A szövegvizsgálatokkor célunk, hogy feltárjuk az egyet nem értésre és egyetértésre vonatkozó érvkészleteket, kutatjuk, hogy a vitahelyzetben az érvelő mely szempontokat tekinti prioritásnak.

Kutatásunk célja az előbbiekben vázolt kutatás módszertanra alapozva a koalíciós évek különböző demokrácia-interpretációinak konstruálása, a demokrácia-diskurzusok „fogalmi hálóinak” ${ }^{24}$ vizsgálata. Fogalmi hálón azt értjük, hogy a használt szavak jelentése idomul vagy új kifejezések születnek a különböző jelenségek leírására, s ezáltal a nyelvhasználat megújul, kibővül.

_t\%C3\%B6rt\%C3\%A9neti_kontextusok_a_k\%C3\%B6z\%C3\%A9pkort\%C3\%B31_a_20._sz\%C3\%A1zadig (A letöltés időpontja: 2016. szeptember 20.)

${ }^{23}$ SZABÓ Márton: Diszkurzív politikatudomány. Bevezetés a politika interpretatív szemléletébe és kutatásába. 575. p.

${ }^{24}$ „A fogalmi hálók” kutatása mint diskurzuselemezési módszertani megközelítés Muri Györgynek az 1848-49es alkotmányozás politikai nyelvéröl szóló tanulmányában jelenik meg elméleti keretként. (MURI György: Az alkotmányozás politikai nyelve 1848-49-ben. L’Harmattan Kiadó-TIT Kossuth Klub, Budapest, 2015. 9-11. p.) 


\section{A korszak közéleti küzdelmeinek beszédmódja: demokrácia- viták, demokrácia-fogalomértelmezések a koalíciós évek közéleti küzdelmeiben}

\section{A koalíciós időszak diskurzusai két fogalom hálójában: reakció és demokrácia}

Még zajlottak a hadmüveletek az ország területén, amikor elindult a demokrácia mibenlétéröl szóló közéleti diskurzusok sorozata. Már a romok árnyékában 1944-1945 fordulóján jelentkeztek a demokráciát érintő nézetkülönbségek, „elkezdődtek a viták." ${ }^{25}$ Takáts József eszmetörténész az 1945 utáni néhány esztendő történetét a demokráciaviták négy éve ${ }^{26}$ fogalommal jellemzi.

1945 Magyarországán - az újjáépités történései és a nélkülözés jelenségei mellett - az egyik legnagyobb érdeklődést kiváltó kérdés maga a „demokrácia” ${ }^{27}$ volt. Nem véletlen, hogy a Pázmány Péter Tudományegyetem 1945 nyarán (június 26. és július 6. között) a demokrácia tematikájával foglalkozó előadássorozatot szervezett - kommunista kezdeményezésre. ${ }^{28} \mathrm{~A}$ meghívott szónokok között értelmiségiek és gyakorló pártpolitikusok is voltak, akik a maguk demokráciaképéről beszélhettek a hallgatóság elött. A konferencián elhangzottak könyv alakjában is megjelentek. „A kötet egymást kiegészítő vagy éppen opponáló értelmezések halmaza"29 - értékeltette eszmetörténeti távolságból az 1945-ös demokrácia-előadásokat és a Demokrácia-kötetet Kovács Gábor. Standeisky Éva így fogalmaz az előadássorozat kapcsán: „Az egyetemi előadóteremben a politikusok pusztán propagandaszólamokkal nem léphettek a hallgatóság elé. A felkérés így politikai álláspontjuk átgondolására és nézeteik igényes

\footnotetext{
${ }^{25}$ BuJdDOSÓ Anna: Vélemények, viták a demokráciáról 1944 novembere és 1945 áprilisa között. In: KISS Endre TÜTŐ László (szerk.): A magyar gondolkodás: 1944 és 1948 között. Eötvös Loránd Tudományegyetem Bölcsészettudományi Kar - Tankönyvkiadó, Budapest, 1990. 30. p.

${ }^{26}$ TAKÁTS József: Modern magyar politikai eszmetörténet. Osiris Kiadó, Budapest, 2007. 136. p.

${ }^{27}$ Szöke Domonkos történész szerint 1945-ben a „demokrácia”, az ,újjáépítés” és a „reakció” volt a közélet három leggyakrabban használt kifejezése. (SzÖKE Domonkos: 1945 szabad választás - szabad választás? In: HoRVÁTH János (szerk.): Tiltott történelmünk. Századvég Kiadó, Budapest, 2006. 40. p.)

${ }^{28}$ STANDEISKY Éva: Remény és szorongás. Demokráciaelképzelések és demokráciaértelmezések. In: RAINER M. János - STANDEISKY Éva (szerk.): A demokrácia reménye: Magyarország, 1945. 1956-os Intézet, Budapest, 2005. 54-91. p.

${ }^{29}$ KovÁCs Gábor: Tervezés és/vagy demokrácia? Demokráciafelfogások a második világháború alatt és után nemzetközi eszmetörténeti körkép. In: RAINER M. János - STANDEISKY Éva (szerk.): A demokrácia reménye: Magyarország, 1945. 1956-os Intézet, Budapest, 2005. 9-28. p.
} 
megfogalmazásra késztette azokat is, akik addig ezt elmulasztották."30 A rendezvénysorozaton előadást tartott: Erdei Ferenc, Fischer Endre, Horváth Barna, Jánosi József, Mezey István, Moór Gyula, Ortutay Gyula, Pamlényi Ervin, Rákosi Mátyás, Szakasits Árpád, Teleki Géza, Tildy Zoltán és Veres Péter. A kiadvány bevezetőjét Hajnal István írta. „Demokrácia: a katasztrófa után a magyar társadalom sorskérése mindaz, ami e szóban foglaltatik"31 - olvasható a Demokrácia-kötet előszavában.

A Demokrácia-konferencia különböző megszólalói egymást kizáró demokráciaértelmezéseket fogalmaztak meg. A '45-ös konferencián elhangzottak alapján felvázolható baloldali/kommunista demokrácia-képbe belefér a társadalmi átalakítás érdekében a formalitások gyengítése, a játékszabályok megkérdőjelezése, e nézőpontból az „ellenséggel” szemben folyamatos harcot kell vívni és nem létezik egy általános, egyetemleges szabadságfogalom, mert az „ellenség” nem kaphat jogosultságokat. Az 1945-ös baloldali demokrácia-értelmezés lényege, hogy a demokrácia valami egészen újat hoz az ország életébe, s ez az új jelenség segíti a társadalmi mobilizációt, a meglévő struktúrák áttörését. Az ekkoriban megfogalmazott baloldali demokrácia-értelmezés hívei nem egy jogokra épített rendszert és életformát látnak a demokráciában, hanem egy társadalom-átalakító keretet, ami évszázados megrögzöttségeket képes lebontani. A nagyon markáns baloldali demokráciaértelmezésekkel szemben számos olyan előadás elhangzott, amely óvott attól, hogy a radikális változások érdekében az általános szabadságjogok súlyos csorbát szenvedjenek - a kommunista demokrácia fogalmat el nem fogadók a polgári demokrácia ethoszát tekintették alapnak, amire az új Magyarország épülhet.

A konferencia megvalósulása már önmagában akár jelképe is lehetne annak, hogy az akkori közélet szereplői valóban hittek abban, hogy lehet ugyan vita a demokrácia kereteiről, formájáról, de mégis valamifajta szabadságközpontú demokratikus államrend fog majd kialakulni. A konferencia idején még a kommunista kötődésű vagy elkötelezettségű előadók sem fogalmaztak meg a demokrácia alaplényegétől eltérő, azzal szögesen ellentétes, azzal ütköző gondolatokat.

Az 1945-öt követő néhány esztendő történetét a demokráciaviták léte, a diskurzus karakterisztikája döntő módon határozta meg. A magyar történelemben egyedülálló, hogy ilyen hosszan elnyúló párbeszédsorozat alakuljon ki egy konkrét államberendezkedési fogalom körül.

\footnotetext{
${ }^{30}$ STANDEISKY Éva: Remény és szorongás. Demokráciaelképzelések és demokráciaértelmezések. 65. p.

${ }^{31}$ ERDEI Ferenc et al.: Demokrácia. A Pázmány Péter Tudományegyetem Bölcsészettudományi Karának kiadása. Egyetemi Nyomda, Budapest, 1945. 3. p. /A továbbiakban: Demokrácia, 1945./
} 
A demokrácia-viták a koalíciós években zajlottak az elméleti folyóiratok hasábjain, a parlament üléstermeiben, politika nagygyüléseken, a napi sajtóban, a társadalmi diskurzus különböző színterein. Egy jelképes jellemzője, hogy milyen szinten volt meghatározó szegmense az 1945 utáni néhány esztendőnek a demokrácia tematika, hogy még a Szent István Társulat is önálló demokrácia-kötettel jelentkezett 1946-ban. A Kereszténység és demokrácia című kiadványban kilenc tanulmány járta körül a katolikus egyházi társadalmi tanításához illeszkedően a demokrácia témakörét. ${ }^{32}$ A bevezetőben Nizsalovszky Endre, az Actio Catholica kulturális szakosztályának országos elnöke azzal a reménységgel indította útjára a könyvet, hogy hozzájárulhat az ,igaz demokrácia” megvalósításához. A kötet esszéi a konkrét helyzetet érdemben nem kívánták elemezni, inkább egyfajta teoretikus állásfoglalássorozatnak tekinthetők. Perneczky Béla Korszerü demokrácia címü cikkének első mondatai azonban sokat elmondanak a koalíciós évek demokrácia vitáinak világáról: „A demokrácia körül valósággal bábeli nyelvzavar kavarog. Nem csupán azok nem értik meg egymást, akik a demokráciát csak divatból, vagy csak jelszóként emlegetik, de igen gyakran más malomban örölnek olyanok is, akiknek a demokrácia komoly elmélyedést követelő probléma vagy politikai program, sőt mi több, világnézet és lelki élmény. Ez a nyelvzavar hovatovább elviselhetetlenné válik." ${ }^{33}$ Az aktuális politikai vélemények, demokrácia-viták tekintetében az imént idézett szöveg politikai értelemben súlytalannak tekinthető, de a „nyelvzavar” mint fogalom használata figyelemreméltó jelenség; ez arra utal, hogy a korabeli közéleti mezőben az apolitikusabb valóságértelmezők is érzékelték a demokrácia fogalom használata kapcsán megjelenő feloldhatatlan ellentétet.

A demokráciaviták kialakulásának hátterében és a jelenség éveken keresztüli fennmaradásában döntő szempont volt, hogy a magyar közgondolkodásban a demokrácia kifejezéshez - követlen tapasztalatok hiányában ugyan, de - a polgári-jogállami demokrácia ethosza kötődött, s a kommunisták e fogalom tartalmával kezdetben még csak enyhén, majd a hónapok, évek múltával radikálisan ellentétes gondolatokat, vélekedéseket fogalmaztak meg a közéleti kommunikációs térben, s mindeközben a maguk sajátos politikai struktúráját is demokráciának nevezték. A kommunisták valami olyan jelenségre használták a demokrácia kifejezést, ami nem volt az, s amit a korabeli közvélemény sem érzékelt annak. A közvéleményben egyfajta kognitív disszonancia alakult ki a kommunista demokrácia fogalom kapcsán, mindeme helyzet adott kommunikációs-szellemi muníciót a demokráciaviták számára. E ideológiai-világnézeti ütközőpont diskurzusra ingerelte a közélet szereplőit, s ez a

\footnotetext{
${ }^{32}$ Kereszténység és demokrácia. A Szent István Társulat kiadása, Budapest, 1946.

${ }^{33}$ PERNECZKY Béla: Korszerü demokrácia. In: Kereszténység és demokrácia. 11. p.
} 
vita mindaddig zajlott, amíg a párbeszéd pszichés és fizikai lehetőségei adottak voltak. Az így kialakult folyamatos fogalmi zürzavart szándékoztak a vita szereplöi tisztázni, artikulálni. A diskurzus lényegi célja a nyelvi mező fogalomtisztítása volt, hogy ezáltal az aktuálpolitikai törekvések koordinátái egyértelmübbek lehessenek. A diskurzus középpontjában végig a kommunista demokráciaértelmezés állott, hiszen ők mondtak valami egészen mást, mint ami rögzült a társadalom tudati struktúrájában; ezért a kommunisták demokrácia fogalomhasználata lett a viszonyítási pont a koalíciós évek demokráciavitáiban. Ezt a viszonyítási pontot még történelmi távlatból sem egyszerủ modellezni.

Ivan Majszkij szovjet külügyi népbiztos-helyettes 1944 elején $A$ jövendő világ kivánatos alapelveiről címü feljegyzése foglalta össze a Szovjetunió stratégiai céljait a második világháború utáni „rendezéssel” kapcsolatosan. A vezető diplomata arról ír, hogy a szovjetek célja a háború utáni időszakra vonatkozóan az, hogy a Vörös Hadsereg által megszállt országok ,társadalmi berendezkedése a népfront eszméjének szellemében a széles demokrácia elvein nyugodjék.” ${ }^{34}$ A Majszkij-terv demokrácia-értelmezése meglehetősen kétértelmü. A szöveg egyik vetülete arról szól, hogy a háború befejezését követően a megszállt területeken a Szovjetunió nem szándékozik azonnal - a polgári demokrácia ellentétpárjának tekintett - proletárdiktatúrát bevezetni, vagyis elfogadja a „széles demokrácia” elveit, de a másik szövegréteg már azt a szempontot érinti, miszerint létezik valamiféle célkitűzés arra, hogy az érintett országok majdan „az igazi demokrácia útjára” lépjenek, ami Majszkij fogalomhasználatában a szocializmust jelenti. Majszkij két demokrácia-panelt használ: az egyik a „széles demokrácia”, a másik pedig az „igazi demokrácia." E stratégiai fontosságú forrásból is látszik, hogy a szovjetek az antifasiszta koalícióból fakadó szövetségesi kényszerüségből időlegesen elfogadják a demokrácia szélesebb értelmezését, az ,igazi” demokráciának viszont a saját politikai berendezkedésüket tartják.

Érzékletesen mutatja be a kommunista/szovjet demokrácia-felfogás sajátosságait Raymond Aron filozófus, aki a Demokrácia és totalitarizmus ${ }^{35}$ címủ monografikus igényü kötetében foglalkozik a kérdéssel. A filozófus a polgári demokrácia struktúráját „alkotmányos pluralista” rendszerként írja körül, a szovjet/kommunista rezsimet pedig mint az „egypárti monopólium” rendszerét nevezi meg. „A kommunista oligarchia hatalmát úgyis felfoghatjuk,

\footnotetext{
${ }^{34}$ MAJSZKIJ, Ivan M.: A jövendő világ kívánatos alapelveiről (1944). Fordította és közreadja: Baráth Magdolna. In: Külpolitika, II. évf. (1996) 3-4. 154-184. p.

${ }^{35}$ Raymond ARON: Demokrácia és totalitarizmus. L'Harmattan Kiadó - Szegedi Tudományegyetem Filozófia Tanszék, Budapest, 2005.
} 
mint a demokratikus eszme egy másfajta leképezését. A népszuverenitás, illetve a proletariátus szuverenitása egy pártra száll át, amely a nép vagy a proletariátus élcsapata"36 írja Raymond Aron, aki szerint a polgári demokrácia világára az a jellemző, hogy a választási harc szimbolizálja a szuverenitást, míg a szovjet demokrácia karakterét az egyhangú jóváhagyási ceremónia adja meg. Aron úgy véli, ez a különbség a két rendszer között egyáltalán nem formai, nem másodlagos, hanem „lényegbeli”, ami kihat a „közösség létének mikéntjére.” Még 1953-ban Robert V. Daniels arra hívta fel a nyugati közvélemény figyelmét, hogy a kommunisták számára az ,igazi demokrácia” az, amikor a tömegek akarata a munkásosztály érdekeinek alárendelt. Daniels szerint a kommunisták szemében a „,szocializmus”, a „demokrácia” és az „osztálynélküli társadalom” fogalmak szinonimaként értelmezhetőek, s a kommunista nézőponton keresztül a szovjet állam a legdemokratikusabb.

1945 után Magyarországon fokozatosan alakult ki az új kommunikációs mező, „az instrumentalizált ${ }^{, 37}$ nyelv, amely struktúrának lényegi vonása, hogy a politikai kifejezéseket fegyverekként használja; majd a nyelvpolitikai küzdelmek eredményeként kizárólagos jelleggel kívánja birtokolni a demokrácia fogalmát. Miután a társadalmi nyilvánosság tereiben a kommunisták elfoglalták a demokrácia kifejezést, az ellenfeleikre rásütötték a „demokráciaellenesség” vádját. E kommunikációs folyamat jellemzője, hogy a „szavak eredeti jelentéstartalmát” elveszik és kifordítják.

A kommunisták számára '45-öt követően évekbe tellett a demokrácia fogalmának elfoglalása, ezért a kifejezésért éveken keresztül kellett nyelvi offenzívát folytatniuk. E nyelvi offenzívának történelmi terméke az évekig tartó demokráciaviták szövegkorpusza. Ezzel ellentétben a „reakció” fogalom birtoklásáért nem volt szükségük kommunikációs harcra. A reakció nyelvi kifejezést a háború befejezésétől kezdve kizárólagos jelleggel uralták a kommunisták. A reakció fogalom a nyilvános térben történő megbélyegzés leghatékonyabb eszközévé vált az MKP kommunikációs stratégiájában. ${ }^{38}$

A demokrácia fogalomért vívott nyelvi küzdelemben a kommunistákkal szemben álló erők képesek voltak érvelni, védekezni; a nyelvi térben léteztek olyan eszközök, ami által más

\footnotetext{
${ }^{36}$ Uo. 173. p.

37 Ö. KovÁCS József: A paraszti társadalom felszámolása a kommunista diktatúrában. A vidéki Magyarország politikai társadalomtörténete 1945-1965. Korall, Budapest, 2012. 75. p.

38 Kövér György úgy véli, amennyire hatékonyan használták az ellenfeleikkel szemben a kelet-európai kommunista pártok a reakció kifejezést, annyira „,szerencsétlenül jártak” a demokrácia fogalommal, igyekezetük a háború után arról szólt, hogy a polgári demokráciától megkülönböztessék az „új demokráciát,” ami a későbbi hónapokban, években nyerte el végleges kommunikációs formáját a „népi demokrácia” terminussal. A fogalmat Kövér szerint viszont soha nem sikerült „világosan” definiálni. (KöVÉR György: Losonczy Géza. 1917-1958. 1956-os Intézet, Budapest, 2012. 155. p.)
} 
demokrácia elképzelések is megfogalmazhatóakká váltak. A „reakció” kifejezés viszont mint „billog” olyan nyelvi eszközt teremtett, amivel szemben nem tudtak védekezni az ellenfelek. Mindezzel is összefügg, hogy demokráciaviták a koalíciós években folyamatosan zajlottak, párbeszédalapú érdemi reakcióviták viszont nem alakulhattak ki.

A reakciósság vádja az 1945-öt követő években a fokozódó nyelvi terror eszközévé vált a kommunisták kezében. ${ }^{39}$

John L. H. Keep a sztálinizmus markáns jellemzőjének, „halálos logikájának” az ellenségkép iránti igényt tartja. Keep úgy véli, a kommunista gondolati struktúra csak úgy tudja fenntartani magát, hogy állandóan mozgósítja a híveit vagy az állampolgárait egy szüntelen küzdelem keretében a külső és belső ellenség ellen. „Ahol nem voltak ellenségek, ott meg kellett teremteni őket" ${ }^{\text {40 }}$ - írja Keep. E jelenséget, folyamatot hívja a politikatudomány az „ellenség megkonstruálásának”. Szabó Márton szerint egy országon belüli ellenség megkonstruálása mindig egy előzetes diskurzust igényel, ami arra irányul, hogy veszélyes ellenségnek lehessen feltüntetni egy embert vagy csoportot. Ezek a személyek vagy csoportok sokak szemében nem tünnek ellenségnek vagy korábban nem tartották annak, ezért szükséges egy alaposabb diszkurzív megkonstruálás. A folyamat során kulcskérdés a veszélyesség hihetősége. Mindebben a nyelvi formáknak különös jelentősége van. Szabó úgy véli, az ellenségkonstruálásban öt nyelvi stratégia létezik. Ezek a következők: átdefiniálás, aszimmetrikus nevek és utalások használata, a szemantikai oppozíciók létrehozása, a sztereotipizálás és a kinyilatkoztatás. ${ }^{41}$

Az átdefiniálás ismert realitásokból indul ki, vagyis például ha a reakciós mint ellenségfogalom kapcsán figyeljük a jelenséget, akkor tény, hogy a második világháború pokla után sok felelőst lehetett találni, akik valóban hatalmas bünöket követtek el a korábbi években. Átdefiniálás során létrejönnek a pejoratív kategóriák. Az aszimmetrikus megnevezések kapcsán történhet meg az ellenségfogalom kiterjesztése, vagyis mások felé is kiterjeszteni a reakciósság bélyegét - majd az ellenséggé tett személyt vagy csoportot a

\footnotetext{
39 „Negyvenötben a legelterjedtebb és leghatékonyabb közbefolyásoló módszer az ellenfél verbális megbélyegzése volt. Erre a »reakciós« szó bizonyult a legalkalmasabbnak. Az ellenség neve a reakciós volt. [...] Olyan gyüjtőfogalommá vált, amelybe tetszés - a napi politika kívánalmai - szerint besorolható volt mindenki, akit éppen uralmon lévő feleslegesnek, politikailag veszélyesnek, gazdaságilag kisajátíthatónak tartottak. A mindennapok embere is lehetett reakciós. A reakciós kifejezést leginkább a legaktívabb párt, a Magyar Kommunista Párt használta. A veszélyes szófegyver segítette ellenségei felszámolásában, szövetségesei morális ellehetetlenítésében.” - írja Standeisky Éva. (STANDEISKY Éva: Demokrácia negyvenötben. Napvilág Kiadó, Budapest, 2015. 133-134. p.)

${ }^{40}$ John L. H. KEEP: Last of the Empires: A History of the Soviet Union. Oxford University Press, New York, 1995. 9. p.

${ }^{41}$ SZABÓ Márton: Politikai idegen. A politika diszkurzív szereplőinek elméleti értelmezése. L’Harmattan Kiadó, Budapest, 2006.
} 
szemantikai oppozíció révén egy kategóriapárba lehet helyezni, vagyis létrejöhet a jó-rossz antagonisztikus szembenállása.

Ezzel a stratégiával történt meg a kommunisták részéről a reakciós ellenségfogalom kiterjesztése és a reakciós „rosszként” való megbélyegzése. A sztereotipizálás eszközével lehet sulykolni, hogy a megkonstruált ellenség veszélyes, végül pedig a kinyilatkoztatás nyelvi stratégiája során lehet arról beszélni, hogy a gonosz támad, a rossz jelen van és alapjaiban veszélyezteti a közösséget.

Reinhart Koselleck szerint nem a nyelv hozza létre az ellenséges érzéseket, hanem a politika „instrumentalizálódása” révén használható a nyelv a megbélyegzésre. ${ }^{42}$ A reakció fogalomnál is megfigyelhető ez a jelenség; a kommunisták hatékonyan tudták létrehozni a reakció nyelvi terét, mint szemantikai oppozíciós struktúrát, amely a kommunikációs stratégia érdekei alapján előhívhatja az ellenséges érzületet. Murray Edelman úgy véli, az a döntő határvonal a politikában, amikor a közéleti ellenfélből „ellenség” konstruálható. ${ }^{43}$ Paul Ricoeur viszont amellett érvel, a nyelv az erőszak korlátozásának az eszköze, mert amíg a diskurzusnak sansza van, addig az erőszak , ,le van fojtva." ${ }^{44}$

A Ricoeur által megfogalmazott keret segítségével azt mondhatjuk: a demokrácia fogalom alkalmas arra, hogy utat nyisson a diskurzusnak, vagyis e tekintetben a nyelv az erőszak korlátozásának a potenciális letéteményese. E gondolatot - Edelman tézisével továbbvíve azt mondhatjuk: a reakció fogalom parttalan kiterjesztésével átléphető a döntő határvonal, vagyis az ellenfélből megkonstruálható az ellenség. A reakció fogalom az ellenség pozícionálásának hatékony eszköze volt a kommunisták számára az 1945-öt követő kommunikációs közegben.

1945 után a kommunisták a kommunikációs térben a reakciós fogalom folyamatos kiterjesztésében voltak érdekeltek. „De nem csak a háborús bűnösökről van szó. A magyar reakció nemcsak nyilasokból és a Horthy-reakció főkolomposaiból áll. A magyar demokrácia nem elégedhetik meg a hazaárulók fejével, a magyar demokráciának a reakció gyökereit kell kitépnie, a reakció fertőző gócait kell kiégetnie"45 - követhetjük nyomon, hogy miként

\footnotetext{
${ }^{42}$ Reinhart KosELLECK: Ellenségfogalmak. In. Szabó Márton (szerk.): Az ellenség neve. Jószöveg könyvek, Budapest, 1998. 12-23. p.

${ }^{43}$ Murray EDELMAN: Politikai ellenségek konstruálása. In. Szabó Márton (szerk.): Az ellenség neve. Jószöveg könyvek, Budapest, 1998. 88-123. p.

${ }^{44}$ Paul RICEOUR: Erőszak és nyelv. In. Szabó Márton (szerk.): Az ellenség neve. Jószöveg könyvek, Budapest, 1998. 122-136. p.

${ }^{45}$ RÉVAI József: A demokrácia támadásban. Szabad Nép, 1945. július 22. 1. p. (Közli: RÉVAI József: Élni tudtunk a szabadsággal. Válogatott cikkek és beszédek 1945-1949. Szikra, Budapest, 1949. 8-14. p.)
} 
terjeszti ki egyre szélesebb, nehezen megfogható körre a reakciósság vádját Révai József, majd így folytatja: „Hamarosan éreznie kell az egész országnak, hogy ez a támadás a reakciós gócok ellen fejlődik és kibontakozik. Vannak, akik még mindig naivnak tettetik magukat és mesterséges csodálkozással kérdik: ugyan mi is az a reakció? Pontos definíciót követelnek és a definíció pontosságától teszik függővé, hogy helyeslik-e a reakció elleni harcot."46

A kommunista föideológus nem kíván pontos definíciót vázolni, de mint mondja, „szolgálhat” néhány „csalhatatlan ismertetőjellel.” Az ismertetőjelek közül már az első mellbevágóan őszinte: „Reakciós az, aki antikommunista” - vallja Révai, vagyis ezen „ismertetőjel” alapján bárki, aki a kommunistákétól eltérő véleményt fogalmaz meg, egyben megbélyegezhető, mint reakciós. Révai szerint az is reakciós, aki „az ország háborús vereségénél a nemzetet ért erkölcsi és anyagi pusztulásnál sokkal nagyobb szerencsétlenségnek tartja azt, hogy a Kommunista Párt a magyar dolgozó nép hatalmas pártjává, a nemzeti s állami élet formáló tényezőjévé lett. A vereséggel még csak megbékélne, de a Kommunista Párttal nem. Reakciós az, aki nem a hazaáruló nyilasokat, nem a reakciós Horthy-rendszert, nem a német szövetséget, hanem a kommunistákat okolja minden ránk szakadt bajért és nélkülözésért." ${ }^{47}$ A cikkíró azt is reakciósnak bélyegzi, aki az MKP „elszigetelésén” dolgozik, de arra már nem téri ki, hogy mit ért elszigetelés alatt.

A reakció fogalmát a kommunisták kizárólagosan birtokolták és használták; a koalíciós évek politikai küzdelmeiben a kisgazdák és más antikommunista erők tehetetlenek voltak az e fogalom mint kommunikációs fegyver által vívott nyelvi terrorral szemben. Erre a feloldhatatlan kommunikációs helyzetre példa, hogy paradox módon a különböző FKgP-s közéleti megnyilatkozásokban is kiemelésre kerül úgymond a „a reakció elleni küzdelem” fontossága. Reakción természetesen mást értenek, mint a kommunisták; pontosabban a kisgazda demokrácia értelmezés horizontján a reakció fogalom tisztázott; ellentétben a kommunisták totálisan kiterjeszthető reakció-megközelítésével. A kisgazdák reakción az 1945 előtti rendszer szellemiségét értették. „Van-e reakció? Kétségtelenül van. Politikai rendszerek, élet és termelési formák a történet tanulságai szerint nem tünnek el nyomtalanul máról holnapra s a magyar demokrácia még nem válhatott kétségbevonhatatlan többségi elvvé. Ma még vannak nagyszámmal titkos, nemtitkos ellenségei, akik epedve várják vissza a múltat”"48 - olvashatjuk a Kis Újság publicisztikájában. A szerző, Balla Antal kifejti, „reakciós az, aki vissza akarja hozni az 1939 előtti Magyarországot. [...] Ez ellen küzdenünk kell a végsőkig,

\footnotetext{
${ }^{46}$ Uo.

${ }^{47}$ Uo.

${ }^{48}$ BALLA Antal: Ki a reakciós? Kis Újság, 1946. április 14. 1. p.
} 
minden rendelkezésünkre álló törvényes eszközzel.”49 Balla ugyanakkor szembeszáll a kommunisták parttalan reakció fogalmával, fontosnak tartja leszögezni, hogy a szabad véleménynyilvánítás „még nem reakció,” hanem a demokrácia kelléke. Antallfy Gyula, a Kis Újság felelős szerkesztője 1946 őszén a Temessük be a lövészárkokat! című cikkében elemzi azt a jelenséget, hogy aki ,jelzőtlen” vagy polgári demokráciát akar, az egyre inkább megkaphatja a „reakciós” jelzőt. „Ezért nincs megértés, ezért fenyeget harc és újabb lövészárkok" ${ }^{\circ 0}$ - írja Antallfy.

Antallfy fogalomhasználata pontosan adja vissza a kommunista kommunikációs stratégia lényegét: a megbélyegzésre használatos reakció kifejezés újabb és újabb vesztes helyzeteket generált azokkal szemben, akikre ezt a billogot rásütötték. A koalíciós években a demokrácia kifejezés antagonisztikus vitákat provokált, a reakció-fogalom pedig a kommunikációs térben átjárhatatlan lövészárkokat teremtett.

\section{Diszkurzív csomópontok a koalíciós évek demokrácia-diskurzusaiban}

A közélet szereplői a nyelv struktúrái által hozzák létre a politikai valóságot. A diszkurzív politikatudomány alapvetése szerint a politikumnak vannak olyan területei, ahol összesűrüsödik a politizálás; ezeket hívhatjuk diszkurzív csomópontoknak. A diszkurzív csomópontok körül határozható meg a politikai valóság egy-egy markáns szelete. A diszkurzív csomópontokban az összetett politikai helyzet beszédcselekvései beszédszituációkká állnak össze: az időben és térben kiemelkedő alkalmak összessége diszkurzív csomópontot alkot. ${ }^{51}$

Ebben a fejezetben a koalíciós időszak három diszkurzív csomópontjának szövegpaneljeit vizsgáljuk. Az első megközelítésünkben az idő-szegmens által jönnek létre csomópontok. Két időszakban, 1946 februárjában-márciusában, illetve 1947 májusábanjúniusában tekintjük át, hogy a kisgazdák és a kommunisták milyen nyelvpolitikai harcot vívtak a demokrácia fogalom birtoklásáért. A második és a harmadik diszkurzív csomópont viszont már nem idősíkok alapján metszi ki a politikai valóságot, hanem a sajátos terek

\footnotetext{
${ }^{49}$ Uo.

${ }^{50}$ ANTALLFY Gyula: Temessük be a lövészárkokat! Kis Újság, 1946. október 20. 1. p. 1. p.

${ }^{51}$ SzABÓ Márton: A diszkurzív politikatudomány alapjai. Elméletek és elemzések L'Harmattan Kiadó, Budapest, 2003. 226-230. p.
} 
nézőpontjából teremt összesürüsödött politikai kommunikációs mezőt: parlamenti disputákon és a pártközi értekezletek mint speciális hatalmi fórumok vitáin keresztül elemezzük a különböző beszédszituációkat és a nyelvi struktúrákat.

\section{1. A kisgazdák és a kommunisták harca a demokrácia fogalom birtoklásért 1946} februárjában-márciusában, illetve 1947 májusában-júniusában

1944 decemberét követően - egészen 1948/49-ig - mind a napi politikai csatározások során, mind a szellemi-intellektuális közéleti küzdőtér fórumain folyamatos volt a demokráciáról szóló értelmezések, viták sokasága. A koalíciós korszak egészének demokrácia diskurzusait felfejteni, teljességre törekedve elemezni lehetetlen, ezért is választottunk ki diszkurzív csomópontként két rövidebb, áttekinthető időszakot az 1945 utáni korszakon belül. Az egyik csomópontunk 1946 februárja-márciusa, míg a másik kiemelt időintervallumunk 1947 májusa-júniusa. Ebben a két rövid periódusban azt vizsgáljuk, hogy a demokrácia fogalmát miként használják a kommunisták és a kisgazdák nyelvi eszközként a mindennapi politikai harc során.

E két diszkurzív csomópont mint rövid periódus, a koalíciós korszak két fontos időbeli szeletét jelenti. 1946 februárja és márciusa lehetőséget ad arra, hogy a köztársaság kikiáltása utáni két hónap alatt, ebben a korabeli közvéleményben előzetesen harmonikusnak remélhetett időszakban miként mélyül a demokrácia-értelmezések közötti ellentét.

1947 májusa és júliusa az a periódus, amikor Nagy Ferenc - politológiai értelemben puccsszerünek - tekinthető lemondatása jeleni a politikai diskurzusok legfontosabb témáját. Ebben a két hónapban a kommunisták a demokrácia-fogalom birtokolásáért vívott kommunikációs hadműveletben - az erő államhatalmi vetületű pozíciójából - döntő győzelmet arattak a kisgazda demokrácia-értelmezés felett: a polgári-jogállami demokráciát akaró kisgazda tömb megszünt legitim és szervezett keretek között müködni Magyarországon, politikusai emigrációba kényszerültek; a kommunisták iránt lojális kisgazda körök pedig a kommunista demokrácia-fogalomhoz szorosan illeszkedő demokrácia-értelmezést használtak 1947 júniusától. Ebben az időszakban megfigyelhető, rekonstruálható az a jelenség, amikor a hivatalos kisgazda álláspont a demokrácia terén éles fordulatot vesz, és döntő módon átalakul.

1946. február elején majdhogynem kizárólagos jelleggel a kisgazda demokráciaértelmezés számára adatott meg a szükséges közéleti és kommunikációs tér. Február 1-jén a 
köztársasági elnökké választott Tildy Zoltán első, a nemzetgyülés előtt elmondott államföi megszólalásában ${ }^{52}$ nem mondta ki ugyan a demokrácia kifejezést, de beszédében az emberi jogok és a szabadságvágy fontosságát hangsúlyozta, amely nyelvi panelek a kisgazda demokrácia-fogalom meghatározó elemei voltak.

A kisgazda Kis Újságban 1946. február 2-án Dessewffy Gyula nemzetgyủlési képviselő, a lap felelős szerkesztője üdvözölte a köztársaság kikiáltását, szerkesztői jegyzetében a kisgazda szellemiségü demokrácia-értelmezést népszerüsítette. Dessewffy szerint a szabadság és a demokrácia szellemi és lelki tartalma az új magyar államiság alapja. „A magyar élet immár írott törvények alapján a szabadság, az emberi jogok és a demokrácia jogait és kötelességeit állami berendezkedésünk és mindennapi életünk tízparancsolatává, alkotmányává avatja ${ }^{\text {"53 }}$ - fogalmazott a kisgazda politikus.

Kulcsfogalomként jelenik meg e cikkben is a szabadság, a jogok és az alkotmányosság. Dessewffy amellett érvel, hogy a demokrácia iránti igény a magyar lélekből fakad, erre jelentenek példát a magyar szabadságharcok és a vallásszabadságért folytatott évszázados küzdelmek; paradoxnak nevezi, hogy csak legutolsónak tudott az ország a „csatlósállamok kényszerü sorából” szabadulni, ugyanakkor a magyar nemzetnek „,a lelkében volt legkorábban jelen" a szabadságszeretet. A következö demokratikus feladatnak az önkormányzatiság kiépítését és a „félelemmentes élet kereteinek” a meghatározását nevezi. Elvként mondja ki, hogy ,jogoktól törvényes ítélet nélkül megfosztani” senkit se lehessen.

A kommunista Szabad Népben a köztársaság kikiáltása kapcsán, azokban a napokban nem jelenik meg demokrácia-értelmező cikk. Csak napokkal később, február 6-án lát napvilágot a demokrácia narratívához kötődő írás „Demokratikus közigazgatás” címmel. „Jó szívvel egyetlen dolgozó sem tudja lenyelni, hogy a demokrácia nevében, most is azok uralkodjanak, akiknek egész életét, müködését a népellenesség jellemezte" ${ }^{\text {"54 }}$ - olvasható a név nélkül közölt vezércikkben. Demokratikus feladatnak a jegyzet az államapparátus radikális megtisztítását tartja a reakciósoktól és a fasisztáktól, azért hogy - ahogy a cikk fogalmaz - a demokrácia legyen „az úr”.

E két cikk összehasonlításából is kitetszik a kisgazda és a kommunista demokráciaértelmezések közötti aktuálpolitikai különbség. A kisgazdák számára e hónapokban a legfontosabb a szabadság rendjének a biztosítása és a demokratikus önkormányzatiság megteremtése, míg a kommunistáknak a közigazgatás „demokratikus” átalakítása a prioritás.

\footnotetext{
52 Elhangzott a nemzetgyülés 13. ülésén 1946. február 1-jén. Nemzetgyülési Napló 1945-1947. Athenaeum, Irodalmi és Nyomdai Részvénytársulat Könyvnyomdája, Budapest, 1946. I. kötet. 353-354. p.

${ }^{53}$ DESSEWFFY Gyula: Az új világrend eszményei köztársasági törvényünkben. Kis Újság, 1946. február 2. 1.p.

${ }^{54}$ Demokratikus közigazgatás. Szabad Nép, 1946. február 6. 1. p.
} 
Február 7-én hangzott el a nemzetgyülésben Varga Béla házelnöki székfoglaló beszéde és Nagy Ferenc első miniszterelnöki expozéja. Mindkét megszólalás a jogállami jellegű demokrácia ethoszának megfelelő kommunikációs paneleket tartalmazott. Varga a demokrácia legfontosabb tereként a parlamentet nevezte meg. „A parlament fö rendeltetése az egyéni akaratoktól független nemzeti akarat kifejezésre juttatása" ${ }^{\natural 5}$ - mondta a nemzetgyülés elnöke, aki szerint a „nemzeti akarat” fogalmában összhangba kerül az egyén és a köz, a rész és az egész, a társadalom és az állam, a szabadság és a tekintély. Nagy Ferenc kormányföi szüzbeszédében döntő politikai feladatnak nevezte a jogrend megszilárdítását, a demokrácia megvédését (,„naggyá nevelését” ${ }^{, 5}$ ), illetve a demokratikus szabadságjogok és a demokrácia vívmányainak biztosítását a nép számára.

Február első hetében a nyilvánosság terein az FKgP demokrácia-értelmezése dominált. A kisgazda köztársasági elnök, a kisgazda kormányfő és a kisgazda házelnök nemzetgyülési beszédei formális módon voltak képesek erősíteni a jogállami demokrácia-fogalom nyelvikulturális pozícióját a közgondolkodásban.

$\mathrm{Az}$ volt várható, hogy február második hetében, a Nagy Ferenc-kormány programjának parlamenti vitája során - többek között a kisgazda demokrácia-értelmezés további sulykolása kapcsán - a közbeszédet az FKgP tudja majd dominálni. Erre azért is kínálkozott esély, mert a kormányprogram vitájában az egyik legjobb kisgazda szónok, Sulyok Dezső is felszólalt. Sulyok február 8-i beszéde elején leszögezte, hogy a koalíciós kormányzásnak nincs alternatívája. „A polgári kisgazdapárti többség és a munkáspárti kisebbség végeredményben kétségtelenül ugyanazt akarja: a modern demokrácia szellemében újjáépíteni az országot" ${ }^{\$ 57}$ - fejtegette Sulyok. Ezt követően az ország demokratikus teljesítményét a béketárgyalások dimenziójában kezdte elemezni, érvelése szerint azért is kell a demokrácia szellemében a haza ügyeit intézni, mert ha a magyar demokrácia tekintélyt tud kivívni, akkor a nagyhatalmak részéről hamarabb alakulhat ki bizalom Magyarország iránt, s ebből fakadóan gyorsabban megszűnhet a magyar területek katonai megszállása. Ezzel a kisgazda politikus nyilvánvalóan a szovjet megszállás tényére utalt, $\mathrm{s}$ abbéli reményének adott hangot, hogy ha a demokratikus államrend helytáll, akkor a nyugati hatalmak a szovjet jelenlét felszámolásában lesznek érdekeltek. Egy folyó-metafora keretében a távoli jövőre vonatkozóan ugyan, de felvetette annak lehetőségét, hogy majdan a demokrácia szellemében többségi kisgazda kormány alakuljon. A kommunista padsorokban döbbenten hallgatták

\footnotetext{
${ }^{55}$ Elhangzott a nemzetgyülés 15. ülésén 1946. február 7-én. Nemzetgyülési Napló 1945-1947. I. kötet. 364. p.

${ }^{56}$ Uo. 366. p.

${ }^{57}$ Elhangzott a nemzetgyülés 16. ülésén 1946. február 8-án. Nemzetgyülési Napló 1945-1947. I. kötet. 392. p.
} 
Sulyok gondolatait, de egyelőre szó nélkül türték az elhangzottakat. Mikor azonban az FKgPs vezérszónok történelmileg igazságtalannak nevezte annak lehetőségét, hogy az új békemegállapodásban is elveszik a színmagyar területeket, akkor óriási hangzavar kerekedett. Maga Rákosi Mátyás is bekiabálva kelt ki Sulyok ellen. A kommunisták „országrontó sovinizmusnak” bélyegezték a kisgazda szónok gondolatait. „Sulyok Dezső képviselőtársam beszédét úgy is, mint a többségi párt szónokának a beszédét, hazánkra rendkívül károsnak, rossznak tartom" aláhúzta, hogy a politika feladata az úgymond „országpusztító sovinizmussal” szemben csakis a demokrácia „továbbfejlesztése” és a reakció elleni kíméletlen harc folytatása lehet.

A kommunisták látszólag Sulyok „,sovinizmusával” szemben pozícionálták magukat, de valójában a kisgazda politikusnak a szovjet csapatkivonulásról és a többségi demokráciaeszményről mondott szavai vághattak az MKP elevenjébe. A verbális és kommunikációs attakot azonban a „sovinizmus” elleni harc örve alatt tudták megindítani Sulyokkal és az FKgP-vel szemben. Valóságos támadássorozat nyitánya lett Sulyok beszéde, a megszólalás szövege nyilvánvalóan ürügy és nem ok volt a kommunisták számára. Az addig offenzívában lévő kisgazda valóság- és demokráciaértelmezés védekezésre kényszerült, a nyilvánosság fórumain a kommunisták ettől a jelképes pillanattól átvették az irányítást és agresszív kommunikációs stratégia jegyében kényszerítették defenzívába az FKgP-t. Február 9-én a Szabad Nép ,felelőtlen beszédnek” minősítette Sulyok szavait, ${ }^{59}$ a vezércikk úgy fogalmazott: fel kell feltenniük a kérdést, vajon támogatja-e egyáltalán a Kisgazdapárt és vezérszónoka a magyar demokratikus államberendezkedést. Az írás a baloldal képviselőit nevezi az ,igazi demokratáknak" ${ }^{\circ 0}$ és egyúttal felszólítja a demokratákat, hogy zárják szorosabbra soraikat, mert meg kell védeni a „demokratikus kormányzást.”

Február 16-án Rákosi Mátyás a sportcsarnokban mondott nagyszabású beszédet. A szónoklat legfontosabb üzenete a következő volt: harcolunk a demokráciáért, s egyetlen lépést sem teszünk visszafelé. „A reakció felbátorodott és támadásra indult. Ez kötelességünkké teszi, hogy ezt a támadást ne csak feltartóztassuk, hanem ellentámadásba menjünk át és visszaverjük őket úgy, hogy egyszer és mindenkorra elmenjen a kedvük a fiatal demokrácia támadásától”61 - hangoztatta Rákosi. Ez az az időszak, amikor a kommunisták tömeggyülések szervezésével próbálják átvenni a kezdeményezést és még dinamikusabban igyekeznek

\footnotetext{
${ }^{58}$ Uo. 405. p.

${ }^{59}$ Felelőtlen beszéd. Szabad Nép, 1946. február 9. 1. p.

${ }^{60}$ Amint arra már utaltunk, feljegyzésében Majszkij is az „,igazi demokrácia” kifejezést használta a kommunista nézőpontú demokrácia tekintetében.

${ }^{61}$ Harcolunk a demokráciáért, s egyetlen lépést sem teszünk visszafelé! Szabad Nép, 1946. február 18. 1. p.
} 
tematizálni a közbeszédet. Február 24-én Horváth Márton, a Szabad Nép felelős szerkesztője „demokratikus jognak” nevezi, hogy a munkásság élhessen véleményalkotási jogával és tömegtüntetéseket szervezhessen, ahol kinyilváníthatja: „demokratikus közigazgatást” szeretne. „Nyugtassuk meg az aggodalmaskodókat. Ne a néptől féltsék a demokráciát... Ettől csak a fenyegetett reakciósoknak és magas pártfogóiknak van okuk félni" ${ }^{\circ 2}$ - érvel Horváth.

A kisgazdák ezzel a fajta kommunikációs offenzívával szemben bénultan álltak. Tehetetlenül nézték, hogy a kommunisták - a demokrácia fogalom egyre intenzívebb elbirtoklása által is - átvették a nyilvános közéleti tér uralását, a tematizáció irányítását. Február első hetét még a demokráciaértelmezés tekintetében is az FKgP dominálta, utána viszont heteken keresztül érdemben nem szólaltak meg; úgy tűnhetett, hogy a demokrácia fogalomértelmezés szempontjából is defenzívába szorultak. Dessewffy Gyula kisgazda nemzetgyülési képviselő február 24-én írt cikkében próbált valamiféle ellenerőt felmutatni. A politikus a kompromisszumok szükségessége és a bizalom megerösítése mellett érvelt, leszögezte, hogy nem türnek „semmiféle formában reakciós jelenségeket.”63 E szavak védekezési kommunikációs formának minősíthetőek. Dessewffy egyetlen ponton, a jogállami demokrácia-felfogás normatív alapja tekintetében igyekezett határozott álláspontot megfogalmazni. „Az új demokratikus magyar élet továbbfejlesztése során azonban a reakció elleni harc alcíme alatt nem kezdeményezhető olyan politikai akció, amely eltér azoktól a normáktól és szabályoktól, attól a szellemtől, amely együttműködésünknek és eddigi sikeres kooperációnknak lényege és alapja"64 - írta a kisgazda politikus. Dessewffy e gondolatmenet közlését követően a kommunista kommunikációs offenzíva egyik céltáblájává vált és a március 11-i koalíciós állapodásnak megfelelően távozni kényszerült a Kis Újság felelős szerkesztői pozíciójából.

Ezekben a napokban a kisgazda vezető politikusok általános állásfoglalásokat tettek közzé nyilatkozataikban a demokrácia védelméről, az új demokrácia értékeiről és a koalíciós együttmüködés szükségszerüségéről. Nyelvileg teljesen egyértelmünek látszik a korabeli politikai szövegeket vizsgálva, hogy a kisgazdák nem találták meg a kommunista kommunikációs taktikával szembeni ellenszert. Az FKgP valóságértelmezésében a tematizációs bénultság február végén és március elején is tetten érhető.

A kommunista kommunikációs stratégák február második felétől érzékelhették a kisgazda tematizációs képesség legyengülését; nem lassítottak azonban a tempón, hanem még

\footnotetext{
${ }^{62}$ HORVÁTH Márton: Betelt a mérték. Szabad Nép, 1946. február 24. 1. p.

${ }^{63}$ DESSEWFFY Gyula: Veszedelmes forduló. Kis Újság, 1946. február 24. 1. p.

${ }^{64}$ Uo.
} 
intenzívebbé tették a demokrácia kifejezés elfoglalásáért vívott csatát. Február végén, március elején folyamatosak voltak országszerte az MKP által szervezett népgyülések, tömegtüntetések, ahol a „demokrácia védelméért” szálltak síkra. A munkás- és bányászgyülések sokasága során ,a demokrácia ellenségei ellen” emeltek szót: ekkoriban fogalmazódott meg az az üzenet, hogy a dolgozók „,csákánnyal és kemény proliököllel védik meg a magyar demokráciát." ${ }^{\text {, }}$ A Baloldali Blokk által március 7-re meghirdetett budapesti tömeggyülés célja a kommunikációs panelek szintjén az volt, hogy az esemény legyen „tisztító vihar”, amelynek következtében „,a magyar demokrácia egészségesebben, erősebben” kerüljön ki! ${ }^{66}$

Fogalomtörténeti nézőpontból azonosítható, hogy a március 7-i többszázezres gyülésen elhangzott megnyilatkozásokban már erőteljesebben jelenik a meg a népi demokrácia kifejezés, amely majd 1946 őszétől lesz hangsúlyos eleme a kommunista kommunikációnak.

Rákosi beszédében még „kíméletlenebb” harcot hirdetett annak érdekében, hogy a demokrácia „minden jogos követelése” megvalósuljon. „Addig nem nyugszunk, amíg be nem váltottuk az ígéreteket és győzelemre nem vittük azt az ügyet, amelynek képviseletét reánk bízták: a magyar népi demokrácia megalapozásának és felépítéséinek ügyét” ${ }^{\text {,67 }}$ - hangoztatta Rákosi. Az MKP agresszív nyelvhasználati stratégiája továbbra is bénult állapotban tartotta a kisgazdákat. A kommunista panelek hatékonyságát érzékelteti, hogy Nagy Ferenc kisgazda miniszterelnök részéröl csak erőtlen válaszkommunikációra futotta, amelyben még csak megjelenni sem volt képes az FKgP saját demokrácia-értelmezése. „Nem adunk menedéket a demokrácia ellenségeinek"68 - nyilatkozta a kormányfö. Nagy Ferenc beszélt még a demokratikus fejlődés fontosságról, illetve, arról hogy a demokratikus állami rendet meg kell megszilárdítani, amelyhez „nyugalom” szükséges. A miniszterelnök a „nyugalom” fogalom hangoztatásával szerette volna önmérsékletre, a nyelvi agresszió tompítására bírni a kommunistákat. Megállapíthatjuk, a nyugalom fogalom használata Nagy részéről ebben a rendkívül kiélezett nyelvpolitikai szituációban inkább a gyengeség jelének számított, amire a kommunista kommunikátorok újabb és újabb attakkal reagáltak. Március 10-én a Szabad Nép vezércikkében arról írt, hogy a Kisgazdapárt mint mamutpárt a maga parlamenti többségével „eltorlaszolja”69 a demokrácia fejlődésének lehetőségét; Vásárhelyi Miklós, a Szabad Nép

\footnotetext{
${ }^{65}$ Szabad Nép, 1946. március 5. 1-2. p.

${ }^{66}$ Megmozdul a nép. Szabad Nép, 1946. március 6. 1. p.

${ }^{67}$ Szabad Nép, 1946. március 8. 2. p.

${ }^{68}$ Kis Újság, 1946. március 8. 1. p.

${ }^{69}$ Döntést! Szabad Nép, 1946. március 10. 1.p.
} 
újságírója a demokrácia érdekében követelt a Kisgazdapártban ,alapos tisztogatást” - a kommunista álláspont szerint ugyanis az $\mathrm{FKgP}-b o ̋ l$ való kizárások nem egy párt belügyét jelentik, hanem „a demokrácia elvi kérdésének”70 számítanak. Eközben március 11-én megtörtént a Baloldali Blokk és a Kisgazdapárt közötti megállapodás, amelynek részeként az FKgP kénytelen volt kizárni 20 nemzetgyülési képviselőjét a pártból. Mindezt a kommunista pártsajtó úgy kommentálta, hogy a „magyar demokrácia ügye győzött.",71

A március 11-i koalíciós megállapodást követően Nagy Ferencnek kísérletet kellett tennie a kisgazdák demokrácia-felfogásának újrapozícionálására, hiszen a korábbi hetekben a kommunisták stratégiai lépéseket tettek a demokrácia fogalmának elfoglalása felé. Az FKgPnek muszáj volt a nyilvánosság előtt ismét érdemben a demokrácia kifejezésével foglalkoznia, hiszen politizálása fundamentumát jelentette a jogállami polgári demokrácia ethoszának tisztelete - ugyanakkor a kisgazdák érzékelhették, hogy a kommunisták nyelvi offenzívája következtében a demokrácia fogalma mint harci kifejezés egyre inkább kezdett a baloldalhoz kapcsolódni.

Nagy Ferenc március 13-i nyilatkozatában a demokrácia nemzeti-hazafias tartalmát próbálta érzékeltetni, s ez a megközelítés alkalmas volt arra, hogy a kisgazda demokrácia érzület tekintetében új élményanyagot adjon, új tematizációs keretet szabjon. „A mi magyarságunk az egy nemzetben született emberek összefogásán túl a demokratikus magyar haza alázatos szeretetében van"72 - mondta a kormányfö. Nagy a „demokrácia magyarságáról" mint új fogalomról beszélt, s szerinte ez a sajátos magyar demokrácia a parasztságnak és a munkásságnak együttesen „,biztosítja a túlsúlyt.” A miniszterelnök szövegéből kiolvasható, hogy a február második felétől bekövetkező folyamatos kisgazda nyelvi térvesztést, politikai hátrálást követően a saját nemzeti-paraszti-polgári bázisát szeretné ideológiailag-szellemileg megerősíteni. A demokrácia-diskurzusban új témákat, megközelítéseket, érzéseket próbál keresni és felmutatni. Ennek az útkeresésnek az is a célja, hogy a híveiknek érzelmi táplálást tudjanak biztosítani. Nagy Ferenc leszögezi: a kisgazdák képviselik a magyar közéletben a demokrácia „tiszta törekvéseit”, de mivel ők a demokrácia eszméjének a leghitelesebb képviselői, ezért is kellett megegyezni március 11-én, s ezért is kell fenntartani a koalíciót, mert a kommunistákkal való alku nélkül káosz következne be, ami viszont ellentétes lenne a kisgazdák demokrácia-felfogásával.

\footnotetext{
${ }^{70}$ VÁSÁRHELYI Miklós: Alapos tisztogatást! Szabad Nép, 1946. március 12. 3. p.

${ }^{71}$ Végrehajtani! Szabad Nép, 1946. március 13. 1. p.

${ }^{72}$ Kis Újság, 1946. március 13. 1-2. p.
} 
A március 11-ét követő hetekben a kisgazda valóságmagyarázók ismét nyomatékosabban használták a „tiszta demokrácia” kifejezést, amire az is lehetőséget adott, hogy a március 7-i tüntetésen a baloldal a népi demokrácia fogalmát kezdte hangsúlyosabbá tenni. 1946 februárja-márciusa a „tiszta demokrácia” és a „népi demokrácia” hívei közötti háború egyik fontos nyelvi és politikai csatáját hozta el. A csatát a kommunisták nyerték, de a kisgazdák a kommunikációs veszteségek után ekkor még képesek voltak új kereteket szabni és a saját demokrácia-értelmezésüknek megújított szellemi formát adni.

1947 tavaszán a kisgazdák túl vannak számos koalíciós válságon, már majdhogynem hozzászoktak a kommunisták nyelvi agressziójához. '47 májusára Kovács Béla elrablását is kezdik emberileg, politikailag és kommunikációs szempontból is kiheverni. Addigra már sokszor megtapasztalhatták, hogy a rendkívüli a szokásos, s nincs nyugalmi állapot. 1947. május elejére elkészül a Független Kisgazdapárt programtervezete. A szövegen a párt politikusai és szakértői 1946 őszétől dolgoztak. Az írásos anyag elkészülte, kiadása és nyilvánosság elé tárása önmagában is szimbolizálta, hogy a kisgazdák öntudatosabbakká váltak, s erösödött reményük, hogy a polgári demokrácia szabályrendszere hosszabb ideig érvényesülni fog Magyarországon.

A programban a kisgazdák hitet tettek a jogállami demokrácia és az állampolgári alkotmányos jogok mellett. Megfogalmazásuk szerint a demokrácia „alaptétele” az állampolgárok önkormányzati jogának szabad gyakorlása. Kiálltak a szabad önkormányzati választás, a parlamenti többségi elv mellett és követelték a „demokrácia fogalmával már összeférhetetlen"73 rendeleti kormányzás megszüntetését és a nemzetgyülés ellenőrző funkciónak visszaállítását az állami szféra, a végrehajtó hatalom minden szintjére - ez nyilvánvalóan a rendőrség kontrollálhatóságát, illetve a Gazdasági Főtanács ellenőrizhetőségét akarta jelenteni. Azt külön is aláhúzták, hogy „,a rendészetből ki kell vonni a pártpolitikát” és a nép által ellenőrizhetővé kell tenni. A program legélesebb fogalmazása is a kommunista kézben lévő rendőrségről szól: „A pártpolitikai elfogultságból származó törvénysértéseket, a hivatali hatalommal való bünös visszaélést, a hivatalosan vagy a rendészeten keresztül érvényesített pártpolitikai kényszert éppúgy kell elbírálni, mint a panamát és a korrupció bármely formáját, amely a közszolgálat tekintélyét s ezen keresztül a

\footnotetext{
${ }^{73}$ A Független Kisgazda-, Földmunkás- és Polgári Párt programtervezete. Budapest, 1947. Közli: BIHARI Mihály-GAZSÓ Ferenc-VIDA István (szerk.): Magyarországi pártprogramok 1944-1988. 104-118. p.
} 
demokrácia hitelét sérti."74 A szöveg leszögezte, a pártok nem „urai” az államnak, hanem „örei” a népuralomnak.

Az összeesküvési ügyet jellemző brutális kommunista kommunikációs hadjáratot követően a kisgazdák e panelek megfogalmazásával jelképesen ismét képesek voltak erőt mutatni a nyilvános közéleti térben.

1947. május 4-én az FKgP fővárosi szervezete nagygyülést hívott össze, a rendezvény kommunikációs üzenete a következő volt: csak a parasztság tömegbázisán lehet Magyarországon demokráciát építeni. ${ }^{75}$ Kővágó József, Budapest kisgazda polgármestere arról beszélt, hogy a Kisgazdapárt két éve szolgálja a magyar demokráciát; a demokrácia pedig nem más, mint az „autonómiák politikája.” Nagy Ferenc miniszterelnök a Kis Újság május 8-i számában idézett nyilatkozatában kijelenttette: széles néptömegek állnak a kisgazdák mögött és az FKGP a „letéteményese” a magyar demokráciának. A kisgazda miniszterelnök szerint kialakult „,a magyar polgári demokráciának olyan acélváza, amely még a legnagyobb világégésben sem rendült meg." ${ }^{, 76}$ A programtervezet szövegéből és az előbbi panelekből is látszik, hogy 1947 májusának első felében a kisgazdák határozottan fogalmazva álltak ki a jogállami jellegü demokrácia ügye mellett. A nyelvhasználat módjából arra következtethetünk, hogy egy kitartó polgári demokrácia-védő mentalitásra trenírozták magukat.

1947 májusának első heteiben is jellemzi a kommunisták megszólalásait a szokásos nyelvi agresszivitás, de e néhány hétben a demokrácia-fogalom körüli csatározás tekintetében velük szemben a kisgazdák dinamikusabb kommunikációt voltak képesek generálni. Figyelemreméltónak tekinthető ugyanakkor - még május 1-jén - Révai József azon okfejtése, miszerint ,a demokrácia konszolidációjához”77 a 45-ös választáson kialakult erőviszonyok „alkalmatlanok”, ezért indirekten megelőlegezi azt a gondolatot, hogy szükséges lehet a közeljövőben egy új választás kiírása. Rákosi Mátyás május 9-én angyalföldi beszédében a demokrácia és a reakció szembenállását ezúttal nem a magyar belpolitika, hanem a világpolitika viszonyrendszerében elemezte. „Egyik oldalon ott áll a Szovjetunió, amely mindenütt támogatja a demokratikus népi erőket, az országok önállóságát és függetlenségét mindenféle imperialista törekvéssel szemben. A másik oldalon áll az amerikai és angol imperialista körök törekvése",78 - mondta Rákosi. Ez a szöveg arra utal, hogy a kommunista

\footnotetext{
${ }^{74}$ Uo. 109. p.

${ }^{75}$ Kis Újság, 1947. május 6. 1. p.

${ }^{76}$ Kis Újiság, 1947. május 8. 3. p.

${ }^{77}$ RÉVAI József: Célok és kilátások. Szabad Nép, 1947. május 1. 1.p.

${ }^{78}$ Szabad Nép, 1947. május 10. 2. p.
} 
pártvezetés ezekben a hetekben a nemzetközi politika történéseire figyelt, s ez a jelenség azt is megmagyarázza, hogy május első heteiben miért nem volt a hazai kommunikációban dominánsan jelen az MKP demokráciaértelmezése.

A kommunisták részéről a hangvételben, a kommunikáció stílusában, a demokráciafogalom használatának módjában május 24. körül történik újabb változás. Május 24-én Rákosi Kaposvárott mondott nagyszabású beszédet. Ebben a megszólalásban a kommunista pártvezető a demokrácia és a régi úri rend közötti küzdelemként írta le a magyar belpolitikát. Rákosi arról is beszélt, hogy „a demokrácia ellenségei”, a régi rend hívei újra jelen vannak a Kisgazdapártban és ,,ismét sötét erök müködnek»79 az FKgP körül.

Ismerjük a politikatörténeti tényt: Nagy Ferenc kormányfő́t május 31-én lemondásra kényszerítették. A Szabad Nép május 31-én rendkívüli kiadással jelent meg a miniszterelnöki lemondás apropójából fakadóan. Aláírás nélküli vezércikkben értékelte a kommunista napilap a történteket; megállapították, Nagy Ferenc „titokban a demokrácia megbuktatást készítette elő, miközben a nyílt színen a demokrácia szükségességét hirdette." ${ }^{80}$ A Szabad Nép a helyzet elemzése kapcsán az „erős” és a „szilárd” demokrácia kifejezést használta, a vezércikk szerint a magyar demokrácia Nagy Ferenc lemondása, a „gennyes seb kioperálása” után erősödni fog. Rákosi ezekben a napokban a következő jelzőket ismételgette a magyarországi demokrácia vonatkozásában: „egészséges” és „erőskezű." 81 Bizarr jelenség, hogy a Nagy Ferenc lemondatása utáni helyzetben Tildy Zoltán is ${ }^{82}$ „megszilárdult demokráciáról” beszélt államfői rádióbeszédében. ${ }^{83}$

A kormányfői lemondás másnapján, június 1-jén a kisgazda Kis Újságban külön értékelés nélküli tárgyszerü információk jelentek meg Nagy Ferenc távozásáról. Június 3-án az aláírás nélküli vezércikkben már a kommunistákéhoz hasonlatos valóságértelmezés lát napvilágot a kisgazda napilapban: eszerint Kovács Béla és Nagy Ferenc beengedték az FKgP sáncai mögé a demokrácia ellenségeit. ${ }^{84}$

A demokrácia fogalom használatát tekintve is éles fordulat áll be a Nagy Ferenc utáni FKgP-nél. 1947 júniusára a kommunista és a társutas kisgazda demokráciaértelmezés már csak nüanszokat tekintve tér el egymástól. „A magyar demokrácia nyílt és egyenes úton jár” mondta első nyilvános szereplésén az új kisgazda miniszterelnök, Dinnyés Lajos. A Kis Újság

\footnotetext{
${ }^{79}$ Szabad Nép, 1947. május 28. 1. p.

${ }^{80}$ Nagy Ferenc bukása. Szabad Nép, 1947. május 31. 1. p. /rendkívüli kiadás/

${ }^{81}$ Szabad Nép, 1947. június 3. 1. p.

82 1947-ben a közélet számos szereplője, például Bibó István is hitelt adott a köztársaság elleni összeesküvés koholt vádjainak.

${ }^{83}$ Kis Újság, 1947. június 10. 1. p.

${ }^{84}$ A Válság. Kis Újság, 1947. június 3. 1. p.
} 
tudósított arról, hogy a friss kormányfő szerint „,a magyar demokráciának most már van annyi ereje, hogy kitaszítsa soraiból mindazokat, akik a magyar demokrácia ellenségei." ${ }^{\circledR 5}$ Az új pártelnök, Dobi István első megszólalásában - a kommunisták felé bizonyítandó - azt hangoztatta, hogy ők is demokraták: „Higgyék el, mi is demokraták vagyunk” ${ }^{\text {- mondta }}$ Dobi. Ez a demokrata szerepfelfogás természetesen a társutas kisgazdák nézőpontjából már a kommunisták értelmezése szerinti demokrata fogalmat jelenti. Néhány nappal később az új kisgazda vezető még mindig arról igyekezett a közvéleményt meggyőzni, hogy ők számítottak korábban is a „demokrácia igazi harcosainak”87 az FKgP-ben, csak háttérbe voltak szorítva azok miatt, akik most „szökevényekként” és „hazaárulókként” Nyugatról a „demokráciánkra szórják rágalmaikat.” Dobi nyilatkozatában leszögezte: „Fel kell számolni teljesen a vétkes múltat, új utakra kell térni, az igazi útra, amely meg fogja őrizni a meg nem hamisított eszméket a múltból és félreismerhetetlen, egyértelmü törekvésekkel tölti meg a demokrácia kereteit." ${ }^{88}$ A társutas kisgazda Dobi és Dinnyés számára a „demokrácia kereteit” ekkorra már egyértelműen a kommunista jellegü demokráciaértelmezés fogalmai, paneljei töltötték meg politikai tartalommal.

„A demokrácia két embertípust különböztet meg. Az egyik, aki dolgozik, a másik pedig spekulál, rémhíreket terjeszt, suttog a demokrácia ellen. Az előbbi tiszteletet érdemel, bármely pártnak is legyen a tagja, a másik azonban, bármelyik demokratikus pártnak a jelvényét is hordozza a gomblyukában, hitvány ember marad, aki csak tehertétel a nemzet életében" - mondta a kormányprogram vitájában Dinnyés Lajos miniszterelnök 1947 júniusában. A dinnyési miniszterelnöki retorika, az általa használt kommunikációs panelek már nem bírnak érdemi megkülönböztető jelleggel a kommunista nyelvi struktúrákat tekintve. Az előbb idézett szavakat akár Rákosi Mátyás is használhatta volna.

1947 júniusára a kommunisták és a társutas kisgazdák között demokráciaértelmezésben megszünik a lényegi különbség. Pusztán árnyalatnyi különbözőségek maradnak meg, erre példa Z. Nagy Ferenc kisgazda nemzetgyülési képviselő megszólalása 1947 júniusából. Z. Nagy szerint a kisgazdák nem voltak és nem lesznek marxisták, de nem is marxistaellenesek, s ebből fakad a demokrata kifejezést érintő fogalomhasználata is: „A magántulajdon alapján álló demokraták vagyunk.”

Az árnyalatoktól függetlenül kijelenthető: 1947 nyarán a Kisgazdapárt megszűnt önálló demokráciaértelmező aktorként müködni a magyar politikai kommunikációs mezőben.

\footnotetext{
${ }^{85}$ Uo.

${ }^{86}$ Kis Újság, 1947. június 4. 1. p.

${ }^{87}$ Kis Újság, 1947. június 7. 1. p.

${ }^{88}$ Uo.
} 
1947 júniusa radikális változást hoz a kisgazda tematikájú demokrácia-diskurzus tekintetében; e folyamat jelképes végállomása, amikor 1948 márciusában az FKgP balatonkenesei értekezletén a Szovjetunió államhatalmi struktúráját, mint a „demokrácia, új, biztosított formáit kereső” rendszerként írják el, amelyhez a kapcsolódás „biztos alapja lesz Magyarország felemelkedésének." 89

\section{2. A parlamenti vita mint a demokrácia-diskurzus sajátos terepe}

A koalíciós években a parlamenti viták kiemelt terepét jelentették a demokrácia fogalmát, értelmezését érintő diskurzusnak. A nemzetgyülésben a köztársasági államforma bevezetéséről vagy a Károlyi Mihály érdemeinek törvénybeiktatásáról szóló jogszabályjavaslat vitájakor is elökerültek demokrácia-értelmező kommunikációs panelek. Élesen kitetszett a demokrácia fogalom-használatbéli különbözőség a kormányprogramok vitáiban vagy a képviselöi interpellációk elhangzásakor, ugyanakkor a demokratikus államrend védelméről, illetve az emberi jogok védelméről szóló törvényjavaslat vitái tekinthetőek leginkább diszkurzív csomópontnak, ugyanis az eltérő nyelvi struktúrák e diskurzusokban azonosíthatóak legmarkánsabban.

A demokratikus államrend védelméről szóló törvényjavaslatot ${ }^{90}$ tárgyaló 1946-os parlamenti vita egy sajátságos demokrácia-diskurzus volt. Sajátságos, hiszen egy büntetőjogi jellegű jogszabály megalkotásáról vitáztak a közélet szereplői; a nemzetgyülésben elhangzottaknak törvényalkotói vetülete, az érveknek jogfilozófiai, befolyásolási tétje volt, ${ }^{91} \mathrm{~s}$ ezáltal nem pusztán elméleti disputáról beszélhetünk - ugyanakkor a törvényjavaslat vitája során nagyon plasztikusan bontakozott ki a különböző demokrácia-képek közötti különbség,

\footnotetext{
${ }^{89}$ Kis Újság, 1948. március 9. Közli: Magyarországi pártprogramok 1944-1988. 187-189.p.

90 A demokratikus államrend védelméről szóló törvény része lett a koalíciós évek alkotmányos rendjének. „1945-1946 folyamán számos alaptörvényi jellegü jogszabály született, amelyek lényegében új alapokra helyezték a magyar államiságot. Úgy is fogalmazhatunk, hogy »új történeti alkotmány « jött létre, amelynek legfontosabb jogszabályai a következö törvények voltak: az 1945: III. tc. a Nemzeti Fötanács létrehozásáról, az 1945: VII. tc. a népbíráskodásról, az 1945: VIII. tc. a választójogról, az 1945: XI. tc. az államhatalom gyakorlásának ideiglenes rendezéséről, az 1946: I. tc. Magyarország államformájáról, az 1946: VII. tc. a demokratikus államrend és a köztársaság büntetőjogi védelméről és az 1946: X. tc. az emberi alapjogok hatályosabb védelméröl" - írja Bencsik Péter. (BENCSIK Péter: Az európai népi demokratikus és szocialista országok alkotmányainak összehasonlító vizsgálata. Múltunk, LVII. évf. (2012) 3. 153-205. p. /162. p./)

${ }^{91} \mathrm{Az}$ 1946. évi VII. törvény, a demokratikus államrend védelméröl szóló törvény alapján 1946 és 1950 között 12276 emberrel szemben indítottak eljárást, végül 5861 személyt el is marasztaltak. (SZAKÁCS Sándor-ZINNER Tibor: A háború „megváltozott természete”. Adatok és adalékok, tények és összefüggések. 1944-1948. Genius Gold Rt. - Batthyány Társaság, Budapest, 1997. 196. p.)
} 
ezért úgy gondoljuk, az 1946. március 12-én lefolytatott nemzetgyülési vita a koalíciós évek demokrácia vitáinak az egyik legspeciálisabb és legizgalmasabb diskurzusának számít.

Arról, hogy szükség lenne a demokratikus struktúrák államjogi védelmére, Varga Béla kisgazda politikus beszélt a Tildy-kabinet kormányprogramjának vitájakor, 1945. december 1jén a nemzetgyülésben. „Törvény fog születni a demokrácia védelméről”92 - tette egyértelművé Varga Béla, aki a demokrácia védelméről szóló törvényt egészen másként képzelte el, mint ami végül megvalósult a kezdeményezésből. ${ }^{93}$ A kisgazda szónok határozott hangon szólt arról, hogy „megvédjük minden támadás ellen”94 a magyar demokráciát. „Aki ellenünk van, a demokrácia ellen van, az érezze és lássa be törekvésének hiábavalóságát"95 mondta Varga Béla.

Ries István igazságügyi miniszter 1946. február 7-én nyújtotta be „A demokratikus állami rendszer és a köztársaság büntetőjogi védelméről” szóló törvényjavaslatot. A drasztikus tervezet a „demokratikus rend” elleni bűntettet elkövetőket halálbüntetéssel fenyegeti. A törvényjavaslatot február 20-án tárgyalta meg a Nemzetgyülés Közjogi- és Alkotmányjogi Bizottsága. A bizottsági ülésen Zsedényi Béla jogászprofesszor, az Ideiglenes Nemzetgyülés egykori elnöke szóvá tette, hogy „a demokratikus állami rendszer” fogalma jogilag értelmezhetetlen, mert „nincsen tételes jogi teste." ${ }^{\text {96 }}$ Zsedényi inkább a „demokratikus köztársaság” védelmét tartaná helyesnek, mivel szerinte a demokrácia a nép uralma, melynek „lényege a népnek az állami élet irányításában való részvétele és a többségi elv érvényesülése." ${ }^{97}$ (Palasik Mária vizsgálta a bizottsági ülésen elhangzottakat. A történész úgy véli, a közjogi bizottság ülésén a kisgazda képviselök által elmondottakban benne rejlik a kommunista hatalomátvételtől való ki nem mondott félelem.) ${ }^{98}$

A Közjogi- és Alkotmányjogi Bizottság vitájában a legfontosabb javaslatot Zsedényi Béla fogalmazta meg, aki úgy gondolta, a büntetőjogi védelmet a parlamentáris demokrácia állami rendszerének kellene megkapnia, és büntetendő az lenne, aki a parlamenti demokrácia

\footnotetext{
${ }^{92}$ Elhangzott a nemzetgyülés 3. ülésén 1945. december 1-jén. Nemzetgyülési Napló 1945-1947. I. kötet. 57. p.

${ }^{93}$ Palasik Mária úgy véli, ,,a kisgazdapárt valószínüleg azért sürgette egy ilyen jellegü törvény meghozatalát, mert biztosítékot látott benne arra, hogy ne kerülhessen sor egy alkotmányellenes kommunista hatalomátvételre." (PALASIK Mária: A jogállam megteremtésének kísérlete és kudarca Magyarországon: 19441949. Napvilág Kiadó, Budapest, 2000. 110. p.)

${ }^{94}$ Nemzetgyülési Napló 1945-1947. I. kötet. 60. p.

${ }^{95}$ Uo.

${ }^{96}$ Zsedényi Béla bizottsági hozzászólását idézi: PALASIK Mária: A jogállam megteremtésének kísérlete és kudarca Magyarországon: 1944-1949. 112. p.

${ }^{97}$ Uo.

${ }^{98}$ Uo. 114.p.
} 
megdöntésére, „parancsuralmi vagy egypártrendszeren alapuló kormányzat”,99 létesítésére törekedne. ${ }^{100}$

A bizottsági ülésen megállapodás nem született, a baloldal kitartott az eredeti törvényjavaslat-szöveg mellett, ezért február 21-én pártközi értekezletet tartottak a témáról. Az ügy komolyságát mutatja, hogy az MKP képviseletében Rákosi Mátyás, Rajk László és a bizottsági vita napirendi előadója, Orbán László voltak jelen. Az értekezletről jegyzőkönyv nem készült, korabeli sajtértesülések szerint a több órán át tartó pártközi megbeszélésen a kisgazdák enyhíteni kívánták a javaslatot, míg a munkáspártok álláspontja az volt, hogy ,a köztársasági államformát nem lehet eléggé szigorúan védelmezni." ${ }^{101}$ A felek abban megállapodtak, hogy ,a demokratikus állami rendszer” védelme helyett ,a demokratikus államrend" védelméről szól majd a törvényjavaslat.

Február 27-én Orbán László az MKP parlamenti frakciója előtt számolt be a törvényjavaslattal kapcsolatos történésekről. Orbán arról beszélt, hogy az FKgP megpróbálja ,jobbra tolni” a tervezetet. ${ }^{102}$ „Az egyik módosító javaslat be akarta venni, hogy a demokrácia megdöntésére avagy a parancsuralmi rendszerrel való felcserélésére irányuló cselekmény büntetendő. Igen sokan vannak a kisgazdapárti képviselők közül, akik félnek a proletárdiktatúrától. Természetesen a Szociáldemokrata Párt és a Parasztpárt is élesen visszautasította ezt a javaslatot, de nemcsak a javaslatot, hanem a mögötte meghúzódó szándékot is" $" 103$ - hangoztatta Orbán. A kommunista képviselő, aki arról is beszélt, hogy az FKgP bele akarná venni a törvénybe az emberi szabadságjogok védelméről szóló rendelkezéseket, de a kommunisták ez ellen tiltakoznak, mert a kisgazdák „ennek segítségével akarják terror alá venni a demokratikus köztisztviselőket, és menlevelet biztosítani a fasisztáknak és a reakciósoknak az internálótáborral szemben."104 Orbán e legutóbbi megjegyzése a demokrácia-értelmezések tekintetében is különös jelentőséggel bír. Közvetve utal arra, hogy a kisgazdák demokrácia-képébe szervesen beletartozik az emberi szabadságjogok védelme, a kisgazda demokrácia-koncepció lényegi része a jogosultságokra épülő államberendezkedés. A másik fontos tanulság, hogy a kommunista nézőpontból az

\footnotetext{
${ }^{99}$ Uo.

${ }^{100}$ Sulyok Dezső életrajzírója, Szerencsés Károly arról ír, hogy a demokratikus államrend védelméről szóló törvényjavaslatot Sulyok „kodifikált terrornak minősítette, mely az állam büntetőjogi rendszerébe beépítve törvényes alátámasztást adott a kommunista erőszaknak.” (SzERENCSÉs Károly: A nemzeti demokráciáért. Sulyok Dezső 1897-1997. 131. p.)

101 Élénk vita a pártközi értekezleten a köztársaság védelméről. Világosság. 1946. február 23. Közli: HoRVÁTH Julianna et al. (szerk.): Pártközi értekezletek. Politikai érdekegyeztetés, politikai konfrontáció. 1944-1948. Napvilág Kiadó, Budapest, 2003. 191.p.

${ }^{102}$ Uo. 193. p.

${ }^{103}$ Uo.

${ }^{104}$ Uo. 194. p.
} 
egyéni szabadságjogok érvényesülése megnyitja az utat, hogy a „demokratikus” tisztviselőkkel, vagyis a kommunista kötődésű középvezetőkkel szemben „terror” kezdődjön. Szintén figyelemreméltó, hogy a szabadságjogok büntetőjogi törvényi védelme az MKP-s dimenzióból „menlevelet” jelent a „fasiszták” és „reakciósok” számára. E rövid szövegpanelböl is kiderül, hogy a koalíciós évekbeli kommunista stratégia tekintetében a büntetőjogilag deklarált védelem alatt álló szabadságjogok fölösleges korlátot jelentenek a kialakítandó „népi demokrácia”, a jövőben formálódó proletárdiktatúra szempontjából.

A Független Kisgazdapárt 1946. március 1-jei frakcióülése Nagy Ferenc miniszterelnökre ruházta a jogszabállyal kapcsolatos döntést. ${ }^{105}$ A március 5-i pártközi értekezleten a koalíciós felek megegyezésre jutottak, pontosabban Nagy Ferenc lényegében feltétel nélkül engedett a kommunista törekvéseknek a jogszabály tartalmával kapcsolatban. ${ }^{106}$

A törvényjavaslat parlamenti vitájára március 12-én került sor. A vitában elhangzottak csak megerősítették a korábbi formális döntést, de az érvkészletek rekonstruálásával vázolható a koalíciós évekbeli kisgazda és a kommunista demokrácia-megközelítés lényege.

A plenáris ülésen a kommunista Orbán László volt a törvényjavaslat előadója. Orbán arról beszélt, hogy a demokratikus államrend és köztársaság védelméről szóló törvényjavaslat „nem valami speciális, újszerü alkotása a magyar demokráciának, "107 mert korábban a dualizmus időszakában és a Horthy-rendszerben is büntetőjogi rendelkezésekkel védték az állami struktúrát. „Minden állami rend védi a maga létét ellenfeleivel szemben és az államban az uralmat gyakorló társadalmi erők, társadalmi osztályok védik a maguk uralmát az ellentétes érdekű társadalmi osztályok támadásával szemben"108 - érvelt a kommunista képviselö, azzal a megközelítéssel nem törődve, miszerint sem a dualizmus, sem a Horthykorszak joggyakorlata nem tekinthető demokratikus jogállami jellegü struktúrának.

Orbán demokráciáról és demokratákról beszél, de a mintaszerüen megalkotott panelek mögött érvelésének lényege, hogy a kommunista stratégiával szemben álló erők ellen a lappangó kommunista előrenyomulásnak jogi bázisra van szüksége: „Felvetődik a kérdés, szükség van-e erre a védelemre. Egyesek szeretik a dolgot úgy beállítani, mintha a magyar demokráciát már semmiféle veszély sem fenyegetné, mintha a fasizmust és a reakciót Magyarországon már végérvényesen sikerült volna eltörölni a föld színéről. Nézetem eszerint ez az álláspont csak arra jó, hogy lefegyverezze és elaltassa a magyar demokrácia híveit

\footnotetext{
${ }^{105}$ Uo. 195. p.

${ }^{106}$ Uo. 203. p.

107 Elhangzott a nemzetgyülés 24. ülésén 1946. március 12-én. A demokratikus államrend védelméről szóló törvényjavaslat vitája megtalálható: Nemzetgyülési Napló 1945-1947. I. kötet. 701-744. p. (703. p.) ${ }^{108}$ Uo.
} 
akkor, amikor pedig éppen éberségre, ébrenlétre volna szüksége ellenségeivel szemben. Lemondani egy ilyen törvényről és egy ilyen védelemről annyit jelentene, mint letenni egy erős fegyvert az ellenség előtt. Az lenne a csoda, ha ez a friss, fiatal magyar demokrácia, amely tradícióval alig-alig rendelkezik, nem szorulna büntetőjogi védelemre. Ilyen csodák azonban — jól tudjuk — nincsenek, nem léteznek. És különösen az elmúlt év története minden jószándékú, becsületes demokratát meggyőzhetett arról, hogy a magyar demokráciának igenis szüksége van ilyen védelemre."109 Orbán expozéjában jószándékú és becsületes demokratákról és friss magyar demokráciáról beszél, de a szöveg maga a koalíciós évek magyar demokráciájának egyik végzetes történeti dokumentuma, a kommunista diktatúra jogi és politikai előkészítésének jelképes országgyülési momentuma, a kettős beszéd nyelvi formája, a demokrácia fogalom kommunisták által történt elfoglalásának textuális rekvizituma.

Visszatérő elem a koalíciós évekbeli kommunista érvelésben, hogy a weimari demokrácia bizonyította, a demokrácia ellenségeivel szemben erővel kell fellépni. ${ }^{110} \mathrm{Ez}$ a megközelítés Orbán beszédében is megtalálható: „Kipróbálták ezt a weimari demokráciában és jól tudjuk mindnyájan, hogy milyen eredménnyel. Ez a törvényjavaslat erélyes, kemény rendszabályokat tartalmaz a demokrácia és a köztársaság ellenségeivel szemben."111

A burkolt fenyegetőzés mint kommunikációs stílus attitüdje is tetten érhető Orbán László mondataiban: „A börtön és a bitó lehet jó és lehet rossz; az a kérdés, ki alkalmazza kivel szemben és milyen cél érdekében. A magyar demokráciának egyelőre nem az a baja és nem abban áll a veszély, hogy túlságosan szigorú és túlságosan kemény."112 A törvény elfogadása utáni évek történéseinek fényében történelmi perverziónak nevezhető a parlamenti szónoklat alábbi része: „Meg kell állapítani, hogy a jelen törvényjavaslat semmivel sem csorbítja a demokratikus szabadságjogokat. Éppen ellenkezőleg: védi és biztosítja őket a szabadság ellenségeivel szemben."113

Az előbb idézett metanyelvi állásponttal ellentétben ez a megközelítés a nyílt kommunista demokrácia értelmezés markáns eleme: „aki a demokrácia ellensége, azt nem illetik meg az alkotmányos szabadságjogok" ${ }^{\text {114 }}$ - hangoztatta Orbán.

\footnotetext{
${ }^{109}$ Nemzetgyülési Napló 1945-1947. I. kötet. 707. p.

${ }^{110}$ A weimari alkotmány 48. cikkelyének (2) bekezdése a jogi normák szintjén biztosította az alkotmányos közrend védelmét, de ez az alkotmányjogi és egyben közbiztonsági garancia nem volt elegendő a demokrácia struktúráinak hosszú távú megvédéséhez. (SzABÓ István: Német alkotmányfejlődés 1806-1945. Szent István Társulat, Budapest, 2002. 195-219. p.)

${ }_{111}^{11}$ Nemzetgyülési Napló 1945-1947. I. kötet. 706. p.

${ }^{112}$ Uo.

113 Uo.

${ }^{114}$ Uo. 708. p.
} 
Érveléstechnikai tekintetben különösen figyelemreméltó, ahogyan a szónok a szabadságjogok iránti igényt összemossa a fasiszta veszéllyel: „Olyanok is akadnak, akik a jogról és szabadságról beszélnek, de közben a fasizmus és a reakció jogát és szabadságát értik alatta és szeretnék szolgálni. Ma már a változott viszonyok között a demokrácia ellenségei is csak álarcban és jelmezben merészelnek jelentkezni és sokszor éppen az emberi jogok és szabadság jelszavait hangoztatják képmutató módon, hogy valódi célkitüzéseiket leplezni igyekezzenek.",115

Orbán László beszédében igyekezett a törvényjavaslatot a demokratikus történelmi hagyományok rendszerébe illeszteni. „Ez a törvény a magyar demokrácia, a magyar szabadságharcosok legjobb hagyományaira támaszkodik és onnét meríti erejét, a Dózsák, a Petőfiek, a Kossuthok, a Táncsicsok hagyományaira támaszkodik, arra a kérlelhetetlenségre és hajthatatlan szellemre, amely a magyar demokrácia hőseit és legjobbjait jellemezte a nép ellenségeivel szemben. Petőfi sem alkudott 48-ban. A »belső bitangokat« tartotta legnagyobb

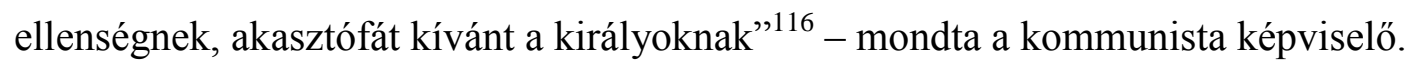

A demokratikus államrend védelméről szóló törvényjavaslat parlamenti vitájában a kisgazdapárti szónok Bognár József volt. Bognár beszédében Orbánhoz képest jóval gyengébb retorikai erővel igyekezett a pártja álláspontját és közvetve annak demokrácia értelmezését illusztrálni. A kisgazda képviselő beszélt a törvényesség, a demokratikus intézmények megerősítésének fontosságáról, illetve arról, hogy mennyire kiemelt feladat az „emberi jogokhoz való szilárd ragaszkodás,"117 de összességében a megszólalás nem tekinthető demokrácia-hitvalló beszédnek. Bognár meg sem próbált érveket gyüjteni arról, hogy a jövendöbeli törvény milyen veszélyeket hordoz magában, ezért csak az általános demokrácia elvek rutinszerü felmondása jellemzi a parlamenti felszólalást. „Tartsuk meg a demokrácia törvényeit, hajtassuk végre a demokrácia rendelkezéseit az élet egész területén. Annak érdekében, hogy ez a harc, amelyet a demokráciáért folytatunk, ne csak büntetőjogi téren vívott harc legyen, szükség van a stabil rendre"118 - hangoztatta a honatya, aki a koalíciós évek második felében már a kommunistákkal kompromisszumot kereső kisgazda közéleti személyiségnek számított. ${ }^{119}$

A következő felszólaló a kommunista Horváth Márton volt, aki nagy lendülettel adta elő a kommunista álláspontot: „,Jól tudjuk, hogy maga a törvény nem elég a védelemre. Lehet

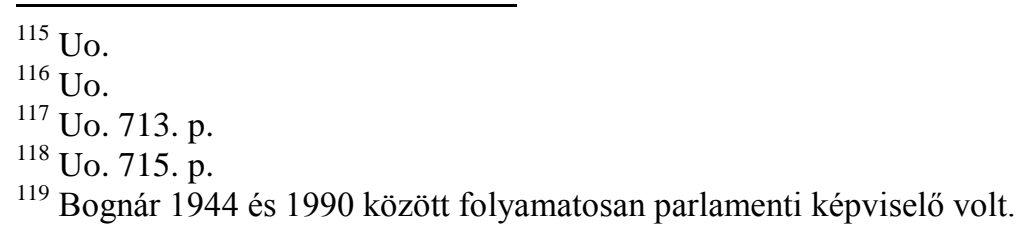


olyan elképzelés, [...] amely túlságosan megnyugszik, túlságosan úgy képzeli, hogy ha meghozzuk a törvényt, akkor rábízhatjuk a jogászokra, rábízhatjuk magára a törvény erejére, hogy megvédje, s hogy így fejezzem ki magam: helyettünk megvédje a magyar demokrácia érdekeit. Nem! Megtanultuk az elmúlt évtizedek alatt és ezt a leckét meg kell most is jegyeznünk, hogy ezek a törvények annyit érnek, amennyi eröt felvonultatunk a törvények mögött, különben üres paragrafussá, papírronggyá válnak. A demokrácia megvédése csak azt jelentheti, hogy megerősítsük ezt a demokráciát, hogy továbbfejlesztjük a demokráciát azokkal az ellenségekkel szemben, amelyek már kimutatták a foguk fehérét és amelyekre tudjuk, — a legfőbb ideje — hogy a törvény erejével és szigorával sokkal határozottabban csapjunk le" ${ }^{" 120}$ - fogalmazta meg parlamenti szónoklatában a kommunista ellenségkép iránti igény karakterológiáját Horváth. Beszédének következő részében egyrészt hitet tett amellett, hogy a „demokrácia erőinek nem szabad szétforgácsolódniok”"121 - s ezzel a más véleményt korlátozó, kizáró összefogás-érvelés manipulációs technikáját alkalmazza -, másrészt viszont gyorsan hozzáteszi, hogy az összefogásban, vagyis a létező koalícióban „nem lehet helye” azoknak az „elemeknek, amelyek demokráciaellenes erőket, tényezőket, érdekeket képviselnek." ${ }^{\prime 22}$ Horváth érvelésében egyszerre érhető tetten a kirekesztés és a korlátozás nyelvi panelje.

Bechtler Péter, a szociáldemokraták vezérszónoka őszintén beszélt arról, hogy 1945 óta egyetlen törvényjavaslat sem váltott ki ,annyi ellenhatást," ${ }^{2123}$ mint a napirenden lévő javaslat. „A törvényjavaslat bizottsági tárgyalásánál láthattuk, hogy a törvényhozók közül nem mindenki tartja szükségesnek a demokratikus rendszer és a köztársasági államforma hathatós védelmét." ${ }^{124}$ Bechtler szerint a törvényjavaslat ellenzői azzal érveltek, hogy ,a nyugati demokrácia rendszerét nem védik ilyen szigorú törvények." ${ }^{125}$ A szociáldemokrata képviselő szerint ezek az erők „nem akarják tudomásul venni azt, hogy az elmúlt évtizedekben sokat tanultunk és nem akarjuk, hogy a magyar demokrácia [...] a weimari Németország sorsába jusson"126 - hozta elő a munkáspártok ekkoriban, a második világháború lezárását követő évben teljesen jogos félelmekre, valós aggodalmakra alapozott, de 1946-ra már szokásos weimari hasonlatát Bechtler Péter. Egyértelműen látható, hogy a weimari példa sulykolása a baloldal részéről 1946-ban egyben a választások demokratikus

\footnotetext{
${ }^{120}$ Nemzetgyülési Napló 1945-1947. I. kötet. 718-719. p.

${ }^{121}$ Uo. 722. p.

${ }^{122}$ Uo.

${ }^{123}$ Uo. 725. p.

${ }^{124}$ Uo.

125 Uo.

${ }^{126}$ Uo.
} 
ethoszának és természetesen a '45-ös kisgazda parlamenti győzelem relativizálásának is eszköze.

Nánási László a Parasztpárt nevében támogatásáról biztosította a törvényjavaslatot. Beszédében nem azonosítható a demokrácia-tematika szempontjából érdemi elem. A parasztpárti szónok kijelentette: „Minden becsületes demokratikus ember egyetért velem, hogy a demokráciát, a köztársaságunkat meg kell védenünk. Abban lehet csupán vita közöttünk, hogy milyen módon, milyen törvényekkel - enyhe vagy esetleg túlzottan is erös törvényekkel. Ebben a kérdésben [...] a Nemzeti Parasztpártnak az az álláspontja, hogy inkább túl erős törvényekkel védjük." ${ }^{127}$ A Parasztpárt meg sem próbált saját érvkészletet behozni a demokratikus államrend védelméről szóló törvényjavaslatról szóló diskurzusba, kommunikációs tekintetben e kérdésben is megelégedett a kommunisták segédcsapatának szerepével.

A Polgári Demokrata Párt nevében Szent-Iványi Sándor arról szólt, hogy „a törvényjavaslatot nem tartom sem túl szigorúnak, sem túl enyhének, különösen azért nem, mert minden ellenkező kísérlet ellenére úgy látom, a demokrácia is és a köztársaság is eléggé erős nálunk, eléggé meggyökeresedett már ahhoz, hogy komolyan nem veszélyeztetheti semmiféle ellenséges, akár nyílt, akár földalatti ármánykodás."128 A koalíción kívüli PDP képviselője elfogadta a javaslatot, de annyiban más tematikai keretet vázolt, hogy abbéli meggyőződésének adott hangot, miszerint valójában nincs a demokráciát veszélyeztető komoly tényező. Ezzel szembement az MKP ellenségképre alapozott stratégiájával, de nem vállalta fel ugyanakkor, hogy egyetértsen a kisgazdák által - burkoltan - megfogalmazott gondolattal, miszerint a demokráciára a kommunisták jelentik az igazi veszélyt. ${ }^{129}$

A törvényjavaslat parlamenti vitájában egyedül Bálint Sándor néprajztudós, a Demokrata Néppárt képviselője ${ }^{130}$ nézett szembe a jogszabály által generált valós fenyegetéssel, egyedül ${ }^{131}$ Bálint Sándor fogalmazott meg olyan érveket, amelyek a jogállami

\footnotetext{
${ }^{127}$ Uo. 728. p.

${ }^{128}$ Uo. 729. p.

${ }^{129}$ Szent-Iványi Sándor a nemzetgyülésen elmondott ezen beszéde után néhány hónappal emigrált.

${ }^{130}$ A Demokrata Néppártnak az FKgP-vel kötött választási megállapodása alapján az 1945-ös választásokon Bálint Sándor egyike volt annak két DNP-s képviselö-jelöltnek, aki mandátumot szerzett a kisgazdák listáján.

${ }^{131}$ Slachta Margit pártonkívüli képviselő a kommunista értelmezéssel szembemenő, antikommunista felszólalást tett a demokratikus államrend védelméről szóló jogszabály plenáris vitájakor, de érvei mögött inkább valláserkölcsi megfontolások és nem a jogállami demokrácia védelmének szempontjai húzódtak meg. „Amikor tehát mi őszintén demokráciára törekszünk, szemben állunk avval a nehézséggel, melyet a demokráciáról tudomást nem vevő nyers természet jelent, amelyet valamennyien magunkban hordozzuk és amely például ilyenekben fejeződik ki, hogy holott a demokrácia mindenkinek általában szabadságot kíván és ígér, — hiszen a demokráciának a lényege ez — mégis természet szerint arra hajlunk, hogy szeretjük a saját szabadságunkat, de ugyanolyan könnyedséggel vagyunk hajlandók átgázolni a mások szabadságán. [...] Az emberi természet
} 
demokrácia védelméről szóltak. A DNP-s képviselő egyetértett azzal, hogy „az új magyar demokráciát büntetőjogi intézkedésekkel kell megóvni azokkal szemben, akik azt erőszakosan vagy fondorlattal megingatni próbálják."132 Ez a megközelítés már önmagában éles ellentétben állt a kommunisták által tematizált valóságértelmezéssel. Bálint Sándor szerint a javaslat szövegében a fogalmak elmosódnak: „Ez a pontatlanság bőven ad alkalmat arra, hogy a tételes jog helyét hatóságok és bírák érzelmei, vonzalma, esetleg ellenszenve foglalják el, amikor arról van szó, hogy egyes állampolgárok politikai megnyilatkozásait kell megítélni. A büntetőjogi törvények első kelléke pedig az, hogy szövegezésük szabatos legyen, máskülönben könnyen a terror eszközévé válhatnak; a terror érzése pedig a demokrácia halálos ellensége, mert kiöli az állampolgárokból a szeretetet és bizalmat azzal az államformával szemben"133 - fogalmazott profetikus előrelátással a képviselő.

Bálint Sándor konkrét - a modern jogállami demokrácia államstruktúrájába illeszkedő - javaslatokat is tett. Úgy vélte, az „államrend” védelme helyett az „alkotmányt” kellene büntetőjogi eszközökkel óvni, s az emberi jogok megsértése is külön védendő területet jelentene; a büntetőjogi védelem pedig megvalósulhatna „minden antidemokratikus, parancsuralmi mozgalommal vagy ideológiával szemben."134 Magát a védelem jogi alapzatát a képviselő szerint egy alkotmánybíróságra kellene bízni. ${ }^{135}$ „A törvényjavaslat szándékában, amely a magyar demokrácia szilárd megalapozására irányul, mindnyájan egyetértünk. De egyet kell értenünk abban is, hogy a szabadság levegője, a kritika lehetősége üdvösebb, termékenyebb lehet a demokráciának, mint a mindenütt kémet, feljelentőt, rendőrt látó, büntetéstől szorongó állampolgár félelemérzése" ${ }^{\text {136 }}$ - zárta gondolatait Bálint Sándor. ${ }^{137}$

Ries István igazságügyi miniszter aznap, március 12-én nyújtotta be a parlamentnek az emberi alapjogok hatályosabb védelméről szóló törvényjavaslatot, amikor a nemzetgyülés a demokratikus államrend védelméről szóló törvényjavaslatról vitázott és elfogadta a törvényt az eredeti formában benyújtott szöveggel. Kompromisszumos megoldás volt, hogy a

vallásos kiművelés nélkül antidemokratikus, aki tehát a vallásosság ellen dolgozik, az a demokráciának ellensége” - mondta Slachta. (Nemzetgyülési Napló 1945-1947. I. kötet. 737-738. p.)

${ }^{132}$ Uo. 731. p.

${ }^{133} \mathrm{Uo}$

${ }^{134}$ Uo. 732. p.

${ }^{135}$ Bálint Sándor életrajzírója, Csapody Miklós szerint Bálint Sándor volt az első, aki felvetette a koalíciós évek parlamentjében az alkotmánybíróság mint intézmény szükségességét. (CSAPODY Miklós: Bálint Sándor (19041980). Életrajz. Akadémiai Kiadó, Budapest, 2013. 184.p. )

${ }^{136}$ Nemzetgyülési Napló 1945-1947. I. kötet. 734. p.

${ }^{137}$ Csapody Miklós ekképpen írt Bálint Sándor imént elemezett parlamenti beszédéről: „Így beszélt a magyar nemzetgyülésben 1946 tavaszán egy demokrata polgár, akinek félelmeit a következő évtizedek tragikus története sokszorosan és mindent felülmúlóan igazolta.” (CSAPODY Miklós: „A világban helyt állani...” Bálint Sándor élete és politikai müködése 1904-1980. Korona Kiadó, Budapest, 2004. 143.p. ) 
demokratikus államrend védelméről szóló törvény megalkotása után külön jogszabály szülessen az emberi jogok államrendszerbe illeszkedő óvásáról.

Az emberi jogok védelméről szóló törvényjavaslat plenáris vitájára 1946. május 9-én került sor. ${ }^{138}$ Maga az emberi jogok hatályosabb védelméről szóló törvény érdemben nem lett része a magyar jogrendnek. Ítélet e jogszabály alapján nem született. A formálódó kommunista diktatúrának erre a jogszabályra nem volt szüksége. E törvényjavaslat vitája tágan értelmezve tekinthető a demokrácia-diskurzus részének. A szöveg előadója Hám Tibor kisgazda képviselő volt. Ez a jogszabály az FKgP számára számított fontosnak, hiszen a kisgazda demokrácia-értelmezés központi eleme volt a mindenkire egyaránt vonatkozó szabadságjogok rendszere; ez a támogató, aktív hozzáállás a vita lefolyásából, menetéből is kitünik. Mindezzel szemben - ahogy az MKP szónokának érveiből is egyértelmüen látszik - a kommunista taktika e téren a relativizálás volt, mert a koalíciós években a kommunista demokrácia megközelítésbe és társadalom-átalakító stratégiába nem fért bele a mindenkire érvényes szabadságjogok tiszteletben tartása.

„A törvényjavaslat a szörnyü rémuralom után született meg, amelyet a zsarnoki őrület Európában és hazánkban megteremtett. Hirdetője és megalkotója akar lenni annak a tiszta demokráciának, amelyet nekünk, a magyar demokrácia pártjainak kell megvédenünk és biztosítanunk."139 - mondta szónoklata elején Hám Tibor a tiszta demokrácia fogalmát használva. Hám emlékeztetett arra, hogy az éppen legyőzött fasizmus legnagyobb büne az volt, hogy az embert „az állam szolgájává tette”, s ebből fakadóan „megszünt az emberi személyiség és az ember méltósága." ${ }^{140}$ A kisgazda képviselő úgy vélte, a törvényjavaslat „,́géret” a magyar demokrácia számára, hogy „az ember soha többé terrorlegények és pártszolgálatosok vak eszköze nem lehet." ${ }^{, 141}$

Hám Tibor a jogállami demokrácia mellett kiálló, demokrácia-hitvalló parlamenti beszédében leszögezte: „A magyar politikai élet számára komoly felelősség, hogy ez a törvény ne csak törvény legyen, ne csak törvénytárunk része legyen, hanem a társadalomban és az állami életben élő valóság, hogy soha többé az állami apparátus képviselői, demokratikus intézményeink bármelyik közege meg ne sérthesse a személyes szabadságot, a vélemény- és gondolat szabadságát, a vallás szabad gyakorlatát, a munkához és a tulajdonhoz való jogot. [... ] E törvényjavaslattal a magyar demokrácia éppen azt akarja elérni, hogy minden állampolgár szabad lehessen az államhatalom végrehajtó közegeivel szemben is a

\footnotetext{
${ }^{138}$ A törvényjavaslat vitája: Nemzetgyülési Napló 1945-1947. I. kötet. 1021-1050.p.

${ }^{139}$ Uo. 1027-1028. p.

${ }^{140}$ Uo. 1028. p.

${ }^{141}$ Uo.
} 
törvény keretein belül és jogait háboríthatatlanul és csorbíthatatlanul gyakorolhassa. A magyar demokrácia elvárja az államhatalom közfunkcionáriusaitól, az állami apparátus közegeitől, hogy a demokráciaadta jogait minden állampolgárnak biztosítsa"142 - fogalmazta meg a későbbi történések alapján naivitásnak nevezhető reményeit Hám, akit e beszéde után nyolc hónappal, 1947 januárjában mint az összeesküvési ügy gyanúsítottját a kommunista irányítás alatt álló államvédelem koholt vádakkal letartóztatta és nyolc hónapig kínoztatta. ${ }^{143}$

„Vannak, akik csak fasiszta összeesküvésekről beszélnek. Azt hiszem, a demokrácia fejlődése szempontjából egyetlen helyes magatartás, ha a magyar demokráciának minden problémáját egységben látjuk és egységben akarjuk megoldani. Mert, aki objektíven nézi a politika jelenségeit, meg kell, hogy állapítsa, hogy a magyar demokrácia számára veszélyt jelent a fasiszta összeesküvések jelentkezése és elharapózása, de kárt jelent a rendörség keretében mutatkozó atrocitások jelensége is, mert a magyar népben félelmet ébresztenek és

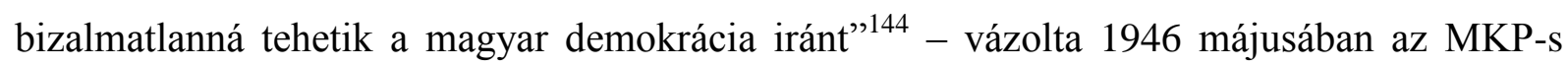
kommunikációs stratégiai törekvésekkel a lehető leghatározottabban szembemenő okfejtését Hám Tibor.

Kiss Károly volt a kommunista vezérszónok az emberi jogok hatályosabb védelméről szóló törvény vitájában. Kiss érvelése, amelyben mégis csak addig jut el, hogy a szabadságjogok nem mindenkire egyaránt érvényesülő jogosultságok, a következő: „Legyünk tisztában azzal, hogy az emberi alapjogok védelmét csak erős alapokon nyugvó belső demokrácia adhatja meg. Minél alaposabban, minél mélyebben vesznek részt az állami életben a munkásság, a parasztság és a demokratikusan gondolkodó értelmiség képviselői, annál szilárdabbak és megtámadhatatlanabbak lesznek ezek a jogok. Aki biztosítani akarja ezeket az emberi jogokat, annak minden erejével segítenie kell, hogy a magyar köztársaság egy minden részében valóban erős, demokratikus állam legyen, annak segítenie kell, hogy gyorsan és könyörtelenül számolhassunk le a belső állami életünket még mindig aláaknázni akaró fasiszta összeesküvőkkel, reakciósokkal, a nép ellenségeivel. Csak ez biztosíthatja e jogokat nemcsak papíron, hanem valóban az életben, csak ez biztosíthatja az életbe való átvitelüket. Védelmet jelent ez a törvény és védelem jár a demokrácia határain belül, de nem jár védelem a fasisztáknak, a demokrácia ellenségeinek. [...] Ez a törvény nem lesz menedék a demokrácia ellenségei részére, nem jelent menlevelet, jogvédelmet az összeesküvők és a múltat visszaállítani törekvők részére. A nép ellenségeire, demokratikus államrendünk

\footnotetext{
${ }^{142}$ Uo. 1029. p.

${ }^{143}$ Hám Tibort a bíróság a koholt vádak alól 1947 szeptemberében felmentette, akkor szabadult. 1948-ban emigrált.

${ }^{144}$ Nemzetgyülési Napló 1945-1947. I. kötet. 1031-1032. p.
} 
felforgatóira a köztársaságunk védelmére hozott törvény teljes szigorával kell sújtani"145 _ húzta alá Kiss Károly. Érvelését érdemes elemenként áttekinteni, elemezni. A legfontosabb megállapításunk az lehet a szöveget vizsgálva, hogy Kiss - és a mögötte álló kommunisták a szabadságjogok érvényesülését nem önmagában létezőnek tekintik, hanem feltételekhez kötik. A jogok érvényesülésének első feltétele az idézett megszólalásban az, hogy „erős belső demokrácia" legyen; ilyen demokrácia pedig csak akkor lehet - ez már a második feltétel -, ha a munkásság, a parasztság és a demokratikusan gondolkodó értelmiség képviselői markánsan részt vesznek az államéletben, s végül egy újabb feltétel, a harmadik, hogy a nép ellenségeivel, a fasiszta összeesküvőkkel és a reakciósokkal megtörténjen a leszámolás. Láthattuk, ez az érvelés azt jelenti, hogy a szabadságjogok csak akkor érvényesülhetnek, ha a lehető legkülönbözőbb feltételek teljesülnek, vagyis a kommunista nézőpontból tekintve nem léteznek mindenkire feltétel nélkül vonatkozó emberi szabadságjogok.

\section{3. Fogalomértelmezö viták a demokráciáról a párközi értekezleteken}

A koalíciós évekbeli demokrácia-vitáknak nem lehettek fórumai a pártközi értekezletek, hiszen a pártközi egyeztetések nem a nyilvánosság előtt zajlottak, az ott elhangzott érvek, szócsaták azonban döntően befolyásolták az időszak politikai történéseit. A demokráciaértelmezés tekintetében ugyanakkor az 1946. október 30-i tanácskozásnak komolyabb jelentősége volt. Nagy Ferenc miniszterelnök a megbeszélés nyitóelőadójaként úgy érezte, először talán a demokrácia alapértékei szempontjából érdemes egyetértésre jutni, s ezt követően a konkrét kormányzati munka ügyeiben is könnyebben szót tudnak érteni a különböző pártok. Történelmi távlatból ez a kiindulópont rendkívül naivnak, irreálisnak tűnik, a kormányfő felvetése azonban arra mindenképpen alkalmasnak bizonyult, hogy nem a nyilvánosság előtt ugyan, de markánsan jelezze az elérő ideológiai viszonyulásokat, nézőpontokat a demokrácia vonatkozásában.

Nagy Ferenc arról beszélt az 1946. október 30-i értekezleten, hogy sem ellenforradalmi (reakciós), sem bolsevizálódási veszély nem áll fenn, a demokrácia rendszere nincs veszélyben. A közéleti szereplöknek ugyanakkor azért kell megegyezniük az alapelvekben, mert minden oldalról bizalmatlanság jellemzi a felek közötti kapcsolatot - a bizalmatlanság pedig ,elviselhetetlenné” teszi a magyar politikát, s mindez ellehetetleníti a

\footnotetext{
${ }^{145}$ Uo. 1033. p.
} 
kormányzati munkát. Nagy Ferenc megállapította, hogy „a demokráciának sokszor merőben eltérő értelmezései”"146 vannak jelen, de ha a közéleti szereplők között a demokrácia eszményének megfelelő együttműködés alakul ki, akkor „tiszta politikai légkör”147 alakulhat ki. Azt is mondhatjuk, Nagy Ferenc felvetése egyfajta demokratikus minimum felvázolására, kimunkálására vonatkozott.

A miniszterelnök javaslatára Rákosi Mátyás közel sem konszenzuskereső hangnemben válaszolt, így már a pártközi értekezlet elején eldőlt, hogy a nyilvánosság kizárásával sem képesek a koalíciós időszak politikai erői demokratikus minimumot kialakítani. Rákosi szerint „a demokrácia eröi” mellett gyorsan „reorganizálódik” a reakció, de a „kisgazdák ezt nem akarják hivatalosan elismerni." ${ }^{148}$ A kommunista pártvezető azt is leszögezte, hogy a kiagazdák „nagy többségben” nem alkalmasak a „demokratikus építésre." 149 Rákosi a tanácskozást a kisgazdák elleni általános politikai támadásra használta, de azt is kijelentette, hogy „a magyar nép jelentékeny része nem demokrata,"150 a kommunisták ugyanakkor „a demokráciából nem fognak engedni." ${ }^{151}$ Szakasits Árpád, az SZDP fötitkára is arról beszélt, hogy a magyar népnek „,nincsenek demokratikus élményei," ${ }^{152}$ ezért is lehet jellemző szerte az országban, hogy „féktelen uszítás” van a „demokrácia ellen.”153 A szociáldemokrata pártvezető amellett érvelt, hogy „tisztább demokráciára” van szükség, ahol a „kinyírják” a nemzet testéből a „reakciós elemeket.” Veres Péter, a Nemzeti Parasztpárt elnöke a demokrácia eszményéről szóló elméleti vitát értelmetlennek tartotta, szerinte nem bolsevizálódási veszély van, hanem az a probléma, hogy a társadalmi változások „megrekedtek."

A pártközi értekezleten a kisgazdák képviseletében - Nagy Ferenc kormányfö, Varga Béla házelnök és Rácz Jenő pénzügyminiszter mellett - jelen voltak Bognár József és Oltványi Imre nemzetgyülési képviselök is. Bognár és Oltványi néhány hónappal később, Nagy Ferenc lemondatása után egyértelmüen az FKgP kommunistákkal kollaboráló balszárnyára sodródott. Ekkor, 1946 októberében azonban még mindketten egyértelműen a

\footnotetext{
${ }^{146}$ Az 1946. október 30-i pártközi értekezlet jegyzőkönyvét közli: HORVÁTH Julianna et al. (szerk.): Pártközi értekezletek. Politikai érdekegyeztetés, politikai konfrontáció. 1944-1948. Napvilág Kiadó, Budapest, 2003. 292-326. p. /294. p./

${ }^{147}$ Uo.

${ }^{148}$ Uo. 295. p.

${ }^{149}$ Uo. 296. p.

150 Uo.

${ }^{151}$ Uo. 299. p.

${ }^{152}$ Uo. 300. p.

${ }^{153}$ Uo.

${ }^{154}$ Uo. 303. p.
} 
jogállami jellegű polgári demokrácia eszménye mellett álltak ki. ${ }^{155} \mathrm{~A}$ pártközi értekezleten elhangzott megszólalásaikból nyilvánvalóan érzékelhető: ebben az időszakban szemben álltak a baloldali/kommunista demokrácia-értelmezéssel. Mindez azért is érdekes jelenség, hiszen fél évvel korábban, a demokratikus államrend védelméről szóló törvényjavaslat parlamenti vitájakor Bognár József nem állt ki egyértelműen a polgári demokrácia ethosza mellett. „Mi a demokráciát olyan politikai rendszernek tartjuk, amely a demokratikus alapelveket a lehető legtöbb ember bevonásával, a lehető legtöbb ember kívánsága, felfogása és érdekei szerint valósítja meg"156 - adta meg a tanácskozáson a jogállami demokrácia-felfogás adekvát meghatározását Bognár József, aki azt is leszögezte, a kisgazdák a „demokrácia dolgában” bárkivel felvehetik a versenyt. „A több jog, a több szabadság, a több életlehetőség és a nagyobb jólét felé akarjuk ennek a népnek a sorsát terelni”" ${ }^{157}$ - mondta Bognár. „A több jog, több szabadság, több életlehetőség” filozófiája jelképesen illusztrálja a kisgazdák koalíciós évekbeli demokrácia-felfogását.

Oltványi Imre azt tette szóvá a tanácskozáson, hogy ha a Baloldali Blokk politikusai egy kisgazda közszereplőt támadnak, akkor az a „demokrácia védelme”, míg amennyiben a Kisgazdapárt kritizál egy baloldali politikust, akkor az a „reakció” megnyilvánulása. Oltványi azt is elismerte, hogy a kisgazda tömegbázisban valóban megvan a bolsevizálódástól való félelem. A kisgazda nemzetgyülési képviselő arról is beszélt, hogy nem érvényesül a demokratikus kisgazda többség. „Egy csomó intézményben úgynevezett többségünk van, ténylegesen azonban nagyon kevés a beleszólásunk az ország dolgaiba”"158 - mondta Oltványi.

E disszertációnak nem vállalt feladata, hogy feltárja, mi történhetett Bognár József és Oltványi Imre életében, abban a tekintetben miszerint az elkötelezett kisgazda demokráciafelfogástól néhány hónap múlva eljutottak a kommunistákkal való kollaborációig, a „demokrácia” kommunista értelmezésű elfogadásáig. Tény, 1946 őszén mindketten a polgári demokrácia ethosza mellett foglaltak állást, míg 1947 nyarától egyértelműen a kibontakozó kommunista diktatúra csendestársaiként vállaltak közéleti szerepet.

Az 1946. október 30-i pártközi értekezlet kisgazda közszereplőinek megszólalásai a magyar jogállami demokráciáért folytatott küzdelem apró mozzanatainak tekinthetőek. Nagy

\footnotetext{
${ }^{155}$ Hogy Bognár az 1946. október 30-i pártközi értekezleten a jogállami demokrácia ethosza mellett állt ki, azért is érdekes jelenség, hiszen - ahogyan azt elemeztük - néhány hónappal korábban a demokratikus államrend védelméről szóló törvényjavaslat parlamenti vitájában, vagyis a nyilvánosság előtt nem vállalta fel a jogállami normák melletti kiállítás ódiumát.

${ }^{156}$ HoRVÁTH Julianna et al. (szerk.): Pártközi értekezletek. Politikai érdekegyeztetés, politikai konfrontáció. 1944-1948. 306. p.

${ }^{157}$ Uo. 309. p.

${ }^{158}$ Uo. 316. p.
} 
Ferencnek a demokratikus minimum megformálása érdekében megtett kezdeményezése nem volt több mint egy jószándékú, illuzórikus politikai felvetés.

A pártközi értekezletek keretei között Nagy Ferenc még egyszer kísérletet tett egyfajta demokratikus minimum kimunkálására. 1946 őszéhez képest még terheltebb időszakban; Kovács Béla elrablása után néhány nappal, március 1947. március 4-én a koalíciós együttműködés fenntartásáról szóló pártközi tanácskozás során a kisgazda kormányfő azt javasolta, hogy térjenek vissza „1945” demokráciájához, amikor még szerinte létezett a demokrácia közös értelmezési kerete. Nagy Ferenc az általa kívánatosnak tartott közmegegyezéses demokráciát „abszolút demokráciának” nevezi. „Mi a választások után kialakult állapotot kívánjuk visszaállítani" ${ }^{159}$ - fejtegette az FKgP-s miniszterelnök, aki azt is leszögezte, hogy számukra a demokrácia megvalósítása a közéleti tevékenységük „álma”. Rákosi Mátyás érdemben nem reagált Nagy Ferenc konszenzuskereső demokráciaértelmezésére, csak felszólította a Kisgazdapártot a további „demokratizálódásra”. Rákosi azt is egyértelművé tette, hogy e fogalmon aktuálisan a kisgazda miniszterek kormányból való visszahívását, illetve a kisgazda nemzetgyülési frakció újabb csonkítását érti.

A demokratikus minimum megfogalmazására vonatkozó megismételt kísérlet elbukott. Ami nem sikerült 1946 őszén, arra 1947 márciusában még kevesebb esély kínálkozott. '47 márciusától 1948. szeptember 10-ig - ekkor volt az utolsó formális pártközi értekezlet a koalíciós években - már nem adatott meg a politikai-kommunikációs tér az újabb demokrácia-értelmező diskurzusok számára a pártközi egyeztetéseken.

A pártközi értekezletek imént elemzett demokrácia párbeszédei azért értelmezhetőek diszkurzív csomópontként, mert nincs a koalíciós évek időszakának olyan fóruma, ahol egy demokrácia-keretet kijelölni igyekvő felvetésnek - amit értelmezésünk szerint a demokratikus minimum megteremtésére tett kezdeményezésnek nevezhetünk - a nyelvi reakcióit térben és időben ennyire koncentráltan, s ilyen egyértelmüen érzékeltetni lehetne.

\section{A diskurzus szereplöi: demokráciaértelmezök, demokrácia-hitvallók}

\subsection{Kisgazda demokráciaértelmezök}

\footnotetext{
${ }^{159}$ Uo. 460. p.
} 
A koalíciós évek közéleti küzdelmeiben a kisgazdák főszabály szerint a szabadságjogokra épülö jogállami demokrácia mellett álltak ki, a polgári demokráciáért harcoltak. Hiába kapott a '45-ös választásokon abszolút többséget az FKgP, már az 1945 utáni néhány esztendőben is - a szovjet katonai jelenlétnek köszönhetően - a domináns szerepet a kommunisták akarata, demokrácia-értelmezése játszotta. Ennek ellenére kiemelt figyelmet érdemes fordítanunk arra, hogy - kisgazda szellemiségü publicisztikák, politikai beszédek és parlamenti szónoklatok segítségével - a kisgazdák koalíciós évekbeli demokrácia-felfogását rekonstruáljuk.

Az 1945 és 1947 közötti FKgP egy gyüjtőpárti jellemzőkkel bíró monstrumszervezet volt, de a demokrácia-felfogás tekintetében csak az úgynevezett balszárny, a Dobi István vagy Ortutay Gyula fémjelezte csoportosulás nézőpontja tért el a pártkonglomerátum alapértékeitöl. Azt is állíthatjuk, az FKgP különböző szárnyai között a közös pont a polgári demokrácia igenlése számított, a jogállami demokrácia akarása összetartó erő volt a polgári konglomerátum számára. Hozzá kell tennünk, az Ortutay-kör, a balszárny nem volt részese ennek a pártkonszenzusnak, a kisgazda „baloldal” nem tekintette a polgári demokráciát olyan alapértéknek, amelyért komolyabb küzdelmet vállaltak volna, számukra a radikális társadalom-átalakító szándék fontosabb volt, mint a jogállami demokrácia ethosza.

$\mathrm{Az}$ FKgP demokrácia-eszményének középpontjában a szabadságjogok álltak. Dessewffy Gyula alig néhány nappal a ’45-ös kisgazda választási siker után nem győzte hangsúlyozni, hogy „,a szabadságon felépülő demokrácia”"160 ideje jött el. „A most kezdődő korszaknak nagyszerü feladata, hogy a nehézségek árán megszerzett új demokráciánkat megszilárdítsuk" ${ }^{\prime 161}$ - írta Dessewffy.

Futó Dezső nemzetgyülési képviselő - a választási győzelem eufóriájában - arról szólt: „a vasárnapi képviselőválasztások meghozták az új magyar demokrácia fáján az első komoly termést." "162 Mindezen túl Futó leszögezte: az új demokrácia az „emberi szabadságjogokra”"163 kell hogy épüljön. „Joggal elvárja a magyar nép széles tömege, hogy a demokrácia biztosítsa a mindenkit megillető emberi jogok maradéktalan és becsületes megtartását"164 - tesz hitet a jogállami jellegű polgári demokrácia mellett Futó.

$\mathrm{Az}$ idézet legfontosabb gondolata, hogy a szabadságjogok „mindenkit” egyaránt megilletnek - ez a megközelítés rámutat a kisgazda és a kommunista demokrácia-értelmezés közötti alapvető különbségre: a kisgazdák szerint a demokratikus alapjogok az emberi létből

\footnotetext{
${ }^{160}$ DESSEWFFY Gyula: Új korszak küszöbén. Kis Újság, 1945. november 10. 1. p.

${ }^{161}$ Uo.

${ }^{162}$ FuTó Dezső: Az emberi szabadságjogok. Kis Újság, 1945. november 9. 1. p.

${ }^{163}$ Uo.

${ }^{164}$ Uo.
} 
fakadnak, amelyeket csak speciális esetben, helyzetben lehet korlátozni, ezzel ellentétben a kommunisták nem fogadják el a mindenki egyaránt érvényes jogok létezését; kommunikációs paneljük szerint a demokrácia ellenségeinek nem járnak jogok. Ez azonban valóban csak érveléstechnika a kommunisták részéről, mert elvként nem fogadják el a mindenkire érvényes jogok rendszerét, mert ezáltal jogi, filozófiai, ideológiai kontroll alá kerülnének a radikális erejü társadalom-átformáló szándékaik.

„A demokrácia alapeleme a szabadság és az ezen alapuló további követelmények: a népakarat legkülönbözőbb formában való megnyilvánulásai - biztosítva vannak: az ideiglenesség állapotából elérkeztünk a véglegesség állapotába"165 - ez már Gulyás Gábor, a kisgazda szellemiségű Kis Újság publicistájának gondolatsora. Az idézet egy újabb illusztráció arra, hogy milyen mértékig meghatározó eleme a koalíciós évekbeli kisgazda demokrácia-koncepciónak az emberi szabadságjogok eszménye. Varga Béla kisgazda honatya, a párt ügyvezető alelnöke 1945. december 1-jén a nemzetgyülésen elmondott beszédében a demokrácia ,princípiumának" "166 nevezte a szabadságot, a szabadságjogokat. Nagy Ferenc kormányának programvitájakor, 1946. február 7-én a nemzetgyülés előtt tett hitet amellett, hogy a „demokratikus szabadságjogok biztosítása" 167 a demokrácia alapvető feladata.

A szabadság, az egyének autonómiája mellett az általános jogegyenlőség, az alkotmányosság politikai kultúrája, a szabad vita intézményes joga és a hatalom ellenőrzésének lehetősége is a kisgazda demokrácia koncepció markáns elemei voltak. „A társadalmi ellenőrzés a demokráciának egyik legfontosabb alappillére. A társadalomnak a sajtószabadságon, gyülekezési szabadságon és az ebből fakadó szervezkedési szabadságon keresztül meg kell lennie annak a jogának, hogy mindig és mindenkor kezdeményezhessen és bírálhasson"168 - írja egyik demokráciaértelmező cikkében Gulyás Gábor kisgazda újságíró.

A koalíciós évek kisgazda demokrácia-értelmezésében komoly szerepet kapott a konszenzus és a kompromisszum mint érték is. Ennek főként Tildy Zoltán adott hangot különböző megnyilatkozásaiban. „A magyarság nagy kérdéseinek a megoldásához a szellemi és fizikai újjáépítés munkájának sikeréhez kell valami belső szilárdság, az a tényekből táplálkozó tudat, hogy demokratikus átalakulásunk nem múló kísérletezés, hanem biztos

\footnotetext{
${ }^{165}$ GULYÁs Gábor: A központi hatalom. Kis Újság, 1945. november 22. 1. p.

166 Elhangzott a nemzetgyülés 3. ülésén 1945. december 1-jén. Nemzetgyülési Napló 1945-1947. Athenaeum, Irodalmi és Nyomdai Részvénytársulat Könyvnyomdája, Budapest, 1946. I. kötet. 57. p.

${ }^{167}$ Elhangzott a nemzetgyülés 15. ülésén 1946 évi február 7-én. Nemzetgyülési Napló 1945-1947. I. kötet. 378. p.

${ }^{\text {p. }}{ }^{168}$ GULYÁs Gábor: A központi hatalom. Kis Újság, 1945. november 22. 1. p.
} 
valóság. Ezért annyira döntő fontosságú a demokrácia tiszta erőinek komoly összhangja"169 véli Tildy 1945 nyarán. Nagy Ferenc miniszterelnök is a konszenzuális demokrácia híve volt: „A közügyek intézéséből minden erőszakot, hatalmaskodást és megtévesztést ki kell zárni és a nemzet nagy ügyeit közmegegyezéssel kell intézni." ${ }^{170}$

A többségi elv, a jogszabályok (játékszabályok) és az intézményi struktúrák tiszteletben tartása szintén központi eleme az 1945 utáni kisgazda demokrácia koncepciónak.

A különböző FKgP-s megszólalók többször is megpróbálták tisztázni a „polgári” és a „népi” demokrácia közötti átjárhatóság elvi kereteit. Nagy Ferenc miniszterelnök 1946 szeptemberében arról nyilatkozott, hogy a kisgazdák a demokráciát „a magyar nép örökös politikai életformájának" ${ }^{\text {171 }}$ tekintik. Néhány hónappal később arról beszélt a kormányfö, hogy „radikálisabb és erőteljesebb demokráciát” ${ }^{172}$ szeretne ő maga is. A radikálisabb és erőteljesebb demokrácia panel arra utalhat, mintha '46 decemberében Nagy Ferenc a „népi” demokrácia felé tett volna gesztust, de ismerve Nagy politikai tevékenységét, ez nem helyes értelmezési keret, mert a kisgazda miniszterelnök végig a jogállami jellegü polgári demokrácia mellett állt. 1946 októberében beszélt így Békésen: „Kimondjuk, hogy soha, semmi körülmények között nem engedjük megdönteni a magyar nép politikai életformáját, a demokráciát, ragaszkodunk a népuralmi rendszerhez és sem ellenforradalommal, sem forradalommal, sem semmiféle törekvéssel ezt a népuralmi rendszert megdönteni nem engedjük, hanem gondoskodunk, hogy a döntés joga örök időkre a magyar népé legyen." "173

Hám Tibor kisgazda nemzetgyülési képviselő a Népi vagy polgári demokrácia címü cikkében 1946 szeptemberében abban bízott, hogy - noha a kommunisták hosszú távú célja a szocializmus - az MKP elfogadja a „polgári szabadság” eszményét és a viták ellenére a közös pont a jogokra épülő demokratikus struktúra. „Hisszük, hogy a marxista pártok őszintén és hátsó gondolat nélkül vállalják a polgári demokráciát. És hisszük, hogy a magyar koalíció alapja csak ez a polgári demokrácia lehet és ez kell, hogy összekapcsoljon bennünket"174 elemezi a demokrácia-felfogások közötti átjárhatóság lehetőségeit Hám.

Eszmetörténeti vonatkozásban - és nem feltétlenül a kommunista kontra kisgazda demokrácia-értelmezések tekintetében - figyelemre méltóak még a nemzetgyülési képviselő alábbi gondolatai: „Nem értjük és nem vállaljuk a polgári demokrácia liberális fogalmát, a

\footnotetext{
${ }^{169}$ TILDY Zoltán: Magyar kérdések. Kis Újság, 1945. július 11. 1. p.

${ }^{170}$ A demokráciát a magyar nép örökös politikai életformájának tekinti. Nagy Ferenc miniszterelnök a Kisgazda Párt készülő programjáról. Kis Újság, 1946. szeptember 29. 2. p.

${ }^{171}$ Uo.

172 Radikális gazdasági programot adott a Független Kisgazdapárt. Kis Újság, 1946. december 5. 1. p.

${ }^{173}$ Nagy Ferenc Békésben meghirdette a Kisgazda Párt új programját. Kis Újság, 1946. október 22. 1. p.

${ }^{174}$ HÁM Tibor: Népi vagy polgári demokrácia. Kis Újság, 1946. szeptember 22. 1. p.
} 
polgári jogrend olyan értelmezését, amely az elvi egyenlőség ürügye alatt a gyakorlatban a nagytőke [...] uralmát jelenti, mert csak a lehetőségei egyenlőek a néprétegeknek, de nem az adottságai."175 Ezzel Hám a kisgazda demokrácia felfogásnak a szociális változások érdekében a struktúrákat - egy bizonyos pontig - áttörni akaró szándékát demonstrálja, ez a fajta antiliberalizmus a korabeli szóhasználatban a nagytőke-ellenességet jelentette.

A cikkben a honatya összefoglalja azt is, hogy a kisgazdák számára milyen fontos tartalma van még a polgári demokráciának. Úgy látja, a polgári életforma esélye szintén a demokrácia létének feltétele, mint ahogy a szilárd jogrend és a konszolidáló társadalmiközéleti környezet is. „Mit jelent a mi számunkra a polgári demokrácia? Jelenti a parlamentarizmuson, népképviseleti rendszeren, az önkormányzaton, sajtószabadságon, az állampolgári szabadságon felépülő állami életet. Jelenti az élethez, a szabadsághoz, a munkához való jogot és politikailag azt jelenti, hogy a politikai hatalom a magyar nép akaratából megválasztott politikai vezetők kezében van"176 - írja Hám, aki azt is leszögezi, hogy a hatalom a „parlamentáris többség alapján” kell, hogy álljon.

A kisgazda koalíciós évekbeli demokrácia-felfogásban a jogosultságokra épülö társadalmi berendezkedés eszmeisége jelentette a gondolati alapot; a polgári demokrácia alapértékeihez való viszonyulás jelentette a vízválasztót. ${ }^{177}$ Azok a kisgazda közéleti szereplők, akik 1947-48 után is kitartottak a polgári demokratikus ethosz mellett, emigrációba kényszerültek vagy lekerültek a közéleti színpadról. Míg akik engedtek a demokratikus eszményképből, periférikus szerepben ugyan, de társutasként megmaradhattak a politika világában.

\subsection{Kommunista demokráciaértelmezök: Révai József és Rákosi Mátyás}

\section{Révai József}

„A magyar átalakulás nem lesz szocialista jellegü, de nem lesz polgári-demokratikus jellegü sem a szó közkeletű értelmében"178 - írta még 1938-ban Révai József, a magyar kommunisták

\footnotetext{
${ }^{175}$ Uo.

${ }^{176}$ Uo.

177 Rathmanné Túry Mária, aki A Kisgazdapárt demokrácia-koncepciója 1945-1947 címmel írt tanulmánykötetet, úgy véli, a kisgazdák demokrácia koncepciójának a lényege, hogy megakadályozzák a kommunistáknak a forradalom továbbvitelére és a demokrácia továbbfejlesztésére vonatkozó szándékát. (RATHMANNÉ TÚRY Mária: A Kisgazdapárt demokrácia-koncepciója. 1945-1947. Oktatási Minisztérium Marxizmus-Leninizmus Oktatási Főosztály, Budapest, 1977. 5. p.)

${ }^{178}$ RÉVAI József: Marxizmus és népiesség. In: RÉVAI József: Marxizmus, népiesség, magyarság. Szika Kiadó, Budapest, 1948. 326. p.
} 
kiemelkedő ideológusa. Révai eszmetörténeti jelentőségü Marxizmus és népiesség címü tanulmányban azt elemzi a második világháború kirobbanása előtt, hogy a fasizmus remélt legyőzése után milyen lehet az új Magyarország. Révai úgy fogalmaz, meg kell majd teremteni a polgári demokratikus formákat és vívmányokat, „melyek a nép kispolgári rétegei - elsősorban a parasztság - számára is lehetővé teszik, hogy önállóan, az úri osztály gyámkodása alól felszabadulva, számuknak, gazdasági súlyuknak, szervezettségüknek és politikai öntudatuknak megfelelő mértékben vegyenek részt az ország politikai életében és kormányzásában." ${ }^{179}$ Ezt követően viszont kifejti, hogy miben tér majd el az általa remélt új rendszer a polgári demokrácia struktúráitól: „Az átalakulás jellege annyiban lesz több mint a polgári-demokratikus, amennyiben a nép ellenségei elleni harcban nem fog visszariadni attól, hogy az egész nép érdekében belenyúljon a monopoltőke tulajdonviszonyaiba, amennyiben a szocialista munkásság lesz legmegbízhatóbb, legszervezettebb, legéberebb, legtettrekészebb támasza: más szóval: vezető ereje. ${ }^{\Perp 180}$ Ebben az írásában Révai leszögezte, hogy az átalakulás „demokratikus alapjellegét” nem érintheti semmi és az egész rendszert jellemezni fogja a „megállapodásra törekvő tendencia.” Az ideológus nem cáfolja ezzel párhuzamosan, hogy ők mint marxisták a „továbbfejlődésért”, vagyis a szocializmusért fognak küzdeni, de anélkül, hogy szembefordulnánk ,a népi demokrácia korlátoltabb, polgáribb, megállapodottabb”181 formájával.

1944-ben miközben a hazai kommunisták még a gyorsabb módon bevezethető munkás-paraszt diktatúra megteremtésének lehetőségén töprengtek, a moszkoviták a szovjet fóvárosban Rákosi Mátyás elnökletével tanácskoztak, s a „demokratikus program” kimunkálásáról hoztak döntést. Ahogy a moszkvai megbeszélésen Révai József főideológus mondta: „demokratikus célokat kell kitüzni.” A Magyar Kommunista Párt 1944. novemberi programjavaslata szerint a kommunisták „a magyar hazafiak harcos összefogását, Magyarország demokratikus újjáépítését” ${ }^{182}$ kívánják szolgálni.

A moszkovita pártvezetés Révai aktív közremüködésével a sztálini útmutatásnak megfelelően a demokratikus átmenet modelljéről döntött - egy olyan átmeneti modellről, aminek az időbeli kifutását ők maguk sem ismerhették. Az viszont egyértelmű volt:

\footnotetext{
${ }^{179}$ Uo.

${ }^{180}$ Uo.

${ }^{181}$ Uo. 327. p. /,A kommunista, a szociáldemokrata és a népi gondolkodásban már a harmincas-negyvenes évek fordulóján kialakult a »népi demokrácia« koncepciója; egy olyan demokráciáé, amely nem azonos a polgári demokrácia modelljével, de nem azonos a szovjet típusú proletárdiktatúrával sem.” (ERÉNYI Tibor: Többpárti választások és parlamentarizmus Magyarországon 1920-1947. In: FöLDES György - HUBAI László (szerk.): Parlamenti választások Magyarországon. 1920-2010. Napvilág Kiadó, Budapest, 2010. 278. p.)/

${ }^{182}$ RÁKOSI Sándor-SzABÓ Bálint (szerk.): A Magyar Kommunista Párt és a Szociáldemokrata Párt határozatai 1944-1948. Kossuth Kiadó, Budapest, 1967. 38. p.
} 
időlegesen lemondanak a proletárdiktatúra lehetőségéről és teret engednek a polgári demokrácia struktúráinak. A hazai kommunisták a hosszú évek illegalitása után azonban abban bíztak, egy olyan berendezkedés kialakítása kezdődhet meg, mint egykoron 1919-ben. A magyarországi pártmunkások 1944/1945-ben nem tudtak Sztálinnak a nyugati hatalmakkal kötött alkujáról, a számukra korlátozó tényezőként ható polgári demokratikus kibontakozás kelet-közép-európai verziójáról, így míg az országos pártvezetés erőteljesebben be nem avatkozott, elkezdték a saját maguk területein a kis „tanácsköztársaságok” kialakítását. ${ }^{183}$

A kommunista pártmunkások és aktivisták fejében tapasztalható ideológiai zürzavar tisztázását is szolgálták Révai József demokrácia-értelmező cikkei, beszédei. A demokrácia fogalom kommunista nézőpontú értelmezéséről szól Révai József 1944. november 25-i Harcos demokráciát című cikke a Délmagyarországban. Révai a címben is jelzett „harcos” demokráciát szeretne, érvei egy úgymond határozottan fellépő demokrácia mellett szólnak. „Nem asszisztáló, hanem cselekvő demokratákra van szüksége a nemzetnek!”184 - írja Révai. A jegyzet elején a kommunista politikus az „aggódalmaskodók” ellen emeli fel szavát, azok ellen, akik az „adminisztratív intézkedéseket” érintően óvatoskodnak, és folyton a jogszerüséget kérik számon. Az elkövetkezendő évek formális demokráciával szembeni kommunista retorikája is felbukkan már ekkor: „Idézzük ezekkel a jogi aggodalmaskodókkal szemben Kossuth Lajost, aki 1848 szeptemberében azt mondotta, hogy a haza megmentésének eszközeit nem a Corpus Jurisból, hanem a hazát fenyegető veszélyből kell meríteni? Idézzük a római demokrácia elvét, amely szerint a legfőbb törvény a közjó?"”185 _ fogalmaz Révai.

Egészen plasztikusan, nyíltan bontakozik ki érvelése mögött már ekkor is az ellenségkép iránti igény - az „ellenség” 1944 őszén természetes módon „a nyilas”, a későbbi hónapokban a „régi rend emberei”, utána pedig - a bárkire ráhúzható tipizálás szerint - ,a reakciósok.” Az alábbi idézet azért figyelemreméltó, hiszen e gondolat már nem a nyilasokkal szembeni harcról szól, hanem arról, hogy a tömegek mozgósításához mindig szükséges a kommunista felfogás szerint egy általános, de mégis konkretizálható ellenségkép: „Ha a bűnösöknek hajaszála sem görbül meg, akkor a népet nem lehet rávenni arra, hogy segítsen megoldani a nehézségeket. A nép akkor fog segíteni magán és az országon, ha látja, hogy a

\footnotetext{
${ }^{183}$ Az 1945 után néhány esztendőben a hivatalos kommunista kommunikációban az 1919-es proletárdiktatúra mint használható múlt nem is jelent meg. (APOR Péter: Az elképzelt köztársaság. A Magyarországi Tanácsköztársaság utóélete. 1945-1989. MTA Bölcsészettudományi Kutatóközpont Történettudományi Intézet, Budapest, 2014)

184 RÉVAI József: Harcos demokráciát! Délmagyarország. 1944. november 25. 3. p.

${ }^{185}$ Uo.
} 
bűnösök lakolnak! [...] Enélkül pedig nincs demokratikus újjászületés" ${ }^{\text {186 }}$ Révai ezt követően felteszi a kérdést, hogy milyen legyen a demokrácia, amelynek jegyében az összeomlott országnak újjá kell születnie? A cikkíró az alábbi ellentétpárt veti fel a különböző demokrácia-képek kapcsán: „Gyenge, vérszegény demokráciát akarunk-e, mely engedi magát letaglózni, vagy harcos, népi demokráciát-e, mely könyörtelenül leszámol a nemzet ellenségeivel?” A megkonstruált ellenség mint fogalom ebben az évelésben is megjelenik.

A következő dilemmája arról szól, hogy a demokrácia biztosította jogok „mindenkit” így „a demokrácia ellenségeit” is - megilletik vagy csak ,a demokraták, a hazafiak, a tisztességes magyarok számára” járnak a jogosultságok. „Harcos demokráciát akarunk! Tudjuk, hogy vannak nálunk demokraták, akik a demokráciát nem ilyennek akarják. Demokrácián valami elvont, általános jogegyenlőséget értenek, nem pedig egy olyan állami rendet, mely a népet szolgálja és üldözi a nép ellenségeit. Az ő számukra a demokrácia tőrvényekből, hatóságokból, állami intézményekből áll és nem a saját érdekein és az ország érdekein éberen őrködő, az ország belső ellenségeire lesújtani tudó népből” - sulykolja az ellenségkép-központú demokráciaértelmezést Révai József, de arra is rávilágít a szöveg, hogy a kommunista hozzáállás szerint a demokrácia nem törvényekből, vagyis játékszabályokból, körülírt jogok halmazából áll és nem is önmagában demokratikus intézményekből.

E gondolat kapcsán egy jellemző, karakteres eleme érhető tetten a koalíciós évekbeli kommunista közgondolkodásnak: az „ellenség” számára nincsenek jogok, az „ellenségre” le kell sújtani, csak a „tisztességesek” kaphatnak lehetőségeket, s azt viszont mindig a kommunista hatalmi érdekek határozzák meg, hogy ki az „ellenség” és ki a „tisztességes.” Nincsenek abszolút jogok, a jogosultságok nem rögzítettek, a jogok lehetőségét a kommunista párthoz való viszonyrendszer, a barát-ellenség dimenzió dönti el.

$\mathrm{Az}$ 1945. november 4-én megtartott szabad, demokratikus választás ${ }^{187}$ a Független Kisgazdapárt 57 százalékos győzelmét hozta, a Magyar Kommunista Párt csak 17\%-ot ért el. A választási vereséget a kommunistáknak elméleti dimenzióból is meg kellett magyarázniuk. Révai József a kisgazdák győzelmével kapcsolatosan egy szélesebb okfejtésbe kezdett, amely a koalíciós évekbeli kommunista demokráciaértelmezés szempontjából is mérvadó. Révai a választási eredményekből az alábbi következtetéseket vonta le: „a magyar reakció gyökerei mélyebbeknek, a Horthy-rendszer hatása a nép gondolkodására nagyobbnak bizonyult, mint

\footnotetext{
186 Uo.

187 Szücs László megállapítása: „Az ország lakosságának a választásokon megnyilvánult, a polgári demokráciát igenlő akarata - és az ország sorsát meghatározó szovjet politikai törekvés között mélyenszántó ellentét húzódott.” (SzűCs László (szerk.): Nagy Ferenc első kormányának minisztertanácsi jegyzőkönyvei. A. kötet. 1946. február 5. - 1946. július 19. Magyar Országos Levéltár, Budapest, 2003. 64. p.)
} 
hittük." ${ }^{188}$ Révai arra is felhívja a figyelmet, hogy a magyar demokrácia nem forradalom eredményeképpen jött létre, emiatt a „néptömegek” nem érzik annyira a magukénak. A kommunista föideológus szerint a választások után a „harc” a „demokrácia továbbfejlesztésére törekvő erők” és a „demokrácia visszafejlesztésére törekvők között” fog majd zajlani. Nyilvánvalóan a „demokrácia továbbfejlesztésére törekvő erők” meghatározó részben a kommunistákat jelentik, a „demokrácia visszafejlesztésére törekvők” terminológia pedig a Független Kisgazdapárt mint ernyőszervezet körül összpontosuló polgári demokráciapárti tömegeket írja körül. Révai a választási eredményt a reakció elöretöréseként értelmezte és úgy ítélte meg, hogy a következő hónapokban a „demokraták” és a „reakciósok” ellentétei fognak kiéleződni.

Révai 1944 őszén a „harcos” demokrácia fogalmat járta körül, a ’45-ös választások után a „tettek” demokráciájáról kezdett beszélni és megalkotta a „,cselekvő demokrácia”189 megnevezést. Révai meghatározása szerint a cselekvő demokrácia azt jelenti, hogy „rendkívüli helyzetben rendkívüli eszközökkel kormányozzanak” - konkrétan ez rendeleti kormányzást takar, ami ugyan „nem forradalmi diktatúra”190 - hanem Révai szóhasználatával - „lépés” a „cselekvő demokrácia” felé.

A MKP III. Kongresszusán Révai József „Népi és polgári demokrácia” címmel mondott beszédet. ${ }^{191}$ Révai ekkor még csak mint a magyar demokrácia balszárnyáról beszél a kommunistákról, vagyis e nyelvi struktúra azt mutatja, még nem kizárólagosan állítja, hogy csakis ők képviselik a magyar demokrácia ügyét. Ez arra utal, hogy a kommunisták ebben az időszakban, 1946 őszén a kommunikációs térben még nem tudták kizárólagos igénnyel elfoglalni a demokrácia fogalmát. A „demokrata” fogalom használata és a kommunisták identifikációja tekintetében különösen érdekes Révai következő mondata: „Mi nem egyszerűen demokraták vagyunk, mi demokraták is kommunista módra vagyunk."192

$\mathrm{Az}$ úgynevezett összeesküvési ügy ${ }^{193}$ újabb fordulatot hozott a koalíciós évek történetében. Az „összeesküvési válság” során a kommunista párt részéről tapasztalt verbális

\footnotetext{
${ }^{188}$ RÉVAI József: A választások és a magyar demokrácia néhány alapkérdése. Társadalmi Szemle, I. évf. (1946) 1. 6. p.

${ }^{189}$ Uo. 12.p.

${ }^{190}$ Uo.

${ }^{191}$ A népi demokrácia útja. A Magyar Kommunista Párt III. kongresszusának jegyzőkönyve. 129-140. p.

192 Uo. 137. p.

193 A „Magyar Közösségi ügy”, az úgynevezett összeesküvési ügy tanulságairól: PALASIK Mária: A jogállam megteremetésének kísérlete és kudarca Magyarországon. 1944-1949. 183-254. p.; illetve SzEKÉR Nóra: A Magyar Testvéri Közösség története. „Norma” Nyomdász Kft., Hódmezővásárhely, 2010.

M. Kiss Sándor úgy véli, 1945 után megtörtént a rendszerváltozás és a demokratikus intézményrendszer kiépülése, az összeesküvési ügy kapcsán kibontakozó politikai leszámolás és per „a demokrácia intézményrendszerének korai kiürülését és megsemmisítését mutatta fel.” (M. KISS Sándor: Bevezető. In:
} 
brutalitás és a rendvédelmi hatóságok által felmutatott kreált vádak/koncepciógyártás és nyílt erőszak olyan közéleti kulturális közeget eredményezett, ahol egyre szükülő mértékben voltak biztosítottak a párbeszéd-feltételek a demokrácia-viták számára. A kommunisták demokráciaértelmezése még jobban keményedik, ridegedik, s válik egyre kategorikusabbá.

A Szabad Nép, a Magyar Kommunista Párt lapja 1947. január 5-i számában közölte a hírt arról, hogy a hatóságok egy köztársaság-ellenes összeesküvés nyomaira bukkantak. Révai József Összeesküvők és cinkosok címmel írt vezércikket a témában. Már a címadás, a „cinkosok” kiemelése utal arra, hogy többről van szó, mint egy szimpla állambiztonsági ügyről. Révai magát a „szervezkedést” egyértelmüen „,demokrácia-ellenesnek” láttatja. A főideológus érvelése szerint aki részt vett az összeesküvésben, az úgymond mind a demokratikus rend ellen lépett fel, aki pedig ebben cinkos, az szintén demokrácia-ellenes magatartást tanúsít. A politikus úgy véli, mivel komoly a tét, ezért a nyomozást „kíméletlen eréllyel” kell lefolytatni, mert a reakció legkomolyabb támadását érték tetten. „Ezt ne próbálja senki elbagatellizálni. A reakciós törekvések elbagatellizálásával eleget ártottak már a magyar demokráciának, eléggé bátorították már a nép ellenségeit." ${ }^{\circledR 194}$ Az összeesküvőket Révai a „demokrácia trójai falovának” nevezi. A cikk szövegéből teljesen egyértelmü, hogy már az ügynek ebben a szakaszában a kommunisták a kisgazdákkal szembeni fellépésre használják a megszervezett információkat. „Országot építeni nem lehet úgy, hogy a koalíció legnagyobb pártja reakciósok fedezéke."195

Ma már megvan a szükséges történelmi távlat és létezik egy történettudományi szakmai konszenzus arról, hogy az összeesküvési ügy a kommunisták számára egy rendkívül fontos lépéssorozat volt a demokratikus jogállam, a polgári szabadságjogokra épülő demokrácia állami struktúráinak lebontása felé vezető úton. Éppen ezért különlegesen érdekes kommunikációs stratégiai elem, hogy a kommunisták ebben a helyzetben is a „demokrácia védelmére” hivatkoznak - a jogállami karakterü demokrácia visszametszése, megszüntetése érdekében végzett politikai cselekményeket a demokrácia védelmének szövegburkába csomagolják. Erre látunk markáns példát Révai idézett cikkében is: „A demokrácia ellenségeivel szemben alkalmazni kell a törvény teljes szigorát"196 - fenyegetőzik a politikus,

SzEKÉR Nóra: A Magyar Testvéri Közösség története. „Norma” Nyomdász Kft., Hódmezővásárhely, 2010. 7 11. p.)

Az ügy kommunista nézőpontú történeti feldolgozása: KIs András: A Magyar Közösségtől a Földalatti Fővezérségig. Zrínyi Katonai Kiadó, Budapest, 1969. A történet szélsőjobboldali megközelítésủ áttekintése: KUBINYI Ferenc: A Katonapolitika regénye. Malomfalvi Kiadó, California, 1994.

${ }^{194}$ RÉVAI József: Összeesküvők és cinkosok. Szabad Nép, 1947. január 5. 1. p.

195 Uo.

196 Uo. 
s egyben kijelöli azt a tematikus keretet, melyben a demokrácia lényegi struktúrái körüli közéleti mozgások immáron kriminalisztikai kontextusban zajlanak.

Az összeesküvési ügy hiszterizált légkörében jelentkezett egy figyelemreméltó jegyzettel Z. Nagy Ferenc kisgazda nemzetgyülési képviselő a kisgazdapárt napilapjában, a Kis Újságban. Z. Nagy azt veti fel, tisztázni kellene a koalíció szereplőinek a maguk koordinátáit a demokrácia fogalmáról, mert tisztázás nélkül nem egyértelmü, hogy tovább akarják-e építeni az eddigi politika tényezői a magyar demokráciát. A nemzetgyűlési képviselő úgy véli, amennyiben a koalíció szereplői továbbra is demokráciában gondolkodnak, akkor „meg kell egyezniük”, mert „,különben menthetetlenül a diktatúra felé haladunk."197 A kisgazdák részéről a polgári demokrácia megmentése érdekében felvetett kiegyezési gondolatok a kommunisták felöl indulatos elutasításban részesültek. Révai József Amiben nincs alku címmel publikált vezércikket a Szabad Népben. Az úgynevezett összeesküvési ügy újabb szálaira utalva - ekkor már Kovács Béla, a Kisgazdapárt főtitkára volt a célkeresztben ${ }^{198}$ - írja: „Ebben a kérdésben a magyar demokrácia számára nincs és nem lehet kompromisszum.”199 A megfogalmazásából is kitetszik, hogy a „magyar demokrácia” kifejezés mögött Révai immár csakis és egyértelműen, kizárólagosan a kommunista világ- és demokrácia-felfogást érti - itt már szó sincs arról, amiről 1938-ban a demokrácia ethosza kapcsán írt, miszerint az akkor általa remélt jövendőbeli átalakulás „demokratikus alapjellegét” nem érintheti semmi és az egész rendszert jellemezni fogja a „megállapodásra törekvő tendencia.",200

Az 1947. február 16-i Révai-cikk határozott hangon teszi egyértelművé: „A Kovács Béla ügy ma a magyar demokrácia legfontosabb politikai kérdése. Ebben a kérdésben próbál revansot venni, támadásba átmenni az összeesküvőkre mért csapás következtében megingott,

\footnotetext{
${ }^{197}$ Z. NAGY Ferenc: A koalíció válsága és a kivezető út. Kis Újság, 1947. február 7. 1. p.

${ }^{198}$ A Kovács Béla-ügy részleteiről: SZAKÁCS Sándor-ZINNER Tibor: A háború „megváltozott természete”. Adatok és adalékok, tények és összefüggések. 1944-1948. Genius Gold Rt. - Batthyány Társaság, Budapest, 1997. 294-307. p.

Kovács Béla élete utolsó nemzetgyülési beszédében, 1947. február 7-én, a személyét övező támadások légkörében szellemi mentsvárként még mindig a különböző demokrácia-értelmezések közötti tisztázásban bízott. Beszédében egyértelművé tette: „demokraták vagyunk, demokraták akarunk lenni és ha ezt akarjuk, könnyü nekünk elférnünk egymás mellett. Én mindenki mellett elférek, aki a demokráciát akarja. Ha azonban nyíltan, vagy suttyomban ebben az országban van olyan irányzat is, amely nem demokráciát akarna esetleg, hanem szocializmust, vagy ebből kifejlődő kommunizmust, megbocsásson a világ nekem, akkor szükre kezd szabódni ez az amúgy is szük magyar tér. [...] Nincs veszélyben a demokrácia, amelynek egyik legnagyobb harcosa én, az alig tízegynéhány holdas paraszt vagyok. Van akkora érdekem és okom; hogy édes gyermekként - fiam, lányom életeként — védjem, féltsem, istápoljam ezt a demokráciát, mert gyermekeimnek én a tízegynéhány hold földem mellé örökségül és hagyatékul a demokráciában adandó tiszta, ideális szabadságot szeretném hagyni." (Elhangzott a nemzetgyülés 92. ülésén 1947. február 7-én. Nemzetgyülési Napló 1945-1947. V. kötet 214-221. p.)

${ }_{199}^{19}$ RÉVAI József: Amiben nincs alku. Szabad Nép, 1947. február 16. 1. p.

${ }^{200}$ RÉVAI József: Marxizmus és népiesség. In: RÉVAI József: Marxizmus, népiesség, magyarság. 215-336. p.
} 
szétzilált reakció. Ha Kovács Béla számára sikerül büntetlenséget biztosítani, akkor nincs még veszve semmi! Akkor újra rendezni lehet a megbomlott sorokat, új haditerveket lehet kidolgozni, új gócokat lehet teremteni! Ha Kovács Bélát sikerül megmenteni tetteinek törvényes következményeitől, akkor az összeesküvők szabadon lévő cinkosai erejüket és befolyásukat demonstrálták és bebizonyították, hogy a magyar demokrácia ellen lehet és érdemes folytatni az aknamunkát." ${ }^{201}$ Ismerjük a történeti tényeket arról, hogy a kommunisták egy súlytalan jobboldali kötődésü csoportosulás asztaltársasági összejöveteleiből, az azokon elhangzott - minden konkrét cselekvést nélkülöző - ködös fantáziálásból fakadóan építették fel a hatalmas méretü köztársaság-ellenes szervezkedés rémképét, majd erre a rémképre utalva szalámizták le teljes mértékben a kisgazdapártot. ${ }^{202}$ Amikor viszont láthattuk, hogy Révai arról beszél, hogy a Kovács Béla-ügy kapcsán akar „támadásba átmenni” a reakció, és egyben óv a demokrácia elleni újabb „aknamunkától”, akkor megállapíthatjuk: a koalíciós időszaknak ezen részében a kommunisták részéről a demokrácia-értelmezés már kifejezetten metanyelvi formában jelenik meg. ${ }^{203}$

Révai József a kompromisszum mint pozitív politikai tett eszmeiségével szemben érvel, vagyis számára a demokrácia világába, a demokrácia nyelvi közegébe ekkor már nem fér bele, hogy a koalíció szereplöi között valódi, lényegi megegyezések legyenek szükségesek. Mint írja: „egyesek szerint a demokrácia és különösképpen a koalíciós kormányzási forma: kompromisszumokból áll. Ez persze igen egyoldalú és igen korlátolt igazság, de mi sem tagadjuk, hogy ez - bár egyoldalúan és korlátoltan - de igaz. Tegyük hozzá azonban: a demokrácia nemcsak kompromisszumokból áll. Vannak dolgok, melyekben nincs és nem lehet kompromisszum, ha a demokrácia nem akar jóvátehetetlenül kompromittálódni [...]. A koalíció van a demokráciáért, nem a demokrácia a koalícióért [...]. De Kovács Béla kérdésében, tehát az összeesküvők elleni következetesség kérdésében még a kisgazdapárti parasztképviselők kedvéért sem vagyunk kaphatóak rothadt és a demokrácia létét veszélyeztető kompromisszumokra. Sajnálnánk és fájlalnánk, ha nem sikerülne meggyőznünk őket arról, hogy itt nem a mi pártügyünkről, hanem a demokrácia, tehát az ő

\footnotetext{
${ }^{201}$ RÉVAI József: Amiben nincs alku. Szabad Nép, 1947. február 16. 1. p.

202 SZAKÁCS Sándor - ZINNER Tibor: A háború „,megváltozott természete” - Adatok és adalékok, tények és összefüggések - 1944-1948. 308-319. p. ill. PALASIK Mária: A jogállam megteremetésének kísérlete és kudarca Magyarországon. 1944-1949. 183-310. p.

${ }^{203}$ A megalkotott metanyelvi struktúrák a „,bemutatott világkép szubjektív értelmezését” teszik lehetővé a használóik számára. A metanyelvi operátorok a fogalmak jelentésének a terjedelmét módosítják oly módon, hogy azokat a tapasztalataink általános rendszeréhez, magatartásunkhoz és meggyőződésünkhöz, a bennünket körülvevő valóság osztályozásához és kategorizációjához viszonyítják. (Janusz BAŃCZEROWSKI: Metanyelvi struktúrák szerepe a jelentés módosításában. Elérhető: http://www.c3.hu/ nyelvor/period/1241/124101.htm\#002. A letöltés időpontja: 2015. szeptember 15.)
} 
ügyükről is szó van, de ha kell, még velük szemben is védelmezni fogjuk a demokrácia [...] ügyét." ${ }^{204}$ Révai tehát úgy ábrázolja, hogy a demokrácia - általa vélt - ügyét a kisgazdákkal szemben is meg kell védeni és az ő nézőpontjából a „rothadt” kompromisszumok a „demokrácia létét” veszélyeztetik. Mindezen szavak, gondolatok újra megerősítik, hogy ekkor, 1947 későtelén a kommunisták által használt „demokrácia” fogalom immáron egyre inkább kizárólagos értelmű és kirekesztő tartalmú, abba nyelvileg már csak a kommunista stratégiába illeszkedő álláspontok férnek bele.

Kovács Béla volt kisgazda fötitkárnak a szovjet csapatok által történt elhurcoltatása után két nappal, 1947. február 27-én a Révai József főszerkesztette kommunista Szabad Nép újabb kategorikus demokrácia-értelmezést tett közzé. „A haza: a demokrácia. A demokrácia ellenségei: hazaárulók. Hazaárulókkal szemben pedig nincs helye kíméletnek! Nincs helye kíméletnek azokkal szemben, akik védik az összeesküvőket."205 - olvashatjuk a lap aláírás nélküli vezércikkében, amely a koalíciós idők történetében egy újabb komoly lépés a verbális és nyelvi agresszió jellemezte közéleti viselkedésminta felé.

Révai József 1949-ben a Társadalmi Szemle hasábjain már egyértelmű szavakkal fejtethette ki, hogy a népi demokrácia valójában a proletariátus diktatúrája. ${ }^{206}$ „Nyilvánvaló, hogy nem mindjárt, nem kezdettől fogva volt a mi népi demokráciánk proletárdiktatúra, hanem harcban fejlődött azzá” ${ }^{207}$ - írja a kommunista főideológus. Révai szerint az 1945 és 1947 közötti időszakban sem csak polgári demokratikus átalakulás zajlott, de a valódi fordulat a népi demokráciának proletárdiktatúrává való fejlődése felé „Nagy Ferenc bukásával kezdődött." 208

A „népi demokráciából” a „proletárdiktatúrába” történő átalakulás időszakát Révai Nagy Ferenc bukásától, 1947 májusától 1948 elejéig teszi. Az 1947 májusa előtti két esztendőben a kommunista politikus szerint a népi demokrácia első szakasza zajlott, amikor még úgy tünhetett, hogy a népi demokrácia pusztán a polgári demokrácia „plebejus, harcos”209 válfaja. Révai ugyanakkor helyes politikának tartja, hogy 1945-ben nem vállalták „a kisgazdák jobbszárnyával” a nyílt vitát arról, hogy (polgári) demokrácia vagy (proletár)diktatúra lesz. Amint fogalmaz: „A kártyáinkat nem felfedni helyes volt, de sokszor mi magunk is elfelejtettük, hogy a népi demokrácia már akkor is több volt, mint pusztán

\footnotetext{
${ }^{204}$ RÉVAI József: Amiben nincs alku. Szabad Nép. 1947. február 16. 1. p.

${ }^{205}$ A magyar köztársaság védelmében. Szabad Nép. 1947. február 27. 1. p.

${ }^{206}$ RÉVAI József: Népi demokráciánk jellegéről. Társadalmi Szemle, IV. évf. (1949) 2. 161. p. 161. p.

${ }^{207}$ Uo. 162. p.

${ }^{208}$ Uo. 163. p.

${ }^{209}$ Uo. 164. p.
} 
plebejus válfaja a polgári demokráciának, hogy lépcsőfok volt a szocialista átalakuláshoz, hogy tartalmazta már akkor a proletárdiktatúrává való fejlődés elemeit."210

Révai József 1949-ben meghatározza azt is, hogy mi a diktatúra funkciója: az erőszak alkalmazása az „ellenséggel” szemben. „Az a felismerés, hogy a népi demokrácia válfaja a proletárdiktatúrának, felfegyverez bennünket azzal a tudattal, hogy az osztályellenség ellen még határozottabban és egységesebben kell kiépíteni az osztályhatalomnak azokat a szerveit, melyek ennek az erőszaknak az alkalmazására valók. [...] Tudjuk, hogy a proletárdiktatúra nemcsak erőszak, hanem lényeges funkciói közé tartozik az építés is [...] de ez nem jelenti, hogy a proletárdiktatúra erőszakos, elnyomó funkcióit mellékesnek szabad tekintenünk"211 _ írja Révai, - ha tetszik, őszintén, más megközelítésben brutális nyíltsággal, önleleplező módon, az 1945 utáni kommunista demokrácia-értelmezést újabb megvilágításba helyezve.

Révai idézett és elemzett 1949-es gondolatai a népi demokráciáról közvetett módon bizonyítják, hogy az 1945 utáni évek magyar közéletének demokráciavitáit alapvetően a demokrácia kontra diktatúra dichotómia határozta meg. Révai 1949-es cikke nyelvileg már egyfajta átmenetet képez a kortárs beszédmód és az ideologikus-tudományos beszédmód között.

\section{Rákosi Mátyás}

1945 nyarán Rákosi véleményét, gondolatait a demokrácia kapcsán, egyáltalán a demokratikus gondolkodáshoz való viszonyulását nem ismerte addig összefoglaló módon a magyar közvélemény. Ezért is lehetett a 1945-ös demokrácia-konferencia legfigyelemreméltóbb előadója a Magyar Kommunista Párt főtitkára, Rákosi Mátyás. ${ }^{212}$

Rákosi az előadás elején azt a kérdést tette fel, hogy 1945 nyarán beszélhetünk-e Magyarországon demokráciáról? ${ }^{213}$ A kommunista pártvezér szerint erre a kérésre „két teljesen ellentétes választ kapunk.” Rákosi szerint a földhöz jutott parasztok és a jogokhoz jutott munkások egyértelműen azt mondják: van demokrácia. „Nem adhatunk ilyen

\footnotetext{
${ }^{210}$ Uo.

${ }^{211}$ Uo. 166. p.

${ }^{212}$ Standeisky Éva így ír Rákosi 45-ös demokrácia-referátumáról: „Rákosi Mátyás színes, történelmi és irodalmi példákkal illusztrált előadást tartott. Nem hagyott kétséget afelől, hogy a magyarországi politikai berendezkedés nem tekinthető klasszikus értelemben vett polgári demokráciának. Ennek nem csupán az az oka - érvelt -, hogy a demokrácia, szemben a több száz éves angolszász demokráciákkal, még csak öt hónapos, hanem az is, hogy nincsenek hazai előzményei.” (STANDEISKY Éva: Remény és szorongás. Demokráciaelképzelések és demokráciaértelmezések. 65. p.)

${ }^{213}$ Demokrácia, 1945. 148. p.
} 
kategorikus választ az intelligenciánál"214 - Rákosi úgy vélekedett, az értelmiség hozzászokott a „reakciós elnyomáshoz, amiben 25 esztendeig részük volt.” Rákosi értelmezése szerint mivel az értelmiség nem kapott olyan kézzelfogható lehetőségeket a háború utáni hónapokban, mint a munkásság és a parasztság, ezért „tétovázik” és inkább tagadja, hogy demokrácia lenne az országban. „A válasz rendszerint oda lyukad ki, hogy összehasonlítva az angol demokráciával, bizony nehéz azt mondani, hogy ami ma Magyarországon van, az demokrácia." ${ }^{215}$ - mondta a kommunista politikus, majd történelmi párhuzamot hoz. Azt mondta, Cromwell korszakát annak idején az értelmiség nem tekintette demokráciának, mégis utólag úgy gondolja mindenki, hogy Cromwell vetette meg az angol demokrácia alapjait. Rákosi szerint 1945-ben a magyar demokrácia még „,pelenkában van”216 s tele van „gyermekbetegséggel” és ami hiányzik belőle, az a politikai tapasztalat. „Annál súlyosabban esik latba a demokráciának ez a tapasztalatlansága, mert ugyanekkor vele szemben egy régi, öreg, minden hájjal megkent reakció áll" - fejtegette a pártvezér és utána a „reakció álcázott támadásáról” beszélt, hozzátéve, hogy „,a legnehezebb olyan ellenség ellen harcolni, ki rossz szándékait, reakciós szándékait, a jószándék álarca alá rejti." ${ }^{217}$ Rákosi Mátyás eme demokrácia-értelmező megszólalásából is érzékelhetjük, hogy mennyire markáns elem a koalíciós korszak kommunista demokrácia-értelmezésében az ellenségkép iránti igény, az ellenségképre alapozott stratégiaalkotás és taktikai hadviselés.

Rákosi elismerte, hogy a kommunista befolyás alatt lévő rendőrség „vitatott kérdés”, de ezzel párhuzamosan amellett érvelt, hogy a demokráciának legyen „kardja, éles foga, éles karma, amivel védekezni tud”218 - ez a „kard” és „éles fog” lenne úgymond a rendőrség. Rákosi arról beszélt, hogy a rendőrség nem tökéletes, például a „reakció ellen” nem harcol elég „élesen.” Ezt követően amerikai történelmi hasonlatot hozott fel példaként, miszerint fontosabb a „demokrácia érdeke” mint a „formális törvények” betartása, vagyis ismét egy olyan típusú kommunista érvelést figyelhettünk meg, ami a formális demokratikus játékszabályok jelentőségét relativizálja.

Rákosi Mátyás előadásában azt hangoztatta, hogy a magyar demokráciának „magyar”219 demokráciának kell lennie, hiszen egy „,életmódot, egy kultúrát nem lehet mesterségesen átültetni egyik országból a másikba.” A kommunista pártvezető ezzel az érveléssel persze leginkább az ,angol mintát” akarta kizárni a lehetséges modellek közül, de

\footnotetext{
${ }^{214}$ Uo. 149. p.

${ }^{215}$ Uo.

${ }^{216}$ Uo. 151.p.

${ }^{217}$ Uo. 152. p.

${ }^{218}$ Uo. 157. p

${ }^{219}$ Uo. 162. p.
} 
azt is hozzátette, hogy „a szovjet viszonyokat”220 sem lehetséges átültetni hozzánk. „Elsősorban a saját erőnkből, a magyar erőből felépített demokráciát akarjuk. Ez a demokrácia sokat fog kölcsönvenni keletröl, sokat fog kölcsönvenni nyugatról, de ha megerősödik - magyar demokrácia lesz. A mi véleményünk tehát az, hogy a demokrácia felépítése nem importcikk, annak itt kell teremnie a magyar talajon és meg is terem, akármilyen nagyok is a nehézségek"221 - szónokolt Rákosi, majd e gondolatokkal zárta előadását: ,a közjó legfontosabb törvénye ma Magyarországon a demokrácia megerősítése. A Kommunista Párt minden fegyvert fel fog használni erre a célra.”222

Rákosi Mátyás imponáló szónoki stílusban vázolta gondolatait 1945 nyarán a demokráciával kapcsolatban. Megkerülte az alapkérdést, miszerint hosszútávon demokratikus viszonyokban gondolkodik-e az MKP vagy ,a keleti demokrácia” diktatórikus világát tekinti ideálnak. Hogy ne kelljen érintenie ezt a meghatározó dilemmát, ezért vetette be a „magyar” demokrácia gondolatát. Ebben az adott közönségnek és az akkori magyar közvéleménynek szóló beszédében elrejtette a párt végsőnek tekintett céljait, de ebből a kódolt megnyilatkozásból is kitetszik, hogy a kommunisták számára a demokrácia meghatározó részben „harc” a „reakció” ellen, amely küzdelemben a „demokrácia kardjára”, a kommunista hatás alatt müködő rendőrségre támaszkodik leginkább.

1946 őszétől új korszaka kezdődik a koalíciós évek demokrácia-értelmezéseinek. Szimbolikusan Rákosi Mátyásnak az MKP III. kongresszuson elmondott beszéde nyitja ezt az időszakot. Rákosi frazeológiájában ekkortól kap különös hangsúlyt, hogy a kommunisták célja - immáron rövidtávon is - a szocializmus megteremtése és egy sajátos „népi” demokrácia létrehozása. 223

\footnotetext{
${ }^{220}$ Uo. 163. p.

${ }^{221}$ Uo. 164. p.

${ }^{222}$ Uo. 165. p.

${ }^{223}$ Az új irányról a döntés már '46 tavasán megszületett. Rákosi 1946. április 1-jén találkozott Sztálinnal, ahol a szovjet pártvezér jelezte, hogy mivel nem kell komolyabb háborús helyzetre számítani a nyugattal, ezért megnyílik az út a kelet-európai kommunista pártok számára a meglévő demokratikus struktúrák áttörésére, a „Szocializmus” irányába történő elmozdulásra. A tárgyalásról Rákosi az MKP Központi Vezetősége előtt számolt be és a szükebb körü grémium elött akkor jelentette be az új irányt. (BÉKÉs Csaba: Lopakodó forradalom. Kelet-Közép-Európa szovjetizálása. Rubicon, XXVI. évf. (2015) 9. 78-79. p.) Rákosi beszédének témánkat érintő legtanulságosabb része így hangzott: „Ennek a koncepciónak egyik része az, hogy a változott viszonyok között, amelyik országban meg fog érni a proletariátus felszabadításának, vagy a szocializmusnak az előfeltétele, ott meg is fogják tenni, tekintet nélkül arra, hogy kapitalista környezetben van-e az illető ország vagy sem. Ez is egy új perspektíva, ami annyit jelent, hogy abban az országban, ahol a Kommunista Párt munkájának eredményeképpen ezek az előfeltételek megvannak, ott meg is kell valósítani. Ez minden Kommunista Pártnak egy újabb serkentés, mert mostan elsősorban a saját munkájuktól fog függni, hogy megteremtik-e a saját hazájukban a proletariátus felszabadításának előfeltételeit.” (A beszédet közli: MEZEI Géza (szerk.): Európa és a hidegháború a dokumentumok tükrében. Európa kettészakítása és a kétpólusú nemzetközi rend születése (1945-1949). Új Mandátum, Budapest, 2001. Rákosi Mátyás beszéde az MKP KV ülésén a Kominform megalakításával kapcsolatos moszkvai tervekről, 1946. május 17. 276-278.p.)
} 
Az MKP III. kongresszusa 1946. szeptember 28. és október 1. között zajlott, így a résztvevők az első napon olvashatták a Kis Újságban Kovács Béla, ${ }^{224}$ a Kisgazdapárt fôtitkárának cikkét. Az írás címe is talán üzenni akart a kommunista kongresszusnak: Nélkülünk nincs demokrácia. Kovács sérelme, hogy azzal vádolják a kisgazdákat, veszélyeztetik a demokráciát. „Tudjuk, hogy ez nem igaz, ők is tudják, de elmondják, mert úgy gondolják, hogy napjainkban ez a helyes politika" ${ }^{225}$ - írja a kisgazda fötitkár, aki arra is emlékeztet, hogy az FKgP mögött „hárommillió lélek” áll és ez a tömeg a demokratikus fejlődést szolgálja. „Velük számot kell vetnie minden józan politikusnak és azzal is, hogy ez a tömeg nem kommunista és nem marxista" - szögezi le Kovács. A politikus szerint a kommunisták is tisztában vannak azzal, hogy „nélkülünk csak kisebbségi diktatúrát tudnának csinálni és ez talán még az ő értelmezésük szerint sem volna demokrácia. Bár lehet, hogy tévedek."

A történelmi tények ismeretében - a kisgazda politikus sorsát is ismerve - utólagosan tudjuk, Kovács Béla súlyosan tévedett. Rákosi Mátyás már a Kovács-cikk megjelenésének hétvégéjén meghirdette, hogy az országnak a népi demokrácia útjára kell lépnie, amely fogalom akkor még nem volt tisztázott, a későbbiekben viszont a kommunista diktatúra kvázi szinonimájává vált.

Rákosi a kongresszuson arról beszélt, hogy a Magyar Kommunista Párt a nemzeti demokrácia reformjáért száll síkra. A demokrácia reformjának eszközeként beszélt a kommunista pártvezér arról, hogy küzdeni fognak az állami, községi termelési formák fejlődéséért, a szövetkezetek kiépítéséért és a bankok állami irányításáért.

Rákosi Mátyás e szavai is jelezték az új korszakot: „A reakciós jobboldal fel akarja bomlasztani a koalíciót. Igyekszik rákényszeríteni a formális többséggel rendelkező, de csak a demokratikus kisebbséget képviselő Független Kisgazdapártra akaratát, a demokráciát ténylegesen képviselő Baloldali Blokk ellen. Mi nem a formális, hanem a tényleges demokrácia hívei vagyunk”226 A fötitkár beszédében arról is szólt, hogy „mély kommunista meggyőződésből” építik a magyar demokráciát. „Biztosak vagyunk ügyünk sikerében és tudjuk, hogy csak a népi demokrácia biztosíthatja a magyar termelőerők fejlődését a dolgozók

\footnotetext{
${ }^{224}$ Kovács Béla életútjáról: PALASIK Mária: Kovács Béla 1908-1959. Occidental Press-Ezerkilencszáznegyvenöt Alapítvány-Századvég Kiadó, Budapest, 2002.

${ }^{225}$ KoVÁCS Béla: Nélkülünk nincs demokrácia. Kis Újság, 1946. szeptember 28. 1. p.

${ }^{226}$ Rákosi Mátyásnak az MKP III. kongresszusán elmondott beszédéből idéz: Délmagyarország. 1946. október 1. 1. p. A kongresszus teljes publikált jegyzőkönyve: A népi demokrácia útja. A Magyar Kommunista Párt III. kongresszusának jegyzőkönyve. A Magyar Kommunista Párt Budapesten 1946 szeptember 28., 29., 30. és október 1-én tartott III. kongresszusának jegyzőkönyve. Szikra Kiadó, Budapest, 1946.
} 
javára. Csak a népi demokrácia ${ }^{227}$ teszi lehetővé, hogy országunk a társadalmi fejlődés útján haladjon a szocializmus felé. Hassa át pártunk minden tagját az a meggyőződés: Jöjjön aminek jönni kell, a jövő a mienk!" 228 - mondta ki Rákosi Mátyás, hogy a kommunisták rövid távú céljává vált a szocializmus megteremtése.

Rákosi szövegében expressis verbis jelenik meg, hogy a demokráciát „ténylegesen” csakis a baloldal képviseli. A kommunista pártvezér azt is kimondja, hogy ők nem „formális” (vagyis szabályozott, játékszabályok, jogállami normák alapján müködő) demokráciát kívánnak építeni, hanem „tényleges” demokráciát. Kitünik, hogy a „tényleges” kifejezés használata rendkívül hangsúlyos Rákosi megszólalásában, a szöveg dinamikájából egyértelmü: csakis a népi demokrácia lehet a tényleges demokrácia. A kongresszusi beszéd nyelvhasználata nyilvánvalóan kizáró/kirekesztő jellegü, a beszélő homogenisztikus pozícióra tör.

Rákosi Mátyás a Társadalmi Szemle 1949. januári számában A népi demokrácia néhány problémájáról címmel publikált elméleti jellegü tanulmányt. Rákosi cikke elején leszögezi, hogy a népi demokrácia új államtípus, mert csak a második világháború után keletkezett, s a Szovjetunió háborús győzelmének köszönhetően jött létre. A kommunista pártvezető így deklarálta a népi demokrácia fogalmát 1949 elején: „A kapitalizmusból a szocializmusba való átmenet állama, mely csak úgy teljesítheti történelmi hivatását, ha következetesen halad a szocializmus felé vezetö úton."229 Rákosi a népi demokrácia jellemzőjének tekinti azt is, hogy a szovjet rendszer átvétele nélkül zajlik az átmenet a szocializmusba, ugyanakkor kijelenti: „A népi demokrácia funkciójára nézve proletárdiktatúra szovjet forma nélkül.",230

Rákosi történeti elemzése arról szól, a szovjet formára azért volt szükség, mert a fiatal szovjet államnak létrejötte után rendkívüli mértékben kellett védekeznie. „Ez az életre-halálra menő küzdelem kényszerítette ki azt a kíméletlen terrort, amellyel a Szovjet védekezett"231 fogalmaz a kommunista pártvezető, aki úgy vélte, egészen más a „népi demokráciák” helyzete, mert „a felszabadító szovjet hadsereg” jelenléte 1945 után Kelet-Európában biztosította, hogy ,a dolgozó nép vegye kezébe a hatalmat.” S a szovjet hadsereg fizikai itt

\footnotetext{
${ }^{227}$ A kongresszusi Rákosi-beszéd után Horváth Márton kommunista ideológus a Társadalmi Szemlében, a Magyar Kommunista Párt tudományos folyóiratában világította meg a népi demokrácia kifejezés értelmét: „A népi demokrácia nem semmisíti meg a termelöeszközök magántulajdonát: egyszerüen a polgári demokrácia leghaladóbb (helyesebben: egyetlen haladó) formájának is lehet tekinteni." (HORVÁtH Márton: A III. kongresszus. Társadalmi Szemle, I. évf. (1946) 10. 693-701. p.)

${ }^{228}$ Délmagyarország. 1946. október 1. 1. p.

${ }^{229}$ RÁKOSI Mátyás: A népi demokrácia néhány problémájáról. Társadalmi Szemle, IV. évf. (1949) 1. 1. p.

${ }^{230}$ Uo. 2. p.

${ }^{231}$ Uo. 4. p.
} 
léte eleve kizárta, hogy a burzsoázia nyílt fegyveres felkeléseket robbantson ki. „Ez a körülmény tette lehetővé, hogy a népi demokrácia állama viszonylagosan békésen, véres polgárháborúk nélkül el tudja végezni a proletárdiktatúra funkcióit anélkül, hogy a proletárdiktatúra szovjet formáját öltené"232 - fejtegette Rákosi.

Rákosi Mátyás tanulmányában azt írja, három esztendős „,kemény munka” után tudták döntésre vinni azt a kérdést, hogy „polgári” vagy „népi” demokrácia lesz Magyarországon. „A szovjet hadsereg leverte a kezeinkröl a bilincset, de a demokráciát nem építheti fel helyettünk, ezt nekünk kell elvégezni. S amíg meg nem nyertük a dolgozó nép nagy többségét, addig a mi országunkban is olyan »kettős hatalom«-féle volt, mint 1917-ben Kerenszkij idején" 233 - hangsúlyozta Rákosi, aki a kommunista hatalomátvétel, a proletárdiktatúra kialakításának folyamatát az „amíg meg nem nyertük a dolgozó nép nagy többségét" eufémizmussal írta le.

\subsection{Szociáldemokrata demokráciaértelmezök}

Szakasits Árpád, a magyar szociáldemokraták vezéregyénisége A demokráciáról és a szocializmusról címmel beszélt a Demokrácia-előadássorozaton 1945 nyarán. Szakasits Rákosival ellentétben nyíltan szólt arról, hogy a végső cél nem lehet más mint a szocializmus. 1945-46-ban a szociáldemokraták jelszava volt: „Ma a demokráciát, holnap a szocializmust!” A szociáldemokrata politikus leszögezte, hogy a polgári demokrácia „,válságba jutott."234 Szakasits szerint „ha a demokrácia tökéletes rendszer lenne, nem született volna meg a szocializmus.” A szociáldemokrata politikus a demokrácia gazdasági rendjének hibájául rója fel, hogy „,szabadjára eresztette a kereskedelmet." ${ }^{235}$ Szakasits Árpád a következő kérdést veti fel: „mit ér az a szabadság, mely a tőkést és a proletárt egymás mellé állítja?” ${ }^{236}$ A maga által felvetett dilemmára azt válaszolja, hogy „ez csak annyit ér, hogy a tőkés felfalja a proletárt.” Az eddig ismertetett szakasits-i gondolatokból is kitetszik, a politikus ellene megy a polgári demokrácia eszményének, de csak elvi szinten mer szembenézni azzal, hogy a szocializmus egyben diktatúra és a szabadság korlátozása. „Átvesszük a szabadság eszményét, mert

\footnotetext{
${ }^{232}$ Uo. 5.p.

233 Uo.

${ }^{234}$ Uo. 168. p.

${ }^{235}$ Uo. 172. p.

${ }^{236}$ Uo. 173.p.
} 
kezünkön vannak a terror, a bilincsek okozta sebek. De ez a szabadság sem gáttalan, parttalan"237 - mondja Szakasits.

1945 nyarán az ország már egyre inkább a parlamenti választásokra várt, készült. A napi pártpolitikai csatározásokon túlmenően a demokrácia mibenlétéről szóló értelmezési vita sem szünt meg a választások előtti hónapokban. Már a választási előkészületek alatt jelent meg Faragó László ${ }^{238}$ Öngyilkos demokrácia címü tanulmánya a szociáldemokraták elméleti lapjában, a Szocializmusban. Faragó szerint a szociáldemokraták a szocializmust és a demokráciát „ugyanolyan komolyan”239 veszik. Faragó úgy véli, a polgári demokrácia „csonka demokrácia,” amely megadja „a szabad futás lehetőségét a munkásosztálynak, de ugyanakkor gazdasági téren gondosan ügyel a tőke szupremáciájára." ${ }^{240}$ Faragó egy új fogalmat használ, szerinte a „proletárdemokrácia országútjára” kell térni. Faragó László ugyanakkor kifejti, „öngyilkos” az a demokrácia, amely „nem-demokratákat enged falai közé." ${ }^{241}$ Az öngyilkos demokrácia egyik példájának tekinti a weimari demokráciát. Arról ír, hogy a „munkásosztály demokráciáját” szükséges kialakítani, amely a szociáldemokrácia elveinek megfelelően tartalmazza a politikai demokráciákra jellemző „politikai szabadságot” is, ami biztosítja a „másként” akarás lehetőségét, vagyis a proletárdemokráciában is létezne a véleménynyilvánítás szabadsága. Úgy véli, „,kijár a demokrácia”242 a polgári elemek számára is - de csak akkor, ha „nem állnak a gazdasági demokrácia kiteljesedésének útjába.”

A köztársasági törvény javaslatának parlamenti vitájakor a szociáldemokraták vezérszónoka, Kéthly Anna abbéli reményét fejezte ki, hogy az új köztársaság, a létrejövő magyar demokrácia fogja „megajándékozni” a magyar népet azokkal a demokratikus élményekkel", amelyekhez eddig hozzá nem jutott. Kéthly Anna a Szocializmus címü szociáldemokrata lapban fejtette ki bővebben a maga demokrácia-koncepcióját 1946 márciusában. A Szocializmus Bibó István A magyar demokrácia válsága cikkének megjelenése és az azt követő vita után a saját felületén hirdetett fórumot a demokrácia értelmezéséről. ${ }^{243}$ Kéthly cikkében hibának nevezte, hogy a koalíció szereplői korábban nem

\footnotetext{
${ }^{237}$ Uo. 176. p.

${ }^{238}$ Faragó László közéleti tevékenységéröl: FARAGÓ László (1896-1967). A demokrácia kilátásai. Egy politikus írástudó gondolataiból. Összeállította, jegyzetekkel ellátta és szerkesztette: JEMNITZ János - SzÉKELY Gábor. Magyar Lajos Alapítvány, Budapest, 1998.

${ }^{239}$ FARAGÓ László: Öngyilkos demokrácia. Szocializmus, XXIX. évf. (1945) 2. 82. p.

${ }^{240}$ Uo. 83. p.

${ }^{241}$ Uo. 84. p.

${ }^{242}$ Uo. 86. p.

${ }^{243}$ A lap szerkesztőbizottsági tagja, Justus Pál utalást is tett arra, hogy a Bibó tanulmánya gerjesztett disputára kíván reagálni a szociáldemokrata folyóirat a „Vita a demokrácia értelmezéséről” felütésü lapszámmal. Justus szerint a „küzdelem” a demokrácia válságáról ,jóindulatú” vita ugyan, de „kellő szociológiai megalapozás
} 
tisztázták felfogásukat a demokráciáról. A szociáldemokrata politikus kerüli „,a demokrácia válsága” fogalmat, ő inkább a demokrácia „funkciózavara”244 kifejezést használja. Kéthly aggódik amiatt, hogy a katonai vereséget szenvedett fasizmus megkísérli „a bevonulást a demokrácia keretébe" ${ }^{245}$ - úgy ítéli meg, hogy a régi és az új világ közé éles vonalat kell húzni és kiemelt figyelmet szükséges arra fordítani, hogy a „demokrácia eszméinek” a táborát szélesíteni lehessen, mert a korábbi évtizedek „lélekmérgezése” eltántorítja a demokrácia eszméitől a népet. A szociáldemokrata pártvezető azt a jelenséget is elemzi, hogy a totális államokban nem lehet kritika, ezért úgy tűnhetett, hogy nincs is baj, míg a demokráciában véleményszabadság létezik, ki lehet beszélni a gondokat, így viszont óhatatlanul úgy érzékelhetik a tömegek, hogy a demokráciában állandóan csak hibák vannak. Kéthly jogosnak tartja, hogy az egyenlőség érdekében a demokrácia szabadságeszményének a rovására történjenek politikai döntések, cselekmények, de mindezt csakis úgy, hogy a szabadságeszmény „csődjét” ne jelentsék e lépések. „Vannak, akik demokráciánk funkciózavarai ellen orvosságként a diktatúrát követelik. Ki-ki a magáét, a reakció »reálpoltikusai« a »szakemberek«, a szélsőbal romantikusai a proletártöbbség jogán”246 - írja Kéthly Anna, majd kissé illuzórikusan leszögezi, hogy a demokrácia bajait csak a „demokrácia gyógyszerével” lehet megszüntetni. ${ }^{247}$

A Szocializmus e demokrácia-számában a szociáldemokrata Justus Pál a már akkoriban is használatos - fóként a kommunisták által hangoztatott - népi demokrácia kifejezést kívánta górcső alá venni. Tanulmányában feltette a kérdést, mi értelme van a népi demokrácia kifejezésnek? És mi a tartalma a „népi” demokráciának? „A jelző mit sem ad a főnévhez, nemhogy pontosabbá tenné jelentését, inkább elvesz élességéből: de jellemző tünet. Úgy látszik, napjainkban éppen a demokrácia lényege, egyetlen értelme vált bizonytalanná, vagy forog veszélyben, ha a népuralom népi jellegét kell hangsúlyozni” ${ }^{248}$ - írja Justus. Ebben a formában ez az idézet arra utalhat, hogy Justus a kommunista demokrácia-koncepciót

\footnotetext{
hiányában" nem visz elöre. (Justus Pál: Demokrácia és szocializmus. Szocializmus, XXX. évf. (1946) 3-4. 102-106. p.)

${ }^{244}$ KÉTHLY Anna: Vita a demokrácia értelmezése körül. Szocializmus, XXX. évf. (1946) 3-4. 97-102. p.

${ }^{245}$ Uo.

${ }^{246}$ Uo. 102. p.

${ }^{247}$ Strassenreiter Erzsébet, a Kéthly Anna életútját kutató történész úgy véli, Kéthly már a koalíciós időszakban nyíltan szembefordult nemcsak a jobboldali, hanem a baloldali diktatúra lehetőségével, eszmeiségével és gondolatával is. A kommunistákkal ellentétben, akik csak a jobboldali veszélyre irányították a tüzet, Kéthly állította: jobbról és balról is vannak, akik a „funkciózavarok elleni orvosságként, megoldásként a diktatúrát keresik.” Strassenreiter idézi Kéthly idevágó szavait: „Ki-ki a maga diktatúráját, az egyik a »szakértelem«, a másik a proletártöbbség jogán. Természetesen egyik sem orvosság, és egyik sem tudná megoldani a kérdéseket.” (STRASSENREITER Erzsébet (szerk.): Kéthly Anna válogatott levelei (1921-1976). Napvilág Kiadó, Budapest, 2011. 38-39. p.)

${ }^{248}$ Justus Pál: Demokrácia és szocializmus. Szocializmus, XXX. évf. (1946) 3-4. 102-106. p.
} 
bírálja, de a szöveg összességét elemezve, inkább azt feltételezhetjük, hogy Justus pusztán nyelvileg támadja a népi demokrácia kifejezést és nem politikai tartalmú értékítéletet mond. A szociáldemokrata közéleti személyiség abban viszont feltétel nélkül a kommunista álláspontot vallja magáénak, miszerint ,a demokrácia nem terjed ki a demokrácia ellenségeire.”249 Justus Pál - a koalíciós időszak szociáldemokrata politikusaihoz hasonlatosan ${ }^{250}$ - nem tartja összeegyeztethetetlennek a demokráciát és a szocializmust - az MKP-tól eltérően az SZDP beszél a nyilvános kommunikáció színterein is a szocializmus szükségességéről vizsgált korszakunkban. Justus szerint „,az osztálynélküli társadalom ad majd reális, megbonthatatlanul egységes tartalmat a demokráciának."251

Faragó László $A$ demokrácia kilátásai című tanulmányában ${ }^{252}$ a kommunisták által emlegetett „harcos demokrácia” kommunikációs panel gondolati testvéreként - persze erős habitusbéli különbséggel - a „védekező demokrácia” fogalmat hozza be a nyelvpolitikai térbe. Faragó úgy véli, a demokráciának folyamatos önvédelemre van szüksége. A szerző szerint a demokrácia ,a szabadság organizált államrendje [...] Az osztályharc ugyanis a demokráciában is tovább folyik." ${ }^{253}$ Faragó László demokrácia-koncepciójának központi eleme az osztályharc, az igazi demokráciát is olyan struktúrának láttatja, amely keretet ad az osztályküzdelemnek.

Szintén a Szocializmus Demokrácia-értékelő számában Erdődy János úgy vélekedik, hogy a demokrácia megteremtése „felmérhetetlen nagyságú feladatot” ${ }^{254}$ jelent, mert egy „,antidemokratikus beállítottságú országban” kell demokráciát teremteni. E feladat ellátáshoz a szociáldemokrata politikus szerint át kell nevelni a nép egyéneit, hogy úgymond „alattvalókból állampolgárokká” válhassanak. „Nem szabad a demokrácia doktrinér értelmezésével útjára engednünk, hiszen a nem demokratikus nép demokráciája a kormányzáshoz nem értő nép uralma nem lenne demokrácia. Ízelítőt kaptunk már ebből a választásokon, amikor a választójog váratlan és erős italától elbódult nép azt a furcsa és keletlen gyurmát tette a nemzetgyülés asztalára, amit ma ott látunk"255 - fogalmaz keményen és egyben lefegyverző őszinteséggel Erdődy. A metafora lényege, hogy a kisgazdák hatalmas választási győzelmét „,keletlen” gyurmához hasonlítja a szociáldemokrata közéleti szereplő,

\footnotetext{
${ }^{249}$ Uo.

${ }^{250}$ A szociáldemokraták koalíciós évekbeli demokrácia-felfogásáról: MOLNÁR János: A Szociáldemokrata Párt demokrácia-felfogásának fö vonásai 1944 után. In: A Magyar Politikatudományi Társaság évkönyve. Magyar Politikatudományi Társaság, Budapest, 1984. 168-175. p.

${ }^{251}$ JuSTUS Pál: Demokrácia és szocializmus. Szocializmus, XXX. évf. (1946) 3-4. 102-106. p. 105. p.

${ }^{252}$ FARAGÓ László: A demokrácia kilátásai. Szocializmus, XXX. évf. (1946) 3-4. 106-112. p.

${ }^{253}$ Uo. 111. p.

${ }^{254}$ ERDÖDY János: Magyar demokrácia. Szocializmus, XXX. évf. (1946) 3-4. 116-118. p.

${ }^{255}$ Uo. 118. p.
} 
az egész koalíciós időszakon átívelő elméleti-politológiai dilemma pedig úgy fogalmazható meg: mennyiben szolgálja a demokráciát a demokratikus választásokon létrejövő többség? A szociáldemokraták válasza erre a jelenségre az 1945-ös esztendőt követő esztendőkben a Weimar-szindróma kommunikációs panelként való használata.

\subsection{Parasztpárti demokráciaértelmezők: Erdei Ferenc kontra Kovács Imre}

\section{Erdei Ferenc}

Erdei koalíciós évekbeli demokrácia-felfogásának fontos jellemzője a polgári vagy jogállami demokrácia, a szabadságjogok rendszerére épülő demokrácia fogalmának relativizálása. Erre utaló nyelvi paneljei már a Demokrácia előadássorozaton elhangzott Népi demokrácia címü előadásában is megjelentek. ${ }^{256} \mathrm{Az}$ előadó a népi demokrácia kifejezést kívánta „negatív” és „pozitív” megközelítésben ábrázolni. A negatív nézőpont, vagyis a nemleges értelmü fogalomalkotás szerint a népi demokrácia azt jelenti, „a nép, a társadalom fölött ne uralkodjék semmiféle önkény."257 A Nemzeti Parasztpártot képviselő Erdei amellett tesz hitet, hogy a népi demokrácia azt is jelenti, hogy sem „,egyetlen diktátor”, sem „akár egy megszervezett vékony uralkodó réteg” nem uralhatja a nép életét. Figyelemreméltó a belügyminiszter azon véleménye, miszerint „hatalmas tévedésben” van az, aki „,napjaink népi demokráciájában” a polgári demokrácia „klasszikus szabályokban kifejezheto” formáit keresi. Erdei a liberális polgári demokrácia „légkörét,” szabályait „,anakronisztikus” szemléletűnek bélyegzi. Érvei a sajtó- és szólásszabadság korlátozásáról szólnak, mert úgy véli, ha a szólás szabadságát „korlátlanul” értelmeznénk, akkor „lehetőséget adnánk a nép ellenségei számára is, ami a demokrácia igen közeli felborulását eredményezné.” ${ }^{258}$ Az előadó a „,személyes szabadságot” és a „szerzett jogokat” is ilyen dimenzióból tartja korlátozhatónak. Erdei szerint, ha nem lehetne hozzányúlni a személyes szabadság eszményéhez, akkor lehetetlenné válna a társadalom gyökeres átalakítása. A belügyminiszter kísérletet tett a népi demokrácia definiálására is: „Mi tehát sajátlagosan a mi népi demokráciánk? A nép felszabadulásának a politikai módszere és pedig nem aranyszabályokkal körülírt nyugvó rend, hanem

\footnotetext{
${ }^{256}$ HUSZÁR Tibor: Erdei Ferenc. Politikai életrajz 1910-1971. Corvina Kiadó, Budapest, 2012. 78-136. p., 294307. p.

${ }^{257}$ Demokrácia, 1945. 8. p.

${ }^{258}$ Uo. 9. p.
} 
felszabadulási folyamat." ${ }^{, 259}$ Érdemes magát az Erdei-féle fogalmat külön kiemelni, szerinte a népi demokrácia nem más mint egy „felszabadulási folyamat,” aminek célja a népuralom biztosítása. Erdei demokrácia-felfogása egyértelmüen a kommunista demokrácia-képhez áll közel. A parasztpárti politikus is úgy véli, a formális szabályok nem fontosak, a lényeg a társadalom gyökeres átalakítása, nincsenek általánosan, mindenkire egyaránt érvényesülő jogok, mert ezzel az „ellenség” kapna plusz lehetőséget.

„Azt nem lehet örök érvényüen megmondani, hogy mi a demokrácia. [...] Az elvont okoskodásoktól teljesen függetlenül a történelem folyásában különböző elvi demokráciák követik egymást” - ezt már egy 1947. januári nem nyilvános előadásában mondja Erdei. „A demokráciát tehát nem magában véve, kortól és helytől eltekintve s elvonatkoztatva kell megítélni, hanem mindig aszerint, hogy milyen társadalmi helyzetről és milyen történelmi korszakról van szó. ${ }^{\text {260 }}$ Erdei 1947 elején arról beszél, hogy a polgári demokrácia - hiába léteztek a mindenkire egyaránt vonatkozó szabadságjogok - nem tette boldogabbá az emberiséget, ezért nem is lehet az „egyedül lehetséges” formája a demokráciának. „A szabadságjogok általános biztosítása megerősíti, konzerválja a dolgozó osztályok kizsákmányolását és elnyomását"261 - fejtegette Erdei. A népi demokráciát így igyekszik definiálni: „A népi demokrácia nem a szocializmus felé vezető út, hanem a demokrácia valóságos megteremtésének az útja. [...] A népi demokrácia valóságos népuralmat, a dolgozó osztályok uralmát akarja megvalósítani.",262

Az imént idézett Erdei-féle gondolatokból az tünik ki, hogy a szociológus-politikus élesen elutasítja a szabadságjogok rendszerére épülő demokráciát, de nem szeretne proletárdiktatúrát sem, ${ }^{263}$ hanem a két struktúra között képzeli el a népi demokrácia világát, amely uralmi forma képes hatékonyan megváltoztatni a társadalom kialakult rendjét. ${ }^{264}$

Erdei a Fórum című társadalomelméleti lap 1946. novemberi számában publikálta $A$ Válság vitájához címü esszéjét. Az írásban a parasztpárti politikus szociológusi-tudósi és

\footnotetext{
${ }^{259}$ Uo. 10. p.

260 ERDEI Ferenc: Demokrácia, népi demokrácia, szocializmus. In: ERDEI Ferenc: Politikai írások. 2. kötet. Válogatás. Szerkesztette: Tamasi Mihály. Bába Kiadó, Szeged, 2003. 9. p.

${ }^{261}$ Uo. 11. p.

${ }^{262}$ Uo. 12. p.

${ }^{263}$ Tóth István szerint Erdei abban bízott 1946-ban, hogy a kommunisták által dominált „harcos demokrácia” konszolidálódni fog és nem jutnak el a proletárdiktatúra stádiumáig. (TóTH István: A Nemzeti Parasztpárt demokráciafelfogása (1945-1946). In: FEITL István (szerk.): Köztársaság a modern kori történelem fényében. Napvilág Kiadó, Budapest, 2007. 310-323. p.)

${ }^{264}$ Köpeczi Béla Erdei demokrácia-dilemmájáról és demokrácia-értelmezéséről így ír: „1948-ig meg van győződve arról, hogy [...] a népi demokratikus szakasz nem rövid. [...] Ez az álláspont távol áll Bibó István demokráciakoncepciójától, amelyet ma sokan az Erdei által említett körülményeket nem tekintve, idealizálnak. De a népi demokrácia Erdei számára mégsem szocializmus, és nem is vezet szükségszerüen oda: a népi demokrácia szerinte nem szocialista rendszer, csak kapitalistaellenes politika.” (KÖPECZI Béla: Erdei Ferenc, a politikai gondolkodó. A Makói Múzeum Füzetei 39. Makó, 1985. 8. p.)
} 
közéleti szerepe keveredik. E keveredés által a szöveg élőbbé válik, hiszen a politikai propagandaelemek és sablonos kommunikációs panelek kellő mértékben szorulnak vissza, teret adva a gondolatilag tisztább elemzés számára. A tanulmány egyes részei kifejezetten a tudományos nyelvhasználati mód jellegzetességeit mutatják. Erdei pontos szociológusi elemzése szerint az akkori közélet szereplői két nyelven beszélnek, a két nyelv egymással folyton szembekerül, s a nyelvek grammatikája végzetesen eltérő. „Ez a két nyelv nem tud úgy vitatkozni egymással, hogy ebből a vitából valami közös álláspont kialakulhasson” fejtegeti Erdei. ${ }^{265}$ A szerző úgy látja, a demokráciának magának is a „legelső és legnehezebb” próbája a demokrácia értelmezése, s a baj gyökere itt is a két egymással antagonisztikus viszonyban lévő nyelv megléte. Erdei azt boncolgatja, hogy az egyik nyelv szerint a demokrácia az „egyenlő feltételeket nyújtó játékszabályok” érvényesítését jelenti, míg a másik nyelv demokrácián a „régi uralkodó osztályok hatalmának, kiváltságainak megszüntetését” és ,,a parasztság és a munkásság felszabadulási harcának a módszerét” érti. ${ }^{266}$ Az elemzésnek eddig a szakaszáig beszélt Erdeiből a tudós, innentől jött a közéleti szereplő, aki arra tett javaslatot, hogy miként lehetne a két nyelvet egymáshoz közelíteni; mert a cél „,valamiféle közös nyelv” kialakítása lenne. A közös nyelv alapjának tekinti Erdei az „objektív hozzáállást” és a „nyelvi alkalmazkodás” lehetőségét; ehhez szerinte a marxistáknak le kell mondaniuk „,a marxista frazeológia egynémely kiművelt formulájáról.” ${ }^{\text {„67 }}$ A másik nyelv képviselőinek pedig nagyobb megértést kell tanúsítaniuk a marxista nyelvhasználattal szemben. Erdei a közös nyelv megvalósításának gyakorlati alapját abban látja, hogy a két különböző nyelvet beszélő politikai erő megállapodik abban, hogy fel kell számolni a régi rend kiváltáságait, a parasztság és a munkásság számára új rendet kell teremteni és modernizálni szükséges a közigazgatást. E felsorolásból az is kitetszik, hogy e pontok azok, amelyek alapvetőek és lényegiek Erdei demokrácia-értelmezésében.

A szöveg érveléstechnikáját megvizsgálva az tünik ki, hogy Erdei Ferenc 1946 őszén még hitelesesnek mondható módon hitt ennek a bizonyos közös nyelvnek a megvalósíthatóságában. Erdei a közös nyelv struktúráját a népi demokrácia általa képviselt eszmeiségében látja megalkothatónak. A szociológus-politikus e szövege arra is illusztratív

\footnotetext{
${ }^{265}$ ERDEI Ferenc: A Válság vitájához. Fórum, I. évf. (1946) 3. 243-250. p. /245. p./

${ }^{266}$ Uo. 245-247. p.

${ }^{267}$ Uo. 246. p.
} 
bizonyíték lehet, hogy Erdei a közös nyelv megteremtésével a nyílt proletárdiktatúra elkerülésében bízik. ${ }^{268}$

\section{Kovács Imre}

Mind Erdei, mint Kovács Imre a Nemzeti Parasztpártban politizáltak Kovács 1947. februári kilépéséig. Demokrácia-értelmezésük azonban élesen szemben áll egymással. Erdei a radikális társadalom-átalakítás érdekében nem fogadja el a mindenkire egyaránt érvényes szabadságjogok alkotmányos szerepét, ezzel ellentétben Kovács Imre nagyobb fontosságot tulajdonít a jogállamiság eszméjének. Erdei maga úgy látja, Kovács Imre „középre” akarja helyezni „a magyar demokrácia súlypontját” és a többségre támaszkodva „megegyezéses” demokráciát kívánna. ${ }^{269}$ Erdei a megegyezéseknek mint politikai cselekvéseknek szánna kisebb szerepet, az ő nézőpontjából a népi demokrácia államának - akár a szabadságjogok korlátozása által - határozottan kell elvégezni a társadalom-átalakító munkát.

Erdei Ferenc 1945 óta megszólalásaiban felvállalja a népi demokrácia fogalom használatát. A kommunisták viszont csak 1946 őszétől birtokolják intenzívebben a népi demokrácia kifejezést. Erdei akkor került fogalmi-nyelvi vákuum helyzetbe, amikor egyre inkább szembesülni kényszerült azzal, hogy az általa népi demokráciának láttatott struktúra lényegesen különbözik a kommunisták népi demokrácia fogalmától, merthogy az alapvetően a proletárdiktatúra államberendezkedéséhez közelít. Erdei felvállalta a belső eszmei meghasonlást és nem ment szembe a formálódó diktatúrával, Kovács Imre számára viszont a demokrácia rendjének a megdöntése nem volt vállalható érzelmi-politikai kompromisszum.

„A demokrácia újabb megjelölése, a népi demokrácia, ahogy azt Rákosi Mátyás ismeretes kongresszusi beszédében kijelentette, út a szocializmushoz [...] Könnyen megtörténhetik azonban, hogy átugorjuk a demokrácia klasszikus fejlődési szakaszát és hirtelen belépünk a szocializmusba, amennyiben a szocializmus lesz a következő, vagy végső fejlődési periódus" ${ }^{270}$ - írja A demokrácia útja Magyarországon címü tanulmányában Kovács Imre parasztpárti író-politikus 1946 novemberében. ${ }^{271} \mathrm{Az}$ esszé Bibó István A magyar

\footnotetext{
${ }^{268}$ A Nemzeti Parasztpárton belüli küzdelmekröl bővebben: TóTH István: Két fordulat a Nemzeti Parasztpártban. In. FeITL-IZSÁK-SZÉKELY: Fordulat a világban és Magyarországon 1947-1949. Napvilág, Budapest, 2000. 281290. p.

${ }^{269}$ Uo. 244. p.

${ }^{270}$ KovÁCS Imre: A demokrácia útja Magyarországon. Válasz, II. évf. (1946) 11. 97-106. p.

${ }^{271}$ Tóth István, a Nemzeti Parasztpárt történetével foglalkozó történész szerint Kovács Imre $A$ demokrácia útja Magyarországon címü tanulmányában megfogalmazottak lényegében Kovács „politikai krédójának tekinthetőek.” (TóTH István: Kovács Imre, a parasztpárti vezető 1939-1947. In: SIPOS Levente (szerk.): Kovács
} 
demokrácia válsága írása mellett a korszak különösen figyelemreméltó demokrácia-elemzését mutatja fel. Természetesen sem terjedelmében, sem későbbi hatásában Kovács Imre publikációja nem mérhető Bibó sokat hivatkozott A magyar demokrácia válsága dolgozatához. ${ }^{272}$ Ha azonban a lényeglátás elemei szempontjából figyeljük a szöveget, akkor azt mondhatjuk, Kovács a kommunisták diktatórikus szándékait illetően tisztábban, realisztikusabban lát, mint Bibó $^{273}$. A hasonlóságokat figyelve azt is kijelenthetjük, a két parasztpárti szerző annyiban azonos nézeteket vall, hogy mindketten a hagyományos demokratikus szabadságjogoknak komoly szerepet szánnának a jövendő demokráciájában, ugyanakkor mindkettőjük markáns szociális tartalommal kívánná megtölteni a demokrácia kereteit. A két szerző akár közéleti szövetséges is lehetett volna, már csak azért is, hiszen mindketten a Nemzeti Parasztpárt tagjai voltak, de viszonyuk inkább rossznak nevezhető. Ami azzal is összefüggött, hogy Kovács Imre legnagyobb párton belüli riválisa és politikai ellenfele Bibó személyes jó barátja, Erdei Ferenc volt, ezért személyes nexusukban nem tudott bizalmi helyzet kialakulni.

Kovács kiindulópontja A demokrácia útja Magyarországon című tanulmányában az, hogy Magyarországon nincsenek hagyományai a demokráciának: ${ }^{274}$ „Úgy lettünk

Imre centenáriuma. Tudományos emlékülés a Politikatörténeti Intézetben. Napvilág Kiadó, Budapest, 2013. 149. p.)

A Kovács Imre demokráciafelfogásáról szóló tanulmányában Sipos Levente történész azt a jelenséget is elemzi, hogy 1945 után Kovács saját meggyőződésének illusztrálására sohasem használja a „népi demokrácia” fogalmat, noha a második világháború előtt azt megtette. „A népi kifejezést a Magyar Kommunista Párt (és Erdei Ferenc is) használta egy olyan hatalmi rendszernek a jelölésére, amely ugyan többpártrendszer, de a kommunista párt vezető szerep érvényesül benne, s amely valójában a szocializmus elöszobája. Később a proletárdiktatúra fedőneve lett. Kovács Imre, aki kiváló politikai érzékkel megáldott, a nemzetközi helyzet alakulását figyelemmel kísérő, mindig a jövőt fürkésző, messzelátó politikus volt, belelátott a kommunisták lapjaiba. Ezért tekintett el a "népi« és a »demokrácia« fogalom összekötéséröl” (SIPOS Levente: Kovács Imre demokráciafelfogása. In: SIPOS Levente (szerk.): Kovács Imre centenáriuma. Tudományos emlékülés a Politikatörténeti Intézetben. Napvilág Kiadó, Budapest, 2013. 124-125. p.)

${ }^{272}$ Szabó A. Ferenc egyértelmüen Kovács Imre demokrácia-értelmező publicisztikáját Bibóéhoz hasonlítja: „Kovács Imréhez hasonló szívós következetességgel az ország nemzetközi helyzetének javításával - kortársai közül - csak Bibó István foglalkozott. Szintén Bibó nevét kell említenünk, ha Kovács demokráciafelfogását vizsgáljuk meg. 1946 őszén nagy tanulmányt jelentetett meg a Válaszban A demokrácia magyar útja címmel, amely több ponton emlékeztetett Bibó egy évvel korábbi, nagy port és vitát felkavart tanulmányának gondolatmenetére (Bibó 1945). Bibó Istvánhoz hasonlóan Kovács Imre a magyarországi politikai helyzet legaggasztóbb vonásának a szélsőségek felülkerekedésének veszélyét tartotta. Az egyik szélsőséget az 1946-ban már egyre leplezetlenebbül a hatalomra törö kommunista pártban, a másikat a régi társadalmi-politikai rendszer restaurálására törekvő erők között találta meg.” (SZABÓ A. Ferenc: Kovács Imre és a politikatudomány. Politikatudományi Szemle, II. évf. (1993) 4. 72-83. p. /80.p./)

Szintén a Bibó István-Kovács Imre párhuzamot emeli ki Nagy Endre: „Mint Bibó, Kovács Imre is megírta maga A magyar demokrácia válságát A magyar demokrácia útja címmel" (NAGY Endre: Kovács Imre 2. Kritika, XLIII. évf. (2014) 3-4. 27-29. p. Elérhető: http://www.kritikaonline.hu/kritika_14marc-aprilis nagyendre.html /A letöltés időpontja: 2016. február 7./)

${ }^{273}$ Bibó István koalíciós évekbeli demokráciaértelmezéseivel egy későbbi alfejezetben foglalkozunk.

${ }^{274}$ Standeisky Éva szerint „Kovács Imre a demokrácia megszállottja volt” (STANDEISKY Éva: Demokrácia negyvenötben. Napvilág Kiadó, Budapest, 2015. 206. p.), aki egyetlen területen ment szembe a saját maga által 
demokraták, hogy nem voltunk demokraták. A múltunkban vannak demokratikus törekvések, a nép minden időben a maga módján és eszközeivel, a lehetőségek határain belül demokráciát akart, a magyar történelem kettős mozgású, társadalmi és nemzeti harcok szűnni nem akaró folyamata, a nép fölfelé, a nemzet kifelé harcol szabadságáért, életéért: a magyar uralmi szerkezet azonban a legutóbbi időkig antidemokratikus"275 - véli az író. Egyértelművé teszi, 1945 után a demokrácia „számunkra véletlen kérdése” - mint fogalmaz: „Magyarországon nem fejlődéssel, nem forradalommal: háborús műveletek közepette született meg a demokrácia"276 Kovács véleménye e tekintetben Révai József álláspontjához hasonlatos, miszerint a magyar demokrácia nem természetes fejlődés eredményeképpen jött létre, hanem a háború történéseiből kifolyólag, a szovjet hadsereg ittléte által alakulhatott ki. Mindennek az egyébként nyilvánvaló ténynek - az elismerése azonban óhatatlanul azzal járt együtt, hogy a szovjetek támogatta politikai erő, a kommunisták közéleti közösségének képviselői komolyabb pozícióval rendelkezhettek a demokrácia-viták tekintetében is, hiszen a diskurzus során utalhattak arra, hogy a demokrácia léte az általuk feltétlenül szolgált Szovjetuniónak köszönhető.

Kovács értelmezése szerint a demokrácia nem is népuralom, hanem inkább egyfajta sajátos „közmegegyezés.” Az író nem tagadja a reakció mint olyan létezését, de az ő reakciófogalma eltér a kommunistákétól. „Antidemokratikusnak” és „reakciósnak” azokat a gondolatokat tartja, melyek az „egész szép úri világot” akarják visszahozni. ${ }^{277}$ Ugyanakkor látja azt a jelenséget, hogy a kommunista stratégia lényegi eleme, hogy az ellenvéleményt megfogalmazókat ${ }^{278}$ reakciósnak bélyegezze és így tegye lehetetlenné a demokratikus párbeszédet. ${ }^{279}$ „A demokráciában a kisebbségi véleménynek érvényesülni kell, azt reakciósak

vázolt demokrácia-koncepcióval, ,az általa oly hevesen óhajtott demokrácia alapelveivel” - ez pedig a magyarországi svábok kitelepítésének antidemokratikus követelése volt. (Uo. 207. p.)

${ }^{275}$ KOVÁCS Imre: A demokrácia útja Magyarországon. 97. p.

${ }^{276}$ Uo. 98. p.

${ }^{277}$ Kovács reakció-értelmezése is hasonlóságokat mutat Bibó ebbéli nézeteivel.

278 Szeredi Pál Kovács Imre demokráciafelfogásában központi elemnek tartja, hogy nem létezik állandó „autentikus vélemény”, mert a különböző nézetek egymást fejlesztik és a vélemények szabad áramlása a demokrácia intézményrendszerének a lényegi eleme. Szeredi szerint ez volt az egyik legfontosabb különbség Kovács demokráciafelfogása és a kommunisták demokrácia-értelmezése között. (SzEREDI Pál: Szárszó vesztese. A népi mozgalom perifériáján - Kovács Imre. In: SIPOS Levente - TóTH Péter Pál (szerk.): A népi mozgalom és a magyar társadalom. Tudományos tanácskozás a szárszói találkozó 50. évfordulója alkalmából. Napvilág Kiadó, Budapest, 1997. 252-259. p.)

${ }^{279}$ Kovács Imre a tanulmány megjelentetését a Nemzeti Parasztpárt '46. november 2-3-i nagyválasztmányi ülésére időzítette. A nagyválasztmányon Kovács megpróbálta elérni, hogy a NPP változtasson a kommunistákhoz füződő kapcsolatain, de ez nem sikerült. (PAPP István: A magyar népi mozgalom története. 1920-1990. Jaffa Kiadó, 2012. 200. p.) Papp István szerint Kovács Imre A demokrácia útja Magyarországon címü tanulmányával feladta ,a hosszú taktikázást” és egyértelművé tette álláspontját. Kovács Imre bátor kiállása azért is nagyon fontos volt, mert baloldali politikusként kimondta, hogy ,az MKP által hirdetett szocializmus a diktatúrával egyenlő." (Uo.) 
minősíteni nem lehet [...]. Nem lehet reakciósnak minősíteni azt, aki demokráciát akar, csak a demokrácia hibáira, mulasztásaira mutat rá, tevékenykedésével, jóindulatú, megértő kritikájával segítő, építő és nem romboló a szándéka" ${ }^{280}$ - írja Kovács Imre.

Kovács kétféle demokrácia-típust nevez meg: az egyik a globális, a másik a totális demokrácia. A „globális” a klasszikus értelmű demokrácia, míg értelmezése szerint a „totális” demokrácia inkább a kommunisták által vallott demokráciaképet jellemzi. A totális demokrácia „szovjetszerü” és keleti típusú.

A szerző a kommunista pártot a „,demokrácia motorjának” tartja, de mint mondja: „ez a motor néha erősen rákapcsol, és olyankor túlsebesen száguldana előre." ${ }^{281}$ Kovács a 45-ös választások eredményét így magyarázza: amikor az ország többsége a kisgazdáknak szavazott bizalmat, akkor nem a párt programjára mondott igent, hanem ,a választók arra a föl nem tett kérdésre feleltek: akartok-e kommunizmust vagy sem?"282

Az író-politikus szerint ki kell mondani: „,valójában a demokrácia és a szocializmus küzdelme folyik a magyar politikában." ${ }^{283}$ Kovács azt is bátran kijelenti, hogy a kommunista attitűdű „totális” demokráciában nincs helye más véleménynek - ,a totális demokrácia egyre szükülő kör, amelyben végül már csak egyetlen akarat érvényesül”"284 - írja profetikus lendülettel a parasztpárti személyiség. Különös nyelvi jelenség, hogy Kovács számára ekkorra, 1946 késő őszére már egyértelmű, hogy a „totális demokrácia” maga a proletárdiktatúra eszmei és politikai struktúrája, de a nyílt közéleti beszédstílust képviselő írópolitikus mégsem mondja ki kendőzetlenül, hogy elkezdődött a diktatúra kiépítése, a diktatúra fogalmat nem használja, csak utal magára a kibontakozó diktatórikus közegre. A tanulmány utolsó bekezdésében - a diktatúra kifejezést nem használva - Kovács pesszimistán írja, hogy a jövő az általa „szocializmusnak” nevezett kommunista diktatúra, de amellett érvel, hogy mégis inkább demokráciát kellene építeni. Az írás végső mondata pedig már inkább egyfajta demokrácia-hitvallás: ${ }^{285}$ „A demokrácia, amely a többség uralma a kisebbség jogainak tiszteletbentartásával, azé a többségé, amelyik valóban demokráciát akar, s a kisebbség jogait

\footnotetext{
${ }^{280}$ KovÁCs Imre: A demokrácia útja Magyarországon. 105. p.

${ }^{281}$ Uo. 101.p.

${ }^{282}$ Uo. 102. p.

${ }^{283}$ Uo. (Ez az az elem, amit ilyen formában egyik tanulmányában sem mond ki Bibó, míg Kovács érzékeltetni kívánja ezt a fajta összefüggést.)

${ }^{284}$ Uo. 105. p.

285 Valuch Tibor „demokrata magyar közírónak” nevezi Kovács Imrét, aki „demokrata beállítottságából eredendően rendíthetetlen ellenfele volt a totális rendszereknek, az ezeket képviselő eszméknek és embereknek. Nyilvánvalóan ez vitte az antifasiszta mozgalomba, és ebből (is) ered következetes kommunizmusellenessége is.” (VALUCH Tibor: Egy demokrata magyar közíró a XX. században. Vonások Kovács Imre portréjához. In: SIPOS Levente (szerk.): Kovács Imre centenáriuma. Tudományos emlékülés a Politikatörténeti Intézetben. Napvilág Kiadó, Budapest, 2013. 273.p.)
} 
csak annyiban respektálhatja, amennyiben ténykedésével a demokrácia hibáinak kiküszöbölésére, nem pedig a demokratikus rend megdöntésére törekszik."286 Ebből az utolsó mondatból is kiolvasható: Kovács szerint 1946 őszén elindult a demokratikus rend megdöntésének előkészítése.

Kovács Imre még mint a Nemzeti Parasztpárt képviselője 1947. február 6-án markáns demokrácia-hitvalló beszédet mondott a nemzetgyülésben. E megszólalásában Kovács nyilvánvalóvá tette, hiába a NPP tagja és ezáltal a Baloldali Blokk politikusa, ő nem lesz a kommunista demokrácia-értelmezés és politikai stratégia társutasa. ${ }^{287}$ Kovács Imre a koalíciós évek demokrácia-vitái tekintetében is fontos gondolatot mond ki, a felek között a „határvonal” ott húzódik, hogy ki akar demokráciát és ki tör diktatúrára, de a „diktatúra” kifejezést még mindig nem használja, helyette a „demokrácia megdöntése” fogalmat használja.

Kovács már mint pártonkívüli képviselő mondta el politikai karrierje legutolsó nemzetgyülési beszédét 1947. április 18-án. A megszólalás mint általában „az utolsó” parlamenti felszólalások erőteljesen demokrácia-hitvalló attitüddel bír: „A demokrácia nemcsak a koalíció problémája, hanem valamennyiünké. Ez a nemzet mindig igen magas, igen drága tandíjat fizet a politika iskolájában. Vigyázzunk, hogy ezúttal ismétlésre ne kényszerüljünk. Demokrácia és parlament egymást nevelik. Mi a parlamentáris demokrácia hívei vagyunk, a parlamentet a szuverenitás legmagasabb formájának tekintjük”288 - tette egyértelművé parlamenti-demokráciapárti elvi álláspontját Kovács. Ezt követően burkoltan, de mégis rendkívüli szókimondással olvasta a kommunisták fejére, hogy ellenfeleik kiiktatására törnek. „A politikai türelmetlenség leszúkíti a demokrácia körét”289 - mondta Kovács Imre, aki alany nélkül, a személytelen „politikai türelmetlenséget” vádolja ugyan azzal, hogy az ellenfelek likvidálására törekszik, de nyilvánvalóan a „politikai türelmetlenség” általános mumusán konkrétan az MKP-t, a kommunista hatalmi politikát érti.

„A kommunisták ellenállás nélkül törtek elöre s a kisgazdapárt ott követte el a legnagyobb hibát, hogy az összeesküvés teljes ódiumát a nyakába hagyta varrni és ezzel igazolta azt az újabban hangoztatott állítást, hogy aki a kommunistákat támadja, az a demokráciát támadja, amiből dialektikusan következik az új tétel: a demokrácia egyenlő a

\footnotetext{
${ }^{286}$ KovÁCS Imre: A demokrácia útja Magyarországon. 106. p.

287 E beszéde után 19 nappal, 1947. február 25-én, Kovács Béla, az FKGP főtitkára elhurcolása napján az eljárással szembeni tiltakozásképpen Kovács Imre kilépett pártjából, a Baloldali Blokk részét képző Nemzeti Parasztpártból. Kovács Imre parlamenti beszéde: Nemzetgyülési Napló 1945-1947. V. kötet. Athenaeum, Budapest, 1952. 1947. február 6. 126-145. p.

${ }^{288}$ Nemzetgyülési Napló 1945-1947. VII. kötet. 1947. április 18. 701-716. p. (701. p.)

${ }^{289}$ Uo. 703. p.
} 
kommunizmussal”290 - mondta immár kendőzetlen nyíltsággal Kovács. Az akkor már pártonkívüli képviselő az aktuális történések közepette is képes volt a történelemi ítélet próbáját álló, távolságtartó elemzésre, melynek lényegi megállapítása a következő: a kommunista kommunikációs stratégia központi eleme, hogy a kommunista ideológusok és közéleti szereplők egyenlőségjelet tesznek a „demokrácia” és a „kommunizmus” között. Kovács 1947-ben a nemzetgyülés plénumán állapítja meg, a kommunista demokráciaértelmezés markáns vonása, hogy „demokrácia” csakis a kommunista nézőpontú államberendezkedés lehet.

Kovács szerint a kommunista párt olyan, „mint egy malom”, amely állandóan müködik és „,sajátságos módon” öröl - „nincs megállás, mozgó az értékelése, a tegnapi haladó holnap már reakciós. [...] Ez az örökmozgó, a megvalósult politikai perpetuum mobile, nem

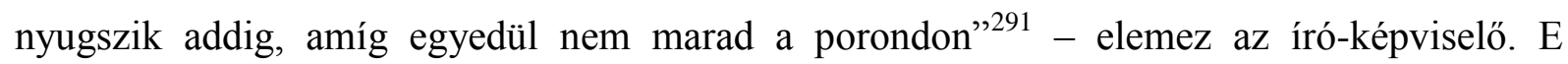
szavakból újólag kitetszik, Kovács 1947 tavaszán már bizonyos abban, formálódik a diktatúra. Utolsó parlamenti felszólalásának jövőbetekintő gondolata már nem minősíthető többnek, mint a végső remény hangjának: „Nemcsak az a haladás, amire a kommunistapárt ráüti bélyegét. Lehet a boldogulást más utakon is keresni. Nem szabad erőszakoskodni, inkább arra kell törekedni, hogy megértsük egymást, tiszteletben tartsuk egymás meggyőződését és politikáját, különben ideológiai háború borzalma szakadhat az emberiségre." 292 Amit Kovács az ideológiai háború borzalmának nevez, lett végül a világ számára a hidegháború fogalma, s hidegháborús logika részeként Magyarországon a kommunista ,perpetuum mobile” valóban megdöntötte a demokrácia struktúráját.

\section{5. Ellenzéki demokráciaértelmezők: Sulyok Dezső, Moór Gyula és Barankovics István}

\section{Sulyok Dezsö}

1945-ben Sulyok Dezső is és főleg Moór Gyula hatalmas távolságra volt az ellenzéki politikai pozíciótól. Sulyok 1946 elején a kisgazdák potenciális miniszterelnök-jelöltje, a jogtudós Moór pedig csak 1947-re aktivizálódik politikailag, amikor a szabadságjogokra építkező

\footnotetext{
${ }^{290}$ Uo. 704-705. p.

${ }^{291}$ Uo. 709. p

${ }^{292}$ Uo. 711. p
} 
demokráciát látja veszélyeztetve a kommunisták által. Barankovics István közéleti szerepe 1947 őszétől azonosítható egyértelmüen ellenzéki pozícióként.

Sulyok személyiségétől nem állt távol az ellenzéki lelkület, ${ }^{293} 1935$ után is büszkén és dinamikusan vállalja fel a Gömbös-kormányzattal szembeni ellenzékiséget. 1945-46-ban azonban a legkevésbé sem ellenzéki szerepre készül, akkoriban Sulyok a kisgazdák egyik legismertebb és népszerübb politikusa; habár tény, már 1945 nyarán érzékeli a polgári demokráciát fenyegető kommunista veszélyt, amellyel szemben szükségessé válhat az ellenállás, az ellenerő felmutatása, de ő mindezt a többségi párt egyik vezető alakjaként képzelte el véghezvinni.

Sulyok Dezső a koalíciós korszak egyik legizgalmasabb közéleti szereplője, aki a demokrácia-értelmezés tekintetében is markáns szerepet vitt, érvei figyelmet követeltek a korabeli nyelvpolitikai küzdelmek során, kommunikációs paneljei egységes nézetrendszert alkottak. Sulyok - ahogy Standeisky Éva fogalmaz - „megrögzötten”294 demokráciapárti volt. Értelmezésünk szerint Sulyok modern demokrácia-értelmezőnek és adenaueri értelemben vett kereszténydemokratának számít a második világháború utáni két esztendő magyar köztörténetében. A közvetlen politikai cselekvés terén érdemben kibontakozni nem tudott, de beszédcselekvései arra utalnak, Sulyok a polgári demokrácia híveként kereszténydemokrata programot akart volna megvalósítani.

A köztársasági államformáról szóló törvényjavaslat parlamenti vitájakor, 1946. január 30-án hangzott el a kisgazda Sulyok Dezső vezérszónoki beszéde. ${ }^{295}$ A megszólalás elején Sulyok nyilvánvalóvá tette, hogy „csak a szabad állam, az emberi szabadságot megvalósító állam tud maradandó értéket adni az emberiségnek, a hatalmi állam, katona vagy rendörállam erre képtelen." ${ }^{296}$ A kisgazda politikus kifejtette, a szabadság: eszmény, a demokrácia: elv, a parlamentarizmus: eszköz; s a parlamentáris demokrácia képes megvalósítani a „szabadság emberi eszményét." ${ }^{297}$ Sulyok abban bízik, ${ }^{298}$ hogy a demokrácia igenlése lehet a közös pont a

\footnotetext{
${ }^{293}$ STANDEISKY Éva: Egy demokrata ellenzéki. Élet és Irodalom, LX. évfolyam, 2016. január 8.

${ }^{294}$ STANDEISKY Éva: Emigránscsapda. Sulyok Dezső Amerikában. Élet és Irodalom, LVIII. évfolyam, 2014. február 28.

${ }^{295}$ Sulyok Dezső biográfusa, Szerencsés Károly úgy véli, Sulyok e nyílt, a parlamentáris demokrácia értékei mellett kiálló beszéde miatt nem lehetett Magyarország miniszterelnöke. Rákosi az MKP frakciója elött arról beszélt, hogy Sulyok beszéde „rossz, politikailag is helytelen és nívótlan volt.” (SzERENCSÉs Károly: A nemzeti demokráciáért. Sulyok Dezső 1897-1997. Pápa Város Önkormányzata, Pápa, 1997. 125. p.)

${ }^{296}$ SULYOK Dezső 1946. január 30-i parlamenti beszédét közli: Földet, köztársaságot, állami iskolát! Viták a magyar parlamentben 1944-1948. Válogatta és a bevezetést írta: Balogh Sándor. Gondolat Kiadó, Budapest, 1980. 141-173. p.

${ }^{297}$ Uo. 146. p.

${ }^{298}$ Hogy hitt benne, lehet közös pont a kommunista és kisgazda demokrácia-felfogás, gondolkodás között, azt az támasztja alá, hogy kilenc nappal később újabb parlamenti beszédében hasonló gondolatot fejtett ki: „A polgári kisgazdapárti többség és a munkáspárti kisebbség végeredményben kétségtelenül ugyanazt akarja: a modern
} 
különböző közéleti szereplők között: „,meg kell győznünk egymást arról, hogy becsületesen, jó szándékkal és fenntartás nélkül a demokráciát akarjuk megvalósítani” - mondta. Egy következő gondolatsorban már diplomatikus hangvétellel ugyan, de a kommunista stratégiát bírálta: „A történelem tanúsága szerint a viszonyok megjavítására irányuló törekvéseket valamely államban a kisebbség csak akkor szokta erőszakos úton megvalósítani, ha azok megvalósítására alkalmas többség nem tud kialakulni” - érvelt a szónok. A beszéd elhangzása után másfél hónappal Sulyok már nem volt tagja a Kisgazdapártnak, mert a Baloldali Blokk nyomására 19 társával együtt kizárták a szervezetből. Ekkortól kezdve lesz a koalíciós kormányzás, de leginkább a kommunisták ellenzéke. Sulyok nem sokkal később megalakította a jobbközép irányultságú ellenzéki Magyar Szabadság Pártot.

A koalíciós évek közéleti diskurzusában arra is volt példa, mikor személyes polemizálás, sajtóbéli pengeváltás keretében vitatták meg a felek a demokrácia-felfogásokban lévő különbözőségeket. Mindennek egy egészen európai stílusú esete volt Zsolt Béla, a polgári radikális író-újságíró és Sulyok Dezső nemzetgyülési képviselő polémiája '46 nyarán.

$Z_{\text {Zsolt Béla }}^{299}$ az általa főszerkesztett Haladás címủ lap címoldalán nyílt levelet intézett a nem sokkal korábban a kisgazda parlamenti frakcióból kizárt Sulyok Dezsőhöz. Ebben a dokumentumban Zsolt kifejti, hogy ő maga továbbra sem kételkedik abban, hogy Sulyok jó demokrata lenne - ,akkor is tudtam, amikor Téged reakciósnak bélyegeztek, hogy célodat a demokratikus fogalmi körön belül akartad megvalósítani." ${ }^{300}$ A főszerkesztő magáról így ír: „a politika, amelyet szolgálok, szorosan füz a demokrácia baloldalához,” Sulyok Dezső közéleti koordinátáit pedig úgy határozza meg, hogy Sulyok „metodikailag merevebb és programjában körülhatároltabb demokratikus" törekvéseket képvisel, de mindezek ellenére a demokrácia jegyében lehetnek közös pontok. Zsolt ugyanakkor attól fél, hogy létezik egy komoly társadalmi réteg - mely az író szerint akkoriban Sulyok mögött sorakozott fel - és ez a befolyásos kör „még mindig nem fogadta el végleges helyzetként s minden magyar politika kiindulási alapjaként a demokráciát." Zsolt cikkében lényegében arra kéri Sulyok Dezsőt, hogy inkább válassza a demokráciát, és ne engedjen a nagybirtokos-nagytőkés támogatóinak.

demokrácia szellemében újjáépíteni az országot. A módszerekben azonban természetszerüleg van közöttünk eltérem, hiszen más és más ideológiai alapon állunk. A véleményem azonban az, hogy eredményes munkát is csak akkor tudunk végezni, ha hosszú-hosszú időn keresztül együtt haladunk éppen az országnak ilyen vegyes képlete miatt, amelyben egyformán megtaláljuk a polgári gondolatnak haladó formáiban átvitt alakját, mint, ahogyan megtaláljuk a marxizmuson felépülő szocialista világnézet gyakorlati érvényesülését is" - mondta Sulyok Dezső 1946. február 8-i parlamenti beszédében. (Nemzetgyülési Napló 1945-1947. I. kötet. 392. p.)

299 Zsolt Béla publicisztikai életművéről: SzALAI Pál: Zsolt Béla politikai publicisztikája. In: ZsOLT Béla: A végzetes toll. Publicisztikai írások. Nyilvánosság Klub - Századvég, Budapest, 1992. 380-394. p.

${ }^{300}$ ZSOLT Béla: Levél dr. Sulyok Dezsőhöz. Haladás, 1946. július 25. 1. p. 
Sulyok örült a megkeresésének és az így kapott sajtónyilvánosságnak. Válaszcikket írt, melyben kifejtette, hogy becsületes embernek tartja Zsolt Bélát, aki reményei szerint rájött, hogy „mégsem lehet egyszerủen a reakció nagyon elkoptatott frázisával elintézni embereket és jelenségeket."301 A politikus írásában egyértelművé tette: az, hogy a világháború után „polgári állam” jöhetett létre Magyarországon, az pusztán a szövetségesek megegyezésén és a „szovjetkormány tiszteletreméltó önmérsékletén” múlott, vagyis a szovjetek rábízták „a magyar népre, hogy alakítsa ki a polgári demokrácia keretein belül életsorsát úgy, ahogy tudja." Sulyok a demokráciát nem a nagytőkétől, hanem a Kommunista Párt erőszakosságától félti, demokrácia-párti hitvallásként írja: „Én vallom politikai pályám első percétől kezdve, toloncházon, bújdosáson, internáláson keresztül, hogy ezt a népet boldoggá tenni csak és egyedül a demokrácia módszereivel lehet." ${ }^{\text {302 }}$ A Sulyok-Zsolt pengeváltás azért érdemel említést, mert a vitaszövegek stílusa meglepően higgadt; egy konszolidálódó demokráciában, egy stabilizálódó politikai kultúrában ez a fajta habitus határozhatta volna meg a közéleti diskurzusok karakterét.

Sulyok már mint a Magyar Szabadság Párt vezére nagyszabású beszédet mondott 1946. november 24-én a budapesti sportcsarnokban. A politikus e megszólalásában is egyértelműen a polgári demokrácia eszménye mellett állt ki. Az aktuális politikai viszonyokat a „koalíciós rendszer” fogalommal írja le, s amellett érvel, hogy a koalíciós rendszer megváltoztatása nem a reakció irányába vinné a folyamatokat, hanem éppen hogy egy „magasabbrendű” demokráciát teremthetne. ${ }^{303}$ A szónok egy „tisztultabb” demokráciát szeretne megvalósítani, ahol a politikai hétköznapokban nincs jelen az erőszak és nincs a szabadság olyan szinten korlátozva, mint a „koalíciós rendszerben.” A szövegből egyértelmüen látszik, hogy a beszélő a mindenkire egyformán kiterjedő szabadságjogok fontosságát kívánja hangsúlyozni; az osztályharcos demokrácia helyett a nemzeti szolidaritás demokráciáját akarja létrehozni. A demokrácia-fogalom használata tekintetében e megnyilatkozásában van még egy újszerü kommunikációs panelje: arról beszél, hogy a demokrácia, legyen „mértéktartó”304 és álljon ellen a „politikai licitálóknak.” Az általános választójogon alapuló szabad választást tartja a demokrácia biztosítékénak, követeli, hogy az 1945-ben hatályos választójogi szabályokat ne korlátozzák, mert az ahhoz való hozzányúlás valóban demokrácia-ellenes tett lenne a hatalom részéről.

\footnotetext{
${ }^{301}$ SULYOK Dezső: Ellenzékiség vagy ellenzékieskedés? Haladás, 1946. augusztus 1. 1. p. ${ }^{302}$ Uo.

${ }^{303}$ Sulyok Dezső 1946. november 24-i beszédét közli: SzERENCSÉS Károly: A nemzeti demokráciáért. Sulyok Dezsö 1897-1997. 327-339. p.

${ }^{304}$ Uo. 336. p.
} 
A Holnap címü lap számára írt 1947. március 15-i cikkében azt fejtegeti Sulyok Dezső, hogy „rossz szó” polgári demokráciának nevezni a parlamentáris struktúrát, mert ez a fogalom nem adja vissza a demokrácia lényegét. Mivel azonban e kifejezés „közkeletü”, ezért ő maga sem veti el, hanem inkább árnyalja a fogalmat és érdemi tartalommal kívánja megtölteni. Szerinte a demokrácia a következő elemeket kell hogy tartalmazza: egyéni kezdeményezés, teljes politikai szabadság, szabad véleménynyilvánítás, félelem nélküli élet, magántulajdon, megbocsátás, kiengesztelődés, békés építőmunka, a pozitív keresztény hit és „társadalmi, faji és erkölcsi szolidaritás.”305 A cikk végén Sulyok leszögezi: a párttitkárok uralma helyett „szabad hazát” és „tiszta demokráciát” szeretnének, ahol nem a gyülölködés légköre a meghatározó, hanem a „kiegyenlítődés.”

Sulyok Dezső 1947. június 12-én a Dinnyés-kormány programjáról szóló vitában nagyszabású demokrácia-hitvalló beszédet mondott a magyar parlamentben, ez volt az egyik utolsó megszólalása az országházban.

A kommunisták által folyamatosan bekiabálásokkal megzavart egyórás szónoklatának a nemzetgyülési napló számára rögzített szövege a koalíciós évek és az egész magyar demokrácia történetének egyik legismertebb, legszimbolikusabb dokumentuma, egy klasszikus demokrácia-hitvalló megszólalás. A nagyszabású beszéd elhangzását követő napon az amerikai szenátus határozatában e szónoklat miatt a történelem halhatatlanjainak sorába emelte Sulyok Dezsőt. ${ }^{306}$ „A A közelmúltban lefolyt eseményekből meg kell állapítanom, hogy a magyar demokrácia képviselete és ügyvitele két és félévi ügyködés után csődbe került. Nem a demokrácia került csődbe, csak a demokrácia képviselete és ügyvitele. Erre vallanak azok az események, amelyek a közelmúltban szemünk elött leperegtek"307 - kezdte parlamenti szónoklatát Sulyok Dezső, majd felemlítette, hogy az utóbbi időkben a szabadon megválasztott miniszterelnök, egyben a legnagyobb parlamenti párt vezetője (Nagy Ferenc) és a nemzetgyűlés kisgazda elnöke (Varga Béla) „dezertálásra”, vagyis emigrációba kényszerült. „Ekkora válság egy két és féléves demokratikus uralom történetében szinte példátlan és páratlan”308 - mondta a képviselő. Sulyok szerint ahhoz, hogy az ehhez hasonló „megrázkódtatások” a jövőben ne érjék a demokráciát, „ha azt akarjuk, hogy ez a demokrácia a nemzet és a nép üdvére szabadon fejlődhessék tovább," ${ }^{309}$ akkor meg kell vizsgálni, mi okozta az esemény ilyetén alakulását. Az okok keresését illetően kendőzetlen őszinteséggel és

\footnotetext{
${ }^{305}$ SULYOK Dezső: Mivégre vagyunk a Földön? A Holnap, I. évfolyam. 1947. március 15.

306 SzERENCSÉS Károly: A nemzeti demokráciáért. Sulyok Dezső 1897-1997. 223-224. p.

307 Elhangzott a nemzetgyülés 129. ülésén 1947. évi június hó 12-én. Nemzetgyülési Napló 1945-1947. VII. kötet. Athenaeum, Budapest, 1952. 836-856. p. /836. p /

${ }^{308}$ Uo.

${ }^{309}$ Uo. 837. p.
} 
nyíltsággal beszél a nemzetgyűlési képviselő, a Magyar Szabadság Párt elnöke: „Nem fognak velem egyetérteni azok sem, akik nyíltan vagy leplezve egy baloldali parancsuralom megvalósítására törekednek" ${ }^{310}$ A baloldali parancsuralom fogalmának használatával Sulyok kimondja, hogy immáron „vitatható” az, hogy Magyarország demokratikus ország.

E beszédben is kiütközik a két demokrácia-kép közötti különbség. Sulyok határozottan állítja, hogy a demokrácia ügyéért küzdenek. A Sulyok által vallott demokrácia-értelmezés arról szól, hogy egy nemzeti-keresztény alapon álló polgári demokrácia szolgálja leginkább az országot, míg a kommunisták ekkorra már egyértelműen, kikristályosodott módon „demokrácián” a népi demokrácia kifejezést értik, ami számukra út a szocializmushoz, lényegében az eljövendő proletárdiktatúrához, kommunista diktatúrához. Sulyok utal rá, hogy éppen őket, akik a tiszta demokrácia ügyéért harcolnak, bélyegzik demokrácia-ellenesnek. Mikor a szabadságpárti vezér e gondolatot fejti ki, többen is bekiabálnak a kommunista párt padsoraiból. Sulyok Dezső megismétli, hogy ők a demokráciáért harcolnak, de mint mondta: „Egyszerüen: a demokráciának nem azért a válfajáért, amelyet önök helyesnek tartanak...”311 - veti oda a kommunista frakciónak. Erre Orbán László kommunista párti képviselő így reagált: „Kutyából nem lesz szalonna és Gömbös tanítványából ${ }^{312}$ nem lesz demokrata.”313

A bekiabálások keltette zavart követően Sulyok visszatért beszéde eredeti gondolatmenetére, s kijelentette: „ma Magyarországon nincs sajtószabadság - a sajtószabadság a politikai szabadságjogoknak az első és legértékesebb része [...]. Ahhoz, hogy valamely országban demokrácia fejlődhessék ki és a demokrácia elve a szabadság eszményét, mint a legfontosabb és mindennél elöbbre helyezendő emberi eszményt megvalósíthassák, az első és elengedhetetlen követelmény, hogy az országban sajtószabadság legyen."314 Utána a szabadságpárti szónok arról beszélt, hogy nem képesek pártjukkal politikai gyüléseket tartani, mert akárhol rendeznek politikai gyülést, megjelenik ott egy több száz fös rendbontó tömeg, akik ellehetetlenítik a rendezvény megtartását. Sulyok különösnek tartja, hogy, akik fizikai erőszakkal - a demokrácia egyik legfontosabb részének tekintett gyülekezési szabadság gyakorlását megakadályozzák, ők a demokrácia védelmezői, míg akik a demokrácia adta jogokkal élni kívántak és részt akarnak venni egy szabályosan, jogszerüen megszerezett politikai gyülésen, azok viszont a demokrácia ellenségei. „Magyarországon

\footnotetext{
${ }^{310}$ Uo.

${ }^{311}$ Uo. 846. p.

312 Sulyok 1935-ben a Gömbös Gyula vezette Nemzeti Egység Pártja tagjaként indult Pápán a parlamenti választásokon, de az elnyert mandátum birtokában szembefordult a gömbösi politikával. (SZERENCSÉS Károly: A nemzeti demokráciáért. Sulyok Dezső 1897-1997. 19-34. p. /)

${ }^{313}$ Nemzetgyülési Napló 1945-1947. VII. kötet. 846. p.

${ }^{314}$ Uo. 847. p.
} 
csend van itt és nyugalom, csak éppen nem az élet ütemének megszokott és kedves csendje, hanem a félelem és terror csendje, mert [...] rendőrállammá alakultunk át, valóságos rendőrállammá, ahol a rendőrség befolyása nemcsak a közéletre, hanem az egyes emberek magánéletére is elviselhetetlenül ránehezedik és súlyosodik. Tele vagyunk

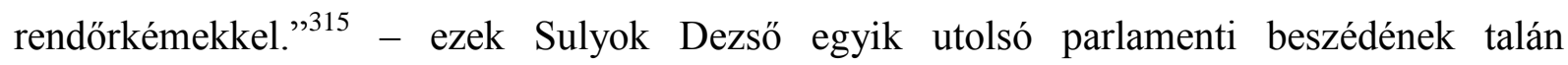
legismertebb és egyben legszókimondóbb részei. A képviselő az aktuális közéleti vonalvezetést egyszerủen csak ,szélsőbaloldali politikai iránynak”316 nevezi. Sulyok szerint a demokrácia Magyarországon élő valóságból „ma már panoptikumba kívánkozó viaszfigura, gólem” lett, amelynek „ellopták a szívét.”317

1947. július elsején hangzott el Sulyok Dezső utolsó parlamenti megszólalása; kimondta: Magyarország „letér a demokrácia útjáról”, majd e szavakkal fejezte be beszédét: „A magyar parlamentben a szólásszabadságot megszűntnek tekintem és a szótól elállok!”318

Sulyok üldözött demokrataként érzelmileg megalapozottan és - a vegytiszta jogállami normák szempontjából - joggal beszélhetett 1947 nyarán arról, hogy az ország letért a demokrácia útjáról és hogy a parlamentben szólásszabadság megszünt létezni. Tény ugyanakkor, 1947 augusztusában a magyar nép egy legitim, többpárti - bár többszörös csalással és visszaéléssel sújtott - választáson még szabadon szavazhatott a diktatúrára törő kommunisták ellen és a 1947. szeptember elején összeülő új országgyülésben még több fontos demokrácia-hitvalló beszéd is elhangozhatott - ilyenre példa Moór Gyula 1947. októberi parlamenti megszólalása is.

\section{Moór Gyula}

Moór 1945-ben a közélet egyik köztiszteletben álló alakja, megkérdőjelezhetetlen tekintély. Moór Gyulának 1945-ben felajánlották a moszkvai követi posztot, amit később Szekfü Gyula töltött be. Moór neve felmerült ekkoriban igazságügyi miniszter-jelöltként, sőt a köztársasági elnöki posztra jelöltek között is. Ö maga inkább az egyetemi karriert kívánta tovább vinni, ezért is vállalt rektori posztot a Pázmány Péter Egyetemen. Mindemellett a '45-ös

\footnotetext{
${ }^{315}$ Uo. 850-851.p.

${ }^{316}$ Uo. 852. p.

${ }^{317}$ Uo. 853. p.

318 Elhangzott a nemzetgyülés 137. ülésén 1947. évi július hó 1-én. Nemzetgyülési Napló 1945-1947. VIII. kötet. 288-292. p.
} 
nemzetgyülés 12 olyan tagja között volt, akiknek közéleti vezető szerepük miatt kínálták fel a képviselői mandátumot. ${ }^{319}$

1945-ben a Demokrácia előadássorozaton Moór Gyula jogfilozófus még egyáltalán nem ellenzéki politikusként, hanem pártok feletti személyiségként szólalt meg, így beszéde óvatos, inkább konfliktuskerülő jellegü.

Moór $A$ demokrácia örvényei ${ }^{320}$ című referátumában a veszélyekre kihegyezve mondta el korreferátumát. Fenyegetésként értelmezte azt a jelenséget, mikor a fiatal demokráciákban „neofita túlbuzgók” tevékenysége által morajlani kezd az „örvény."321 Moór képletes és óvatos utalásai már ekkor, 1945 nyarán a kommunista térhódítás kapcsán az alapvető és lényegi veszélyekről szólnak. Cizellált jogfillozófiai elemzéssel él, így a tartalom gyakran rejtett, „becsomagolt”, de fontos megállapításokat mégis kimond: szerinte a szovjet-rendszer nem ismeri az államhatalmak elválasztásának elvét, ami a demokrácia egyik meghatározó alapelve. Arról ír, hogy „demokratikus gondolatok”322 jelen vannak ugyan a szovjet világlátásban, de ,egyébként a bolsevizmus a politikai demokráciát nem túlságosan sokra értékeli.” Moór azt is leszögezi, hogy a demokráciának az a „lényeges ismertetőjele”, hogy a szabadság és az egyenlőség gondolatai „szintézisként” egyesülnek benne. „Ha a szabadság védelmében szabadságunk van arra is, hogy eltiporjuk és kiirtsuk a más-meggyőződésűeket, akkor a szabadság szomorú szolgaságba $\mathrm{s}$ a demokrácia zsarnoki önkényuralomba, diktatúrába süllyed" - figyelmeztet Moór, aki már '45 nyarán megfogalmazta a veszélyt, hogy a „demokrácia hajója” a „diktatúra örvénye” ${ }^{323}$ felé vihet. Hogy honnan, melyik irányból érzi a veszélyt, abból is kitetszik, hogy egyértelművé teszi: a demokrácia ,jelző nélküli." ${ }^{224}$ Moór referátuma végén egyértelmüvé teszi: a demokráciát fenyegető veszélyek közt a legnagyobbnak ,„a mértéktartás hiányát, doktrinér elveknek túlzó és végzetes erőszakolását”325 tartja. A történelmi rálátás biztosítja számunkra azon értékítélet lehetőségét, hogy kimondjuk: amikor Moór doktrinér elveknek túlzó és végzetes „erőszakolásáról” ejt szót, akkor a kommunista párt stratégiájára utal.

\footnotetext{
${ }^{319}$ SZABADFALVI József: Moór Gyula. Egy XX. századi magyar jogfilozófus pályaképe. Osiris - Századvég, Budapest, 1994. 153. p.

${ }^{320}$ Moór Gyula koalíciós évekbeli demokrácia-értelmezéséről bővebben: SZABADFALVI József: „A demokrácia örvényei" - Moór Gyula demokráciafelfogása (1945-1947). Valóság, XXXIV. évf. (1991) 7. 28-40.; SZABADFALVI József: „A demokrácia örvényei” - Moór Gyula demokráciafelfogása (1945-1947). Valóság, XXXIV. évf. (1991) 7. 28-40., ill. SZABADFALVI József: Moór Gyula (Egy XX. századi magyar jogfilozófus pályaképe). Kandidátusi értekezés tézisei. Miskolc, 1992.

${ }_{321}$ Demokrácia, 1945. 98. p.

${ }^{322}$ Uo. 105. p.

${ }^{323}$ Uo. 100. p.

${ }^{324}$ Uo. 102. p.

${ }^{325}$ Uo. 108. p.
} 
Moór következő markáns demokrácia-értelmező megszólalására két év múlva - egy egészen más politikai és kommunikációs közegben - került sor; a jogfilozófus ekkor már mint ellenzéki „pfeifferista” képviselő szólalt meg és mondott demokrácia-hitvalló beszédet az országgyülésben.

Az 1947. augusztusi választáson Pfeiffer Zoltán vezette Magyar Függetlenségi Párt több mint 13\%-ot kapott. Az MFP 49 mandátumot szerzett, egyik képviselőjük a tekintélyes tudós, Moór Gyula volt. A függetlenségi párt mandátumainak törléséért ${ }^{326}$ már nem sokkal a szavazás után megindult a hadviselés a baloldal részéről. ${ }^{327} \mathrm{E}$ harc közepette mondta el nagyszabású parlamenti beszédét Moór Gyula képviselő 1947. október 8-án.

Moór '47-es szövege egyértelműen demokrácia-hitvalló megszólalás, amelynek hangvétele élesen különbözik az 1945-ös demokrácia-konferencián elhangzott távolságtartóbb szónoklattól. Az 1947. október 8-i megszólalás szókimondó, erőteljes, konfliktust-vállaló megszólalás.

A különbség természetesen magának a helyzetnek a megváltozásában keresendő. Demokrácia-értelmezés tekintetében és a politikai atmoszféra állapotát vizsgálva is „1945” és „1947” között alapvető eltérések voltak. 1945-ben a közélet szereplői egy jogállami jellegü, a polgári szabadságjogokat értéknek tekintő demokráciában bízhattak. Ezzel szemben 1947-ben mindennek a lehetősége már elveszni látszott és végül valóban el is veszett. Ez a szituáció Moór korábbi távolságtartóbb magatartását is felülírta. ${ }^{328}$

A beszéd elején Moór a szociáldemokratákhoz fordult és tőlük kért szimbolikus segítséget. „Sorsunk attól függ, hogy sikerül-e ennek a pártnak a maga 75 éves múltjában gyökerező tiszteletreméltó programját: a tiszta demokráciát és a jogállam gondolatát a magyar kommunista párttal szemben megvédelmeznie" ${ }^{329}$ - mondotta a jogtudós képviselő. Moór a bevezetőjében rámutatott arra, hogy a ’47-es választás tulajdonképpen ,,az ellenzék erkölcsi

\footnotetext{
326 „Az MKP vezetői »épülő ideális államukban« [...] nem türtek meg semmiféle alternatívát, a sajátjukkal ellentétes politikai nézetet. Pfeiffer Zoltán és pártja nem az első és nem is az utolsó volt, csak az egyik a likvidálandó politikai erők között. De most rajta volt a sor” - írja Földesi Margit és Szerencsés Károly. (FÖLDESI Margit-SzERENCSÉs Károly: A megbélyegzés hatalma. Pfeiffer Zoltán (1900-1981). Kairosz Kiadó, Szentendre, 2003. 207. p.)

327 Károlyi Mihály akkori párizsi nagykövet a Pfeiffer-párt mandátumainak törléséről egyfajta sajátos demokrácia-értelmezési gondolat keretében így írt Révai Józsefnek: „Ti azt nem értitek meg kellőképpen, hogy a mi demokráciánkat itt szinte lehetetlen demokráciaként prezentálni. A formális demokraták soha nem fogják belátni, hogy Pfeifferék kiakolbólítása demokratikus cselekedet volt...” (Károlyi 1947. december 11-i jelentését idézi: HAJDÚ Tibor: Ki volt Károlyi Mihály? Napvilág Kiadó, Budapest, 2012. 251. p.)

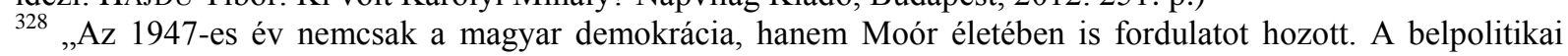
helyzet, a hatalmi erőviszonyokban bekövetkező változások egyre határozottabb közéleti-politikai szerepvállalásra késztették" - írja Szabadfalvi József, Moór Gyula biográfusa. (SzABADFALVI József (szerk.): Moór Gyula. Magyar Panteon sorozat. Új Mandátum Könyvkiadó - IV., Budapest, 2001. 15. p.)

${ }^{329}$ Az 1947. évi szeptember hó 16-ára összehívott Országgyülés naplója. Országgyülési Napló 1947-1949. I. kötet. Athenaeum, Irodalmi és Nyomdai Részvénytársulat Könyvnyomdája, Budapest, 1948. 116-146. p.
} 
győzelme volt” és a voksoláskor „,a polgári gondolat kapott többséget.” Azt, hogy a kommunisták a kékcédulás választások után magukat győztesnek kiáltották ki, „bűvészmesterségnek” nevezi. „Bűvészmesterség szempontjából ez a mutatvány mindenesetre nagyon szép, sőt gyönyörü, a demokrácia szempontjából azonban nagyon elszomorító [...]. Ha valaki ezek után még azt mondaná, hogy demokrácia van Magyarországon, nyilvánvalóan nem volna igaza" 330 - mondta ki Moór. Ekkor a kommunista párt soraiból komolyabb hangoskodás kezdődött. A honatya közben arról szólt, hogy 1945 óta „sok csalódás” érte, de szeretné újra leszögezni, hogy „a demokrácia a legmagasabbrendű, a legemberibb életforma." 331

Az MFP-s képviselő a Magyar Kommunista Pártnak címezte szavait, miszerint figyelembe kellene venniük, hogy demokráciában nem lehet „népszerüség nélkül kormányozni, népszerüséget pedig nem lehet erőszakos módszerekkel szerezni.” Erre a gondolatra a kommunista padsorból azt kiáltották, hogy „maguk fasiszták”, illetve egy másik hang a kommunista pártból ezt kiabálta be: „Ne oktasson ki minket a demokráciára!”

A jogtudós országgyülési képviselö kitért arra, hogy öket, a Magyar Függetlenségi Pártot „reakciósnak” és „fasisztának” titulálják, akik visszafelé akarják fordítani az idők kerekét, akik úgymond „a demokráciának halálos ellenségei.” Erre a vádra, az ilyen tartalmú támadásokra reagálva mondta ezt Moór: „Ez az állítás teljesen nélkülözi az igazságot. Mi nagyon jól tudjuk, hogy a felszabadulás óta sok olyan változás történt, ami igazságos, amit többé visszacsinálni nem lehet és amit mi visszacsinálni nem is akarunk.” Moór Gyula ugyanakkor azt is leszögezi, hogy ,,igen sok igazságtalanság is történt” az 1945 utáni években, ahogy ő fogalmaz: „sok szégyenfoltja” is van ennek az időszaknak.

A dolgozatunkban elemzett híres 1945-ös demokrácia-előadáson még módfelett óvatosan nyilatkozó Moór az 1947. október 8-i parlamenti beszédében rendkívül élesen fogalmazott a '45-öt követő kilengésekről, amelyeket - ismerjük a történeti tényeket meghatározó részben a kommunisták által felügyelt rendőrség, államvédelem követett el. A képviselő úgy vélte, ezek a „szégyenfoltok” a „letünt fasiszta módszerekre” emlékeztetnek, és „amelyeket éppen a demokratikus haladás érdekében orvosolni kell.”332

\footnotetext{
${ }^{330}$ Uo. 129. p.

${ }^{331}$ Uo. 130. p.

${ }^{332}$ Uo. 135. p.
} 
Beszédének záró részében demokrácia-hitvalló érveléssel fogalmazza meg a maga demokrácia-felfogásának lényegét: „Mi tiszta és szabad demokráciát szeretnénk, amely tisztán és demokratikusan valósítja meg a szociális igazságosság követelményeit." 333

A Moór Gyula által a parlamentben elmondott demokrácia-érvek egyértelműen egy jogállami demokrácia struktúra eszmei kereteibe illeszkednek. 1947 őszén azonban az egyre durvuló nyelvpolitikai küzdelmek során a polgári demokrácia képviselői által használt fogalmi panelek már nem voltak képesek a demokratikus diskurzus részeként artikulálódni. A kommunista véleményformálók részéről a polgári demokrácia eszmerendszerét még ekkor is felvállalni képes erők gondolataival, érveivel szemben már nyilvánvalóan a nyelvi megbélyegzés likvidáló karakterisztikájú kommunikációs stratégiája érvényesült.

\section{Barankovics István}

Barankovics István 1939-től a kisgazdapárti Kis Újság szerkesztője volt, 1943-tól lett a Magyar Nemzet föszerkesztője. Főszerkesztői bemutatkozó vezércikkében 1943. május 13-án kiállt az emberi jogok egyenlősége mellett és elutasította a diktatúra minden változatát. ${ }^{334}$ 1945-ben az alakuló Demokrata Néppárt főtitkárának választották. A pártkezdeményezés a 45-ös választásokon nem indult, két képviselőjelöltjük az FKgP listáján kapott helyet. 1945. szeptember 25-én a DNP zászlóbontásakor Barankovics nagyszabású beszédet ${ }^{335}$ mondott, amelyben meghatározó tartalmi elemnek tekinthetőek a demokrácia-értelmező nyelvi panelek. Barankovics leszögezte, a demokrácia kiépüléséhez szükséges a „demokratikus erkölcs” megléte, formálódása is; érvelésében folyamatosan visszatérő szempont, hogy a demokrácia formális struktúrája mellett a „kultúrdemokrácia” megerősítését kell szolgálni. A szónok kultúrdemokrácián a formalitás alatti réteget érti, ahol a társadalmi szolidaritás, a mások jogainak tiszteletben tartása, a közművelődés kiterjesztése az igazán lényeges tartalmi kérdés. E megközelítés arra utal, Barankovics 1945-ben majdhogynem biztos alapnak tekintette, hogy formális értelemben parlamenti demokrácia lesz Magyarországon, ezért - mivel nem érezte érdemben veszélyeztetve a demokrácia eszményét - sem kívánt mindenáron hivatásos politikus és nemzetgyülési képviselő lenni, nem is lett 1945 novemberében honatya. 1946-ban

\footnotetext{
${ }^{333}$ Uo.

${ }^{334}$ IzSÁK Lajos: Barankovics István. In. IzSÁK Lajos: Pártok és politikusok Magyarországon 1944-1994. Napvilág Kiadó, Budapest, 2010. 294-300. p.

${ }_{335}$ Barankovics István 1945. szeptember 25-ei beszédét idézi: BIHARI Mihály-GAzsó Ferenc-VIDA István (szerk.): Magyarországi pártprogramok 1944-1988. 73-91.p.
} 
a közélet szereplője, de nem állítható, hogy komolyabb aktivitást fejtene ki. 1947-ben a demokrácia rendjét érő kihívások hatására kezd intenzívebb politizálásba.

A DNP programját 1947. augusztus 10-én Győrben hirdette meg ${ }^{336}$, leszögezte: ellenzéki pártként indulnak a választásokon. Beszédében azt is nyilvánvalóvá tette: politikai eszményképe a „szabadság és egyenlőségelvü” demokrácia. Amellett érvelt, hogy a demokrácia az előjogok eltörléséért folytatott „verseny.” Megszólalása alapján egyértelmü, Barankovics egyfajta társadalmi demokráciát szeretne, ahol a keresztényszocializmus pápai enciklikákban megfogalmazott értékei kapnának hangsúlyt. Az 1947-es győri beszédében hasonlatosan a korábban elemzett '45-ös megszólaláshoz - is tetten érhető az a gondolat Barankovicsnál, miszerint a demokrácia nem egy statikus állapot, hanem inkább egy változó struktúra, ahol folyamatosan kell dolgozni a szabadság értékeiért. „A demokrácia nem olyan egyszerü és könnyü kormányforma, amelyet pusztán jogi intézményekkel máról holnapra elő lehet varázsolni. A szabadság nem zsákmány, amelyet forradalmi rohammal birtokba lehet venni. A forradalom csak a szabadság külső lehetőségét nyitja meg. A szabadságra azonban az önuralom és a jogtisztelet kemény fegyelmében kell ránevelődnünk" ${ }^{337}$ - hangsúlyozta Barankovics, aki azt is leszögezte, a jó demokratát a mérsékletesség jellemzi.

Az 1947. augusztus 31-i választáson több mint 16\%-os támogatottságot kapott a Demokrata Néppárt, s ezáltal 60 mandátumot szerzett az Országgyülésben. A DNP várakozáson felüli választási eredményéről és Barankovicsról írta a Szabad Nép: „olyan, mint az egyszeri ember, aki oroszlánt nyert, és nem meri hazavinni." ${ }^{338}$ Hogy Barankovics „hazavitte az oroszlánt”, abból is kiderülhetett a későbbiekben, hogy a DNP elnöke első parlamenti szónoklatában a kormányprogram vitájakor 1947. október 7-én határozott hangvételü demokrácia-hitvalló gondolatokat fogalmazott meg. Már a beszéd ${ }^{339}$ elején az egyik legfontosabb feladatként egy „félelemmentesebb élet körülményeinek megteremtéséröl” beszélt. Barankovicsnak a szabadság- és egyenlőségelvű demokráciáról szóló panelje e megszólalásban is megjelent („A magyar nép valóban demokráciát akar, még pedig egy szabadság- és egyenlőségelvű demokráciát, amely a népi önkormányzatokban valósul meg és a parlamentáris demokratikus kormányformában csúcsosodik ki."340)

\footnotetext{
${ }^{336}$ Barankovics István 1947. augusztus 15-ei beszédét idézi: BIHARI Mihály-GAZSÓ Ferenc-VIDA István (szerk.): Magyarországi pártprogramok 1944-1988. 147-165.p.

${ }^{337}$ Uo. 154. p.

338 Idézi: PETRÁs Éva: Barankovics István és pártja az 1945-ös demokráciában és annak utóvédharcában. Múltunk, 2016/1 90-107. p.

${ }^{339}$ Barankovics István beszéde elhangzott az Országgyülésben 1947. október 7-én. Országgyülési Napló, 19471949. I. kötet. 54-80. p.

${ }^{340}$ Uo. 65-66- p.
} 
A DNP vezérszónoka egyértelmüvé tette, ellenzéki pártként fognak a parlamentben politizálni. A beszédben hangsúlyosan megjelenő fogalom a társadalmi demokrácia - e kifejezés alatt Barankovics a szabadversenyes monopolkapitalista struktúrával szemben egy szociális attitüdü államberendezkedés mellett érvel.

Huszonegy nappal később, 1947. október 30-án Barankovics a rendeleti kormányzásról szóló törvényjavaslat vitájában ismét a parlamentáris demokrácia védelméről beszél. $^{341}$ „A parlamentáris demokráciától elválaszthatatlan az a követelmény, hogy a parlament elvileg mindig törvényhozó maradjon. Éppen ezért a törvényhozásnak nincs joga arra, hogy törvényhozó hatalmáról egy másik általa teremtett hatalom javára lemondjon, hanem a törvényhozásnak, mint szuverén szervnek csupán arra lehet joga, hogy törvényalkotó hatalmának ideiglenes és bizonyos keretek között való gyakorlásával a kormányt vagy egy másik szervet bízzon meg, ${ }^{342}$ - érvelt elvi éllel Barankovics az egyre erőteljesebb rendeleti kormányzás ellen. A szónok kimondja: a rendeleti kormányzás elburjánzása „,a demokratikus elvek leépülését” jelentik. „A klasszikus elveknek az élettől való eltávolítása, végül is a demokratikus formaságok mögé rejtett diktatúrához vezet”343 - húzza alá Barankovics.

A koalíciós korszak és egyben az 1944/45 és 1948 közötti magyar jogállami jellegü polgári demokrácia végének jelképesen 1948. december 14-ét tekintjük; Barankovics István ellenzéki politikus ekkor mondta el demokrácia-hitvallónak tekinthető utolsó parlamenti beszédét. Barankovics e megszólalása egyben az utolsó olyan szónoklat volt a rákosista diktatúra előtt álló magyar országgyülésben, mely a jogállami demokrácia elveiért állt ki, így értelmezésünk szerint ez a szimbolikus dátum zárja a koalíciós évek időszakát, a második világháború utáni néhány esztendő mint sajátos történeti átmenet korszakát.

E parlamenti beszédben Barankovics hitet tett a polgári demokrácia elvei mellett, megszólalása az utolsó nyilvános demokrácia-hitvallás volt az egyre erőteljesebben sztalinalizálódó Magyarországon.

Beszéde első részében Barankovics szóvá tette a sajtószabadságot érintő korlátozásokat: „Hogy csak a sajtószabadságnál maradjak, amely nélkül a XX. században a gondolat- és szólásszabadság nem sokat ér, és amely nélkül a világnézetek civiljogi egyenjogúsága csak írott malaszt marad, ma a kormány diszkrecionárius döntése méri ki,

\footnotetext{
${ }^{341}$ Barankovics István beszéde elhangzott az Országgyülésben 1947. október 30-án. Országgyülési Napló, 19471949. I. kötet. 703-721. p.

342 Uo. 704. p.

${ }^{343}$ Uo. 705. p.
} 
hogy a sajtószabadság jogának gyakorlásából kinek, mikor és mennyi jut."344 A Demokrata Néppárt elnöke konkrét példaként említette, hogy nemcsak az időszaki sajtótermékek engedélyezésének és betiltásának, hanem a könyvkiadásnak a joga is minden jogorvoslat kizárásával a kormány hatáskörébe tartozik, amit „részrehajlóan alkalmazott hatalmi eszközként” használ. „Mindezek a körülmények a sajtószabadságnak és az egyesülési szabadságnak sérelmei, amelyeknek jóvátételét hovatovább már remélnünk sem lehet önámítás nélkül”345 - beszélt egyben lemondóan és egyben a valóságot pontosan elemezve Barankovics. A szónoklat egy következő részében ekképpen foglalt állást a polgári demokrácia ethosza mellett: „Mi a különböző állami hatalmak, a törvényhozó, a végrehajtó és a bírói hatalom szétválasztását, továbbá a különböző társadalmi és gazdasági hatalmak, a szakszervezetek, az érdekképviseletek és a szövetkezetek olyan egymástól elválasztottságát, hivatásuk szerinti autonómiáját kívánjuk, hogy a különböző hatalmi tényezők a közjóban ugyan harmonizálják müködésüket, de bírjanak az önállóságnak azzal a fokával, hogy egymást ellensúlyozhassák, és a hatalmak koncentrációját kizárhassák. Nem értünk egyet az olyan koncepcióval, amelyben a politikai, a jogi, a gazdasági és a társadalmi hatalmat

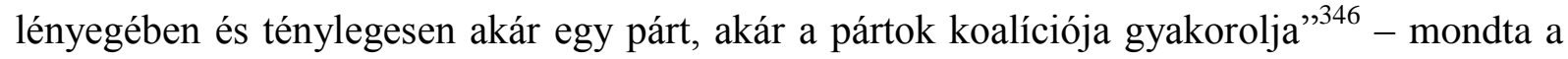
Demokrata Néppárt elnöke 1948 decemberében, s miközben e gondolatot fejtette ki, a Magyar Dolgozók Pártja frakcióját folyamatos, egyet nem értő hangoskodás jellemezte.

Barankovics István ezt követően azt a helyzetet elemezte, hogy ha a szabadságjogokról beszélnek, akkor a szavakban, a hatalom és az ellenzék között az ellentét „,igen csekély, mondhatni semmi a különbség” - mert a szavak szintjén mindenki vallja, az állampolgárokat megilleti a vallásszabadság, a szólásszabadság, a gyülekezés, a munka szabadsága, a tulajdonszerzés és -birtoklás szabadságjoga, „a közakarat kialakításába való beleszólás joga” és még egész sor emberi és demokratikus állampolgári szabadságjog. „,Az ellentét nem a szavakban, hanem a szabadságjogok elvi és gyakorlati tartalmában mutatkozik és ez mutatja a helyzet fonákságát. A kormány és mi sokszor eltérő, sőt sokszor merőben ellentétes fogalmi tartalmat tulajdonítunk egyes emberi és egyes állampolgári szabadságjogoknak, aminek következtében eltérő vagy ellentétes következményeket is füzünk hozzájuk" ${ }^{\prime 34}$ - jellemezte azt a helyzetet az országgyülési képviselő, amikor az egyes kifejezéseknek, fogalmaknak végzetesen különbözővé vált a jelentése az eltérő oldalak és

\footnotetext{
${ }^{344}$ Barankovics István 1948. december 14-én elmondott parlamenti beszédét közli: SZALAI Pál: Barankovics István utolsó beszéde. Beszélő, I. évf. (1985) 2. Elérhető: http://beszelo.c3.hu/cikkek/barankovics-istvan-utolsobeszede (A letöltés időpontja: 2015. szeptember 15.)

${ }^{345}$ Uo.

346 Uo.

347 Uo.
} 
leginkább a kibontakozó kommunista diktatúra hívei, valamint a polgári demokrácia ethoszát magukénak vallók között.

Utolsó parlamenti beszédében Barankovics azt is szóvá tette, hogy minduntalan azzal vádolják őket, hogy „a demokratikus jellegü állam eszméjének” az ellenségei, és hogy müködésükkel a demokráciát veszélyeztetik - „holott semmi egyebet sem teszünk, mint mértéktartással és felelősségtudattal képviseljük azt a programot, amelynek képviseletét a nép elött az országgyülési választásokon vállaltunk" - mondta.

A felszólalás legmarkánsabb demokrácia mellett kiálló állásfoglalása így hangzott: „A demokrácia végső soron nem egyéb, mint állandó törekvés arra, hogy az emberi jogokat a legföbb jogi hatalom nyomatékával állampolgári jogokként biztosítsuk. Valamely demokratikus rendszer - akár népinek, akár másnak nevezi magát - annál demokratikusabb, minél emberibb; és annál emberibb, minél teljesebben és hatásosabban képes előmozdítani az emberi jogoknak állampolgári jogokként való szavatolását. [...] Egy állam annyira közelíti meg a demokrácia eszményét, amennyire minden alattvalója számára az emberi jogoknak teljességét képes állampolgári jogokká átalakítani. [...] Az emberi személyiség ugyanis annál akadálytalanabbul és teljesebben bontakozik ki a társadalomban, minél szélesebb körben és minél teljesebben képesek az állampolgárok emberi szabadságjogaikat érvényesíteni”"348 fogalmazott utolsó nyilvános megszólalásában Barankovics István, aki e gondolatsorral immáron a polgári demokráciát védő, demokrácia-hitvalló megszólalásokra jellemző nyelvi stílusban a történelemnek beszélt.

Barankovics imént idézett álláspontja és maga az egész 1948. december 14-én elhangzott utolsó parlamenti beszéde a magyar demokrácia ügyéért folytatott sok évtizedes küzdelem politika- és eszmetörténetének egyik sokat idézett, fajsúlyos dokumentumává vált.

\section{6. Útkereső tudósi-publicisztikai demokráciaértelmezök}

\section{Szekfü Gyula}

A két világháború közötti Magyarország szellemi életének reprezentánsa, a tekintélyes történettudós, Szekfü Gyula 1945 utáni politikai publikációban nem a polgári demokrácia és a

\footnotetext{
${ }^{348}$ Uo.
} 
proletárdiktatúra küzdelméről ír, nála a polgári demokrácia az úgynevezett „proletárdemokráciával” áll szemben. ${ }^{349}$

Szekfü Gyula több cikkben fejtette ki 1945-ben a Világ hasábjain a demokrácia tematikát érintő meglátásait. Szekfü a szabadságjogokat elsőszámú politikai értéknek tartó erőket a „polgári demokrácia” követőinek, az „egyenlőség híveit” pedig az úgynevezett proletárdemokrácia támogatóinak tekinti. Szekfü 1945-ös publikációinak legfőbb jellemzője a polgári demokrácia értékeinek, gondolatiságának a relativizálása. Úgy véljük, Szekfü elemzései '45-ben a polgári demokrácia esélyeit illetően a valósághoz közeliek, nem hagyja magát illúziókba rángatni, ugyanakkor szövegeiből érződik, nem is tartja a polgári demokrácia eszmerendszerét adekvátnak a háború utáni viszonyokra - 1947 nyarán a Forradalom utánban mindezt már nyíltan ki is mondja.

Az is a relativizálás nyelvi eszköztárába tartozik például, hogy Szekfü a demokráciát gúnyosan csak „,varázsigének” nevezi. „Csak hinni kell benne, sokat kell hívni nevén és meg fog valósulni’350 - írja 1945 júliusában. Cinikusan tekint arra a '45-ös közkeletü kommunikációs panelre, miszerint a magyarság hagyományaiban jelen lenne a demokrácia ethosza; lesajnálóan fejtegeti, hogy bizonyosan a „népi bölcsőben, Pusztaszeren” összegyülekezett honfoglalók is demokraták voltak. ${ }^{351}$

Szintén a demokrácia fogalmának a viszonylagossá tételét jelenti, amikor Szekfü arról ír, hogy nincs és nem is lehet klasszikus demokrácia, mert az államberendezkedések történelmileg eltéröek. ${ }^{352}$ Az önmagát 1945-ben is polgári gondolkodóként azonosító Szekfü a klasszikusnak számító polgári demokrácia történelmi jelentőségü hibájaként rója fel, hogy a munkásság tömegeit mindaddig nem tudta megszólítani. ${ }^{353}$

Ebben az időszakban Szekfü a polgári demokrácia szellemi pozícióit gyengítő, demokrácia-kritikus mentalitást képvisel, ugyanakkor a „proletárdemokrácia” fogalom használata '45-ben arra utal, hogy abban bízott, nem a szovjet típusú totális hatalmi struktúra kiépítése következik, hanem valamiféle átmenet. Azzal ugyanis tisztában volt már ekkor, hogy olyan politikai rendszer fog létrejönni, ahol a szovjet politikának ${ }^{354}$ érdemi szerepe lesz:

\footnotetext{
349 DÉNES Iván Zoltán: A történelmi Magyarország eszménye. Szekfü Gyula a történetíró és ideológus. Kalligram Kiadó, Pozsony, 2015. 372. p.

${ }^{350}$ SZEKFÜ Gyula: A két történeti erő. Világ, 1945. július 29. 1. p.

${ }^{351}$ SZEKFÜ Gyula: Értelemhiány. Világ, 1945. június 3. 3. p.

${ }^{352}$ SZEKFÜ Gyula: A „klasszikus demokrácia”. Világ, 1945. július 22. 1. p.

${ }^{353}$ SzEKFÜ Gyula: Egy pünkösdi pártnap. Világ, 1945. május 29. 1. p.

354 Standeisky Éva szerint Szekfü szemében a Horthy-rezsim „tehetetlensége” és a „szélsőjobb 1944-es orgiája” felértékelte a szovjet megszállókat és az 1945-ben józannak tünő kommunistákat, akik a gyökeres változás ígéretével érkeztek a háború utáni közéleti küzdőtérre. (STANDEISKY Éva: Demokrácia negyvenötben. 177. p.) Dénes Iván Zoltán úgy látja: Szekfü Gyula „,a nagyhatalmi adottságok fenntartás nélküli elfogadására” szólította fel olvasóit, méghozzá erősen leckéztető hangnemben. (DÉNES Iván Zoltán: Egy igazságtalanság két értelmezése.
} 
„A Szovjet-Világbirodalom szomszédunk lett, az is fog maradni, s mint ilyen, anyagi és szellemi téren természetes módon is nagy befolyást fog ránk gyakorolni” - írta 1945 augusztusában. ${ }^{355} 1945$ derekán azonban még nem feltételezhette, hogy néhány éven belül közvetlenül a sztálinista berendezkedés valósul meg.

Azt valószínüsítette '45 kora őszén, hogy a háború utáni időket „a szabadság és egyenlőség közti feszültség”, illetve a „polgári” és a „proletárdemokrácia” eltérései, különbözőségei fogják meghatározni. ${ }^{356}$ Úgy gondolta, a polgári demokrácia híveinek erősödése által a szabadságjogok ,érvényesülhetnek tisztábban” a politikai rendszerben, a proletárdemokrácia dominánsabbá válása pedig a munkásság társadalmi szerepét fogja megerősíteni. ${ }^{357}$ Rideg, határozott és metszően pontos történeti logikát, érvkészletet használva azt is elemzi, hogy a nagyobb egyenlőség kevesebb szabadságot jelent, illetve a több alkotmányos szabadságjog kevesebb lehetőséget enged a szociális egyenlőség és a radikális társadalom-átalakítás tekintetben. Szerepel Szekfünél az „egyenlősítő demokrácia” kifejezés is, a háború utáni hónapok történéseit ezzel a fogalommal jellemzi, s megállapítása szerint az egyenlősítő demokrácia komoly szociális teljesítményt tudott felmutatni mindaddig. ${ }^{358}$

Szekfü Gyula 1947 nyarán írta a Forradalom után címü történeti esszéjét. A politikai tendenciákat a történész szemüvegén át látó Szekfü ekkorra már egyértelmüen úgy ítéli meg, Magyarország sorsa eldőlt, s a kommunista nézőpontú „demokrácia” fogja meghatározni a nemzet életét. ${ }^{359}$ A gondolkodó a szovjetek háború utáni magatartásának hátterét kívánta megérteni, megértetni a Forradalom utánban: „Igaz, hogy az angolszászoknak megígérték az elfoglalandó államok demokratikus berendezését, de viszont ők a szovjet berendezést tartják demokratikusnak, és egyébként is sokféle út állott rendelkezésre, ha akarták volna az ígéret megkerülését. A valóságban már akkor elhatározták az államok demokratikus berendezését, amikor ezt megígérték" 360 - érvel ekkorra már egyértelmüen opportunista módon Szekfü. A történész a Szovjetunió érdemének tekintette, hogy nem akart egyből proletárdiktatúrát rákényszeríteni az országra; helyesnek véli ugyanakkor, hogy a háború után nem olyan

Szekfü Gyula és Bibó István a párizsi békeszerződésről. Magyar Tudomány, CX. évf. (2003) 6. Elektronikusan elérhető: http://www.matud.iif.hu/03jun/denes.html /A letöltés időpontja: 2016. február 6./)

${ }^{355}$ SzEKFÜ Gyula: A szabadság hívei. Világ, 1945. augusztus 26. 1. p.

${ }^{356}$ SZEKFü Gyula: Az egyenlöség hívei. Világ, 1945. szeptember 2. 1. p.

${ }^{357}$ SZEKFŰ Gyula: A választás után. Világ, 1945. október 21. 3. p.

${ }^{358}$ SZEKFÜ Gyula: Tavasz óta. Világ, 1945. augusztus 12. 3. p.

${ }^{359}$ Hatos Pál szerint „az 1945 utáni öreg Szekfü pesszimista értékelésében Kelet és Nyugat küzdelmében Kelet erői győztek Magyarországon.” (HATOS Pál: Nyugatról Keletre? A köztes lét bukásai Szekfü Gyula történeti narratíváiban. Kommentár, X. évf. (2015) 6.73-89. p. /88. p./)

${ }^{360}$ SzEKFŰ Gyula: Forradalom után. Hasonmás kiadás. Sajtó alá rendezte, a jegyzeteket és a bevezető tanulmányt írta: GLATZ Ferenc. Gondolat Kiadó, Budapest, 1983. 83-84. p. Idézi: BALOGH Sándor: Népi demokratikus örökségünk: parlamentáris és közvetlen demokrácia Magyarországon, 1944-1948. Századok, CXIX. évf. (1985) 2. 385-422. p. 
demokrácia jött létre Magyarországon, amely „hirtelen” bevezette volna az emberi szabadságjogokra alapuló állami struktúrát, mert a „tömeg” azzal nem tudott volna mit kezdeni és csak visszasírták volna a régi rendszert. Szekfü szerint a sajtószabadság, az egyesülési szabadság, a „nyugati demokrácia alappillérei” a régi rend erői kezében az új államberendezkedéssel szemben csakis „fegyverekké” váltak volna. ${ }^{361}$

Szekfü Gyula 1945-ben még csak relativizálja a szabadságjogokra alapuló demokratikus berendezkedés értékeit, a Forradalom után címü nagyesszéjében viszont már kategorikusan fordult szembe a polgári demokrácia értékrendjével. Márai Sándor 1948-ban, a Forradalom után olvasását követően „ravasznak” és „sunyinak” nevezi a szerzőt. Márai maró gúnnyal ítéli el Szekfüt: „S ahogyan a Három nemzedékben az ellenforradalom szájába adja az eszmei terminológiát, oly óvatos-alamuszian fogalmaz most új müszavakat a forradalom számára. [...] Kétségtelen, hogy most vagyunk azon az úton, amikor társadalmi berendezkedésünk lassan eléggé »fejlett« lesz ahhoz, hogy »kiérdemelje« a szovjetrendszerbe való beilleszkedés kitüntetését... Szekfü ezt helyesli. Négyezer dollárt kap havonta, mint moszkvai követ, ezt se feledjük el; ha nem vállalja a szerepet, itthon ma koldus lenne vagy üldözött tudós, mint Moór Gyula, akit hasonlóan megkínáltak e tisztséggel, de nem fogadta el; s ma nyugdíjban tengődik, politikai számkivetettségben."362

\section{Bibó István}

Bibó István A magyar demokrácia válsága című cikke nemcsak tartalmilag markáns forrása a koalíciós korszak demokrácia-vitáinak, hanem elö- és utóéletét tekintve is meghatározó dokumentum. ${ }^{363}$ Bibó koalíciós évekbeli publikációi mind a mai napig vitát generálnak, mind a mai napig nem sikerült felfejteni Bibó gondolkodásának egynémely bizonytalan elemét. Mindezen szempontok jelennek meg a bibói recepcióban elemzett naivitás-vitában.

\footnotetext{
${ }^{361}$ Uo. 90. p.

${ }^{362}$ Márai gondolatait idézi: HATOs Pál: Az öreg Szekfü Gyula (1945-1955). Kommentár, VI. évf. (2011) 2. Elektronikusan elérhető: http://kommentar.info.hu/iras/2011_2/az_oreg_szekfu_gyula_1945_1955_\#foot14 /A letöltés időpontja: 2016. január 31./)

363 Egy markáns vélemény Bibó István mint politikai gondolkodó hatásáról: „Magyarországon és a szülőhazájukon kívül élő magyar származásúak között egyaránt, széles körökben Bibó Istvánt tekintik a XX. század két utolsó harmada - de talán az egész évszázad - legbefolyásosabb magyar politikai gondolkodójának. Ösztönzést jelentett a demokratikus ellenzék számára, eszmei, filozófiai meglapozást nyújtanak a most kialakulóban lévő magyar demokráciának.” (MuRAY, Leslie A.: Bibó István politikai gondolkozása. Magyar Filozófiai Szemle, XXXVIII. évf. (1994) 3-4. 521-528. p.)
} 
A magyar demokrácia válsága elöélete azért kiemelendő, mert a publikáció megjelentetésének históriája is sokat elmond a koalíciós időszak közegéről. Szabó Zoltán, ${ }^{364}$ A magyar demokrácia válsága címü terjedelmes írásnak helyt adó Valóság szerkesztője írta meg a tanulmány 1945 végi megjelenésével kapcsolatos bonyodalmakat. ${ }^{365}$ Bibó István tanulmányának nyomdai kefelevonata már készen volt, amikor a Valóság két kommunista párti tagja arra hivatkozva, hogy a dolgozat „veszélyezteti a demokráciát”, óvást emeltek a közlése ellen, majd Révai József is a Bibó-tanulmány közlésének elhalasztását kérte. Révai a Bibó-tanulmányt hol ellenforradalminak, hol reakciósnak minősítette. A kommunista ideológus azzal is fenyegetőzött, hogy a lapot a rendőrséggel foglaltatja le a nyomdában, majd azt vetette fel, hogy hívják oda döntőbíróként Lukács Györgyöt, a tekintélyes kommunista esztétikus-filózófust. Lukács úgy vélte, a Valóság elkobzása „egy sereg jó demokratát” jobbra tolna, fontos azonban, hogy ebben az ügyben a kommunista párt is kifejthesse a maga álláspontját, ezért azt ajánlotta: Révai törődjön bele a cikk megjelenésébe, de a publikálás után a Valóság rendezzen nyilvános vitát a cikkről, s ezen szólaljon fel Révai József is. ${ }^{366}$

Bibó István A magyar demokrácia válsága címủ elemzése ${ }^{367}$ a Valóság 1945 októberdecemberi számában jelent meg. „A magyar demokrácia válságban van. Válságban van, mert félelemben él. Kétféle félelem gyötri: fél a proletárdiktatúrától, és fél a reakciótól. Tárgyi okok nem indokolják egyik félelmet sem: Magyarországon mindazok, akik proletárdiktatúrát akarnak, és mindazok, akik a reakció visszatérését akarják, elenyésző kisebbségben vannak, s külső erők sem néznék szívesen egyik fordulatot sem"368 - kezdi legendássá vált ${ }^{369}$ soraival a

\footnotetext{
${ }^{364}$ Szabó Zoltán közéleti szerepvállalásáról: RÉvÉSZ Sándor: Szabó Zoltán, az antiteoretikus. Mozgó Világ, XXXVIII. évf. (2012) 3. Elérhető: http://www.mozgovilag.hu/revesz-sandor-szabo-zoltan-az-antiteoretikus/ (A letöltés időpontja: 2016. január 31.)

${ }^{365}$ Szabó Zoltán visszaemlékezését közli: BIBÓ István: Életút dokumentumokban. Szerkesztö: LITVÁN György, S. VARGA Katalin. 1956-os Intézet - Osiris - Századvég, Budapest, 1995. Elérhető: http://epa.oszk.hu/02200/02201/00005/pdf/EPA02201_Magyar_Fuzetek_1979_04_006-043.pdf (A letöltés időpontja: 2015. június 5.) 327-331. p.

${ }^{366}$ A Bibó koalíciós évekbeli publicisztikájával foglalkozó filozófus, Perecz László A magyar demokrácia válsága megjelentetéséről szóló történetet egyszerre tartja félelmetesnek és nevetségesnek. „Az egyszerre félelmetes és nevetséges történet önmagában is figyelemre méltó bizonyítékkal szolgál a Bibó-vitacikk kommunizmuskritikájának relevanciájára" - fogalmaz Perecz. (PERECZ László: Kimért időben. Bibó István koalíciós válságelemzése. In: DÉNES Iván Zoltán (szerk.): Bibó 100. Recepciók, értelmezések, alkalmazási kísérletek. Argumentum Kiadó - Bibó István Szellemi Műhely, 2012. 98-114. p.)

${ }^{367}$ Balog Iván szociológus a Politikai hisztériák Közép- és Kelet-Európában címủ könyvében arra hívja fel a figyelmet, jelentősége van annak, hogy Bibó az 1945-ös demokrácia kapcsán „,válságról” és nem „zsákutcáról” beszél, vagyis Bibó 1945-ben úgy érezhette, a kialakult válsághelyzetből van kiút. (BALOG Iván: Politikai hisztériák Közép- és Kelet-Európában. Bibó István fasizmusról, nacionalizmusról, antiszemitizmusról. Argumentum Kiadó-Bibó István Szellemi Műhely, 2004. 175. p.) „Bibó sokkal nagyobb mozgásteret érzékelt 1945 és 1948 között, mint amennyi valójában volt - ez a három év ugyanis inkább tartozott a történelem bemerevedett, mint a cseppfolyós időszakai közé" - írja Balog Iván. (Uo. 185. p.)

${ }^{368}$ BIBÓ István: Válogatott tanulmányok. Második kötet. Szerkesztette: HUSZÁR Tibor, VIDA István, NAGY Endre. Magvető Kiadó, Budapest, 1986. 15. p.
} 
tanulmányt Bibó. ${ }^{370}$ A szerző úgy véli, hogy 1945 őszére a magyar demokrácia válságba került. A válság döntő tényezőjének tekinti a félelmet magát - ráadásul ez polarizációt generáló kettős félelem. A társadalom egyik része a kommunisták diktatórikus törekvéseitől fél, míg mások a „reakciótól.”

Meg kell jegyeznünk, Bibó reakció fogalma egészen más, mint a kommunistáké. Ahogy a korábbiakban idéztük, Révai kiterjesztően értelmezi a reakciós kifejezést, szerinte például reakciós az is, aki antikommunista, vagyis aki a kommunistákétól eltérő véleményt fogalmaz meg. Bibó reakciós jellegűn a Horthy-korszak továbbélő valóságát érti. A tanulmányban így ír erről: „A reakcionárius elsősorban nem támadó emberfajta, hanem mindenekfelett egy valamihez kötött, érdekviszonyokba vagy elöítéletekbe mereven beágyazott emberfajta." ${ }^{371}$ A reakciónak ez a bibói megközelítése teljességgel ellentétes volt 1945-ben a kommunista nyelvhasználati stratégiával.

A tanulmányíró érvelésének lényege, hogy egyik félelmet sem indokolják „tárgyi okok.” Bibó 1945 őszén - és utána még évekig - elhitte a Magyar Kommunista Párt hivatalos kommunikációjában foglalt állításokat, miszerint nem törnek proletárdiktatúrára. ${ }^{372}$ (,A kommunista párt jelenlegi hosszú lejáratú irányvonala a demokratikus erők koalícióján alapuló, népfrontos, demokratikus politika." $)^{373}$ Ez kétségtelen tévedés a koalíciós évek bibói demokrácia-publikációiban - ebből következően A magyar demokrácia válsága egyik

\footnotetext{
${ }^{369}$ A tanulmány „legendássá” válásáról egy rövid történet: Kenedi János 1979-ben a Bibó-emlékkönyv számára írott rövid esszéjéből tudjuk meg, hogy a hetvenes évek puha diktatórikus világában, az írás megszületése után több mint harminc esztendővel $A$ magyar demokrácia válsága címü tanulmányt gépiratos formában spontán terjesztették egymás között a fiatalok. A gépiratról ezt derül ki: „Egyes sortávolsággal, faltól falig gépelve, nem is egy másolódiáktól származó melleütésekkel. Háromféle margótávolság tanúsította, hogy legalább hárman feszültek neki.” (KENEDI János: A hajthatatlan és a megalkuvó. In: Bibó-emlékkönyv. Századvég Kiadó Európai Protestáns Magyar Szabadegyetem, Budapest - Bern, 1991. 194-230. p.)

${ }^{370}$ Dénes Iván Zoltán eszmetörténész úgy véli, Bibó 1945 öszén A magyar demokrácia válsága tanulmányában arra figyelmeztette a közélet szereplőit, „hogy el kell kerülni a proletárdiktatúrától való félelem és a reakciótól való félelem önálló életre keltését - mindenekelőtt, úgy, hogy a merő és gátlástalan hatalmi érdekérvényesítéssel szemben ki kell alakítani és be kell tartani a koalíciós demokrácia müködésének szabályait és erkölcsét." (DÉNES Iván Zoltán: Egy igazságtalanság két értelmezése. Szekfü Gyula és Bibó István a párizsi békeszerződésről. Magyar Tudomány, CX. évf. (2003) 6. Elektronikusan elérhetö: http://www.matud.iif.hu/03jun/denes.html /A letöltés időpontja: 2016. február 6./)

${ }^{371}$ BIBÓ István: Válogatott tanulmányok. Második kötet. 1945-1949. 29. p.

${ }^{372}$ Figyelemreméltó jelenség, hogy Bibó István 1946-ban írt, de akkor nem publikált $A$ magyar demokrácia mérlege címü tanulmányában a szerző „a pszichotikus félelem korszakáról” írt, amelyet az jellemez, hogy a jogbiztonságra vágyó erők kialakítottak egy olyan közgondolkodást, miszerint „,a megszállás különféle velejárói és az agresszív kommunista politikai akciók együttvéve előkészítései egy pillanatnyilag nem hangoztatott, de fel nem adott ördögi politikai tervnek: Magyarország bolsevizálásának.” (Uo. 179. p.) E szövegrész azért érdekes témánk szempontjából, mert arra utal, Bibó tudott arról, létezett olyan álláspont már 1946-ban is, hogy az akkori közéleti küzdelmek a kommunisták részéről nem irányulnak másra, mint az ország bolsevizálására. Bibó ezt a gondolatot némi iróniával „ördögi politikai tervnek” nevezi és érezhetöen nem hisz benne, de tény, hogy magának a gondolati struktúrának, a „félelemnek” a létezésével tisztában volt, csak maga nem vallotta és nem tartotta reálisnak.

${ }^{373}$ BIBÓ István: Válogatott tanulmányok. Második kötet. 1945-1949. 20. p.
} 
alapvetése is bizonytalan alapokon nyugszik. („A kommunizmus és a parlamentáris demokrácia összeegyeztetésének ugyan elég keskeny az ösvénye, de az ösvény járható." $)^{374}$

Mindennél azonban talán fontosabb az a nézőpont, hogy Bibó koalíciós platformról először meri kimondani, hogy a társadalom egy része fél a proletárdiktatúrától, másrészt ami talán még ennél is fajsúlyosabb intellektuális tett, hogy a kommunisták „reakció” fogalmát ami ugyebár a kommunista kommunikációs hadviselés legfontosabb terminológiai fegyvere árnyalja, gyengíti és végeredményben megfosztja eredeti létjogosultságától.

„Áthidalhatatlannak látszó ellentét áll fenn a demokrácia értelmezése tekintetében”375 - állapítja meg Bibó István, s példának hozza a demokráciaértelmezéssel kapcsolatos eltérő megközelítésekre a formális szabályokhoz való viszonyulás kérdését. Ahogy a különböző megszólalásokban már láthattuk, a kommunisták a formális szabályokkal szemben foglalnak állást, mert az általuk elképzelt radikális változások ethoszába, illetve a kommunista párttaktikába nem fért bele a formális szabályok elismerése, illetve az azok alapján történő közéletformálás.

Bibó bírálja a kommunista hozzáállást, elemzése arról szól, hogy a kommunisták azért nem fogadják el a játékszabályokat, mert azok megléte korlátozó erővel bír a végső stratégiai és politikai céljaik elérése szempontjából - és e stratégiai célok tekintetében pedig a kommunisták ,rugalmatlanok.”

Bibó István úgy véli, a demokrácia magyarországi válságának ,a központi része” a reakció elleni harc válsága. A szerző enyhe gúnnyal emlékezik meg arról, hogy a kommunista párt egy esztendő óta az ország társadalmi, gazdasági és politikai életének legkülönbözőbb pontjain „ragadja üstökön” a reakciót, és minden héten „újabb és újabb fészkeket” fedez fel. „A csodálatos csak az, hogy a reakciónak és a fasizmusnak minél több fészkét fedezik fel, annál szükebb lesz a demokrácia platformja”376 - fogalmaz Bibó. A szerző a reakció elleni harc legnagyobb betegségeként értelmezi, hogy e harc nem tud különbséget tenni a szorosan vett reakció szűk köre és azok között a konszolidációs elemek között, akik azáltal válnak reakciósokká, hogy a reakció elleni harc megfélemlíti őket.

Bibó a kommunisták parttalan reakció fogalmával szemben igyekszik megérteni a reakciósság lelki attitüdjét, a tanulmányban végig egy valós társadalmi jelenségeken nyugvó reakció-képet vázol; a konzervativizmus legfontosabb lélektani ösztönzőjének a háború utáni

\footnotetext{
${ }^{374}$ Uo. 27. p. (A Bibó-interpretációtörténet ezt az elemet „ösvény”-metaforaként emlegeti. Lásd: PERECZ László: Kimért időben. Bibó István koalíciós válságelemzése.)

${ }^{375}$ Uo. $15-16$. p.

${ }^{376}$ Uo. 27-28. p.
} 
hónapokban a biztonság iránti vágyat tekinti. Azt is egyértelművé teszi, hogy aki konszolidáló demokráciát és biztonságot szeretne, az lehet hogy konzervatív, de nem reakciós.

„Az egész válságban a rendőrség ügye központi jelentőségü, mert a kommunistáktól és a proletárdiktatúrától való félelem konkrét okait elsősorban a rendőrség szolgáltatja” - jelenti ki Bibó. Emlékezhetünk, Rákosi 1945 nyarán a Demokrácia-előadássorozaton elmondott beszédében a kommunista befolyás alatt müködő rendőrséget „a demokrácia kardjának” nevezte.

Meggyőződésünk, Bibó alábbi álláspontja - noha egyszerủen csak a kommunisták rendőrségi pozíciójáról szól - azt is illusztrálja, hogy a szerző (részben tévesen vagy naivan) mit gondolt 1945-ben a kommunisták demokrácia-felfogásáról. „A kommunista párt semmivel sem vesztett annyit év eleji magyarországi pozíciójából, mint azzal, hogy a rendőrségben tartott pozícióihoz ragaszkodott. A rendőrség nem az a terület, ahol nagyméretü, haladó szellemű alkotó munka számára sok lehetőség volna"377 - írja a tudós. Bibó abból indul ki, hogy a demokratikus közélet küzdőterein a gondolat ereje a meghatározó, a gondolatok fórumai a sorsdöntők és nem a rendörségi tetteké. Illúziórikusan azt feltételezi, hogy a kommunisták a maguk demokráciájáért és a haladás eszméjéért a gondolatok fórumain fognak megküzdeni. Az utólagos történésekből pontosan tudjuk, hogy a kommunisták számára a rendőrségi pozíciók birtoklása olyan hatalmi kérdés volt, ami minden felett állt. Bibó azonban a rendőrségre pusztán mint a társadalom rendjéről gondoskodó szervezetre tekintett és nem érzékelte, hogy a kommunista befolyás alatt müködő rendőrségnek a presztalinalizálás korában kiemelt hatalomtechnikai szerepe van. Hiába látta és analizálta Bibó a demokrácia ethoszával összeegyeztethetetlen durva rendőrségi jogsértéseket, túlkapásokat - azt akkor még nem látta át, hogy a kommunisták rendőrségi pozíciói egyben ugródeszkát jelentettek a demokratikus jogállam lebontásához. ${ }^{378}$

A demokrácia értelmezése és a forradalom szükségessége körüli zavar címü alfejezetében érintette leginkább a demokrácia-felfogások közötti végletes különbségeket a

\footnotetext{
${ }^{377}$ Uo. 41. p.

${ }^{378}$ A magyar demokrácia mérlege címü, 1946-ban írt, akkoriban nem, csak 1984-ben publikált írásában a rendőrségi kérdéshez kapcsolódóan így írt Bibó: „Az önkénynek, az egyéni akcióknak, a hatalmi túltengésnek a kilengései szintén a kommunisták akcióihoz kapcsolódnak.” (Uo. 179. p.)

Kovács Imre az Irodalmi Újság számára írt tanulmányában foglalkozott Bibónak a kommunista kézben lévő rendőrség kapcsán megfogalmazott álláspontjával: „Kezdettől fogva jó barátság füzte Erdei Ferenchez (szegedi kapcsolat), s az Erdei-féle hírhedt belügyminisztérium egyik fő oszlopa volt mint a közigazgatási osztály vezetője (ebben a minőségében kidolgozott reformterve kitűnő). A rendőrség viselkedését, amivel tanulmányaiban részletesen és árnyalati elfogultsággal foglalkozott, elsősorban Erdei előtt kellett volna kifogásolnia, hogy számon kérje tőle a kilengéseket, a brutalitást, amivel rászorítja tárgyilagosabb, határozottabb magatartásra" (KovÁCS Imre: Népiség, radikalizmus, demokrácia. Publicisztikai írások. Gondolat Nyilvánosság Klub - Századvég, Budapest, 1992. 323. p.)
} 
szerző: „A válság összes elemeit összefoglalja s egyben megmagyarázza az az ellentét, mely a demokrácia helyes értelmezése tárgyában a két oldal között fennáll. E két szemben álló oldal, nevezzük őket egyszerűség kedvéért kisgazda oldalnak és kommunista oldalnak, kölcsönösen ajkbiggyesztve beszél a másik oldal demokráciájáról, és körülbelül úgy állítja be a kérdést, hogy Magyarországon addig nem lesz igazi demokrácia, amíg a másik fél ki nem kapcsolódik a játékból”379 - jellemzi a koalíciós korszak szereplőinek demokrácia-képéből következő különbséget Bibó István. Két oldalt nevez meg: vannak a „nyugati fogalmazású” demokrácia hívei és létezik úgymond a „keleti fogalmazású” demokrácia a maga követői körével. A nyugati demokraták szemében a „keleti demokrácia” egyenlő a diktatúrával, a „keleti demokraták" szemében pedig a nyugati demokrácia egyenlő a reakcióval. Bibó fogalomhasználata 1945-ben arra utal, hogy a maga részéről mindkét megközelítést, a „nyugati” és a „keleti” demokráciát is a nagy közös demokratikus értékrend részének tartja. Visszatekintve megállapítható, ez tévedés volt Bibó részéről, hiszen a kommunisták, ahogy ő fogalmaz, a „keleti demokraták” nem fogadták el vagy csak átmenetileg, taktikai okokból fogadták el a koalíciós években a jogállami demokráciát konszenzuális keretnek.

A nyugati demokráciát a magyarországi helyzetre vonatkoztatva „kisgazdapárti” stílusú demokráciának nevezi. ${ }^{380}$ A szerző elemzése szerint a kisgazdapárti demokrácia legfőbb jellemzője az, hogy a hangsúly a játékszabályokon van: „gondos, precíz jogalkalmazáson, a szerzett jogok tiszteletén s a többségi elv fenntartás nélküli és zokszó nélküli elfogadásán.”381 A keleti demokrácia terminus technicust más helyen „kommunista atmoszférájú demokráciáként" írja körül. A kommunista atmoszférájú demokráciát Bibó így kategorizálja: a saját maguk által elképzelt demokrácia-modell ellenfeleivel „szemben való keménység”, mindezen csoportoknak „a demokrácia előnyeiből való kizárása”, továbbá a tömegakciók jelentőségének a hangsúlyozása. Bibó konklúziója szerint a kisgazda stílusú demokrácia „mindenekelőtt bizonyos eljárási módok összessége”, míg a kommunista atmoszférájú demokrácia pedig egyfajta sajátos „,harci állapot." 382

Bibó meggyőződése: a demokráciát, a demokrácia struktúrájának kiépítését jelképes vagy valóságos forradalomnak kell megelőznie, véleménye szerint „,a változás” eddig soha sehol nem jött létre választással, szavazással, többségi akarattal és a szabályok pontos

\footnotetext{
${ }^{379}$ Uo. 49. p.

380 Talán itt érdemes utalnunk rá, hogy Rákosi Mátyás ismerte Bibó István A magyar demokrácia válsága címü munkáját. Minderről Bibótól magától értesülhetünk. A Huszár Tibornak adott életút-interjúban nyilatkozott arról, hogy „Rákosi olvasta a cikket és megjegyezte belőle azt a részt, ahol a kisgazdapártot jellemeztem, és ez nagyon tetszett neki.” (BIBÓ István (1911-1979). Életút dokumentumokban. 259. p.)

381 BIBÓ István: Válogatott tanulmányok. Második kötet. 1945-1949. 49. p.

${ }^{382}$ Uo. 50. p.
} 
betartásával. A szerző e téren a szociális demokrácia platformján áll, maga is úgy véli, a megcsontosodott merev társadalmi szerkezetek feltörése csakis radikális eszközökkel történhet meg. Szövegének e része alapján úgy tünhet, a kommunista érveléshez közeledik a szerző - Bibó és a kommunisták között a közös pont a radikális szociális fordulat igenlése jelenti. Bibó István úgy ítéli meg, hogy egy választás csak fennálló erőviszonyokat juttathat kifejezésre, a demokrácia elindulásának feltétele pedig a meglévő beidegződések megtörése. Mint írja: „Minden nagy demokrácia történetének kiindulópontjánál forradalom áll.”383 - írja Bibó az emberi méltóság felkeléséről mint sajátos társadalmi pszichés folyamatról. A bibói megfogalmazás szerint az emberi méltóság forradalmának a „határolt forradalom” keretei között kell lezajlania a demokrácia lelki megteremtése érdekében. ${ }^{384}$

Ahogy a megjelenést megelőző diskurzus során Lukács György javasolta, a publikálás után széleskörű vitát rendeztek a dolgozatról. ${ }^{385}$ Lukács a vitafórumon ${ }^{386}$ mint első felszólaló már a referátuma címében ,jobboldali kritikának” nevezte Bibó álláspontját. ${ }^{387}$ Lukács György meggyőződéses marxista tudós volt, akinek intellektuális képességeit nem csak a kommunista holdudvarban ismertek el, így az ő megszólalásainak az értelmezése különösen tanulságos lehet. ${ }^{388}$

\footnotetext{
${ }^{383}$ BIBÓ István: Válogatott tanulmányok. Második kötet. 1945-1949. 50-51.p.

${ }^{384}$ Bibó a Huszár Tibornak adott életút-interjúban kritikusan állt $A$ magyar demokrácia válsága címü tanulmányában a kommunista párttaktikát és demokráciaértelmezést illetöen kifejtett önnön nézeteihez, meglátásaihoz: „Nem hittem azt sem, hogy egyáltalán mindaz, amit a kommunisták csinálnak, csak ravasz taktika, aminek a végén végül mégis a proletárdiktatúra fog bekövetkezni, ami ennek a félelemben élő középosztálynak magától értetődő axiómája volt. Ebben viszont nem ők, hanem én tévedtem. Én a népfrontpolitikát olyan mértékben belső és kikerülhetetlen szükségszerüségnek éreztem, és abban a hiszemben voltam, hogy ez a kommunisták részéről is valóságos realitásérzék eredménye, hogy meg voltam győződve, hogy ez hosszú lejáratú program. [...] Végül a beijedt értelmiségieknek lett igazuk, de ma sem szégyellem, hogy én mekkorát tévedtem akkor." (BIBÓ István (1911-1979). Életút dokumentumokban. 226. p.)

385 Bibó maga csalódott volt a tanulmány kapcsán miatt kirobbant vita után: „A vita végeredményben diszharmonikus volt számomra: nemcsak a hozzászólásokról, de ugyanúgy saját magamról is az volt az érzésem, hogy az ügyet semmivel sem vittük előbbre" - írta Bibó István 1946 februárjában egykori professzorának, Marót Károlynak. A levelet idézi: PERECZ László: Kimért időben. Bibó István koalíciós válságelemzése.

${ }^{386}$ A vitában elhangzottakat elemzi Lukács György nézőpontján keresztül Sziklai László Demokrácia és realizmus címü 1981-es tanulmányában. Ez egy egyetlen olyan elemző írás, amely Lukács Györgynek ad igazat a jövőből visszatekintve Bibóval szemben. Sziklai szerint Lukács egyik legnagyobb érdeklődéssel vizsgált filozófiai témája a „demokrácia” kérdésköre volt. Sziklai úgy véli, 1946-ban Lukács demokrácia-felfogása volt a realistább. „A politikai szerepet vállaló tudós történelmi realizmusa, amely egy átmeneti korszakban a demokráciát a magyar társadalom sorsdöntő forradalmi átalakulásának tükrében értelmezi - Bibó István felett áll.” (SzIKLAI László: Demokrácia és realizmus. Világosság, XXII. évf. (1981) 1. 41-44. p. /44. p./)

${ }^{387}$ A magyar demokrácia válsága cikk vitáját közli: BIBÓ István: Válogatott tanulmányok. Második kötet. 19451949. 84. p.

${ }^{388}$ Standeisky Éva úgy látja, Rákosi Mátyás és Révai József beszédei, újságcikkei és Lukács György tanulmányai még a „kettős kommunista nyelvhasználatban nemigen járatos értelmiségiekkel” is el tudták hitetni, hogy „új típusú demokrácia van kialakulóban”, amit legfeljebb a „reakciósok” veszélyeztetnek. (STANDEISKY Éva: Gúzsba kötve. A kulturális elit és a hatalom. 1956-os Intézet- Állambiztonsági Szolgálatok Történeti Levéltára, Budapest, 2005. 68. p.)
} 
Lukács György 1945-46-ban a „radikális forradalmi demokrácia” szükségességéről beszél megszólalásaiban. A radikális forradalmi demokrácia célja Lukács szerint a társadalmi egyenlőtlenségek felszámolása. A filozófus azt vallja, hogy hiába létezik a polgári demokráciában a szabadságjogok rendszere, ha az nem biztosítja „az emberek tényleges szabadságát." ${ }^{389}$ Lukács e dilemma felvetésével a koalíciós évek demokrácia diskurzusainak lényegi elemét ragadja meg. A jogállami értékekre épülő polgári demokrácia hívei a szabadságjogok meglétét tartják abszolút prioritásnak a közéleti dialógus során; a polgári demokráciát meghaladni igyekvők - mint például a kommunisták - viszont abból indulnak ki, a szabadságjogok alkotmányos megléte önmagában nem bír társadalmi jelentőséggel. „A formalisztikus liberális demokrácia puszta magánemberré torzítja az embert"390 - írja Lukács.

Lukács a Bibó-vitában hangsúlyozta: a harc létkérdés (csak emlékeztetünk Révai „harcos demokráciáról” szóló alapvetésére), a demokrácia ellenségeit folyamatosan ártalmatlanná kell tenni, mert csak így lehet „továbbfejleszteni” a demokráciát.

Lukács részletes elemzésnek veti alá a bibói érvelés kiindulási pontját: a demokrácia „válságban van, mert félelemben él” felvetést. A filozófus nem fogadja el, hogy a kétféle félelem (a proletárdiktatúrától és a reakciótól) egyenrangú lenne, szerinte „ezt a két félelmet” nem lehet összehasonlítani. Lukács úgy véli, a régi világ „még mindig hatalmas gazdasági eszközökkel, fontos politikai és társadalmi kulcspozíciókkal”391 rendelkezik. Lukács György nyilvánvalóan egyetért azzal, hogy a reakció valós veszély - míg kategorikusan visszautasítja, hogy a proletárdiktatúra a közeljövőben létező valóság lehetne, merthogy úgymond nincsen komoly ember Magyarországon, amely a proletárdiktatúrát akarna, vagyis Bibó következtetései helytelenek. Az utókor és a történelem ítélete alapján egyértelmü: e téren nem Bibó, hanem Lukács György tévedett.

A vitában először Bibó István reagálhatott Lukács György szavaira. „A demokráciát egészben ez a cikk semmiképpen sem a jobboldal felől taglalja, a kommunista pártot azonban, minthogy nem állhat tőle balabbra, kívülről nyilván csak jobboldalról lehet taglalni”392 _ kezdte a jobboldaliság bélyegéről szóló válaszát Bibó. A proletárdiktatúra kontra reakció témakörben tesz egy különös kijelentést: „A cikk kivehetően a reakciót tekinti a nagyobb veszélynek, s egy helyen kifejezetten meg is mondja, hogy a demokrácia igazi harca a reakció

\footnotetext{
${ }^{389}$ LUKÁCs György: Arisztokratikus és demokratikus világnézet. Fórum. I. évf. (1946) 3. 197-216. p. ${ }^{390}$ Uo.

${ }^{391}$ A magyar demokrácia válsága cikk vitáját közli: BIBÓ István: Válogatott tanulmányok. Második kötet. 19451949. 88. p.

${ }^{392}$ Uo. 105. p.
} 
elleni harc. ${ }^{\text {393 }}$ Ez a sarkosabb kijelentés azzal függhet össze, hogy - amint arról korábban szót ejtettünk - Bibó a reakció elleni harcot nem hatalomtechnikai kérdésnek tekinti, hanem a régi világ továbbélésével szembeni társadalmi küzdelemnek. Ezt követően azonban a cikkben érintetteknél is élesebben fogalmaz a kommunisták által tematizált reakció elleni „veszély” relativizálását illetően. Így nyilatkozik Bibó: „Ma azonban a reakció is lassan kezd olyan mumussá válni, amilyen a proletárdiktatúra volt az elmúlt huszonöt esztendőben.”394

Felszólalt a vitában Horváth Zoltán szociáldemokrata újságíró, politikus is, aki arról beszélt, hogy „,nehéz demokráciát csinálni olyan országban, ahol kevés a demokrata." ${ }^{395}$ A szövegösszefüggésből nyilvánvaló, hogy „demokratákon” baloldali elkötelezettségü embereket ért. ${ }^{396}$ Figyelemreméltó az alábbi kijelentése is: „próbálunk olyan demokráciát építeni, amelyik nem hagyja magát agyondemokráciázni.” A Horváth által használt fogalom (,agyondemokráciázni”) viszont e helyütt inkább a demokrácia nyugati stílusú változatára utal, tehát érvelése lényege, hogy nem kell a polgári demokrácia játékszabályrendszerét piedesztálra emelni, és ha a baloldali érdekek megkövetelik, e formáktól el lehet térni, vagyis nem szabad agyondemokráciázni a közéleti küzdelmeket.

Révai József is megszólalt, ${ }^{397}$ a vitában úgy vélte, hogy a Bibó írásában megfogalmazott gondolatok alkalmasak arra, hogy „elszigeteljék” a kommunista pártot. (Amint azt korábban elemeztük: Révai $A$ demokrácia támadásban ${ }^{398}$ címü cikkében körbejárta, hogy ki a reakciós, és az egyik kategória arról szólt, hogy reakciós az is, aki a kommunista párt elszigetelésére tör. Ezáltal rekonstruálható, hogy Révai a maga és a kommunisták nézőpontjából $A$ magyar demokrácia válsága tanulmányt reakciósnak tartja, mint ahogy a megjelenést megelőző szenvedélyes vitahelyzetben ennek hangot is adott. Ez lehetett a véleménye, még akkor is, ha a nyilvános fórumokon már nem él e fogalom használata által biztosított megbélyegzési lehetőséggel.) ${ }^{399}$ Révai azt is kifejtette a vitában,

\footnotetext{
${ }^{393}$ Uo. 107. p.

${ }^{394}$ Uo.

${ }^{395}$ Uo. 110. p.

${ }^{396}$ Uo.

397 Schöpflin Gyula, aki a koalíciós években a Magyar Rádió kommunista párti műsorigazgatója volt, visszaemlékezésében arról ír, hogy az ominózus A magyar demokrácia válsága-vita során látta ,igazán elemében” Révai Józsefet. (ScHÖPflin Gyula: Szélkiáltó (Visszaemlékezés). Magvető Kiadó - Pontus Kiadó, Budapest, 1991. 204. p.)

${ }^{398}$ RÉVAI József: A demokrácia támadásban. Szabad Nép, 1945. július 22. 1. p.

399 Bibó István a Huszár Tibornak 1977-78-ban adott életútinterjúban így emlékezett a vitában Révai szerepére: „Révai volt az egyik főszereplő, aki kifejezetten ingerültséggel fogadta ezt az egész kritikát. Holott ebben a cikkben többek között az volt végiggondolva és konkretizálva, ami Révai Józsefnek abból az akkori tételéből következett, hogy a népfrontos, többpártrendszeres demokrácia a proletárdiktatúrával egyenértékü, lehetséges alternatíva a teljes értékü szocializmushoz való átmenetben. Tudom, hogy ezt utóbb Sztálin és Rákosi Révaival szigorúan revidiáltatta [...]. Én azonban a többpártrendszeres népfrontos demokráciát a fasizmus megjelenéséből szükségszerüen és nem merőben taktikailag következő programnak tartottam [...]. Ebben a cikkben leírtam, hogy
} 
hogy „olyan demokrácia még nem volt a világon, amibe a nép még nem szólt volna bele. És ha valaki azt kéri tőlünk, hogy mondjunk le a játékszabályok kedvéért a tömegek bevetéséröl, ha erre szükség van, akkor lehetetlent kér tölünk. A magyar demokrácia megmerevedése, egy helyben topogása következnék be ezzel." ${ }^{400}$ A kommunista párti érv megint arról szól, hogy a demokrácia játékszabályainál fontosabb szempontot jelent, hogy a társadalom struktúrái ne merevedjenek meg. ${ }^{401}$

Bibó a vita sodrásában kijelenti, hogy a kommunisták által sulykolt reakció fogalom „majdnem lokalizálhatatlan.” ${ }^{402}$ E megfogalmazásban Bibó újólag gyengíti a kommunisták demokrácia-értelmezését, hiszen a kommunisták szerint - ahogy arra már többször kitértünk folyamatos harcot kell folytatni a demokrácia továbbfejlesztéséért a „reakció” ellen.

A vitát levezető Ortutay Gyula zárszavában úgy vélte: „,egy limitált forradalmat meg lehet valósítani most is”, de a Bibó által felvetett demokrácia-konszolidáció szerinte „,nagyon hamar elbuktatná demokráciánk ügyét." ${ }^{\text {403 }} \mathrm{E}$ megfogalmazásból is kitetszik, hogy noha Ortutay ebben az időszakban még a Független Kisgazdapárt prominense, de már ekkor, 1946 elején is a kommunista demokrácia-értelmezést fogadja el és azt képviseli. Ortutay azt is leszögezte zárszavában, hogy nem akarhatnak „olyan konszolidációt”, amely „társadalmi megmerevedést” okoz. Végül maga is a Révai által megalkotott fogalom mellett áll ki, mint mondta: „Nekünk is harcos demokráciát kell megteremtenünk.”404

ilyen helyzetben milyen hangszerelésbeli átállítás volna szükséges a kommunisták részéről. És pontosan ezt a hangszerelésbeli átállítást utasította vissza Révai a legnagyobb haraggal: ő valahogy úgy képzelte, hogy a népfrontos demokrácia ugyanolyan harcias és agresszív kommunista magatartásokkal járhat, mint amilyennek a proletárdiktatúrára törő kommunistákat jellemezték.” (Közli: BIBÓ István (1911-1979). Életút dokumentumokban. 234. p.)

${ }^{400}$ BIBÓ István: Válogatott tanulmányok. Második kötet. 1945-1949. 113. p.

${ }^{401}$ A vitán részt vett Kárász Artúr, a Magyar Nemzeti Bank Nemzeti Parasztpárti főfelügyelője-igazgatója. Kárász úgy emlékszik, a rendezvényen „mintegy” harmincan lehettek, rá Révai érvelése hatott igazán. Memoárjában is csak Révai gondolatatait idézi. Leszögezi, hogy a kommunista politikus „,rendkívül arrogánsan” szólalt fel. „A támadás élessége meglepő és váratlan volt. Bibó tanulmánya reakciós - mondotta -, mert nem illeszkedik a párt kizárólagos vonalába. Minden ilyen szó, minden ilyen gondolat a fasiszta erőket szolgálja. Révai beszéde egyértelmü volt: aki nem ért egyet a párttal, az nem ért egyet a Szovjetunióval és így fasisztának tekintendő. [...] Intés volt e beszéd: vigyázzatok az ideákkal, ideák csak egyetlen helyről jöhetnek, a demokráciát akarhatjátok, de csak a mi demokráciánkat szabad akarnotok, minden más fasiszta. Mindez hidegzuhanyként hatott. Félelmetes beszéd volt, mert e kíméletlen szavak mögött a megszálló hatalom bajonettjei meredeztek. Íme, alig telt el egy kis idő és a fiatal demokráciánkba újfajta félelem költözött egyelőre még formátlanul, névtelenül, az új moszkvai totalitáriusok ugyanis még nem érezték magukat elég erősnek, hogy ránk tudják akaratukat kényszeríteni, de fenyegetni már tudtak" - írja visszaemlékezéseiben Kárász Artúr. (KÁRÁsz Artúr: 80 év alatt a Föld körül. Bethlen Gábor Könyvkiadó-Irodalmi Újság, Budapest Párizs, 1990. 76-77. p.)

${ }^{402}$ BIBÓ István: Válogatott tanulmányok. Második kötet. 1945-1949. 116. p.

${ }^{403}$ Uo. 118. p.

${ }^{404}$ Uo. 
Bibó István koalíciós évekbeli közéleti vonatkozású publikációi közül $A$ magyar demokrácia válsága címü tanulmány a legmarkánsabb politikai tartalmú írás és a demokráciaértelmezés nézőpontjából is ez a forrás tartalmazza a legtöbb érdemi gondolatot. A bibói demokrácia-felfogásra az aktuális közéleti jelenségekre reflektáló publikációk között is találunk azonban utalásokat. A kelet-európai kisállamok nyomorúsága címü 1946-ban publikált írásának $A$ demokrácia meghamisitása címü alfejezetében olvasható a későbbiekben legendássá vált gondolat: „Demokratának lenni mindenekelőtt annyit tesz, mint nem félni”405 Bibó ebben a tanulmányában elemzi, hogy Közép- és Kelet-Európa országai „nem voltak kész, érett demokráciák, s minthogy féltek, nem is tudtak azokká válni.” Bibó István e helyütt arról is ír, hogy „,a félelem, a veszély állandó érzésében szabállyá vált mindaz, amit az igazi demokráciák csak az igazi veszély órájában ismernek: a közszabadságok megkurtítása, a cenzúra, az ellenség bérenceinek, az árulónak a keresése."406 Bibó demokrácia-értelmezésébe belefér a jogok korlátozása rendkívüli helyzetben, a kommunista demokrácia-felfogás szerint viszont nincsenek is mindenekfelett álló mindenkire vonatkozó jogosultságok. Többek között ez az a döntő különbség, ami miatt Bibó sosem tudja elfogadni a kommunisták demokráciaértelmezését.

Sokan Kovács Béla elrablását tekintik sorsfordítónak, több történész ezt az eseményt tartja a második világháború utáni magyar demokrácia határpontjának. Bibó nem érezte akkoriban a tragikus történés sorsfordító és demokrácia-megtörő jellegét: „Pontosan abban a pillanatban, amikor az egész huzavonában a baloldal kezdett felülkerekedni - Kovács Béla a rendörség előtt megkezdte vallomását, s az ügybe való belekevertségének a körvonalai kezdtek kialakulni -, történt a Szövetséges Ellenőrző Bizottság közbelépése és Kovács Béla letartóztatása, ami úgy hatott, mint mikor kötélhúzás közben egy harmadik személy középen elvágja a kötelet. Mind a két fél érezte, hogy megütötte magát, s talán ennek volt egyik következménye, hogy a pártközi béke oly hirtelen helyreállott"407 - írja a demokráciamegtörés mechanizmusát nem értve, az egész esemény sorsfordító jelentőségét át nem látva, a drámai történéssort fájdalmasan relativizálva Bibó István az Válság után - választás előtt címü 1947 nyarán publikált írásában.

Ez a tanulmány Bibó István utolsó aktualitásokat érintő közéleti publikációja. Ebben a cikkben is van még demokráciaértelmezési kísérlet a szerző részéről, mint írja: „A demokratikus formalizmus ellenségeinek teljesen igazuk van abban, hogy szabályos

\footnotetext{
405 BIBÓ István: Válogatott tanulmányok. Második kötet. 1945-1949. 220. p.

${ }^{406}$ Uo.

${ }^{407}$ Uo. 531-532. p.
} 
választásokból, a többség tiszteletéből, a bírói jogvédelem biztosításából, sőt szólási, gyülekezési szabadságból magából még nem lesz demokrácia, ha közben épen maradnak a társadalomban a jobbágyi alázat és társadalmi kiváltságtudat kölcsönös beidegződései. Igazuk van abban is, hogy az ellenzék jogainak a tisztelete csak ott képzelhető, ahol a kormány és ellenzék bizonyos alapvető eszményei megegyeznek, s mindegyik biztos benne, hogy ezeket a

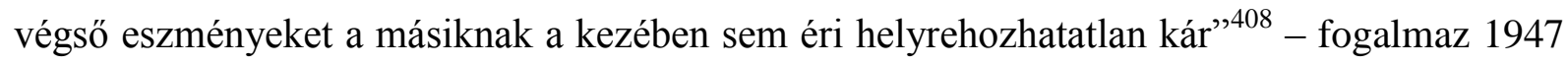
nyarán Bibó. A szövegben egyensúlyozni próbál a konszenzuális demokrácia ethosz felvállalása és a radikális társadalmi változások igenlése között, Bibó mindkettőt szükségesnek tartja és magáénak tartja, de érzékeli az antagonisztikus különbséget a kétfajta célkitüzés között.

A weimari demokrácia bukása Bibó számára is riasztó példa, ugyanakkor az „ellenség” körét a kommunisták parttalan és taktikai szempontok szerint alakítható ellenségfogalmával szemben szükítené és kifejezetten definiálná. A formalitások relativizálását Bibó István nem fogadja el, a szabályok mellőzésének lehetőségét viszont nem zárja ki, alkotmányjogi aspektusból vizsgálja a kérdést, s úgy véli, a játékszabályok felrúgása csak pontosan körülírt rendkívüli állapot esetén lehetséges. A manipulált kékcédulás választások $^{409}$ előtt néhány héttel - mintha megérezte volna, hogy valós veszély a csalás lehetősége - így fogalmaz: „Manipulált választás s általában minden eljárás, melynek tisztasága körül viták kezdődnek és kezdődhetnek, hosszú időre helyrehozhatatlan politikai demoralizáló hatással van, mely a pillanatnyi előnyt hamar semmivé teszi” ${ }^{410}$ - írja utolsó politikai publicisztikájában Bibó István. Beszédes hallgatás a részéről, hogy 1947 nyara után nem ír és közöl több közéleti elemzést. Nincs róla konkrét tudomásunk, de Bibó ezzel a finom megoldással üzenhette a közvéleménynek és az utókornak: 1947 őszétől már nem érzékelte a demokratikus párbeszéd lehetőségét.

Bibó István a koalíciós években írott politikai publicisztikáiban a kommunisták diktatórikus magatartását illetően - ahogy arra az alfejezetekben utaltunk, azt elemeztük számos ponton tévedett. A szövegelemzések során nem találunk olyan bibói idézetet a koalíciós korszakból, ahol egyértelművé tenné, hogy milyen szintü veszély fenyegeti a kommunisták részéről a formálódó jogállami demokráciát.

A proletárdiktatúra megvalósult, de Bibó nem érzékelte, hogy ez a korábban csak feltételezett veszély valóságos fenyegetéssé vált. S hogy miért nem? Bibó úgy gondolta, hogy

\footnotetext{
${ }^{408}$ Uo. 544. p.

409 Az 1947-es választási csalásokról készült összefoglaló kötet: FöLDESI Margit-SzERENCSÉS Károly: Halványkék választás. Kairosz Kiadó, Budapest, 2001.

${ }^{410}$ BIBÓ István: Válogatott tanulmányok. Második kötet. 1945-1949. 545. p.
} 
a magyar társadalmat radikálisan meg kell változtatni, szociális forradalomra van szükség. A történetfilozófus 1945 utáni gondolkodásának ez volt a legfontosabb eleme, fontosabb, mint a polgári demokrácia eszménye. Bibó egy konszenzuális demokrácia megteremtésében bízott a koalíciós években, folyamatosan emellett érvel a politikai publicisztikájában, de a markáns társadalmi változás érdekében hajlandó volt szemet hunyni a jogállami demokrácia sérelmein, mert úgy vélte, a szociális forradalom érdekében szükség lehet átmenetileg a demokratikus jogok korlátozására. 


\title{
III. Az önéletírói beszédmód: a „demokrácia” mint narratív elem a koalíciós időszakot érintő önéletírásokban
}

\author{
1. Narratíva, diskurzus, demokrácia: elméleti megfontolások az \\ önéletírói beszédmód kapcsán
}

Az önéletírások, visszaemlékezések és a naplók is sajátos „én-nyomok”, melyek alkalmasak arra, hogy feltárják - igaz az írás, az emlékezés pillanatától visszatekintve - az egyén múltbéli gondolatait, a történeti tényekhez, folyamatokhoz, jelenségekhez való viszonyulását és a személyiség létállapotait érintő fontos fogalmak és az önéletíró kapcsolatát. Az önéletrajz „önreflexív szelf konstrukció”, ami Bókay Antal megfogalmazása szerint egy olyan „tükrös pillanatot" mutat, mely egyszerre tartalmaz valós és fikciós vagy éppen metaforikus jellegü elemeket. $^{411}$

E jelenséghalmaz a koalíciós éveket érintő visszaemlékezésekre is érvényes - a korszaknak megvan a maga sajátos habitusa az önéletírásokban is, de az egyes csoportosulások nyelvi készlete eltér a vizsgált korszak után sokkal vagy kevésbé sokkal később született visszaemlékezésekben. Ahogy a fejezet során kifejtjük, ugyanazon fogalom alatt mást értenek; vagyis a demokrácia fogalomköre kapcsán az önéletírói reflexiók a csoportazonosság szempontjai szerint egymással szögesen ellentétesek.

Gyáni Gábor az Esemény és narrativa: A múlt és jelen mint nézöpont címü tanulmányában fejti ki, a döntő kérdés mindig az, hogy milyen nézőpont határozza meg a

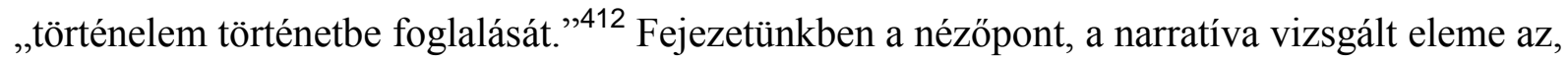
hogy miként értelmezik, helyezik szövegösszefüggésbe a visszaemlékezők a demokrácia kifejezést. A koalíciós évekről szóló visszaemlékezésekben a „demokrácia” megkerülhetetlen fogalom, mindenkinek muszáj valamiképpen hozzá viszonyulnia, a demokrácia kifejezés kiindulópont, amelyhez képest magát a narratívát a visszaemlékező megalkotja, a „demokrácia” a történetmesélés alapvető kódjává válik, ezért is állíthatjuk, hogy a „demokrácia” narratív elem. Jane Stokes kultúrakutató állapítja meg: „A narratívaelemzés

\footnotetext{
${ }^{411}$ BÓKAY Antal: Önéletrajz és szelf-fogalom a dekonstrukció és pszichoanalízis határán. In: MEKIS D. János Z. VARGA Zoltán (szerk.): Î́rott és olvasott identitás - Az önéletrajzi műfajok kontextusai. L’Harmattan Kiadó, Budapest, 2008. 33-65. p.

${ }^{412}$ GYÁNI Gábor: Esemény és narratíva: A múlt és jelen mint nézőpont. In: Esemény és narratíva. Történetiség elbeszélés(ek) - interpretáció. Bibliotheca Nationalis Hungariae - Gondolat Kiadó, Budapest, 2013. 11-27. p.
} 
hasznos módja annak is, hogy felfejtsük az általunk elemzett szöveg ideológiai üzenetét, amely a struktúrában rejlik." ${ }^{413}$ Más megközelítésben: a narratív forma alkalmas mások cselekedeteinek a megértésére. ${ }^{414}$

Azért is vizsgáljuk a demokrácia fogalmat a koalíciós éveket érintő önéletírások szövegében, mert korszakunkban - mint a korábbi fejezetünkben elemeztük - markánsan jellemzőek a demokrácia-értelmezések. Ebből fakadóan a demokrácia fogalma körül valós narratívák építhetőek fel az önéletírások során, s mindezen túl azt a jelenséget sem hagyhatjuk figyelmen kívül, hogy - amint Szabó Márton azt érzékletesen leírja - a modern történelem során a demokrácia vált a „minden jó politikai rendszer ernyőkategóriává."415 A visszaemlékezések, naplók szempontjából kiemelt fogalom a demokrácia, amelyben nemcsak a különböző demokrácia-képek érhetőek tetten, hanem azt is felfejthetjük, hogy miként válik a „demokrácia” a magasztosult ,jó” politikai struktúra körülírására alkalmas narratív és leíró eszközzé.

Varga Zoltán szerint az önéletírás kommunikációs aktus, performatív megnyilatkozási mód, amely a „ki vagyok én?”, „mi vagyok én?” kérdésekre válaszol és amelyben a „szavak bátorítóan hatnak, lelkesítenek akár egy csatakiáltás: nem jelentésük, hanem hangzósságuk,

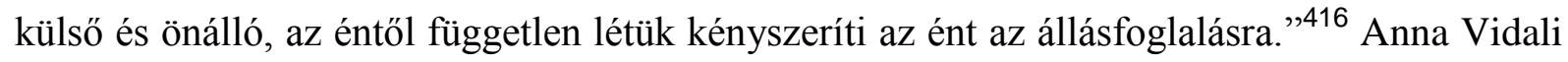
arra hívja fel a figyelmet, hogy az önéletírásokban - amelyek a tudományos és az irodalmi stílus között mozognak - az élmény nem tekinthető ,igazságnak”, az emlékezet pedig nem számít feltétlenül „eredetnek.”417 Heller Ágnes Az önéletrajzi emlékezés filozófiája címü müvében kifejti: minden önéletrajzi elbeszélés óhatatlanul fikció, már csak azért is, mert ,az emléknyomokat folyamatos történetté köti össze." ${ }^{\text {418 }}$ A filozófus azért hozzáteszi, hogy a fikcionált önelbeszélés viszont önmagában még nem ,inautentikus.” Az önéletrajzi narratíva a múlt emléknyomairól szól, de a ,jelen” nézőpontján keresztül. „Emlékeink így nemcsak a múltra vonatkoznak, hanem a jövőre is. Elsősorban, természetesen a múlt jövőjére. ${ }^{419}$

\footnotetext{
413 Jane STOKES: A média- és kultúrakutatás gyakorlata. Gondolat Kiadó - PTE Kommunikáció- és Médiatudományi Tanszék, Budapest - Pécs, 2008. 82. p.

${ }^{414}$ HoRVÁTH Dóra - MiTEV Ariel: Alternatív kvalitatív kutatási kézikönyv. Alinea Kiadó, Budapest, 2015.211. p.

415 SzABÓ Márton: Az összehasonlító politikai fogalomtörténet-írás lehetőségei. In: A történész szerszámosládája. A jelenkori történeti gondolkodás néhány aspektusa. Szerkesztette: SzEKERES András. L'Harmattan - Atelier, Budapest, 2002. 159-171. p.

${ }^{416}$ VARGA Zoltán: Önéletrajzi töredék, talált szöveg, illetéktelen olvasó. Doktori értekezés (tézisek). Elérhető: http://modernirodalom.btk.pte.hu/files/tiny mce/File/tezisek/tezisekvargazoltan.pdf (A letöltés időpontja: 2015. szeptember 27.)

417 Anna VIDALI: Trauma és történelem. Múltunk, LI. évf. (2006) 2. 258-275. p.

${ }^{418}$ HeLLER Ágnes: Az önéletrajzi emlékezés filozófiája. Múlt és Jövő Kiadó, Budapest, 2015. 76. p.

${ }^{419}$ Uo. 83. p.
} 
K. Horváth Zsolt amellett érvel, hogy ,a résztvevő autentikusságánál” közvetlenebb „autoritás" ${ }^{420}$ nehezen képzelhető el. Takács Tibor arra hívja fel a figyelmet, hogy már a megfigyelés is szelektív, az emlékeke megkopnak, éppen ezért „nem várható el, de nem is fontos, hogy az emlékek pontosak legyenek", mert az emlékezésnek nem a múlt pontos feltárása az elsődleges funkciója, hanem a pszichológiai perspektíva felvázolása. ${ }^{421}$

Amikor e fejezetben a demokrácia fogalmára vonatkozó „emléknyomokat” keressük, akkor tisztában vagyunk vele, hogy az önéletírásokban megjelenő demokrácia-kép egyrészt egyfajta identitáserősítő önigazolás, másrészt tipikusan a „múlt jövőjéről” szóló okfejtés, hiszen a visszaemlékezők többsége úgy gondolta: a demokrácia struktúráihoz a majdani feltételezett jövőben is lesz közük, így érvelésük súlyponti eleme a demokrácia-élményekhez való viszonyulás. Ezáltal az önéletíró válaszokat ad a második világháború utáni évek lényegi történéseire, de egyben magát is meg tudja fogalmazni, és a demokrácia-fogalom ebből fakadóan identitásteremtő és -formáló narratív elemmé válik.

Kövér György Biográfia és társadalomtörténet címü kötetében az önéletíró müveket, a naplót és a visszaemlékezést úgynevezett ego-dokumentumoknak nevezi, melyekből a „megélt történelem sokszínűsége ${ }^{422}$ bontakozik ki. Kövér szerint mikor az egodokumentumokat vizsgáljuk, először választ kell adnunk arra a kérdésre, hogy mit keresünk ezekben a forrástípusokban?

Dolgozatunk ezen fejezetében a koalíciós évek különböző szereplőinek a korszakot érintő demokrácia-fogalmait kívánjuk vizsgálni, áttekinteni. E szövegelemzésekből is kitünik majd a demokrácia-értelmezések kapcsán az a fajta különbség, amelyet az 1945 utáni évek demokrácia vitáiról szóló előző fejezetünkben elemeztünk. Továbbá törekszünk arra, hogy az önéletírások által be tudjuk mutatni a fogalomértelmezéseken túl azt, hogy az egyes szereplőknek, önéletíróknak milyen demokrácia-élményt jelentett az a bizonyos néhány év. S mindemellett azt a helyzetet is ábrázolni szeretnénk, ahogy a demokrácia fogalom még a visszaemlékezésekben is egyfajta harci eszköz és fegyver; más megközelítésben identitást építő narratíva-elem.

Gyáni Gábor Narrativitás és jelentésgeneráló retorikai elemek a történetírói diskurzusban című tanulmányában emlékeztet: „a szavakat mögöttes és kimondatlan

\footnotetext{
${ }^{420}$ K. HORVÁTH Zsolt: Önarcképcsarnok. A személyes emlékezés mint történeti probléma. In: SZEKERES András (szerk.): A történész szerszámosládája. A jelenkori történeti gondolkodás néhány aspektusa. L'Harmattan Atelier, Budapest, 2002. 81-103. p.

${ }^{421}$ TAKÁCS Tibor: Besúgók a besúgásról. Ügynök-visszaemlékezések a Kádár-korszakról. L’Harmattan Kiadó TIT Kossuth Klub, Budapest, 2013. 24-25.p.

${ }^{422}$ KÖVÉR György: Biográfia és társadalomtörténet. Osiris Kiadó, Budapest, 2014. 99-102. p.
} 
jelentések itatják át. ${ }^{, 423}$ Fejezetünkben a demokrácia mint fogalom önéletírásokban feltárható mögöttes jelentéseit igyekszünk elemezni, felfejteni.

\section{A polgári demokrácia ethosza mellett kitartó kisgazda közéleti szereplök memoárjaiban megjelenö demokrácia-kép}

A koalíciós korszak egyik legbefolyásosabb, legfajsúlyosabb kisgazda politikusa, Nagy Ferenc miniszterelnök 1947. júniusi lemondatása után nem sokkal később az Egyesült Államokban írta meg visszaemlékezéseit.

Nagy Ferenc tudatosan a világ közvéleményének írta meg gondolatait, foglalta össze életútját, hiszen az Egyesült Államokba érkezése után nem sokkal a New York-i MacMillan Company bízta meg a visszaemlékezés rögzítésére azzal a céllal, hogy az önéletírás sokat olvasott bestsellerré válhasson a nyugati világban. ${ }^{424}$ Nagy Ferenc hat hét alatt mondta tollba a visszaemlékezést. Az angol nyelvű sajtó tudósításainak a segítségével tudott időpontokat, eseményeket pontosan rekonstruálni. Az angol nyelvü kötet 1948-ban látott napvilágot, magyar földön, magyar nyelven a rendszerváltozás után, 1990-ben jelenhetett meg a memoár.

A visszaemlékezésben Nagy Ferenc felidézte azt a háború utáni jelenséget, miszerint a kommunisták úgymond „okulva” az 1919-es tapasztalatokból „hirdették a demokráciát.„425 Nagy memoárjában leírta egy a kommunista pártvezetőkkel Debrecenben, az Ideiglenes Kormány és Nemzetgyülés megalakulása idején lezajlott tárgyalás részleteit, amely a demokrácia narratíva szempontjából is mérvadó. Ezen a megbeszélésen Révai József elmondta, hogy „demokratikus és független Magyarországot akarnak."426 Révai arról beszélt, hogy a kommunisták nem akarják „saját akaratukat” rákényszeríteni az országra, de a többi demokratikus pártokkal együtt küzdeni fognak ,a reakció” és „,a fasizmus visszatérése ellen.” Ekkor - az önéletírás tanúsága szerint - Nagy Ferenc közbeszólt, hogy Tiszántúl sok falujában és városában a kommunisták „lehetetlenné” teszik a „,becsületes demokratikus erők” érvényesülését. A kommunista pártvezetők erre konkrétumokat kértek. Nagy Ferenc már ekkor, 1944 végén a kommunista vezetéssel a Tiszántúlon megalakult helyi rendőri hatalom

\footnotetext{
${ }^{423}$ GYÁNI Gábor: Narrativitás és jelentésgeneráló retorikai elemek a történetírói diskurzusban. In: RÁKAI Orsolya -Z. KovÁCs Zoltán (szerk.): A narratív identitás kérdései a társadalomtudományokban. Gondolat Kiadói Kör - Pompeji, Budapest, 2003. 84. p.

424 A memoár születéséről: HőGYE Mihály: Állomások egy életpályán. In: NAGY Ferenc: Küzdelem a vasfüggöny mögött. 2. Európa - História, Budapest, 1990. 223-243. p.

${ }^{425}$ NAGY Ferenc: Küzdelem a vasfüggöny mögött. I. Európa - História, Budapest, 1990. 94. p.

${ }^{426}$ Uo. 115. p.
} 
kegyetlenkedő tetteit említette, ahogy írja: „valóságos rémuralmat teremtettek” a kommunista

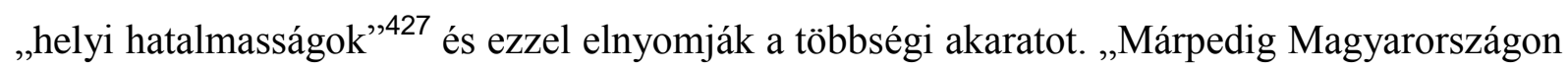
nem lehet igazi demokrácia mindaddig, amíg minden magyar paraszt fenntartás nélkül nem

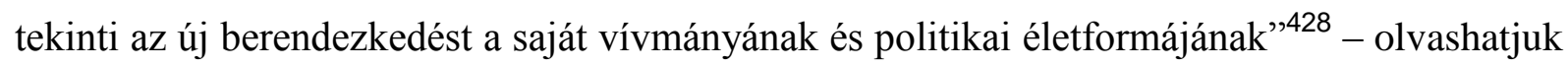
a visszaemlékezésben a tanácskozáson elhangzottakról. Nagy Ferenc e megbeszélésen arról is szólt, hogy a demokráciában érvényesíteni kell a többségi elvet, s ha a parasztság nem vesz vagy nem vehet részt a közélet alakításában, akkor „nem lesz demokrácia.”429

Nagy Ferenc arról ír, miszerint már 1945 júliusában ráébredtek arra, hogy a kommunisták demokratikus hozzáállása „,nem őszinte.”430 Az 1945-ös választások kapcsán leszögezi: „a nép a demokrácia mellett döntött."431 A „leggyalázatosabb állításnak” nevezi, hogy a kisgazdák 57\%-os választási győzelme arról szólna, hogy a nép többsége ,,a reakció” mellett döntött volna. Nagy Ferenc memoárjában egyértelmüvé tette, hogy „tiszta demokráciát” és „radikális haladást” kívántak elérni, megteremteni. A visszaemlékezésben Nagy a „tiszta demokrácia” mellett még az „,igazi demokrácia” kifejezéssel igyekezett leírni azt a fajta demokrácia-modellt, amelyet a Független Kisgazdapárt és személyesen ő maga akart volna megteremteni a második világháború utáni években. A kisgazdák a koalíciós évek közéleti küzdelmeiben is előszeretettel használták a „tiszta demokrácia” és az ,igazi demokrácia” kifejezést. E fogalmak mögött a paraszt-polgári tömb egy olyasfajta polgári demokráciát képzelt el, ami a társadalmi átalakulás érdekében „radikális haladásra” is hajlandó, de mindez a formális demokrácia szabályainak, a többségi elvnek a betartásával, a jogállami struktúrák tiszteletben tartásával, a játékszabályok gondolatiságának az elfogadásával és elfogadtatásával történhet.

„A polgári pártok számára a demokrácia a konszolidációt, a megbékélést és a többségi akaraton nyugvó kormányzást jelentette. A kommunisták számára a múlttal szembeni harc fokozását, az erősödő rendőri beavatkozást [...] és a Szovjethez való fenntartás nélküli közeledést jelentette a demokrácia. Ök maguk is tudták, hogy demokráciájuk hazugság, de hazudtak bátran, a meggyőződés látszatával”432 - írja Nagy Ferenc. A hazugság tematika Nagy iménti érvelésében indulati elemnek is tekinthető, ugyanakkor ezáltal ismét az oldalak, közéleti táborok közötti demokrácia-értelmezésbeli különbségek érthetőek tetten. Nagy Ferenc nézőpontja a jogállami demokrácia, míg - ahogy a korábbi fejezetünkben és e részben

\footnotetext{
${ }^{427}$ Uo.

${ }^{428}$ Uo. 116. p.

${ }^{429}$ Uo.

${ }^{430}$ Uo. 174. p.

${ }^{431}$ Uo. 202. p.

${ }^{432}$ Uo. 248. p.
} 
pedig Rákosi visszaemlékezésének elemzésekor igyekeztük körbejárni - a kommunisták a „demokrácia” fogalma alatt az idő elörehaladásával, főként 1946-tól „népi demokráciát” értettek, ami a marxista terminológia és kódnyelv szerint már lényegében a proletárdiktatúrára utalt.

1946-ban zajlott egy tárgyalás Rákosi Mátyás, Veres Péter, Kovács Béla, Tildy Zoltán és Nagy Ferenc között. E megbeszélésen hangzott el Rákositól - Nagy memoárja szerint - a következő gondolat: a „Kommunista Párt őszinte és erőteljes demokráciát akar, a Kisgazdapárt jobbszárnya visszafelé akarja forgatni a demokrácia kerekét." ${ }^{433}$ Erre válaszolta azt Kovács Béla, hogy a kisgazdák nem akarják visszahozni a múltat, ők csak „igazságot” és „rendet” szeretnének.

Nagy az úgynevezett összeesküvési ügyre épített kommunista offenzívát ,a magyar demokrácia elleni merényletnek" ${ }^{\text {434 }}$ nevezi. Már az összeesküvési válság idején zajlott egy magánbeszélgetés Kovács Béla és Nagy Ferenc között. A memoárban Nagy idézi Kovácsot: „amíg ők tüzzel-vassal a szocializmus megvalósításáért harcolnak, addig mi ezt akadályozva a polgári demokráciáért kell hogy harcoljunk. ${ }^{435}$ Egyetértettek abban, hogy ki kell várniuk a szovjet hadsereg kivonulását Magyarországról és azt követően teremthető meg egy „átmenet”, amely után meg lehet szüntetni az „,egyoldalú kommunista erőszakoskodást."436

A lemondatásához vezető folyamatot Nagy Ferenc a Döntő roham a demokrácia ellen című fejezetben mondja el. „A magyar politika történetének egyik legszomorúbb korszaka, az összeesküvés első fejezete, lezárult. Óriási veresége volt ez a magyar polgári demokráciának. Félig-meddig egyenlő harcban ezt a vereséget nem is lehetett volna elviselni. De a magyar demokrácia nem a kommunista kisebbségtől, nem Rákosi Mátyástól, hanem két világrész legnagyobb hatalmától, a Szovjetuniótól szenvedte el ezt a vereséget. Amennyire nem volt szégyen ez a vereség a magyar demokráciára, annyira nem volt dicsőség a Szovjetunióra. Ez után a szörnyü küzdelem után, amelyben elveszítettük Kovács Bélát, nyolc képviselőnket, több száz jóravaló egyszerü magyar embert, még mindig állt a magyar demokrácia, és konok elszántsággal vártuk tovább a hajnalhasadást”"437 - írja Nagy, aki „hajnalhasadáson” azt a reményt érti, hogy a békeszerződés aláirását követően a szovjetek kivonulnak és akkor ismét esélyt kap ,„a magyar polgári demokrácia.”

\footnotetext{
${ }^{433}$ Uo. 400. p.

${ }^{434}$ Uo. 401. p.

${ }^{435}$ NAGY Ferenc: Küzdelem a vasfüggöny mögött. II. Európa - História, Budapest, 1990. 53. p.

${ }^{436}$ Uo. 54. p.

${ }^{437}$ Uo. 109 . p.
} 
Miután visszaemlékezett arra, hogy egy autó sárhányóján aláírta a lemondónyilatkozatát, így értékel Nagy Ferenc: „A kommunista elnyomás alatt álló Magyarország megszabadult utolsó demokratikus miniszterelnökétől. Leomlott az utolsó akadály is a teljes kommunista befolyás elől. Az ország elvesztette függetlenségét, mielőtt a békeszerződés folytán visszanyerhette volna. A magyar nép ki volt szolgáltatva a kommunista és szovjet önkénynek. [...] Magyarország ebből az igából a maga erejéből többé sohasem veheti ki a fejét”,438 - írta váteszi erővel 1948-ban keletkezett memoárjában Nagy Ferenc, akinek visszaemlékezése mint szöveg, mint forrás maga egyfajta hitvallás a paraszt-polgári megközelítésü jogállami demokrácia ügye mellett.

Sulyok Dezső, a koalíciós évek meghatározó polgári (kisgazda, majd szabadságpárti) politikusa - Nagy Ferenchez hasonlatosan - emigrációja első hónapjait a memoárja elkészítésével töltötte. 1947. augusztus 24-én kezdte el írni visszaemlékezéseit és december 24-én fejezte be azokat. Az önéletírás a szovjet hadsereg Somló hegyi megjelenésétől Sulyok emigrációjáig tekinti át az eseményeket. A kötet 1948-ban német nyelven jelent meg Két éjszaka nappal nélkül címmel. ${ }^{439}$ Sulyok Dezső nem volt források, dokumentumok birtokában, így valóban csak az emlékezetére hagyatkozhatott, ezért vannak pontatlanságok, tárgyi tévedések a szövegben.

„Másképp álmodtam meg a magyar demokrácia megszületését”,440 - írja Sulyok „a német iga alól való” felszabadulás utáni időszakról, ekkor fejtegeti azt is, hogy a „magyar nép csöbörből vödörbe esett.” Az 1945-ös választás eredményeit úgy értékeli memoárjában Sulyok, miszerint a választók a kommunisták demokrácia-felfogásával szemben, a „szovjet rendszer ellen foglaltak állást." ${ }^{441}$ A koalíciós évek egészének politikai folyamatait kívánja érzékeltetni $A$ párturalom elfajulása címü fejezetében. Ebben a részben írja Sulyok: „ez egy diktatúra, amely demokratikus frázisok mögé rejtőzik és moszkvai parancsokra dolgozik.”,442

A kommunisták demokrácia-felfogásáról és a reakcióról mint ellenségképről gúnyos hangvétellel ekképpen fogalmaz: „Reakciós az, aki a kommunista párt politikáját nem követi. A reakciós a demokrácia ellensége. A demokrácia ellensége fasiszta. Aki fasiszta, az a Szovjetunió ellensége. A Szovjetunió ellensége a nép ellensége, és aki a nép ellensége, annak nincs joga az élethez. [...] A demokráciában csak az érvényesülhet, aki lemond a kommunista

\footnotetext{
${ }^{438}$ Uo. 160. p.

439 A visszaemlékezés létrejöttéröl Pölöskei Ferenc írt a Sulyok-önéletírás előszavában. SULYOK Dezső: Két éjszaka nappal nélkül. Éghajlat Kiadó, Budapest, 2004. 9. p.

${ }^{440}$ Uo. 51. p.

${ }^{441}$ Uo. 94. p.

${ }^{442}$ Uo. 105. p.
} 
párt bírálatáról”443 - olvashatjuk az önéletírásban. A kifejezésmód - a cinikusnak tünő érvelésmód mögött is kitetszően - egyértelmủen és egyben jelképerővel demonstrálja, hogy miként vélekedik a memoáríró a kommunisták demokrácia-képéről. Sulyok úgy ítéli meg, hogy Magyarország 1947-re szovjetállammá alakult át, mely „a demokrácia álarcában él.„^44 Arról is beszél, hogy a kommunizmus ,,a demokrácia álarcát”445 viseli.

Sulyok visszaemlékezésében beszámolt egy kiszivárgott Révai-beszédről, mely a hírforrás szerint a kommunista pártföiskolán hangzott el. Amint korábban említettük, az önéletíró számára nem álltak rendelkezésre felhasználható források a visszaemlékező munka során, így a most idézett Révai-beszédet is fejből próbálta felidézni: „Hazafiak és demokraták vagyunk. De nem a haza miatt vagyunk hazafiak és nem a demokrácia miatt vagyunk demokraták. Hazafiak és demokraták vagyunk azért, hogy ezek álarcában megvalósítsuk nagy célunkat, a szocializmust"446 - hivatkozik Révaira a memoárban Sulyok, aki egyből hozzáteszi, hogy a szocializmus szórt érdemes a bolsevizmussal helyettesíteni. A polgári politikus e gondolatmenet keretében azt is leszögezi, hogy a kommunisták „semmilyen erkölcsi törvényt nem ismernek." ${ }^{447}$

A visszaemlékezés egy másik részében írja Sulyok Dezső: „Gyakorlatilag egész röviden »haladónak« azt nevezték, aki kommunista volt vagy a kommunizmussal bensőleg egyetértett, »reakciósnak« azt, aki nem volt kommunista, sőt harcolt a kommunizmus ellen. A Népbíróság felfogása szerint mindenki reakciós, aki a demokráciát gyalázza, aki a kommunizmusról becsmérlően nyilatkozik"448 - fejtegeti Sulyok. Láthatjuk, Sulyok Dezső szenvedélyesen utasítja el visszaemlékezésében is a kommunisták demokrácia-felfogását, fogalomhasználatát, de különös, hogy az önéletírás szövegelemeiben - mint a legutóbb idézett részben is - maga Sulyok a korábrázolás részeként illusztrálja a kommunista nyelvezet paneljeit, amelynek egyik eleme, hogy „demokráciaként” a kommunisták által vallott államberendezkedési ethoszt értik. („A Népbíróság felfogása szerint mindenki reakciós, aki a demokráciát gyalázza, aki a kommunizmusról becsmérlően nyilatkozik.”) Noha kétség sem férhet ahhoz, hogy a nyugati emigrációjában Sulyok nemzeti demokrata meggyőződésü polgárként jegyezte le önéletírását, de figyelemreméltó jelenség, hogy nem jelzi mindig a demokrácia-képekből fakadó nyelvi kontextuális különbségeket, hanem alkalmanként a kommunista nézőpontból népi demokratikusnak tekintett „demokráciát” maga is

\footnotetext{
${ }^{443}$ Uo. 123. p.

${ }^{444}$ Uo. 171. p.

${ }^{445}$ Uo. 117. p.

${ }^{446} \mathrm{Uo}$

${ }^{447} \mathrm{Uo}$

${ }^{448}$ Uo. 233. p.
} 
fogalomhasználatát tekintve demokráciának nevezi - pedig a leírása egyértelműen utal arra, hogy a polgári demokrácia aspektusából az a bizonyos demokrácia már nem tekinthető „,igazi” demokráciának. E szempontból egészen más a Sulyok-visszaemlékezés nyelvezete, mint Nagy Ferenc memoárja. Nagy egyetlen mondatában sem fogadta el - még korillusztrációként sem -, hogy a „demokrácia” fogalmat használja, mikor a kommunisták ideológiájáról vagy államberendezkedési fogalomhasználatáról szól. Nagy Ferenc egyértelműen „magyar demokrácián” csakis a polgári demokrácia nézőpontjából még elfogadható struktúrákat és időszakot érti. Sulyok önéletrajzi szövegeiben előfordul, hogy illusztratív szándékkal a kommunizmus és a demokrácia nyelvileg egymás szinonimájaként bukkan fel. Ismét hangsúlyozzuk: ezzel semmiképpen sem azt állítjuk, hogy Sulyok akár csak elviekben engedett volna 1945 és 1947 közötti közéleti küzdelmei során - illetve később a visszaemlékezés megszövegezésekor - a kommunista retorikával, különös tekintettel a demokrácia-képpel szemben. Pusztán arra a jelenségre kívántunk utalni, hogy Sulyok egyfajta cinikus tónusú érvelésmód keretében nem húz határt fogalomhasználatilag a demokrácia kifejezés tekintetében, s előfordul, hogy illusztratív megoldásként helyezi egy nyelvi térbe a „kommunizmust” és a „demokráciát.” Talán maga is érezte, hogy a visszaemlékezésben értékelt korszak, a háború utáni évek története és nyelvhasználata több mint bonyolult, ezért is írhatta e mondatot: „Bábel a mai világ zürzavarával összehasonlítva csak jelentéktelen epizód."449

Nagy Vince, Károlyi Mihály 1918-as miniszterelnökségi államtitkára, majd belügyminisztere 1960-ban fejezete be visszaemlékezéseit. Nagy 1945-től 1946-ig a Kisgazdapárt nemzetgyűlési képviselője volt, '46-ban kizárták a pártból; még ebben az évben az alakuló sulyokista Magyar Szabadság alelnöke lett. 1947-ben emigrációba kényszerült. Emlékiratait New Yorkban írta, az emlékiratok elkészítésével 1960. július 1-jén végzett, vagyis már több mint egy évtizedes távlatból tudott visszatekinteni a koalíciós évek történéseire és már az 56-os forradalom élményanyaga, tapasztalatai, intellektuális és pszichés értelemben is rendelkezésére álltak.

Nagy Vince szövegében egyértelmüvé teszi, meggyőződése: a kommunisták kezdettől fogva diktatúrát akartak építeni, míg a kommunistákkal szemben álló polgári erők a demokrácia megmentéséért, védelméért tevékenykedtek. „Míg a [...] látszatra demokráciát építő, de valójában kommunista gazdasági rendszert előkészítő tervszerű munka folyt, addig a

\footnotetext{
${ }^{449}$ Uo. 324. p.
} 
kormányzás eszközeiben, módszereiben a kommunista vezérek álcázatlanul a diktatúrát vezették be ${ }^{, 450}$ - olvasható Nagy memoárjában.

Nagy Vince visszaemlékezésében felidézi Rákosi Mátyással folytatott tárgyalását, mely eseményt a szerző a demokrácia narratíva segítségével ismerteti. Az 1945-ben lezajlott megbeszélést Rákosi kezdeményezte. A kommunista pártvezető a találkozáskor felemlegette Nagy Vincének, hogy 1919-ben az őszirózsás forradalom belügyminisztereként őt mint kommunista aktivistát letartóztatta. Nagy erre azt válaszolta: akkor most itt az idő, hogy Rákosi visszaadja és letartóztassa. E helyzetben mondta - Nagy visszaemlékezése szerint Rákosi a következőket: „No arról szó sincs. Felejtsük el a Kun Béla-féle kísérletet. Az diktatúra volt. Mi igazi demokráciát akarunk bevezetni."

A megbeszélésen Rákosi azt hangoztatta, hogy a Kisgazdapárt tele van reakcióssal. Nagy kifejtette, hogy ő természetesen nem tartja a pártot reakciósnak. „Mint nagy pártnak természetesen van jobbszárnya és balszárnya. Az bizonyos, hogy én a balszárnyhoz fogok tartozni. Nem olyan értelemben, hogy kommunistaszimpatizáns leszek, hanem hogy a demokratikus evolúció vonalán a haladóbbakkal fogok tartani”,452 - írja Nagy Vince, aki sajátosan használja memoárjában a koalíciós évek közéleti kommunikációját uraló és az időszakról szóló történeti diskurzust is meghatározó ellentét-pár (balszárny kontra jobbszárny) fogalmi kontextusát. A rögzült kép arról szól, hogy a balszárnyhoz tartozó, a kommunisták beépített embere, szimpatizánsa vagy legalábbis társutas, míg a jobbszárny-kifejezés arra utal, hogy az adott személy vagy erő a kommunista törekvésekkel szemben pozícionálta önmagát. Nagy Vince előbb idézett fogalmi konstrukciója eltér mindettől, mert a polgári politikus nem fogadja el ezt a keretet és inkább történetszociológiai megközelítésben tekinti magát baloldalinak, aki a szociális tartalmú változások érdekében kíván radikális haladást, de mindezt a jogállami demokrácia és a demokratikus szabadságjogok rendszerén belül gondolja megvalósítandónak.

A Rákosival folytatott tárgyalások végén a kommunista politikus elköszönésképp a következőket mondta Nagy Vincének: „A demokrácia felépítésében együtt kell müködnünk. "453 Nagy azt válaszolta, abban szívesen közremüködik, de mint írja: „kétségeim nagyok voltak, hogy amit ők építeni akarnak, az valóban demokrácia lesz-e, avagy csak annak

\footnotetext{
${ }^{450}$ Uo. 368. p.

${ }^{451}$ Uo. 330. p.

${ }^{452}$ Uo. 330-331.p.

${ }^{453}$ Uo. 334. p.
} 
álarcában igazi kommunizmus. Legfeljebb lassú ütemben, ügyesen adagolva, hogy vakulj, magyar!",454

Nagy Vince önéletírói fogalomhasználata alapján egyértelműen látszik: a veterán közéleti szereplő - Böhm Vilmoshoz hasonlatosan és Károlyi Mihállyal ellentétben politikusként a koalíciós években, majd memoárja megírásakor is a polgári demokrácia eszmerendszerét, értékeit vallja magáénak.

Drozdy Győzö ${ }^{455}$, aki a koalíciós években kisgazda, majd szabadságpárti nemzetgyülési képviselő volt, a 60-as esztendőkben a kádári Magyarországon, a Magyar Tudományos Akadémia felkérésére írta meg memoárját. Drozdy határozottan szegült szembe 1945 után a kommunista hatalomátvétellel szemben, Rákosi Mátyás 1945-ös szónoki teljesítménye azonban hatott a képviselőre. Erről így írt: „Nyomát sem találjuk benne a népszerütlen, a parancsuralmi törekvés emlegetésének. Polgári eszmefuttatás - kommunista szájból. [...] Ez a beszéd nem rokona a »kommunista demokrácia« szofisztikájának. Egyáltalán nem vesszük észre, hogy Moszkva beszél belőle. ${ }^{„ 456}$ Drozdy szavai szerint tehát a „kommunista demokrácia” egy sajátos szofisztika, de Rákosi retorikai képességeivel mindez „polgárinak” tünik. Egy másik helyen a kommunista befolyás alatt müködő demokráciát Drozdy Győző „moszkvai demokráciának”457 nevezi. Drozdy úgy véli, az 1945-ös választások megrendezése a kommunisták részéről valóban komoly gesztus volt az ország számára, mert a kommunista államhatalmi gondolkodásmód egyik lényege, hogy nem fogadja el a választások magasabbrendűségét. Drozdy szerint a kommunista világon belül ,a vezetésre, irányításra hivatott legmegfelelőbb embereket képességeik és megbízhatóságuk szerint nem választják, hanem kiválasztják.",458

Horváth János, aki az 1945-ös nemzetgyülés kisgazda képviselője volt, 2012-es életútinterjújában az 1945 novemberében lezajlott első demokratikus választások „csoda” jellegét emeli ki: „Nem vesszük észre, hogy az 1945-ös választás milyen csoda volt. Szovjet katonai megszállás, és annak ellenére! Nem vesszük észre, éppen azért volt nagy, mert a szovjet megszállás ideje alatt a magyar nép képes volt a szovjet kommunista rendszer ellen szavazni. Pedig tíz évvel később a forradalom is ebben gyökeredzett. Két és fél év után kommunista

\footnotetext{
${ }^{454}$ Uo.

455 Drozdyt 1920-ban kisgazdapárti színekben választották parlamenti képviselőnek, egyike volt annak a 9 honatyának, aki Horthy kormányzóvá választása ellen szavaztak. 1944 októberében Bajcsy-Zsilinszky Endrével együtt vett részt a fegyveres ellenállásban.

${ }^{456}$ DROZDY Győző: Elvett illúziók. Drozdy Győző emlékiratai. Kossuth Kiadó, Budapest, 2007. 372-373. p.

${ }^{457}$ Uo. 390. p.

${ }^{458}$ Uo.
} 
diktatúra valósult meg, amit nem a kommunista párt, hanem a szovjet hadsereg csinált." ${ }^{, 459}$ Horváth János egy visszaemlékező újságcikkben az 1945-ös voksolás kapcsán írta, hogy az a szavazás a demokrácia és a diktatúra közötti választás volt: „mérföldkő a magyar történelemben az 1945. november 4-i országos választások napja, amikor a szavazók több mint négyötöde kiállt a polgári demokrácia mellett. A diktatúra szálláscsinálóinak gyanított kommunisták egyötödnyi szavazatot sem kaptak, annak ellenére, hogy a megszálló szovjet hadsereg éppenséggel az eredmény fordítottját óhajtotta."

Horváth János az 1945 és 1947 közötti időszakot az 1848-1849-es évek „,sikereihez”, „eredményeihez” és „,vereségeihez”461 hasonlítja, ugyanakkor azt is kifejti, hogy az 1956-os forradalom törekvései a '45 utáni két esztendő tapasztalataiból „,gyökereznek."462

Kővágó József 1945 decemberétől 1947 júniusáig Budapest polgármestere volt. ${ }^{463}$ 1986-ban Chicagoban írta meg visszaemlékezéseit a 45-ös budapesti és az országos választásokról. Kővágó szerint 1945-ben a magyar nép „drámai erővel” bizonyította, hogy Magyarország ,a parlamentáris demokrácia szabályai alapján óhajtja megkezdeni a háború utáni politikai életet." ${ }^{464}$ Kővágó memoárjában a kisgazdák koalíciós évekbeli demokráciafelfogását így próbálja összefoglalni: „A kisgazdapárt rendezte sorait és tisztázta politikai alapelveit, amelyeknek a lényege az volt, hogy demokratikus, többpártrendszeres, parlamentáris, haladó szellemü, de nemzeti hagyományokra épülő társadalmi rend megteremtéséért küzdünk."465

Hám Tibor a kisgazdák nemzetgyülési képviselője volt 1945 és 1947 között. Megvádolták az összeesküvési ügyében, de a bíróság felmentette. Hám 1984-ben írt visszaemlékező cikkében úgy fogalmaz, hogy a második világháború utáni két évben a Független Kisgazdapárt politikai stratégiáját a „nagyferenci” ${ }^{466}$ irányzat demokrácia-felfogása határozta meg. Hám szerint ennek az irányzatnak a jellemzője az volt, hogy a nyugati

\footnotetext{
${ }^{459}$ HORVÁTH János: Élő történelem. Horváth Jánossal, a parlamenti képviselők doyenével beszélget Spangel Péter. Kairosz Kiadó, Budapest, 2012. 39. p.

${ }^{460}$ A Demokrácia fellegvárának építői. CSICSERY-RÓNAY István, HORVÁTH János, TÖRÖK Bálint írásaiból. 54. p.

${ }^{461}$ HORVÁTH János (szerk.): Tiltott történelmünk. Századvég Kiadó, Budapest, 2006. 7. p.

462 Standeisky Éva szerint ötvenhat „,restaurációs jellegü”, „visszatérő”, „múltba forduló”, „,kiújuló” forradalom volt, mert ,a közéleti szereplők zöme alapvetően az 1945-47-es időszakhoz kívánt visszatérni.” (STANDEISKY Éva: Népuralom ötvenhatban. Kalligram - 1956-os Intézet, Pozsony - Budapest, 2010. 539. p.)

${ }^{463}$ Kővágó József közéleti szerepvállalásáról: HAAS György: Egy elfeledett szabadsághős - Kővágó József munkássága. Magyar Szemle, XXIII. évf. (2014) 3-4. Elérhető: http://www.magyarszemle.hu/cikk/egy_elfeledett_szabadsaghos_kovago_jozsef_munkassaga (A letöltés időpontja: 2016. január 31.)

${ }^{464}$ KőVÁGÓ József: Az 1945-ben tartott budapesti és országos választások lefolyása és jelentősége. Történelmi dokumentum. Vetés Kiadó, Budapest, 1994.

${ }^{465}$ Uo. 20. p.

466 HÁM Tibor: A Magyar Köztársaság megalakulása. In: Nagy Ferenc miniszterelnök. Visszaemlékezések, tanulmányok, cikkek. Ezerkilencszáznegyvenöt Alapítvány - Occidentál Press, Budapest, 1995. 70-78. p.
} 
demokrácia, a szociális igazságosság, a földreform megvalósítása és a népi kultúra mellett álltak. Dessewffy Gyula (1945-47 között kisgazda nemzetgyülési képviselő) az önéletrajzi jellegű Tanúvallomás címü kötetében közölt 1986-os írásában fejti ki, hogy a 45-ös kisgazdák „a szabadságon felépülő demokráciát "467 tekintették elérendő célnak.

„A teljes demokrácia felé való fejlődést akasztotta meg az oroszok egyre gyakoribb beavatkozása, végül 1947-ben a parlamenti többségnek koncepciós perek útján való felszámolása és a közvetlen szovjet intervenció (Kovács Bélának, a Független Kisgazdapárt főtitkárának elhurcolása), amely a Kommunista Pártot juttatta uralomra és a magyar történelem legzsarnokibb korszakát valósította meg»"468 - írja Csicsery-Rónay István, aki a koalíciós években a Kisgazdapárt külügyi osztályvezetője volt. ${ }^{469}$ Arany Bálint, a Kisgazdapárt szervezési osztályvezetőjeként dolgozott 1945-46-ban. Aranyt 1946 decemberében az összeesküvési ügyből kifolyólag tartóztatták le és ítélték el, 1987-ben hunyt el. 1990-ben megjelent memoárjában olvashatunk arról, hogy Nagy Ferenc és Kovács Béla 1946 őszén komolyan fontolgatta a koalíció felmondását, mert a baloldali pártok „semmibe veszik a demokratikus együttmüködés kötelmeit." ${ }^{470}$

Kiss Sándor, a koalíciós idők kisgazda nemzetgyülési képviselője, a Magyar Parasztszövetség fötitkára, 1956-os emigrációja után az Egyesült Államokban írta meg visszaemlékezéseit; a dokumentumot csak Kiss Sándor 1982-ben bekövetkezett halála után publikálta az emigráns Bessenyei György Kör 1983-ban. Az önéletírás címe is különösen érdekes témánk szempontjából, Kiss A magyar demokráciáért címmel vetette papírra emlékeit - meghatározó részben a koalíciós évekről. Kiss Sándor számára is 1945 az az esztendő, amikor még úgy tűnt, a magyar demokrácia esélyt kap a sorstól vagy a világpolitikától: „1945 tavasza a háború utáni korszak viszonylag legszabadabb időszaka volt. [...] A nép leleményessége, találékonysága nem ismert határt. Mi több a fejekben és a szívekben kezdett épülni az öntudat, az emberi méltóság, amely, párosulva a közösségi érzéssel, minden demokráciának alapja"471 - olvashatjuk Kiss Sándor emlékirataiban. Kiss önéletírásában külön kiemeli, hogy milyen fontos szerepet játszott a kommunista párttaktikában és

\footnotetext{
${ }^{467}$ DessewfFy Gyula: Tanúvallomás. Agroinform Kiadó, Budapest, 1997. 147. p.

468 CSICSERY-RÓNAY István (szerk.): Saláta Kálmán, az ifjú szürkeeminenciás. Fejezetek a Független Kisgazdapárt 1945-ös küzdelméből. Occidental Press, Budapest, 2004. VI. p.

${ }^{469}$ Csicsery-Rónay István az 1989-90-ben létrejött demokratikus politikai rendszer jogi, morális, eszmetörténeti alapját egyértelmüen és konzekvensen az 1945-ös választások után kialakuló „16 hónapnyi” demokráciában látja. (CSICSERY-RÓNAY István: Az 1946. évi I. törvénycikk történelmi perspektívában. In: HoRVÁTH János (szerk.): Tiltott történelmünk. Századvég Kiadó, Budapest, 2006. 141-146. p.)

${ }^{470}$ ARANY Bálint: Koronatanú. Emlékirat 1945-57. Püski, Budapest, 2006. 23.p.

${ }^{471}$ KISS Sándor: A magyar demokráciáért. Magyar Öregdiák Szövetség - Bessenyei György Kör, New Brunswick NY, 1983. 49. p.
} 
nyelvpolitikai küzdelemben a „reakció” kifejezés, mert a kommunisták nézőpontján keresztül a reakció úgymond csak erélyes fellépéssel győzhető le, s a reakciós fogalmat „rugalmasan” alkalmazták az ellenfeleikkel szemben. Mindezen jelenséget „rabulisztikának” nevezi.

Kiss bemutatja azt a jelenséget, miszerint a kommunista befolyás alatt müködő rendőrség átalakult a „népi demokrácia öklévé.”472 Kiss szövegében a „népi demokrácia” a kommunista ideológiájú államberendezkedési struktúra megnevezése; a kisgazdák által kívánatos rendszert ,jelző nélküli” demokráciaként vagy „parlamentáris” demokráciaként írja le.

Kiss szerint is „a magyar demokrácia diadala" ${ }^{\text {473 }}$ volt az 1945 . novemberi kisgazda győzelemmel végződő voksolás. Ismerteti azt a politikai folyamatot, melynek lényegi pontja volt, hogy a szovjet megszálló hatóságok elvárták: „demokratikus” kormány alakuljon. Kiss megjegyzi, parlamentáris rendszerben a kisgazdák demokratikusan kormányozhattak volna egyedül is, tehát a polgári demokrácia elvárás-rendszere szerint az egyszínű kisgazda kormány is „demokratikus” kormánynak lett volna tekinthető. A szovjetek szemében azonban a „demokratikus” azt jelentette, abban legyenek benne a kommunisták és leginkább, hogy a belügyminisztériumot a kommunisták felügyeljék, vagyis e látásmódon keresztül akkor „demokratikus” a kormány, ha a rendőrség kommunista befolyás alatt marad. Kiss Sándor önéletírásából tudhatjuk, a kommunisták azt üzenték, ha a kisgazdák nem fogadják el a „demokratikus” megoldást, vagyis a kommunista kormánybéli jelenlétet, akkor kormányozhat egyedül is az FKgP, de akkor vállalja a felelösséget. Ezt a kisgazda pártvezetök úgy értelmezték, hogy mindez azt jelentette volna, hogy akár már 1945 novemberében megvalósulhatott volna egy a szovjet szuronyokra épülő kommunista hatalomátvétel. ${ }^{474}$

Futó Dezső kisgazda újságíró és nemzetgyülési képviselő volt 1945 és 1947 között. A 47’-es választásokon a Magyar Függetlenségi Párt jelöltjeként szerzett mandátumot, 1947. október 30-án lemondott mandátumáról. Futó megérte a rendszerváltozást, memoárja halála után egy évvel, 1995-ben látott napvilágot.

A kisgazda közéleti szereplő így idézi fel a második világháború végnapjai során érzetteket: „... Béke következik. Demokrácia lesz és megvalósulhat álmunk, az ezeréves álom. ${ }^{475}$ Futó őszintén beszél arról, hogy 1945-ben az ország népe valóban elhitte azt, a

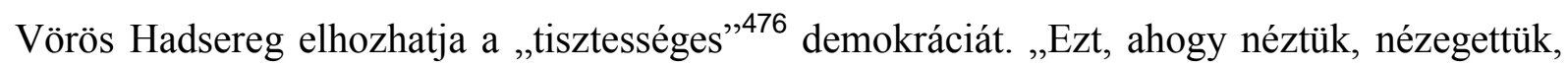

\footnotetext{
${ }^{472}$ Uo.

${ }^{473}$ Uo. 50. p.

${ }^{474}$ Uo. 57. p.

${ }^{475}$ FUTÓ Dezső: Önéletírás. Világlátás. Országos Eckhardt Tibor Alapítvány, Budapest, 1995. 70. p.

${ }^{476}$ Uo. 144. p.
} 
ez az illúziónk egyre inkább fogyott, mert rá kellett, hogy jöjjünk, hogy a Vörös Hadsereg nem biztosítja Magyarországon a demokráciát. A polgári demokráciát. Ők akkor, illetve a Kommunista Párt fából vaskarikát csinálva »népi demokráciát« hirdettek. Hát ez a »népi demokrácia« egy nonszensz valami." ${ }^{477}$ Futó úgy véli, a népi demokrácia azon túl, hogy fogalmilag nonszensz, lényegében a diktatúrának ágyazott meg. Erről így ír: „Az 1947-es választás után, a diktatúra egyre világosabbá vált és 1948-ra már teljes mértékben érvényesült.",478

Futó önnön demokrácia-képét is illusztrálja: „Hittem abban, hogy van igazság és van demokrácia. A többségi véleménynek, akaratnak van formáló ereje. Ennek érdekében, ebben a meggyőződésben írtam riportjaimat, jártam az országot és mondtam népgyüléseken beszédeket."479 Futó arról ír, hogy ha 1945 előtt volt „bátorsága” szembenézni a diktatúrákkal, „miért ne lett volna 1945 után.”480 A diktatúrához való viszonyulás egy másik szövegrészben is előjön önéletírásában. „Az idő engem igazolt. A diktatúrák ellen voltam, tehát kész marhaság lett volna, hogy tudjam vállalni Rákosi diktatúráját. Itthon maradtam! Ha agyonvernek, becsuknak, Istenem ez jutott osztályrészemül, mint ahogy ez jutott tíz- és tízezer embernek, akik itthon maradtak. Mi lett volna ebből az országból, ha kinyargal az ország nagyobbik része. Megszünt volna a nemzet, mint olyan!”

Futó a jogállami demokrácia híve volt egész életében és valóban szembeszállt a diktatórikus törekvésekkel, de történelmi tény, hogy 1948. augusztus 20-án visszavételét kérte az akkor már a kriptokommunisták befolyása alatt müködő társutas kisgazdapártba, ami valami furcsa, nehezen megmagyarázható kvázi legitimálása is lehet szimbolikus értelemben a kibontakozó kommunista diktatúrának. Ez a pszichés megközelítés indokolja, hogy Futó miért tartja fontosnak az előbbi hosszas magyarázatot arra vonatkozóan, hogy erkölcsi értelemben magasabb rendünek tudja felmutatni azt a magatartásmintát, ha valaki az emigráció helyett a kommunista diktatúra kibontakozása ellenére az országban maradást választotta.

Varga Béla, a Nemzetgyülés egykori elnöke 1991-ben mondta magnóra visszaemlékezését. Az életút-interjúk során aláhúzta: a kisgazdák a koalíciós időkben mindvégig egy demokratikus Magyarországról ,álmodtak” ${ }^{, 481}$ - ez volt politikai alapvetésük. Vargának ugyanakkor elmondása szerint nem volt illúziója arról, hogy az 1945-ben létrejövő

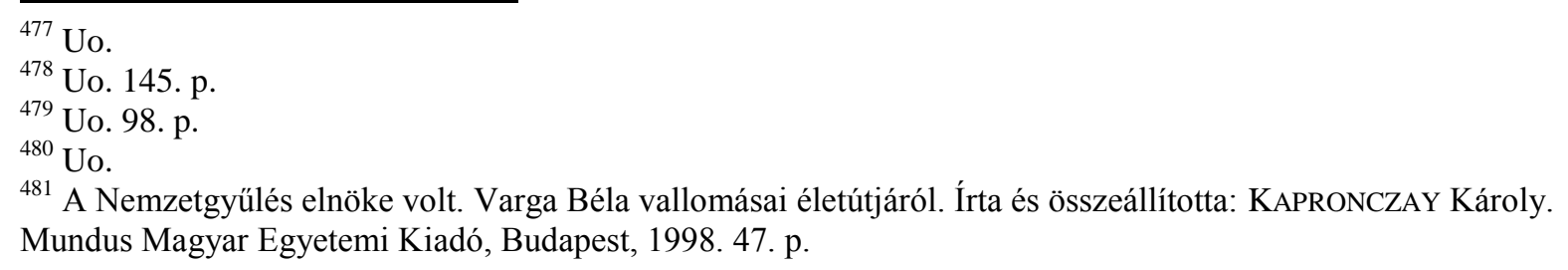


demokráciának esélye lehet hosszabb távon. Varga Bélának gyerekkori barátja volt a tekintélyes kommunista gazdaságpolitikus, Varga Jenő, aki már a háború után elmondta a kisgazda politikusnak, itt teljes „kommunizálás” lesz, és csak idő kérdése, hogy az oroszok „meddig engedik a demokráciát." ${ }^{482}$ A nemzetgyülési elnök számára Kovács Béla elhurcolása után vált világossá, hogy elindult az a folyamat, amiről Varga Jenő beszélt neki és megkezdődött a kommunista hatalomátvétel. ${ }^{483}$

Vörös Vince, aki 1945 és 1947 között az FKgP nemzetgyülési képviselője volt - a rendszerváltozás után, a politikába való visszatérését követően - a 90-es évek első felében írta meg hosszú közéleti pályafutása történetét. Önéletírásában mintegy összegző kisgazda-polgári álláspontként fogalmazza meg a koalíciós korszaknak a kisgazdapárt nézőpontján keresztüli legfontosabb demokrácia-történését: „A nemzet minden rétege felzárkózott a párt mögé, és nagyon is egységes volt abban, hogy a demokrácia mellett kiállva védekezett a kommunizmus ellen."484

Mizsei Béla, aki FKgP-s tagja volt az 1945-ös szabadon választott nemzetgyülésnek, 1984-ben, vagyis még a Kádár-korszakban írta meg a koalíciós évekre is vonatkozó visszaemlékezéseit. Az önéletírás több mint 20 esztendeig, 2006-ig várt a publikálásra. Mizsei 1989 után ismét közéleti szerepet vállalt, 1990-ben parlamenti képviselő lett - 1994-ig volt kisgazda honatya -, ezért is várhatott önéletírása kiadásával. A koalíciós évekre vonatkozó memoárszövegen nem érződik, hogy még a puha diktatúra időszakában íródott, azt persze nem tudjuk, hogy a 2006-os kiadás előtt mennyit változott az eredeti kézirat.

Mizsei visszaemlékezésében a koalíciós időszak kisgazda szereplőit tekinti

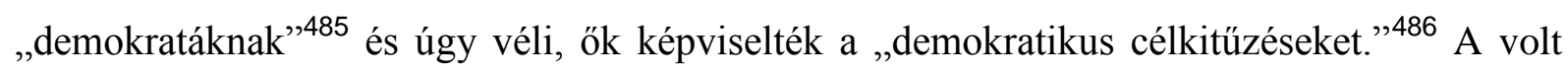
kisgazda képviselő memoárjából érdekes adalékok kerülnek elő az 1945-ös kommunista demokrácia-felfogás kapcsán. Mizsei beszámol az 1945. augusztusi balatonlellei ifjúsági konferenciáról, amely rendezvényen az MKP nevében Révai József ideológus is felszólalt. Révai ekképpen próbálta elmagyarázni a résztvevőknek, hogy milyen demokráciában gondolkodik a kommunista párt: népi demokráciát akarnak, ami „,munkás-paraszt demokrácia parlamentarizmussal és nem szovjetrendszerrel."487 Mizsei úgy emlékezett közel 30

\footnotetext{
${ }^{482}$ Uo. 44. p.

${ }^{483}$ Uo. 66. p.

484 VÖRÖS Vince: Politikai utam. Magyar Történelmi Társulat Dél-Dunántúli Csoportja - Pannon História Alapítvány, Pécs, 1995. 91. p.

${ }_{485}$ MIZSEI Béla: Életpályám. Kossuth Kiadó, 2006. 111.p.

${ }^{486}$ Uo. 87. p.

${ }^{487}$ Uo. 41. p.
} 
esztendővel később, hogy Révai még amellett is hitet tett, hogy „rá kell hagyni a nemzetre, hogy saját maga döntsön."488

Az imént idézett koalíciós évekbeli kisgazda közéleti személyiségek mindegyike megérte, megélte a kommunista diktatúrával szembeni 56’-os magyar forradalmat. A forradalom élményanyagának a tudatában írták meg, mondták el visszaemlékezéseiket a koalíciós évek tapasztalatairól. (Drozdy Győző, Kiss Sándor, Nagy Vince és Arany Bálint kivételével a többi idézett visszaemlékező a 89'-es rendszerváltozást is megérte.) Az 1956-os forradalom ismeretében megfogalmazott visszaemlékező gondolatok egyértelmüen arról szólnak - nem kételkedve abban, hogy az idézett szereplők az aktuális 1945-48 közötti történések alatt is így élték meg a koalíciós évek demokráciájának mindennapjait -, hogy úgy fogták fel a visszaemlékezések megfogalmazásakor a jövőből a múltba visszapillantva saját maguk és pártjuk szerepét, miszerint a jogállami jellegü, a polgári szabadságjogokra épített demokráciáért és a kibontakozó kommunista diktatúrával szemben küzdöttek. A visszaemlékező gondolatok egyértelmüen egyfajta polgári demokrácia-védő mentalitást tükröznek, illetve kifejezik a népi demokráciának is nevezett proletárdiktatúrával szembeni érzésvilágot, kulturális attitüdöt. Az '56-os forradalom diktatúra-ellenes élményanyagának a birtokában e véleményüket, a felvázolt emlékképet egyfajta magasabb erkölcsi pozícióból fogalmazhatták meg. Az e részben idézett kisgazda visszaemlékezők mindegyikének szövegeiből - az ő nézőpontjukon keresztül - a történelmi távlatból tekintve megfogalmazott idealizált ,„jó” álláspont magukénak vallása bontakozik ki. Ezen szereplők úgy érveltek emlékező szövegeikben, úgy fogalmazták meg visszaemlékező gondolataikat, miszerint az aktuális korszakban az általuk képviselt ügy vereséget szenvedett ugyan, de történelmi szempontból viszont úgy vélekedhetnek, hogy ök voltak a ,jó” oldalon - ez a morális felsőbbrendűség egyértelműen jellemzője a kisgazda szereplők önreflexiós visszatekintéseinek.

\footnotetext{
${ }^{488}$ Uo.
} 


\section{A kommunisták mellett társutas szerepet vállaló kisgazdák önéletírásaiban megjelenö demokráciaértelmezési paradoxonok}

Az alábbiakban öt olyan kisgazda kötődésü szereplő visszaemlékezéseit elemezzük a koalíciós évekbeli demokrácia-fogalomhasználat fényében, akik a kommunista diktatúrában is vállaltak közéleti szerepet. Dobi István a koalíciós években kisgazda miniszter volt, a proletárdiktatúra idején miniszterelnök és államfö (az Elnöki Tanács elnöke); Z. Nagy Ferenc az 1945 utáni esztendőkben és 1949-et követően is parlamenti képviselö; Bognár József 1946-47-ben tájékoztatási miniszter, majd 1949 után egészen 1956-ig végig miniszter; Barcs Sándor 1946-tól a Magyar Központi Híradó - kisgazdák által delegált - ügyvezető elnöke, 1948-ban az FKgP alelnöke, 1950-től 1963-ig a Magyar Labdarúgó Szövetség elnöke, 19501980 között a Magyar Távirati Iroda vezérigazgatója volt. Dancs József a koalíciós években kisgazda parlamenti képviselő, a kommunista diktatúra alatt a Szabad Föld újságírója.

Dobi István 1962-ben publikált memoárjában nincs jelen a demokrácia-fogalom mint narratív elem. A visszaemlékezés szövegéből is egyértelmü: Dobi 1945 után nem demokratikus politikai struktúrákban gondolkodik, hanem jóval inkább társadalom-átalakító változásokban. Önéletírásában az 1945-ös időszak kapcsán az azonnali proletárdiktatúra dimenziójában jön elő a demokrácia kontra diktatúra ellentétpár. Említést tesz a helyi szektás kommunisták törekvéseiről, akik lokális diktatúrákat vezetnek be és helyi diktátorként tünnek fel. „Diktáltak, parancsoltak, elrendeltek, utasítottak olyan helyzetekben is - nem ritkán drasztikus, durva módon -, amikor az emberekkel tanácskozni, okosan szót érteni kellett volna, és közmegelégedésre születhettek volna meg a döntések" ${ }^{\text {,49 }}$ - írja Dobi.

A Dobi-visszaemlékezésből a koalíciós évek demokráciája kapcsán is fontos tények tudhatóak meg. A paraszti származású politikus maga számol be arról, hogy Rákosi Mátyás terelte abba az irányba, hogy az FKgP-ben maradjon, merthogy úgymond „hasznosabb, "490 ha Dobi nem a kommunisták között, hanem a kisgazdapártban folytatja közéleti munkáját. Dobi úgy emlékszik, Rákosi 1945-ben valóban egy komolyabb koalíciós szakaszban gondolkodott: „Ha a koalíció jól működik, meglátod, 15-20 éven belül mintaországot csinálunk Magyarországból”491 - idézi a kommunista pártvezető szavait a kisgazda-kommunista kettős kötődésű politikus. Dobi István saját pártjáról, az FKgP-ről visszaemlékezéseiben igen rossz

\footnotetext{
${ }^{489}$ DOBI István: Vallomás és történelem. II. kötet. Kossuth Könyvkiadó, Budapest, 1962. 415. p.

${ }^{490}$ Uo. 426. p.

${ }^{491}$ Uo. 427. p.
} 
véleménnyel van - úgy gondolta, a kisgazda választási győzelem után a pártban „többségi gőg"492 alakult ki, amit ő veszélyesnek és kártékonynak tartott.

Dobi demokrácia-képéről közvetetten a visszaemlékezés azon részéből tudhatunk meg a legtöbbet, mikor Rákosinak a koalíciós évekbeli szerepét elemzi. „A felszabadulás után kialakult helyzetben, a szocialista fordulat előkészítésében és megvalósításában Rákosi valóban múltjához és híréhez méltó módon dolgozott. A munkáshatalom és a proletárdiktatúra megszervezésében nagy érdemeket szerzett"493 - olvasható a memoárban, vagyis Dobi történeti értelemben pozitívnak tartja Rákosinak a koalíciós demokrácia leépítésében, a kommunista diktatúra kialakításában vitt szerepét. Mindebből az összefüggésből is látszik, Dobi István számára a jogállami jellegü demokrácia ethosza nem bírt értékkel, számára a radikális társadalom-átalakítást felvállaló „szocializmus” jelentette a szellemi iránytüt. „Becsületes koalíciót akarok, s azután mielőbb szocializmust” ${ }^{\natural 94}$ - ez volt Dobi koalíciós évekbeli ars poetica-ja.

Z. Nagy Ferenc kisgazda parlamenti képviselő a koalíciós években a jogállami demokrácia híveként küzdött a szabadságjogokra épülő demokratikus struktúráért. Ahogy arra a disszertáció korábbi fejezetében utaltunk, Z. Nagy 1947 februárjában is, az összeesküvési ügy hiszterizált légkörében kiállt a megegyezéses demokrácia ethosza mellett és figyelmeztetett: ha nincsenek megállapodások, akkor diktatúra következhet. ${ }^{495}$

A polgári demokrácia eszmeiségét védő mentalitásnak Z. Nagy 1965-ben a kádári Magyarországon megjelent visszaemlékezésében ${ }^{496}$ nyoma sincs. Sőt, a korszak koalíciós demokráciáját, a koalíció világát inkább bírálja, mintsem védi. Panaszkodik a különböző politikai erők pozícióharcára és negatív jelenségként állítja be „a pártok marakodásait."497 A koalíciós időszak egyik jellemzőjeként ír arról, hogy „a reakciós erők nem mondtak le a hatalomról." ${ }^{498}$

\footnotetext{
${ }^{492}$ Uo. 422. p.

${ }^{493}$ Uo. 427. p.

${ }^{494}$ Uo. 445. p.

495 Z. NAGY Ferenc: A koalíció válsága és a kivezető út. Kis Újság, 1947. február 7. 1. p.

496 Drámai módon esik szó Ortutay Gyula naplójában Z. Nagy Ferenc egykori kisgazda képviselőtársa visszaemlékezéséröl.

Ortutay 1966. január 30-i bejegyzésében írja le, Barcs Sándor miként számolt be neki arról, hogy Dobi Istvánt fia halálhíréről kellett tájékoztatnia. Kádár János Barcs Sándort mint Dobi egykori kisgazda párttársát bízta meg azzal, közölje az Elnöki Tanács elnöki posztját betöltő Dobi Istvánnal, hogy fia öngyilkos lett. Barcs személyesen mondta el Dobinak a halálhírt. Dobi nem rendült meg, hanem néhány perc elteltével Z. Nagy Ferenc visszaemlékezéseit kezdte el éles hangon kritizálni és „félórás dühös elöadásban szétszedte, cáfolta” (ORTUTAY Gyula: Napló II. 1955-1966. Alexandra Kiadó, Budapest, 2009. 384. p.) a Z. Nagy memoárjában foglaltakat. Ortutay maga is elítélően ír Z. Nagy visszaemlékezéseiről, „hírhedt”, „szemtelen”, „hazug” és „ravasz” (Uo.) könyvnek nevezi a visszaemlékezést.

${ }^{497}$ Z. NAGY Ferenc: Ahogy én láttam. Gondolat Kiadó, Budapest, 1965. 235. p.

${ }^{498}$ Uo.
} 
Z. Nagy memoárjában mint előrevivő megszólalást idézi Révai Józsefnek a Dinnyéskormány parlamenti programvitájakor elmondott beszédét, mikor Révai arról szólt, hogy Nagy Ferenc és Varga Béla emigrálása után - akik a kommunista szónok szerint az embereket a demokrácia ellen hangolták - végre a „népet a demokrácia felé kell vezetni." ${ }^{\circ 99} \mathrm{Z}$. Nagy beszámol arról, hogy mivel „Révai beszéde megnyugtatóan hatott, ${ }^{\circ 50}$ személyes találkozót kezdeményezett vele, amely megbeszélés létre is jött. Ezen találkozón Révai kifejezte, reméli, Z. Nagy segíteni fogja a kommunisták és a kisgazdák közötti együttmüködést. ${ }^{501}$

Nem sokkal később, 1947 sorsdöntő történéseire vonatkozó megállapítása így hangzik: „Már kezdtem látni, hogy a népi demokratikus fejlődés csak szocializmushoz vezethet, s abban a parasztságnak meg kell találni a maga helyét." ${ }^{\text {502 }}$ Történettudományi szempontból egyelöre feltáratlan, hogy Z. Nagy demokrácia-felfogását, politikai nézeteit érintő pálfordulásának milyen konkrét oka lehetett. ${ }^{503}$

Dancs József 1978-ban kiadott memoárjában a demokrácia fogalma többször is szerepel narratív elemként. A demokrácia kifejezés a szövegben azonban egyértelműen a kommunista nézőpontú demokrácia-fogalmat jelenti, leginkább arra törekszik a visszaemlékező, hogy megmagyarázza, a kisgazdák haladó körei is „demokráciát” akartak az 1945-öt követő esztendőkben. ${ }^{504}$

Bognár József 1987-ben adott életút-interjújában nincs jelen a demokrácia témája mint narratíva. $^{505}$

A kisgazda kötődésű sportmúlttal bíró Barcs Sándor mint „társutas” a kommunista diktatúra sportpolitikájának lett az egyik meghatározó alakja - a londoni olimpia alatt a

\footnotetext{
${ }^{499}$ Uo. 265. p.

${ }^{500}$ Uo. 266. p.

${ }^{501}$ Mizsei Kálmán (kisgazda nemzetgyülési képviselő, 1945-1947) szerint Z. Nagy Ferenc 1947-48-ra „elcserélt ember” lett. (MIZSEI Béla: Életpályám. 103. p.)

${ }^{502}$ Uo. 272. p.

${ }^{503}$ Az 1945-47-es nemzetgyülés almanachja számára készített Z. Nagy Ferenc életrajzban Vida István történész és Vörös Vince egykori párttárs így fogalmaz: Z. Nagy „a párt paraszti centrumához tartozott, de Nagy Ferenc miniszterelnök lemondása után és emigrációba kényszerítése után csatlakozott a Dobi-Gyöngyösi fémjelezte balszárnyhoz.” (VIDA István (szerk.): A Nemzetgyülés Almanachja 1945-1947. Magyar Országgyülés, Budapest, 1994. 387-388. p.) Ungváry Krisztián Z. Nagy Ferencet a Kisgazda politikusok és az állambiztonság címü tanulmányában a kisgazdapárt balszárnyához, a társutasok csoportjába sorolja. „A társutasság határai szinte definiálhatatlanok: a szervilis Dobi Istvántól egészen az integritására kínosan ügyelő id. Antall Józsefig terjed azok sora, akik szerepet vállaltak a rendszerben." (UNGVÁRY Krisztián: Kisgazda politikusok és az állambiztonság. In: UNGVÁRY Krisztián (szerk.): Búvópatakok. A jobboldal és az állambiztonság 1945-1989. 1956-os Intézet Alapítvány - Jaffa Kiadó, Budapest, 2013. 87. p.) Ungváry tanulmányából megtudhatjuk, Z. Naggyal kapcsolatban az állambiztonság 1966-ban felújította az adatgyüjtést, mert 1966. április 18-án visszaemlékezésének gödöllői bemutatásakor arról beszélt, hogy ,az oroszok ugyanazt csinálják Magyarországon, mint az amerikaiak most Vietnámban.” (Uo. 91. p.) Z. Nagyról '66 után a BM nem tudott érdemi anyagot gyüjteni, az egyik állambiztonsági jelentés megállapította: „,egyértelműen a jelenlegi rendszer mellett foglalt állást." (Uo. 134. p.)

${ }^{504}$ DANCS József: Utak és állomások. Kossuth Könyvkiadó, Budapest, 1978. 319-320. p.

505 BoGNÁr József: „Én azt gondolom...”. Kritika, XVI. évf. (1987) 8. 19-35. p.
} 
Magyar Olimpiai Bizottság társelnöke. A koalíciós években Barcs a Magyar Központi Híradó vezetője. A Dlusztus Imrének adott - már a rendszerváltozás után készült, s 1997-ben megjelent - életútinterjújában beszél arról, hogy a Magyar Központi Híradó ügyvezető elnökeként az egyik legfontosabb feladata az volt, hogy betartassa a demokratikus pártok által megszabott „demokratikus szabályokat, a koalíciós rendet." ${ }^{, 506}$ Mindezen túlmenően Barcsnál sem érdemi a demokrácia narratíva az életút-interjú során. Hogy a polgári demokrácia ethoszát valló kisgazda szellemi körből indulva miként került egyre közelebb a kommunisták népi demokráciájához, így magyarázza: „Sohasem tudtam pártban gondolkodni, én mindig népfrontos gondolkozású voltam."507 Magában már 1948-ban felismerte a „baloldali aktivistát, a kommunisták szövetségesét." ${ }^{, 508}$ Arról is beszélt a visszaemlékező interjúban, hogy egész életében lelkiismeret-furdalása volt amiatt, hogy vállalta - a kommunista diktatúra bekövetkeztét visszavonhatatlanul demonstráló - Rajk-perben a népi ülnöki szerepet. „Nekem korábban is lelki konfliktust okozott, különösen azért, mert humanista embernek tartottam és tartom magamat, de akkor Péter Gábor szobájában gyengének bizonyultam., 509

A kisgazda „társutas” közéleti szereplők - zömmel a Kádár-korszakban írt visszaemlékezéseinek közös jellemzője, hogy a jogállami demokrácia mint érték nem jelenik meg a forrásokban. A demokrácia mint narratíva nem szövegformáló tényező e memoárokban. Megállapítható: a társutasság mint jelenség felvállalásához pszichésen szükséges volt a teljes szakítás a szabadságjogokra épülő demokrácia eszményétől, így a demokrácia mint ethosz nem jelenik meg a visszaemlékező szövegekben sem.

\section{A (népi) demokrácia mint narratíva a hithü kommunisták koalíciós évekröl szóló visszaemlékezéseiben}

A koalíciós korszak legfontosabb szereplője, Rákosi Mátyás 1958-tól szovjetunióbeli emigrációjában írta visszaemlékezéseit. Az MDP megalakulásáig tartó részt Tokmakban 1966. június 27-én fejezte be. Ahogy arról már szót ejtettünk, az önéletrajzi narratíva a múlt emléknyomairól szól, de a ,jelen” nézőpontján keresztül. Ezt Rákosi visszaemlékezései kapcsán különösen is hangsúlyoznunk kell. Az egykori pártvezér emigrációban, lényegében a

\footnotetext{
${ }^{506}$ DLUSZTUS Imre: Barcs Sándor. Délmagyarország Kft., Szeged, 1997. 111.p.

${ }^{507}$ Uo. 123. p.

${ }^{508}$ Uo. 142. p.

${ }^{509}$ Uo.
} 
szovjet hatóságokkal és a kádári hatalommal szemben kiszolgáltatva jegyezte le önéletírását. Az önreprezentáció biztonságát számára az adta meg, hogy nem változtatott az 1945 és 1948 közötti érvkészletén - ez azzal is összefügg, hogy a korabeli beszédeihez mint forrásokhoz a szovjet pártvezetők közbenjárására hozzá tudott jutni, így az emléknyomokon kívül ezek a dokumentumok lehettek az alapjai a visszaemlékezéseinek. „Pozitív szereplőket itt már alig találunk nála: aki kezdetben demokrata volt az reakcióssá, aki baloldali volt az jobboldalivá, egyesek rendőrspiclivé válnak" ${ }^{\Perp 10}$ - írja a visszaemlékezés anyagát szerkesztő, gondozó Feitl István történész.

Rákosi Mátyás visszaemlékezéseiben egyértelművé teszi, hogy 1945 után a szovjet érdekekre való tekintettel nem lehetett szó kezdettől fogva a kommunizmus terjesztéséről, mert a szövetséges nagyhatalmak megállapodtak abban, hogy pusztán „,nemzeti, felszabadító” harcot engednek az általuk megszállt területeken. Emiatt nem beszéltek a magyar kommunisták az általuk remélt forradalomról. „Elhatároztuk, hogy nem használjuk a proletárdiktatúra szót. [...] Ehelyett azt mondottuk, hogy a népi demokrácia állama betölti a kapitalizmusból a szocializmusba való átmenet államának szerepét. Aki marxista, az megértette, hogy az ilyen átmenet államformája a proletárdiktatúra, ellenségeink viszont nem köthettek bele olyan könnyen." ${ }^{511}$ - írja Rákosi, aki az önéletrajz egy másik részében azt fejtegette, hogy a kommunisták a „tényleges”,512 demokrácia hívei voltak, ellentétben a kisgazdákkal, akik a „formális” demokrácia keretei között képzelték el a jövőt. Az egykori pártvezér úgy vélte, a kommunisták által szervezett koalíciós évekbeli tömegmegmozdulások részei a demokrácia világának - még akkor is, ha ,gyakran becsületes demokraták is hajlandóak arra, hogy a tömegmegmozdulások fegyverét, mint a demokráciával össze nem egyeztethetőt, elvessék." ${ }^{, 513}$

Amikor az MKP III. kongresszusának (1946) eseményeit idézte fel, akkor ismét kitért Rákosi a demokrácia kontra diktatúra tematikára: „Még a pártkongresszuson is csak általánosságban, éles meghatározások nélkül beszéltünk a népi demokrácia szocialista jellegéről. Ez az általánosság és éles formulák hiánya azonban nem abból keletkezett, mert magunk sem voltunk tisztában azzal, hogy merre megyünk és mire törekszünk. [...] hanem

\footnotetext{
510 FeITL István: Rákosi Mátyás - Visszaemlékezések 1940-1956. Elérhető: http://napvilagkiado.eu/webaruhaz/shop.product details/11-forraskiadvanyok/flypage.tpl/113-rakosi-matyasvisszaemlekezesek-1940-1956/ (A letöltés időpontja: 2015. október 1.)

${ }_{511}^{511}$ RÁKOSI Mátyás: Visszaemlékezések 1940-1956. 1. kötet. Napvilág Kiadó, Budapest, 1997. 239. p.

${ }^{512}$ Uo. 321. p. (Ahogy az a dolgozatban már többször elemeztük, a kommunisták a koalíciós években a polgári demokrácia formalizmusával szemben a maguk demokrácia-fogalma kapcsán gyakran az „igazi”, a „tényleges” és a leginkább a „népi” kifejezéseket használták, hogy ezáltal is ellenpontozni tudják a jogállami demokrácia normatív jogfelfogását.)

${ }^{513}$ Uo. 323. p.
} 
mert akkor taktikailag ez volt a helyes. Megállapodtunk, hogy a proletárdiktatúra kifejezést, mely bel- és külpolitikailag ekkor csak megnehezítette volna munkánkat, kerüljük. [...] Tudvalevőleg, amikor az erőviszonyok megváltoztak - no meg a kommunista párt sikerei az osztályharc frontján ezt lehetővé tették -, mi azonnal nyíltan beszéltünk."514 A fötitkár visszaemlékezésének szövegéből egyértelmüen kitetszik, hogy a „népi demokrácia” kifejezés számukra metanyelvi fogalom volt, amiről ők maguk, ,a marxisták” úgyis tudták, hogy az a proletárdiktatúrát jelenti. Rendkívül érdekes jelenség bontakozik ki e kérdés kapcsán, hiszen a visszaemlékezés szövegéből egyértelmü, hogy a kommunisták 1945 után nem sokkal már proletárdiktatúrára törtek, a cél a kommunista diktatúra kialakítása volt, de magában az önéletírásban is Rákosi is végig „magyar demokráciáról” és „,demokráciáról” beszél, mikor a maguk célkitüzéseit értékeli és a koalíciós évek államstruktúráját írja le. E különös nyelvi zavarra példa a visszaemlékezésből az alábbi idézet: „A magyar demokrácia nem egyetlen hatalmas ütközetben verte meg az ellenségét, a reakciót, hanem egy sor kisebb-nagyobb győzelem és siker együttes eredményeképpen állott elő az a helyzet, hogy a reakció lényegében elvesztette a csatát. A demokrácia mennyiségi győzelmei összeadva minőségibe csaptak át." ${ }^{515}$ Rákosi okfejtését vizsgálva az a logikai következtetés olvasható ki, miszerint „a demokrácia mennyiségi győzelmei” olyan minőségbe csaptak át, ami már magát a klasszikus értelembe vett proletárdiktatúrát hozta létre.

Mindezeket figyelembe véve önreflexiós hiánynak tünik, hogy ezzel párhuzamosan Rákosi Mátyás megvetőleg ír arról, miszerint a ,jobboldali kisgazdák” folyamatosan támadták a kommunista kézben lévő „demokratikus” rendőrséget és merészeltek a koalíciós években arról beszélni, hogy a kommunisták „kisebbségi diktatúrára”,516 törnek.

Az 1945 októberében megrendezett budapesti törvényhatósági választást, melyen a kisgazdák - váratlanul - egyedül többséget szereztek, Rákosi „az első demokratikus választásnak" ${ }^{\text {517 }}$ nevezi, amelynek tanulsága az ő szempontjukból az volt, hogy „,a reakció” milyen erős. A kommunista pártfőtitkár úgy emlékszik, a budapesti voksolás után novemberben a nemzetgyülési választások eredménye már nem volt meglepetés: „A választások után az első dolgunk volt, hogy megakadályozzuk a demokrácia táborában az ijedtséget és zavart." ${ }^{518}$ Rákosi az önéletírásban „a demokrácia táboráról” szól, ahol a zavarodottság tünetei jelentkeztek a kisgazdák 57 \%-os győzelmét követően, vagyis

\footnotetext{
${ }^{514}$ Uo. 325. p.

${ }^{515}$ Uo. 464. p.

${ }^{516}$ Uo. 311. p.

${ }^{517}$ Uo. 382. p.

${ }^{518}$ Uo.
} 
nyilvánvalónak tünik, hogy a baloldalról vagy leginkább a kommunista bázisról beszél, mikor „a demokrácia tábora” kifejezést emlegeti. Ismét tetten érhető tehát ez a furcsának ható kettősség, ahol a kommunisták kezdettől fogva a proletárdiktatúrára törnek, de erről taktikai okok miatt nem beszélnek, ugyanakkor önmagukat a demokrácia táborának nevezik. S mindezen nyelvi kontextus az események után több mint egy évtizeddel íródott visszaemlékezésben is megjelenik, amikor már nem az aktuális politikai kommunikációs koordinátarendszerben kell értelmezni a kimondott, leírt szavakat, hanem a jövőből visszatekintve rekonstruálódik a koalíciós évek világa - és e szituációban is, egy szövegtesten belül Rákosi e kettős fogalomhasználatot alkalmazza. Ezt a látásmódot érthetjük meg jobban, amikor az egykori kommunista politikus a visszaemlékezésében a kisgazdapárt összetételét elemzi. Megállapítja, hogy a pártban jelen voltak a „demokratikus parasztok” is, de 1945 nyarától az FKgP „gyüjtőmedencéjévé” vált azoknak az erőknek, akik „,a kommunista párt ellen és a polgári demokrácia mellett foglaltak állást." ${ }^{519}$ A Rákosi-féle dimenzión keresztül tehát a kisgazdapártban voltak a „,demokratikus parasztok” és velük szemben létezett az a kör, amely viszont a polgári demokrácia mellett állt, továbbgondolva ezen érvkészletet: a demokratikus parasztok ellenpólusai a polgári demokrácia hívei. Ebből az előbbi gondolatfolyamból is kitetszik, hogy Rákosi Mátyás a polgári demokrácia struktúráját a maga világlátása szerint nem tartja „,demokratikusnak.”

Érdemes néhány konkrét történést is elemezni a visszaemlékezés szövege alapján a demokráciaértelmezés nézőpontján keresztül. Például Nagy Ferenc 1947 nyári lemondatását azzal az indokkal magyarázza Rákosi, hogy határozottan kellett fellépni, mert Nagy Ferenc miniszterelnök úgymond azért ment Svájcba, hogy ott „megállapodjon a népi demokrácia” ellen. Ha a korábbiakban már felfejtett kommunista nyelvi kódrendszert vesszük alapul, ami szerint „a népi demokrácia” a „proletárdiktatúra” egyfajta fedőneve, akkor persze már nem tünik olyan valóságtól elrugaszkodott élethelyzetnek, hogy a hivatalban lévő kormányfő a formálódó proletárdiktatúrával szemben kívánt szövetségeseket szerezni a nyugati partnerekről, de mindez a kommunista frazeológia alapján azt jelenti, hogy Nagy Ferenc a „népi demokrácia” ellen tett lépéseket.

Földes László, Halas Lajos, Kállai Gyula és Nógrádi Sándor a kommunista diktatúra alatt, a Kádár-korszakban írta meg, s adta ki memoárját. Kovács István önéletírása a

\footnotetext{
${ }^{519}$ Uo. 199. p.

${ }^{520}$ Uo. 377. p.
} 
rendszerváltozás után készült el. Kádár János 1989-ben, halála előtt néhány hónappal adott életút-interjút. $^{521}$

Földes László visszaemlékezése 1984-ben látott napvilágot. A háború utáni újpesti viszonyokról írja a kommunista politikus: „A város szinte egész lakossága tanulta, próbálta a demokráciát, lassan oldódott a zárkózottság. Nehéz, fáradtságos munka volt ez számunkra."522 Ennél a lokális demokrácia-próbálkozásról szóló megjegyzésnél mérvadóbb a '45-ös választások eredményét kommentáló sorokból kiolvasható demokrácia tematika. Földest csalódással töltötte el az eredmény. Memoárjában egyetértőleg idézi Rajk Lászlót, aki a voksolás után a titkári értekezleten arról beszélt: a rossz eredményekben az is közrejátszhatott, hogy sok kommunista középvezető proletárdiktatúrát ${ }^{523}$ akart volna egyből a háború után megvalósítani és ez félelmet keltett a kommunistákkal szemben. Földes egyértelműen ezt tekintette a vereség okának, mert más mulasztást nem tudott említeni, mikor ezen dilemmázott. Földes László visszaemlékezésében leszögezte, hogy a koalíciós években a kommunisták „,betartották a polgári demokrácia szabályait.”524 A fordulatot 1948-ra teszi, mikor Dimitrovra hivatkozva már olyan népi demokráciaként határozta meg a magyar politikai struktúrát, amely átmenet a szocializmusba. ${ }^{525}$

Nógrádi Sándor is kiemeli memoárjában: a helyi kommunista káderek 1944-45-ben a proletárdiktatúrára való gyors áttérésben bíztak. Nógrádi konkrét esetként Ózd példáját említi. „Bizony sokáig tartott, amíg meg tudtam nekik magyarázni, hogy annak [a proletárdiktatúrának] még nem jött el az ideje; hogy most koalíciós kormány van, amelyben a polgári pártok is részt vesznek, mégpedig túlsúlyban - és ennek így kell lenni, mert velük együtt kell győzelemre juttatnunk a demokratikus forradalmat... Petrei barátom, Ózd város párttitkára úgy nézett rám, hogy azt hittem, mindjárt bekap."

A háború utáni történéseket bemutató fejezet elején töprengett így Nógrádi: „Milyen világ legyen? Szabadság, függetlenség, demokrácia - nos, mutasd meg, milyen vagy, kinek

\footnotetext{
${ }^{521}$ Földes László a koalíciós években az MKP újpesti titkára, majd a budapesti pártbizottság osztályvezetője; Nógrádi Sándor 1945-ben iparügyi államtitkár, 1946-tól az MKP KV agitációs és propagandaosztályának vezetője, majd a miniszterelnökség politikai államtitkára; Kállai Gyula 1945-ben szintén miniszterelnökségi államtitkár, majd a tájékoztatásügyi minisztériumi politikai államtitkára, 1949-ben Rajk László utódaként lett külügyminiszter; Kovács István 1946 és 1949 között az MKP szervezési osztályvezetője, a PB póttagja; ilyen értelemben a pártelit tagja, ugyanakkor befolyása alapján mégsem sorolhatjuk az MKP első vonalához. Kádár János a koalíciós években az MKP KV titkára és a Politikai Bizottság tagja volt; 1948-tól Rajk László után belügyminiszter. Halas Lajos a koalíciós évekbeli kommunista „R Gárda” vezető személyisége, majd később a pártőrség tagja, utána a Magyar Néphadseregben szolgált, 1957-ben a Munkásőrség országos parancsnoka.

${ }^{522}$ FöLDES László: A második vonalban. Kossuth Könyvkiadó, Budapest, 1984. 142. p.

${ }^{523}$ Uo. 148. p.

${ }^{524}$ Uo.

${ }^{525}$ Uo. 161-1672. p.

${ }^{526}$ NÓGRÁDI Sándor: Új történet kezdődött. Kossuth Könyvkiadó, Budapest, 1966. 21. p.
} 
mit hozol?"527 Abból is kitűnhet, hogy „demokrácián” - és „szabadságon”, illetve „függetlenségen” is - mást ért, mint a jogállami jellegü demokrácia-felfogást vallók, hogy az 1947-es választásokat úgy ábrázolta, mint amikor a „demokrácia” és a „reakció” erői „,sorsdöntő"528 harcot vívtak - erre az időszakra Nógrádi egy német mondást is idéz: „az egészre ment." ${ }^{\text {529 }}$ A koalíciós időszak végét az MDP megalakulásához köti - mint írja: „,ezzel az aktussal új fejezet kezdődött a magyar történelemben." 530

Kállai Gyula visszaemlékezésében a koalíciós éveket mint a „kibontakozó népi

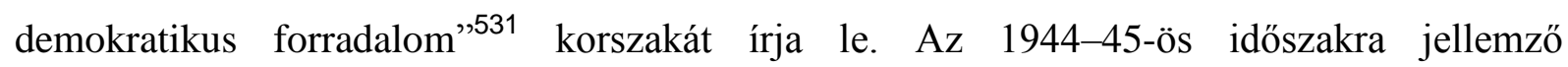
kommunista proletárdiktatúra kontra polgári demokrácia tematika Kállai memoárjában is megjelenik. Arról számol be, hogy 1944 őszén Szegeden is meg kellett küzdeni azzal, hogy a helyi szektás kommunista vezetők rapid módon kívánták volna bevezetni a diktatúrát. „A nézeteknek ebben a kavargásában kellett rendet teremteni. Révainak való feladat volt" ${ }^{\text {"532 }}$ írja Kállai. Révai szegedi érvelése arról szólt - tudjuk meg Kállai önéletírásából -, hogy „ma” a „demokráciáért” kell küzdeni, és aki nem ezt teszi, az „trockista." 533

A demokrácia-narratíva tekintetében is tanulságos az, amikor Kállai Gyula egy Rákosival folytatott 1945-ös beszélgetését idézi fel. Rákosi kifejtette, a népi írók „polgári demokráciát szeretnének, amelynek alappillére a kisbirtokos parasztság." pártvezető úgy vélte, „ez még nem volna baj," ${ }^{, 535}$ de a gond az, hogy a népi írók emellett „munkásellenesek.” ${ }^{, 536}$ Kállai a népi írók védelmében így fogalmazott: ők ugyanakkor „fasisztaellenesek.”537 Rákosi szerint a népi írók a háború elején valóban fasisztaellenesek voltak, de „Sztálingrád után” egyre inkább „,szovjetellenessé”,538 váltak.

Kállai Gyula memoárjának a demokrácia-tematika szempontjából leginkább figyelemreméltó része a Ki a demokrata? címü fejezet. Kállai okfejtése még a nyolcvanas évek első felében írt visszaemlékezésében is arról szól, hogy az igazi demokrata csak az lehet, aki a népi demokrácia híve: értelmezése szerint a népi demokrácia pedig a munkások, a parasztok és az értelmiség demokráciája. „Ám »ha lúd legyen kövér« elve alapján a reakció

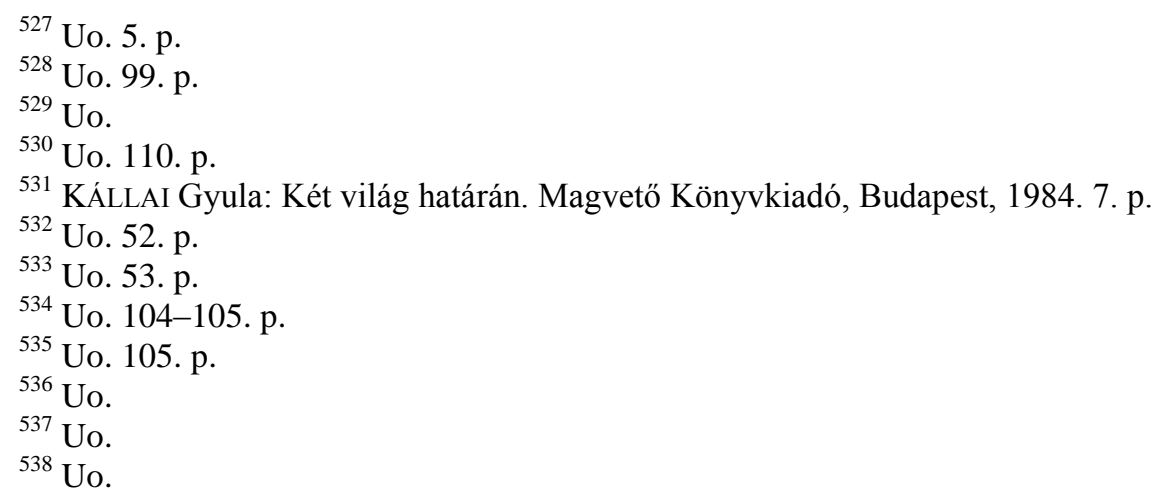


mindenki demokráciájára gondolt. Mindenki élje ki szabadon és minden korlátozás nélkül »demokratikus« hajlamait. [...] Mindenkinek legyen joga demokratának« lenni»539 olvasható a Kállai-visszaemlékezésben a koalíciós évek vitáiból ismert kommunikációs panel, miszerint a „demokrata” a népi demokrácia, vagyis a formálódó proletárdiktatúra mellett áll, és aki a mindenkire érvényes jogokra épülő demokrácia-felfogást vallja, az reakciós.

Halas Lajos a nyolcvanas évek közepén írta meg memoárját, a kötetet 1986-ban adták ki. A visszaemlékezésben a koalíciós időszakot érintő ideáltipikus kommunista demokrácianarratívákat találunk. A kommunista frazeológiával megírt szövegben az olvasható, hogy az úgynevezett összeesküvés a „magyar demokrácia elleni bűntény”540 volt. Természetesen az egykori karhatalmista nem azt érti „büntény” alatt, hogy ezen ügyet használta fel a kommunista hatalmi gépezet a polgári demokrácia következetes lebontására, hanem magukat az „összeesküvőket” tekinti gazembereknek, akik „a reakció boszorkánykonyhájában” lettek kitalálva. „A párt azonban megőrizte higgadtságát, nem adta fel a demokratikus küzdőteret, a választási győzelem lehetőségét, a politikai harcot, a meggyőzés-megnyerés nehéz, de végső soron gyümölcsöző munkáját. Hallottam én is arról, hogy a Kisgazdapárton belül a legszélsőségesebbek a fegyveres megoldás lehetőségét is latolgatták, de a szervezeti formák csak később jöttek létre, és akkor érett meg az idő arra, hogy a törvényes állami keretek között leszámoljunk az összeesküvést szövögetőkkel"541 - írja Halas. Ezen önéletírói szövegéből egyértelműen kitetszik, hogy valóban úgy gondolja, a kommunisták azért tudták elérni a koalíciós években a céljukat, mert „,nem adták fel a demokratikus küzdőteret.” Halas hiszi és vallja, a kommunisták demokratikus körülmények között, demokratikus küzdőtéren szerezték meg a hatalmat.

Még tanulságosabb témánk, a demokrácia-narratívának a koalíciós évekről szóló visszaemlékezésekben való jelenléte szempontjából, mikor az egykori R gárdista egy Magyar Szabadság Párti gyülés általuk, az R Gárda által történt megzavarására emlékszik vissza. Halas egyértelművé teszi: „megszerveztük az akciót."542 Az önéletíró szerint akkor forrósodott fel a hangulat, amikor Sulyok Dezső mint szónok a „demokrácia vívmányait” kezdte „ócsárolni." 543 Ekkor az egyik „hatalmas termetű gárdista” egy széket hajított az elnökség „nyaka közé.” Kirobbant a verekedés, a berendezés „pozdorjává” tört. A négyszáz

\footnotetext{
${ }^{539}$ Uo. 197.

${ }^{540}$ HALAS Lajos: Az R Gárdától a Munkásőrségig. Zrínyi Katonai Kiadó, Budapest, 1986. 93. p.

${ }^{541}$ Uo. 93-94. p.

${ }^{542}$ Uo. 129. p.

${ }^{543}$ Uo. 130. p.
} 
fős „sulyokista” tömeg menekülésre kényszerült. „A lépcső két oldalán is a mieink álltak, s végigpofozták a vert hadat, lábrúgásokkal segítve a lefelé haladást, egészen a földszintig." ${ }^{, 544}$ Halas a történet elmondását követően azon lelkendezik, hogy „ezután a Sulyok-párt nem kísérletezett többé azzal, hogy aktíváit valahol összeverbuválja."

Halas Lajos brutális beszámolója után azt azért hozzáteszi, hogy az „osztályharc éles összecsapásai után nevelkedett nemzedék” most biztosan értetlenül „csóválja a fejét.” A visszaemlékező megkísérli megmagyarázni, hogy miért is volt szükség erre a rendbontásra, mert azt maga is elismeri, hogy „ez egyáltalán nem demokratikus módszer." "546 Saját felvetésére így válaszol: „Én erre azt mondom: a demokrácia ellenségei számára nincs és sohasem lehet demokrácia, mert a történelem megtanított bennünket arra, hogy ők, ha tehetik, visszaélnek a demokrácia adta lehetőségekkel"547 - olvashatjuk 1986-ból a koalíciós években Révai József által kidolgozott demokrácia-értelmezés egyik továbbélő elemét, miszerint a demokratikus jogok a „demokrácia ellenségeinek” nem járnak, vagyis nem léteznek mindenkire egyaránt érvényes szabadságjogok.

Halas önéletírói szövege alapján azt érzékelhetjük, hogy álláspontja, magatartása évtizedek elmúltával sem változott. Memoárkészítői hozzáállásában hiányzik az önreflexió képessége, meg sem próbál szembenézni azzal, hogy az általa folyamatosan „demokráciaként” emlegetett kommunista államstruktúra diktatúrába torkollott - többek között az ő karhatalmista segédletével.

Kádár János 1989-es Kanyó Andrásnak adott életút-interjújában az 1945-öt követő esztendők históriája alig kerül elő. A koalíciós évek demokráciaértelmezéséről szóló narratív elem egyáltalán nem jelenik meg a visszaemlékezésben. Egyetlen olyan szál van, ami témánk szempontjából relevánsnak tekinthető. Láthattuk e fejezetben is és föként a különböző demokrácia-értelmezésekről szóló részben, hogy a kommunista demokrácia-felfogásnak milyen meghatározó eleme a megkonstruált ellenség-fogalom. Erre a jelenségre, az ellenségképre épített politikai stratégiaalkotásra vagy más megközelítésben az ellenség-fogalomra épülő politikai identitás-teremtésre figyelhetünk meg példát Kádár egyik történetéből.:Kádár már belügyminiszter, de nem elégedett Péter Gáborral, az ÁVH főnökével, mert nem lát bele belügyminiszterként az államvédelem munkájába: „Nem engedett betekintést abba, amit csináltak, ő közvetlenül Farkassal, de még inkább Rákosival tartotta a kapcsolatot. Amikor azt

\footnotetext{
${ }^{544}$ Uo.

${ }^{545} \mathrm{Uo}$.

${ }^{546}$ Uo. 131.p.

${ }^{547}$ Uo.
} 
mondtam neki, hogy nekem nagyon nehéz vele dolgoznom, Péter azt felelte, érdekes hogy Rákosi tud vele dolgozni, vele csak az ellenség nem tud együtt dolgozni. "548 Kádárnak ebből az interjúeleméből kibontakozik a csak Rákosinak hüséges Péter Gábor képe, aki egyrészt mindenkiben „ellenséget” lát, másrészt, aki mindenféle támadással szemben a nehezen megfogható, az aktuális érdekviszonyok alapján könnyen átpozícionálható ellenségfogalmat használja a támadás hárítására és egyben ellentámadás indítására. A jelenség mikrotörténetként hasonlatos ahhoz a politikatörténeti helyzethez, amikor a koalíciós évek közéleti küzdelmeiben - így a demokrácia-viták során is - a kommunisták a szélesebb értelmü ellenségfogalommal operáltak.

Kádár János visszaemlékező interjújában a koalíciós évek témája természetszerüleg kevésbé hangsúlyosan jelenik meg a kádári életút későbbi történéseihez képest, ezért nem meglepő, hogy Kádár számára a koalíciós évek demokrácia-értelmezése nem volt releváns kérdés. A még 1982-ben Gyurkó Lászlónak adott életút-interjúban azonban Kádár János arról is beszélt, hogy - s ezáltal Kádár koalíciós évekbeli demokrácia-értelmezésébe is betekintést nyerhetünk - 1948-ban az volt a véleménye, „helyes lett volna a többpártrendszer fenntartása." ${ }^{549}$ A Gyurkó-féle hivatalos Kádár-portrénak tekinthető Arcképvázlat történelmi háttérrel idézi Kádár János egy '48 nyári parlamenti beszédét, amelyben a politikus a következőket mondta: „A mi demokráciánk rendszerével megfér és az ország számára valóban hasznos szolgálatot tehet egy, a demokráciát ténylegesen elfogadó, építő jellegü kritikát gyakorló ellenzék."

Kovács István memoárja a legérdekesebb szöveget jelenti a kommunista vezetők visszaemlékezései közül - föként amiatt, mert Kovács megérte a rendszerváltozást ${ }^{550}$, láthatta a kommunista diktatúra összeomlását és 1989 után a jogállami demokrácia struktúráinak újbóli megjelenését, megismerhette a történettudományi publikációkat a korszak jellegzetességeiről; ugyanakkor világlátása, nézetei, a koalíciós évekre vonatkozó véleménye, a vizsgált korszakot érintő demokrácia-felfogása semmit sem változott a 2005 körül befejezett önéletírásában.

\footnotetext{
${ }^{548}$ KÁDÁR János: Végakarat. Hírlapkiadó Vállalat. Budapest, 1989. Az interjút készítette és a dokumentumokat válogatta: Kanyó András.

${ }^{549}$ GYURKÓ László: Arcképvázlat történelmi háttérrel. Magvető Kiadó, Budapest, 1982. Elektronikusan elérhető: http://dia.jadox.pim.hu/jetspeed/displayXhtml?docId=608\&secId=56564 (A letöltés időpontja: 2017. április 15.)

${ }^{550}$ Kovács István 101 esztendősen 2012-ben hunyt el.
} 
Kovács többször kezdett bele visszaemlékezései megírásába. Már a nyolcvanas években készíthetett feljegyzéseket, majd a '89-es fordulat után abbahagyta a munkát, 1991ben kezdte újra, s tizennégy évvel később fejezte be a visszaemlékezéseket. ${ }^{551}$

A memoárban tetten érhető látásmódja szerint a koalíciós évek a „baloldal” és a „jobboldal” küzdelmének volt a terepe és időszaka. Rekonstruálható, Kovács úgy gondolja, hogy a „baloldal” a demokrácia „továbbfejlesztésére”, a „népi demokratikus rendszer” kialakítására törekedett, míg a ,jobboldali reakciósok” a kommunisták világával szembenálló „nyugati típusú demokráciát” akartak. „A jobboldal egy »harmadik út« politikáját hirdette, a »mérleg nyelvét« akarta megjátszani a koalícióban, »összekötő kapocs« akart lenni és »hidat verni« nyugat és kelet között. Szovjet orientáció helyett, nyugati, főleg angol orientációt, nyugati kölcsönök felvételét, nyugati típusú demokráciát akartak",552 - írja Kovács. Szerinte a Baloldali Blokk egy olyan „politikai erőnek” tekinthető, amely biztosította ,a magyar demokrácia továbbfejlődését." ${ }^{\text {"553 }}$ Ezzel szemben a ,jobboldaliak” demokrácia-ellenesek voltak, s ,idegen érdekeket szolgáltak."554

Kovács a maga metanyelvi világában ír arról, hogy a kommunista hatalomért folytatott harc során létező jelenségnek számított a baloldal részéről - a demokrácia ethoszába nem beleférő - szalámi-taktika mint agresszív nyomásgyakorlásra építő politikai stratégia. Mint írja: „Fokról fokra fokoztuk a nyomást a jobboldalra. Egyik követelésünk teljesítése után újabb követelésekkel álltunk elő. E taktika segítségével lépésről-lépésre zárták ki a jobboldali reakciós képviselőket nemcsak az Országgyülésből, hanem a vidéki képviselőtestületekből is. [...] Lépésről-lépésre fokoztuk a nyomást, széttöredeztük a kisgazdapártban tömörült reakciót, amely így nagyon meggyengült. [...] Megosztottuk az ellenséget, ez volt a szalámi taktika lényege." ${ }^{555}$ Kovács memoárjából kiolvasható, számára a koalíciós években a „nyugati” demokrácia eszménye valamiféle reakciós és szovjet-ellenes kísérlet volt, ami szemben állt a népi demokratikus rendre való törekvéssel. Aki pedig a népi demokrácia ellen tett lépéseket, az „ellenségnek” volt tekinthető. Figyelemre méltó lélektani-tudati jelenség, hogy a '89-es demokrácia hétköznapjai során, 2005-ben, 94 esztendősen is így gondolta mindezt a visszaemlékező.

\footnotetext{
${ }^{551}$ KoVÁCS István: Élet egy eszme szolgálatában. 1911-2011. Visszaemlékezések és dokumentumok. Válogatta, szerkesztette és a bevezetőt írta: MORVA Tamás. Budapest, $2014 . \quad$ Elérhető: http://vilagszabadsag.hu/index.php?f=1935 (A letöltés idöpontja: 2016. január 9.)

552 Uo.

553 Uo.

554 Uo.

555 Uo.
} 


\section{A koalíciós években kommunistaként szerepet vállaló, de később a kommunista diktatúra rendszeréböl kiábrándult közszereplök demokrácia- narratívája}

Hegedüs András 23 évesen kommunista delegáltként tagja volt az Ideiglenes Nemzetgyülésnek, 1945-ben a Magyar Demokratikus Ifjúsági Szövetség vidéki titkára. 1947ben parlamenti képviselőnek választották. A koalíciós időszak végén az MKP KV Mezőgazdasági és Szövetkezeti Osztály vezetője. 1955-56-ban a Minisztertanács elnöke. A Kádár-korszakban visszavonul a politikai szereptől, szociológusként tevékenykedett, a sztálinizmust elvetette, de értelmiségiként marxista alapról bírálta a rendszert, 1973-ban revizionista nézetei miatt kizárták az MSZMP-ből. A hetvenes években már magnóra mondott egy hosszabb visszaemlékezést a MSZMP KB Párttörténeti Intézete számára, majd 1985-ben adott egy hosszabb életútinterjút, ami Bécsben jelent meg, de mindezen visszaemlékező jellegü forrásokat Hegedűs nem tartotta eléggé kiforrottnak, ezért a nyolcvanas évek második felében saját maga kezdte el írni szisztematikusan átgondolt visszaemlékezéseit. A történelem és a hatalom igézetében. Életrajzi elemzések címü kötet még a rendszerváltozás előtt, 1988ban hivatalos formában is megjelent.

Hegedüs András 1946 márciusától egy több hónapos bentlakásos pártiskolai képzésen vett részt. A résztvevők az önéletírás tanúsága alapján a kommunista pártot „,mindenek felettinek" tartották és kvázi messianizmus jellemezte a pártiskolai hallgatóságot.

A visszaemlékezéséből kiderül, hogy akkoriban még markánsan hatott Bibó István nagyszabású tanulmánya ( $A$ magyar demokrácia válsága) és az azt követő vita. Hegedüs úgy emlékszik, hogy ő akkor úgy látta: vagy kommunista vezetés alatt álló „népi demokratikus berendezkedés” jön létre - ami szerinte ,átmenet a proletárdiktatúrába” - vagy polgári demokrácia. Az egykori kommunista politikus önkritikusan elemzi, hogy a korabeli kommunista stratégia szerint „reakciósok azok, akik az így értelmezett népi demokráciát nem fogadják el." $" 556$

A másik út a koalíciós években Hegedüs szerint a „nyugati típusú parlamentarizmus” volt, ahol egyenjogú pártokra szabad választásokon leadott szavazatok aránya dönthetett volna arról, hogy melyik párt milyen arányban vesz részt a hatalomban. Hegedüs úgy véli, mindezen elképzelés azért sem valósulhatott meg, mert a Kommunista Párt a ,partneri

\footnotetext{
556 HEGEDÜs András: A történelem és a hatalom igézetében. Életrajzi elemzések. Kossuth Kiadó, Budapest, 1988. 123. p.
} 
kapcsolatokat fokozatosan csökkentve irányította az egyre szélesebb körben tevékenykedő erőszakszervezeteket." ${ }^{, 557}$

A visszaemlékezésnek a koalíciós évek demokrácia-felfogását érintően az a legérdekesebb narratív eleme, mikor Hegedüs András beszámol arról, hogy a pártiskolán Farkas Mihály, az MKP KV titkára is előadott. „Farkas Mihály a proletariátus ún. erőszakszerveinek fontosságát emelte ki, s a népi demokrácia egyik fő ismérvének azt tekintette, hogy jóllehet az országban a többpártrendszer fönnmaradt, de az erőszakszervek szigorúan a kommunista párt, azaz szerinte a munkásosztály kezébe kerültek. "558 Hegedüs az előbbiekben idézett visszaemlékezés-töredéke - az önéletírás mint forrás által a szerző gondolkodási konstrukciójára vonatkozó támponton túl - a történeti szituáció rekonstruálása tekintetében is mérvadó. A koalíciós évekbeli kommunista demokrácia-felfogás egy újabb fontos elemét tudjuk beazonosítani a Hegedüs-visszaemlékezés segítségével. Farkas álláspontja azt demonstrálja, hogy 1946-ban a kommunisták szerint az úgynevezett népi demokrácia abban különbözött leginkább a polgári demokrácia hagyományos modelljétől, hogy a politikai struktúrák a többpártrendszerü demokrácián alapulnak ugyan, de az erőszakszervekhez viszont a kommunisták nem engednek más politikai erő számára hozzáférést.

A kommunista diktatúra ethoszával szembeforduló Hegedüs alábbi visszaemlékező véleménye is sokat mond a koalíciós évek demokrácia-koncepciójáról: „A felszabadulás óta eltelt egy év bebizonyította, hogy a kommunisták nem mehetnek bele újra szabad választásba, ha meg akarják tartani az erőszakszervezetekben megszerzett abszolút vezető szerepüket, és ha nem akarnak lemondani, mint távolabbi célkitűzésről, a proletárdiktatúráról." 559

Hegedüs arról is ír, ő maga is úgy érezte a koalíciós évek világában, hogy „már csak idő kérdése”, hogy a kommunista párt ,az erőre támaszkodva mikor és hogyan számolja fel a »reakciósok hadállásait« és teremti meg a »népi demokrácia talaján« a Kommunista Párt egyeduralmát." 560

A későbbi miniszterelnök úgy véli, a magyar társadalom 1945 után „megszabadult az úri osztályok elnyomása és politikai manipulációi alól” ${ }^{, 561}$ és ezzel párhuzamosan kezdte kiépíteni és „a maga arculatára formálni” a demokrácia intézményeit. Mindezt - ahogy Hegedüs fogalmaz - ,a kommunista vezetés kvázi népi demokratikus elképzelése ellenére”

\footnotetext{
${ }^{557}$ Uo. 124. p.

${ }^{558}$ Uo. 128. p.

${ }^{559}$ Uo. 124. p.

${ }^{560}$ Uo.

${ }^{561}$ Uo. 135. p.
} 
volt képes megtenni a nemzet. „A koalíciós pártok igazi politikai pártokká váltak, kialakították szervezeti kereteiket, létrehozták saját ifjúsági szervezeteiket és igyekeztek befolyásukat kiterjeszteni a társadalom minél szélesebb rétegeire. Ezt a folyamatot akkor én,

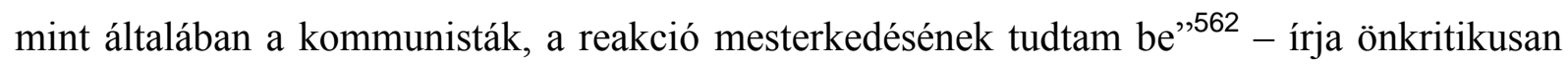
Hegedüs, aki hozzáteszi, az 1947-től bekövetkező fordulat során azonban a társadalom „elvesztette az önálló kezdeményezés lehetőségét, alárendelődött különböző hatalmi apparátusok kontrolljának. S ez akkor is tény marad, ha mi kommunisták hitünk és meggyőződésünk szerint jobb és szebb jövőt akartunk juttatni a nemzetnek." ${ }^{, 563}$ Hegedüs András tehát a jogállami jellegü demokrácia bukását abban látja, hogy a társadalom már nem tudott ellenállni a kommunista kézben lévő erőszakszervi apparátusnak és magatartásnak; nem elemzi viszont azt, hogy mindez a kommunista karhatalmi struktúra csakis a szovjet megszállásra épülve alakulhatott ki és maradhatott fenn. E tematikát Hegedüs a - szovjet megszállást tabu témaként kezelő - Kádár-korszak Magyarországán nem írhatta le, ha a kötetet kiadásra szánta - ne feledjük, a kommunista államhatalmi ethosszal radikálisan szembemenő visszaemlékezés még a rendszerváltozás előtt, 1988-ban jelent meg.

Donáth Ferenc ${ }^{564}$ a koalíciós években a Földművelésügyi Minisztérium kommunista politikai államtitkára, az MKP KV tagja. Az ötvenes éveken koholt vádakkal letartóztatják, 1954-ben szabadult. 1958-ban az '56-os forradalomban való részvétele miatt a Nagy Imre-per másodrendű vádlottjaként 12 év börtönre ítélték. 1960-ban engedték ki. A nyolcvanas években a demokratikus ellenzék megfellebbezhetetlen tekintélye. Nem élte meg a rendszerváltoztatást, 1986-ban hunyt el. ${ }^{565}$

Az 1945 utáni néhány évre vonatkozóan három, a koalíciós évekre visszatekintő, visszaemlékező jellegü írása ismert. A hatvanas évek első felében megírt $A$ közvetlen demokrácia Magyarországon című esszé Donáth hagyatékából került elő. A Közvetlen demokráciáról címü dolgozata, vitairata 1967 decemberéből való. A Bibó István és a magyar demokrácia alapkérdése című tanulmány, amelynek vannak önéletírásszerű elemei is, 1979ben íródott a Bibó-emlékkönyv számára.

\footnotetext{
562 Uo.

563 Uo.

564 IGNÁCZ Károly: Hogyan vált kommunistává egy jómódú vidéki család sarja? Donáth Ferenc indulása. Múltunk, LIX. évf. (2014) 4. 4-11. p.; PAPP István: Donáth Ferenc és a közvetlen demokrácia. Múltunk, LIX. évf. (2014) 4. 23-38. p.

565 „Donáth Ferenc közvetlen demokráciáról vallott nézetei szervesen illeszkednek mind a magyar politikai gondolkodás, mind a kommunista-szocialista eszme világtörténetének hagyományába" - írja Papp István a Donáth közvetlen demokrácia képéről írott tanulmányában. (PAPP István: Donáth Ferenc és a közvetlen demokrácia. Múltunk, LIX. évf. (2014) 4. 23-38. p.)
} 
„1945 tavaszán volt egy nagy népmozgalom Magyarországon, amely a népi szervek határozataiban, állásfoglalásaiban, intézkedéseiben kifejezésre juttatta; a régi rendszer helyébe olyan új rendszert akar, amelyben a nép szervei útján közvetlenül részt vesz a hatalom gyakorlásában” ${ }^{, 56}$ - írja Donáth Ferenc a hatvanas évek elején „A közvetlen demokrácia Magyarországon” című visszaemlékező tanulmányában. Donáth az 1944-45-ös időszak közvetlen demokráciáját tekinti mintának, kissé idealizálja is a nemzeti bizottságok rendszerére épített, általa „közvetlen demokráciának” nevezett államhatalmi struktúrát. Mint írja: „A népi szervek tett[re]készségét, lendületét, forradalmi demokratizmusát az táplálja, hogy a közügyeket a nagy tömegek létükkel vagy jólétükkel a legszorosabban összefüggő, legszemélyesebb ügyüknek érzik."567 Donáth azt elemzi, hogy a nemzeti bizottságok visszaszorulása után, a közvetlen demokrácia visszametszését követően a „demokratikusan gondolkodó néptömegek” elkeseredtek, mert nem valósult meg a „szociális igazság” demokráciája.

Arról már az 1967-es A közvetlen demokráciáról címü dolgozatában ír, hogy számára nem az országgyülési választások jelentik „a mércét” arra vonatkozóan, hogy egy nép demokratikus-e. Donáth ugyanakkor nem tud - '67-ből visszatekintve - azonosulni azzal a koalíciós években közkeletü kommunista állásponttal, hogy csak az lehet igaz demokrata, aki a kommunistákra szavaz: „Ez az egyenlőségtétel baloldali demokratizmus és a Magyar Kommunista Pártra való szavazás között. [...] politikailag veszedelmes dolog, mert zsákutcába visz. Logikailag oda, ahová Rákosi Mátyás jutott, kijelentvén arról az időről, amikor még legfeljebb a lakosság két-három százaléka állhatott a vezetés mögött, hogy: mi magyarok, fasiszta nép vagyunk."

Donáth úgy véli, Rákosiék ezzel az előbb idézett sommás véleménnyel söpörhették le a közvetlen demokrácia eszmeiségét, merthogy úgymond a nép „,nem volt érett rá.” Rákosit és körét, ahogy Donáth fogalmaz ,az MKP vezető magját” teszi felelőssé, hogy 1945 után már nem tudott kibontakozni a közvetlen demokrácia. Az egykori kommunista államtitkár azt fejtegeti, hogy az MKP „vezető magjának” a koncepciójából hiányzott az a szemlélet, hogy a „magyar dolgozóknak cselekvési szabadságot biztosítson kisebb vagy nagyobb közösségi ügyeinek intézésében. Ellene voltak, hogy intézményesen biztosítsák a dolgozók részére a hatalom ellenőrzésének, még inkább a hatalom gyakorlásának demokratikus jogát." ${ }^{569}$

\footnotetext{
566 DONÁTH Ferenc: A Márciusi Fronttól Monorig. Tanulmányok, vázlatok, emlékezések. Válogatta: VALUCH Tibor. MTA Közgazdaságtudományi Intézet - Századvég Kiadó, Budapest, 1992. 149. p.

${ }^{567}$ Uo. 154. p.

${ }^{568}$ Uo. 171. p.

${ }^{569}$ Uo. 178. p.
} 
A Bibó-emlékkönyv számára írt visszaemlékező tanulmányában elemzi - óvatosan ugyan, inkább kérdéseket feltéve - azt a jelenséget, miszerint a koalíción belül „a baloldali pártok pozíciójának” erősítése és a „társadalmi-gazdasági viszonyok radikális átalakítása” érdekében volt szükség a jogállami jellegü demokrácia korlátozására. Donáth 1979-ből visszapillantva is lényegében legitimnek tartja a demokrácia olyanfajta „önvédelmét”, amely magába foglalja - ahogy Donáth írja - „a restaurációs erők rendészeti elnyomását éppen úgy, mint a pártalapítás és a választójog korlátozását." ${ }^{~} 570$ Az egykori kommunista közéleti szereplő úgy véli, a „demokratikus átalakulás kérdése azonban az volt, sikerül-e és milyen mértékben a dolgozók számára szilárd, intézményesített pozíciókat biztosítani a közügyek intézésében." ${ }^{571}$ Donáth szempontrendszerén keresztül a formális demokrácia nem bír társadalmi értékkel, nem elismerően szól a „tiszta demokrácia játékszabályait megtartó parlamentarizmusról”, mert az értelmezése szerint nem a nép uralmát jelenti, hanem pusztán képviseletét. Mindeme intellektuális hozzáállására markáns példa az alábbi idézet tőle: „1945-ben a demokratikus átalakulás mélységét kevéssé tükrözte a pártokra adott szavazatok száma és aránya. A parlamentáris demokrácia magában ezt nem is képes mutatni, mivel a legdemokratikusabb megoldás is csak a képviseleti rendszeren belül marad. Az átalakulás mélységét hívebben fejezi ki, hogy mennyiben sikerült olyan intézményekkel felcserélni a régieket, amelyek nemcsak a feladatok eredményes megoldására alkalmasak, de egyben a demokrácia iskolái is." 572

Donáth 1979-ben is hitet tesz a közvetlen demokrácia eszménye mellett, mikor így fogalmaz: „Igazi demokratikus fordulatot Magyarországon a közügyek intézésének olyan szabályozása hozott volna, amely tekintettel a kedvezőtlen gazdasági és politikai viszonyokra, fokozatosan lehetőséget nyújtott volna, hogy a dolgozók közvetlenül részt vegyenek kis és nagyobb közösségeik - a legnagyobb közösség, a nemzet - fontos ügyeinek intézésében. ${ }^{\text {„573 }}$ Donáthnak a koalíciós évekről szóló visszaemlékező írásaiban megfogalmazott demokráciaértelmezés legfontosabb eleme a közvetlen demokrácia megvalósult jelenségeinek elemzése, illetve az azon való töprengés, hogy milyen lehetett volna az 1945 utáni magyar demokrácia, ha a közvetlen demokrácia ethosza markánsabb szerepet kaphat benne.

„A népi mozgalmak - a földosztó bizottságok, nemzeti bizottságok, üzemi bizottságok - spontán, közvetlen demokráciát képviseltek, s ezért a kormánykoalíció négy pártja (a

\footnotetext{
${ }^{570}$ Uo. 238. p.

${ }^{571}$ Uo.

${ }^{572}$ Uo.

${ }^{573}$ Uo.
} 
Kisgazdapárt, a szociáldemokrata párt, a kommunista párt és a Parasztpárt) egyaránt bizalmatlanul és ellenszenvvel tekintett rájuk, mert valamennyi a befolyását féltette tölük. Ezek a hagyományos, centralizált, régi módon szerveződő pártok egyaránt anarchikusnak és alkotmányellenesnek tekintették ezt a helyzetet, úgy mondták: »a plebs önkényét«, és egyöntetủen meg akarták őket szüntetni. [...] Nem tudom, hogyan müködtek volna később, hogyan épülhettek volna be egy stabil, demokratikus mechanizmusba, egy népképviseleti demokráciába"574 - ez már (a koalíciós évek közvetlen demokráciáját szintén fontos értéknek tekintő) Vásárhelyi Miklós visszaemlékező gondolatmenete, aki a rendszerváltozás hajnalán, 1988-ban adott életútinterjút Federigo Argentierinek. A kötet olaszul 1988-ban, magyarul 1989-ben jelent meg.

Vásárhelyi Miklós a koalíciós években a kommunista napilap, a Szabad Nép vezető újságírója volt. 1954-től a Nagy Imre-kör tagja, az 1956-os forradalom alatt Nagy Imre kormányának sajtófönöke. 1958. június 15-én a Nagy Imre-perben öt év börtönbüntetésre ítélték. 1960-ban szabadult. A demokratikus ellenzék tekintélyes alakjaként megélte a rendszerváltozást. 1990-ben a SZDSZ országgyülési képviselöje lett. 2001-ben hunyt el.

Vásárhelyi az életútinterjúban arról beszél, hogy 1945-46-ban még a bennfentesnek számító kommunista újságírók is azt valószínüsítették, hogy hosszabb távon parlamentáris demokrácia lesz. „45-ben és részben 46-ban a pártnak az volt a stratégiája, hogy hosszú ideig tartó demokratikus küzdelemre kell berendezkednünk, s ennek során kell majd magunkhoz vonzanunk a magyar lakosság többségét. Ezért is szántak olyan fontos szerepet a lapunknak, s ezért töltött Révai egész napokat a szerkesztőségben írással, vezércikkírással és a mi irányításunkkal. Ebben az időszakban azt gondoltuk, hogy a legfontosabb a propaganda, hiszen ezzel nyerhetjük meg az embereket, ennek révén győzhetjük meg őket arról, hogy a nép pártja vagyunk, s hogy tevékenységünk a nemzet javát szolgálja. [...] Túlértékeltük az erőnket. Mi kértük, hogy 1945 novemberére hozzák előre az első választást. Kifogástalan demokratikus választás volt ez, jóllehet korlátozott, mert egyes pártok (a jobboldal) nem indulhattak. Eredménye az lett, hogy a kisgazdák több mint 57\%-ot kaptak, mi pedig csak 17 et”575 - mondja Vásárhelyi, aki szerint a kommunistáknak a formális demokráciához való viszonyukban 1946 végére következett be változás; „ekkor ugyanis a Magyar Kommunista

\footnotetext{
${ }^{574}$ VÁSÁRHELYI Miklós: Ellenzékben. Federigo Argentieri interjúja Vásárhelyi Miklóssal. Szerkesztő: TÓBIÁS Áron. Szabad Tér Kiadó, Budapest, 1989. 34. p.

${ }^{575}$ Uo. 36. p.
} 
Párt arra a meggyőződésre jutott, hogy demokratikus módszerekkel sohasem lesz képes hatalomra jutni, sem olyan baloldali többséget létrehozni, amelyet ellenőrzése alatt tarthat."

Személy szerint Vásárhelyi Miklós számára Kovács Béla 1947. februári elrablása jelentette a demokrácia-fordulatot. Minderre így emlékszik: „Hadd említsek egy döntő mozzanatot: amikor 1947 februárjában Kovács Béla, a Kisgazdapárt fötitkára, vagyis az abszolút többséggel rendelkező párt vezetője ellen összeesküvési vádat emeltek, a Parlament nem volt hajlandó felfüggeszteni Kovács Béla mentelmi jogát, tehát a magyar rendőrség nem tartóztathatta őt le. Erre a szovjetek magukra vállalták a dolgot, kémkedés vádjával letartóztatták, és Oroszországba internálták. [...] A magamfajta felső középkádert tökéletesen váratlanul érte Kovács Béla letartóztatásának híre. Persze rögtön felismertem, hogy ezzel a párt stratégiája megváltozott. [...] Ami ezután következett, az már nem a régi játék, nem a demokratikus pártok koalíciója volt”, ${ }^{, 57}$ - fogalmaz Vásárhelyi, aki szerint az újabb jelentős fordulatot hozó '47-es választás nem az úgynevezett kékcédulák, a kékcédulás csalás miatt nem volt a demokráciának megfelelő voksolás, hanem ,az igazi csalás a demokratikus játékszabályok eltorzításában állt, az erőszakban, a fenyegetésre és zsarolásra épülő gépezetben." 578

Haraszti Sándor a Horthy-korszakban illegális kommunista volt. 1945 és 1948 között a Szabadság címü kommunista napilap szerkesztője, ezt követően az MDP KV Agitációs és Propaganda Osztályának helyettes vezetője. 1950-ben koholt vádakkal letartóztatták és halálra, majd életfogytiglani börtönre ítélték. 1954-ben rehabilitálták, ekkoriban Nagy Imre miniszterelnök köréhez tartozott. 1956. október 31-től a Népszabadság főszerkesztője. November 4-én Nagy Imre csoportjával a jugoszláv követségre menekült, majd 1958-ban hat évi börtönre ítélték. 1960-ban amnesztiát kapott, a későbbiekben lexikonszerkesztőként dolgozott, nem élte meg a rendszerváltozást, 1982-ben hunyt el.

Halála előtt egy évvel a koalíciós éveket is érintő életút-interjút adott Tóth Péter Pálnak. A visszaemlékező beszélgetésben Haraszti felelevenítette, hogy 1945-ben baloldali meggyőződésű emberként radikális változásokban bízott. Sokan a szovjet katonai jelenlétből fakadóan egyből proletárdiktatúrát akartak, de a központi pártutasítás nem erről szólt. Haraszti azt gondolta, a szovjetek ittléte a demokratikus viszonyok közepette is komoly szerepet biztosít a kommunisták számára. „Úgy véltük, hogy a demokratikus játékszabályoknak

\footnotetext{
${ }^{576}$ Uo. 37. p.

${ }^{577}$ Uo. $37-38$. p.

${ }^{578}$ Uo. 46. p.
} 
megfelelően a hatalom egy részét birtokba vehetjük. Arra azonban nem gondoltunk, hogy ez a demokratikus periódus rövid lesz, és hamarosan egypártrendszer jön létre az országban. Haraszti önkritikusan állt az önnön koalíciós évekbeli szerepéhez, felfogásához: hibának nevezve, hogy az 1945 utáni esztendőkben a „tényleg demokratikus csoportokat is az ellenség közé soroltuk akkor, amikor azokkal valójában nem mint ellenségekkel, hanem legfeljebb mint politikai ellenfelekkel kellett volna bánni."

Vas Zoltán 1945-ben Budapest kommunista polgármestere. A koalíciós években - és az ötvenes évek első felében is - Rákosi Mátyás, Gerő Ernő, Farkas Mihály, illetve Révai József mellett tagja volt a Magyar Kommunista Párt úgynevezett ötös fogatának, a szervezet informális vezető stábjának. Vas 1945 és 1949 között a komoly gazdaságirányító hatáskörrel rendelkező - kvázi kormánytestületként is kezelhető - Gazdasági Főtanács fôtitkára. 1954-től Nagy Imre miniszterelnök mellé kerül, ő lesz a minisztertanácsi titkárság vezetője. Az '56-os forradalom idején a közellátási kormánybizottság elnöke. 1956. november 4. után Nagy Imrével együtt menekül a jugoszláv nagykövetségre. A Kádár-korszakban nyugdíjas.

A hetvenes években megírja visszaemlékezéseit. A koalíciós éveket is érintő memoárrész miatt „a Szovjetunió és a magyar nép barátságát sértő izgatás” címén büntetőeljárást indítottak ellene. Visszaemlékezéseinek e kötete csak a rendszerváltozás után, 1990-ben jelenhetett meg.

Viszontagságos életem című emlékirata az 1945 előtti időkről szól, ez a rész 1980-ban jelent meg. Az Akkori önmagunkról címü 1982-ben kiadott visszaemlékezés már érinti vizsgált korszakunkat, a koalíciós éveket. Szintén foglalkozik az 1944 és 1949 közötti időszakkal a memoár harmadik, leginkább szókimondó része. Ezen rész miatt indult ellene eljárás a hetvenes években. E kötet Betiltott könyvem címmel Vas Zoltán halála után hét évvel látott napvilágot.

Vas 1982-ben megjelent visszaemlékezésében a koalíciós évek demokráciaküzdelmeit is - mint a Gazdasági Főtanács főtitkára - közgazdasági szemüvegen keresztül nézte. Vas arról ír, hogy a kisgazdák „Magyarország kapitalista útjának fennmaradásában hittek." ${ }^{581}$ Ezzel szemben a kommunisták viszont a „,szocializmus győzelmét tartották szem

\footnotetext{
${ }^{579}$ HARASZTI Sándor: Befejezetlen számvetés. Magvető Kiadó, Budapest, 1986. 216-217. p.

${ }^{580}$ Uo. 219. p.

${ }^{581}$ VAS Zoltán: Akkori önmagunkról. Önéletírás II. Magvető Kiadó, Budapest, 1982. 173. p.
} 
előtt.” Vas értelmezésében a szocializmus olyan népi demokrácia, amely „betölti a proletárdiktatúra funkcióját., 582

Vas már '82-es visszaemlékezésében is önkritikusan ír Kovács Béla elrablásáról kimondja, hogy „koncepciós rendőrségi" ${ }^{583}$ ügy volt. Hozzáteszi ugyanakkor, erről csak mint „történelmi tanulságról” kíván szólni, mert ő maga is egyetértett azzal, hogy „,rendőrségi eszközöket” vessenek be a kizárólagos kommunista hatalom érdekében, mert ezzel tudták szolgálni régi vágyukat: „megvalósítani az országos hatalom megszerzésével a szocializmust. ${ }^{, 584}$

A Betiltott könyvem címü visszaemlékezésében úgy fogalmaz, hogy az 1946 és 1948 közötti korszakot a „békés átmenet politikája” jellemezte, ekkor még a kommunista stratégia sikeresen tudta alkalmazni a „proletárdiktatúra nélküli" ${ }^{\circ 85}$ irányvonalat. 1949-től viszont „Sztálin új tanításával a proletárdiktatúráról és annak gyakorlatával megerősödött Rákosi, Gerő, Farkas egyeduralma" ${ }^{586}$ - írja Vas.

Noha a Kádár-korszakban Vas memoárjának harmadik részét „,betiltották”, vagyis nem engedték megjelenni, a szöveg stílusát, frazeológiáját, vagy akár demokrácia-értelmezését egyértelmüen a hivatalos kommunista nyelvhasználat jellemzi. Erre példa, amikor arról értekezik, hogy Mindszenty és a „klerikális reakció” a „népi demokratikus rendszer megdöntésére” tört, Vas úgy emlékszik, hogy Mindszenty „demokrácia elleni fellépéseihez felhasználta a templomi szószéket." ${ }^{\text {,587 }}$

Schöpflin Gyula és Háy Gyula a csalódott kommunista értelmiségi visszaemlékezők típusát testesítik meg. 1945-ben mindketten bíztak a kibontakozó új világban, egykori illegális kommunistaként komoly társadalmi változásokban reménykedtek. Mind Schöpflint, mind Háyt elkeserítették a '45-ös választási eredmények, majd a koalíciós években hithü kommunistaként szolgálták a mozgalmat. A proletárdiktatúra hétköznapi valósága azonban mindkettőjüket elidegenítette az eszmétől; Schöpflinnél ez gyorsabban lezajlott, ő már 1950ben emigrált, Háy szemét a Nagy Imre-féle új szakasz nyitotta fel, 1957-ben '56-os

\footnotetext{
${ }^{582}$ Uo. 213. p.

${ }^{583}$ Uo. 241. p.

584 Uo.

${ }^{585}$ VAS Zoltán: Betiltott könyvem. Életem III. Szabad Tér Kiadó, Budapest, 1990. 46. p.

${ }^{586}$ Uo. 48. p.

${ }^{587}$ Uo. 45. p.
} 
szerepvállalása miatt hatévi börtönre ítélték, 1960-ban amnesztiával szabadult, négy év múlva nyugatra távozott. ${ }^{588}$

Háy Gyula 1969-70-ben Svájcban írta meg visszaemlékezéseit. A koalíciós évekről úgy tesz említést, mint „,provizóriumról”, amikor „,több párt létezett, mint a nyugati államokban. ${ }^{, 589}$ A memoáríró úgy véli, a koalíciós évek demokratikus struktúrája illeszkedett a magyar tradíciókhoz, mert Magyarország komoly „parlamentáris hagyományokkal” bírt „még ha felemásokkal is. "590 Háy szerint az 1945 utáni időkben a kommunistákat aligha szerették az emberek, inkább féltek tőlük, de az bizonyos, hogy százezrek sokat vártak a kommunisták törekvéseitől, ezért tudott a kommunista párt tömegeket vonzani.

Az író úgy emlékszik, 1945. november 4-én, az első szabad választásokkor a nap büszkén indult és szomorúan végződött számára mint kommunista meggyőződésű polgár számára. Háy a kommunista vereséget „,megsemmisítőnek”,591 érezte. „Az összes fellegekből pottyantunk le. Ki számolt ilyen hálátlansággal? Lehet, hogy ilyen kevésre becsülnek minket? Nem szeretnek? Nem akarnak?"592 - idézte fel közel negyedszázad elmúltával a '45-ös demokratikus választások eredményeinek a pszichéjére gyakorolt hatását a kommunistából antikommunistává lett író.

Háy szerint Rákosi valójában ellenezte a demokratikus választások megtartását. ${ }^{593} \mathrm{Az}$ író helyzetelemzése arról szól, hogy Rákosi folyamatosan, a koalíciós évek egészében csak a szabad jelzésre várt, hogy a kommunisták átvehessék a hatalmat. „Eleinte jól átgondolt, precízen keresztülvitt választási trükkel, majd egyre brutálisabban alkalmazott nyers erőszakkal lépésről lépésre korlátlan diktátorrá lett." 594 Háy e jellemzésével Rákosi hatalmi

\footnotetext{
${ }^{588}$ Hegedüs Géza irodalomtörténész A magyar irodalom arcképcsarnoka címủ müvében így ír Háy Gyula eszmei pálfordulásairól: „A Rákosi-korszak nem is találhatott volna nála színvonalasabb szószólót, és amikor a történelem szele elfújta ezt a korszakot, Háy Gyula szembefordult az egész szocializmussal. Élettörténete azt látszik bizonyítani, hogy csak a Rákosi-korszak keretei között tudott azonosulni ezzel a világnézettel; ebben az időben minden elismerést, dicsőséget, kitüntetést megkapott. A történelem fintora, hogy később antikommunistaként éppen azokkal szemben vádolta a kommunizmust, akik a Rákosi-korszak áldozatai voltak, mialatt ő magas társadalmi rangokat váltogatva aratta írói sikereit, amelyeknek egy részét valóban meg is érdemelte. [...] Amikor pedig megrendült Rákosi rendszere, Háy azonnal kritikus hangok szószólója, egyelöre a kommunizmus nevében, majd 1956-ban hirtelen mozdulattal átlép a másik táborba. De ha már a másik oldalra került, ott akar fő szószóló lenni, s ezért rövidesen bünhődnie kell. Nemsokára már bíróság előtt áll. Hat évre ítélik. Négy év után kegyelmet kap. A börtönben pedig megint remek íróvá emelkedik. [...] A mérleget valahogy úgy kell megvonnom, hogy néhány drámája a magyar irodalom múlhatatlan klasszikus müve." (HEGEDÜs Géza: A magyar irodalom arcképcsarnoka. Elérhetö: http://mek.oszk.hu/01100/01149/html/index.htm /A letöltés időpontja: 2016. január 16./)

${ }_{589}^{8}$ HÁY Gyula: Született 1900-ban. Emlékezések. Interart Kiadó, Budapest, 1990. 348. p.

${ }^{590}$ Uo.

${ }^{591}$ Uo. 358. p.

${ }^{592}$ Uo.

${ }^{593}$ Uo.

${ }^{594}$ Uo.
} 
karakterológiáját vázolja, de ezen túl az egész koalíciós korszak demokrácia-defenzívájának méltó leírása ez.

Schöpflin Gyula több mint 70 esztendősen írta meg memoárját. A kötet az emigráció viszonyai közepette 1983-ban Párizsban ${ }^{595}$ jelent meg, majd a rendszerváltozás után, 1991ben Magyarországon is napvilágot látott. Az idősödő Schöpflin némi öniróniával szemlélte önéletírói tevékenységét: „Visszaemlékezést fiatalon kell írni. Öregkorában az ember hazudik, de legalábbis megszépíti a messzeséget."

Schöpflin a koalíciós években a Magyar Rádió - kommunista párt által delegált müsorigazgatója. Mint egykori igazgató a memoárban beszámol arról, hogy az 1945 utáni időkben folyamatosak voltak a rádió demokratikus átalakítását érintő viták, megbeszélések. Amint fogalmaz: nem volt „,sétaút”, ${ }^{, 57}$ a „demokrácia megteremtése” a Magyar Rádióban. „Ez idő tájt nem volt könnyü kommunistának lenni a Rádiónál. ${ }^{\text {,598 }}$

Tanulságosak Schöpflinnek a koalíciós évek magyar közvéleményére vonatkozó megállapításai: „a demokrácia fogalmát gyanakodva szagolgatta, tapintgatta, előző élmény híján. ${ }^{, 599}$ E téren eltér Schöpflin véleménye Háy Gyuláétól, hiszen mint arra utaltunk, Háy arról írt, hogy komoly - ugyanakkor persze felemás - parlamentáris hagyományokkal rendelkezett már a koalíciós időszakra az ország. Schöpflin megállapítja: 1945-ben nem létezett Magyarországon „forradalmi hangulat és lelkesedés. „600

Egy töprengéssel, vívódással teli folyamat volt, ahogy a koalíciós években Schöpflin Gyula elkezdett kijózanodni, elkezdett kiábrándulni a kommunista pártból, egyre több dilemma gyötörte. Erről így ad számot: „Az új magyar demokrácia talán nem széles, szilárd országút, hanem ingovány? Ingovány jobbra: a régi jobboldal egyre erösödő hangja ingovány balra: a moszkvai perek, a német-szovjet megegyezés fel-felfortyanó emléke. Ami a kommunizmus orosz fajtáját illette, kevés illúzióm maradt. De azért még mindig úgy éreztem, mi másként fogjuk csinálni, tanulunk az ő hibáikból; évtizedekbe fog telleni, míg a népi demokráciából lassú, szerves fejlődés, meggyőzés és példaadás révén valódi, müvelt, türelmes és szabad kommunizmus lesz, nyugat-európai, magyar kommunizmus." $" 601$

\footnotetext{
595 SCHÖPfLIN Gyula: Szélkiáltó: emlékezések. Irodalmi Újság, Párizs, 1983.

${ }^{596}$ SCHÖPFLIN Gyula: Szélkiáltó (Visszaemlékezés). Magvető Kiadó - Pontus Kiadó, Budapest, 1991. 11. p.

${ }^{597}$ Uo. 182. p.

${ }^{598}$ Uo.

${ }^{599}$ Uo. 197. p.

${ }^{600}$ Uo. 198. p.

${ }^{601}$ Uo. 206. p.
} 
1947 nyarától egyre inkább úgy látta, de még mindig nem mondta ki önmagának sem, hogy ami a magyar közéletben zajlik, az már csak egy „demokratikus látszat."602 Azt is megfogalmazza, hogy a „koalíciós demokrácia” pusztán „taktika”603 és „lényegében mi sem változott 1919 óta."

Élesen különbözik az eddigi életutaktól Farkas Vladimíré. A rettegett államvédelmis nem pusztán a kommunista diktatúrából ábrándul ki; Farkas saját egykori szégyenteljes szerepével számol le memoárjában.

Farkas Vladimír meghasonlott személyiségként tekint vissza az általa már nem vállalt múltba; a visszaemlékező pozíciójából újra kell hogy építse önnön identitását. Farkas visszaemlékezésének címe már önmagában sokat mondó. Az egykori államvédelmi alezredes Nincs mentség címmel publikálta 1990-ben életútinterjúját. A visszaemlékezésben a múltba visszapillantó egykori kommunista karhatalmista - Halas Lajossal ellentétben - a bünbánó ember pozíciójából meséli el élete történéseit.

„Életútja tetemes részére semmiféle forrás nem állt rendelkezésre - csak ő maga. Amit elmondott - egy nyolcvanas évek végére »letisztult«, felépített és megszilárdult konstrukció, amely meglehet, hogy a valóság tégláiból épült, de ő építette"605 - írja a 2002-ben elhunyt Farkas Vladimírröl Kozák Gyula történész.

Farkas Vladimír 1985 és 1988 között, tehát még a rendszerváltozás előtt mondta magnóra életútját. A kézirat megírására 1988-tól kerülhetett sor, a publikáció már a rendszerváltozás után, 1990-ben történhetett meg. Farkas visszaemlékezésével demonstrálni akarta nyílt megtérését.

„Áruló vagyok? Igen, mert elárultam a munkásmozgalom humanista, igazságos és demokratikus hagyományait. Igen, mert a sztálinista-despotista világbirodalom szolgálatában részese voltam annak a mérhetetlen kárnak, amely a magyar nemzetet sújtotta 1945-1956 között" ${ }^{606}$ - fogalmaz Farkas Vladimír visszaemlékező kötete előszavában. Figyelemreméltó, hogy már a ’ 45 utáni esztendőket is „bünös” időszaknak titulálja.

Farkas az 1947-es esztendőt visszaemlékezésében, a „népi demokratikus fejlődés felszámolásának első esztendejeként"607 jellemzi. Az 1945 és 1947 közötti időszakot a

\footnotetext{
${ }^{602}$ Uo. 243. p.

${ }^{603}$ Uo. 206. p.

${ }^{604}$ Uo.

605 KozÁK Gyula: Az identitás nélküli ember. Országos Széchenyi Könyvtár, Budapest, 2006. Elérhető: http://www.rev.hu/portal/page/portal/rev/kiadvanyok/evkonyv03/kozak (A letöltés időpontja: 2015. október 21.) ${ }^{606}$ FARKAS Vladimír: Nincs mentség. Az ÁVH alezredes voltam. Interart Stúdió, Budapest, 1990. 11.p.

${ }^{607}$ Uo. 127. p.
} 
„születőben lévő népi demokráciának” korszakának nevezi. „Évtizedekig magam is vallottam, hogy a hazai torzulások kezdetének időpontja 1949. Amikor a 80-as évek elején hozzákezdtem életutam írásához, még úgy fogalmaztam, hogy az 1949. május 15-i országgyülési választások után már egyetlen tiszta napja sem volt a Rákosi-rendszernek. A múltammal való szembenézés nehéz és gyötrelmes folyamata során azonban be kellett látnom, hogy ez a felfogás alapvetően hamis, hiszen 1946 októbere óta magam is tapasztalhattam, hogy a párt a hatalomért folytatott harcban milyen törvénytelen eszközöket

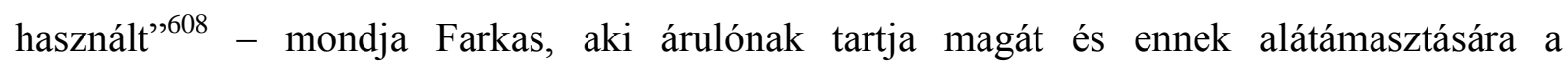
demokrácia témáját is segítségül hívja, mert mint mondja: elárulta a baloldal „demokratikus hagyományait." Szerinte már 1945 után közvetlenül is sok vállalhatatlan történés zajlott, de másfél-két évig mégis megvolt az esély egyfajta demokratikus kísérletre, amit visszaemlékezésében egy olyan időszaknak tekint, amely történelmileg referenciaértékü.

A koalíciós években kommunistaként szerepet vállaló, de később a kommunista diktatúra rendszerében csalódott közszereplők önéletírásaiban megjelenő demokrácia-kép árnyalt; az 1945 utáni évek dimenziójában sem fogadják már el a kommunista megközelítésü demokrácia-értelmezést, kritikusan ítélik meg a koalíciós időkben a kommunistáknak a jogállami demokráciával szembeni lépéseit, utólagosan inkább értékként tekintenek a '45 utáni demokrácia-kísérletre és markáns szempontként kerül elő a háború utáni évek közvetlen demokráciájának tisztelete.

\section{Szociáldemokrata visszaemlékezök demokrácia-értelmezései}

A koalíciós évek közéletében is fontos szerepet játszott a szociáldemokrata Böhm Vilmos. Böhm 1945 után a jogállami értékeket tisztelő, de határozott társadalmi átalakítást felvállaló demokrácia megvalósításában bízott. Böhm Vilmost - az őszirózsás forradalom egykori hadügyminiszterét, a tanácsköztársaság hadügyi népbiztosát - a Szociáldemokrata Párt úgynevezett jobbszárnyához sorolták. Huszonhat éves emigrációból 1945 decemberében tért vissza Magyarországra, s kapcsolódott be a szociáldemokrata mozgalom munkájába, 1946 közepétől 1948 júniusáig Magyarország stockholmi követeként szolgált. Miután az SZDP beolvadt a Magyar Dolgozók Pártjába, Böhm Vilmos ismét emigrációba kényszerült.

${ }^{608}$ Uo. 169. p. 
Második emigrációjában haladéktalanul hozzálátott az 1945 utáni időszakról szóló visszaemlékezése megírásához. A Másodszor emigrációban címü önéletírást 1948-49-ben Stockholmban készítette el. Nem sokkal az írás befejezése után, 1949. október 28-án hunyt el.

Böhm Vilmos emlékirataiban úgy vélekedik, hogy ,,a debreceni kormány programja a minden jelző nélküli demokrácia felépítését tüzte ki célul." ${ }^{, 69}$ A veterán szociáldemokrata politikus szerint az 1945 utáni néhány évben „zökkenőkkel ugyan”, de a demokrácia „nagyjából kifogástalanul” müködött. Böhm arról ír, hogy a sajtószabadság, az egyesülési és gyülekezési szabadság, az általános választójog, a parlamentarizmus, a vallásszabadság és az emberi jogok terén Magyarország „1945/46-ban alig különbözött Európa többi államától.»610 A szociáldemokrata közéleti tényező az 1947 elejétől 1948 nyaráig terjedő időszakot, amit Rákosi a „fordulat évének” nevezett, a „szabadságjogok elkobzásának korszakaként” határozza meg.

Böhm egyik fontos célkitüzése az emlékiratai során, hogy határozottan meg tudja különböztetni a koalíciós évek kommunista és szociáldemokrata demokrácia-felfogását. A kommunisták politikai hadviseléséről, stratégiájáról és stílusáról így ír: „gátlás nélkül igénybe vesznek minden megengedett és meg nem engedett, minden erkölcsös és erkölcstelen, minden demokratikus és antidemokratikus eszközt. Ha kell, eröszakot, terrort, megfélemlítést, korrumpálást és lélekvásárlást űznek. Ezzel szemben a demokrácia s főleg a meggyőződéses szociáldemokraták az akcióképességet nagymértékben befolyásoló gátlásokkal küzdenek. Humanisták, kötelezőnek ismerik el az erkölcsi törvényeket. Lelkileg és a gyakorlatban minden terror, erőszak és megfélemlítést ellen hadakoznak. Ezeket a fegyvereket nem hajlandók igénybe venni. Őszinte demokraták, akik megvetéssel utasítják el a lélekvásárlás, a korrumpálás gondolatát is"611 - olvasható Böhm Vilmos emlékirataiban.

Böhm visszaemlékezésében nem fogadja el a kommunisták által használt demokráciafogalmat. A veterán politikus „demokrácia” alatt egyértelműen a jogállami jellegű polgári demokráciát érti, számára az „őszinte demokrata” az, aki a szabadságjogokra épülő demokrácia eszközrendszerét fogadja el magára kötelezőnek. A demokrácia-fogalmak bábeli zürzavarát érzékeli és maga a „demokrácia” és a „totalitárius népi demokrácia” közé húz határozott fogalmi választóvonalat. A kommunista párt és a szociáldemokraták egyesülését ekképpen értékeli az önéletírásban: „A szociáldemokrata csatavesztés a demokráciáért folyó harc megtorpedózását jelentette. A magyar demokráciára halálos csapást mértek. A

\footnotetext{
${ }^{609}$ BÖHM Vilmos: Másodszor emigrációban... Progresszió Kiadó, Budapest, 1990. 198. p.

${ }^{610} \mathrm{Uo}$

${ }^{611}$ Uo. 200. p.
} 
kommunisták céltudatosan hozzáfogtak a totalitárius népi demokrácia fokozatos előkészítéséhez.",612

Böhmmel ellentétben Marosán György számára a szabadságjogokra épülő demokrácia rendszere nem bírt értékkel; s ez a viszonyulás a visszaemlékezése szövegéből is nyilvánvaló.

Marosán György a koalíciós években nem az első vonalba tartozó személyiségek közé tartozik. 1945 után a Szociáldemokrata Párt vezető titkára volt, később meggyőződéses kommunistává vált, vizsgált korszakunkban a szociáldemokraták balszárnyának képviselője. A koalíciós évekről szóló visszaemlékezései első kiadásban 1972-ben jelentek meg.

1945 őszére, a választási küzdelmekre emlékezik vissza az önéletíró, mikor azon borong, hogy a papok a „demokrácia” és a „baloldal” ellen kampányoltak. „A kommunistákkal együtt földet, jogot, demokráciát, szabadságot adtunk a népnek, a bukott rendszer kisemmizettjeinek, akik ennek ellenére szavazataikat a papokra adják majd"613 - írja Marosán. Felidézi a szerző az 1945 őszi szentgotthárdi gyülését, mikor egy iskolaigazgató azt kérdezte töle: „érvényesülni fog-e a demokrácia?” Marosán György erre azt válaszolta, „demokratikus és szocialista Magyarországot akarunk, ezért folytatjuk harcunkat."614 Az elhangzott kérdések indulatba hozták a szociáldemokrata nemzetgyülési képviselőt, visszaemlékezése tanúsága szerint ezt mondta: „,a grófoktól, a főispánoktól nem féltették az országot, miért féltik most, amikor a politika porondján a szocialisták és a kommunisták jelentek meg, és földet osztottak a nincsteleneknek?"615 A demokrácia narratíva szempontjából azt emelhetjük ki Marosán visszaemlékező szavaiból, miszerint egyszerre akart a memoár alapján 1945-ben „demokratikus” és „szocialista” Magyarországot. Ez annyiban önazonos visszaemlékezői nézőpont, hogy az SZDP hivatalos álláspontja is ez volt '45-ben.

1946 elejéről így ír Marosán: „A politikai élet nagy mozgásba lendült. Telítve vagyunk újabb és újabb jelszavakkal. A demokrácia friss levegője persze pezsdít." ${ }^{~}{ }^{16} \mathrm{E}$ helyütt tehát demokráciaélmény-érzés, egyfajta lelkesedés érződik ki a baloldali politikus szavaiból. Nem sokkal később viszont már másként fogalmaz. Dühíti, hogy abban az időszakban népszerü megszólítássá és egyben a „legdemokratikusabb jelszóvá” vált a „minden magyar testvér” fogalom. „Én a szocializmust tartom mértéknek: ez egyeseket

\footnotetext{
${ }^{612}$ Uo. 179. p.

${ }^{613}$ MAROSÁN György: Az úton végig kell menni. Magvetö Kiadó, Budapest, 1982. 114-115. p.

${ }^{614}$ Uo. 116. p.

${ }^{615}$ Uo. 117. p.

${ }^{616}$ Uo. 149. p.
} 
szétválaszt, másokat összeköt. A demokrácia csak differenciál" ${ }^{\text {617 }}$ - olvashatjuk az emlékiratokban. Szintén a jogállami demokrácia kereteit bírálja, mikor ekképpen fogalmaz: „nem kell olyan demokrácia, amely azt is biztosítja, hogy az antidemokratizmus velünk egyenlő jogokat élvezzen. De az a demokrácia sem kell, amely a koldusnak jogot biztosít ahhoz, hogy a híd alatt aludjon."618

Marosán önéletírásában egyértelmű: a demokrácia ethosza az 1945 utáni években sem volt fontos számára; relativizálja a demokratikus jogokra épülő államberendezkedést. Az külön elemzendő, hogy 1972-ben, a memoár kiadásának évében Marosán a koalíciós évek kapcsán mit ért „,antidemokratizmuson”. Ne feledjük, ekkorra már áldozatként (bebörtönzött közszereplőként), később vezető politikusként (1957-től 1962-ig az MSZMP KB titkáraként, Kádár János helyetteseként), majd a kádári politika bírálata miatt a vezetésből kizárt közéleti tényezőként, megtapasztalhatta a kommunista felfogású demokrácia, a létező szocializmus, a kommunista diktatúra megvalósulását. Mint idéztük, arról ír: neki nem kell olyan demokrácia, mely az „antidemokratizmusnak” is egyenlő jogokat biztosít. Nyilvánvalóan nem a kommunista diktatúra felé tett hatalmi lépéseket minősíti ,antidemokratizmusnak”, hanem a koalíciós évek kommunista stratégiáját szolgáló ellenségkép-kreáló mechanizmus késői utóhatása érhető tetten, mikor minden olyan jelenséget „antidemokratizmusnak” minősít, amely értelmezése szerint hátráltatja - az ő fogalomhasználata szerint - a szocializmus, vagyis a proletárdiktatúra megvalósulását.

Nyers Rezső a koalíciós években szociáldemokrata politikus, 1945-46-ban a kispesti SZDP szervezet titkárhelyettese, a pártegyesítés évében a szociáldemokraták pesti és Pestkörnyéki titkára. A kommunista diktatúra éveiben különböző vezető tisztségeket tölt be, a '89-es fordulat után önmagát ismét szociáldemokratának tekintő politikusként tagja lesz a rendszerváltó országgyülésnek. Nyersnél a szabadságjogokra épülő demokrácia igenlése a koalíciós korszak végére megváltozik, majd idős korára ismét a polgári demokrácia ethoszát felvállaló közéleti szereplő lesz.

Nyers 2003-ban életút-interjút adott Huszár Tibor szociológusnak. A visszaemlékező beszélgetésben fontos szerepet kaptak a koalíciós évek is. Az egykori szociáldemokrata politikus úgy véli, a koalíciós időszakban a „népi demokrácia” fogalmához kapcsolódóan alakult ki az egyik meghatározó „,törésvonal”“19 a különböző politikai szereplők között. Nyers

\footnotetext{
${ }^{617}$ Uo. 150.p.

${ }^{618} \mathrm{Uo}$

${ }^{619}$ HUSZÁR Tibor: Beszélgetések Nyers Rezsővel. Kossuth Könyvkiadó, Budapest, 2004. 54. p.
} 
szerint akkoriban a népi demokrácia ,ironikusan emlegetett kategória volt a szociáldemokrata pártban” és a népi demokrácia tartalma az 1945 utáni években „homályos, lebegtetett”620 volt. „Hát a kommunisták valóban radikális demokráciát akartak. [...] Magam úgy ítélem meg, hogy az első elmozdulás vagy fordulat az 1945 után kialakult status quo-tól az 1947 közepétől 1948 közepéig terjedő időszakban zajlott le"621 - emlékezett Nyers Rezső, aki a népi demokrácia fogalmát így vázolja: „Vállalni a szocialista távlatokat a proletárdiktatúra kinyilvánítása nélkül." ${ }^{622}$ Az ex-szociáldemokrata közéleti szereplő úgy gondolja, 1947 őszéig „népi demokratikus folyamatról van szó, "623 s utána indulnak el a kommunisták „külső hatásra" ${ }^{\text {a }}$ a diktatúra irányába. Nyers arról is beszélt, hogy a szociáldemokraták számára „a demokrácia volt a fundamentum.,

Nyers Rezső ebbéli elemzése valós, ugyanakkor a visszaemlékezői narratíva tekintetében több mint egy egyszerű ténymegállapítás. A szociáldemokraták számára valóban a demokrácia jelentette a törésvonalat, a demokrácia volt a „fundamentum” - s azok számára, akik vállalták a kommunistákkal való társutasságot, éppen ezt a bizonyos alapot kellett feladni. A jelen visszaemlékező is átlépte a Rubicont, hiszen szerepet vállalt a kommunista diktatúrában, s ezáltal a maga életútja tekintetében feladta a demokrácia fundamentumát. 1989 után viszont visszatért a demokrácia 1948 előtti fundamentumához.

\section{Parasztpárti visszaemlékezök demokrácia-narratívái}

Kovács Imre népi író, a Nemzeti Parasztpárt egykori fơtitkára - halála előtt bő egy évvel 1979. február 22-én New Yorkban fejezte be Magyarország megszállása című önéletírását, ${ }^{626}$ mely a német intervenciótól 1947-es emigrációjáig tekinti át a politikus-író életútját. Kovács a kommunista hatalomátvétel mechanizmusáról szóló fejezetben fejti ki, hogy a kommunisták törvénytelenségek sokaságának az elkövetésével teremtették meg a hatalomátvétel alapját. A helyzetet jellemzendő ír arról, hogy a „kisnyilasok” átvétele a kommunista pártba olyan

\footnotetext{
${ }^{620}$ Uo. 55. p.

${ }^{621}$ Uo. 56. p.

${ }^{622}$ Uo. 57. p.

${ }^{623}$ Uo. 58. p.

624 Uo.

${ }^{625}$ Uo. 66. p.

${ }^{626}$ Kovács Imre önéletírói tevékenységéröl: ERDÉsz Ádám: A történelem tanúja - Kovács Imre visszaemlékezéseiröl. In. Kovács Imre centenáriuma. Tudományos emlékülés a Politikatörténeti Intézetben. Napvilág Kiadó, Budapest, 2013. 249-269. p.
} 
szempontból is kihatással volt a kommunista mentalitásra, miszerint a kommunisták „kölcsönvették a nyilas módszereket is, főleg rendőrségi technikájuk tökéletesítésére.”627

Kovács visszaemlékezésében kitér az Erdei Ferenccel, a Nemzeti Parasztpárt kommunistabarát politikusával fennállott kibékíthetetlen ellentétére is. Tiltakozik azon megközelítés ellen, mely szerint Erdei úgymond a Nemzeti Parasztpárt balszárnyát képviselte volna, míg ő a jobbszárnyat. Egyértelműen szögezi le, nem jobbszárnyról volt szó, hanem arról, hogy ő maga és társai a demokratikus gondolkodás híveiként politizáltak: „Mi nem voltunk jobbszárny, mi következetesen demokratikus magatartást tanúsítottunk.",628

Ahogy azzal korábbi fejezetünkben már foglalkoztunk, Kovács Imre már a koalíciós évek időszakában is rávilágított, hogy a kommunisták demokrácia-felfogása szöges ellentétben áll a jogállami-polgári demokrácia világlátásával. Memoárjában is leszögezi: „Mivel a demokrácia fogalmának szabatos meghatározása lehetetlen volt, mást értett alatta a polarizálódott politikai mezőny minden szegmentje: az oroszok és a kommunisták a kérdést könnyedén elintézték azzal, hogy mindenki »fasiszta«, aki orosz- és kommunista-ellenes. És akire rásütötték a bélyeget, hogy fasiszta, akár egyén, akár egyesület, számolnia kellett a következményeivel, a legsúlyosabb következményeivel is."

Kovács a kommunistákkal szemben álló erőket következetesen a „demokratikus politika híveiként" nevezi meg. Demokrácia-értelmezése szempontjából figyelemreméltó az a narratíva, ahogy az 1945. októberi budapesti helyhatósági választásokról ír. A visszaemlékező úgy értelmezi, hogy a budapesti választással a kommunisták „kiestek szerepükből”, mert addig „,szajkózták a demokráciát”, 630 utána viszont „,egyszerre” a párt „,forradalmi” lett. A budapesti választások után nem sokkal - tudjuk meg a memoárból - Kovács összefutott Révai Józseffel, aki azzal magyarázta a baloldal vereségét, hogy a reakciósok úgymond mind a kisgazdákra szavaztak. Erre Kovács visszakérdezett, hogy „ha rátok szavaztak volna, akkor nem lennének reakciósok?”631 Révai így válaszolt: „Persze, hogy nem, [...] ez a dialektika." ${ }^{\text {632 }}$ Mint a korábbi fejezetben és e részben is láthattuk, a kommunista demokráciaértelmezés alapkérdése a „reakcióhoz” való viszonyrendszer, ebből fakadóan ezért is lehet tanulságos Révai magyarázata, miszerint „ez a dialektika”, vagyis végső soron a marxista valóságértelmezés határozhatja meg, hogy ki minősíthető reakciósnak.

\footnotetext{
${ }^{627}$ KOVÁCS Imre: Magyarország megszállása. Katalizátor Iroda, Budapest, 1990. 249. p.

${ }^{628}$ Uo. 254. p.

${ }^{629}$ Uo. 265. p.

${ }^{630}$ Uo. 279. p.

${ }^{631}$ Uo. 279. p.

${ }^{632}$ Uo.
} 
A „demokratikus kísérlet” felszámolására külön fejezetet szentel az önéletíró. Kovács úgy véli, a demokratikus kísérletnek akkor lett volna meg az esélye, ha „,egy Bethlen Gábor-i politika"633 személyi és világpolitikai feltételei adottak lettek volna. Arra emlékeztet a szerző, hogy a demokrácia legyőzéséhez, vagyis a hatalomátvételhez a kommunisták ereje kevés lett volna, ahhoz kellett ,a megszálló Vörös Hadsereg. "634 A memoár egy másik részben írja: „ha nincsenek az oroszok mögöttük”, mármint a kommunisták mögött, akkor „,a demokrácia játékszabályai érvényesülhettek" ${ }^{\text {} 635}$ volna, ami a kommunistákat periférikus helyzetbe sodorta volna.

„Amint a kommunisták realizálták, hogy a hatalmat alkotmányosan nem tudják megszerezni, ők abszolút többséget egy szabad választáson a magyar néptől nem kapnak, rákapcsoltak az erőszakos hatalomátvételre" ${ }^{\text {"636 }}$ - írja visszaemlékezésében Kovács Imre, aki több kortársához hasonlatosan - az úgynevezett összeesküvési válságtól számítja, hogy a polgári demokratikus struktúrával szemben megindult a végzetes támadás. Kovács Imre érzékletesen mutatja be a jelenséget, ami egyszersmind ismét a különböző, egymást kölcsönösen kizáró demokrácia-értelmezések meglétét is illusztrálja: „A kommunisták demokráciaellenes összeesküvésnek minösítették az egészet [mármint az összeesküvés ügyét - M. K.], holott a demokrácia megdöntésére éppen ők indultak rohamra. Szegeden 1944 őszén a függetlenségi frontba (a koalíció kerete) tömörült pártok demokráciára szövetkeztek; a kommunisták ezt a formulát rövidesen dobták, és népi demokráciáról kezdtek beszélni." ${ }^{, 637}$

Kovács Imre visszaemlékezésében írói képességére, eszköztárára alapozva igyekezett összefoglalni, érzékeltetni a koalíciós évek különös demokrácia-vitáját, demokráciarivalizálását, azt a véres közéleti játékot, ami a demokrácia fogalma körül kibontakozott és lezajlott. Az önéletíró így fogalmaz a kommunista pártstratégia kapcsán: „Demokráciát hirdettek, parlamentáris módszereket alkalmaztak, és bolsevizmust teremtettek."638

Kovács Béla 1947. február 25-én bekövetkezett elrablását követően Kovács Imre kilépett a Nemzeti Parasztpártból. „Kovács Béla letartóztatását a magyar szuverenitás olyan súlyos megsértésének tekintettem, mint a németek 1944. március 19-ei bevonulását: többé nem akartam közösséget vállalni a koalícióval, mert a hazaárulás útjára lépett. A demokrácia

\footnotetext{
${ }^{633}$ Uo. 289. p.

${ }^{634}$ Uo. 6. p.

${ }^{635}$ Uo. 310. p.

${ }^{636}$ Uo. 290. p.

${ }^{637}$ Uo. 310. p.

${ }^{638}$ Uo. 312. p.
} 
ellenzéke lettem, azé a demokráciáé, melynek a megteremtéséért annyit küzdöttem”639 _ olvashatjuk az önéletírásban.

Hátborzongatóan érdekes tudati jelenség, hogy a polgári demokrácia elszánt híve egyfajta illusztratív szándékkal ugyan, de nyelvileg mégis - elfogadja a kommunista kommunikáció keretét a demokrácia-fogalom használatát illetően. Minderre láttunk példát Sulyok Dezsőnél is, de Kovács Imrénél még nyíltabban jelenik meg, amikor arról ír, hogy a „demokrácia ellenzéke” lett. Történeti értelemben pontosan láthatjuk: Kovács Imre jogállami demokrácia-védő politikát hirdetett és folytatott 1947 februárja után, s ellenzéki magatartása semmiképpen sem a „demokrácia” rendje ellen irányult, hanem csakis a kommunista hatalmi tárhódítással szemben. Olyan szinten keveredtek azonban a fogalmak a demokrácia kifejezés kontextusában, hogy a szavak emberének számító író, Kovács Imre maga fogalmaz úgy: a demokrácia ellenzéke lett... És ezáltal nyelvileg úgy tünhet, mintha a „demokrácia” rendszerének vált volna az ellenzékévé.

Ez a jelenség is arra mutathat rá: a kommunisták olyan hatékonyan, olyan elemi erővel voltak képesek uralni a kommunikációs tereket a demokrácia-fogalomhasználatot illetően - a koalíciós években és az utólagos valóságmagyarázatok során is - , hogy noha diktatúrára törtek és azt valósítottak meg, mégis a közéleti kommunikációs közegben a „demokrácia” és a „kommunizmus” (a marxista szándékoknak megfelelően) kvázi szinonimává válhatott. S mindeme metanyelvi hatás még utólag, a visszaemlékezői időhorizont tekintetében is érvényesült.

Konklúzióként, végső összefoglalásként Kovács Imre a demokrácia kapcsán metaforát használ, a demokratikus kísérletet a tavaszhoz hasonlítja: „Visszatekintve a merülő időben az 1945-47-es eseményekre, nem tudom másként felfogni, mint egy szép tavaszt az életemben. Robbanó, harsogó, mint a tavasz Kelet-Európában; viharos, kegyetlen, mint a történelem minden tavasza. Egy évszak emberei voltunk, akik akkor megkíséreltük a demokratikus Magyarország megteremtését. Egy évszakot kaptunk csak a sorstól: vetettünk, de nem arattunk, a termést mások takarították be. A nyár kiesett életünkből, a férfikor őszén meg nincs mit várni többé. [...] A magunk táborából nem foghatjuk senkire, hogy bűnös, amiért Magyarország belesodródott a bolsevizálódás tragikus folyamatába. Ha valaki mégis ujjal mutogatna felénk, akkor joggal kérdezhetjük, hogy ő maga miért nem viselkedett bátrabban, miért nem tett többet a csatatereken vagy a politikában, a poszton, ahova foglalkozása vagy hivatása állította a magyar szabadságért, nemzeti függetlenségünkért. Lehullottunk

\footnotetext{
${ }^{639}$ Uo. 314. p.
} 
valamennyien mint nemes, büszke búzaszálak a kasza érintésére. [...] Amit tettünk, férfimunka volt, férfiéveinkkel fizettünk érte!"640 - zárja önéletírását a koalíciós évek meghatározó közéleti személyisége, Kovács Imre, aki egyike volt azoknak a férfiaknak, akik - az ő felfogása szerint - ,a tavasz” embereiként megkísérelték ,a demokratikus Magyarország megteremtését."

A Kovács Imre által memoárjában „naivnak”641 nevezett Veres Péter író, a Nemzeti Parasztpárt elnöke $A z$ ország útján címü önéletrajzi regényként meghatározott visszaemlékezését a Kádár-korszak Magyarországán 1965-ben írta. Veres memoárja főként közvetlenül a második világháború utáni hónapok históriáját igyekszik feldolgozni. A népi író úgy emlékszik, hogy már a háború végén tudta, „,a kommunista párté lesz a főhatalom. "642 Öt ez különösebben nem zavarta, számára a demokrácia-kérdés pusztán úgy vetődött fel, hogy nem akart restaurációt: „semmiképpen nem akartam, hogy úri-polgári restauráció legyen, úgy gondolkodtam: ha a történelem és a forradalom stratégiája most azt parancsolja, hogy legyen koalíció, és abban legyen Nemzeti Parasztpárt is, akkor ennek a pártnak a létfeltételeit biztosítanunk kell’,643 - írja. Veres visszaemlékező szövegéből egyértelműen kitetszik, nyilvánvaló módon rekonstruálható: neki a lényeges kérdés az volt a koalíciós években, hogy a Horthy-rendszert jellemző hatalmi és társadalmi struktúra ne térhessen vissza, mert Veres Péter azzal a berendezkedéssel szemben fogalmazta meg önmagát akár íróként, akár közéleti szereplőként. Ehhez a tematikához képest a demokrácia dilemmája kevésbé foglalkoztatta a parasztpárti vezetőt.

A demokrácia-narratíva Veres memoárjában figyelemreméltó módon a háború utáni hónapok balmazújvárosi hétköznapjain keresztül nyilvánul meg. Az író beszámol arról, hogy egy helyi gyülésre készültek a városháza udvarán. A rendezvényre sokan elmentek, a balmazújvárosiak kíváncsiak voltak, hogy a közülük való, de országos politikai szerepet játszó Veres Péter az új politikai helyzetben mit mond. A politikus arra emlékszik, a beszédében szólt az emberségről és az „,igaz demokratizmusról."644 Veres megjegyzi, óvatosan akart fogalmazni, mert ezek a szavak ,az elvtársainak”, pontosabban a kommunista párt helyi embereinek szóltak, de ki akarta fejezni: „nem élhetünk olyan módszerekkel és

\footnotetext{
${ }^{640}$ Uo. 327.p.

${ }^{641}$ Uo. 311. p.

${ }^{642}$ VERES Péter: Az ország útján. In: VERES Péter: Veres Péter válogatott művei. Szépirodalmi Könyvkiadó, Budapest, 1973. 774. p.

${ }^{643}$ Uo.

${ }^{644}$ Uo. 805. p.
} 
eszközökkel, amilyenekkel a csendőrök éltek." ${ }^{245}$ A balmazújvárosiak keserüen mesélték korábban Veresnek, hogy a kommunista irányítású rendőrség kegyetlenül bánik az emberekkel. „Hát mi ez? Ez lesz a demokrácia? Ilyen lesz a népuralom?”646 - vetették fel a pártvezetőnek. Még a legjobb „régi elvtársai” is elpanaszolták, hogy a városháza pincéjében, ahol egykoron Horthy alatt öt magát is verték a csendőrök, most a kommunista rendőrség kínozza a környékbelieket. „Lám milyen hamar csorbát lehet ejteni egy eszme és rendszer becsületén. [...] Nem engedhetünk utat a demokrácia és a szocializmus nevében sem az egyéni bosszúvágynak, sem a törvénytelen hatalmaskodásnak" ${ }^{\text {647 }}$ - jegyezte meg Veres.

Az önéletíró elismeri, a „pártelnöki ténykedésének” - lényegében a koalíciós évek időszakának - apróbb mozzanataira nem emlékszik, inkább az „akkori életérzést” próbálta visszaidézni a memoárban. Le is szögezi, az 1945 utáni hónapokban, években nem töprengett olyan nagy dilemmákon, mint demokrácia vagy diktatúra: „Gondolkodtam-e én azon akkor, hogy mi lesz ebből a népi demokráciának nevezendő félproletárdiktatúrából? [...] Ebben az értelemben akkor még nem gondolkoztam. Tudtam ugyan, de inkább csak a tudat mélyében őriztem, hogy ebből előbb vagy utóbb szocializmus lesz, és akartam is, hogy az legyen."648

A veres-i önéletírói demokrácia-fogalomhasználat kapcsán arra érdemes rávilágítanunk, hogy nála „a népi demokrácia” és a „félproletárdiktatúra” kvázi szinonimaként jelenik meg. A félproletárdiktatúra mint sajátos fogalom megalkotása Veres Péter közírói teljesítménye, mert ez a fajta fogalomhasználat nem volt elterjedt és azóta sem jellemzi a koalíciós évekröl szóló történeti diskurzust.

Kovács Imre visszaemlékező szövegéből kitünik: a jogállami-polgári demokrácia struktúráját önmagában is értéknek tekinti, míg Veres memoárja alapján látszik: számára a demokrácia-nemdemokrácia dilemma nem volt érdemi társadalmi kérdés - sem a koalíciós években, sem a visszaemlékezései megírása idején.

\section{A demokrácia mint választóvonal Károlyi Mihály és Mindszenty József visszaemlékezésében}

Károlyi Mihály az őszirózsás forradalom vezetőjeként 1918-19-ben, illetve a Horthy-rendszer alatt is a polgári demokratikus átalakulás jelképe, milliók szemében társadalomformáló

\footnotetext{
${ }^{645}$ Uo.

${ }^{646}$ Uo. 806. p.

${ }^{647}$ Uo.

${ }^{648}$ Uo. 848. p.
} 
demokrata. 1945 körül mindez megváltozik. A koalíciós években Károlyi számára a polgári demokrácia nem jelent érdemi viszonyítási pontot.

1945 áprilisában a Czakó Ambróhoz ${ }^{649}$ írt levelében fejtette ki: ,a demokratikus verseny megnyerése attól függ, hogy mennyire tudnak a népi erők a konzervatív erők fölé emelkedni." ${ }^{\text {650 }} 1946$ januárjában a Jászi Oszkárhoz írott levelében a választásokon a konzervatív erők előretörésének tartja a kisgazdák győzelmét és mindezért a túlságosan megengedő választójogi szabályokat hibáztatja: „Csakis a dem. (sic!) elv megsértésén keresztül lehetett volna megakadályozni, hogy a régi erők vissza ne jöjjenek." ${ }^{, 651}$ Ebből a dokumentumból is kiderül: Károlyi nem a demokrácia müködési mechanizmusát félti, hanem attól tart, ha az oroszok kivonulnak Magyarországról, akkor „Magyarország vissza fog esni a régi irányba." ${ }^{652} \mathrm{Az}$ 1946. március 26-án Göndör Ferenchez írt levélben azonban formálisan kiáll a parlamenti demokrácia értékei mellett: „Ha hiszünk a demokráciában, akkor el kell fogadnunk a magyar nép akaratát, mert hiszen semmi kétség, hogy a magyarság szabadon, demokratikusan választott”, ugyanakkor azt is leszögezi: „,a demokratikus forma elfogadása csak egy lépés a demokrácia felé, de nem maga a demokrácia." ${ }^{053}$ A Parragi Györgyhöz intézett 1947. január 21-i levélből kiderül: Károlyi a köztársasági elleni „összeesküvés” kommunista konstrukcióját tényként fogadja el; elítéli az összeesküvőket és az „összeesküvést” demokrácia-ellenesnek tartja. ${ }^{654}$ A Vámbéry Rusztemhez írott 1948. július 7i levélben még indulatosan cáfolja Vámbéry gondolatát, miszerint Magyarország rendőrállam lenne: „ez teljességgel lehetetlen. ${ }^{, 655}$ E dokumentumban ugyanakkor azt is leszögezi, hogy „Magyarország nem egy nyugati, formális, hanem egy új típusú népi demokrácia van kialakulóban." ${ }^{, 656}$

Károlyi Mihály a kommunista párt iránti szimpátiáját nem titkoló politikusként - egy rövid magyarországi jelenlétet követően - a párizsi követi posztot töltötte be 1947 és 1949 között. Károlyi Mihály a koalíciós éveket is érintő Hit, illúziók nélkül címü emlékiratait a követi posztról történő 1949-es lemondása után nem sokkal franciaországi emigrációjában kezdte megírni; e munkát 1954-ben fejezte be Vence-ban. Történelmi pikantéria, hogy a Kádár-korszak hivatalos Magyarországa kiadta ugyan Károlyi memoárját, de csak

\footnotetext{
${ }^{649}$ Czakó Ambró 1918. november és 1919 márciusa között a Vallás- és Közoktatásügyi Minisztérium államtitkára, 1945-ben a kanadai magyar emigráció egyik vezető személyisége.

${ }^{650}$ HAJDÚ Tibor (szerk.): Károlyi Mihály levelezése V. 1945-1949. Napvilág Kiadó, Budapest, 2003. 76-78. p.

${ }^{651}$ Uo. 231. p.

${ }^{652}$ Uo. 233. p.

${ }^{653}$ Uo. 250.

${ }^{654}$ Uo. 312. p.

${ }^{655}$ Uo. 554. p.

${ }^{656}$ Uo.
} 
cenzúrázva. ${ }^{657}$ A visszaemlékezés 1945 utáni évekről szóló részének egyik - a demokrácia narratívát érintő - eleme is a szövegretusálás áldozatául esett. Ebben Károlyi arról ír, hogy Magyarország 1947-ben, 1918 után másodszor is úgymond lekéste „a demokratikus csatlakozást.” A 2013-ban kiadott Károlyi-emlékirat már csonkítatlanul tartalmazza az ominózus részt is: „Magyarország kétszer késte le a demokratikus csatlakozást: először 1918ban az antant hibájából; másodszor 1947-ben az oroszok miatt”"658 - írta az őszirózsás forradalom jelképes személyisége.

A koalíciós évekről szóló fejezet címe a következő: Életünk a népi demokráciában. Károlyi az önéletírásban a kommunisták frazeológiáját vette át, használta. Egy példa: a volt köztársasági elnök utólag is úgy látta, hogy ,a Kisgazdapárt jobbszárnyánál” kerestek „menedéket” az új demokratikus rendszer „ellenségei.”659 Egy másik eset: éppen otthon tartózkodott és a Gellért-szállóban szállt meg, s így szemtanúja volt a szálloda ablakából Mindszenty bíboros - a Gellérthegybe vájt sziklakápolnánál tartott - szentmiséjének. Károlyi úgy vélte, hogy ez az esemény inkább egy ,politikai tüntetés” ${ }^{, 60}$ volt, ahol az új rendszer „ellenségei” vettek részt.

Az utószóban vallja meg, hogy noha nem volt tagja a kommunista pártnak, de „,rokonszenvezett" ${ }^{\text {661 }}$ vele. Károlyi önvallomása szerint a szocializmus ügyének híve volt a koalíciós években (is). A visszaemlékezésben igyekszik ezt annyiban árnyalni, hogy az ő nézőpontjából „Sztálin politikája nem azonos a szocializmussal.”662 A veterán közéleti szereplő arról ír, hogy nem kívánta „firtatni” a Szovjetunióban „mutatkozó hibákat és tévedéseket”, és amellett érvel, hogy mindig „,a nagyobb veszedelem ellen kell küzdeni.” Sem a második világháború idején, sem az azt követő években nem tekintette releváns kérdésnek az ő szavaival élve - a „szocialista demokrácia vagy kommunista terror” dilemmát, mert szerinte „minden haladó európai embereknek” az volt a kötelessége, hogy a szélsőjobboldali térhódítással szembeni küzdelmet szolgálja. Károlyi nézőpontján keresztül akár még az úgynevezett szocialista demokrácia eszmerendszere is csorbát szenvedhet, s úgy véli, a szélsőjobboldallal és a „reakcióval” folytatott harc fontosabb, mint a demokrácia kérdésköre.

Károlyi Mihálynak a koalíciós éveket érintő visszaemlékezéseiben a demokrácia mint narratív elem nem jelenik meg markánsan - az egyetlen kivétel éppen a Kádár-korban cenzúrázott részlet, ami alapján kitünik, Károlyi 1947-re a fordulat éveként tekint; szerinte

\footnotetext{
${ }^{657}$ Kende Péter: A Károlyi-önéletrajz. A megcsonkított üzenet. Irodalmi Újság. 1978. március-április.

${ }^{658}$ KÁROLYI Mihály: Hit, illúziók nélkül. Európa Könyvkiadó, Budapest, 2013. 478. p.

${ }^{659}$ KÁROLYI Mihály: Hit, illúziók nélkül. Európa Könyvkiadó, Budapest, 1982. 365. p.

${ }^{660}$ Uo.

${ }^{661}$ Uo. 395. p.

${ }^{662} \mathrm{Uo}$.
} 
Magyarországon akkortól az „oroszok miatt” már nincs demokrácia. Károlyi ambivalens hozzáállását mutatja az 1945-es esztendőt követő évek demokrácia tematikájához, hogy noha utólag azt gondolta, az ország 1947-ben „lekéste” a demokratikus csatlakozást, de utána még hosszú hónapokig, egészen 1949-ig szolgálta mint diplomata az egyre inkább kommunista befolyás alatt működő magyarországi kormányzatot.

Visszaemlékező szövegében nincsenek olyan részek, amelyben a szabadságjogokra épülő demokrácia ügyét tekintené értéknek. Önéletírása koalíciós évekre vonatkozó része is a szocializmus melletti hitvallásként értelmezhető. Azt is meg kell persze állapítanunk, hogy Károlyi szocializmus-fogalma eltér a sztálinista kánontól, miszerint a szocializmus egyenlő a proletárdiktatúrával. „A szocializmusban láttam és látom ma is, társadalmunk betegségeinek egyedüli gyógymódját. [...] A történelmet sokféleképpen lehet megítélni, a jó és a rossz viszonylagos. Vajon Júdás árulása nem a megváltást tette-e lehetővé a hívők számára?"663 _ tette fel a kérdést Károlyi Mihály 1954 szeptemberében. ${ }^{664}$

Elemeztük azt a jelenséget, hogy a közgondolkodásban demokrata imázssal bíró Károlyi visszaemlékezésében - az 1945-öt követő néhány esztendő vonatkozásában - nem jelenik meg a polgári demokrácia struktúrája mint érték. Mindszenty József történeti megítélésében - a fópapi szerepből is fakadóan - nem mérvadó a demokratikus értékekhez való viszonyulás érzülete. A Mindszenty-memoár szövegében azonban azonosíthatóak a polgári demokrácia értékei melletti kiállást illusztráló nyelvi panelek.

Mindszenty József bíboros 1974-ben, halála előtt egy évvel fejezte be emlékiratainak elkészítését Bécsben. „Azért tanúskodom, hogy a világ újra tudomásul vegye, mit cselekszik a bolsevista rendszer az alája rendelt emberi életekkel és sorsokkal"665 - ezzel a gondolattal indokolta a bíboros memoárjának megírását. Az előbbi idézet azért is fontos, mert

\footnotetext{
${ }^{663}$ Uo. 394. p.

${ }^{664}$ A Károlyi emlékirataiban megjelenő demokrácia-értelmezést egy másik visszaemlékezés, Fejtő Ferenc (1947 és '49 között Károlyi követi müködése alatt a párizsi magyar követség sajtótitkára) életút-interjúja árnyalja. Fejtő úgy véli, Károlyi „még bízott abban, hogy a Szovjetunió betartja a Nyugattal kötött jaltai szerződést, amely biztosítja az új demokratikus országok függetlenségét." (FöLDES Anita: Átéltem egy évszázadot. Utolsó interjúk Fejtő Ferenccel. Scolar Kiadó, Budapest, 2014. 133. p.) Fejtő álláspontja arról szól, Károlyi abban bízott, hogy Magyarország „egyfajta híd lehet” Nyugat és Kelet között, és ezáltal „közvetítődhetnek” elemek a „nyugati szellemü demokráciából,” ezért is vállalta Fejtő szerint Károlyi a párizsi követi tisztséget.

Károlyi Mihály demokrácia-felfogását, koalíciós évekbeli demokrácia-értelmezését illetően szintén támpontot jelenthet Károlyi feleségének a memoárja. Károlyi Mihályné Együtt a számüzetésben címü, 1966-ban befejezett visszaemlékezésében utal arra, hogy férjével sokat töprengtek az őszirózsás „,magyar demokratikus forradalom” kudarcán és gyakran tették fel azt a kérdést is, hogy „elkerülhetetlen-e a diktatúra a burzsoázia féken tartására?” Közös véleményükké vált, hogy elkerülhetetlen a diktatúra, vagyis elfogadták a kommunista diktatúra létjogosultságát. Károlyiné annyit azért megjegyez: „de hát a diktatúra terrort szül és a terror megengedhetetlen.” (KÁROLYI Mihályné: Együtt a számüzetésben. Európa Könyvkiadó, Budapest, 2011. 20-21. p.)

${ }^{665}$ MINDSZENTY József: Emlékirataim. Az Apostoli Szentszék Könyvkiadója, Budapest, 1989. 9. p.
} 
demonstrálja azt a nyelvi kontextust, amelynek részeként a föpap megfogalmazza a jövőből a múltba visszatekintő önéletírását; a memoár textuális stílusa arra mutat, hogy a visszaemlékezést a bíboros a kommunista diktatúrával és a kommunista ideológiával szembeni vádiratszerü szövegként fogalmazta meg. A visszaemlékező legfontosabb célja, hogy a kommunista bünöket bemutassa a világ közvéleményének.

A ,demokrácia” nem érdemi narratív elem a memoárban, de jelen van a szövegben a demokrácia mint eszme, mint a kommunistákkal szembeni világlátási ellenpont. Mindszenty visszaemlékezésének Az Egyház harca a megszállókkal című fejezete szól a koalíciós évek időszakáról.

Az egyházfö önéletírásában mint meghatározó dokumentumot, szó szerint közli a magyar püspöki kar 1945-ös választási körlevelét. A Mindszenty József esztergomi érsek által aláírt dokumentum egyértelmüen hitet tesz a demokrácia ügye mellett: „Az állami élet jövő berendezkedése kétségtelenül csak a demokrácia elvei szerint történhetik. A demokratikus gondolatot már előző pásztorlevelünkben bizalommal üdvözöltük. A zsarnokságtól eleget szenvedett a világ. [...] Az igazi demokrácia alappillére, hogy sértetlen természetjogi elveket ismer el, amelyekhez soha semmiféle emberi hatalomnak erőszakkal nyúlnia nem szabad. [...] Meg kell mondanunk, hogy a magyar közéletben sok, nagyon sok oly jelenséget tapasztalunk, amelyek a tiszta demokrácia elveivel éles ellentétben vannak. Meg kell mondanunk, hogy ez az irányzat újabb veszélyekbe sodorhatja szerencsétlen és súlyosan megpróbált hazánkat"666 _ olvashatóak Mindszenty memoárjában a választási körlevél demokrácia-értelmezést érintő részei.

A bíboros értetlenül állt azzal a ténnyel szemben - és mindez az önéletírásban is tetten érhető -, hogy a kommunista politikusok és a sajtó a katolikus egyháztól, a katolikus iskoláktól féltették ,a demokráciát.” E téma kapcsán is püspökkari körlevelet, az 1946. május 4-i körlevelet idézi Mindszenty: „Nyugodtak lehetnek, az igazi demokratikus szellemmel nem fognak szembekerülni annak az Egyháznak az iskolái és annak az Egyháznak a hitoktatása, amely Egyház az egyszerü népek oktatását és nevelését mindig elsőrendű kötelességének ismerte." ${ }^{\circ 67}$ E részletekből is egyértelmű, hogy Mindszenty a negyvenes évek második felében is és az emlékiratok elkészítésének idején, a hetvenes évek elején is a demokráciát nyilvánvalóan „polgári” demokráciaként képzelte el, ezért sem tudta elfogadni, hogy a kommunisták a maguk államhatalmi elképzeléseit is a „demokrácia” névvel illessék.

\footnotetext{
${ }^{666}$ Uo. 100.p.

${ }^{667}$ Uo. 120. p.
} 
„A Moszkvából hazatért magyar kommunisták tudták, hogy népünk vallási és szellemi színvonala - az ősi magyar tradíció - erős védfalat jelentenek a dialektikus materializmussal szemben. Az anyagelvű ideológiai alapról hallgatva, sőt azt mintegy a tömegek elött rejtegetve, azt hajtogatták, hogy senkire sem akarják rákényszeríteni a marxizmus ateista eszmevilágát. Ezért a demokráciáról, a szabadságról, az emberi jogok védelméről vagy a lelkiismereti és vallásszabadságról tett nyilatkozataik úgy hangzottak, mint ahogyan általában polgári politikusok szoktak szólni azokról. Még vallásos embereket is megtévesztettek annak állandó hangoztatásával, hogy tiszta választásokat akarnak"668 - írja 1974-ben kelt visszaemlékezésében Mindszenty, aki évtizedekkel az a koalíciós évek eseményei után, megélve az ötvenes éveket, majd az '56-os forradalmat - a kisgazda közéleti szereplök visszaemlékezéseiben érzékelt erkölcsi magasabbrendűség nyelvi jellemzőihez hasonlatosan konzekvens karakterként tudott visszanézni a 1974-es ,jelen” pozíciójából az 1945 utáni évekre.

Károlyi Mihály visszaemlékezésében az antifeudális társadalom-átalakító nézőpontnak van prioritása, Mindszenty József memoárjában pedig a katolikus szempontú antikommunizmusnak. Egyik önéletírói szövegben sem kiemelt gondolat a demokrácia eszmeisége. Mindszenty írásában ugyanakkor tetten érhetőek a polgári demokrácia struktúrájának nyelvi paneljei; Károlyinál mindez lényegében hiányzik - csak néminemü keserüséggel említi, hogy Magyarország az oroszok miatt lekéste a demokratikus csatlakozást. A „lekésés” panelt a polgári demokrácia melletti apró kiállásként értelmezhetjük; de az 1918-as polgári demokratikus forradalom történelmi szerepet vitt vezéralakjától többre számíthatna az utókor.

\section{A demokrácia mint narrativa a koalíciós években írott naplókban}

Fejezetünk záró részében az önéletírás egy speciális formájával, a naplóval foglalkozunk. Hat napló segítségével próbáljuk azonosítani a demokrácia narratíva koalíciós évekbeli jelenlétét. Szabó Lőrinc, Illyés Gyula, Márai Sándor, Csécsy Imre, Ortutay Gyula és Grősz József naplóját vizsgáljuk olyan tekintetben, hogy miként jelenik a szövegekben a demokráciafogalom és milyen demokrácia-értelmezések tünnek fel a különböző bejegyzésekben.

${ }^{668}$ Uo. 131. p. 
„A napló fő értéke nem a történeti múltra vonatkozó elsődleges adatok biztosításában, hanem a szubjektív történelem szinte primer dokumentálásában rejlik"669 - írja Gyáni Gábor A napló mint társadalomtörténeti forrás címü tanulmányában. Gyáni szerint a történelem a naplóknak is köszönhetően lesz ,a sokhangúság, a pluralitás történelmévé.”

Kalla Zsuzsa úgy véli, a naplók „a személyiség megalkotásának eszközei és lenyomatai. ${ }^{670}$ Kalla azt fejtegeti, hogy a naplószövegek elemzésekor „,megkerülhetetlen az írás által létrehozott személyiségnek, az énalkotás folyamatának a vizsgálata, a személyes történetek szubjektumképző mechanizmusainak, a hatalmi diskurzusokkal való összefüggésrendszereinek feltárása.",671

A naplóíró nézőpontja azért is értékes, mert a naplót író személy közvetlen „résztvevő”, aki az „ottlét”, a tapasztalás, a hallomás után időben nem sokkal később rögzíti gondolatait, emlékképeit, a történet narratív töredékeit. A naplóíró esetén nincs meg a történelmi távlat vagy egyáltalán a múltba visszatekintés időhorizontja, hanem a ,,jelen” pozíciójából ír az „éppen múltról” - vállalva hogy a jövendő szempontrendszeréből a rögzített szövegbejegyzésekben tetten érhető gondolati panelek hibákat, tévedéseket, pontatlanságokat, kuszaságokat eredményezhetnek, mutathatnak, tárhatnak fel. A napló mint ego-dokumentum az önéletíró dimenziójából kockázatosabb pszichés mechanizmus, hiszen a későbbi potenciális olvasó, elemző könnyebben rekonstruálhatja a történéskori ,jelen” tekintetében létező gondolati struktúrákat.

Szabó Lőrinc költő 1945 áprilisa és szeptembere között írt naplót. Az írás műfaja a napló ugyan, de ez a szöveg jóval több, mint egy hagyományos értelemben vett napló. Ez a forrás inkább egyfajta belső számvetés dokumentuma, ami ugyan nem a nyilvánosságnak szólt, de az alkotó reálisan számolhatott azzal, hogy ez a műve is napvilágra kerül. Szabó Lőrinc naplója nem feltétlenül egy intim szöveg.

\footnotetext{
${ }^{669}$ GYÁNI Gábor: A napló mint társadalomtörténeti forrás. In: Uö: Emlékezés, emlékezet és a történelem elbeszélése. Napvilág, $\quad$ Budapest, 2000. 148-152. p. elérhető: http://www.szabarchiv.hu/drupal/sites/default/files/27-35.pdf (A letöltés időpontja: 2015. október 22.)

${ }^{670}$ KALLA Zsuzsa: „Mivé egykor talán lehetni álmodoztam.” A naplóíró Bártfay László. Doktori disszertáció. Eötvös Loránd Tudományegyetem Bölcsészettudományi Kar, Budapest, 2006. Elérhető: http://doktori.btk.elte.hu/lit/kalla/diss.pdf (A letöltés időpontja: 2015. október 22.) ${ }^{671}$ Uo.
} 
A költővel szemben a második világháború után igazoló eljárást folytattak a hitleri Németországgal szembeni vélelmezett szimpátiája miatt. ${ }^{672} \mathrm{Az}$ eljárás során az irodalmárt igazolták, de mégis „feddést” kapott a korábbi években megfogalmazott gondolataiért.

Horányi Károly irodalomtörténész szerint Szabó Lőrinc meghurcolása mögött a következő tényezők állhattak: „illúziótlansága, a mód, ahogyan a demokratikus intézményrendszereket, a liberális értékrendet, a szocialisztikus reformtörekvéseket szemlélte, és mechanikus társadalomszemlélete lehetett az említett, egyébként baloldali irányultságúnak mondható barátai számára irritáló."673 Szabó Lőrinc monográfusa, Kabdebó Lóránt irodalomtörténész úgy véli, a költő nem írásban, hanem „,baráti együttlétek alkalmával”,674 fejtett ki olyan vélekedéseket, „okoskodásokat”, ${ }^{675}$ amelyek ismerősei számára fájdalmat okozhattak korábban. Ahogy arra Kabdebó Lóránt is utal, 1945 tavaszán, nyarán a szociáldemokrata Népszavában Szabó Lőrincet folyamatos támadások érik, a cikkek szerzői a „demokrácia” nevében határolódtak el Szabótól. ${ }^{676}$

Szabó Lőrinc 1945-ös naplója a megsebzett költő lelkivilágának egyfajta lenyomata. Szabó számára a napló müfaja a mentsvár, hogy gyógyítsa a pszichéjét ért sérelmeket. Ahogy Kabdebó Lóránt fogalmaz: a 45-ös napló „egy ellentmondó lélek drámai dokumentuma.”־77

Noha a támadások arról szólnak, hogy Szabó Lőrinc nem felel meg a „demokrácia” elvárásainak, naplójában nem meghatározó narratíva a demokrácia. Dominánsan azt igyekszik önmagával és a potenciális olvasóval elhitetni, hogy ő nem ,jobboldali "678 - a naplófolyam ugyanis azzal kezdődik, hogy leírja 1919 után mint „,baloldalit” üldözték, 1945-ben pedig a ,jobboldali” billogot sütik rá. ${ }^{679}$

A naplóban nem jellemző, hogy a mindennapi élet történéseiről vagy a családi életről adjon bővebben számot, van azonban egy bejegyzés, ahol egyszerre jelenik meg a demokrácia mint narratíva és a családi viszonyok ábrázolása. A költő beszámol róla, hogy fia, Lóci későn ért haza, több mint másfél órát késett, mert MADISZ-gyülésen volt. Szabó Lőrinc

\footnotetext{
${ }^{672}$ Dolgozatunkban nem törekszünk Szabó Lőrinc igazolási eljárásának rekonstruálására, illetve a vele szembeni vádak vizsgálattára, csak azon tényeket ismertetjük, amelyek szükségesek a Szabó Lörinc-napló demokrácia tematikát érintő részeinek megértéséhez.

${ }^{673}$ HORÁNYI Károly: Vád és emlékezet. Lezáratlan eljárások Szabó Lőrinc ügyében. Kortárs, LIV. évf. (2010) 1. Elérhető: http://epa.oszk.hu/00300/00381/00144/horanyi.htm (A letöltés időpontja: 2016. január 5.)

${ }^{674}$ KABDEBÓ Lóránt: Egy eszmélet története. In: SZABÓ Lörinc: Bírákhoz és barátokhoz (Napló és védőbeszédek 1945-ből). Magvető Kiadó, Budapest, 1990. 253-334. p.

${ }^{675}$ Uo. 262. p.

${ }^{676}$ Uo. 308-314. p.

${ }^{677}$ KABDEBÓ Lóránt: Szabó Lőrinc mühelyében. In: SZABÓ Lőrinc: Napló, levelek, cikkek. Szépirodalmi Könyvkiadó, Budapest, 1974. 5-9. p.

${ }^{678}$ SZABÓ Lörinc: Bírákhoz és barátokhoz (1945). Elhangzott 1945. május 9-én a Magyar Írószövetség igazolóbizottsága elött. In: SzABÓ Lőrinc: Bírákhoz és barátokhoz (Napló és védőbeszédek 1945-ből). Magvető Kiadó, Budapest, 1990. 17. p.

${ }^{679}$ Uo. 7. p.
} 
szomorkodik, a gyermek modora megváltozott az utóbbiakban. Mikor az apa megkérdezi a fiút, hogy mit csinált, Lóci csak annyit mond: „dolgoztam”,680 A naplóíró kérdezi: min? A válasz: „,a demokratikus Magyarország építésén.”681 Szabó Lőrinc a naplójában bosszankodik, hogy a kamasz fiúnak tanulnia kellene inkább. A másik megjegyzése: „építené csak, szerényebben, magát." ${ }^{\text {„62 A }}$ A szövegből kitetszik, a formálódó demokratikus Magyarország által igazolási eljárással vegzált, megalázott költő és fia között közéleti szempontból 1945 áprilisában lelki szakadék tátong; az apa úgy érzi, hogy a „demokráciától” csak egyfajta „belső trombózist”683 kap, míg az 1929-es születésű, 1945-ben 16 éves Lóci szenvedéllyel „építi a demokratikus Magyarországot.”

Szabó Lőrinc életunttá válik - „Meg kell halni. Ilyen világban nem akarok élni." ${ }^{684}$ A költő nem érti, hogy miként lehet az, hogy éppen az új világban hurcolják meg önmagában a gondolataiért, kimondott szavakért. Egyik májusi bejegyzésében nem kimondva ugyan, de kétségbe vonja, hogy demokratikus lenne az őt körülvevő közeg: „No és a szabadság? A gondolatszabadság? Miért mérnek engem alkalmazhatatlan mértékkel?”,685

Már a júniusi blokknál találunk egy különös gondolatfoszlányt, ahol Stendhal korával összevetve ugyan, de arról szól, hogy a „haladás” is lehet „reakció,"686 és ugyanitt azon lamentál, hogy a „,szellemi terror légköre "687 hányféle lehet, milyen módon és különböző helyeken bukkanhat fel. Szintén júniusban leírja, amikre korábban csak utalgatott: „itt ma nincs demokrácia, minek állítjuk, mikor tudjuk, hogy nincs?!”688

Márai Sándornak a koalíciós évekről szóló naplói rendkívül sajátos önéletírási műfajt képviselnek, hiszen első látásra két különböző naplóról, két különböző szövegről van szó. (Márai Sándor: Napló. 1945-1957, Márai Sándor: Ami a naplóból kimaradt. 1945-1946.) Valójában persze az előbb két külön szövegként említett naplótest egy egységes mü. Márainak az emigrációban az 1945 és 1957 közötti időszakról megjelent naplója lényegében csak egy válogatás az egészből. A szerkesztett napló anyagát az önéletíró maga válogatta. Az emigráció szegényes kapacitásai, forrásai csak egy szúkített terjedelmü napló, csak egy töredék megjelenését tették lehetővé. A szerkesztés után kihagyott naplórészt olvashatjuk az

\footnotetext{
${ }^{680}$ Uo. 48. p.

${ }^{681}$ Uo.

${ }^{682} \mathrm{Uo}$

${ }^{683}$ Uo.

${ }^{684}$ Uo. 62. p.

${ }^{685}$ Uo.

${ }^{686}$ Uo. 96. p.

${ }^{687} \mathrm{Uo}$.

${ }^{688}$ Uo. 113. p.
} 
Ami a naplóból kimaradt. 1945-1946. címü kötetben. Szekér Endre, a Márai, a naplórró címü tanulmányában kiszámolta, hogy az első kiadásban megjelent 1945-ös napló 20 húsz oldalával „,szemben ott áll a kimaradt napló 100 oldala,"689 míg az 1946-os rész 14 oldalához 230 oldal „kimaradt” oldal kapcsolódik még.

A „Napló. 1945-1957” kvázi emlékirat jelleggel is bír, hiszen az eredeti naplószöveget Márai szerkeszti, bele nem ír, de kivesz belőle, vagyis megvan a jelen pozíciójából a múltba visszatekintés dimenziója. Terjedelmet is csökkent a válogatással, ahogy az előbb láttuk az oldalszámok változását, illetve igyekszik figyelemmel lenni arra, hogy az emigrációban kiadott naplóban ne maradjanak olyan részek, amelyek bármely ismerőse számára kellemetlenek lennének a nyilvánosság előtt.

Rögzíthetjük, hogy lényegében a „két” szöveg együtt jelenti magát a naplót. ${ }^{690} \mathrm{~A}$ naplóíró Márait érdekli a demokrácia-tematika. Töpreng róla elméleti megközelítésben és reagál a mindennapi történések demokrácia értelmezésére is.

Az emigrációban megjelent naplóváltozatban olvasható az az 1947-es bejegyzés, miszerint előző éjszaka Lenin ${ }^{691}$ egyik tanulmányát olvasta és megállapítja, hogy Magyarországon akkoriban az zajlik, mint amiről Lenin elméleti szempontból ír. Idézi is Lenint: „A demokratikus forradalomból azonnal elkezdjük az átmenetet a szocialista forradalomba. Mi a megszakítás nélküli forradalom mellett vagyunk." Az idézet után megjegyzi: „Ez történik most Magyarországon. "692 Márai tehát látta, érzékelte a polgári demokráciából a kommunista diktatúrába tartó folyamatot. Epésen jegyzi meg: „A hazai szociáldemokraták most levegő után kapkodnak... De miért nem olvasták eddig eléggé figyelmesen a forradalom szakkönyveit?",693

689 SZEKÉR Endre: Márai, a naplóíró. Kalligram, 2000. május. Elérhető: http://www.kalligram.eu/Kalligram/Archivum/2000/IX.-evf.-2000.-majus-100-eve-szueletett-MaraiSandor/Marai-a-naploiro (A letöltés időpontja: 2015. október 22.)

${ }^{690}$ Márai önéletírásairól: SIPOS Balázs: „Az igazi történelmi élmény”.A naplóíró Márai Sándor és az 1945-1948as évek ábrázolásai. Múltunk. 2017/1. 159-186. p.

${ }^{691}$ Lenin A szociáldemokrácia két taktikája a demokratikus forradalomban címü 1905-ben írt művében ír a hatalomátvétel mechanizmusáról. Lenin kifejti, hogy a forradalom befejezéséhez szükséges a diktatúra. (Vlagyimir Iljics LENIN: A szociáldemokrácia két taktikája a demokratikus forradalomban 1905. Szikra Kiadó, Budapest, 1948. 115. p.) Lenin e müvében használja azt a kifejezést, miszerint „az átmenet” a „demokratikus diktatúra” időszaka (Uo. 63.p.)

${ }^{692}$ MÁRAI Sándor: Napló. 1945-1957. Helikon Kiadó, Budapest, 1990. 55. p.

${ }^{693}$ Uo.

Ehhez a gondolathoz köthető: Vas Zoltán kommunista politikus visszaemlékezésében beszámol, hogy Balogh István, Balogh páter miniszterelnökségi államtitkár 1944 végén elmondta neki, ő olvassa a Bolsevik Párt történetét. „Nemcsak ti, én is olvasom a Bolsevik Párt történetét. Itt tartom az íróasztalomon.” (VAS Zoltán: Akkori önmagunkról. Önéletírás II. 154-155. p.; idézi: MIKLós Péter: Balogh István politikai pályája. Doktori értekezés. Szegedi Tudományegyetem, Szeged, 2012.) Balogh páter Révai Józsefnek is felemlítette, hogy ismeri a Bolsevik Párt történetét. „Józsi, én olvastam a Bolsevik Párt rövid történetét, tudom, melyik lap után melyik következik: azt kérem csak, hogy lassabban lapozzatok, és én ezen fogok munkálkodni.” Balogh legendás 
Az Ami a naplóból kimaradt. 1945-1946 szöveg elején - még a 45-ös reménykedőbb időszakban - olvashatjuk Márainak azt a fejtegetését, miszerint „társadalmi nyugalmat” az hozhatna, ha a kommunizmus a demokrácia felé fejlődne és ezzel párhuzamosan a kapitalizmus pedig a szocializmus irányába mozdulna. „S ha ez a két fejlődési folyamat valahol találkozik, ez a találkozás hosszú időre társadalmi nyugalmat adhatna a világnak. Talán ez és ennyi e borzalmas háború értelme" ${ }^{\text {694 }}$ - ír tőle nem is annyira megszokottan meglehetősen optimistán Márai.

Még mindig 45-ös bejegyzés, de már kevésbé optimista tónusú az alábbi demokráciaértelmező rész: „Mi a demokrácia? A lehetőség, hogy párbeszéd közben ezt mondhassam: »I think so, nekem ez és ez a véleményem.« S a másik erre ezt feleli: »I don’t think so, nekem más a véleményem.« S mindenki elmondja a véleményét, s végül, ha ez emberileg lehetséges, megegyeznek az igazságban. Ez a demokrácia legfőbb értelme. De nem demokrácia, ha egy hatalom eltiporja a zsarnokságot, s aztán kijelenti, hogy nincs másféle hatalom, csak az, amelyet hívei képviselnek. Zsarnokságot nem lehet zsarnoksággal gyógyítani.”695 E szövegrész már arra utal, hogy a naplóíró egyre inkább veszélyt érez a kommunista elörenyomulásban és a kommunisták fellépése mögött egy jövendőbeli zsarnokságot, diktatúrát lát kibontakozóban.

Nem sokkal később ír arról, hogy rövidesen eldől: „nyugati demokrácia vagy keleti diktatúra” valósul meg, majd kissé önmagát is nyugtatgatóan leszögezi: „Lehet, hogy egyik sem lesz, a kettő között alakul ki valamilyen társadalmi, politikai helyzet."696

Rendkívül figyelemreméltó és egyedi hangvételü az a bejegyzés, amelyben Márai arról értekezik, hogy a kommunisták „elfogadták ezt a szót: »Demokrácia«."697 Márai szerint a szónak „megnyilatkozásaik szótárában” már polgárjoga van, elfogadták, ismétlik, követelik,

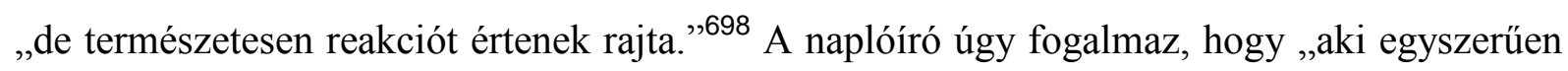

mondatát idézi: UNGVÁRY Krisztián: Magyarország szovjetizálásának kérdései. In: RoMSICS Ignác (szerk.): Mítoszok, legendák, tévhitek a 20. századi magyar történelemröl. Osiris Kiadó, Budapest, 2002. 279-308. p.)

A Szovjetunió Kommunista (Bolsevik) Pártjának története címü könyvből kiolvasható, a kommunisták számára a „forradalmi helyzetben” nem elegendő a „normális alkotmányos élet” biztosítása. (A Szovjetunió Kommunista (Bolsevik) Pártjának története. Szerkesztette: A Szovjet Kommunista (Bolsevik) Párt Központi Bizottságának Komissziója. Jóváhagyta az SZK(b)P KB 1938-ban. Szikra Kiadó, Budapest, 1945. 216. p.) A kötet szerkesztői szerint az ellenséges erők általában a „demokrácia képviselőjének minőségében” tűnnek fel. (Uo. 217. p.) A kommunista hatalomátvétel előtti időkben kettős hatalom alakul ki, amikor két „diktatúra” áll egymással szemben, a formálódó proletárdiktatúra és az alkotmányos megoldások hívének mutatkozó „burzsoá diktatúra.” (Uo. 217. p.) A kötetből egyértelmüen kitünik, ahhoz hogy a kommunista diktatúra megszilárduljon, le kell rombolni a ,polgári államgépezetet s helyébe létrehozni a szovjetállam új apparátusát.” (Uo. 258. p.)

${ }^{694}$ MÁRAI Sándor: Ami a naplóból kimaradt 1945-1946. Vörösváry Publishing, Toronto, 1991. 27. p.

${ }^{695}$ Uo. 65. p.

${ }^{696}$ Uo. 71.p.

${ }^{697}$ Uo. 73. p.

${ }^{698}$ Uo. 
demokrata, az valószínüen reakciós, mert különben nem demokrata lenne, hanem kommunista: így gondolják." ${ }^{\text {,99 }}$ Márai úgy véli, a kommunisták pusztán taktikáznak a demokrácia kifejezéssel, de „a szavakat nem lehet büntetlenül elfogadni.” Az író a demokrácia fogalom birtoklásáért folytatott küzdelem kapcsán is bízik a szavak erejében: „A szavaknak visszaható erejük van; aki egyszer elismerő hangnemben kimondott egy szót, kénytelen számolni vele, akkor is, ha titokban tagadja értelmét és jogosultságát. Aki a demokrácia fogalmával »taktikázni« kezd, egy napon észreveszi, hogy kötelezettséget vállalt., 700

Márai Sándor e sorainál érzékletesebben, eredetibben talán senki sem fogalmazta meg a kommunista demokrácia-értelmezés kétarcúságát, ezért is különös, hogy Márai e részt nem válogatta be az emigrációban kiadott naplójába.

Márai a „Föld, föld!...” című, a koalíciós évekről szóló visszaemlékezésében is jelen a demokrácia fogalma mint narratíva. Az író azt fejtegeti, hogy 1945 után sokan hittek abban, hogy a Szovjetunió a ,határállamokban” megtűr valamiféle „rózsaszín” demokráciát. ${ }^{701} \mathrm{~A}$ rózsaszín demokrácia kifejezése később is előkerül Márainál; 1947 februárja kapcsán, az összeesküvési ügy vonatkozásában ír arról, hogy sokan elkezdtek felébredni a rózsaszín demokrácia „képzelgéséből.”702 Az 1947-es esztendő tekintetében már a „rendőrállam” kifejezés is szerepel Mária emlékiratában. 1948-ról szólóan pedig egyértelműen leszögezi: „a kommunisták sutba dobták a demokratikus komédia játékszabályait, és leplezetlen brutalitással átvették a hatalmat." 703

Illyés Gyula a koalíciós években és azt követően is úgynevezett „,naplófeljegyzéseket” készített. E müfaj magában foglalja a hagyományos napló müfaji sajátosságait, ezen kívül a rendkívül terjedelmes naplófolyam része minden olyan szövegtervezet is, amin Illyés éppen dolgozik, legyen az tanulmány, cikk, esszé vagy akár egy regény alapvetése. Illyés naplófeljegyzése egyfajta virtuális - papír lapokon létező - „írói műhelynek” tekinthető. A naplófolyamba minden jövendőbeli mủve alapvetését, gondolati töredékeit feljegyzi. ${ }^{704}$

„Egy nemzet lelki alkata nem változik egyik évtizedről a másikra. A liberalizmus kora elmúlt, anélkül hogy liberálisok lettünk volna. Ma épp így vagyunk a demokráciával. Azzal a

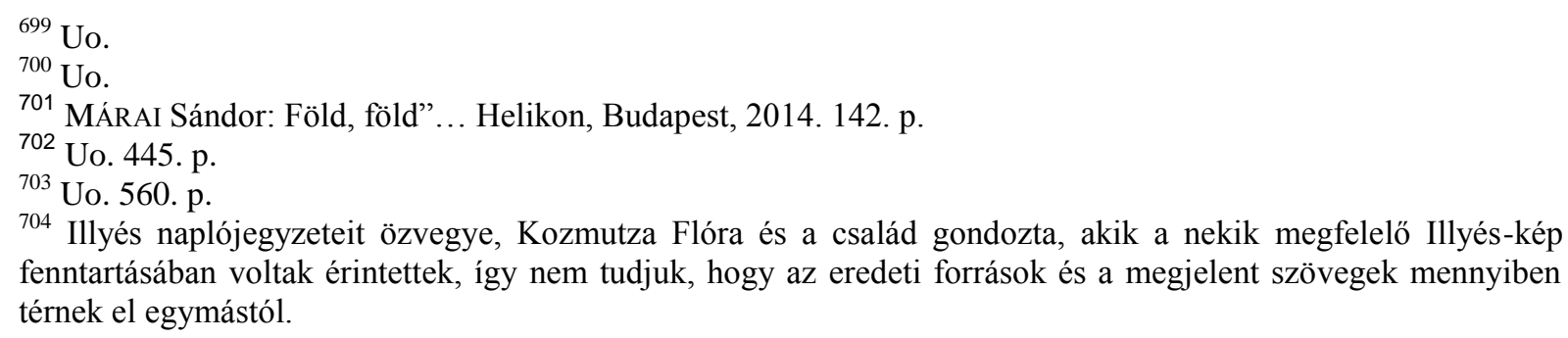
fenntartásában voltak érintettek, így nem tudjuk, hogy az eredeti források és a megjelent szövegek mennyiben térnek el egymástól. 
különbséggel, hogy »ebben a szent hazugságban« nem hisznek annyian”705 - olvasható Illyés naplófolyamának 1946. február 3-i bejegyzésében. A Válasz 1947/1 lapszámának írott cikktervezet is szerepel a naplóban. E részben írja Illyés: „a mi demokráciánk is vagy magyar lesz, vagy semmilyen sem. Elérkeztünk oda, hogy a szavak helyett cselekvéseivel és alkotásaival mérjük hozzá az embert.",706

1947. február 10-én egy hagyományos napló műfajára jellemző bejegyzés található: „Este Rózsiéknál: a magyar demokrácia nehézségeiről."707 Többet nem tudunk meg a beszélgetésről, csak hogy a demokrácia nehézségeit taglalták. A bejegyzés időpontja 1947. február 10., vagyis ekkor már a magyar közélet jócskán kezdett belesüppedni az összeesküvési ügy válsághelyzetébe. Azt feltételezhetjük, hogy az összeesküvési ügy összefüggéseit és a kommunista párttaktika hatását vizsgálhatták a veszélyeztetett magyar demokrácia nézőpontjából, de ez természetesen csak a bejegyzés időpontjából fakadó következtetés. Három nappal később megint előjött a téma: február 13-nál találjuk e sorokat: „Ebéd Aurélnál. A cseh és a magyar demokrácia jövőjéről.”708 Tehát 1947 februárjában Illyést foglalkoztatta a demokrácia kérdése. Sem korábban, sem ezt követően nem találunk ilyen jellegü utalásokat, e napokban viszont igen. A cseh és a magyar demokrácia együttes emlegetése arra utalhat, hogy 1947-ben a kelet-közép-európai régióban már csak a „cseh” és a „magyar” demokrácia müködött mint jogállami jellegü demokratikus állami struktúra. Azt is feltételezhetjük, hogy az ebédtársaság azt vitathatta meg, hogy meddig tudja magát még tartani e két ország a szabadságjogokat értéknek tekintő demokrácia szempontjából, ugyanakkor az is lehet, hogy mivel Illyés 1947 februárjában hosszabb ideig Franciaországban tartózkodott, így a cseh és a magyar demokrácia kifejezés az ottani beszélgetésekben a két ország szinonimája.

Ortutay Gyula, a koalíciós években a kisgazdapárti úgynevezett „balszárny” vezeto személyisége. 1945-47-ben a Magyar Központi Híradó Rt. (Rádió, MTI, Filmhíradó) elnöke. 1947-től három éven át vallás- és közoktatásügyi miniszter. 1978-ban hunyt el, a koalíciós korszakot is érintő naplója 2009-ben látott napvilágot.

\footnotetext{
705 ILLYÉS Gyula: Naplójegyzetek 1946-1960. Digitális Irodalmi Akadémia - Petőfi Irodalmi Múzeum, Budapest, 2011. 23. p.

${ }^{706}$ Uo. 164. p.

${ }^{707}$ Uo. 184. p.

${ }^{708}$ Uo. 185. p.
} 
Ortutay 1938-ban megkezdett naplóját a koalíciós években alig vezeti. A háború után az első bejegyezése 1945. március 26-án kelt: „Nincs kedvem írni”709 - írja, majd hozzáteszi, hogy egyfolytában tárgyal az MTI és a Magyar Rádió ügyeiben. Ugyanakkor azt is megvallja e napon, hogy „ez a néhány sor jelenti valójában, hogy ismét elkezdtem élni.”710 Az 1946. március 4-i bejegyzés arról tudósít, hogy Ortutay ki akarna lépni a politikából és a szíve szerint a néprajzzal kívánna foglalkozni, de erre nincs lehetőség - mint írja: „Viszont a politikai s vállalati helyzet nem enged el most, ami nem ostoba nagyképüség, csupán annak a bizonysága, hogy az úgynevezett demokratikus garnitúra milyen kicsi. Annyira kicsi, hogy engem már a legkomolyabban tervbe vettek külügyminiszternek is, megállapítva, hogy nálam jobb, demokratikusan megbízhatóbb a pártban nincs! (Persze ez munkáspárti megállapítás)."711 Ortutay - kissé önironikus módon - az úgynevezett demokratikus garnitúrát „kicsinek” tartja, ezért is gondolja úgy, hogy maradnia kell a közéleti küzdőtéren. Azt is megtudjuk, hogy „munkáspárti megállapítás” szerint Ortutaynál „demokratikusan megbízhatóbb" politikus nincs a kisgazdák között és ezért is merülhetett fel mint lehetséges külügyminiszter. Ortutay Gyula az FKgP-n belül a kommunista szimpatizánsok közé sorolható. A „demokratikusan megbízhatóbb" szóhasználat arra utal, hogy Ortutay a kommunistákkal való együttmüködés híve, másképpen megfogalmazva olyan közéleti szereplő, aki nem gördít akadályt a kommunista hatalmi politika, majdan a kibontakozó kommunista diktatúra elé.

Az Ortutay mint „demokratikusan megbízhatóbb” személy nyelvi kontextusa ismét azt a paradoxont mutatja meg, ami a demokrácia-értelmezések között a koalíciós évek egészében kibontakozik: a kommunisták demokrácia fogalma szerint, az a „demokratikus”, aki a nyilvánosságnak szánt panel szerint a „népi demokrácia”; belső szóhasználat alapján a proletárdiktatúra előmozdítása érdekében tett kommunista lépéseket elősegíti vagy minimum nem akadályozza.

Mindezen túlmenően Ortutay számára nem narratív elem a „demokrácia” - nem ennek a tematikus keretnek a részeként meséli el a közéleti történéseket, inkább a szocializmus kifejezés számára a meghatározó vonatkoztatási pont.

1946. szeptember 27-én beszámol róla, hogy részt vesz, vendég lesz az MKP III. kongresszusán. A szocializmusról mint „lebírhatatlan jövőről”712 ír. Ezt követően két évig nem jegyez le semmit. Az újabb bejegyzés 1948. november 21-i. Ortutay ekkor már miniszter.

\footnotetext{
${ }^{709}$ ORTUTAY Gyula: Napló I. 1938-1954. Alexandra Kiadó, Budapest, 2009. 366. p.

${ }^{710}$ Uo. 367. p.

${ }^{711}$ Uo. 370. p.

${ }^{712}$ Uo. 372. p.
} 
„Épülünk a szocializmusba” - olvashatjuk e résznél. '48 novemberében a demokratikus jogállamból már alig maradt valami, a kommunista diktatúra államhatalmi struktúrája készen volt. Ekkor, ezen bejegyzés részeként annyit ír még Ortutay naplójába, hogy megszerette a politikát. $^{713}$

Csécsy Imre a koalíciós évek egyik legellentmondásosabb közéleti szereplője. Polgári radikális politikai meggyőződését, demokrácia-felfogását igyekezett képviselni az 1945 utáni magyar közéleti küzdőtéren. A Magyar Radikális Párt alapítója, 1945 és 1949 között a párt parlamenti képviselője. „Csécsy olyan demokrata volt, aki legnagyobb ellenségének a hatalmi barbarizmust tartotta. A bal- és jobboldali etatizmus egyidejü elutasításával a demokratizálás egyik központi kérdésének a hatalom humanizálását, a hatalmi rendszerek toleránsabbá tételét

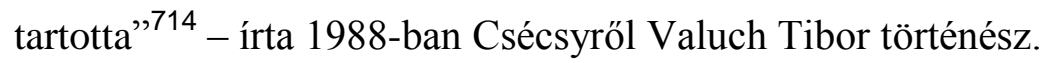

Litván György személyesen ismerte Csécsyt, akiről így emlékezett: „Csécsy külsejében és életstílusában is a szellem embere volt. Sovány testalkata, hajlott háta, bozontos szemöldöke, visszavonult életmódja egyaránt ezt húzta alá. Kicsit hasonlított Bibó Istvánra, bár kevésbé szelíd és türelmes kiadásban."715 Ahogy Litván György is fogalmaz: Csécsy polgári demokratikus világlátása ellenére „túlzott türelemmel”716 viseltetett a koalíciós években a kommunisták diktatórikus törekvéseivel szemben. Ez a jelenség teszi rendkívül ellentmondásossá Csécsy 1945 utáni tevékenységét: a jogállami értékeket elfogadó demokrata volt, aki azonban érdemben nem állt ellen a kibontakozó proletárdiktatúrának.

Ez a kettősség a korszakban írt naplójában is tetten érhető. Csécsy 1940-től 1949-ig vezetett naplót. 1944 előtt a bejegyzések gyakoribbak, 1945-től inkább összefoglaló jellegü leírások találhatóak a dokumentumban. A Csécsy-naplót még a Kádár-korszakban a Kritika közölte 1983 augusztusában. ${ }^{717}$

A koalíciós évekről szóló rész első demokrácia-narratívát érintő bejegyzése 1946. június 3-án található. Csécsy Imre beszámol a Károlyi Mihállyal folytatott beszélgetéséről. Csécsy arról szólt Károlyinak, hogy szerinte a magyar demokráciának két baja van. Erre válaszolta azt Károlyi: „csak két hibája van?”718 Csécsy úgy gondolta, a két probléma a következő: az egyik az, hogy az új államapparátus dilettáns, a másik pedig, hogy merev

\footnotetext{
${ }^{713}$ Uo. 374. p.

${ }^{714}$ VALUCH Tibor (szerk.): Radikalizmus és demokrácia. Csécsy Imre válogatott írása. JATE, Szeged, 1988. 15. $\mathrm{p}_{715}$

${ }^{15}$ LITVÁN György: A magyar polgárság citoyen lelkiismerete. Csécsy Imre (1893-1961). Holmi, XIII. évf. (2001) 6. 736-740. p.

${ }^{716}$ Uo.

${ }^{717}$ CSÉCSY Imre: Napló. 1940-1949. (Részletek) Kritika, XIII. évf. (1983) 8. 13-27. p.

${ }^{718}$ Uo. 24. p.
} 
pártrendszer alakult ki. E helyütt Csécsy még kifejti, Károlyi „komoly értéke” ${ }^{\text {"719 }}$ lenne a demokráciának.

1947 őszén azon töpreng, hogy az emigrációba kényszerített Nagy Ferenc és Pfeiffer Zoltán „kevésbé antidemokraták, mint a hivatalos propaganda hirdeti. ${ }^{\text {720 }}$ Ekkorra már egyre több az enyhe - naplója számára megvallott - kétely Csécsy Imrében. Még a naplóban is óvatosan fogalmaz, de a soraiból kitetszik, hogy már nem tekinti „az igazi demokrácia élcsapatának”721 a kommunista pártot. „De a kommunisták mind határozottabban hirdetik, hogy nem lehet igazi demokrata az, aki nem kommunista. Minthogy pedig az országnak legalább 80\%-a csakugyan nem kommunista, épp az ő aktivitásuk folytán erősödik a reakció. Mit csináljon ez a $80 \%$ ? Kénytelen antidemokratává lenni. Egy része szívből is az, de nagy része hajlanék a demokráciára, ha nem zárnák ki belőle őket épp a kommunisták. Az a magamfajta pár intellektuel, aki mégis kitart a demokrácia mellett, mindinkább elszigetelődik és jelentéktelenné válik",722 - olvashatóak a kijózanodásra utaló sorok.

1948 szeptemberében arról ír, mint házmegbízottnak részt kellett vennie egy úgynevezett házmegbízotti képzésen, ahol az oktató végigpillantott a népi demokrácia egész történetén 1945 után, s megállapította: a kommunistákon kívül mindegyik párt reakciós volt. Az akkor még országgyülési képviselői megbízatással rendelkező Csécsy Imre nem mer szólni, tart attól, hogy akár egy ilyen nem túl fajsúlyos helyen elmondott ellenvetés miatt is kizárhatnák a parlamentből, így inkább mint nem kommunista párti, MRP-s honatya hallgat a házmegbízotti-iskola oktatásán. „Hát igen, a véleménynyilvánítás szabad, de nem kellett volna több, mint hogy csakugyan kiszaladjon a számon az igazság"723 - jegyzi fel meghasonlottan a szabadságjogokra épülő demokrácia elméleti híveként Csécsy '48 őszén.

1949 februárjában megállapítja, már diktatúra van, a proletariátus diktatúrája. Emberi gyengeségre utal, hogy a kialakult helyzet, a proletárdiktatúra megvalósulása és őszinte demokrata mivolta ellenére mégis elvállalná a '49-es népfrontos választásokon a képviselőjelöltséget. A naplóban a jelölés hercehurcáiról sokat olvashatunk. Az egyik utolsó bejegyzésében arról értesülünk, Rákosiék végül nem jelölték képviselönek Csécsyt. 1949-ben a radikális demokrata Csécsy Imre még fügefalevélnek sem kellett a kibontakozó kommunista diktatúra számára. A publikált napló legutolsó - kissé önfelmentő - gondolata így hangzik:

\footnotetext{
${ }^{719}$ Uo. 25. p.

${ }^{720}$ Uo.

${ }^{721} \mathrm{Uo}$

722 Uo.

${ }^{723}$ Uo.
} 
„A történelem végül nekem fog igazat adni, akár megérem, akár nem. [...] Így kellett tennem. Így kellett lenni. Ámen.,"724

Grősz József kalocsai érsek 1944 őszétől vezetett naplót. A feljegyzésfolyam 1946-ig tart. A napló szövege 1951-ben az ÁVH birtokába került, a dokumentumban foglaltakat felhasználták a főpap elleni koncepciós perben.

A Grősz-napló egyértelmüen antikommunista nyelvezetü. A naplóíró Grősz azzal kalkulált 1944-ben, hogy Magyarország jövője a polgári demokrácia. A kommunisták demokratikus elkötelezettségében az első perctől kezdve nem bízott. Az 1945. április 16-i bejegyzésében kifejtette azt, hogy a nép „elsöpörné”725 a kommunistákat, ha a nép megkérdezése megtörténhet.

1945. május 11-én elkeseredett és vulgáris megfogalmazásra ragadtatta magát a naplóíró érsek: „Egyébként a magyar demokrácia közönséges humbug. Miféle demokrácia az, ahol csak egy ember mondhatja el 100 körül a véleményét, a többinek kuss?"726 1945. július 5-én értelmezi a hírt, miszerint Rákosi Mátyás előadott - a korábbi fejezetünkben már elemzett - a budapesti Demokrácia-konferencián. „Rákosi Mátyás a budapesti egyetem bölcsészeti karán nagy hallgatóság előtt előadást tartott a magyar demokráciáról megállapítván, hogy az nem a nyugati hatalmak (Anglia, Amerika) demokráciája, nem is a szovjeté, hanem speciálisan magyar demokrácia. És a hallgatók nem röhögtek a szemébe és nem mondták meg neki, hogy a magyar demokrácia éppen olyan humbug, mint az orosz"727 írja Grősz érsek.

A napló 1945. szeptember 23-i bejegyzésében szintén egy demokrácia tematikájú, indulatos megállapítást olvashatunk. Grősz folyamatosan értesült a kommunista befolyás alatt müködő rendőrség helyi és országos atrocitásairól. Erre a helyzetre reagál: „Ez a gyönyörüséges demokrácia! Ezen persze senki sem csodálkozik, legfeljebb a belügyminiszter úr, aki ezt az aljas bandát rendőrség címén ránk szabadította. Mi régen tudjuk, hogy derék kommunistáink tekintélyes része egy évvel ezelőtt még nyilas volt és hogy a háborús bünösök és a reakciósok kínzóinak egy része az SS pribékektől tanulta mesterségét.",728

A kommunista demokráciaértelmezés és a jogállami/polgári demokrácia világa közötti antagonisztikus ellentét Grősz József lelkében, gondolkodásában komoly disszonanciát

\footnotetext{
${ }^{724}$ Uo. 27. p.

${ }^{725}$ GRŐsz József: Grősz József kalocsai érsek naplója. Szent István Társulat, Budapest, 1995. 203. p.

${ }^{726}$ Uo. 218. p.

${ }^{727}$ Uo. 240. p.

${ }^{728}$ Uo. 260. p.
} 
okozott. Ez a fajta antagonizmus és disszonancia jelképes nyelvi tükröződése, hogy a föpap nyers vagy kifejezetten vulgáris szöveget alkot naplójában. Egy érsektől olyan meg nem szokott kifejezéseket használ, mint „kuss”, „,nem röhögtek a szemébe”, „humbug” és „aljas banda." 


\title{
IV. A tudományos beszédmód - A második világháború utáni néhány esztendő magyarországi demokráciájának jelzői, fogalmi struktúrái a recepcióban
}

\author{
1. Az államszocialista időszak tudományos fogalomhasználata, \\ demokráciaértelmezése a második világháború utáni néhány évet érintöen
}

1950-től az 1945 utáni esztendőkről és a korszak demokráciájáról szóló diskurzusok már nem az aktualitás-beszédmód mint kód által fogalmazódtak meg, hanem a tudományos beszédmód, a recepció beszédmódja, mint másik nyelvezet segítségével azonosíthatóak az időszakot és demokrácia fogalomhasználatát elemző narratívák.

A hatvanas évek közepéig a tudományos beszédmódot az ideologikus beszéd karaktervonásai döntően határozták meg. Az évtized közepétől a fogalomhasznált elkezd objektívebbé válni, a nyolcvanas évekre a tudományos beszédmód még teljességgel nem tud ugyan megszabadulni az ideologikus beszéd kötöttségétől, de a történettudományi diskurzus tényközpontúbbá válik. A rendszerváltozás utáni szabad nyelvi és szellemi közegben formálódhattak ki a koalíciós korszak demokráciáját vizsgáló tudományos beszédmód demokratikus narratívái.

1950 februárjában a Magyar Tudományos Akadémián tartott előadásában Fogarasi Béla filozófus az 1945 utáni évek időszakát „az átmenet korszakának” nevezi. ${ }^{729} \mathrm{Az}$ ideológiai-filozófiai-tudományos kód hivatkozási pontja Fogarasinál Lenin, aki a szocializmusba való átmenetet további különböző átmeneti korokra bontja. Fogarasi leszögezi, a népi demokrácia ,a szocializmus felé haladó út” - sajátos átmeneti időszak, átmenet a szocializmus felé, de azt is aláhúzza, hogy a népi demokrácia ideológiája a szocializmus ideológiája. A népi demokrácia lényege, amely az 1945 utáni éveket is jellemezte, hogy az átmenet időszakában ,a régi és az új elkeseredett harca folyik minden téren." ${ }^{, 30}$ A filozófus úgy véli, a háború utáni évek tekintetében döntő történés volt, amikortól

\footnotetext{
${ }^{729}$ FogARASI Béla: Társadalmi lét és társadalmi tudat az átmeneti korszakban. A Magyar Tudományos Akadémia II. Társadalmi-Történeti Tudományok Osztályának Közleményei. I. kötet 1. szám. Magyar Tudományos Akadémia. Budapest, 1950.

${ }^{730}$ Uo. 19. p.
} 
a kommunisták „a demokrácia eredményeit” képesek voltak „tudatosítani” a reakció „tudatdiverziós”,731 törekvéseivel szemben - Fogarasinál ez az időpont 1948 eleje.

A történettudományt és a filozófiát érintően is - a diktatúra kontra demokrácia tematikát illetően - az ötvenes és a hatvanas évek tudományos beszédmódja (ahogy Fogarasinál is láthattuk) Lenin vonatkozó téziseit tekinti megfellebbezhetetlen ideológiai alapnak, ezért vázoljuk ezt a keretet, amely egészen a hatvanas évek második feléig döntő részben hat a második világháborút követő évekről szóló történettudományi demokrácia diskurzusokra. Lenin A szociáldemokrácia két taktikája a demokratikus forradalomban címü 1905-ben írt müvében ír a hatalomátvétel mechanizmusáról. Lenin kifejti, hogy a forradalom bejezéséhez szükséges a diktatúra. ${ }^{732}$ Lenin e művében használja azt a kifejezést, miszerint „az átmenet” a „,demokratikus diktatúra” időszaka. ${ }^{733}$ Az ortodox marxista magyar történészek egészen a hatvanas évek második feléig használják a lenini átmenet demokratikus diktatúra nyelvi paneljét az 1945 utáni magyar népi demokratikus átalakulásának leírására.

Andics Erzsébet, a Rákosi-korszak reprezentáns történésze már 1950-ben történettudományi megközelítésböl értékelte az 1945 utáni korszakot. Demokrácia és szocializmus 1918-19-ben címü tanulmánya a címböl következően is nem a '45-öt követő időszakról szól, de az írásban Andics érinti az 1945 utáni néhány esztendő időszakunkat is. „Az új történelmi helyzet új lehetőségeket is teremtett a munkásosztály számára, amely lehetőségek az első világháború után korszakban nem álltak rendelkezésre: a népi demokrácián keresztül eljutni a szocializmushoz"734 - írja a második világháború utáni rövid kurzus jellemzésére az ortodox kommunista történész, aki 1919-cel szemben azt tekinti 1945re vonatkozóan döntően új szempontnak, hogy a világégés fájdalma lehetővé tette: a munkásosztály bátrabban merjen szövetségeseket keresni. S ebből fakadóan lehetőség nyílt arra, hogy ne egyből a proletárdiktatúrán át, hanem a „népi demokrácián keresztül békés fejlődéssel”735 jussanak el a szocialista társadalomig.

„A népi demokratikus hatalom szervei kezdettől fogva magukban hordták a proletariátus diktatúrájának csíráját - a demokratikus forradalom szocialista forradalomba való átnövésének a lehetőségét” ${ }^{736}$ - írta G. Fazekas Erzsébet ${ }^{737}$ alig tíz esztendővel a

\footnotetext{
${ }^{731}$ Uo. 21. p.

${ }^{732}$ Vlagyimir Iljics LENIN: A szociáldemokrácia két taktikája a demokratikus forradalomban 1905. Szikra Kiadó, Budapest, 1948. 115. p.

${ }^{733}$ Uo. 63. p.

${ }_{734}^{7}$ ANDICS Erzsébet: Demokrácia és szocializmus 1918-19-ben. Szikra Kiadó, Budapest, 1950. 24. p. ${ }^{735}$ Uo.

${ }^{736}$ G. FAZEKAS Erzsébet: Magyarország felszabadítása és a népi demokratikus forradalmunk érlelődésének néhány kérdése. In: LACKÓ Miklós (szerk.): Tanulmányok a magyar népi demokrácia történetéből. Akadémiai Kiadó, Budapest, 1955. 7-87. p. / 87. p./
} 
második világháború befejezése után, 1955-ben a Magyarország felszabaditása és a népi demokratikus forradalmunk érlelödésének néhány kérdése címü tanulmányában.

1955-ben a „felszabadulás” tizedik évfordulójára egy grandiózus, közel hétszáz oldalas kiadvány jelent meg Tanulmányok a magyar népi demokrácia történetéböl címmel az ötvenes évek hivatalos történeti kánonja szellemében a „magyar népi demokrácia első szakaszának” időszakáról. Az „első szakasz” az akkori ideológiai alapvetés szerint az 1945től 1949-ig terjedő évek korszakot jelenti. ${ }^{738}$

G. Fazekas Erzsébet a koalíciós évek időszakát ${ }^{739}$ a „demokratikus forradalom” periódusának tartja. A történész úgy látja, hogy a „népi demokratikus forradalom erői” már a háború végén ,gyülekezőben” voltak, de még nem bírtak olyan erővel, hogy megdöntsék a „Horthy-fasizmust”, ezért a „népi forradalomnak ezt a feladatát” a Vörös Hadsereg kellett megoldania. G. Fazekas arról ír, hogy az 1944-et követő években a népi demokratikus forradalom „első szakasza” valósult meg; s ezt a szakaszt az jellemezte, hogy a polgári demokratikus és az antifeudális forradalom egy időben zajlott le.

Mérei Gyula 1955 tavaszán tartott előadásai alapján adták ki A magyar népi demokrácia története címü kiadvány. A történész szerint 1948 júniusától számítható a „szocialista forradalom” időszaka, az előtte lévő szűk négy esztendő pedig a „népi demokratikus forradalom” korszaka. „Nálunk azért volt szükség népi demokratikus forradalomra a szocialista forradalom előtt, mert hiányoztak a proletárdiktatúra megteremtésének feltételei"740 - írja Mérei Gyula, aki szerint a népi demokratikus forradalom legfontosabb tartalma, hogy a munkásosztály és a parasztság részesévé lett a hatalomnak: „,Az üzemek túlnyomó részében munkásellenőrzés érvényesült. A földreform lényegében befejeződött." ${ }^{, 741}$ Mérei úgy véli, mindezen jelenségek összessége különbözteti meg a népi demokratikus forradalmat az egyszerü, hagyományos értelemben vett „,polgári demokratikus forradalomtól."

\footnotetext{
${ }^{737}$ G. Fazekas Erzsébet (1900-1967) Gerő Ernő felesége volt. G. Fazekas a húszas években a Sorbonne-on történelmet hallgatott. 1940-1941-ben Moszkvában aspiráns a Szovjetunió Tudományos Akadémiája Történeti Intézetében. 1950-től a szegedi József Attila Tudományegyetem oktatója, 1953-tól az ELTE egyetemes történeti tanszékének vezetöje.

${ }^{738}$ A kiadványról így ír Molnár Erik A magyar történetírás fejlödése az elmúlt évtizedben címü 1960-ban publikált írásában: „A népi demokrácia történetének megírása, tekintettel arra, hogy a forrásanyag rendezetlen és nehezen hozzáférhető, újszerü kutatási módszerek kialakítását kívánta meg. Ennek ellenére ezen a területen is voltak eredmények. [...] Terjedelmes tanulmánykötet jelent meg a felszabadulás 10. évfordulójára, amely az 1945-49-ig terjedő korszak legtöbb fontos kérdését tárgyalta." (MOLNÁR Erik: A magyar történetírás fejlődése az elmúlt évtizedben. Századok, XCIV. évf. (1960) 1-3.45-58. p. /53. p./)

${ }^{739}$ Hangsúlyoznunk kell, az ötvenes évek párttörténetírása még egyáltalán nem használja a „koalíciós időszak” kifejezést.

${ }^{740}$ MÉREI Gyula: A magyar népi demokrácia története. Felsőoktatási Jegyzetellátó Vállalat, Budapest, 1959. 18. p. ${ }^{741}$ Uo. 77. p.
} 
Az ötvenes évek kommunista történetírói úgy ítélték meg, hogy már 1944/45 és 1948 között is jelen volt a törekvés a proletárdiktatúrára és az az időszak is diktatúra volt, csak még nem színtiszta proletárdiktatúra, hanem a munkásság és a parasztság úgynevezett lenini értelmü „demokratikus diktatúrája.” Ez az ortodox kommunista történeti nyelvi kánon alapján 1948/49-től már „létrejöttek” a proletárdiktatúra „feltételei”, megvalósult az államhatalom struktúráiban is a proletárdiktatúra világa, ezzel szemben az 1944 utáni négy-öt évben a proletárdiktatúra előzménye érhető tetten egyfajta „demokratikus diktatúra” fogalmi kerete formájában, eszerint a nyelvi kód alapján a koalíciós évek időszaka a „demokratikus diktatúra" időszaka.

A ,demokratikus diktatúra” metanyelvi fogalomvilágát használja Nemes Dezső - már az '56-os események után - 1960-ban megjelent Magyarország felszabadulása. Magyarország fejlődése a felszabadulás után címü monográfiájában. „Az új, demokratikus hatalmat a magyar nép forradalmi alkotó ereje teremtette meg. A magyar tőkések és földbirtokosok fasiszta diktatúráját a magyar munkások és parasztok demokratikus diktatúrája váltotta fel”742 - olvashatjuk a kötetben. E történeti megközelítésben 1944-ben egyik diktatúra váltotta a másikat, a tőkések és a földbirtokosok „fasiszta” diktatúrája után jött a munkások és a parasztok diktatúrája. Az 1944 és 1949 közötti időszak államhatalmi jellegzetességeit ekképpen érzékelteti Nemes: „A munkás-paraszt demokratikus diktatúra fejlődött át a demokráciának egy magasabb fokára, amit a proletárdiktatúra valósít meg.,"743

Az ortodox kommunista történeti látásmód alapján a proletárdiktatúra a demokrácia „magasabb foka.” Nemes arra is igyekszik választ adni, hogy mi a különbség az 1944 és 1949 közötti „demokratikus diktatúra” és az 1948/49 utáni proletárdiktatúra között: „a demokratikus diktatúrának proletárdiktatúrává fejlődése azt jelentette, hogy a munkásosztály a hatalom kizárólagos birtokosa lett." ${ }^{\text {744 }}$

Nemes Dezső A népi Magyarország fejlődése címü - szintén 1960-ban közölt tanulmányában azt is megfogalmazta, hogy mi volt a „demokratikus diktatúra” időszakának történelmi feladata: a munkások és parasztok demokratikus diktatúrája megvédi a „demokratikus vívmányokat a reakciós támadásokkal szemben, és biztosítja a forradalom viszonylag békés továbbfejlődését: átnövését a szocialista forradalomba."745 Nemes e publikációjában is egyértelművé tette, hogy a koalíciós évek időszakát a proletárdiktatúra

\footnotetext{
742 NEMES Dezső: Magyarország felszabadulása. Magyarország fejlődése a felszabadulás után. Kossuth Könyvkiadó, Budapest, 1960. 235. p.

${ }^{743}$ Uo. 236. p.

${ }^{744}$ Uo. 259. p.

${ }^{745}$ NEMES Dezső: A népi Magyarország fejlődése 1945-1960. Századok, XCIV. évf. (1960) 1-3. 1-44. p. /2. p./
} 
előtti „demokratikus diktatúra” korszakának tekinti. Nemes szerint tehát az 1944/1945 utáni néhány esztendő időszakát egy olyan munkás-paraszt diktatúra határozta meg, amely diktatúra viszont még 1949 előtt nem tudott maradéktalanul „érvényesülni” az ország életében.

Balázs Béla éppen a Népmozgalom és a nemzeti bizottságok 1945-1946 címü müvét írta, mikor elhunyt, a kötet posztumusz kiadásként 1961-ben jelent meg. Balázs a korábbiakban elemzett történeti panelek kapcsán tapasztaltakhoz képest árnyalatnyival enyhébben fogalmaz, nála jelenik meg először markánsan az a vélekedés, miszerint a második világháború utáni néhány esztendő egy referenciaértékkel bíró időszak. Nem tér el a marxista történetírás narratívájától, nem mond mást mint az ötvenes évek ortodox kommunista történetírói, de ugyanakkor új megközelítésü fogalmakat használ a koalíciós évek vonatkozásában: megítélése szerint az 1945 utáni éveket „forradalmi demokratizmus»"746 jellemezte, amikor a demokratikus tömegmozgalom „ragyogó tettei” határozták meg a közéleti küzdőtér karakterét.

Földesi Tamás filozófus a Néhány gondolat a népi demokrácia fogalmáról címü 1962ben publikált cikkében a lenini elméleti narratívára alapozva úgy látja, az 1944 utáni esztendők jellemzője az ,átmeneti hatalom”, amikor egyszerre van jelen a kisgazda parlamenti többség és a kommunisták „kezdeményező” szerepe. ${ }^{747}$ Földesi arról ír, hogy a népi demokrácia demokratikus többletet jelent a „legdemokratikusabb” polgári demokráciával szemben, mert a népi demokrácia államhatalmi berendezkedése a polgári demokráciával szemben már magában foglalja a munkásosztály és a parasztság „részvételét” is a hatalomban. A munkásosztály és a parasztság hatalmi jelenléte viszont nem jellemzi a polgári demokráciát, vagyis a népi demokrácia ilyen megközelítés alapján demokratikus többlettel bír. A filozófus úgy gondolja, a „diktatúra” és a „demokrácia” struktúráinak „merev, metafizikus szembeállítása” a polgári ideológia sajátja. A polgári demokrácia hívei szerint a diktatúra „feltétlenül elvetendő”748 - erre Földesi azt veti fel, hogy nem létezik eleve „tiszta demokrácia”, mert az államhatalom objektíve már önmagában „diktatórikus” jellegü viszonyokat hoz létre, így a „tiszta” polgári demokrácia is magában foglal represszív elemeket. Földesi szerint „potenciálisan 1948 tavaszáig még nem dőlt el a kérdés: proletárdiktatúrává vagy burzsoá diktatúrává fejlődik-e az ország,",749 vagyis Földesi úgy érzékeli, a koalíciós évek időszaka pusztán arról szólt, hogy milyen „diktatúra” fog kialakulni,

\footnotetext{
${ }^{746}$ BALÁzs Béla: Népmozgalom és a nemzeti bizottságok 1945-1946. Kossuth Könyvkiadó, Budapest, 1961. 25. ${ }_{747}^{\mathrm{p}}$

${ }^{47}$ FöLDESI Tamás: Néhány gondolat a népi demokrácia fogalmáról. Magyar Filozófiai Szemle, VI. évf. (1962) 1. 80-111.p. /84. p./

${ }^{748}$ Uo.

${ }^{749}$ Uo. 90. p.
} 
mert az ő látásmódja alapján a „tiszta” polgári demokrácia is magában hordoz a diktatúrákra jellemző elnyomó karaktervonásokat. Azt az időszakot, melyben formálódott, hogy melyik diktatúra valósul meg, nevezi Földesi népi demokráciának.

Kárpáti Sándor 1963-ban publikált A szocialista forradalom hazánkban mint a népi demokratikus forradalmak egyik formája címü írásában ${ }^{750}$ úgy fogalmaz, hogy 1944-45-től „népi demokratikus forradalom” kezdődött. E népi demokratikus forradalom volt az első szakasz, a második szakasz „1948 tavaszára-nyarára” alakult ki, amikor a Kommunista Párt és szövetségesei „kivívták” a proletárdiktatúrát.

Ez az 1963-as tanulmány az első olyan esszé, amely már kritikus elemeket is tartalmaz a kommunisták koalíciós években játszott szerepével kapcsolatban - az első tudományos közlés, amelyben megjelenik az a szempont, hogy milyen hibákat követett el a Rákosi-féle vezetés. E publikáció a formálódó kádárista történeti nézőpont egyik első megnyilvánulása, a szöveg elsőként illusztrálja a Kádár-korszak hivatalos álláspontjának hangvételét.

Kárpáti alapvetésként leszögezi, hogy a kommunisták 1945 és 1948 között „hatalmas eredményeket” értek el a „szocializmus felé haladás”751 érdekében. Kárpáti úgy véli, „a forradalom átnövése időszakában”, vagyis 1946-1948 között - a kommunista pártvezetés nem törekedett eléggé az általa vezetett népfront erősítésére és szélesítésére, „a legszélesebb tömegek bevonására” a hatalomért folytatott harcban. Kárpáti mindezt azzal magyarázza, hogy a kommunista pártban kezdtek „elötérbe kerülni a dogmatikus vonások, megjelentek a személyi kultusz és a tömegektől való elszakadás tünetei” és ezzel párhuzamosan Rákosiék túlbecsülték ,a burzsoá és fasiszta elemek” befolyását. ${ }^{752}$

Az a megállapítás egészen újszerü, amely arra mutat rá - igaz kellőképpen óvatos megfogalmazással - miszerint a koalíciós években a kommunisták „túlbecsülték” a fasiszta veszélyt. Annak kimondása lehetetlen volt és teljességgel életszerütlen lett volna 1963-ban, hogy a kommunista stratégia tudatosan építette fel a fasiszta veszélyről szóló metanyelvi világot, hogy utána az ellenfelek, a proletárdiktatúra ellenfeleinek megbélyegzésére rendelkezésre álljon mindez, ugyanakkor a koalíciós évekbeli kommunista taktika vonatkozásában a kritikus hang megjelenése egy új tudományos-ideológiai nyelvezet kialakulására utal.

Kárpáti érvelése, miszerint Rákosi és klikkje hatalomgyakorlása „dogmatikus” jellegű volt, a kádárista felfogás egyik első rögzített nyelvi panelje a második világháborút követő

\footnotetext{
${ }^{750}$ KÁRPÁTI Sándor: A szocialista forradalom hazánkban mint a népi demokratikus forradalmak egyik formája. In: Magyar Filozófiai Szemle, VII. évf. (1963) 3. 361-378 p.

${ }^{751}$ Uo. 367. p.

${ }^{752}$ Uo.
} 
néhány esztendő magyarországi történeti kánonja kapcsán. Markánsnak tünő nyelvi kód, hogy a „torzulás” már a koalíciós években is megjelent mint jelenség.

1964-ben, a „felszabadulás” huszadik évfordulóján egy komolyabb tudományos diskurzus alakult ki ,a népi demokratikus forradalom” jellegéről. Erről írja Csizmadia Andor öt évvel később: „A vita lényege a körül forgott, vajon a népi demokratikus forradalom már kezdettől szocialista forradalom volt-e, vagy a népi demokráciánkban két külön forradalom zajlott le: egy plebejus-demokratikus és egy szocialista." ${ }^{753}$ Romsics Ignác több mint három évtized múltán, 1996-ban ekképpen fogalmazott a diskurzusról: „Ezek a viták [...] álviták, illetve igen erősen cenzúrázott és öncenzúrázott látszatviták voltak., ${ }^{, 754}$

Magunk is úgy ítéljük meg, a 1964/1965-ös népi demokrácia vita valóban áldisputa volt, a korszak hivatalos tudományos szereplői metanyelvi fogalmakat használnak diskurzusuk során. Mindezek ellenére a második világháború utáni néhány év demokráciájáról szóló tudományos beszédmód formálódása tekintetében a „vita” érdemes arra, hogy megvizsgáljuk a megjelenő érvkészletek alakulását.

A vitaindítónak tekinthető tanulmányt Sipos János filozófus írta. Sipos úgy véli, 1944 előtt az uralkodó osztályok „féktelen demagógiával” és a „legális ellenzék közremüködésével” el tudták hitetni: ,a magyar fasizmus megszelídült, hogy a rendszer már nem fasiszta diktatúra, hanem alkotmányos parlamentarizmus, szemben az olasz és a német faizmussal, tartós illúziókat tápláltak a demokratikus erők soraiban a Horthy-rendszer irányában."755 Sipos szerint a „szelídített” konzervatív struktúrák miatt nem voltak biztosítottak a „népi demokratikus forradalom” feltételei 1944-ben. Sipos gondolatsorának lényegi eleme, hogy a reakciós társadalmi szerkezetet áttörő népi demokratikus forradalom csak a szovjet katonai jelenlétnek köszönhetően tudott teret nyerni. Sipos nyelvi paneljei még az ötvenes évek ideologikus beszédmódját mutatják, nála még nem érzékelhető narratív elmozdulás.

Ágh Attila inkább történetfilozófiai szempontból elemzi a második világháború utáni magyar viszonyokat; szerinte a magyar népi demokrácia a népi demokrácia típusai közül a közép-kelet-európai típusba tartozik. A „közép-kelet-európai” népi demokrácia típust az

\footnotetext{
753 CSIZMADIA Andor: A nemzeti bizottságok állami tevékenysége 1944-1949. Közgazdasági és Jogi Könyvkiadó, Budapest, 1968. 86-87. p.

${ }^{754}$ ROMSICS Ignác: Az 1945 és 1948 közötti magyar történelem a magyar historiográfiában. In: IzSÁK Lajos STEMLER Gyula (szerk.): Vissza a történelemhez... Emlékkönyv Balogh Sándor 70. születésnapjára. Napvilág Kiadó, Budapest, 1996. 293-299. p. /293. p./

${ }^{755}$ SIPOS János: A népi demokratikus forradalom magyarországi sajátosságaihoz. Hozzászólás néhány vitás kérdéshez. Magyar Filozófiai Szemle, VIII. évf. (1964) 1. 16-74. p. /49. p./
} 
különbözteti meg a „balkáni” népi demokrácia formájától, hogy „,a demokratikusabb szakasz hosszabb”. ${ }^{756}$ Maga a népi demokrácia Ágh nézőpontjából az ,átmeneti típusok egész sorát” jelenti. Az ,átmenetnek” van egy „antifasiszta” diktatúra jellegü szakasza is, „melyben részt vesznek a népfront összes pártjai, tehát koalíció van hatalmon." ${ }^{, 757}$ A népi demokrácia már a forradalom elején „,széttöri a polgári demokrácia kereteit.”758 Ágh érveléséből kiolvasható az a gondolat, miszerint mind a „közép-kelet-európai”, mint a „,balkáni” népi demokrácia-forma végső értelme a proletárdiktatúra, de a „balkánival” szemben a „közép-kelet-európai” népi demokrácia esetén a „demokratikus” szakasz hosszabb. Ágh nyelvi struktúrái annyiban hoznak újdonságot a diskurzusba, hogy noha az ideológiai elemek markánsan jelen vannak, de a publikációban a tudományos mérlegelésre, fogalmi elemzésre is tér nyílik.

Szabó Bálint történész esszéjének elején utal rá: a „népi demokratikus korszakunk történetének kutatása alig néhány éves múltra tekinthet vissza." ${ }^{, 759}$ A történész nem fogadja el azt a megközelítést, miszerint a népi demokrácia korszakának lenne egy demokratikus szakasza és 1948 után pedig jön a proletárdiktatúra, mert helyzetítélése szerint „demokratikus feladatok" maradtak bőven '48-at követően is. Szabó úgy véli, hogy például az egyházi iskolák államosítása úgymond „demokratikus feladat”, pedig ezt az intézkedést az országgyűlés már a proletárdiktatúra időszakában hozta meg. Szabó azt is leszögezi: a második világháború utáni esztendők jelentik „,népünk történetének egyik legragyogóbb”760 fejezetét és az 1948 után „elkövetett hibákat”"761 nem szabad úgymond „visszavetíteni”762 az 1945-48-as időszakra.

A tudományos beszédmód aspektusából vizsgálva megállapíthatjuk: Szabó tanulmányában a „demokratikus” kifejezés nem a demokratikus jogok meglétére vonatkozik, hanem a „demokratikus” fogalom pusztán azt jelenti, hogy az új intézkedések által megtörténik a régi rend túlhaladása.

A tudományos beszédmódban panelteremtő Szabó azon érvelése, miszerint a koalíciós évek a magyar történelem „egyik legragyogóbb” fejezete. Ekkor jelenik meg - Balázs Béla írását követően - először a második világháború utáni néhány év mint referenciaértékü történéssor a hivatalos párttörténetírás hivatalos szövegében.

\footnotetext{
756 ÁGH Attila: Vita a népi demokratikus forradalom jellegéről. Magyar Filozófiai Szemle, VIII. évf. (1964) 2. 381-386. p. /385. p./

${ }^{757}$ Uo. 383. p.

${ }^{758}$ Uo. 384. p.

${ }^{759}$ SzABÓ Bálint: Népi demokráciánk történetének néhány vitatott problémájáról. Párttörténeti Közlemények, X. évf. (1964) 2. 128-148. p.

${ }^{760}$ Uo. 143. p.

${ }^{761}$ Uo. 144. p.

${ }^{762}$ Uo.
} 
Berend T. Iván és Szakács Sándor gazdaságtörténeti aspektusból szóltak hozzá a népi demokrácia jellegéről szóló 1964-65-ös vitához. A szerzők megállapítják, hogy Magyarországon 1945 és 1946 folyamán - már nem a tőkés gazdaság jelelemzői uralkodtak, hanem ebben az időszakban ,a munkás-paraszt demokratikus diktatúra államhatalma által ellenőrzött és irányított, monopolszervezetek nélkül működő, igen aktív és hatásos munkásellenőrzés alatt álló,763 gazdaság müködött. Berend T. és Szakács úgy vélik, az 1945 és '48 közötti időszak egy sajátos korszakot, „egy addig ismeretlen átalakulási”"764 utat jelentenek a szocialista forradalmak történetében. Berend T. Iván és Szakács Sándor tanulmányukban „a munkásosztály és parasztság demokratikus diktatúrájában” azért látnak értéket, mert e represszív struktúra által lehetett megbontani a kapitalizmus gazdasági rendjét.

Mód Aladár a háború utáni néhány esztendő időszakát „,a magyar népi demokrácia első, 1949-ig tartó stratégiai szakaszának"765 nevezi A népi demokratikus forradalom és a magyar népi demokrácia elvi és történelmi kérdései című tanulmányában. A történész megütközve elemzi, hogy az 1947-es választásokon „,a népi demokrácia nyílt ellenzéke” a szavazatok 40\%-át tudta megszerezni. Mód szövegéből egyértelmü, számára a népi demokrácia fogalma és a proletárdiktatúra, a kommunista diktatúra szinonima. Mód 1965-ös érvkészlete a nyelvi paneleket tekintve inkább az ötvenes évek ortodox marxista megközelítésére emlékeztet.

Az 1964-65-ös népi demokrácia-vita szövegeit öt évtized elmúltával vizsgálva megállapíthatjuk, az akkori történészek, filozófusok, politika-kutatók egy metanyelvi közeget, nyelvi apparátust hoztak létre és ebben a mesterségesen megteremtett kommunikációs kontextusban fogalmazták meg érveiket. A diskurzusra visszatekintve azt viszont mindenképpen történetfilozófiai értéknek tekinthetjük, hogy - minden metanyelvi álszituációja ellenére - egyáltalán kvázi vitahelyzet, tudományos párbeszéd teremtődhetett meg, vagyis kialakulhatott, létrejöhetett a lehetőség arra, hogy árnyalatokban ugyan, de különbözőképp láthassák a vita szereplői a kommunista diktatúra megteremtésének időszakát, a koalíciós évek világát, a tudományos diskurzus résztvevőinek nyelvi panelje szerint a „népi demokratikus forradalom" jellegét.

\footnotetext{
${ }^{763}$ BEREND T. Iván - SzAKÁCS Sándor: Hozzászólás a népi demokratikus forradalom jellegéről folyó vitához. Párttörténeti Közlemények, X. évf. (1964) 3. 207-233. p. /212. p./

${ }^{764}$ Uo. 232. p.

765 MóD Aladár: A népi demokratikus forradalom és a magyar népi demokrácia elvi és történelmi kérdései. Valóság, II. évf. (1965) 3. 1-16. p. /1. p./
} 
A vita során föként filozófusok és történészek folytattak egymással vitát vagy legalábbis vitaszerủ párbeszédet. E tény is alátámasztja azt a megállapítást, hogy a hatvanas évekbeli kádári kultúrpolitikában az irodalmi élet szereplőivel szemben a filozófusok, társadalomtudósok, történészek kaptak nagyobb társadalmi teret, tudományos felületet. Kalmár Melinda kutatásaiból tudjuk, hogy a hatvanas évek közepétől a pragmatikus kádárizmusban a történettudomány fontos szerepet kapott, hivatalos művelődéspolitikai céllá vált a legújabbkori magyar történelem elemzése és értelmezése. ${ }^{766}$

Az 1960-as „A filozófia lenini pártosságáért” címü párthatározat a hazai filozófia és társadalomtudomány feladataként deklarálta a kommunista ideológiai felfrissítését és injektálását. ${ }^{767}$ Mindeme jelenségből is következik a koalíciós évek népi demokráciájáról szóló beszédmód lassú átalakulása, formálódása, nyelvi finomodása.

Az MSZMP 1962-es VIII. kongresszusa kimondta, hogy megszüntek a tőkés restauráció feltételei. E tétel rögzítése által a társadalomtudományok „bizonyos mozgástérre"768 tettek szert. A párt 1964-ben deklarálta a tudományos témaválasztás szabadságát, ami óhatatlanul a történettudományos beszédmód kereteit is képes volt fellazítani. A hatvanas évek második felétől ideológiai téren egyre nagyobb nyitottság jellemezte a tudománypolitika fórumait. ${ }^{769}$

A tudományos beszédmód vizsgálatát elemezve megállapíthatjuk: a hatvanas évek közepétől fokozatosan nagyobb jelentősége lett a történettudományi tényeknek, szempontoknak, szakmai jellegü érveléstechnikának. A beszédmód egyértelmüen a marxista nyelvi kód alapján írható körül, de érzékelhető egyfajta textológiai felfrissülési tendencia. A hatvanas évek második felére kialakuló kádári reformideológia ${ }^{770}$ alapvetése a realista látásmódról teret nyitott az összetettebb, érvelő nyelvi konstrukciók számára a koalíciós évekről szóló történettudományi diskurzusok számára.

Minderre a kultúrpolitikai és nyelvi trendfordulóra lehetnek példák Ságvári Ágnes publikációi. Ságvári a második világháború utáni esztendőkre mint korszakra - az 1945 utáni

\footnotetext{
${ }^{766}$ KALMÁR Melinda: Ennivaló és hozomány. A kora kádárizmus ideológiája. Magvető Kiadó, Budapest, 1998. 163-193. p. években. In. RAINER M. János (szerk.): „Hatvanas évek” Magyarországon. Tanulmányok. 1956-os Intézet, Budapest, 2004. 198-236. p. /216. p./

${ }^{769}$ STANDEISKY Éva: Bomlás. A hatalom és a kulturális elit. In. RAINER M. János (szerk.): „Hatvanas évek” Magyarországon. 227-317. p

${ }^{770}$ KALMÁR Melinda: Az optimalizálás kísérlete. Reformmodell a kultúrában 1965-1973. In: RAINER M. János (szerk.): „Hatvanas évek” Magyarországon. 161-197. p.
} 
évek demokrácia-vitáiban is felbukkanó - „új demokrácia” megnevezést használja. Az 1965ben publikált A demokratizmus formái és tartalma Magyarországon (1944-1948) címü tanulmányában eszme- és társadalomtörténeti áttekintéssel, a korábbi tudományos-ideológiai beszédmódra jellemző kinyilatkoztató jellegü panelektől eltérően nagyobb hangsúlyt fektetve az érvelő szerkezetekre igyekszik bizonyítani: a polgári demokráciának már csak azért sem lehetett létjogosultsága az 1945 utáni években, mert nem voltak meg a polgári demokrácia tapasztalásai, nem voltak meg a polgári demokratikus jogokra épülő államberendezkedés tradicionális alapjai. „Demokratikus hagyományokon nevelődött polgárság hazánkban nem volt. Az éles társadalmi ellentétek és a Tanácsköztársaság kísértő emléke miatt a magyar burzsoázia a demokratizálás legkisebb mértékétől is visszariadt. [...] Magyarországon számottevő, radikális kispolgári demokratikus irányzat sem volt."771 - fejtegeti Ságvári. A történész szerint azonban 1945-ben és azt követő években a polgári demokratikus hagyományok hiánya azért nem okozott gondot, mert így „,a demokratizálás élére” állhattak a kommunisták. Ságvári megállapítja, hogy „,sajátos helyzetet” teremtett az, hogy hivatalosan az 1945-öt követő években „mindenki demokrata” volt, de ugyanakkor mindenki mást értett rajta. A szerző előbbi érvelése mögött egy olyan kép mutatkozik meg, ami szerint az 1945 utáni „új demokrácia” keretei egyfajta demokrácia-labort teremtettek, ahol a különböző antifasiszta erők igyekeztek a maguk demokrácia-felfogását erősíteni, érvényre juttatni. Ságvári Ágnesnek a koalíciós éveket érintő demokrácia-értelmezései a hatvanas évek időszakában már kifejezetten a későbbi puhuló kádári diktatúra tudományos beszédmódjára emlékeztetnek.

A második világháború utáni évek történetének meghatározó jelentőségü marxista kutatója volt Balogh Sándor történész. ${ }^{772}$ Áttekintjük a történész gondolkodásának, érvkészletének a koalíciós évek demokráciájára vonatkozó változásait. Balogh a korszakról szóló tanulmányait a hatvanas évektől kezdve publikálta, utolsó ebbéli tartalmú tanulmánya

\footnotetext{
771 SÁGVÁRI Ágnes: A demokratizmus formái és tartalma Magyarországon (1944-1948). In: Marx Károly Közgazdaságtudományi Egyetem 1965. évi ünnepi ülésszaka. Közgazdasági és Jogi Könyvkiadó, Budapest, 1966. 121-132. p. /123. p./

${ }_{772}$ A 2004-ben elhunyt Balogh Sándorról írja Glatz Ferenc történész: „Írói-kutatói munkásságának legmaradandóbb része az 1945-48 közötti magyar történelem forrásszerü feltárása. Az első volt, aki a publicisztikát félretolva, levéltári kutatás tárgyává tette a proletárdiktatúra előtti évek történelmét (1945-48). Témái is úttörők voltak: az utolsó többpártrendszeri demokrácia története (benne az 1948 után felszámolt pártok történelmével), a megszállt Magyarország, mint a külpolitika játéktere (1945-47), a 20. századi kultúrpolitika és az értelmiség történelme. S mindez alig két évtizeddel a második világháború után." (GLATZ Ferenc: Balogh Sándor. Elérhető: http://www.historia.hu/archivum/2005/0509glatz2.htm /A letöltés időpontja: 2015. október $30 . /)$
} 
2000-ben jelent meg, vagyis rendelkezésünkre áll a szövegvizsgálat tekintetében egy több mint három évtizeden át gyarapodó szöveganyag.

Balogh 1964-ben az előbbiekben ismertetett népi demokrácia-vita részeként írta meg $A$ népi demokratikus forradalom néhány kérdéséről címü tanulmányát. A történész azt fejtegeti, hogy 1945-ben a „,népi demokratikus forradalom” elindulása után nem az volt a kérdés, hogy úgymond veszély-e a polgári demokráciához való visszatérés, hanem az jelentette a lényegi kihívást, hogy valóságosan visszaállhat-e a „két világháború közötti fasiszta uralmi rendszer” valamiféle ,demokratikusabb kiadásban." ${ }^{\text {773 }}$

Balogh egy másik - Ságvári Ágnessel közösen jegyzett - tanulmányában amellett érvelt, hogy a döntő fordulatot a népi demokrácia „továbbfejlődése” szempontjából a '47-es választás jelentette: „Nem érthetünk tehát egyet az olyan véleményekkel, amelyek kizárólag a választások számszerü eredményeiből igyekeznek a népi demokratikus erők gyengeségét bizonyító következtetést levonni. Az 1947-es választások jelentős állomás volt a

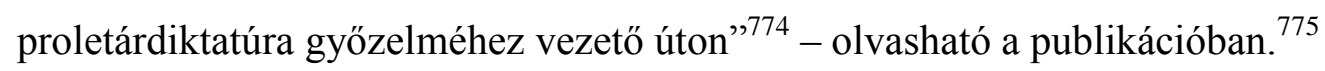

1965-ben az MKP értelmiségi politikájáról írott dolgozatában még meglehetősen sematikusan kezeli a (népi) demokrácia tematikát; ekkor még a koalíciós évek történetét ${ }^{776}$ úgy láttatja mint a „népi demokrácia ellenségei” és a népi demokrácia hívei közötti harcot. ${ }^{777}$ 1975-ben már a demokrácia különböző „válfajairól”778 és „irányzatairól” beszél, és azt elemzi, hogy a háború után mindegyik párt a demokrácia jelszavával igyekezett feltủnni a nyilvánosság fórumain. Immáron nem a népi demokrácia „ellenségei” és a hívei között látja a döntő ellentétet '75-ben már úgy fogalmaz, hogy a „legnagyobb távolság” a kommunistákat és a kisgazdákat választotta el, mert a kommunisták „szocializmust” akartak, míg a kisgazdák

\footnotetext{
773 BALOGH Sándor: A népi demokratikus forradalom néhány kérdéséről. Magyar Tudomány, LXIX. évf. (1964) 11. 687-698. p. / 697. p./

774 BALOGH Sándor - SÁGVÁRI Ágnes: A népi demokratikus forradalom magyarországi győzelmének történetéhez. Századok, XCVII. évf. (1963) 6. 1322-1340. p. 1336. p.

${ }^{775}$ Hogy az 1947-es választásokat döntő fordulópontnak tartja Balogh Sándor, abban is megnyilvánul, hogy a parlamenti és pártharcok történetét a '47-es voksolásig tekinti át Parlamenti és pártharcok Magyarországon 1945-1947 című monográfiájában. Mint a kötet záró soraiban írja: „Az 1947. évi országgyülési választás a népi demokrácia szocialista jellegü továbbfejlesztéséért folytatott küzdelem kiemelkedő jelentőségü eseménye, állomása volt. Nem döntötte ugyan el egymagában a hatalom kérdését, de nagymértékben hozzájárult ahhoz, hogy a kommunista párt a korábbiaknál sokkal kedvezőbb politikai feltételek között vezethesse a munkás- és dolgozó paraszttömegek harcát a néphatalom, a proletárdiktatúra kivívásáért." (BALOGH Sándor: Parlamenti és pártharcok Magyarországon 1945-1947. Kossuth Könyvkiadó, Budapest, 1975. 532. p.)

${ }_{776}$ A koalíciós évek kifejezést ekkor még nem használja Balogh.

777 BALOGH Sándor: A Magyar Kommunista Párt értelmiségi politikájának felszabadulás utáni történetéből, Századok, XCIX. évf. (1965) 3. 458-483. p.

778 BALOGH Sándor: A demokrácia kérdései a magyarországi politikai pártok szervezeti felépítésében a felszabadulás után. Történelmi Szemle, XVIII. évf. (1975) 1. 50-67. p. /50. p/.
} 
polgári demokráciát. ${ }^{779}$ Balogh nézőpontjából a polgári demokrácia kifejezés 1975-ben egyértelmủen negatív fogalomként azonosítható.

Közel tíz évvel később, 1984-ben publikált tanulmányában úgy ír: a népi demokrácia a hatalomgyakorlás tekintetében inkább a parlamentáris demokráciára emlékeztetett. ${ }^{780}$ Balogh szerint a leglényegesebb választóvonal az volt, hogy a polgári pártok csakis a parlamentáris demokráciát fogadták el igazi demokráciaként. E tanulmányában a koalíciós korszakot érintő legfontosabb terminus technicusa a „népi demokrácia”, magát az időszakot is e fogalommal írja körül. Balogh e helyütt a népi demokrácia kiemelt jellemzőjeként a nemzeti bizottságokat, üzemi bizottságokat említi; szerinte a második világháború utáni évek történetét meghatározó népi demokrácia annyiban más mint a parlamentáris demokrácia, hogy a parlamentarizmus szigorú formalizmusán túl magában foglalja a közvetlen demokrácia ethoszát is.

Balogh Sándor a kommunista diktatúra utolsó évtizedében a második világháború utáni esztendők, a koalíciós évek vonatkozásában korszakmegjelölő fogalomként egyértelműen a népi demokrácia kifejezést használta. Számára az 1944 és 1947-48 között történtek a „népi demokrácia” időszakához tartoznak. A rendszerváltozást követően ez az álláspontja egyértelműen kikristályosodott, az 1998-as Fordulat a világban és Magyarországon című konferencián mondta: „A »népi demokrácia« fogalmát azonban az uralkodó politika Magyarországon is évtizedeken keresztül lejáratta és prostituálta. Akkor emlegette s hivatkozott legtöbbször a »népidemokráciára«, amikor az már egyáltalán nem volt jelen. A fordulat éveiben végbement hatalmi-politikai változások talán legátfogóbb jellemzője, hogy az említettek következményeként 1949-re Magyarországon végérvényesen megszünt létezni mind a népi demokrácia, mind annak politikai intézményrendszere" - vallja Balogh Népi demokrácia vagy »népidemokrácia«? ${ }^{781}$ címủ előadásában. Balogh életútja végére fogalmazta meg pregnánsan azt a nézetét, miszerint az 1944-et követő évek a „népi demokrácia" korszakát jelentik, amely számára - posztkommunista nézőpontból - egy pozitív időszak. A népi demokrácia számára a parlamentáris demokrácia és a közvetlen demokrácia intézményrendszerének egyfajta sajátos keveréke. Balogh Sándor szempontjából ez a struktúra a „népi demokrácia” és ezzel szembe állítja a kommunista diktatúra hivatalos valóságmagyarázatát, amely alapján maga a proletárdiktatúra jelenti - így egybeírva - a „népidemokráciát.” Balogh tehát az egybeírás-különírás dilemmájával igyekszik illusztrálni

\footnotetext{
${ }^{779}$ Uo. 52.p.

${ }^{780}$ BALOGH Sándor: A magyar népi demokrácia demokratizmusáról (1944-1946). Történelmi Szemle, XXVII. évf. (1984) 1-2. 279-291. p.

${ }^{781}$ BALOGH Sándor: Népi demokrácia vagy „,népidemokrácia”? In: FeITL István - IZsÁK Lajos - SzÉKELY Gábor (szerk.): Fordulat a világban és Magyarországon 1947-1949. Napvilág Kiadó, Budapest, 2000. 381-389. p. /389. p./
} 
azt a különös helyzetet, miszerint a kommunista diktatúra saját identifikációjának része volt, hogy magát „népidemokráciának” nevezte, de ezzel párhuzamosan a „népi demokrácia” koalíciós évekbeli intézményhálózata valóságosan tartalmazott jogállami jellegü demokrácia kísérleteket, amelyek élesen szembeállíthatóak a későbbi proletárdiktatúra karakterével.

Balogh Sándor a korszak egyik legtekintélyesebb kutatója volt. Több mint három évtizednyi publikációmennyiség áll a rendelkezésünkre tőle, így a koalíciós évek demokráciadiskurzusa tekintetében is nyomon tudjuk követni a gondolatok, a tudományos beszédmód változásait. Ez a három évtized egy rendkívül hosszú időszak volt: a korszak elején, a hatvanas években még az ortodox kommunista tudományos nyelvhasználat formái jelennek meg, a későbbiekben a tartalom objektivizálódik és Balogh publikációiban a tárgyilagos elemzés válik hangsúlyossá. A rendszerváltozás után egyfajta önreflexió keretében tesz kísérletet arra, hogy a sok évtizedes tevékenysége után a koalíciós demokrácia-tematika szempontjából saját és egyedi álláspontot vázoljon fel: e kísérlet eredménye a „népi demokrácia” kontra „népidemokrácia” fogalmi elkülönítése. Értelmezésünk szerint ez a fogalomértelmezés egy intellektuális szembenézés Balogh Sándor részéről a saját tudományos múltjával. A magunk részéről tartalmilag nem érezzük az egybeírás-különírás dilemmáját a tudományos beszédmód tekintetében relevánsnak, inkább olyan értelemben tanulságos mindez, hogy Balogh Sándor példájából látható: képes volt arra törekedni, hogy a korábbi tevékenysége egymással ellentétes fogalmi elemei között szintetizáljon és reflektáljon önnön magára, pontosabban egykori álláspontjára.

A koalíciós évek kutatása a kádári puha diktatúra hetvenes éveiben már biztosíthatott egyfajta relatív intellektuális szabadságot, vagy legalábbis maga a téma alkalmas volt arra, hogy a kutató más, rendszerérzékenyebb témákhoz képest nagyobb gondolati mozgástérrel rendelkezzen. Ebből is következett, hogy a második világháború befejezését követő esztendők a hetvenes évek világában - ahogy Standeisky Éva fogalmaz - „kedvelt kutatási területe lett azoknak a történészeknek, akik lazítani kívántak a Kádár-kori politikai-ideológiai béklyókon.,"782

A kádári Magyarországon a hatvanas évek második felében megindult ideológiaitudományos fellazulás a hetvenes évek elejére megtorpant. Mindennek a tendenciának jelképes történése volt, hogy az 1944-45-ös dokumentumokat közlő Sorsforduló címü kötetet

782 STANDEISKY Éva: Tétova újraértelmezések. Magyarország második világháborút követő évei a rendszerváltozás utáni történetírásban. In: ERDŐS Vilmos - TAKÁCS Ádám (szerk.): Tudomány és ideológia között. Tanulmányok az 1945 utáni magyar történetírásról. ELTE Eötvös Kiadó, Budapest, 2012. 134-150. p. /135./ 
a hivatalos kultúrpolitika lényegében betiltotta; árusítását megtiltották, a könyvtári példányokat zárolták, mert a kiadvány forrásai úgymond az antimarxista, objektivista történelemszemléletet erősíthették. ${ }^{783}$

Az „objektivista történelemszemlélet” bírálójának számított Szabó Bálint, 1972-ben „túl megengedőnek”784 tartotta az MSZMP kultúrpolitikáját. Szabó 1974-ben monografikus igényü kötettel jelentkezett az 1945 utáni népi demokrácia értelmezéséről szóló könyvével.

Szabó Népi demokrácia és forradalom-elmélet. A marxista forradalom-elmélet

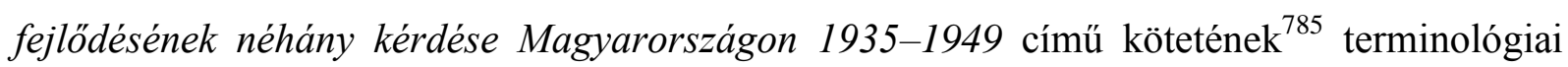
újítása az a megközelítés, amely szerint a koalíciós évek időszakát a polgári demokrácia híveinek és a „polgári demokrácián túlmutató” erőknek a politikai harca illusztrálja. E nézőpont alapján már kibontakozik az a verzió, miszerint az 1944 utáni néhány esztendő döntő közéleti kérdése maga a demokrácia dilemmája volt. Azzal, hogy a népi demokrácia híveit a „polgári demokrácián túlmutató” demokráciafelfogást vallóknak nevezi - akár akarata ellenére - az objektívebb történeti tudományos beszédmódot erősíthette.

A nyolcvanas években a második világháború utáni korszak két meghatározó kutatója, Izsák Lajos és Vida István már egyértelmüen koalíciós időszakként határozza meg az 1945-öt követő évek terminusát. A magyar népi demokrácia pártpolitikai struktúrája 1944-48 címmel 1985-ben publikált írásában Vida István „népi demokratikus pártrendszerről” beszél a koalíciós évek tekintetében. ${ }^{786} \mathrm{E}$ tanulmányában Vida úgy fogalmaz, hogy a koalíciós években egészen 1949-ig „demokratikus többpártrendszer”787 müködött Magyarországon. A demokratikus többpártrendszer jellemzője az volt, hogy nem létezett „,rendszerellenes párt” és „kétoldalú ellenzék” ${ }^{788}$ sem. Vida 1985-ben így elemzi a koalíciós évek demokratikus többpártrendszerének politikai egyensúlyát: „Amíg a törvényhozásban a kisgazdapárt rendelkezett jelentős többséggel, addig az államapparátusban, a gazdaságirányításban, az erőszakszervezeteknél a baloldal szerezte meg a hatalmi pozíciók nagyobb hányadát." ${ }^{, 789}$ Izsák Lajos Polgári ellenzéki pártok Magyarországon 1944-1949 című könyvében „népi

\footnotetext{
${ }^{783}$ STANDEISKY Éva: Bomlás. A hatalom és a kulturális elit. 312-313. p. (KARSAI Elek-SOMLYAI Magda (szerk.): Sorsforduló. Iratok Magyarország felszabadulásának történetéhez. 1944 szeptember - 1945 április. I-II. kötet. Levéltári Igazgatóság, Budapest, 1970.)

${ }^{785}$ SZABÓ Bálint: Népi demokrácia és forradalom-elmélet. A marxista forradalom-elmélet fejlődésének néhány kérdése Magyarországon 1935-1949. Kossuth Könyvkiadó, Budapest, 1974.

${ }^{786}$ VIDA István: A magyar népi demokrácia pártpolitikai struktúrája 1944-48. Történelmi Szemle, XXVIII. évf. (1985) 1. 26-53. p. /41. p./

${ }^{787}$ Uo. 38. p.

${ }^{788}$ Uo.

${ }^{789}$ Uo.
} 
demokratikus korszaknak" nevezi az 1944-1949 közötti időszakot. A 1986-ben megjelent A koalíció évei Magyarországon 1944-1948 címü kiadványban az 1944 és 1948 közötti időszakot a magyar demokrácia megszületése korszakának tekinti. ${ }^{790}$ Izsák 1983-as kötetében az elemzői-történészi tényszerüséget érzelmi többlettel kiegészítő sorokat vetett papírra a koalíciós évekről: „kevés olyan sorsfordulója van nemzeti történelmünknek, amely iránt olyan nagy érdeklődés mutatkoznék - s tegyük hozzá, amellyel kapcsolatban annyi félreértés lenne a közvéleményünkben -, mint az 1944-1949 közötti néhány esztendő eseményekben és drámai fordulatokban gazdag időszaka»791 - fogalmazott Izsák. Izsák a rendszerváltozás után 1944-49-et - a „koalíció évei” kifejezésen túl - a „többpártrendszerü demokratikus

jogállamiság"792 korszakának tekinti. A fordulat Izsák érvelése szerint 1947-től megkezdődik, s 1949-re megszünik a többpártrendszer és kialakul a proletárdiktatúra - ahogy Izsák fogalmaz: létrejön a „rendőrállam.”

A hetvenes-nyolcvanas éveknek a koalíciós éveket értelmező tudományos beszédmódja egyértelműen a tárgyilagosabb nyelvhasználat irányába mutat. Elfogadott, legitim fogalommá válik a koalíciós korszak fogalma. Vida István és Izsák Lajos ebben az időszakban közölt publikációiban még tetten érhetőek a marxista történeti kánon nyelvi kategóriái, de az objektivizáció szándéka nyilvánvaló. Hogy Vida és Izsák már a hetvenes és a nyolcvanas években is törekedtek a tárgyilagosabb beszédmódra, lehetővé tette számukra, hogy a rendszerváltozás után történészként önazonos módon, identitás-deformáció nélkül legyenek képesek elemezni a koalíciós évek demokráciáját.

\section{Emigráns történészek koalíciós évekbeli demokrácia-értelmezései az államszocialista korszakban}

Fejtő Ferenc 1952-ben Párizsban írta meg az egy évvel később a francia fővárosban kiadott $A$ népi demokráciák története című könyvét. Fejtő az 1945 és 1947 közötti időszakról szól külön, vagyis nála ez az időintervallum jelenti a második világháború utáni évek történetében az elkülöníthető korszakot, s ennek a következő nevet adja: „Az újjáépítés és a demokratikus

\footnotetext{
${ }^{790}$ IzSÁK Lajos: A koalíció évei Magyarországon 1944-1948. Kozmosz Kiadó, Budapest, 1986.

${ }^{791}$ IZSÁK Lajos: Polgári ellenzéki pártok Magyarországon 1944-1949. Kossuth Kiadó, Budapest, 1983. 6. p.

${ }^{792}$ IZSÁK Lajos: „Két fordulat” jelenkori történelmükben: 1944-1945 és 1947-1949. In: IzSÁK Lajos: Pártok és politikusok Magyarországon 1944-1994. Napvilág Kiadó, Budapest, 2010. 178-187. p.
} 
reformok korszaka.”793 Az író-történész ezt a két éves periódust mintegy „duális rendszert”,794 láttatja, ahol a parlamentáris demokráciára jellemző metódusok jelen vannak ugyan, de ezzel párhuzamosan „,a kommunista klikkek által gyakorolt hatalom”795 a döntő jelentőségü. A duális rendszer végét pedig az jelenti, amikor a kommunista klikk az összes külső ellenfelét felszámolja, ekkor zárul a demokratikus reform időszaka. „Mikor egyedül maradnak a porondon, ahogy tervezték, eltörlik a parlamentáris demokráciát, kikiáltják a proletariátus diktatúráját, vagyis a kommunista párt diktatúráját, s minthogy a kommunista párt a maga részéről nem más, mint a Szovjetunió eszköze",796 - írja Fejtő.

Az emigráns történész úgy véli, a rendőri szervek „kommunista ellenőrzése” és a „megszálló hatóságok által kifejtett közvetlen vagy közvetett nyomás” még nem lett volna elegendő ahhoz, hogy a demokratikus reformok időszakát felváltsa a kommunista diktatúra. Mindehhez kellett a kommunisták ellenfeleinek „középszerűsége, politikai dilettantizmusa, gondolatszegénysége és fantáziátlansága."797 Fejtő ezen 1952-es megállapítása mögött megítélésünk szerint a történelmi távlat hiánya és mint kortársnak a személyes ellenszenvei is állhatnak, hiszen a források ismeretében állítható: önmagában a szovjet megszállás ténye meghatározó volt a demokrácia kontra diktatúra dichotómia kapcsán.

Deák István számára már biztosított volt a történelmi távlat - 1981-ben közölte az Ötventöl a száz százalékig - Magyarország a nagyhatalmi érdekszférák kialakulása és megszilárdulása korában című tanulmányát. Deák esszéjében úgy fogalmaz: „A demokrácia aránylag rövid ideig tartott.”,798 A történész 1947-ben látja a korszakhatárt. A demokrácia időszaka nála 1945 és 1947 közé tehető. Deák szerint az 1945-47 közötti korszak belpolitikailag azért érdekes, mert külpolitikailag már eldőlt, hogy Magyarország a szovjet érdekszféra része lesz, de az a kérdés még nyitott volt, hogy a szovjetek eltürnek-e vagy pontosabban meddig türnek el egy nem kommunista kormányt.

Schöpflin György nézőpontjából a koalíciós éveket az 1944-1948 közötti időszak jelenti. A történész-politológus arról értekezik, hogy a második világháború utáni évek magyar pártrendszerét politikatudományi értelemben hegemón pártrendszerként lehet leírni. A hegemón pártrendszer a magyar politikai kultúrában a dualizmusig megy vissza. „A négy pártból álló kormány, jól lehet, 1945 végén sok szempontból kivételes helyzetben találta

${ }^{793}$ FEJTŐ Ferenc: A népi demokráciák története. 1-2. kötet. Magvető-Magyar Füzetek, Budapest- Párizs, 1991. I. 77. p.

${ }_{794}^{70.79 . p .}$

${ }^{795}$ Uo. 80. p.

${ }^{796}$ Uo. 79. p.

${ }^{797}$ Uo. 81. p.

798 DEÁK István: Ötventől a száz százalékig - Magyarország a nagyhatalmi érdekszférák kialakulása és megszilárdulása korában, 1943-1947. Új Látóhatár, XXXII. évf. (1981) 2. 207-219. p. /216. p./ 
magát, nem nagyon hasonlít a nyugaton elfogadott demokratikus modellre. Inkább a hagyományos kormánypárt leszármazottjának tekinthető: kormányon kívüli ellenzék nem létezett, a természetes és várható politikai versengés a kormányon belül játszódott le"799 - írja Schöpflin.

A politológus tehát a koalíciós évek időszakát nem tekinti nyugati értelemben vett demokratikus modellnek, hanem inkább a korábbi magyar közéleti tradíciókra építkező sajátosan magyar struktúrát látja az 1944 és 1948 közötti években és e jelenség szerinte legyengítette a demokratikus fejlődés esélyeit. Schöpflin hozzáteszi ugyan, hogy ezek a fogyatékosságok nem jelentették eleve a magyar demokratikus fejlődés kudarcát. A koalíciós éveknek véget vető döntő tényezőnek ő maga is a szovjet „súlyt” tekinti.

Figyelemreméltó álláspont Schöpflin idézett véleménye, amely a koalíciós évek struktúráját a dualizmus és a Horthy-korszak hegemón pártrendszerével rokonítja, eszerint a koalíciós évek demokráciáját a magyar politikai tradíció, közéleti kultúra továbbélő hatásaként írja le, ugyanakkor fel kell vetnünk, hogy a mintaszerü demokratikus hagyományokkal rendelkező Csehszlovákiában szintén a magyar koalícióhoz hasonlatos szerkezet jön létre az 1945-öt követő esztendőkben.

Borbándi Gyula 1985-ben Bernben megjelent monográfiájában emigrációtörténeti megközelítésben határozza meg a második világháborút követő különböző korszakokat. Nála a koalíciós évek kapcsán 1947 a szakaszhatár, hiszen ekkor indult el egy komolyabb emigrációs folyamat: 1947-ben kezdődött meg az 1939-1945-ös világháború utáni magyar emigráció történetének második szakasza, amely 1956-ig, a magyar októberi forradalom és szabadságharc menekültjeinek megjelenéséig tartott. Borbándi az emigrációtörténeti szemponton túl is megfogalmaz a koalíciós időszakot értékelő gondolatokat, szerinte az 1945 és 1948 közötti koalíciós korszak „a magyar nép demokratikus törekvéseinek nagyszerü és maradandó jelentőségű megnyilatkozása volt”, amely demokráciakísérlet bukása ellenére is „megérte a sok erőt, energiát és fáradozást, amit az ország lakossága e vállalkozásba belefektetett ${ }^{800}$ - írja a nyolcvanas években Borbándi, aki a koalíciós évekre 1956 vonatkozásában is hivatkozási pontként tekint. Borbándi idézett 1985-ös szövege - egyfajta profetikus írói szemüvegen keresztül, négy esztendővel a rendszerváltozás előtt - a koalíciós időszak demokráciájában potenciális közéleti referenciát lát.

\footnotetext{
${ }^{799}$ SCHÖPFLIN György: A politikai intézmények szerkezete 1944-1948. Új Látóhatár. 1981/2. 220-227. p. $/ 225$. p./

${ }_{800}$ BORBÁNDI Gyula: A magyar emigráció életrajza. 1945-1985. Európai Protestáns Magyar Szabadegyetem, Bern, 1985. Elérhető: http://mek.oszk.hu/03400/03472/html/ (A letöltés időpontja: 2015. április 15.)
} 
Charles Gati szintén emigrációban alkotta meg a koalíciós korszakot is érintő, 1986ban az Egyesült Államokban megjelent összefoglaló müvét. Gati 1944-48-as időszakot említ és mindezen korszak jellemző kifejezéseként „demokratikus közjátékról”801 beszél. A történész-politológus szerint a második világháború utáni Magyarország számára három út kínálkozott: az első a polgári demokrácia, amely evolúciós társadalmi változást kívánt létrehozni, a második a populista agrárium modell, mely a mezőgazdaságra és a könnyüiparra épített volna és végül a harmadik, a kommunista iparosító alternatíva. Gati a Columbia Egyetem kutatási dokumentációjára hivatkozik, amely szerint a polgári demokratikus evolúciós modellnek volt meghatározó $\left(46,7\right.$ \%-os) ${ }^{802}$ támogatottsága a magyar társadalmon belül, már csak azért is, mert az agrárius irány mögött is sok olyan kisgazda lehetett, akik szintén a polgári demokrácia modellje mellett álltak. Gati felhívja a figyelmet, hogy egy másik nézőpontból tekintve a revolúció híveinek (51,7\%) volt enyhe többsége, de a radikális társadalmi mobilizációt akaróknak a többsége mindezt nem diktatórikus megoldások útján képzelte el. Az amerikai-magyar történész szerint a legfontosabb tényező az volt, hogy „a Szovjetunió határozott támogatást éppen azoknak nyújtott, akik forradalmi változásokat hirdettek meg és az indusztriális szocializmusban jelölték meg a haladás irányát." ${ }^{803}$ Gati a koalíciós évek „demokratikus közjátékként” jellemzett közéleti küzdőterén belül markáns megkülönböztető elemnek a társadalmi változásokhoz való eltérő hozzáállást tekinti - vagyis nem a demokrácia kontra diktatúra gondolatkört látja a lényegi vízválasztónak, hanem az evolúció-revolúció dichotómiát.

Az emigráns magyar történészeknek a témánkra vonatkozó vélekedései a tudományos beszédmód vizsgálata szempontjából azért fontosak, mert az időhorizontot tekintve abban a terminusban fogalmazódnak meg, amikor Magyarországon a kommunista diktatúra időszakában, az államszocialista rendszer nyelvi struktúrái által fogalmazódhatnak csak meg történészi álláspontok. Az emigrációban élő történészek a diktatúrától független szabad nyelvi közegben érvelhetnek, vagyis az emigráns történészek véleményei mintegy referenciái annak, hogy ha kivonjuk a tudományos diskurzusból a szocialista rezsim kötelező marxista nyelvi paneljeit, akkor milyen történeti álláspontok alakulhatnak ki. Az emigráns történészek véleményeiben közös pont, hogy a koalíciós években demokratikus kísérlet zajlott, amelyet a kommunisták hatalmi törekvése ellehetetlenített. Ez a fajta nyelvi panel a rendszerváltozás

\footnotetext{
${ }^{801}$ Charles GATI: Magyarország a Kreml árnyékában. Századvég, Budapest, 1990. 120. p.

${ }^{802}$ Uo. 74. p.

${ }^{803}$ Uo. 75. p.
} 
utáni tudományos diskurzusban jelenik meg ismét markáns formában - a koalíciós évek demokráciája tekintetében az emigráció történészei lényegében „előfutárai” az 1989 utáni magyarországi történészi gondolkodásnak és nyelvhasználatnak

\section{Terminológiai diskurzusok a második világháború utáni esztendök természetéröl és a demokrácia jelzöiröl a rendszerváltozás utáni tudományos közéletben}

A rendszerváltozás utáni szabad tudományos közegben Standeisky Éva kutatott, vizsgálódott és publikált legtöbbet a koalíciós évek demokráciájával mint témával kapcsolatban, ezért először Standeisky e tematikához illeszkedő szakmai állásfoglalásait, történeti érvrendszerét, fogalomhasználatát, demokráciaértelmezését elemezzük.

Disszertációnk írása közben 2015 decemberében jelent meg Standeisky Éva Demokrácia negyvenötben címü könyve, amelyben a szerző összegezte korábban különböző publikációkban részben már kifejtett álláspontját az 1945-re vonatkozó demokrácia tematikáról, illetve számos új megállapítást tett, amelyek által a kérdéskör monografikus igényü feldolgozása született meg. Standeisky a kötetben arról szól: '45-ben „a megszállás ellenére valamiféle jogállamiság”804 kialakult és formálódni kezdett „az egymás ellenőrizhetőségére épülő demokrácia." ${ }^{805}$ A történész szerint 1944-45 fordulóján egy „korlátozottan plurális hatalmi rendszer”,806 jött létre, amit a kommunisták a szovjet típusú szocializmust „megelőző hatalmi formának” tekintettek. Standeisky úgy véli, 1945-ben ${ }^{807}$ még nem lehetett feltenni a kérdést, de a koalíciós évek döntő dilemmája az volt, hogy polgári demokrácia lesz-e Magyarországon vagy „szovjet típusú totalitarizmus."

Standeisky Éva az 1945 utáni időszak leírására használja a „vajúdó demokrácia”809 kifejezést is; megállapítása szerint a „korlátozott” demokrácia „,nem mindig érzékelhetően és láthatóan csúszott át diktatúrába." ${ }^{810}$ A Demokrácia negyvenötben címü kötet végső konklúziója arról szól, hogy a háború utáni „sokféleségből és hamvába holt számos

\footnotetext{
${ }^{804}$ STANDEISKY Éva: Demokrácia negyvenötben. Napvilág Kiadó, Budapest, 2015. 17. p.

${ }^{805}$ Uo.

${ }^{806}$ Uo. 36. p.

${ }^{807}$ Standeisky Éva azt is kijelenti, 1945-ben a demokrácia „szinte minden feltétele hiányzott”, (Uo. 55. p.) de az emberek bíztak benne, hogy ez csak átmeneti állapot és a szabad választások után a demokratikus játékszabályok határozzák meg a közélet történéseit.

${ }^{808}$ STANDEISKY Éva: Demokrácia negyvenötben. 38. p.

${ }^{809}$ Uo. 222. p

${ }^{810}$ Uo.
} 
közmegnyilvánulásból"811 végül nem lett demokrácia, nem alakulhatott ki hosszútávon demokratikus politikai struktúra.

Periodizációs tematikájú, a saját maga által „,problémafelvetőnek szánt” írása végén a korábbi óvatosabb véleménye után határozottabb tónust használva jelenti ki: „Az 1945 és 1950 közötti periódus szerintem a kudarcos demokratizálódás időszaka volt." ${ }^{812}$

Standeisky Éva elfogadja mind a „koalíciós évek”, mind a „szovjetizálás” kifejezéseket, de önmaga egy újabb terminus technicust vezet be a korszakra vonatkozóan - a második világháború utáni néhány év történeti korszakát „a kudarcos demokratizálódás időszakának" nevezi és a korszakhatárokat 1945 és 1950 között jelöli ki. E helyen is érdemes idézni Standeisky Éva másik, a korszakról szóló tanulmányából, melyet a korabeli demokráciaértelmezésekről írt 2005-ben. ${ }^{813}$ A periodizáció szempontjából ez az írás kevésbé karakteres, de ebben a publikációban is előfordulnak az idődimenzióra, illetve a korszakmegnevezésre utaló fontos kitételek. A szerző a közgondolkodás szempontjából vet fel figyelemreméltó periodizációs gondolatokat, eszerint „,az 1989-90-es rendszerváltozás után a közvélemény fokozatosan elfogadta, hogy a kommunista uralom kezdő éve 1945."814 Ez a felvetés azt a későbbi szakmai vitát előlegezi meg, amely Gyarmati Györgynek a Rákosikorszakról megjelent monográfiája váltott ki történész és nem történész berkekben egyaránt 2011-ben. Standeisky előbb idézett mondata arra utal, hogy a magyar közvélekedésben létezik egy olyanfajta gondolati elem, miszerint a kommunista rendszer már 1945-ben elkezdett kiépülni. E megközelítés egyértelműen a koalíciós éveket pusztán egy presztalinizációs korszaknak láttatja. A kérdéskörröl bővebben szólunk, amikor Gyarmati Györgynek a koalíciós évek periodizációjáról szóló koncepcióját vizsgáljuk.

A Demokráciaelképzelések és demokráciaértelmezések című tanulmányában a koalíciós korszak kezdetének 1944-45 fordulóját tartja Standeisky Éva. Magára a koalíciós évek korszakára jellemző struktúrát pedig mint „,korlátozottan plurális hatalmi rendszert”815 írja körül. A „kudarcos demokratizálódás” mint a koalíciós évekre vonatkozó újszerü fogalom Standeisky egy másik tanulmányában is előfordul. Kudarcos demokratizálódás: Magyarország a második világháború utáni években címü írásában szintén olvashatunk a korszak megnevezését érintő egyedi fogalom-meghatározásokat, értelmezéseket a szerzőtől,

\footnotetext{
${ }^{811}$ Uo. 225. p.

812 STANDEISKY Éva: Tétova újraértelmezések. Magyarország második világháborút követő évei a rendszerváltozás utáni történetírásban. 146. p.

${ }^{813}$ STANDEISKY Éva: Remény és szorongás. Demokráciaelképzelések és demokráciaértelmezések. In: RAINER M. János - STANDEISKY Éva (szerk.): A demokrácia reménye: Magyarország, 1945. 1956-os Intézet, Budapest, 2005. 54-91. p.

${ }^{814}$ Uo. 54. p.

${ }^{815}$ Uo. 57. p.
} 
illetve - a konszolidáció és a rendszerváltozás elméleti nézőpontjából kiindulva - a periodizációra vonatkozóan is szerepelnek új megközelítések. A korszak végpontjának is tekinthető „fordulat évei” időszakhoz kapcsolhatóan írja: „1947-1949-ben a kommunisták nem demokratikus rendszert döntöttek meg, hanem magakadályozták annak éppen kezdődő

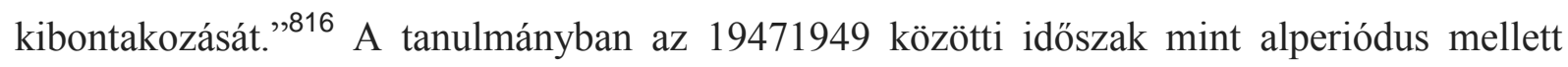
külön korszakrészként értelmezi az 1944 vége és az 1947 eleje közötti intervallumot. Az 1944-1947-es időszakon belül pedig belső korszakhatárként jellemzi - az 1945-ös választásokra utalva - 1945 őszét. Mivel fenti tanulmányában a konszolidáció problematikáját elemzi, így e szempontból értelmezendő az 1944 végétől 1947 közepéig terjedő időszak leírása, miszerint ebben a szakaszban Magyarország „nem konszolidálódott." ${ }^{817}$

A korábbiakban már ismertettük Standeisky Éva álláspontját, amely szerint a korszakhatár akár 1950 is lehet. Ehhez a gondolati konstrukcióhoz köthető a következő idézet: „1947-50 között erőszakos és erőltetett, és az ország hagyományaitól idegen rendszerváltás következett be.",818

Standeisky Éva 1950-et mint korszakhatárt a kulturális élet dimenziójából vázolja. Standeisky történészi megállapításait a második világháború utáni évek korszaka szempontjából kiemelkedő jelentőségü tudományos teljesítménynek tekintjük, ugyanakkor úgy érezzük, 1950 - különös tekintettel a témánk szempontjából mérvadó demokráciatartalom tekintetében - nem lehet korszakhatár. Úgy gondoljuk, a Rajk-per után már - ha kulturális nézőpontokat kívánnánk egyébként érvényesíteni - sem lehet demokratikus struktúráról beszélni, a Rajk-per jelképesen illusztrálja, hogy olyan diktatúra épült ki, amely nem kegyelmez a saját bázisának, saját politikai híveinek és vezetőinek sem. A Rajk-per léte önmagában azt demonstrálja, hogy a koalíciós évek demokráciakísérlete véget ért és új rendszer született. Demokráciaértelmezésünk szerint 1950 már a kommunista diktatúra, a Rákosi-rendszer éve volt.

Összegzésként elmondatjuk: Standeisky Éva az 1945 és 1950 közötti időszakot „meghatározó” és egyben önálló történeti korszaknak tekinti, értelmezése szerint ez a szakasz a „kudarcos demokratizálódás” időszaka. Standeisky publikációiban az 1945 utáni néhány esztendő kapcsán kulcsfogalom a kudarcos demokrácia kifejezés, amely fogalmi összetétel

\footnotetext{
${ }^{816}$ STANDEISKY Éva: Kudarcos demokratizálódás: Magyarország a második világháború utáni években. In: GOMBÁR Csaba (szerk.): A konszolidációról: elméleti és történeti elemzések. Kalligram Kiadó, Pozsony, 2012. 68. p.

${ }^{817}$ Uo. 46. p.

${ }^{818}$ Uo.
} 
arra utal, hogy a szerző elfogadja a demokrácia létét, de kénytelen megállapítani, hogy ez a népuralmi kísérlet eleve csak korlátozottnak tekinthető és bukásra volt ítélve.

Standeisky Éva álláspontjához hasonlatos Rainer M. János szakmai véleménye a koalíciós éveket érintő terminológiai és periodizációs kérdésekben. Rainer A magyarországi fordulatok és a szovjet politika, 1944-48 címmel írt tanulmányában - akárcsak Standeisky alperiódusokra osztja a háború utáni néhány esztendő történeti korszakát. Rainer ,az ideiglenes magyar törvényhozás” létrejöttétől számítja az új korszak beköszöntét. Miután mindezt tisztázza, azt elemzi, hogy ez az első szakasz, amit ő „az első magyar népi demokrácia” periódusnévvel illet, az 1945. novemberi választásokig tart.

Rainer M. János úgy véli, ez az időszak ,álkoalíciónak is nehezen tekinthető”, mert az Ideiglenes Nemzetgyűlés nem volt egyéb a kommunisták „uralta kormányt és adminisztratív apparátusokat fedő alakulatnál.”819 A következő alperiódus megnevezésére a „népi demokráciából demokráciába" terminust használja. Azzal érvel, hogy az 1945-ös parlamenti választásokkal új politikai helyzet állt elő, mégpedig azáltal, hogy „legitim parlamenti erőviszonyokra alapozott nagykoalíció” valósult meg. Ez az alszakasz azonban gyorsan véget ért, mert a szerző szerint már a kormányalakítás során „visszaépítették bele” a népi demokrácia sarkalatos elemeit, mint például a kommunista kézben lévő Belügyminisztériumot és a színfalak mögötti pártközi egyeztetést.

A „népi demokráciából demokráciába” alkorszak tehát lényegében alig „élt”, hiszen Rainer M. János értelmezésében gyorsan, a választások után közel öt hónappal elkezdődött a „Demokráciából népi demokráciába: szívósan és lassan” elnevezésű alperiódus. E folyamat 1946 márciusától Nagy Ferenc lemondásáig tartott, amelyek során folyamatosan szűkült a demokratikus politika ,játéktere”. Ezt követte a Rainer által „harmadik fordulatnak” nevezett új ciklus 1947 őszétől, mikor ismét a „népi demokrácia” politikai struktúrája állt össze. A Rainer-féle „,negyedik fordulat” már a szovjetrendszer kialakulásának szakaszát jelenti. Ez a szakaszhatár lezárja magát a koalíciós évek időszakát is. Rainer szerint 1949 májusában ért véget a második világháború utáni ötéves történeti korszak.

„1945 után Magyarországon nem volt a szó nyugatias-polgári értelemben vett demokrácia, de a magyar berendezkedés néhány évig (1947-48-ig) nem volt sztálini mintájú

\footnotetext{
${ }^{819}$ RAINER M. János: A magyarországi fordulatok és a szovjet politika, 1944-48. In: Rubicon, IX. évf. (1998) 45. sz. 50-57. p.
} 
szovjet rendszer sem"820 - írja A magyarországi sztálinizmusok - diskurzusok címü tanulmányában Rainer. A történész ezáltal a koalíciós évek időszakát úgy jellemzi, hogy 1945 és 1948 között nem létezett ugyan „tiszta” demokrácia, de nem volt még meg a szovjetizált struktúra sem, tehát egy sajátos átmenetet jelentett ez a néhány esztendő.

A 2010-ben megjelent Demokrácia volt-e Magyarországon 1945 után? címü tanulmányában Rainer a magyar demokratikus átalakulás lehetősége szempontjából meghatározó tényezőnek a szuverenitás kérdését tekinti. A történész szerint a szuverenitás hiánya „negatívan befolyásolta a demokrácia ügyét”, de ugyanakkor úgy véli: ezzel a magyar demokrácia kérdése még nem került le a napirendről, mert Moszkvában csak pár évi habozás után döntöttek úgy, hogy szovjetizálják Magyarországot. ${ }^{821}$ Rainer utal rá, nem lehet figyelmen kívül hagyni a koalíciós évek demokrácia vitái kapcsán, hogy 1944/45 előtt lényegében nem beszélhetünk demokratikus berendezkedésről. A koalíciós évek szempontjából a demokrácia bizonyítékaként tekint azokra a tényekre, hogy „a politikai paletta többszínü volt”, nagykoalíció létezett és ,a nyilvánosságban megjelenhetett többféle politikai ideológia." ${ }^{822}$ A történész az 1945 utáni esztendők politikai struktúráját ,jelentősen korlátozott magyar demokráciának" nevezi.

Rainer publikációiban a periodizációhoz köthetően különböző demokráciafogalmakat használ: jelző nélküli demokráciának pusztán az 1945-ös választások körüli heteket, hónapokat tekinti (ugyanakkor azt sem tartja nyugati értelemben vett demokráciának), amikor a népi demokráciáról beszél, akkor az a struktúra értelmezése szerint már csakis egy megterhelt, korlátozott demokrácia felfogást jelent. A koalíciós évek demokráciájára vonatkozó álláspontjának markáns kifejezése a korlátozott demokrácia fogalom-összetétel.

Kalmár Melindának az 1945-öt követő évek demokratikus világáról szóló állásfoglalásában is döntő jelzőnek a „korlátozott” kifejezés számít. Kalmár Történelmi galaxisok vonzásában. Magyarország és a szovjetrendszer, 1945-1990 című nagyszabású monográfiájában a második világháborút követő időszak kapcsán „2-3 éves” időhorizontot vázol, szerinte ez a rövid korszak a „korlátozott képviseleti demokrácia”823 kora, amelynek végpontja 1948 tavasza. Kalmár Melinda szerint lehet vita arról, hogy az 1945 utáni sztálini módszerek mögött meghúzódtak-e ,,nyitott végű stratégiák, azaz volt-e bármi más lehetősége

\footnotetext{
${ }^{820}$ RAINER M. János: A magyarországi sztálinizmusok - diskurzusok. In: RAINER M. János: Bevezetés a kádárizmusba. 1956-os Intézet - L'Harmattan, Budapest, 2011. 41-78. p. /77. p./

${ }^{821}$ RAINER M. János: Demokrácia volt-e Magyarországon 1945 után? A „koalíciós időszak” és a Rákosi-korszak átmenetének kérdése. In: LŐRINC László (szerk.): Egyezzünk ki a múlttal! Műhelybeszélgetések történelmi mítoszainkról, tévhiteinkröl. Történelemtanárok Egylete, Budapest, 2010. 85-90. p.

${ }^{822}$ Uo. 89. p.

${ }^{823}$ KALMÁR Melinda: Történelmi galaxisok vonzásában. Magyarország és a szovjetrendszer, 1945-1990. Osiris Kiadó, Budapest, 2014. 52. p.
} 
a térség államai számára"824 mint a szovjetizálás. Ugyanakkor azt is leszögezi, hogy az 1944 és 1948 közötti szovjet módszerek lényegi azonosságot mutatnak a lenini hódító taktikával, amely rávilágít rá a végső kimenetel esélyeire is.

A történész úgy véli a szovjetizáló forgatókönyvnek külön szakaszai vannak: az első időszakban az alkotmányos rend „látszatának” megteremtésére törekszenek a kommunisták, ekkor az ellenséges erőkkel szembeni nyílt erőszakot „politikai várakoztatással”825 kombinálják. A történész Magyarország szempontjából a szovjetizálási folyamat „végpontjának”826 1948 tavaszát tekinti.

A korlátozott demokrácia mint kulcsfogalom jelenik meg Hubai Lászlónál is. Hubai a II. Magyar Köztársaság diskurzusait tekinti át tanulmányában, melyben a korszak periodizációs és terminológiai vitatémáit is érinti. Emiatt is természetes, hogy 1949-et, a sztálinista alkotmány megszületését tartja fordulópontnak a történész, de megítélése szerint 1948 júniusától, az MDP megalakulásától már csak formailag létezett a többpártrendszer. ${ }^{827}$ Hubai úgy látja, „korlátozott polgári demokrácia” volt a koalíciós években Magyarországon. A történész szerint a „korlátozott” szó kellőképpen hangsúlyozza a korszak lényegi vonását: „a korlátozás időben egyre nagyobb mértékét."828 A kutató hozzáteszi, az általa „korlátozottnak” megnevezett polgári demokrácia elsősorban plebejus jellegű volt. Hubai ezzel a korábbiakban, föként a kommunista diktatúra éveiben a történészek által használt „népi demokrácia” panelre, annak társadalmi, szociális vetületére utal, azt igyekszik árnyaltabb módon visszaadni a korlátozott polgári demokrácia fogalmával. A történész úgy véli, legitim polgári demokráciáról beszélni a koalíciós évek kapcsán, mert a polgári demokrácia a hatalmi ágak elválasztásán és a pártok szabad versengésén alapul és az 1945. novemberi választások után megalakult kormány négy párt koalíciójaként müködött $\mathrm{s}$ a közéleti küzdelmek a parlamentben zajlottak, illetve a kormány mint végrehajtó hatalom a parlamentnek tartozott felelősséggel.

Hubai miután elemezte, hogy miért beszélhetünk polgári demokráciáról az 1945 és 1948 közötti esztendőkben, igyekszik a „korlátozott” kifejezést megindokolni. A történész elsősorban emlékeztet arra, hogy a polgári demokrácia megvalósítására '45 után egy olyan demokratikus hagyományok híján lévő - ország tett kísérletet, amely korábban a náci Németország szövetségese volt. A kutató arra külön felhívja a figyelmet, hogy a koalíciós

\footnotetext{
${ }^{824}$ Uo. 40. p.

${ }^{825}$ Uo. 46. p.

${ }^{826}$ Uo. 52. p.

${ }^{827}$ HUBAI László: Viták és álláspontok a II. Magyar Köztársaságról. Múltunk, L. évf. (2005) 2. 203-220. p.

${ }^{828}$ Uo. 208. p.
} 
években a végrehajtó hatalom nagyobb súllyal rendelkezett, mint a nyugati polgári demokráciában és a kommunisták rapid módon elfoglalták és kizárólagosan uralták a rendvédelmi pozíciókat. A rendeleti kormányzás gyakorlata és a közvetlen demokrácia intézményei szintén korlátozó tényezőnek számítottak a polgári demokrácia struktúráihoz képest.

A koalíciós évek demokráciájáról a rendszerváltozás után a legkomolyabb történeti vitát Gyarmati György álláspontja váltotta ki. A diskurzus 2011-2012-ben Gyarmati A Rákosi-korszak: rendszerváltó fordulatok évtizede Magyarországon,1945-1956 címü monográfiájának megjelenése után bontakozott ki. Elöljáróban Gyarmati témához illeszkedő korábbi publikációnak unikálisabb megállapításait vizsgáljuk.

Gyarmati György a Demokráciából a diktatúrába 1945-1956 címü kötetben az 1945 és 1948 közötti időszakra teszi „,a koalíció éveit.”829 A „belső” korszakolásról a kiadvány egyes fejezetei árulnak el többet: Gyarmati 1945-öt az ,ideiglenes államhatalom” időszakának tartja, 1946 nála „,a belpolitikai erőegyensúly éve,” 1947-48 kapcsán pedig az alfejezetének címe a következő: „útban a kommunista egyeduralom felé.”

Egy másik írásában Gyarmati kifejezetten az 1948 és 1950 közötti évekre helyezi a diktatúra intézményrendszerének kiépítési időszakát, de álláspontja szerint már 1945 végétől csak formálisan müködött a parlamentáris demokrácia. Gyarmati szerint 1945 és 1947 között, a formálisan működő demokráciában a kommunisták hegemóniája érvényesült, míg a parlamentáris demokrácia gleichschaltolását követően, vagyis diktatúra kiépülése után már a totális pártállam hatalmi omnipotenciája valósult meg. ${ }^{830}$

A '46-os év politikai történéseit elemző tanulmányában Gyarmati arról ír, hogy 1946ban a koalíciós erők által megvívva ,adminisztratív polgárháború" ${ }^{831}$ folyt az országban. E fogalmat a történész csak az 1946-os évre vonatkoztatva használja, de a terminus technicus a koalíciós évek egészére is érvényes lehet.

A magunk részéről az adminisztratív polgárháború fogalmából kiindulva nem tartjuk túlzásnak annak kijelentését, hogy a koalíciós években egyfajta hideg polgárháború zajlott.

\footnotetext{
${ }^{829}$ GYARMATI György: Magyarország története: Demokráciából a diktatúrába 1945-1956. Kossuth Kiadó, Budapest, 2010. 7. p.

830 GYARMATI György: A diktatúra intézményrendszerének kiépítése Magyarországon (1948-1950). In: Jelenkor, XXXIV. évf. (1991) 2. 138-147. p.

${ }^{831}$ GYARMATI György: Harc a közigazgatás birtoklásáért. A koalíción belüli pártküzdelmek az 1946. évi hatalmi dualizmus időszakában. Századok, CXXX: évf. (1996) 3. 497-570. p.
} 
Gyarmati György 2011-ben ${ }^{832}$ megjelent A Rákosi-korszak: rendszerváltó fordulatok évtizede Magyarországon,1945-1956 címü monográfiájában az 1945 és 1956 között időszakot a „fordulatok évtizedének” nevezi: amikor is „,volt három rendszerátalakítási kísérlet: egy parlamentáris demokráciát teremteni igyekvő, egy diktatórikus és egy ettől szabadulni próbáló." 833

A szerző az 1945-öt követő néhány év időszakát egy parlamentáris demokráciát teremteni igyekvő „,rendszerátalakítási kísérletnek” nevezi, majd azt is hozzáteszi, hogy ez a bizonyos kísérlet, a „próbálkozó” demokrácia „kérészéletű lett.”834 E felvetésnél természetesen jóval vitatottabbá vált Gyarmati Györgynek az az érvelése, miszerint az általa „fordulatok évtizedeként” aposztrofált időszak, vagyis az 1945 és 1956 közötti esztendők egésze nevezhető Rákosi-korszaknak. Gyarmati ekképpen támasztja alá kijelentését: Rákosi „volt a legmeghatározóbb szereplője a korabeli magyar belpolitikai életnek. Már akkor is, amikor formálisan még nem mondhatta magáénak a legfontosabb országkormányzói posztot (posztokat). Ez indokolja a »Rákosi-korszak« elnevezést."835

Gyarmati az általa Rákosi-korszaknak tartott 1945 és 1956 közötti időszakot alperiódusokra bontja, így értelmezése szerint a háború utáni esztendők, a koalíciós évek történeti értelemben vett „önállósága” is megmarad, amely részszakaszt különböző elnevezésekkel illeti a könyvben: 1946-47 kapcsán mint a „hatalmi dualizmus” időszakáról ír, de használja minderre a „köztes évek”836 fogalmat is. Az 1945-47-es időszak Gyarmati szakmai álláspontja szerint a „presztalinalizálás” korszaka - mint írja: „1945-1947 között a politikai nyilvánosság elött zajló demokratizálás közepette zajlik a kulisszák mögött, rejtőzködve érvényesített presztalinalizás." ${ }^{837}$ Kulcskifejezésnek tekinthetjük ,,a nyilvánosság előtt zajló demokratizálás” fogalmi összetételt; Gyarmati ezzel a megfogalmazással utal az 1945-öt követő néhány év demokráciájának kettősségére: a felszínen a formális demokrácia szabályai alapján alakultak a politika történései, de eközben rejtetten, lopakodó jelleggel zajlott a diktatúra előkészítése.

\footnotetext{
${ }^{832}$ E megközelítés gondolati előzménye 1988-ban a Gyarmati György által társszerkesztett és -írt Magyar hétköznapok Rákosi Mátyás két emigrációja között 1945-1956 című kötet bevezetőjében is tetten érhető. A bevezetőben a szerzők leszögezik, az 1944 decemberétől következő „tizenkétesztendős korszakot” két nagyobb időszakra lehet osztani, a kommunista egyeduralom létrejöttéig terjedő, majd az azt követő periódusra (Botos János-GYARMATI György- Korom Mihály- Zinner Tibor: Magyar hétköznapok Rákosi Mátyás két emigrációja között 1945-1956. Minerva, Budapest, 1988. (5.p.)

${ }^{833}$ GyaRMATI György: A Rákosi-korszak: rendszerváltó fordulatok évtizede Magyarországon, 1945-1956. Állambiztonsági Szolgálatok Történeti Levéltára - Rubicon, Budapest, 2011. 23. p.

${ }^{834} \mathrm{Uo}$

${ }^{835}$ Uo. 24. p.

${ }^{836}$ Uo. 65. p.

${ }^{837}$ Uo. 24. p.
} 
A korábbiakban idézett tanulmányában Standeisky Éva arról ír, miszerint Gyarmati György könyve „már címével - Rákosi-korszak, 1945-1956 - is azt sugallja, hogy szerzője a háború befejezését követő éveket lényegében nem tartja külön történelmi entitásnak, hanem csupán a Rákosi-kor némi egyedi sajátossággal rendelkező bevezető szakaszának tekinti.”ß38 Standeisky úgy gondolja, Gyarmati azzal, hogy a koalíciós évek periódusát a Rákosikorszakhoz csatolja, ,végső soron megfosztja ezt az időszakaszt demokratikus jellegétől.",839

Püski Levente a Gyarmati György-féle korszakjelölő „,presztalinizálás” kifejezést vizsgálta, s arra hívta fel a figyelmet, hogy Gyarmati az egész monografikus feldolgozását a sztalinizálás fogalma köré csoportosítja. „Így kapja az 1944 végétől 1947-ig tartó bő két év a presztalinizálás, az 1948-1953 közötti időszak a sztalinizálás, az 1953 júniusával induló szakasz pedig a de-, illetve a resztalinizálás megjelölést”840 - írja Püski Levente. Szerinte Gyarmati György fogalomhasználata sokrétü és összetett, de a presztalinizálás kifejezést árnyalná Püski, aki úgy gondolja, az események nemcsak a későbbi diktatúra, hanem egy demokrácia kialakulásának a lehetőségét is magukban hordozták. Ebből következően Püski inkább 1947-1948-től datálja magát a Rákosi-korszakot; akkortól, amikor megindult a politikai berendezkedés „többarcúságának” a felszámolása és egy szovjet típusú rendszer kiépítése.

Szajda Szilárd szintén a ,presztalinizálás” fogalommal foglalkozott kritikájában. Szajda nem fogadja el például a presztalinizálás egyik jellemzőjének az igazolóbizottságok létét, tevékenységét, amit Gyarmati viszont a presztalinalizálás tünetének tekint. „A társadalmi pozíciók ilyetén leosztása lehet egy pilléresedő, vagy nagykoalíciós demokrácia

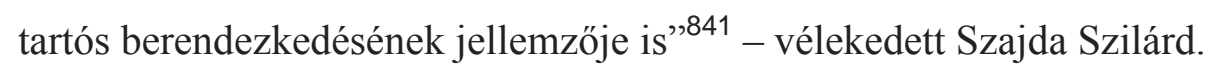

Sipos Levente történész Az 1945 utáni Rákosi Mátyás című elöadásában, majd publikációjában - még Gyarmati György monográfiájának megjelenése előtt - szintén azt az álláspontot fogalmazta meg, miszerint nevezhető az 1945 és 1956 közötti időszak Rákosikorszaknak. „1945-ben annyira új időszámítás kezdődött, a korábbival teljesen szakító, a magyar történelem minden más szakaszától elütő berendezkedés alakult ki, s ez annyira összefonódott Rákosi nevével, hogy okkal használható a Rákosi-korszak, vagy ritkábban a

\footnotetext{
838 STANDEISKY Éva: Tétova újraértelmezések. Magyarország második világháborút követő évei a rendszerváltozás utáni történetírásban. 137. p.

${ }^{839}$ Uo.

${ }^{840}$ PÜSKI Levente: Az államtól az államosított társadalomig. In: Korall, XIII. évf. (2012) 49. 132-136. p.

${ }^{841}$ SZAJDA Szilárd: A Rákosi korszak (Gyarmati György: A Rákosi-korszak). In: Múltunk, LIX. évf. (2014) 1. 74-83. Elérhető: http://epa.oszk.hu/00900/00995/00037/pdf/EPA00995 multunk_2014_01_074-083.pdf (A letöltés időpontja: 2015. május 26.)
} 
Rákosi-éra elnevezés"842 - vallja Sipos, aki az 1949 utáni időszakra vonatkoztatva külön használja a „rákosizmus” terminus technicust.

Gyarmati György álláspontjának összegzésként megállapíthatjuk: a szerző a koalíciós évek időszakát 1944/45 és 1947 közé helyezi és maga ezt a korszakot a presztalinalizálás periódusának tartja - részének a szerinte 1945-ben kezdődő Rákosi-korszaknak, ezáltal viszont azt üzenve, hogy a háború utáni néhány évet nem tekinti teljes értékü történeti korszaknak, hanem csak az 1945-től 1956-ig tartó „fordulatok évtizede” egyik önálló szakaszának.

Láthattuk, Sipos Levente is azt vallja, hogy a koalíciós évek is része a Rákosikorszaknak, míg Standeisky Éva, Püski Levente és Szajda Szilárd nem ért egyet mindezzel.

Láthattuk, Gyarmati György különböző publikációiban, hogy az 1945 utáni néhány esztendő dimenziójában érzékel demokráciatartalmat: egyik kötetének a címe is erre utal (Demokráciából diktatúrába). Ha a demokrácia megléte szempontjából vizsgáljuk a fogalomhasználatot, logikailag a Rákosi-korszak akkor kezdődhet, amikor a kommunista pártvezér már - Gyarmati korábbi kifejezésével élve - omnipotens jellegü hatalmat birtokol. Önmagában a (kvázi) demokratikus struktúrán belüli hegemón hatalombirtoklás még nem tünik elegendőnek ahhoz, hogy Rákosi-korszaknak nevezzük például az 1945 és 1947 közötti időszakot is. A demokráciaértelmezés szempontrendszeréből kiindulva fogalmilag nehezen értelmezhető Rákosi-rendszernek tekinteni azt az időszakot is, amikor a magyar nép kétszer is képes volt a hegemón kommunista hatalom ellen szavazni. Ha az 1945-ös és a '47-es választások eredménye ellenére az 1945 és 1947 közötti időszak is a Rákosi-korszak része, akkor ezzel logikailag azt állítjuk, hogy a demokratikus formák egyáltalán - a legkisebb mértékben sem - számítottak és 1945-tel kezdve csakis kommunista erőhatalom uralkodott. Gyarmati korábban meggyőzően érvelt amellett, hogy a hegemón kommunista hatalmi struktúra létezett már 1945-ben is, ezt a magunk részéről is elfogadjuk, ugyanakkor Nagy Ferenc kormányzásának időszakát még nem lehet az kommunista omnipotens hatalmi berendezkedés részének tekinteni.

A demokrácia „gleichschaltolása" mint fontos fogalom már Gyarmati Györgynál is előfordult. Ez a kifejezés érhető tetten Szerencsés Károly koalíciós éveket érintő

\footnotetext{
${ }^{842}$ SIPOS Levente: Az 1945 utáni Rákosi Mátyás. In: ABLONCZY et al. (szerk): A magyar történelem vitatott személyiségei. Kossuth Könyvkiadó, Budapest, 2008. 347. p.
} 
demokráciaértelmezésénél is. ${ }^{843}$ Szerencsés úgy véli, az a kiindulópont, hogy a magyar társadalom 1945-ben ,alkalmas állapotban volt ahhoz, hogy meginduljon a demokratikus evolúció útján." ${ }^{844}$ A történész az „alkalmas állapot” mint tény alátámasztására említi, hogy addigra már a dualizmustól számítva sok évtizedes parlamentáris hagyomány állt a magyar közélet rendelkezésére, majd azt is hozzáteszi, hogy a polgárság súlyos veszteségei ugyanakkor gyengítették a demokrácia bázisát. Szerencsés cikkében amellett tesz hitet, hogy 1945-46-ban még „realitás, de legalábbis remény volt” a demokratikus jövőkép - „1947 végére kiderült, hogy illúzió volt." ${ }^{845}$ A történész a koalíciós évek talán legfontosabb tapasztalatának nevezi, hogy a választások szükségesek, de nem elegendőek a demokrácia létezéséhez. A koalíciós esztendők magyar demokráciájának bukása kapcsán a legfontosabb szempontként arról ír Szerencsés, hogy hiába voltak, lettek volna meg a demokrácia belső feltételei, de „a magyar demokrácia külső feltételei”846 hiányoztak; mert a Szovjetuniónak nem volt érdeke a magyar polgári demokrácia fennmaradása.

Szerencsés a Földesi Margittal közösen írt Halványkék választás címü kötetükben az 1944 decemberétől 1947 augusztusáig tartó időszakot „a demokráciakísérlet” fogalommal írják körül. ${ }^{847} \mathrm{~A}$ demokráciakísérlet mint fogalom jellemző kifejezésévé vált a rendszerváltozás utáni történettudományban a koalíciós időszak leírására, értelmezésére Romsics Ignác is demokráciakísérletnek tekinti az 1945 és 1949 közötti időszakot. Romsics Ignác a Magyarország története a XX. században című munkájában az 1945 utáni néhány év időszakát fogalom-meghatározásában „átmeneti időszaknak” nevezi és a népi demokrácia kifejezés mellett nem fogadja el a koalíciós évek fogalmat sem - sőt, a „koalíciós évek” terminus használata szerinte eufémizmus. ${ }^{848}$ Romsics Magyar sorsfordulók című könyvében az 1949-es esztendő dimenziójában „a demokrácia végéről” ír, ${ }^{849}$ vagyis érvelése arról szól, hogy 1949 előtt a „demokrácia” időszakáról érdemes beszélni, de használja az ,átalakulás” kifejezést is. A periodizáció tekintetében Romsics álláspontja egyértelmü: 1944-től 1949-ig egy demokráciakísérletről mint jelenségről beszélhetünk, de a korszakra rányomta a bélyegét a már egész korán megfigyelhető szovjetizálási tendencia. ${ }^{850}$ A Huszadik századi magyar

\footnotetext{
843 SZERENCSÉS Károly: Hová tünt a demokrácia? Magyarország gleichschaltolása, 1945-1949. Rubicon, XXI. évf. (2010) 2. 4-19. p.

${ }^{844}$ Uo. 7.p.

${ }^{845}$ Uo. 19. p.

${ }^{846}$ Uo.

${ }^{847}$ FÖLDESI Margit-SzERENCSÉS Károly: Halványkék választás. Kairosz Kiadó, Budapest, 2001. 48. p.

${ }^{848}$ RoMSICS Ignác: Magyarország története a XX. században. Osiris, Budapest, 1999. 271-272.p.

${ }^{849}$ RoMSICS Ignác: Magyar sorsfordulók. Osiris, Budapest, 2012. 170. p.

${ }^{850}$ Scheibner Tamás irodalomtörténész szerint a szovjetizálás mint jelenség leírására „nem nagyon létezik hasonlóan tömör alternatív fogalom. A »kommunizálás« jóval tágabb jelentéssel bír, a »sztalinalizálást« pedig a
} 
politikai rendszerek címü 2011-ben megjelent tanulmányában korszakhatárként szintén 1949et említi, s az 1945 utáni időszakot úgy jellemzi, mint „demokratikus megújulási kísérletet." 851

Palasik Mária 2000-ben publikált A jogállam megteremtésének kísérlete és kudarca Magyarországon: 1944-1949 ${ }^{852}$ címủ kötetében demokráciakísérletnek tartja az 1944 és 1949 közötti időszakot. Palasiknál a demokrácia fogalmát lényegében szinonimaként a jogállam kifejezés helyettesíti. 2011-ben angol nyelven megjelent monográfiájában (Chess Game for Democracy) ${ }^{853}$ az 1944 és 1947 közötti időszakot jelöli meg a demokráciáért vívott sakkjátszma" rövid történeti korszakaként. Palasik Mária, a korszak meghatározó kutatója is több periodizációs verziót vázol, ami magának a témának a sokrétüségéből is fakad, hiszen Palasik 2011-ben kiadott könyvében jogosan érvel amellett, hogy a demokráciáért vívott „sakkjátszma” valóban lezárult 1947-ben, de a jogállamiságnak a szovjetizálódó magyar struktúrában is maradtak még „nyomai” két éven át.

Agárdi Péter irodalomtörténész a Nemzeti értékviták és kultúrafelfogások címü monográfiájában is a „kísérlet” kifejezést használja az 1945-öt követő évek vonatkozásában. Agárdi a „demokratikus pluralizmus kísérlete”854 korszakának nevezi a koalíciós éveket. Agárdi szerint az 1945 utáni néhány esztendőt a „demokratikus építkezés” és az „ideológiai pluralizmus”855 jellemezte. A „kísérlettel” kvázi szinonimaként ható fogalmat, az „ígéretet” használja Pók Attila. Póknál az 1945 és 1949 közötti időszak megnevezésére ,,a demokrácia ígéretét hordozó időszak" ${ }^{856}$ kifejezés szerepel.

A történészi szóhasználatban a koalíciós évek demokráciájára vonatkozó különböző jelzőket vizsgálva találkozhatunk még a „törékeny” és a „megfojtott” fogalmakkal is. Gantner Péter a „törékeny demokrácia éveiröl”857 ír; Gantner szerint 1945 és 1947 között beszélhetünk koalíciós időszakról, ekkor voltak demokratikus viszonyok, amely rövid korszak

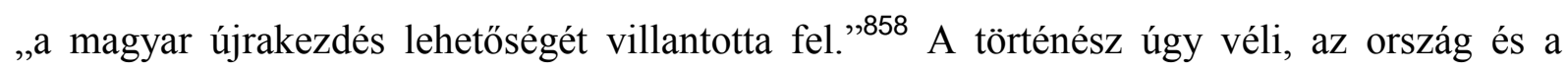

\footnotetext{
szovjetizálás egyik alszakaszára szokták alkalmazni.” (SCHEIBNER Tamás: A magyar irodalomtudomány szovjetizálása. A szocialista realista kritika és intézményei, 1945-1953. Ráció Kiadó, Budapest, 2014. 13. p.)

${ }^{851}$ ROMSICS Ignác: Huszadik századi magyar politikai rendszerek. In: KovÁCS KISS Gyöngyi - RoMSICS Ignác (szerk.): A mi 20. századunk. Komp-Press Kiadó, Kolozsvár, 2011. 27. p.

${ }^{852}$ PALASIK Mária: A jogállam megteremtésének kísérlete és kudarca Magyarországon: 1944-1949. Napvilág Kiadó, Budapest, 2000.

${ }^{853}$ PALASIK Mária: Chess Game for Democracy. Hungary Between East and West 1944-1947. McGill-Queen's University Press, Montreal \& Kingston, 2011.

${ }^{854}$ AGÁRDI Péter: Nemzeti értékviták és kultúrafelfogások. 1847-2014. Napvilág Kiadó, Budapest, 2015. 36. p.

${ }^{855}$ Uo. 178. p.

${ }^{856}$ Pók Attila: A javíthatatlan girondisták. A radikális demokrácia alternatívája 1945 után. Világosság, XL. évf. (1999) 3. 47-54. p. /47.p./

${ }^{857}$ GANTNER Péter: Egy elfelejtett államfö. Zsedényi Béla életpályája. I.A.T. Kiadó, Budapest, 2008. 12. p.

${ }^{858}$ GANTNER Péter: Valentiny Ágoston, az elfelejtett államférfi. I.A.T. Kiadó, Budapest, 2010. 5. p.
} 
magyar demokrácia sorsát a „Szovjetunió területszerző politikája” ${ }^{859}$ határozta meg, ezekben az esztendőkben szovjet politikai, gazdasági és kulturális „behatolás” történt, amely jelenséget Gantner „az ország szovjetizálása"860 fogalommal írja le. Stefano Bottoni A várva várt Nyugat: Kelet-Európa története 1944-töl napjainkig címü könyvében kérdőjelesen felvet több fogalmat is a koalíciós évek szempontjából, így a „többlépcsős forradalom,” a „népi demokrácia” és a „szovjetizálás” kifejezések is szerepelnek nála, de maga inkább a „megfojtott demokrácia” terminus technicust használja. ${ }^{861}$

Bihari Mihály alkotmányjogász a Magyar politika 1944-2004 címmel írt könyvében a koalíciós éveket érintően a ,fenyegetett demokrácia” fogalmi összetételt szerepelteti. A „korlátozott és fenyegetett demokrácia”862 kifejezésen túl a korszakot jellemző fogalmakként mindezeket is használja: „társadalmi átalakulás és demokratikus rendszerváltozás, "863 az „első demokratikus rendszerváltozás "864 időszaka, „demokratikus kiegyezés”865 periódusa, de előfordul a korszakra vonatkozóan a „,szovjetizálás”866 kifejezés is nála. Bihari Mihály szerint 1945 és 1950 között két rendszerváltozás következett be: 1944/45-ben történt meg a demokratikus rendszerváltozás, 1948 és 1950 között pedig végbement a kierőszakolt rendszerváltozás. Az alkotmányjogász szerző megítélése szerint 1944/45 és 1948 között Magyarországon korlátozott, bizonyos értelemben fenyegetett demokrácia működött.

Az egyik legegyedibb szóhasználat azonban Feitl István nevéhez köthető, aki szerint „antiliberális demokráciakonstrukció” volt Magyarországon az 1945 utáni néhány esztendőben. Feitl István egyértelmüen amellett tesz hitet, hogy 1944-45-ben és az azt követő években, egészen 1948-ig „demokratikus tendenciák”,867 jellemezték a kialakuló államstruktúrát és közéletet. Feitl úgy véli, a „demokráciaideál” számon kérése ugyanakkor „képtelenség” 1945-tel és egészében a koalíciós korszakkal szemben, mert a „demokratizálás rendkívüli körülmények között”868 formálódott. „Ki lehet jelenteni, hogy demokráciáról nem lehetett szó, hiszen túlságosan szűkek voltak azok a keretek, amelyek között a politikai és

\footnotetext{
${ }^{859}$ Uo.

${ }^{860}$ GANTNER Péter: Magyar diplomaták küzdelme a párizsi békekonferencián. Publikon Kiadó, Pécs, 2015. 18. p.

Stefano BotTONI: A várva várt Nyugat: Kelet-Európa története 1944-től napjainkig. MTA BTK Történettudományi Intézet, Budapest, 2015. 60. p.

${ }^{862}$ BIHARI Mihály: Magyar politika 1944-2004. Politikai és hatalmi viszonyok. Osiris, Budapest, 2005. 15. p.

${ }^{863}$ Uo. 14. p.

${ }^{864}$ Uo.

${ }^{865}$ Uo. 65. p.

${ }^{866}$ Uo. 85. p.

${ }^{867}$ FEITL István: Az ideiglenesség időszaka: Magyarország 1944-1945-ben. Eszmélet. 2015 nyár. 5-41. p. Elérhetö: http://eszmelet.hu/wp-content/uploads/2015/10/eszmelet106nyomdai.pdf (A letöltés időpontja: 2015. november 15.)

${ }^{868}$ Uo. 22. p.
} 
szellemi pluralizmus kibontakozhatott. Egy demokráciaeszmény szemszögéből mindez igaz, de itt a totális fasizmus és az ahhoz vezető út teljes szellemi tárházának kizárólagos uralma

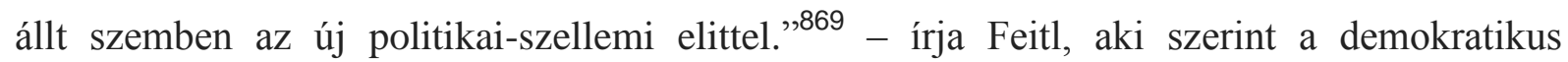
politizálás „bizonyos készsége” 1945-ben megvolt a magyar kommunistákban - már csak azért is, mert nem tudták, hogy mi lesz Sztálin jövendőbeli szándéka.

Feitl az „antiliberális demokráciakonstrukció" ${ }^{870}$ fogalom alátámasztására kiemelten „a magántulajdont semmibe vevő” földreformot hozza fel hozza példaként. A háború utáni nélkülözések közepette Feitl szerint a demokrácia egyet jelentett „az emberhez méltó körülmények megteremtésével, ezért a munka világában létező milliók számára kellett esélyt, jogot biztosítani" ${ }^{871}$ - érzékelteti ezáltal a történész, hogy az antiliberális demokráciakonstrukció lényegében egyfajta szociális demokrácia jellemzőit viselte magán.

$\mathrm{Az}$ eddig ismertetett fogalomhasználatok tekintetében szerepelt a „kudarcos”, a „gleichschaltolt”, a „korlátozott”, a „törékeny”, az „antiliberális”, a „korlátozott” vagy a „megfojtott” kifejezés, de mindezen jelzők szempontjából azonos tartalom, hogy a szerzők mindegyike - még ha különböző jelzős szerkezeteket használva, de demokráciakonstrukciónak tekinti az 1945 utáni néhány év magyar politikai struktúráját.

A Szakács Sándor és Zinner Tibor A háború »megváltozott természete» - Adatok és adalékok, tények és összefüggések - 1944-1948 címü 1997-ben kiadott könyvükben legfeljebb demokráciaszerüségnek tartják a jelzett időszakot, de ezt a fogalmat sem használják. A kiadvány első fejezetének címében a koalíciós idők kifejezés sokatmondóan idézőjelben szerepel. A „koalíciós politika” - „nagykoalíció” fejezetrészben a szerzők a korszak előzményként 1944 augusztusát jelölik meg, vagyis amikor a Vörös Hadsereg Magyarország területére lépett. ${ }^{872}$ Szakács és Zinner kiadványuk epilógusában világítják meg leginkább álláspontjukat, miszerint a „megszállás” jelenségét tekintik mindenek feletti, abszolút politikai ténynek, mint írják: ,a kommunista párt itthon változatlanul gyökérzet nélkül, nem »társadalmi« támogatottságra, hanem alantas ösztönzésekre támaszkodott és ún. »sikerei« teljességgel elválaszthatatlanok voltak a megszállók beavatkozásaitól.»,873

A koalíciós éveket és a demokráciaesélyeket tekintve is a megszállás ténye valóban kiemelkedő jelentőségü tényező, ugyanakkor úgy véljük, hogy a megszállás tényét abszolúttá

\footnotetext{
${ }^{869}$ Uo. 23. p.

${ }^{870}$ Uo. 25. p.

${ }^{871}$ Uo.

${ }^{872}$ SZAKÁCS Sándor-ZINNER Tibor: A háború „megváltozott természete”. Adatok és adalékok, tények és összefüggések. 1944-1948. Genius Gold Rt. - Batthyány Társaság, Budapest, 1997. 8. p.

${ }^{873}$ Uo. 446. p.
} 
tenni egyet jelent azzal, hogy a koalíciós esztendők időszakára pusztán mint hadtörténeti kötődésű eseménysorra tekintünk. Ez a megközelítés pedig teljességgel relativizálja a korszak politikatörténeti megközelítéseinek létalapját, s közvetve azt is kétségbe vonja, hogy demokrácia-diskurzus létezett, létezhetett egyáltalán a második világháború utáni években Magyarországon.

Szakács Sándor és Zinner Tibor - komparatív szemüvegen át - a következő történeti korszak, a rákosista diktatúra nézőpontjából látja csak értékelhető demokráciaszerüségnek a koalíciós időszak politikai struktúráját. Szakács és Zinner szerint a „koalíciós években” számtalan jogtalanság, jogtiprás történt, de a bekövetkező sztálinista elnyomás felől közelítve mégis idillinek tünik az az időszak.

Ungváry Krisztián kiindulópontja az, hogy „Magyarország 1945-ös sorsát a Szovjetunió döntötte el." ${ }^{874}$ Ungváry elemzi a folyamatot, amelynek lényege, hogy a szovjetek még a második világháború befejezése előtt kidolgozták ,,a szocializmushoz vezető békés, fokozatos út koncepcióját. Taktikai okokból lemondtak a kommunista doktrína leggyülöltebb tételeiről, a proletárdiktatúra bevezetéséről”875 - írja Ungváry, aki azt viszont egyértelművé teszi, mivel a kommunista politika lényege a hatalomátvétel, ebből fakadóan 1945 után nem létezhetett Magyarországon demokráciakísérlet. „Az elérendő cél, az ország bolsevizálása adott volt, a hozzá vezető utat pedig a mindenkori erőviszonyoknak megfelelő

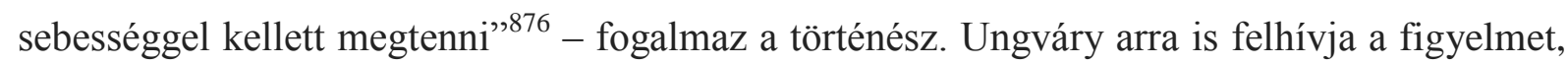
hogy a magyar kommunista vezetők „,személyüknél fogva is” ${ }^{\text {} 877 ~ a l k a l m a t l a n o k ~ v o l t a k ~ a r r a, ~}$ hogy hosszabb távon demokratikus viszonyokat tartsanak fenn. ${ }^{878}$ Ungváry Krisztián szövege alapján egyértelmü, a történész nem tekinti demokráciakísérletnek a koalíciós évek államberendezkedését.

\footnotetext{
${ }^{874}$ UNGVÁRY Krisztián: Magyarország szovjetizálásának kérdései. In: Mítoszok, legendák, tévhitek a 20. századi magyar történelemről. Szerk. ROMSICS Ignác. Osiris, Budapest, 2002. 279. p.

${ }^{875}$ Uo. 286. p.

${ }^{876}$ UNGVÁRY Krisztián: Magyarország szovjetizálásának kérdései. 294. p.

${ }^{877}$ Uo. 298. p.

878 Horváth Attila a Diktatórikus berendezkedések a 20. századi magyar alkotmánytörténetben címü tanulmányában arra hívja fel a figyelmet, hogy már a cári Oroszország első világháborús terjeszkedési ambícióival is a Kelet-Közép-Európai térség felé tekintett „A II. világháború után a szovjet érdekszféra már nagyjából ugyanarra a területre terjedt ki, amelyek megszerzésére az Orosz Birodalom első világháborús tervei irányultak." (HORVÁTH Attila - RÉVÉsz T. Mihály: Diktatórikus berendezkedések a 20. századi magyar alkotmánytörténetben. In: MEZEY Barna (szerk.): Magyar alkotmánytörténet. Osiris Kiadó, Budapest, 2003. 466. p.)
} 
Schmidt Mária sem tekinti a demokratikus kísérlet időszakának az 1945 utáni néhány év korszakát; álláspontja szerint Magyarország sorsa „Jaltában elrendeltetett” ${ }^{\text {} 879 ;}$; második világháború után az ország függetlenségétől megfosztva, egy totális kommunista diktatúra uralma alá került. ${ }^{880}$ Schmidt szerint nem volt átmenet, mert az „ország szovjet megszállásával kijelöltetett a proletárdiktatúra felé vezető irány." ${ }^{881}$ A történész úgy véli, a szovjet megszállás megvalósulásával eldőlt, hogy „a cuius regio eius religio elvének megfelelően" szovjet típusú kommunista rendszer épül ki Magyarországon is. A történész úgy véli, 1944 őszén kezdetét vette az ország szovjetizálása, amelyet fokozatosan, lépésről lépésre haladva 1949-re be is fejeztek. „Mindössze annyi történt, hogy totális térnyerésük, szovjetek által támogatott hatalmi szerkezetük kiépülésének befejeződése előtt a magyar kommunisták taktikai okokból palástolni igyekeztek valódi céljaikat."882 - fogalmaz Schmidt Mária, aki szerint a '45-ös választások hiába voltak demokratikusak, a választások eredményei „,a gyakorlatban nem számítottak, "883 ezért a demokratikus választás ténye nem igazolja azt, hogy a demokráciának esélye lett volna 1944-45 után. Schmidt nem beszél a koalíciós korszak vonatozásában demokráciáról, hanem csak „demokratikus látszatról” tesz említést.

Megítélésünk szerint az 1945 utáni néhány esztendőt, a koalíciós évek korszakát és a Rákosi-rendszert éppen a demokratikus párbeszéd nyelvi tere/választóvonala különíti el egymástól. Amíg a demokráciának voltak legalább tüneti megnyilvánulásai (például míg volt ellenzéki/antikommunista párt a parlamentben), addig beszélhetünk önálló történeti időszakról. Amikor a demokratikus feltételek nincsenek meg, nyomokban sem találhatóak meg a jogállami jellegű múködés elemei, akkor az a berendezkedés már a kommunista diktatúra struktúrája. Úgy véljük, a demokrácia-tartalom mennyisége, minősége alkalmas lehet a korszakok (a koalíciós- és a Rákosi-korszak) közötti elhatárolás felvázolására.

Papp István nem a koalíciós évek demokráciáját értelmezi, hanem magát a korszakot igyekszik történelmi perspektívába ágyazni, s ezáltal kijelölni a parlamentáris demokrácia helyét az 1945 utáni néhány év történetében. Papp az „1945 tavasza” és „1947 tavasza” közötti „időszakot” az „elveszett reformkornak” tartja. A szerző úgy véli: a kezdő és a

\footnotetext{
${ }^{879}$ A történész minden bizonnyal „Jaltáról” mint jelképröl beszél, hiszen tudjuk, hogy Kelet-Közép-Európa mint szovjet érdekszféra sorsa nem az 1945 februári jaltai tanácskozáson, hanem már jóval hamarabb eldőlt. A jaltai egyezmény szövege nem érinteti az érdekszféra-lehatárolások kérdéskörét.

${ }^{880}$ SCHMIDT Mária: „Most majd mindent úgy csinálnak, mint az oroszoknál.” A kommunizmus kiépülése Magyarországon. In: LŐRINC László (szerk.): Egyezzünk ki a múlttal! Műhelybeszélgetések történelmi mítoszainkról, tévhiteinkröl. 90-101. p.

${ }^{881}$ Uo. 92. p.

${ }^{882}$ Uo. 93-94. p.

${ }^{883}$ Uo. 97. p.
} 
végpontot „viszonylag könnyü” kijelölni. ${ }^{884}$ Kezdődátumként azért szerepelteti '45 tavaszát, mert az ideiglenes kormány akkorra tudta kiterjeszteni szuverenitását az egész országra, míg 1947 tavasza azért záróidőpont a szerző szerint, mert noha a párizsi békeszerződés megkötésével '47 februárjában az ország visszanyerte szuverenitását - ekkora azonban a „kisgazdapárttal szemben elhatalmasodó támadás szétzúzta a magyar politikai elitnek azt a

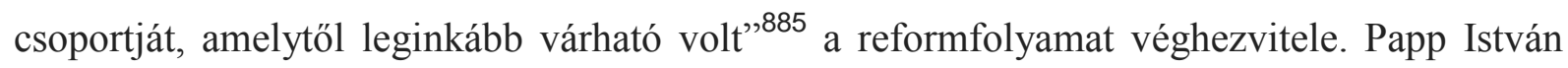
szerint azonban „e történelmi mércével mérve leheletnyi ideig tartó kor mégsem tekinthető elvesztegetett időnek, sokkal inkább egy elfelejtett reformnemzedék színrelépésének lehetünk tanúi." ${ }^{886}$ Papp számára egyértelműen 1947 zárja a koalíciós éveket, ahogy ő mondja; az elveszett reformkor időszakát, mert ekkor olyan „elkanyarodás” történik, ami után már Magyarország a proletárdiktatúra felé fordul. Papp István az alábbi szempontok, intézkedések, történések, jelenségek miatt tartja egyfajta elveszett reformidőszaknak a koalíciós éveket: a földreform, szabad választások a térségben egyedülálló módon, a kisgazdák közéleti stílusában „az európai minták” követése, új elit a közigazgatásban, az ebben az időszakban a tudomány, a müvészet és az oktatásterületén történt változások, az újjáépítés gyors véghezvitele.

Papp azt állapítja meg, hogy a többség úgy érezte: az újrakezdés páratlan esélye adódott a magyar társadalom számára. A szerző e „leheletnyi ideig tartó kor” teljesítményét nem tartja rossznak, ezért is ítéli méltónak ,az elveszett reformkor” terminus technicus használatát, mint írja: „az 1945 és 1947 közötti magyar politikai elitnek a parlamentáris demokrácia iránt elkötelezett része összességében nem teljesített rosszul. „887

Papp Istvánnak a koalíciós évekre mint „elveszett reformkorra” vonatkozó metaforája érzelmileg visszaadja a korszak pszichés dinamikáját, az újrakezdés mint közösségi élmény politikát és társadalmat formálni képes felhajtóerejét. Értelmezésünk szerint ugyanakkor a reformkor kifejezés olyan szinten foglalt a magyar történeti gondolkodásban, hogy más időszakra kevésbé hatékonyan alkalmazható. A koalíciós évek a kulturális emlékezetben közel sem maradt fenn olyan markáns időszakként mint a reformkor. Az 1945 utáni néhány esztendőknek nem érzékelhető olyan történeti kihatású történeti teljesítménye mint az 1825 utáni bő két évtizednek - a demokrácia-teljesítményt és közösségi élményt tekintve viszont az 1945-öt követő 3-4 esztendő valós és markáns referencia-keret, amely időszak kapcsán az „elveszett lehetőség” mint kifejezés legitim és egyben érzelmi többletet kifejező fogalmi

\footnotetext{
${ }^{884}$ PAPP István: Az elveszett reformkor. Kommentár, I. évf. (2006) 2. 46-54. p.

${ }^{885}$ Uo. 46. p.

${ }^{886}$ Uo.

${ }^{887}$ Uo. 53. p.
} 
összetétel. Az elveszett lehetőség nyelvi panelként a demokrácia minősítése szempontjából is joggal használható: úgy érezzük, a koalíciós évek vonatkozásában az elveszett lehetőségek demokráciája is mint fogalom megfelelő módon írhatja le a korszak demokráciára vonatkozó jellemzőit.

Bódy Zsombor a demokráciák és a diktatúrák közötti szimbolikus kommunikációs térben helyezi el a koalíciós évek korszakát. Fogalom-meghatározásakor használja a demokráciák jellemző vonásának tekintett „többpárti” kifejezést, de mindehhez hozzáilleszti az egyértelműen a diktatúrák leírásakor szereplő „totalitarizmus” terminológiát. Bódy 2008ban Két totalitarizmus között? Az 1945-48-as évek értelmezéséröl címmel publikált tanulmányt. Ebben a szerző - igaz, kérdőjeles formában, de - felveti, hogy a koalíciós évek világa, időszaka egyfajta „,többpárti totalitarizmusként" ${ }^{\text {888 }}$ is értelmezhető. Bódy írása elején arra hívja fel a figyelmet, hogy az ötvenes éveket és a nyilas rémuralmat egyaránt totalitarizmusként nevezik meg, viszont - ahogy a szerző fogalmaz: „azzal kapcsolatban azonban, ami e két korszak között történt, nincs konszenzus. ${ }^{889}$ Az álláspontok szerinte „két csomópont körül” rendeződnek el az „1945-48-as évek” értelmezésében. Bódy úgy véli, némelyek demokratikus újrakezdést látnak ezekben az években, amit később a kommunista hatalomátvétel szakított meg, míg ,a másik pólushoz tartozók szerint ez »a kommunista diktatúra bevezető fázisát képezi«."890 Bódy Zsombor szerint a koalíciós korszak és az 1945 előtti, illetve az 1948 utáni korszakok között kontinuitás fedezhető fel a tekintetben, hogy hol húzódnak a pártpolitikai szféra határai a társadalomban. Bódy már-már forradalmi módon veti fel, hogy noha az általa idézőjelbe tett „koalíciós évek” terminusa önálló történeti korszakot jelent, de megítélése szerint érzékelhető hasonlóságok vannak a korábbi és a későbbi „totalitarizmusok”, illetve a 1945-48-as időszak között. Mint megjegyzi: „a politika előrenyomulása a gazdaságban - és más, itt nem tárgyalt szférákban - a többpárti koalíció körülményei között azt a kérdést veti fel, hogy vajon e rövid néhány évben nem lehet-e többpárti totalitarizmusról beszélni Magyarországon?"891

A „többpárti totalitarizmus” mint a koalíciós évekre vonatkoztatott fogalomhasználat egészen újszerű történeti álláspontot sugall, ezért természetes, hogy a többpárti totalitarizmusfogalmat magát Bódy Zsombor is igyekszik árnyalni: „A »többpárti totalitarizmus« kifejezés

\footnotetext{
${ }^{888}$ BÓDY Zsombor: Két totalitarizmus között? Az 1945-48-as évek értelmezéséről. Kommentár, III. évf. (2008) 3. 61-69. p.

${ }^{889}$ Uo. 61.p.

${ }^{890}$ Uo.

${ }^{891}$ Uo. 68. p.
} 
természetesen csupán korlátozott értelemben használható. Nyilvánvalóan nem alkalmas e rövid korszak minden jellemzőjének megragadására."892 Mindezen túlmenően Bódy újabb érvet használ annak alátámasztására, hogy - korlátozott értelemben ugyan, de - legitim szakmai álláspont totalitáriusnak nevezni a koalíciós évek időszakát: „,a politika 1945-1948 között éppúgy elhagyta a modern nyugati társadalmakban elfogadottnak tekintett helyét, és éppúgy borított el más szférákat, mint a megelőző és a rákövetkező korszakokban is. Ezért és ennyiben nevezhető totalitáriusnak ez a korszak is."

A koalíciós évekre vonatkoztatott többpárti totalitarizmus fogalom gondolatgazdag és érdekes történeti felvetés, de főként társadalomtörténeti alapvetésü megközelítést sugall, vagyis nem a politika struktúráira vonatkozik elsősorban, másrészt a közgondolkodásban a totalitarizmus kifejezés alatt kifejezetten a náci-fasiszta és a kommunista diktatúra világát értik, nyelvileg ez a fogalom is foglalt. Egyelöre nem lelhető fel olyan markáns nyelvi apparátus, tematizációs keret, kitartó történészi szándék, amelyre építkezve a koalíciós éveket (többpárti) totalitarizmusként lehetne értelmezni.

\section{A koalíciós évek demokráciájára vonatkozó fogalmi struktúrák angol nyelvü történettudományi és politológiai publikációkban}

Hugh Seton-Watson, a tekintélyes angol politikai elemző és történész, aki a második világháború időszakában a brit diplomácia szolgálatában dolgozott Kelet-Közép-Európában a kommunista hatalomátvétel után rendkívül gyorsan, már 1950-ben terjedelmes monográfiában (The East European Revolution) ${ }^{894}$ elemezte az 1945 utáni kelet-közép-európai eseményeket.

A bevezetésben az angol történész leszögezi, hogy „megbocsáthatatlan lenne”895 a háború előtti rezsimeket demokráciának nevezni, ugyanakkor az sem helyes, ha az 1945 előtti múltra csakis mint a „sötét elnyomás” időszakára tekint valaki. Seton-Watson szerint 1945 őszére Magyarország lenyugodott, noha a törvényenkívüliség és a káosz nem szűnt meg teljesen, de mindezen jelenségek ellenére a parlamentáris választások a demokrácia melletti állásfoglalások voltak. A kommunisták célja a választások utáni másfél évben az volt, hogy lépésről-lépésre hajtsák végre a szovjetizálást, ebben a kisgazdapárt volt az „akadály.”896 A

\footnotetext{
${ }^{892}$ Uo. 69. p.

${ }^{893}$ Uo.

${ }^{894}$ Hugh SetOn-WATSON: The East European Revolution. Methuen, London, 1950.

${ }^{895}$ Hugh SetOn-WATSON: The East European Revolution. XI. p.

${ }^{896}$ Uo. 193. p.
} 
történész megállapítja, hogy a kommunisták propagandájában a kisgazdák elleni lényegi támadási pont az volt, hogy a fasiszták és reakciós városi középpolgári elemek tárhelyévé vált az FKgP. Seton-Watson megállapítja, a kommunisták mindenkit eltüntettek, akik az általuk uralt „köztársaság” vagy éppen az ő értelmezésük szerinti „,demokrácia” ellen vétettek. ${ }^{897}$

A lengyel származású amerikai történész-politológus, Carter elnök későbbi nemzetbiztonsági tanácsadója, Zbigniew Brzezinski a hatvanas években több müvében is (Ideology and Power in Soviet Politics, ${ }^{898}$ Totalitarian Dictatorship and Autocracy, ${ }^{899}$ illetve The Soviet bloc. Unity and Conflict ${ }^{900}$ ) érintette a kommunista hatalomátvétel és ezen belül a koalíciós évek magyar átalakulásának témáját. Brzezinski úgy gondolja, a kommunisták már a kezdetektől fogva totalitárius diktatúrát akartak kialakítani a kelet-közép-európai államokban. $^{901} \mathrm{~A}$ helyi társadalmaknak illúziói voltak erről, hittek a kommunisták demokratikus megnyilatkozásainak - föként Csehszlovákiában és Magyarországon. A lengyel-amerikai politikai elemző amellett érvel, hogy a szovjet vezetőknek valószínűleg nagyon konkrét terveik voltak: a kelet-európai társadalmat arról akarták meggyőzni, hogy népi demokrácia lesz, ez szerepelt a közbeszédben, de valójában ez a sajátos fogalom már a totalitárius diktatúra előzménye volt. ${ }^{902}$

Brzezinski szerint Magyarországon a kommunistáknak nehezebb volt a dolguk, mint Bulgáriában vagy Romániában a társadalomnak a kommunista diktatúrával szembeni erősebb ellenállása miatt. Brzezinski úgy gondolja, Rákosi közvetlenül a második világháború után be akarta bizonyítani, hogy a kommunizmus nem ellentétes a demokratikus rendszerrel. A politológus arról ír, hogy a népi demokrácia fogalma a marxizmus-leninizmus tanaiból levezethető, ennek az átmeneti struktúrának is jellemzője, hogy erősödik az osztálykonfliktus és jelen van a forradalom tudati tényezője. ${ }^{903}$ Brzezinski nézőpontjából a népi demokrácia „átmeneti periódus,"904 amely Zsdanovnak a Kominform 1947-es megalakulásakor mondott beszéde után vált egyre inkább a kommunista diktatúra szinonimájává. E fogalmat a

\footnotetext{
${ }^{897}$ Uo. 200. p.

${ }^{898}$ Zbigniew Kazimierz BRZEZINSKI: Ideology and Power in Soviet Politics. Frederick A. Praeger, New York, N.Y., 1962.

${ }^{899}$ Friedrich J. CARL - K. BRZEZINSKI: Totalitarian Dictatorship and Autocracy. Harvard University Press, Cambridge, 1965.

900 Zbigniew Kazimierz BrZEZINSKI: The Soviet Bloc. Unity and Conflict. Mass Harvard Univ. Press, Cambridge, 1969.

901 Brzezinski élesen megkülönbözteti a kommunista hatalomátvételek metódusát, mechanizmusát. „1917” értelmezése szerint valós társadalmi problémákra adott válasz volt, míg a második világháború után Lengyelországban és Magyarországon csakis a megszálló szovjet hadsereg jelenléte miatt alakulhatott ki kommunista uralom. (Zbigniew Kazimierz BRZEZINSKI: Between two Ages. America's Role in the Technetronic Era. The Viking Press, New York, 1970. 75. p.)

${ }^{902}$ BRZEZINSKI: Totalitarian Dictatorship and Autocracy. 369. p.

${ }^{903}$ BRZEZINSKI: The Soviet Bloc. Unity and Conflict. 27. p.

${ }^{904}$ Uo. 45. p.
} 
kommunista ideológusok folyamatos „,teoretikus változtatások" ${ }^{905}$ által formálták, ami példa a kommunista ideológiai rugalmasságra, de mindezeken túl köznapi értelemben mégis csak megtévesztés volt csupán.

Peter F. Sugar (A History of Hungary) „3 évnyi” politikai és gazdasági „pluralizmusról” szól (1944. december - 1947-48 tele), amit 1948-tól mint fordulóponttól jellemzése szerint - öt évnyi egyre növekedő sztálinista terror követett. A pluralizmus három éves időszakát úgy jellemzi, mint „,demokráciát a szovjet árnyékában." ${ }^{906}$ Sugar szerint a 1944 és 1947 közötti időszak koalíciós érája „demokratikus közjátéknak” ”07 bizonyult csak, majd azt is hozzáteszi, hogy ez a korszak „rövidebb volt a tervezettnél” és csak egy rövid átmenet volt a Horthy-féle tekintélyelvű jobboldaliságból a baloldali kommunista totalitarializmusba.

Jörg Konrad Hoensch (A History of Modern Hungary: 1867-1986) 1945-1946 kapcsán ír „,a magyar népi demokrácia megteremtésének” ${ }^{908}$ időszakáról. Hoensch szerint az 1945 és 1948 közötti években „fokozatos” kommunista hatalomátvétel zajlott. E periódus vonatkozásában használja az „új demokrácia"909 kifejezést is.

Benneth Kovrig (Communism in Hungary: From Kun to Kádár), ahogy a címben is olvasható, Kun Bélától Kádár Jánosig tekinti át a magyarországi kommunista mozgalom történetét. Kovrig a koalíciós évek időszakát „népi demokráciaként” határozza meg - a kommunista hatalomátvétel mechanizmusát pedig úgy írja le, mint egy átmenetet a népi demokráciából a diktatúrába. ${ }^{910}$ A szerző a kommunista történetírásra hivatkozik, amikor a fordulat évéről ír. Kovrig áttekinti a fordulathoz vezető folyamatot, mely szerinte 1947 elején indul és 1948 közepén záródik. A folyamat fontosabb állomásainak tekinti az „összeesküvés” felszámolását, a hároméves terv elindítását, a ’47-es választásokat, a bankok államosítását és a végén a két baloldali párt egyesülését.

Carl Beck 1973-ban napvilágot látott elemzésében arról ír, hogy 1944 és 1948 között a magyarországi történések eltértek az általa „,bolgár modellnek”911 nevezett általános kelet-

\footnotetext{
905 Uo.

${ }^{906}$ Peter F. SuGAR: A History of Hungary. Indiana University, Bloomington - Indianapolis, 1990. 368. p.

${ }^{907}$ E kifejezést használja a magyar származású Charles GATI is a korszakról szóló, 1986-ban megjelent angol nyelvü könyvében, így valószínüleg SUGAR tőle vehette át a fogalmat.(Charles GATI: Hungary and the Soviet bloc. Duke Univ. Press, Durham, N.C., 1986. 5. p. ill. 14. p.)

908 Jörg Konrad HoEnSCH: A History of Modern Hungary: 1867-1986. Longman, London - New York, 1988. 161. p.

${ }^{909}$ Uo. 164. p.

${ }^{910}$ Benneth KovRIG: Communism in Hungary: From Kun to Kádár. Hoover Institution Press, Stanford, 1979. 234. p.

911 Bulgária már 1947-ben „népi demokratikus” alkotmányt fogadott el. (J. F. BROWN: Bulgaria Under Communist Rule. Pall Mall Press, London, 1970.)
} 
európai változástól, amelynek az volt a lényege, hogy a második világháború után a helyi kommunista párt fokozatosan, de gyorsan vette át a hatalmat. Beck szerint 1948 márciusára jutott el a folyamat Magyarországon oda, hogy a magyar változás is a bolgár modellre kezdett hasonlítani. A magyarországi változást a „parlamentáris út a szocializmusba”912 fogalommal írja körül a történész. Beck úgy véli, a parlamentáris és a kényszerítő taktikák kombinációja által tudta megszerezni a hatalmat a kommunista párt Magyarországon és e folyamatot tetézte be a két baloldali párt egyesítése.

Nigel Swain is úgy gondolja, a Magyar Dolgozók Pártja megalakulása jelenti a fordulatot, a háború utáni évekre „a népfronttól a szovjet kommunizmusig"913 kifejezést használja. Mint „nagy változásról” beszél a szerző a háború végétől 1948-ig terjedő időszak kapcsán; ekkorra - mint írja - „Rákosi szalámi taktikája befejeződött.”" ${ }^{\text {,14 }}$ Swain nem látja reálisnak, hogy a demokráciának esélye lehetett volna ebben a kritikus helyzetben, amikor együtt volt jelen „a szovjet dominancia” és az egyre jobban erősödő hidegháború. A létező valóság „a szovjetkommunizmus sztálinista verziója"915 lett, de úgy gondolja a történész, hogy mindez nem volt eleve elrendelve: a magyar kommunistáknak és szövetségeseiknek keményen kellett dolgozniuk, hogy elérjék céljaikat, amely célok viszont nem bírtak soha demokratikus értelemben „többségi támogatással." "916 Nigel Swain is úgy értékeli: a KeletEurópát érintő szovjet célok 1946 közepéig homályosak voltak. A szerző szerint utólag viszont kijelenthető: „a proletárdiktatúra irányába mutató folyamat”917 már elkezdődött akkoriban.

Nigel Swain és testvére, Geoffrey Swain közösen írott monográfiájukban kifejtik, Sztálinnak 1945-ben még nem volt közvetlen érdeke kommunista irányítású „,forradalom „918 megvalósítása Magyarországon és Csehszlovákiában. Mindkét országban koalíciós alapon müködő demokráciában gondolkodott egy ideig a szovjet diktátor. A szerzőpáros rámutat, Csehszlovákia és Magyarország között az volt az érdemi különbség, hogy magyar területen gyenge volt a kommunista mozgalom, míg Csehszlovákiában a háború elött is jelen volt a közéletben egy markáns kommunista párt. Csehszlovákia a két világháború között

\footnotetext{
${ }^{912}$ Carl BECK: Leadership Attributes in Eastern Europe : The Effect of Country and Time. In: Carl BECK et al. (szerk.): Comparative Communist Political Leadership.David McKay Company Inc., New York, 1973. 118. p.

${ }^{913}$ Nigel SwAIN: Hungary: The Rise and Fall of Feasible Socialism. Verso, London - New York, 1992. 38. p.

${ }^{914}$ Uo.

${ }^{915}$ Uo. 44. p.

${ }^{916}$ Uo.

${ }^{917}$ Uo. 45. p.

${ }^{918}$ Geoffrey SWAIN - Nigel SWAIN: Eastern Europe since 1945. Macmillan Press Ltd., Houndmills-Basingstoke

- Hampshire - London, 1998. 29. p.
} 
demokráciaként működött, míg Magyarország „monarchikus diktatúra”,919 volt. 1945 vízválasztó szerintük, hiszen a háború után a kommunisták hirtelen abban a helyzetben találták magukat, hogy társadalmi változásokat indíthattak el; a kommunista párt már nem egy elvont erő volt, már nem egy olyan mozgalom, amelynek keretében „kommunista diákok füstös szobákban megvitatták az eszméket."920 Úgy vélik, 1945 és 1947 között Sztálin megelégedett azzal, hogy a helyi kommunisták komoly befolyást gyakorolnak a közéleti folyamatokra, s alkalmanként a szovjetek beavatkoznak a helyi támogatottjaik érdekében, de 1947-ig e két ország sorsa nem dőlt még el - ellentétben Romániával és Lengyelországgal, ahol Moszkva egyértelmüvé tette, hogy elindult a szovjetizálás. A szerzőpáros e különbségtételt azzal magyarázza, hogy Romániával ${ }^{921}$ és Lengyelországgal szemben 1939 előtt is területi követelése volt a Szovjetuniónak. ${ }^{922}$ Nigel Swain és Geoffrey Swain tehát összefüggést lát a szovjetizáció üteme és a szovjet területi expanzió között.

Nigel és Geoffrey Swain elemzik azt a magyarországi jelenséget is, miszerint a „,balos szektás veteránok" ${ }^{, 923}$ már 1944 őszén azt gondolták, gyorsan létrehozható a proletárdiktatúra, de a moszkvai elvárás viszont az volt, hogy Magyarországon demokratikus, koalíciós politikát folytassanak. A szerzők vizsgálják az Albániában, Bulgáriában és Jugoszláviában ${ }^{924}$ végbement gyors és radikális - és Sztálin által jóváhagyott - kommunista fordulat hétterét is; s úgy gondolják, ezekben az országokban a kommunisták agresszív, változást akaró politikája népszerü és sikeres volt, szerintük a polgári demokrácia elvárásai alapján is - „egy nyugati típusú választáson"925 is nyerhettek volna a kommunisták.

Mark Eduard (Revolution by Degrees. Stalin's National-Front Strategy for Europe, 1941-1947) 2001-ben publikált tanulmányában Magyarország szempontjából az új korszak kezdetének 1944 őszét tekinti, amikor a magyar kommunisták Moszkvában „népi

\footnotetext{
${ }^{919}$ Uo. 10. p.

${ }^{920}$ Uo. 3. p.

921 A román „népi demokratikus” átalakulásról: (Ghita IONESCU: The Politics of The European Communist States. Weidenfeld \& Nicolson, London, 1967.; Stephen FISCHER - GALATI: The New Rumania: From People's Democracy to Socialist Republic. The M.I.T. Press, Cambridge - London, 1967.)

${ }^{922}$ Geoffrey SWAIN - Nigel SWAIN: Eastern Europe since 1945. 47. p.

${ }^{923}$ Uo. 44. p.

${ }^{924}$ Carol S. Lilly Jugoszlávia második világháború utáni történetében az 1944 és 1948 közötti időszakot külön korszakként jellemzi. Jugoszlávia esetén e négy esztendőt nem nevezhetjük sem „koalíciós”, sem „demokratikus” időszaknak. Lilly a ’44-es „felszabadulás” és a Sztálinnal való szakítás közötti időszakot önálló időszaknak tartja. A demokrácia kontra diktatúra fogalmi ellentétpár annyiban a háború utáni Jugoszláviában is előkerül, hogy a proletárdiktatúrától való félelmet a jugoszláv kommunisták is megpróbálták oldani 1944-45ben. A helyi kommunisták radikális politikai fellépését az legitimálta, hogy 1945-ben a társadalomban komoly igény volt a határozott társadalmi változásokra. (Carol S. LILLY: Problems of Persuasion: Communist Agitation and Propaganda in Post-war Yugoslavia, 1944-1948. Slavic Review, LIII. évf. (1994) 2. 395-413. p.)

${ }^{925}$ Geoffrey SWAIN - Nigel SWAIN: Eastern Europe since 1945. 27. p.
} 
demokratikus jegyeket magán viselő programot állítottak össze az országuk számára." ${ }^{926}$ Azt is hangsúlyozza Eduard, hogy e program érvényre jutásához természetesen az is szükségeltetett, hogy a szovjet hadsereg „,szabadítsa fel” a magyar területeket. A szerző a '44től 1947-ig terjedő korszakot a „népi demokrácia” korszakának tartja. Eduard szerint ezt a bizonyos népi demokratikus kurzust az jellemzi, hogy kommunisták által dominált koalíciókat hoztak létre, melyek külsőleg úgy néztek ki, mintha polgári demokratikus szövetségek lettek volna. $^{927}$

Mark Pittaway (The Politics of Legitimacy and Hungary's Postwar Transition) „átmenetként”,928 jellemzi a „sztálinizmus beállta” előtti időszakot a háború utáni magyar történelemben. Charles Gati „demokratikus közjáték” kifejezését veszi át a korszak leírására. Pittaway számára a fordulat 1947 vége, 1948 eleje, a fordulat lényegét pedig úgy fogalmazza meg, hogy ekkorra ért véget Magyarország „átmeneti pillanata." ${ }^{929}$ Pittaway szerint ez az „átmeneti pillanat” akkor fejeződött be, amikor az FKGP parlamenti többségét szétzúzták a szalámi-taktikával. Ennek a folyamatnak volt része a '47-es „fél-manipulált” választás, ami után a Magyar Kommunista Párt lett Magyarország legnagyobb politikai ereje. Ekkorra a baloldal biztosította politikai hegemóniáját, miközben létrehozta az „új demokrácia” gazdasági és társadalmi intézményeit.

Martin Mevius (Agents of Moscow. The Hungarian Communist Party and the Origins of Socialist Patriotism 1941-1953) a második világháború utáni évek korszakolását úgy oldja meg, hogy kettébontja a koalíciós éveket: az első alperiódus 1945-től 1947-ig tart. 1945 azért nyitó dátum, mert Mevius szerint a magyar kommunisták számára a '45-ös választási vereség után egyértelmű vált, hogy az MKP „nem képes a hatalmat megszerezni” szavazatok által, választáson útján, ${ }^{930}$ ezért is döntöttek a szalámi-taktika alkalmazása mellett. Ebből is következik, hogy Meviusnál az 1945-től 1947-ig tartó alszakasz a szalámi-taktika időszaka. A következő, 1947 -1949-es periódust a Szklarska Poreba-i tanácskozástól számítja. ${ }^{931}$ Martin Mevius - aki könyvében döntő részben a magyar kommunistáknak a nemzeti érzéshez való viszonyát vizsgálja - úgy véli, 1949 azért is korszakhatár, mert ezután már a nemzeti

\footnotetext{
${ }^{926}$ Mark EDUARD: Revolution by Degrees. Stalin's National-Front Strategy for Europe, 1941-1947. Cold War International History Project. Working Paper No. 31., Washington, D.C., 2001. 22. p. Elérhető: http://www.wilsoncenter.org/sites/default/files/ACFB11.pdf (A letöltés időpontja: 2015. április 15.) 
tradíciókkal szemben meghatározó módon a proletár internacionalizmus jellemzi a hazai kommunisták gondolkodását. ${ }^{932}$

Harald Wydra 2006-ban publikált kötetében, amelyben a kommunizmus és a demokrácia viszonyrendszerét tanulmányozza, arról ír, hogy a második világháború után Magyarországon létezett egy „,rövid demokratikus közjáték, "933 amikor a nem kommunista erők is megszervezhették magukat a közélet színterein. Wydra szerint a magyarországi „sztálinista uralom”934 kezdete 1948, vagyis 1945 és 1948 között tartott a demokratikus közjáték időszaka. A történész elemezése szerint a kommunisták azért is tudták a demokrácia struktúráit hatékonyan lebontani, mert a fasizmus elleni harc a kommunisták számára komoly önlegitimációs szerepet kínált fel, a saját antifasiszta múlt demokrácia iránti elkötelezettséget biztosított nekik. Az ellenségképre épített kommunista politika legfőbb célja az 1945 előtti állami struktúrák lebontása volt, ezt az irányt nevezték a kommunisták népi demokráciának. ${ }^{935}$ Wydra úgy véli, a háború utáni kelet-európai népi demokráciák jellemzője „a folyamatos antifasiszta harc." 936 A demokratikus közjátékot a háború utáni KeletEurópában és Magyarországon az jellemzi, hogy a demokrácia iránti vágy „,beteljesületlen”,937 maradt, de mivel ebben a térségben ,antidemokratikus hagyomány” uralkodott, ezért a kommunisták számára adott volt a lehetőség, hogy azt állítsák, ők képviselik „,az igazi demokráciát.” Wydra a kommunisták által igaz demokráciának vagy népi demokráciának említett struktúrát „forradalmi demokráciának” és „totalitárius demokráciának”938 nevezi. Érvelése szerint azért lehet helytálló a totalitárius demokrácia fogalom használata, mert a demokrácia lényegi eleme, hogy „modernitás fordulatot” hajt végre és ilyen értelemben az angol, a francia demokrácia mellett létezhet az „orosz demokrácia” is.

Arnold Suppan 2009-es tanulmányában Ausztria és a Kelet-Közép-Európai régió, benne Magyarország 1945 utáni történetét vizsgálja, hasonlítja össze. Suppan emlékeztet: 1945-46-ban kizárólag Magyarországon és Ausztriában voltak teljesen szabad, Csehszlovákiában pedig csak részben szabad választások, míg a többi „népi demokratikus” országban pusztán a kommunisták vezette nemzeti frontok indulhattak a voksolásokon. A

\footnotetext{
932 Uo. 236. p.

${ }^{933}$ Harald WYDRA: Communism and the Emergence of Democracy. Cambridge University Press, Cambridge, 2006. 148. p.

${ }^{934}$ Uo. 149. p.

${ }^{935}$ Uo. 72. p.

${ }^{936}$ Uo. 154. p.

${ }^{937}$ Uo. 293. p.

${ }^{938}$ Uo. 91. p.
} 
szerző kiemeli, Jugoszláviában az új népi demokráciában Tito az ellenzéki polgári erők bárminemü befolyását már kezdettől fogva korlátozta, kizárta. ${ }^{939}$

Az akkor még szovjet megszállás alatt álló Ausztriában is - Magyarországhoz hasonlatosan - 1945 novemberében rendeztek választásokat; az eredmény is emlékeztetett a magyarországiéhoz, a polgári erők kaptak egyértelmű támogatást az osztrák szavazópolgároktól.

Arnold Suppan három olyan kelet-közép-európai országot említett, ahol megvalósulhattak - a háború után nem sokkal - a szovjet megszállás alatt is szabad választások. Ez a három ország (Magyarország, Ausztria és Csehszlovákia) kapott esélyt a demokráciára 1945-46-ban. Ausztria demokráciává formálódhatott. Magyarország és Csehszlovákia nem kapta meg ezt a sanszot. Magyarország 1947-48-ig, Csehszlovákia 1948 februárjáig tekinthető demokráciának. ${ }^{940}$

\footnotetext{
${ }^{939}$ Arnold SUPPAN: Austria and its Neighbors in the East 1945-1989. In: Arnold SUPPAN - Wolfgang MUELLER (szerk.): „Peaceful coexistence” or „Iron Curtain”? : Austria, Neutrality, and Eastern Europe in the Cold War and Détente, 1955-1989. Lit Verlag, Bécs, 2009. 36. p.

9401945 után Magyarországon és Csehszlovákiában jogállami demokrácia müködhetett, a későbbi szovjet blokk államai közül e két országban egy ideig a polgárok reálisan bízhattak abban, demokratikus közéleti viszonyok között élhetik mindennapjaikat. Magyarország és Csehszlovákia '45 utáni demokrácia-teljesítményében kimutathatóak hasonlatosságok, ezért is tekintjük át e lábjegyzetben, hogy angol nyelvü publikációkban milyen jellemzők vázolhatóak az 1945 és 1948 közötti csehszlovák demokrácia kapcsán.

Josef Korbel - a későbbi amerikai külügyminiszter, Madeleine Albright édesapja - az 1945 utáni csehszlovák demokrácia diplomatája, aki 1948 után emigrált és az Egyesült Államokban lett politikatudós 1959-ben írt könyvében az 1945 és 1948 közötti demokrácia legfontosabb karaktervonásának tartja, hogy a „demokratikus” és a „kommunista erők” együtt alkotják a közélet legfontosabb tényezöit. Az az elképzelés azonban, hogy a demokrata szereplök és a kommunista aktorok a demokrácia keretei között megférnek egymás mellett, megbukott, s mindez a tény Korbel szerint „tragikus volt a szabadság szerelmesei számára.” (Josef KoRBEL: The Communist Subversion Of Czechoslovakia 1938-1948 : The Failure of Coexistence. Princeton University Press, Princeton, 1959. VII. p.)

Paul E. Zinner történész 1963-ban New Yorkban kiadott könyvében az 1945 és 1948 közötti éveket a nemzeti és demokratikus forradalom időszakának nevezi. Zinner amellett érvel, hogy a '46-os „,választások szabadok voltak." (Paul E. ZINNER: Communist Strategy and Tactics in Czechoslovakia, 1918-48. Frederick A. Praeger, New York, 1963. 183. p. ) A történész mint „illúzióról” beszél arról a lélektani jelenségröl - ami sok demokrata közszereplöt is sújtott -, hogy úgy tünt, a kommunisták elfogadják a parlamentáris demokráciát. Döntő tényezőnek tekinti Zinner, hogy a „demokraták elszigeteltségben” (Uo. 206. p.) politizáltak és lemondtak a demokrácia megvédéséröl, passzívan várták az eredményt, ami a '48-as februári puccsal be is következett.

M.R. Myant 1981-ben publikált Szocializmus és demokrácia Csehszlovákiában 1945-1948 címü könyvében arról ír, hogy e három esztendős időszakban úgy tünt, megteremthető a parlamentáris demokrácia és a szocializmus „szintézise” és ezáltal elkerülhető a proletárdiktatúra. Myant azt is felveti, az 1948. februári puccs után a kommunisták - a saját maguk nézőpontjából - azt gondolták, hogy a demokrácia ,igazi formája” csak akkortól következik el. (M.R. MYANT: Socialism and Democracy in Czechoslovakia 1945-1948. Cambridge University Press, Cambridge, 1981. 1-5. p.)

Mary Heimann 2009-ben is amellett szól, hogy az 1945 és 1948 közötti csehszlovák demokrácia egy ideig azt a lehetőséget (,illúziót”) mutatta fel, hogy az államstruktúra egyszerre tud szocialista és demokratikus lenni. Csehszlovákia 1945 utáni három éve annak reményében telt, hogy megvalósítható a kompromisszum a „nyugati parlamentáris demokrácia” és „a népi demokráciák, a keleti demokráciák” között. (Mary HEIMANN: Czechoslovakia: The State That Failed. Yale University Press, New Haven - London, 2009. 176. p.)

E gondolat Andrea Orzoff Csata a Várért" címü könyvében a következöképpen jelenik meg: az 1945 utáni években a csehszlovák demokrácia mítosza arra épül, hogy „tolmács” vagy „híd” szerepet játszhatnak az amerikai és a szovjet világlátás/demokrácia-felfogás között. Orzoff szerint mindez a megközelítés pusztán
} 
Az emigráns magyar történészek nyelvhasználata kapcsán már azonosított szabad nyelvi közeg és kutatói szabadság a külföldi történészek között még kiemeltebben érhető tetten. Számukra a szükséges elemzői távolság jobban biztosított, földrajzi okokból fakadóan is távolabbról képesek vizsgálni az 1945 utáni néhány esztendő magyarországi történéseit; érzelmileg kevésbé elkötelezettek a téma iránt, mint a magyar szerzők vagy akár az emigráns történészek, így a történelmi tradíciókból fakadó kötöttségektől való mentesség által nagyobb intellektuális mozgástérrel rendelkeznek a koalíciós évek magyar demokráciájára vonatkozó ténymegállapítások és elemzések megfogalmazása során. Ezzel párhuzamosan természetesen - éppen a távolság miatt - kevesebb információ áll a rendelkezésükre, jóval kevesebb a primer adat lehetősége számukra.

Mindezen túlmenően a külföldi kutatók gyakorta szélesebb földrajzi kitekintéssel élnek, az egész kelet-közép-európai térséget érintően figyelik a folyamatokat, így a magyarországi történések kapcsán egyfajta régiós beágyazottságot tudnak érzékeltetni. A külföldi publikációk esetén a magyar vonatkozás csak egy rész az egészből.

Az angol nyelvü tanulmányok szövegét érintően megállapítható: nem érzékelik demokráciaesélynek az 1945 után Magyarországon történteket, és ebből is fakadóan nem tartják referenciaértékünek a koalíciós évek világát. A demokrácia mint struktúra jelzős szerkezeteit vizsgálva ezekben a publikációkban is természetesen gyakran használt fogalom a „népi demokrácia” panel, de többször kerül említésre az „új demokrácia” kifejezés is. A régiós történeti kitekintésre utal az általánosítóbb értelmű szerkezetek használata (totalitárius demokrácia), illetve a nemzeti karakter alapján rekonstruált demokrácia-értelmezések felvázolása: az „orosz” vagy a „bolgár” demokrácia-modell mint viszonyítási pont léte az angol nyelvű publikációkban egyértelműen azt mutatja, hogy az 1945 utáni magyarországi történések számukra a kelet-európai trendeknek pusztán csak egy részterületét jelentik.

„mítosz” maradt. (Andrea ORzoff: Battle for the Castle. The Myth of Czechoslovakia in Europe,1914-1948. Oxford University Press, New York, 2009. 213. p.)

Heimann és Orzoff is illúziónak nevezik azt a megközelítést, hogy a polgári demokrácia ethosza és a „népi demokrácia" összhangba hozható lett volna a '45-öt követő években.

Bencsik Péter a „Csehszlovákia története dokumentumban” címú 2016-ben megjelent kötet előszavában /Közös sorsunk (Kelet-) Közép-európában/ újszerüen, a nemzetközi szakirodalomnak a csehszlovák demokrácia értékeit demonstráló vélekedésein túlmutató álláspontot megfogalmazva jelenti ki: 1945 és 1948 között sem volt Csehszlovákia „demokratikus” és nem volt jogállam sem. „A demokratikus vonások hiánya azonban nemcsak a megtorlás, a kollektív bünösség, a nemzetiségekkel szembeni fellépés kapcsán mutatkozott meg, hanem a politikai intézményrendszer müködésében is" - írja Bencsik. (BENCSIK Péter: Csehszlovákia története dokumentumokban. Napvilág Kiadó, Budapest, 2016. 23. p.) A történész szerint 1947 elejéig Magyarország „némileg demokratikusabb” (uo. 25. p.) volt északi szomszédjánál. 


\section{V. Összegzés}

A koalíciós években publikált cikkek, tanulmányok, parlamenti megszólalások, közéleti beszédek mint szövegek elemzésével feltártuk az 1945-öt követő néhány esztendő demokrácia-diskurzusainak érvkészletét, a disputák kommunikációs paneljeit, beszédmódját. Azonosítottuk a demokrácia-értelmezések közötti antagonisztikus különbségeket.

Az 1945 utáni politikai életben a különböző vitahelyzetek során a polgári demokrácia alapértékeihez való viszonyulás jelentette a „vízválasztót”; aki kitartott a polgári demokrácia ethosza mellett, az szembekerült a kommunista valóságértelmezéssel, aki engedni tudott a jogállami demokrácia alapértékeiből, az ezáltal megteremtette a kommunistákkal való közös kommunikációs platform lehetőségét.

A koalíciós időkbeli kommunista demokrácia-értelmezés lényege, hogy a „demokrácia” valami egészen újat hoz az ország életében, s ez az „új jelenség” segíti a társadalmi mobilitást, a meglévő struktúrák áttörését. Az ekkoriban megfogalmazott baloldali demokrácia-értelmezés hívei nem egy jogokra épített rendszert és életformát látnak a demokráciában, hanem egy társadalom-átalakító keretet, ami évszázados megrögzöttségeket képes lebontani. E nézetrendszerrel állt szemben a „polgári” megközelítés, amely óvott attól, hogy a radikális változások érdekében az általános szabadságjogok súlyos csorbát szenvedjenek.

Az ellenségkép iránti igény, az ellenségképre alapozott stratégiaalkotás és taktikai hadviselés markáns eleme a koalíciós időszak kommunista demokrácia-felfogásának. Ugyanilyen fontos eleme a kommunista demokrácia-értelmezésnek, hogy a formális demokratikus játékszabályok jelentőségét relativizálják. A kommunisták a formális demokratikus szabályokkal szemben foglalnak állást, mert az általuk elképzelt radikális változások ethoszába nem fért bele a formális szabályok elismerése. A kommunista demokrácia-felfogás jellemzőjeként azonosíthattuk a kompromisszum mint negatív cselekvés karaktervonását. E jellegzetesség vizsgálata keretében külön kitértünk arra, hogy az úgynevezett összeesküvési ügy újabb fordulatot hozott a koalíciós évek történetében és természetesen a demokrácia-viták históriájában is. Az „összeesküvési válság” során a kommunista párt részéről tapasztalt verbális brutalitás és a rendvédelmi hatóságok által felmutatott kreált vádak/koncepciógyártás és nyílt eröszak olyan közéleti kulturális közeget eredményezett, ahol egyre kevésbé voltak biztosítottak a párbeszéd feltételei a demokráciaviták számára. Ennek a helyzetnek egyik fajsúlyos nyelvi és kommunikációs jellemzője, hogy 
a kommunisták demokrácia-felfogásában az összeesküvési ügy idején már a kompromisszum nem pozitív politikai tett; az, hogy a koalíció szereplöi között valódi, lényegi megegyezések legyenek szükségesek, már nem képezik a „demokrácia” lényegi feltételét.

A kisgazda demokrácia-felfogásban a jogosultságokra épülő társadalmi berendezkedés eszmeisége biztosította a gondolati alapot. Feltártuk: a szabadság, az egyének autonómiája mellett az általános jogegyenlőség, az alkotmányosság politikai kultúrája, a szabad vita intézményes joga és a hatalom ellenőrzésének lehetősége is a kisgazda demokrácia koncepció markáns elemei voltak. A többségi elv, a jogszabályok (játékszabályok) és az intézményi struktúrák tiszteletben tartása szintén központi tényezője volt az 1945 utáni kisgazda demokrácia koncepciónak.

A szövegelemzések után megállapítható: a kisgazda-polgári demokrácia-felfogás lényegi gondolata, hogy a szabadságjogok „mindenkit” egyaránt megilletnek. A kommunisták azonban nem fogadják el a mindenkire egyaránt érvényes szabadságjogok létezését; kommunikációs paneljük szerint a demokrácia ellenségeinek nem járnak jogok.

Az 1945-ös esztendőben a demokráciáról folyó diskurzusok hangulatát, szellemiségét a remény érzése döntő módon volt képes meghatározni. Az 1945. november 4-ig, a választásokig tartó időszakot egyfajta reményteli konszenzusérzés határozta meg, a háború végétől a választásokig tartó periódus hosszú hónapjaiban úgy tűnt, a valóságos - és a későbbiekben kiderült, antagonisztikus - ellentéteken (és főként a kommunista befolyás alatt müködő rendőrségi atrocitásokon) túlmenően a demokrácia igenlésében és alapértékeiben konszenzusszerü egyetértések bontakoztak ki. A demokrácia-diskurzus tekintetében e hónapok remény-konszenzusát jelképesen illusztrálta az 1945 nyarán a Pázmány Péter Tudományegyetem által szervezett, a demokrácia tematikájával foglalkozó előadássorozat. Noha a Demokrácia-konferencia különböző megszólalói egymást kizáró demokráciaértelmezéseket fogalmaztak meg, mégis úgy tünt, a jogállami, szabadságjogokra támaszkodó demokráciának esélye van. A konferencia megvalósulása már önmagában szimbóluma annak, hogy az akkori közélet szereplői hittek abban, lehet ugyan vita a demokrácia kereteiről, formájáról, de mégis valamifajta jogállami jellegü demokratikus államrend fog majd kialakulni. A konferencia idején még a kommunista kötődésű vagy elkötelezettségű előadók sem fogalmaztak meg a demokrácia alaplényegétől eltérő, azzal szögesen ellentétes, azzal ütköző gondolatokat.

Az 1945-ös választás eredménye miatt csalatkoztak reményeikben a kommunisták, s ez fordulatot eredményezett a demokrácia-értelmezések nyelvezetének tekintetében is. A szovjet katonai jelenlét és a hegemón politikai pozíció ellenére a kommunisták politikai 
reményei csökkentek. Ezzel is összefügghet, hogy a kommunista közéleti nyelvezet durvábbá vált már a választás után nem sokkal. Ekkoriban elemezte Révai József úgy a történéseket, miszerint a harc a „demokrácia továbbfejlesztésére törekvő erők” és a reakciósok, a „demokrácia visszafejlesztésére törekvők között” fog majd zajlani, vagyis a demokratikus voksoláson győzedelmeskedő, azon abszolút többséget szerző, reményekkel teli Független Kisgazdapártot a „demokrácia visszafejlesztésére törekvők” szóösszetétellel bélyegezték meg a kommunisták.

A szabad választások után kialakult helyzet, a kisgazda abszolút többség ténye erősítette a kommunistákban a félelem érzetét. Erre a jelenségre hívta fel a figyelmet Bibó István A magyar demokrácia válsága című tanulmányában 1945 őszén. A tanulmányíró érvelésének lényege, hogy sem a kommunisták félelmét a reakciótól, sem a polgári tömb félelmét a proletárdiktatúrától nem indokolják „tárgyi okok.” Bibó ekkor - és utána még évekig - hitelt adott a Magyar Kommunista Párt hivatalos kommunikációjában foglalt állításoknak, miszerint nem törnek diktatúrára. Ez kétségtelen tévedés a koalíciós évek bibói demokrácia-publikációiban - Bibó 1947/1948 előtt nem volt hajlandó szembenézni a proletárdiktatúra közvetlen fenyegetésével, mert túl sokáig bízott benne, hogy a kommunisták a demokrácia „ösvényén” maradnak. Nem találunk olyan bibói idézetet a koalíciós korszakból, ahol egyértelművé tenné, hogy milyen szintű veszély fenyegeti a kommunisták részéről a formálódó jogállami demokráciát. A proletárdiktatúra megvalósult, de Bibó nem érzékelte, hogy ez a korábban csak félelmi pszichózisként megjelenő, feltételezett veszély valóságos fenyegetéssé vált.

Bibó úgy gondolta, hogy a magyar társadalmat radikálisan meg kell változtatni, szociális forradalomra van szükség. A történetfilozófus 1945 utáni gondolkodásának ez volt a legfontosabb eleme - fontosabb, mint a demokrácia eszménye. Bibónál a társadalom-átalakító remény erősebb volt, mint a demokráciaféltő aggodalom. Bibó egy konszenzuális demokrácia megteremtésében bízott a koalíciós években, folyamatosan emellett érvel a politikai publicisztikájában, de a markáns társadalmi változás érdekében hajlandó volt szemet hunyni a jogállamiság sérelmein, mert úgy vélte, a szociális forradalom érdekében szükség lehet átmenetileg a demokratikus jogok korlátozására.

Ha 1945 demokrácia-diskurzusainak vonatozásában azt írtuk, hogy az az időszak a remény konszenzusának volt a korszaka, akkor 1946 - a demokrácia-viták tekintetében is - az egyensúly éve. 
Ez a fajta egyensúlyi kommunikációs helyzet jellemezte a nemzetgyülésben a köztársasági államformáról szóló törvényjavaslat parlamenti vitáját 1946. január végén. A különböző közéleti szereplők között a demokrácia-képek szempontjából lényegi különbségek bontakoztak ki, de mindezen antagonizmusok még nem tették lehetetlenné a demokratikus párbeszédet. Az eltérő demokrácia-értelmezésekböl ekkor még nem következett a megbélyegzés és a kirekesztés kommunikációs eszköztára. A parlamenti vita során elhangzó megszólalások kapcsán látható: a kisgazdák az emberi szabadságot megvalósító államot, parlamentarizmust akartak, a szabadság emberi eszményét helyezték demokrácia-képük középpontjába. A kommunisták is szavakban demokratikus államberendezkedést akartak, de a nemzetgyülési vita során is az úgynevezett harcos demokrácia fogalmát használták. 1946-ban kommunista nézőpontból az úgynevezett „harcos demokrácia” egy olyan hatalmi struktúrát jelentett, amely - az MKP társadalom-átalakító ideái szerint - a rögzült társadalmi struktúrák áttörése érdekében félre meri tolni a polgári demokráciákra jellemző játékszabályokat.

A szociáldemokraták ebben az időszakban, 1946 folyamán a kommunisták által emlegetett „harcos demokrácia” kommunikációs panel gondolati testvéreként - persze erős habitusbéli különbséggel - a „védekező demokrácia” fogalmat hozták be a kommunikációs térbe. Ennek a fogalomnak a lényegi eleme, hogy a demokráciának folyamatos önvédelemre van szüksége. A „védekező demokrácia” szociáldemokrata nézőpontból magában foglalta azt az álláspontot is, hogy a demokrácia nem terjed ki ,,a demokrácia ellenségeire”. Az SZDP álláspontja - kissé illuzórikusan - az volt, hogy a demokrácia bajait csak a „,demokrácia gyógyszerével” lehet megszüntetni, de a „védekező demokrácia” panelje egyértelműen korlátozni kívánta a jogállami demokrácia alkotmányjogi kereteit abban a tekintetben, hogy a - konkrétan meg nem határozott - „ellenség” nem lehet részese a demokratikus közéletnek. A szociáldemokraták demokrácia-diskurzust érintő szövegeiben hangsúlyosan jelenik meg a weimarizációtól való félelem. A szociáldemokraták általánosságban nem - a gumifogalomnak számító - „reakciótól” féltek a koalíciós években, hanem valóságos veszélyként tekintettek arra a jelenségre, hogy a demokrácia keretei között a demokratikus felhatalmazással a nem demokratikus erők visszaélhetnek.

Az 1946-os szociáldemokrata szövegekben őszintének tünő reménykedés érződik, olvasható ki a szocializmus megteremtésével kapcsolatban. 1946-ban, az egyensúlyi 1946-os esztendőben a szociáldemokraták számára a szocializmus nem a proletárdiktatúra kialakítását jelentette. A szociáldemokrata közéleti tényezők nem tartották összeegyeztethetetlennek a demokráciát és a szocializmust - az MKP-tól eltérően az SZDP beszél a nyilvános kommunikáció színterein is a szocializmus szükségességéről 1945-1946-ban is. 
A köztársasági államformáról szóló törvényjavaslat vitája után bő egy hónappal, 1946 márciusában már a demokratikus államrend védelméről szóló törvényjavaslatról vitáztak a nemzetgyülési képviselők. A demokrácia védelméről szóló törvényre vonatkozó előzetes ötletek a félelmi pszichózis tekintetében inkább az egyensúlyi állapot és a konszenzus felé mutattak. A kisgazdák részéről vetődött fel az alapötlet; ők egy ilyen típusú törvénnyel rendkívüli naivitással - egy jövendőbeli kommunista hatalomátvétellel szemben kívántak volna garanciális védelmet maguknak és az országnak. A kisgazdák a kommunista diktatúrától való félelmükben fogalmazták meg azt az alapvetést, hogy készüljön egy büntetőjogi jogszabály a demokrácia védelmére. Ezt az alapötletet fordították át a kommunisták úgy, hogy végül a demokratikus államrendről szóló törvény a proletárdiktatúra jogi előkészítésének egyik fontos állomása lett.

A demokratikus államrend védelméről szóló törvényjavaslatot tárgyaló 1946-os parlamenti vita egy sajátságos demokrácia-diskurzus volt. Sajátságos, hiszen egy büntetőjogi jellegű jogszabály megalkotásáról vitáztak a közélet szereplői. Ebben a vitában is kikristályosodott a kisgazdák és a kommunisták antagonisztikus demokrácia-képe. A vita szövegeit, érveit elemezve kitetszik a sajátos koalíciós évekbeli kisgazda demokráciaértelmezés számos eleme: a kisgazdák demokrácia-képébe szervesen beletartozik az emberi szabadságjogok védelme, a kisgazda demokrácia-koncepció lényegi része a jogosultságokra épülő államberendezkedés, a demokratikus intézmények megerősítése. Ezzel ellentétben a koalíciós évekbeli kommunista stratégia tekintetében a büntetőjogilag deklarált védelem alatt álló szabadságjogok fölösleges korlátot jelentenek a kialakítandó „népi demokrácia”, a jövőben formálódó proletárdiktatúra szempontjából.

A demokratikus minimum és az egyensúlyi helyzetre való törekvés része volt az is, hogy a demokratikus államrend védelméről szóló törvénynek legyen egy „társjogszabálya” az emberi jogok védelméről. A kisgazdák és a kommunisták között ez a kompromisszum megköttetett: a kommunisták diktátuma érvényesült a demokratikus államrend védelméről szóló jogszabálynál, míg a kisgazdák arra kaptak lehetőséget, hogy a nemzetgyülés jogszabályban rögzítse az emberi jogok védelmét. A törvények elfogadásával az egyensúlyi állapot megteremtődött, de a mindennapok során végül az emberi jogok védelméről szóló törvényt érdemben nem alkalmazták a magyar bíróságok. A két társjogszabály használata és nem használata jelképesen mutatja a kommunisták koalíciós évekbeli hegemón pozícióját.

Az emberi jogok védelméről szóló törvényjavaslat plenáris vitájára 1946. május 9-én került sor. Ahogy arra utaltunk, ez a jogszabály az FKgP számára számított fontosnak, hiszen a kisgazda demokrácia-értelmezés központi eleme volt a mindenkire egyaránt vonatkozó 
szabadságjogok rendszere; ez a támogató, aktív hozzáállás a vita lefolyásából, menetéből is kitünik. Mindezzel szemben - ahogy az MKP szónokának érveiből is egyértelmüen látszik - a kommunista taktika e téren a relativizálás volt, mert a koalíciós években a kommunista demokrácia megközelítésbe és társadalom-átalakító stratégiába nem fért bele a mindenkire érvényes szabadságjogok tiszteletben tartása.

Az emberi jogok és a demokratikus államrend védelméről szóló törvényjavaslatok plenáris vitáikor markáns módon érhető tetten a demokrácia-fogalmak közötti különbség. E diskurzus során is megállapítható, a felek mindegyike demokráciáról beszél, de tartalmilag mégis a fogalmak mögött antagonisztikus tartalom húzódik meg. A viták szövegvizsgálata alapján az tünik ki, hogy a kommunista szónokok, mikor demokráciáról szólnak, már 1946ban is mást értenek a fogalom alatt - ekkor még rejtve, leplezve, de már '46 koratavaszán is gondolatilag a később bekövetkező diktatúra kereteit vázolják.

1946 őszétől egy új korszaka kezdődik a koalíciós évek demokrácia-vitáinak. Szimbolikusan Rákosi Mátyásnak az MKP III. kongresszuson elmondott beszéde nyitja ezt az időszakot. Rákosi frazeológiájában ekkortól kap különös hangsúlyt, hogy a kommunisták célja - immáron rövidtávon is - a szocializmus megteremtése és egy sajátos „népi” demokrácia létrehozása. Ekkortól az egyensúlyi állapot egyre inkább megborul.

1946 novemberében a demokrácia-remény egy unikális megfogalmazása Kovács Imre parasztpárti író-politikus $A$ demokrácia útja Magyarországon címü tanulmánya. Az írópolitikus alapállítása: 1946 őszére a magyar politika eljutott odáig, hogy már a polgári attitűdű demokrácia és a kommunista értékrendű „totális” demokrácia nyílt küzdelme folyik. Kovács azt is kimondja, hogy a kommunista megközelítésủ demokráciában immár nem lesz helye más véleménynek, de azt még mégsem mondja ki kendőzetlenül, hogy elkezdődött a diktatúra kiépítése, a diktatúra fogalmat nem használja, csak utal magára a kibontakozó diktatórikus közegre. Kovács szerint ugyanakkor egyértelmű: 1946 őszén elindult a demokratikus rend megdöntésének előkészítése.

1947-ben az összeesküvési ügy árnyékában a demokratikus párbeszéd nyelvi keretei lényegesen beszükültek. Az „összeesküvés” újabb fordulatot hozott a koalíciós évek történetében és természetesen a demokrácia-diskurzusok hangvételében is. E válsághelyzet során a kommunista párt részéről tapasztalt verbális brutalitás és a rendvédelmi hatóságok által felmutatott kreált vádak/koncepciógyártás és nyílt erőszak olyan közéleti-kulturális közeget eredményezett, ahol egyre kevésbé voltak biztosítottak a párbeszéd-feltételek a demokrácia-viták számára. A kommunisták demokrácia-értelmezése 1947-re megkeményedik, ridegedik, s egyre kategorikusabbá válik. 
Az összeesküvési ügy a kommunisták számára egy rendkívül fontos lépéssorozat volt a demokratikus jogállam, a polgári szabadságjogokra épülő demokrácia állami struktúráinak lebontása felé vezető úton. Éppen ezért különlegesen érdekes kommunikációs stratégiai elem, hogy a kommunisták ebben a helyzetben is a „demokrácia védelmére” hivatkoznak - a jogállami karakterü demokrácia visszametszése, megszüntetése érdekében végzett politikai cselekményeket a demokrácia védelmének szövegburkába csomagolják. 1947-re a kommunisták által használt „demokrácia” fogalom immáron egyre inkább kizárólagos értelmű és kirekesztő tartalmú, abba nyelvileg már csak a kommunista stratégiába illeszkedő álláspontok férnek bele.

1947-1948-ban még fellelhetőek, rekonstruálhatóak demokrácia-hitvalló nyilvános megszólalások, de már nincs meg a nyílt párbeszéd nyelvi tere, az ehhez a fajta diskurzushoz szükséges szabadságfaktor.

1949-re már a remény korszaka, a koalíciós évek világa lezárult. A kommunista demokrácia-értelmezésben is egyértelmű fordulat következett be. Ekkorra már Rákosi Mátyás és Révai József is kimondja, hogy az úgynevezett népi demokrácia nem más, mint a proletárdiktatúra, a kommunista diktatúra egyik fajtája.

Az 1945-öt követő néhány esztendőben a népi demokrácia fogalma a kommunista nézőpontú demokrácia-értelmezést jelentette, vagyis egyfajta „kvázi-demokráciát" ${ }^{\text {941 } \mathrm{Az}}$ 1948. decemberi sztálini formula szerint a népi demokrácia betölti a proletárdiktatúra funkcióját, azaz - ahogyan Kalmár Melinda fogalmaz - „teljesen el kell felejteni belőle a demokráciarészt." ${ }^{\text {"942 }}$ 1948/49 és 1953 között a népi demokrácia és a proletárdiktatúra szinonimaként értelmezhető; Sztálin halála után azonban a népi demokrácia kifejezése ismét egy a klasszikus szovjetrendszertől való megkülönböztetésre használható elhatárolási fogalomként jelenik meg. A kelet-európai országok népi demokráciaként történő megnevezése szintén erre a megkülönböztetési nyelvi struktúrára utal. A puhuló Kádárkorszakban a népi demokrácia kifejezésnek a nyilvános térben való használata - a proletárdiktatúra fogalmi világával szemben - elhatárolási kommunikációs mintázatként értelmezhető. A hetvenes-nyolcvanas években összeér a népi demokrácia fogalmának a klasszikus szovjetrendszertől megkülönböztető elhatároló újraértelmezése és az 1945 utáni néhány esztendő, a koalíciós évek újrafelfedezése; közbeszédet formáló szándékkal jelenik meg a koalíciós évek fogalma a nyilvánosság fórumain - az 1945 utáni évek mint egy korábban már létezett népi demokrácia-modell kerül felvázolásra. E témakör részletes

\footnotetext{
${ }^{941}$ KALMÁR Melinda: Történelmi galaxisok vonzásában. 51. p. ${ }^{942}$ Uo.
} 
elemezése nem része disszertációnknak, ugyanakkor utalni kívántunk rá, a koalíciós években a magyar nyilvánosságban létjogosultságot nyerő népi demokrácia fogalom újraértelmezései évtizedekkel később is politikaalakító erővel bírtak.

A diskurzuselemzés segítségével foglalkoztunk a koalíciós évekről szóló önéletírásokban megjelenő beszédmód demokrácia-értelmezéseivel. Megállapíthatjuk, hogy a visszaemlékezésekben a demokrácia-fogalom identitásteremtő és -formáló narratív elemmé válik. Feltártuk a demokrácia mint fogalom önéletírásokban tetten érhető mögöttes jelentéseit. Az önéletírók szemszögéből - a korabeli demokrácia-értelmezéseket bemutató fejezetet követően - újabb perspektívából tudtuk megvilágítani, hogy milyen különbségek mutatkoztak a korszak szereplőinek gondolkodásában a demokrácia-kép vonatkozásában. Az önéletírásokat jellemző plusz intimitás, őszinteség segítségével rekonstruáltuk a korabeli demokrácia-vitákban megjelenő érvek mögötti érzéseket, viszonyulásokat. Az önéletírások vizsgálata által, az időbeli vertikalitásnak köszönhetően egyedi nézőpontot igyekeztünk felmutatni a koalíciós időszak demokrácia-diskurzusának kutatásához.

A hithű kommunisták koalíciós éveket érintő visszaemlékezéseiben megjelenik a korszakot elemzendő a demokrácia mint narratív elem - közös bennük, hogy a demokrácián egyértelműen a kommunista világlátásnak megfelelően a népi demokráciát értik, s a népi demokrácia struktúráját értékesebbnek tartják, mint a polgári demokrácia ethoszát. Ezzel szemben a koalíciós években kommunistaként szerepet vállaló, de később a kommunista diktatúra rendszeréből kiábrándult közszereplők önéletírásaiban megjelenő demokrácia-kép árnyalt; az 1945 utáni évek dimenziójában sem fogadják már el a kommunista megközelítésü demokrácia-értelmezést, kritikusan ítélik meg a koalíciós időkben a kommunistáknak a jogállami demokráciával szembeni lépéseit és utólagosan inkább értékként tekintenek az 1945 utáni demokrácia-kísérletre és markáns szempontként kerül elő a háború utáni évek közvetlen demokráciájának tisztelete.

A polgári demokrácia ethosza mellett kitartó kisgazda közéleti szereplők a jogállami jellegű demokrácia híve voltak a koalíciós időszakban. Visszaemlékezéseik is erről tanúskodnak. Önéletírásbeli demokrácia narratívájuk meghatározó eleme az 1945-ös budapesti és országos választások kisgazda győzelme. Értelmezésük szerint az 1945. novemberi parlamenti voksolás lényegében egyfajta népszavazás volt a jogállami jellegü demokrácia, a demokratikus szabadságjogokra építkező államhatalmi struktúra mellett. A visszaemlékező gondolatok egyértelmüen egyfajta polgári demokrácia-védő mentalitást tükröznek, illetve kifejezik a népi demokráciának is nevezett proletárdiktatúrával szembeni 
érzésvilágot, kulturális attitüdöt. Ezen szereplök úgy érveltek emlékező szövegeikben, úgy fogalmazták meg visszaemlékező gondolataikat, miszerint az aktuális korszakban az általuk képviselt ügy vereséget szenvedett ugyan, de történelmi szempontból viszont úgy vélekedhetnek, hogy ők voltak a ,jó” oldalon - ez a morális felsőbbrendüség egyértelmüen jellemzője a kisgazda szereplők önreflexiós visszatekintéseinek.

A kommunisták mellett társutas szerepet vállaló kisgazdák visszaemlékezéseinek viszont az a közös jellemzője, hogy a jogállami demokrácia mint érték nem jelenik meg a forrásokban. A demokrácia mint narratíva nem szövegformáló tényező e memoárokban. Megállapítható: a társutasság mint közéleti jelenség felvállalásához pszichésen szükséges volt a határozott szakítás a szabadságjogokra épülő demokrácia eszményétől, így a demokrácia mint eszmény nem jelenik meg a visszaemlékező szövegekben sem.

A visszaemlékezések mint a demokrácia-narratívát feltáró források segítségével nyomon követtük azt a folyamatot, miszerint azok a kisgazda közéleti szereplők, akik 194748 után is kitartottak a polgári demokratikus ethosz mellett, emigrációba kényszerültek vagy lekerültek a közéleti színpadról; míg akik engedtek a demokratikus eszményképböl, periférikus szerepben ugyan, de társutasként megmaradhattak a politika világában a kommunista diktatúra időszakában is.

1950-től jelenik meg az 1945 utáni esztendőkről és a korszak demokráciájáról szóló diskurzusokban a tudományos beszédmód. Ekkor már egy másik nyelvezet, a recepció beszédmódja mint kód által azonosíthatóak az időszakot és demokrácia fogalomhasználatát elemző narratívák.

Az ötvenes évek kommunista történetírói úgy ítélték meg, hogy már 1944/45 és 1948 között is jelen volt a törekvés a proletárdiktatúrára és az az időszak is diktatúra volt, csak még nem színtiszta proletárdiktatúra, hanem a munkásság és a parasztság úgynevezett lenini értelmü „demokratikus diktatúrája.” Ez az ortodox kommunista történeti nyelvi kánon alapján 1948/49-től már „létrejöttek” a proletárdiktatúra „feltételei”, megvalósult az államhatalom struktúráiban is a proletárdiktatúra világa, ezzel szemben az 1944 utáni négy-öt évben a proletárdiktatúra elözménye érhető tetten egyfajta „demokratikus diktatúra” fogalmi kerete formájában, eszerint a nyelvi kód alapján a koalíciós évek időszaka a „demokratikus diktatúra" időszaka.

A hatvanas évek közepéig a tudományos beszédmódot az ideologikus beszéd karaktervonásai döntően határozták meg. A hatvanas esztendők közepétől a fogalomhasznált elkezd objektívebbé válni, a nyolcvanas évekre a tudományos beszédmód még teljességgel 
nem tud ugyan megszabadulni az ideologikus beszéd kötöttségétől, de a történettudományi diskurzus tényközpontúbbá válik. A beszédmód egyértelmüen a marxista nyelvi kód alapján írható körül, de érzékelhető egyfajta textológiai felfrissülési tendencia. A hatvanas évek második felére kialakuló kádári reformideológia alapvetése a realista látásmódról teret nyitott az összetettebb, érvelő nyelvi konstrukciók számára a koalíciós évekről szóló történettudományi diskurzusok számára. A hetvenes-nyolcvanas éveknek a koalíciós éveket értelmező tudományos beszédmódja egyértelműen a tárgyilagosabb nyelvhasználat irányába mutat. Elfogadott, legitim fogalommá válik a koalíciós korszak fogalma, a publikációiban még tetten érhetőek a marxista történeti kánon nyelvi kategóriái, de az objektivizáció szándéka nyilvánvaló.

Az emigráns magyar történészeknek a témánkra vonatkozó vélekedései a tudományos beszédmód vizsgálata szempontjából azért fontosak, mert az időhorizontot tekintve abban a terminusban fogalmazódnak meg, amikor Magyarországon a kommunista diktatúra időszakában, az államszocialista rendszer nyelvi struktúrái által fogalmazódhatnak csak meg történészi álláspontok. Az emigrációban élő történészek a diktatúrától független szabad nyelvi közegben érvelhetnek, vagyis az emigráns történészek véleményei mintegy referenciái annak, hogy ha kivonjuk a tudományos diskurzusból a szocialista rezsim kötelező marxista nyelvi paneljeit, akkor milyen történeti álláspontok alakulhatnak ki. Az emigráns történészek véleményeiben közös pont, hogy a koalíciós években demokratikus kísérlet zajlott, amelyet a kommunisták hatalmi törekvése ellehetetlenített. Ez a fajta nyelvi panel a rendszerváltozás utáni tudományos diskurzusban jelenik meg ismét markáns formában - a koalíciós évek demokráciája tekintetében az emigráció történészei lényegében „előfutárai” az 1989 utáni magyarországi történészi gondolkodásnak és nyelvhasználatnak.

Az angol nyelvű tanulmányok szövegét érintően megállapítható: nem érzékelik demokráciaesélynek az 1945 után Magyarországon történteket, és ebből is fakadóan nem tartják referenciaértékünek a koalíciós évek világát. A demokrácia mint struktúra jelzős szerkezeteit vizsgálva ezekben a publikációkban is természetesen gyakran használt fogalom a „népi demokrácia” panel, de többször kerül említésre az „új demokrácia” kifejezés is. A régiós történeti kitekintésre utal az általánosítóbb értelmű szerkezetek használata (totalitárius demokrácia), illetve a nemzeti karakter alapján rekonstruált demokrácia-értelmezések felvázolása: az „orosz” vagy a „bolgár” demokrácia-modell mint viszonyítási pont léte az angol nyelvü publikációkban egyértelmüen azt mutatja, hogy az 1945 utáni magyarországi történések számukra a kelet-európai trendeknek pusztán csak egy részterületét jelentik. 
A rendszerváltozás utáni szabad nyelvi és szellemi közegben formálódhattak ki a koalíciós korszak demokráciáját vizsgáló tudományos beszédmód demokratikus narratívái. Az 1990 után megjelent publikációkban a következő fogalmakat azonosítottuk a koalíciós korszak demokráciájára vonatkozóan: a demokratikus többpártrendszer időszaka, az újjáépítés és a demokratikus reformok korszaka, a demokratikus reform időszaka, a demokratikus közjáték szakasza, a nagykoalíció időszaka, a demokratikus látszat évei, a koalíciós közjáték ideje, a kényszerkoalíciós időszak, a demokratikus evolúció időszaka, a korlátozott parlamentarizmus kialakításának kísérlete, a korlátozott polgári demokrácia szakasza, a jogállam megteremtésének kísérlete és kudarca, a demokráciáért vívott sakkjátszma, a demokráciaviták négy éve, rendszer-átalakító kísérlet, kétarcú hatalmi struktúra, a korlátozott képviseleti demokrácia kora, antiliberális demokráciakonstrukció, többlépcsős forradalom, megfojtott demokrácia, fokozatosan véghezvitt szovjetizálás, formális többpártrendszer, lopakodó forradalom, a polgári és a marxista erők közötti élet-halál harc időszaka, a két totalitarizmus közötti időszak, a kommunista diktatúra bevezető fázisa, a többpárti totalitarizmus időszaka, az elveszett reformkor, a népi demokratikus átalakulás ideje, a fokozatos kommunista hatalomátvétel periódusa, a sztálinizmus beállta előtti időszak, az átmenet pillanata, az átalakulás évei, a demokráciakísérlet időszaka, a szovjetizálási tendencia évei, a demokratikus megújulási kísérlet ideje, a második világháború utáni néhány év korszaka, a szovjetizálás kezdeti szakasza, a fordulat évei, a kudarcos demokratizálódás időszaka, a presztalinizáció korszaka, az erőltetett rendszerváltás évei, álkoalíciós időszak, a korlátozott és fenyegetett demokrácia időszaka, a demokratikus kiegyezés korszaka, útban a kommunista egyeduralom felé, a parlamentáris demokrácia gleichschaltolásának időszaka, a hatalmi dualizmus korszaka, a köztes évek, a rákosizmus előszobája, a demokratikus pluralizmus kísérlete, a demokrácia ígéretét hordozó időszak, a törékeny demokrácia évei.

A modern politológiai szakirodalom demokrácia-tipizálása támpontokat jelenthet arra vonatkozóan, hogy az 1945 utáni esztendők magyar demokráciáját a demokrácia-hozzáférés nézőpontjából újszerü kontextusba helyezzük. Robert A. Dahl politikatudós a demokrácia egyik formájának tekinti az úgynevezett bizottsági demokráciát. ${ }^{943} \mathrm{E}$ demokráciaforma egyik jellemzője, hogy nem klasszikus képviseleti demokrácia müködik, ahol a parlamentnek van döntő szava, hanem egy - akár változó összetételben ülésező - testület (bizottság) deliberatív

\footnotetext{
${ }^{943}$ DAHL, A. Robert: Forradalom után. Autoritás a jó társadalomban. Osiris Kiadó - Readers International, Budapest, 1995. 55-90. p.
} 
aktus után hoz formális vagy informális döntéseket, amelyek az adott közösség napi életét meghatározzák. A döntéshozatal gyakorta nem a többségi elv alapján történik, hanem a döntésnek a résztvevők általi kimondásával, összefoglalásával. Értelmezésünk szerint az 1945 utáni néhány esztendő magyar demokráciáját a pártközi értekezleteknek a politikai rendszerben történő dominanciája révén, nevezhetjük a bizottsági demokrácia időszakának is, amikor a változó összetételű pártközi értekezleteknek (bizottság) döntő szerepük volt a közélet formálásában. A legújabb politológiai kutatásokban a bizottsági demokrácia mellett a tanácskozó demokrácia fogalma is megjelenik mint hangsúlyos demokrácia-értelmező kifejezés. Az ezredforduló konszenzusorientált deliberatív demokrácia fogalmát nyilvánvalóan nem lehet visszavetíteni az 1940-es évekre, ugyanakkor a tanácskozó demokrácia egyik eleme markáns módon tetten érhető a koalíciós idők demokráciájában is: a deliberatív demokrácia ethosza a tanácskozásra épül, ezzel párhuzamosan azonban a többségi döntés mint prioritás elhalványul. ${ }^{944} \mathrm{~S}$ tény, a koalíciós években a politikai döntések nem a többségi elv alapján történtek, az egyetlen kivétel az volt, amikor a nemzetgyülés kisgazda kötődésű többsége Kovács Béla mentelmi ügyében egyedi többségi döntést hozott. E nézőpont alapján az 1945 utáni magyar demokráciát egyfajta koraszülött, korlátozott és csonka deliberatív demokráciának is nevezhetjük.

Jürgen Habermas történetfilozófus a tanácskozó demokrácia fontos jellemzőjének tekinti, hogy biztosított legyen a nyílt társadalmi diskurzusban az úgynevezett „nyilvános okoskodásnak" nevezett jelenség. Mindezen nyilvános okoskodás egy folyamatot hoz létre, amelynek révén közösségi disputák alakulnak ki és formálják a társadalmi döntéshozatalt. „A politikai arénában megvívott véleményharcnak nemcsak abban az értelemben van legitimáló ereje, hogy felhatalmaz a hatalmi pozíciók megragadására; az állandóan folytatott politikai diskurzus a politikai uralom kifejtésének módjára is meghatározó hatást gyakorol”"945 - véli Habermas. Úgy gondoljuk, a koalíciós években a véleményharc a demokrácia fogalmának értelmezése tekintetében különösen hangsúlyosan tudott megjelenni, a politikai uralom kifejtésére viszont nem gyakorolhatott döntő hatást; ugyanakkor az, hogy az 1945 utáni esztendőket e véleményharc meghatározhatta, azt illusztrálja, hogy a tanácskozó demokrácia csírái, csökevényei jelen voltak a korabeli magyar társadalmi gondolkodásban.

\footnotetext{
${ }^{944}$ MoLNÁR Attila Károly: A tanácskozó demokrácia és a megváltó csevegés. Nemzeti Közszolgálati Egyetem Molnár Tamás Kutató Központ, Budapest, 2014. 22-45. p.

${ }^{945}$ HABERMAS, Jürgen: A demokrácia három normatív modellje. In: HABERMAS,

Jürgen: Inklúzió, bevonás vagy bezárás. A nemzet, a jogállam és a demokrácia viszonyáról. http://epa.oszk.hu/02100/02121/00003/pdf/EPA02121_Fordulat_2009_5_10-87.pdf (A letöltés időpontja: 2017. április 29.)
} 
Dahl a demokratikus müködés szempontjából 7 lényegi tényezőt emel ki: legyenek választott tisztségviselök, szabad választások, általános választójog, biztosított legyen minden szavazópolgár számára a megválaszthatóság esélye, legyen véleményszabadság és információszerzési szabadság, s a polgárok szabadon alakíthassanak szervezeteket. ${ }^{946}$ Dahl úgy véli, ha ezek az elemek formálisan léteznek, akkor az önmagában még csak poliarchia, amennyiben a felsorolt tényezők valóságosan is jelen vannak a társadalmi gondolkodásban, akkor beszélhetünk demokráciáról. A koalíciós évek időszakában Dahl kategorizálását tekintve a 7 formális tényező mindegyike létezett, ugyanakkor tudjuk, a társadalom napi életében ezek az elemek nem álltak össze zavartalan demokratikus müködéssé. Dahl fogalomhasználata alapján azt állíthatjuk, az 1945 utáni néhány esztendőben nem kellően demokratikus formális poliarchia létezett Magyarországon.

Az 1945 utáni esztendők demokrácia-diskurzusait vizsgálva az alábbi kifejezéseket tekinthetjük a korszak kulcsfogalmainak: félelem, remény, totális megosztottság, bizalmatlanság, kényszerü kompromisszum.

A koalíciós évek közéleti világát a totális megosztottság jellemezte, a politikai aréna szereplői között esély sem volt arra, hogy egyfajta demokratikus minimumban megegyezzenek, a demokrácia struktúráinak nem léteztek vitán felül álló elemei. A teljes bizalmatlanság lelki tényezőjének hátterében az állt, hogy az antikommunisták nem bíztak a kommunisták demokratikus elkötelezettségében, míg a kommunisták bizalmatlanok voltak mindenkivel szemben. A korszak kommunikációs terét mégis az állandó és kényszerü kompromisszumok jellemzik: a kommunisták számára kényszerü kompromisszum volt eleve a népfrontos politikából fakadó engedmény a polgári demokrácia eszményei felé. A kisgazdáknak pedig a koalíciós válságok során a kommunista követelésekkel szemben kellett folyton hátrálniuk és kényszerü kompromisszumokat elfogadniuk.

A félelem a korszak kiemelt jelentőségű fogalma. A koalíciós évek demokráciáját végig jellemezte, hogy a kommunisták, a kommunistákkal szimpatizáló erők „féltek” attól, hogy az 1944 decemberében megindított társadalmi és politikai változások megrekednek és a kommunistákat - az esetleges szovjet csapatkivonulás után - kiszorítják a hatalomból, s ezt követően megindul egy olyan visszarendeződési folyamat, amely 1919-1920-ban lezajlott Magyarországon. A kommunisták hegemón pozíciója ellenére ez a pszichés hozzáállás jellemezte a koalíciós évek baloldali közösségének mentalitását. A disszertációnkban elemzett

\footnotetext{
${ }^{946}$ LÁNCZI András: Demokrácia és politikatudomány. Aula, Budapest, 2000. 193-204. p.
} 
korabeli kommunista kommunikációs panelek alátámasztják ezt a fajta félelemi struktúrát. Minden magabiztosságuk ellenére, a kommunisták valóban tartottak attól, hogy a weimarizáció bekövetkezhet a negyvenes évek Magyarországán.

Az antikommunisták a koalíciós korszak kezdetétől fogva tartottak a kommunista diktatúra kialakulásától. Hiába tünt úgy 1944-1945-ben, hogy a Szovjetunió engedi a parlamentáris demokrácia rendszerének kialakulását és hiába kötelezte el magát szavak szintjén a Magyar Kommunista Párt a demokrácia ügye mellett, az antikommunista attitüdü erők a koalíciós időszak alatt mindvégig szkeptikusak voltak a kommunisták valós szándékát illetően. A közélet történései rendre felerősítették ezt az antikommunista félelmi spirált. E folyamat jelképes tetőpontját az összeesküvési ügy által generált válság, Kovács Béla elrablása és Nagy Ferenc lemondatása jelentette. Hogy mindezek után 1947. augusztus végén - minden inkorrektség és szabálytalanság ellenére - mégis megtörténhetett egy kvázi szabad választás, a rögzült antikommunista félelem ellen hatott. A „kékcédulás” választás után a Pfeiffer-párttal szembeni antidemokratikus fellépés és az ellenzéki politikusok tömeges emigrációba kényszerítése szintén erősítette a félelemi érzületet. 1948/1949-re a kommunista diktatúra rendszere kiépült.

A koalíciós évek alatt a kommunista és az antikommunista nézőpont híveiben is megélt, rögzült és antagonisztikus félelmek munkáltak. A politika lépéseit, a kommunikációs stratégiák megalkotásának háttérmechanizmusát is markáns módon félelmi reflexek mozgatták.

1944 decembere és 1948/1949 között demokrácia müködött, amely referenciaértékkel bír a későbbi történeti korok számára. Ennek a néhány évig müködő demokráciának viszont meghatározó jellemzője és tényezője volt a félelem.

A félelem érzése mellett a koalíciós korszak másik fontos közösségi attitüdje a remény volt. 1944 decemberétől a demokrácia keretei között tevékenykedő antikommunisták és az új rend hegemón szerepben lévő építői, a kommunisták is tele voltak reménnyel. Az antikommunista demokraták egy jogállami jellegü demokrácia felépítésében bíztak és reménykedtek, míg a baloldal híveit a radikális társadalmi változás esélye töltötte el reménnyel.

Az antikommunisták reményét táplálta, hogy 1944 decemberétől a demokrácia intézményei elkezdtek kiépülni, létrejöttek a véleményszabadság fórumai, demokratikus pártok müködhettek, komoly társadalmi változások indulhattak meg. 1945 őszén szabad választásokat bonyolítottak le, amelyeket az antikommunista erők nyertek meg (a budapesti törvényhatósági voksolást október 7-én és a parlamenti választások november 4-én 
rendezték), a paraszt-polgári demokrata erők vezetői fontos pozíciókat tölthettek be: Tildy Zoltán köztársasági elnök; Nagy Ferenc miniszterelnök; Varga Béla nemzetgyülési elnök; Valentiny Ágoston, Vásáry István, Kovács Béla, id. Antall József, Keresztury Dezső miniszter; Pfeiffer Zoltán államtitkár lehetett. A demokráciareményeket erősítette, hogy a Független Kisgazdapárt 1945 novemberében megválasztott képviselői sorsdöntő parlamenti voksolásokkor - például Kovács Béla mentelmi ügyében - képesek voltak egységesen szavazni. A koalíciós évek antikommunista tömeggyülései, mint például az 1946. szeptember 7-9. között megrendezett parasztnapok szintén reményekkel tölthették el a jogállami demokrácia híveit. Hogy az ismert csalások, hatalmi manipulálások ellenére a szavazatok közel 40 százalékát ellenzéki pártok tudták megszerezni az 1947. augusztus 31-i választásokon, vagy hogy lényegében 1949 februárjáig ellenzéki párt müködhetett az országban (a Barankovics-féle Demokrata Néppárt), mind-mind a jogállami demokráciában reménykedők számára némi bizakodásra adhatott okot.

Mindszenty József bíboros letartóztatásával és perbefogásával, illetve a Demokrata Néppárt megszünésével a polgári demokrácia utolsó reményei is megszüntek - ahogy nőtt a félelem az antikommunista demokrata erők körében, úgy csökkent ezzel párhuzamosan a remény. 1949-re a kommunista diktatúra megvalósulásával egyidejüleg az antikommunisták félelmei beteljesedtek, közösségi reményeik pedig elporladtak.

A koalíciós esztendők miért voltak a remény évei a kommunisták számára? 1944 decemberében 25 évnyi illegalitás után közéleti tér nyílt számukra, ráadásul a szovjet hadsereg jelenléte hegemonisztikus szerepet biztosított nekik. 1945-től kezdve elkezdhették megvalósítani radikális társadalom-átalakító programjukat. 1945 tavaszán megtörténhetett a földreform, a munkásság presztízse megerösödött, elitcsere zajlott le a gazdasági életben és a közigazgatásban. A kommunista harci taktika és az úgynevezett osztályharc folyamatos sikereket hozott az MKP számára. 1947-től elindult a hároméves terv és megtörtént a nagybankok államosítása. A kommunista pártvezetés, a kommunista szimpatizánsok és a baloldali kötődésű állampolgárok tömegei számára is a koalíciós évek a remény évei voltak, nem véletlen, hogy az ötvenes évek „torzulásai” után a koalíciós esztendőkre úgy tekinthettek, mint egy vállalható, a jövőre vonatkozóan is referenciális reményt magában hordozó időszakra.

A koalíciós években a félelem és a remény egyszerre volt képes a politika meghatározó érzésévé válni. Egymással ellentétes érzelmi tendenciák bontakoztak ki a közéleti térben, a pszichózis lényegi elemeként azonosítható: minél erősebb volt a remény, annál kisebb a félelem, és fordítva, ahogy felerősödött a félelem, annál kisebbé vált a remény 
lehetősége. A félelem és a remény dimenziója tekintetében a koalíciós esztendőkben a kommunisták győzedelmeskedtek, az antikommunisták pedig vereséget szenvedtek. Ennek ellenére a történeti tudatban a koalíciós évek az antikommunista nézőpontból is a demokrácia referenciális kereteként rögzült.

A félelemnek mint érzésnek a koalíciós évek magyar demokráciájának létrejöttében, kialakításában is van szerepe. A második világháború előtti években, a háború alatt és közvetlenül a világégést követő esztendőkben a kommunisták Magyarországon és szerte Európában is elfogadták történeti kompromisszumként - a fasizmussal, a nácizmussal, a szélsőjobboldallal szembeni harc, illetve ebből következően a nyugati demokráciákkal való együttműködés részeként -, hogy a közeljövőben lemondjanak a proletárdiktatúra bevezetésének lehetőségéről. A kommunisták számára ekkoriban egyfajta minimum célkitüzésként az fogalmazódott meg, hogy alakuljon ki egy kereteit tekintve jogállami jellegü polgári demokrácia, ami végrehajt egy radikális társadalmi fordulatot, egy kvázi szociális forradalmat. Ez a kompromisszum a létező fasizmus ${ }^{947}$ embertelen viszonyai miatt, az azzal szembeni küzdelemből fakadóan jöhetett létre, vagyis a háború előtt és alatt még veszedelmes fenyegetést jelentő fasizmus kiváltotta félelmi reakciók miatt fogadhatta el a kommunista világmozgalom a polgári demokráciát, mint köztes megoldást. Nyilvánvalóan fontosabb volt akkoriban a kommunisták túlélési mechanizmusa szempontjából a valódi, konkrét és brutális fenyegetést jelentő szélsőjobboldal elleni harc, mint a proletárdiktatúra. A nyugati demokráciákkal való együttmüködés viszont csak úgy volt életképes, ha a kommunisták a fasizmussal szembeni közvetlen küzdelem idején garanciákat adnak arra vonatkozóan, hogy ideiglenesen lemondanak a nyugati demokrácia modelljének felszámolásáról. Ez a történelmi kompromisszum a szélsőjobboldal fenyegetésének hatására alakulhatott ki.

A második világháború befejeztével a magyar kommunisták tele voltak társadalomátalakító reménnyel. Ismerték és elfogadták ugyan a harmincas években a fasizmussal szemben megfogalmazott népfrontos politika taktikai irányát, de ezzel párhuzamosan egyfajta identitásválságot eredményezett számukra, hogy rövidtávon le kellett mondaniuk a lényegi stratégiai célkitüzésrool, a proletárdiktatúráról. Ennek az identitás-dilemmának a politikai-

\footnotetext{
${ }^{947}$ A fasizmus szó maga is egy kommunista metanyelvi kategória, ami alatt összemosták a náci, a ténylegesen fasiszta és az autoriter rendszereket, a szociálfasizmus fogalma alatt néha még a szociáldemokráciát is. E kérdéskörről bővebben: ToMKA Béla: A Harmadik Birodalom. A kutatás új útjai. JATEPress, Szeged, 1999. 9. 29. p., JANOS Andrew C.: Haladás, hanyatlás, hegemónia Kelet-Közép-Európában. Helikon Kiadó, Budapest, 2003. 135-227. p.
} 
kommunikációs „terméke” a népi demokrácia fogalmának kommunikációs panelként való használata.

Az 1945 utáni évek magyar közéletének demokrácia-diskurzusait alapvetően a demokrácia kontra diktatúra, más megközelítésben a félelem és a remény dichotómia határozta meg: a viták lényege az volt, hogy demokrácia vagy diktatúra lesz-e, vagyis a diskurzus valódi tartalma nem arról szólt, hogy polgári vagy népi demokrácia formálódik, hanem hogy van-e bármi esélye a szabadságjogokra épülő demokrácia gondolatának a formálódó diktatúrával szemben. 1949-re ez a vita „eldőlt”, a demokrácia-remény megszünt létezni. A félelem érzése pedig a következő évek, a kialakuló Rákosi-diktatúra szempontjából új dimenziót nyert.

Az 1945 utáni néhány esztendőt, a koalíciós évek korszakát és a Rákosi-rendszert éppen a demokratikus párbeszéd választóvonala különíti el egymástól. Amíg a demokráciának voltak legalább tüneti megnyilvánulásai (például míg volt ellenzéki/antikommunista párt a parlamentben), addig beszélhetünk önálló történeti időszakról. Amikor a demokratikus feltételek teljességgel eltünnek, s nyomokban sem találhatóak meg a jogállami jellegü müködés elemei, akkor az a berendezkedés már a kommunista diktatúra struktúrája. Úgy véljük, a demokrácia-tartalom mennyisége, minősége alkalmas lehet a korszakok (a koalíciósés a Rákosi-korszak) közötti elhatárolás felvázolására.

Demokratikus jelenségek kétségkívül léteztek az 1945-öt követő néhány esztendő magyar közéletében. A társadalom többsége demokráciát akart, elindított egy demokráciakísérletet, amely azonban csak addig haladhatott a maga útján, amíg a szovjetek engedték valójában kezdettől fogva nem volt semmi esély arra, hogy hosszabb ideig tartó demokratikus berendezkedés alakulhasson ki Magyarországon.

Mindebből következően az 1945 utáni esztendők demokrácia-törekvései kapcsán a demokrácia-szándék fogalma tünik legitim kifejezésnek, hiszen a diszkurzív szövegek elemezése után is arra a következtetésre juthatunk, hogy a magyar közéletben az 1945-öt követő esztendőkben a demokrácia-szándék nyilvánvalóan azonosítható.

A magyar társadalom demokrácia-szándékát bizonyítják a közvetlen demokrácia intézményei, a demokrácia-viták, a pártok müködése, a pártprogramokban szereplő demokrácia-hitvallások és a sajtó viszonylagos szabadsága.

1945 és 1948/49 között a demokrácia-szándékok és demokrácia-élmények soksága korszakformáló tényezővé tudott válni. 
Disszertációnk célja volt, hogy hozzájáruljunk a magyar politikai kultúra egyik legellentmondásosabb demokratikus tradíciójának, a koalíciós évek demokráciájának az újrapozícionálásához. Meggyőződésünk, hogy az 1945 utáni években a jogállami demokráciáért vívott küzdelmek demokratikus tapasztalata közös szellemi élményt ad mindenkor, minden demokrata számára. 


\section{Függelék}

A lokális beszédmód: demokrácia-megnyilvánulások a lokális demokrácia fórumain - A demokrácia mint fegyver a koalíciós évek makói közéleti küzdelmeiben

\section{1944/45: A kisvárosi demokráciaépitkezés kezdetei}

A lokális demokrácia-megnyilvánulások tekintetében Makó városa alkalmas terep lehet annak tanulmányozására, hogy az országos viták, demokrácia-értelmezések, kommunikációs panelek miként hatottak helyben, miként alakították, formálták a helyi demokráciát a különböző demokrácia-felfogások.

Makó $^{948}$ a koalíciós években azon ritka megyeszékhelyek egyike volt az országban, ahol nem volt a megyében másik város, vagyis a megyei és a városi politika egymásra utaltsága erősebb jelentkezett mint máshol. Makó volt az „első felszabadult magyar város”,

\footnotetext{
${ }^{948}$ Makó város a koalíciós években Csanád vármegye székhelye. Az 1949-es népszámlálás szerint Makón 34059 ember élt, 18015 nő és 16044 férfi. (Központi Statisztikai Hivatal 1949 évi népszámlálás. 1. Előzetes adatok. Állami Nyomda. Budapest, 1949. XIV. p.) Az 1947-es hivatalos adatok arról tájékoztatnak, hogy Makó város területén ekkor 14971 római katolikus, 1196 görög katolikus, 715 evangélikus, 16791 református, 86 görögkeleti, 2056 zsidó és 184 egyéb vallású személy lakott. (Schematismus Cleri Dioecesis Csanadiensis Pro Anno Domini 1947. Edito Ordinariatus Csanadiensis, Szeged, 1947. 20. p.)

A dualizmus (Makó története 1849-töl 1920-ig. Makó Monográfiája 5. Szerkesztette: SzABó Ferenc. Makó, 2002.) és a Horthy-rendszer (TóTH Ferenc (szerk.): Makó története 1920-tól 1944-ig. Makó Monográfiája 6. Makó Város Önkormányzati Képviselőtestülete. Makó, 2004.) alatt is Makón markáns tényezőt jelentett a városi közéletben a polgári demokrácia ethosza, a polgári demokratikus erőknek komoly tömegbázisa volt. A polgári demokrata gondolkodású Justh Gyula, a Függetlenségi és Negyvennyolcas Párt politikusaként 1884-től egészen 1917-es haláláig képviselte Makót és Csanád vármegyét az országgyülésben. A 48-as Függetlenségi Párt a Horthy-rendszerben is döntő szerepet játszott a város életében, ebben az időszakban már a köznyelvben inkább Kossuth-pártként emlegették az akkorra az országos politikában nem funkcionáló politikai formációt.

Makó polgári demokratikus hagyományairól Erdei Ferenc szociológusként írt. (ERDEI Ferenc: Város és Vidéke. Akadémiai Kiadó, Budapest, 1977. 245-310. p.) A polgári demokratikus helyi közgondolkodás társadalmi alapját az adta, hogy Makón a hagymakertészetnek köszönhetően az önálló egzisztenciát teremteni képes kisbirtokos paraszt-polgárságnak volt döntő szerepe, vagyis létezett egy széles helyi alsó-középosztály. A hagymás gazdálkodási kultúra meghatározó jellemzője, hogy kis földterületen meg lehet annyi hagymát termelni, ami önálló egzisztenciát képes biztosítani a gazdálkodó számára. (TóTH Ferenc: A makói hagyma. Makó Város Önkormányzati Képviselőtestülete. Makó, 1998. TóTH Ferenc: A makói hagyma történetéhez. A Makói Múzeum Füzetei 4. Makó, 1969.)

„Makó abban is eltér a hagyományos mezővárosoktól, hogy autonómiája nagyobb azokénál, a nagybirtok nem jellemző. Ez pedig a város paraszttársadalmának nagyobb önállóságot, nagyobb szerepet biztosít a várost érintő döntésekben. Mindez összekapcsolódik a piacra orientált termelés által megkövetelt nyitottsággal, a világra való érzékenyebb reagálással, ami a makói életformát is individualizáltabbá és urbánusabbá teszi." (GÁBOR Kálmán - VÁGVÖLGYI András: A kisvárosi fejlődés sajátos útja. Adalékok Makó demográfiai helyzetéhez. A Makói Múzeum Füzetei 12. Makó, 1974. 6. p.)

1945 májusában az MKP makói taglétszáma 478 fő volt. (TAMASI Mihály: A népi demokratikus forradalom győzelme. In: KoROM Mihály (szerk.): Makó az első felszabadult magyar város. II. kötet. Makó Városi Tanács, Makó, 1974. 37-162. p.)
} 
vagyis a Makón történtek komolyabb jelentőséggel bírtak, hiszen az első „felszabadult magyar város"949 komolyabb referenciaértékkel bírt. Makó a hagymatermelés miatt egy sajátságos társadalmi helyzettel rendelkezett a két világháború között és 1944 után is. Ebből is következett, hogy a polgári szabadságjogoknak és az egyéni autonómiának nagyobb tere volt, a helyi társadalom szereplői már hozzászoktak ahhoz, hogy a különböző jogosultságok bonyolult összességéből demokratikus jogok kovácsolódnak. A marxista történetírók ezt a jelenséget értelmezték úgy, hogy Makón a kispolgári demokráciának tradicionálisan komoly bázisa teremtődött. ${ }^{950}$

Makó a maga komoly (kis)polgári demokratikus hagyományaival, létező munkásmozgalmi tradícióival egyfajta helyi demokrácia-laborként tudott múködni a koalíciós évek időszakában. A város az 1944 utáni bő négy esztendőben demokrácia-élményeket élhetett meg, ez az időszak Makó történetében is a demokrácia-remény korszaka volt.

Makót 1944. szeptember 26-án „szabadították fel”, foglalták el a szovjet csapatok. Az addig illegális kommunisták azt valószínűsítették, hogy a szovjet megszállás konszolidálásával együtt - az 1919-es viszonyokhoz hasonlatosan - a proletárdiktatúra világa következhet el. ${ }^{951}$

A helyi kommunisták delegációja 1944. szeptember 30-án találkozott Aradon Vas Zoltánnal, a kommunista pártvezetés - Moszkvából nem sokkal hamarabb visszatért prominens tagjával. ${ }^{952}$ A megbeszélésen Vas ismertette a makói párttagokkal a moszkvai álláspontot, miszerint többpártrendszerű demokráciára kell felkészülniük és együtt kell müködniük a demokratikus helyi erőkkel. A makói kommunisták többségét meglepte ez a politikai irány, ez a fajta külsődleges demokrácia-elvárás. „A párttagok többsége, akik már az 1919-es tanácsköztársaság idején is végeztek politikai munkát, úgy vélték, hogy most is olyan módszereket kell alkalmazni és a politikai cél sem lehet más, mint a proletárdiktatúra

\footnotetext{
${ }^{949}$ A kommunista diktatúra idején külön kultusza volt e ténynek. A városi tanács Makó legújabbkori történetéről Makó az első felszabadult magyar város címmel adta ki több kötetes monografikus feldolgozását. A Makó környéki hadműveletekröl: KoROM Mihály: Makó felszabadulása. In: Makó negyven éve szabad. Várospolitikai füzetek 6. Makó, 1985. 5-15. p.; HALMÁGYI Pál: A Makó és környékéért vívott harcok 1944 öszén. A Makói Múzeum Füzetei 65. Makó, 1989.

${ }^{950}$ TAMASI Mihály: A népi demokratikus fejlődés Makón. In: Tanulmányok Csongrád Megye Történetéből IX. Csongrád Megyei Levéltár. Szeged, 1985. 173-194. p.; SzABÓ János: Csanád vármegye a népi demokratikus forradalom időszakában 1944-1948. Bölcsészdoktori disszertáció. 1983. A kézirat a Magyar Nemzeti Levéltár Csongrád Megyei Levéltárának könyvtárában megtalálható. Disszertációjában Szabó az 1944 és 1948 közötti időszakról úgy ír mint Makó város és Csanád megye „,demokratizálódási folyamata” (225. p.) és a „népi demokratikus átalakulás" (358. p.) korszaka.

${ }^{951}$ TAMASI Mihály: A népi demokratikus fejlődés Makón. 175. p.

952 VAS Zoltán: Viszontagságos életem. Magvető Kiadó, Budapest, 1980. 664. p.; KISS Imre: Egy munkásháztól a városházáig (Önéletírás). Makó. 1989. 147-152. p.
} 
kikiáltása"953 - olvashatjuk az akkori makói kommunista életérzésről a helyi kommunista vezető, Kiss Imre visszaemlékezéseiben.

A november 11-én megtartott helyi párttaggyülésen ${ }^{954}$ a többség a pártfegyelem leninista-sztálinista elvéből kiindulva tudomásul vette, hogy nem lesz egyelöre proletárdiktatúra, hanem a formális polgári demokrácia elvárás-rendszerének kell megfelelni és a jogállami demokrácia mindennapi világában kell a kommunista érdekeknek megfelelően politizálniuk, de a kisebbség érzelmi alapon nem tudta elfogadni, hogy együtt kell müködni a polgári demokratikus erőkkel. Kiss Imre, későbbi kommunista polgármester úgy emlékezett e helyzetre, hogy ezek a párttagok azt akarták volna, hogy ,azonnal”955 valósítsák meg a proletárdiktatúrát és nincs szükség demokratikus megalkuvásra. ${ }^{956}$

Tamasi Mihály marxista helytörténész szerint a makói kommunisták „nem mindenben értették meg” "957 a párt új irányvonalát, de ennek ellenére mégis hozzáláttak a „fasisztaellenes demokratikus erők tömörítéséhez." ${ }^{958}$ Ennek a demokrácia ethoszát - ideiglenesen, taktikai okok miatt - elfogadó stílusnak volt jelképes megnyilvánulása, hogy a háborús viszonyok közepette az úgynevezett polgári városparancsnok (az ideiglenes polgármester) a kommunisták jóváhagyásával, egyetértésével az egykori Kossuth-párti, polgári demokratikus gondolkodású Könyves-Kolonics József ügyvéd lehetett.

A ,demokratikus politikai napilap” fejléccel megjelenő, de a kommunisták befolyása alatt müködő Makói Népújság első számában, 1945. január 23-án a helyi kommunisták

\footnotetext{
${ }^{953}$ KISS Imre: Uo. 152. p.

954 A november 11-ei gyülésről bővebben: TAMASI Mihály: Makó felszabadulása. Harc a népi demokratikus fejlődésért. In: TAMASI Mihály (szerk.): Makó az első felszabadult magyar város. Makó Városi Tanács Kossuth Könyvkiadó, Makó - Budapest, 1969. 244-279. p.

${ }^{955}$ KISS Imre: Uo. 155. p.

${ }^{956}$ A különböző belső pártjelentések azt a csoportot, amely az 1944 utáni esztendőkben érzelmileg nem tudott azonosulni a demokratikus irányvonallal, úgy emlegetik, mint a szektás csoportot. A szektás csoport tagjai alkalmanként egészen groteszk helyzeteket is produkáltak: Puja Frigyes megyei káderes az MKP KV Káderosztályának írott 1946. december 31-i leveléből megtudjuk például, hogy az R Gárda bálján Nacsa József párttag ,részeg-fejjel elkotyogta, hogy a párt tagjai titkos összejöveteleket tartanak magánházaknál és ott olyan kijelentések is elhangzanak, hogy Sztálin és Rákosi elvtárs is elárulta a munkásosztályt.” (Puja Frigyes megyei káderes levele az MKP KV Káderosztályának, 1946. december 31. Politikatörténeti Intézet Levéltára /a továbbiakban PIL/ 274. f. 25. cs. 47. őe.) Szintén a szektásoknak tudták be a megyei pártvezetők, „hogy a legtöbb Csanád megyei községben még mindig félnek a Kommunista Párttól. Még mindig vannak tömegek, akik a kommunistákat kétszarvú ördögnek képzelik. [...] Egy-két ember terror alatt tartja a falut és rengeteget árt a Pártunknak. Ezek az elvtársak minden jómódú parasztot, minden értelmiségit, de minden jobban öltözködő iparost, vagy ipari munkást a Kommunista Párt ellenségének tekint.” (Puja Frigyes megyei káderes beszéde az MKP II. Csanád megyei konferenciáján. PIL 274. f. 16. cs. 153. őe)

Erdei Ferenc a Város és vidéke című városszociográfiájában is írt erről a bizonyos makói szélsőbaloldali szektás csoportosulásról: „Makón erős és aktív volt a munkásmozgalom. [...] De nem kevés szektás hajlam is kifejlődött a munkásmozgalom soraiban. A szocializmusba vetett hit és az osztályharc elszántsága olykor messianisztikus elképzelésekig vezetett.” (ERDEI Ferenc: Város és vidéke. Akadémiai Kiadó, Budapest 1977. 282. p.)

${ }^{957}$ TAMASI Mihály: A népi demokratikus fejlődés Makón. 175. p.

${ }^{958}$ Uo.
} 
álláspontját közlő szerkesztőségi cikk leszögezte, hogy a kommunisták a „demokratikus államrend" ${ }^{959}$ pártján állnak és a demokrácia alapvető részének tekintik a szabadságjogokat, a „szervezkedési szabadságot” és a gyülekezési szabadságot. A négy nappal később megjelenő, aláírás nélküli, de szintén a kommunisták véleményét tükröző írásban az ismeretlen szerző hitet tett amellett, hogy a kommunisták a „,demokratikus utat”960 választották. „Nem akartunk terrorisztikusan eljárni" "961 - olvasható a cikkben, ahol a szerző azt is kifejti, hogy a demokrácia „formai lehetőség”, amelyben ,a nép többsége dönt” a kormányformáról. E publicisztikában megnyilvánuló demokrácia-értelmezésben is tetten érhető az a jellegzetes kommunista megközelítés, amely szerint a demokrácia viszonyai közepette is a „reakcióval” szemben „könyörtelenül” kell elbánni, máskülönben veszélybe kerül maga a demokrácia.

Gajdi István Rólunk, kommunistákról! című cikkében arról ír, hogy a demokrácia adta keretek között sem gyakorolható afféle „humanizmus”, ${ }^{962}$ amelynek köszönhetően a demokrácia ellenségei olyan szinten „eröre kapnak, hogy szépen-lassan kiácsolnák szívükben

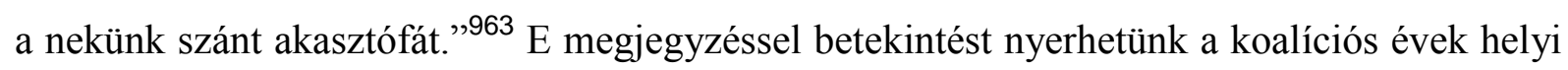
kommunista lelkivilágába, amelynek egyik jellemzője a félelem a későbbi, potenciális „ellenforradalmi” megtorlástól. Gajdi írásában van még egy tanulságos demokrácia-értelmező megjegyzés: „A demokráciát választottuk, mikor kész lehetőség állt előttünk az osztályuralom megvalósításához." 964 E mondat arra utal, a helyi kommunisták 1944 őszétől több hónapokon keresztül érzelmileg nehezen élték meg, hogy nincs lehetőség a proletárdiktatúra megteremtésére - noha formailag minden erőforrás rendelkezésükre állna. Másrészt ezen érvelés mögött rekonstruálható az a fajta vitakultúra, miszerint véleményeltérés esetén a polgári demokratikus erőkkel szemben döntő érv lehetett a kommunisták részéről, hogy nekik lehetőségük lett volna diktatúra kialakítására is, de ők a demokratikus utat választották, így a szemben álló felek értékeljék mindezt, és ne ragaszkodjanak adott esetben egy konkrét állásponthoz.

A demokrácia védelméért címü 1945. április 12-i vezércikkben a makói közéleti sajtófórumon először érhető tetten a demokrácia védelme ürügyén az „ellenségkép” markáns megjelenítése. „A demokrácia érdekében nem engedhetjük meg azt a luxust, hogy emberiességből ne sújtsunk le a legnagyobb eréllyel a demokrácia ellenségeire"965 _

\footnotetext{
${ }^{959}$ Kommunisták a magyar közéletben. Makói Népújság, 1945. január 23. 1-2. p.

${ }^{960}$ Gondoljuk meg! Makói Népújság, 1945. január 27. 1-2. p.

${ }^{961}$ Uo.

${ }^{962}$ GAJDI István: Rólunk, kommunistákról! Makói Népújság, 1945. február 4. 1. p.

${ }^{963} \mathrm{Uo}$

964 Uo.

965 A demokrácia védelméért. Makói Népújság, 1945. április 12. 1-2. p.
} 
olvasható az írásban. A vezércikk szerint éppen a humanizmus érdekében kell fellépni az „ellenséggel” szemben és ezt a határozott cselekvést Makón is fel kell vállalni. „Ha az egyik testrészünk annyira megbetegszik, hogy az egész szervezetet romlással fenyegeti, akkor az orvos eltávolítja azt, ugyanúgy a társadalomnak is joga van, hogy azokat az elemeket, akik az egészet romlásba dönthetik, kioperálja magából”966 - hangzik az „ellenséggel” szembeni radikális fellépést alátámasztó hasonlat.

A demokrácia-értelmező helyi publicisztikákban felmutatható egy olyan elem is, mikor a szerzők azért aggódnak a demokráciáért, mert a demokratikus struktúrák nincsenek kellőképpen valós tartalommal megtöltve. „Demokrácia van a falakon, a plakátokon, de nem ég a szívekben”967 - olvasható a Közöny című írásban. „A magyar demokrácia fiatal és ennek következtében nem tudott még teljesen beleépülni a nép lelkébe. Évek kellenek ahhoz, hogy a nép elfelejtve az elnyomást, a szónak igazi értelmében szabadon tudjon élni”"968 - e gondolatok már $A$ demokrácia elvének gyakorlata címü cikkben találhatóak. Szintén a tartalom nélküli demokrácia-képhez tartozó érvkészlet jelenik meg a Lelkek újjáépitése címü írásban: „A mi demokráciánknak még csak a keretei vannak meg, de a kereteket kitöltő demokratikusan gondolkodó embertömegek még hiányoznak."969 Még 1946 áprilisában is található írás, mely erre a tartalmilag hiányos demokrácia-kérdésre reflektál. „Demokraták nélkül nincsen demokrácia. A nép minden egyes fiának meg kell mutatni, hogy valóban akarja a demokráciát, a nép uralmat"970 - olvasható a Makói Népújság Köztársaság és szabadság címü publicisztikájában.

Az a gondolat is feltünik a demokráciáról szóló lokális értelmezésekben, miszerint nincs szükség pártharcokra a demokráciában, mert azzal a demokrácia erői csak megosztják magukat. A pártpolitikai küzdelmekkel - és ebből fakadóan a demokratikus verseny ethoszával - szemben határozottabb hangot megütő érvelés így hangzik: „Az egyéni törekvések, [...] a belvillongás, a pártküzdelem, a hatalmi kérdés olyan fényüzés, amit most, ebben a tragikus pillanatban nem engedhetünk meg magunknak, mert ha megengedjük, öngyilkosságot követünk el."971 Mindeme gondolatnak egy mérsékeltebb megnyilvánulása $A z$ együttműködésről szóló cikkben található meg: „Az újjáépítés, országunk anyagi és szellemi javainak újjáteremtése a demokratikus erők nagy próbájától függ, mely egyet jelent a

\footnotetext{
${ }^{966}$ Uo.

${ }^{967}$ Közöny. Makói Népújság, 1945. május 6. 1-2. p.

${ }^{968}$ A demokrácia elvének gyakorlata. Makói Népújság, 1945. május 26. 3. p.

${ }^{969}$ Lelkek újjáépítése. Makói Népújság, 1945. június 22. 1. p.

${ }^{970}$ Köztársaság és szabadság. Makói Népújság, 1946. április 7. 1. p.

${ }^{971}$ A béke és ami mögötte van. Makói Népújság, 1945. június 16. 1. p.
} 
demokratikus pártok őszinte együttmüködésével."972 1945 lélektanilag felszabadult hónapjaiban teljesen legitim érvelés a demokratikus verseny veszélyeire figyelmeztetni, hiszen a pártpolitikai küzdelmek óhatatlanul a közélet konszenzusos területeit gyengítik, de ez az előbb idézet álláspont által azon kommunista párti érvelés érhető tetten, amely már 1945ben is legszívesebben elkerülte volna a szabad választásokon megnyilvánuló akaratképzés lehetőségét.

A demokrácia iránti közöny mint téma szintén karakteres eleme az 1945-ös makói publicisztikáknak - minderre egy jellemző példa: „Amióta elült a harci zaj és dolgaink, ügyeink úgy ahogy kerékvágásba kezdenek térni, az emberek lelkesedése, a demokrácia utáni vágy mintha egy kicsit lelohadt volna. Bizonyos tespedtség jelei észlelhetők”"973 - írja a „ds” szignóval publikáló szerző 1945. június 20-án.

Az 1945 utáni makói közéletben kifejezett demokrácia-vita nem létezett, mert sem szellemi, intellektuális értelemben, sem megjelenési lehetőséget tekintve nem voltak biztosítottak a mindehhez szükséges feltételek. Demokrácia-vita tehát nem volt, de számos demokrácia-értelmező cikk látott napvilágot.

Nem jellemző elemként, de található olyan írás is a koalíciós évek makói publicisztikái között, ami arra a lényegi pontra kíván utalni, miszerint a demokrácia meghatározó vonása, hogy ellentétes a diktatúra világával. „A mostani világháború bizonyította be a legfényesebben, hogy terrorra tartósan építeni nem lehet. Parancsuralmat egyébként sem vállal egyetlen demokratikus párt sem, mert nem is vállalhat"974 - tesz hitet a demokrácia mellett és a diktatórikus megoldásokkal szemben a Lelkek újjáépitése címü cikk. A Vezetők a demokráciában címü írás szintén abban látja a demokrácia lényegét, hogy abban nem a diktatúra jellemzői vannak jelen. „A demokráciában a vezetőkre nem hivatalfőnökként néznek le és nem alárendeltek néznek föl, mint a szamárlétra magas célja felé, hanem milliók nézik, ellenőrzik, mozgatják és fejezhetik ki tudatos szervezettséggel tetszésüket vagy nemtetszésüket."975 E cikk a demokrácia lényegi elemének a vezetők ellenőrzésének lehetőségét tekinti; megállapíthatjuk, ezen álláspont teljes mértékben illeszkedik a jogállami demokrácia-értelmezés fogalmi kereteihez. Az ilyen típusú demokrácia-publikációk léte a lokalitás fórumain arra utal, hogy 1945/1946-ban még őszintének tűnő bizakodás jellemezte az országos és a helyi véleményt formáló elitet abban a tekintetben, hogy a demokratikus

\footnotetext{
${ }^{972}$ Az együttműködésről. Makói Népújság, 1945. július 14. 1. p.

${ }^{973}$ Van-e még szükség a Nemzeti Bizottságokra? Makói Népújság, 1945. június 20. 1. p.

${ }^{974}$ Lelkek újjáépítése. Makói Népújság, 1945. június 22. 1. p.

${ }^{975}$ Vezetők a demokráciában. Makói Népújság, 1946. május 12. 1. p.
} 
jogok léte biztosított, s a demokratikus jogok jövendőbeli biztosítása szempontjából sincsenek alapvető veszélyek.

A reakció kontra demokrácia fogalmi ellentétpár, publicisztikai elemzési kérdés csakúgy, mint országos szinten, a makói közéletben is gyorsan napirendre került. Az $U_{j}^{\prime}$ fogalom címü vezércikk névtelen szerzője 1945. augusztus 9-én a „demokratikus élet” kulcsfogalmának tekinti a reakció kifejezést, a reakciósságot pedig a demokrácia „ellenpontjaként”,976 határozza meg, filozofikusabb hangvételű okfejtéssel úgy véli, a demokratikus cselekvés ellenhatása a reakció maga. E nézőpont szerint a reakció célja a népuralom megakadályozása. „Nem hangoztathatjuk elégszer, hogy a most kialakuló, még kétségtelenül gyenge demokráciánknak legkönyörtelenebb ellensége a reakció. Megtépázottan, de megszervezve lapul lesállásaiban és onnan figyeli éberen az eseményeket [...] és akadályozza, ha lehet, elgáncsolja a demokrácia építő törekvéseit"977 - olvashatjuk az értelmező publicisztikában. Mindeddig ez az érvelési stílus teljes mértékben illeszkedik a korszak kommunista ideológiai alapvetéséhez, de a cikknek van egy különösen figyelemreméltó része, ahol a korábbi konzekvens szélsőbaloldali retorikával szemben jóval megengedőbb álláspontot fogalmaz meg. A publicista ugyanis szót emel azzal a jelenséggel szemben, hogy gyakran a reakciós jelzővel illetik azokat is - és ezzel ,álmatlan éjszakákat okoznak haladó szellemű jószándékú embereknek"978 -, akik pusztán a demokrácia biztosította jogokkal élve a véleményüket fogalmazzák meg. „Megengedhetetlen, hogy politikai elfogultság, gazdasági verseny, kenyéririgység, vagy egyéni bosszú lángja sebet égessen hasznos, munkás emberek lelkén azzal, hogy belesüti a reakció bélyegét"979 - írja a szerző, aki ezt követően ugyanakkor hitet tesz amellett, hogy a magyar demokráciának „élethalálharcot” kell vívnia a reakcióval szemben. A szövegösszefüggésből kiindulva megállapíthatjuk, a vezércikk írója a reakció fogalommal a régi rend restaurációs törekvéseit mint veszélyforrást azonosítja, de mint aki hitt abban, hogy valódi népuralom, jogállami jellemzőkkel bíró demokratikus államberendezkedés lesz, úgy ítélte meg, a demokrácia ethoszával ellentétes, hogy aktuális hatalmi- vagy magánérdekek alapján érdemektől függetlenül, ártatlanul bárkire rásüthessék a reakciósság diszkreditáló bélyegét.

Arra, hogy már 1945-ben is éltek a helyi kommunisták a megbélyegzés eszközrendszerével, a reakciósság mint bélyeg ellenfelekre való ráragasztásával, a '45-ös makói polgármester-választás körülményei mutatnak példát. Két polgármester-jelölt közül

\footnotetext{
${ }^{976}$ Új fogalom. Makói Népújság, 1945. augusztus 9. 1. p.

${ }^{977}$ Uo.

${ }^{978}$ Uo

${ }^{979}$ Uo.
} 
választhatott a városi képviselőtestület; az egyik jelölt a szociáldemokrata Kiss Ernő ${ }^{980}$ volt, a másik a kommunista Kiss Imre ${ }^{981}$. Az MKP-s helyi politikus 61 szavazattal nyerte el a polgármesteri pozíciót, Kiss Imre 16 vokssal kapott többet, mint szociáldemokrata ellenfele. ${ }^{982}$

Az MKP délkerületi járási titkárainak 1945. június 22-i üléséről készült jegyzőkönyvből ${ }^{983}$ értesülhetünk arról, hogy miként, milyen módszerek bevetésével nyert a kommunista aspiráns. Szirmai István, aki ekkoriban az MKP dél-magyarországi titkárságának vezető személyisége volt, a zártkörü megbeszélésen arról beszélt, hogy azok a szociáldemokraták, akik nem müködnek együtt a kommunistákkal, reakciósok. Erre hozza fel példának a szűk egy hónappal korábbi makói polgármester-választást. ${ }^{984}$ Szirmaitól tudhatjuk meg, hogy az MKP helyi emberei a képviselőtestületi döntést megelőzően világossá tették a szociáldemokratáknak és Kiss Ernő szociáldemokrata jelöltnek, hogy „csak a kommunista párt győzhet, kár mást is jelölni."985 Tárgyalásokon, megbeszéléseken, de nyilvános fórumokon is a kommunisták azt kommunikálták, hogy Kiss Ernő reakciós politikát csinál. Ahogy Szirmai fogalmaz: „,személy szerint mentünk neki.",986

A meggyőződéses baloldali, SZDP-s Kiss Ernőt a demokrácia-felfogásbéli különbözőség választotta el a kommunisták világnézetétől; mivel Kiss Ernő a jogállami jellegű demokrácia-értelmezés híve volt és ebből fakadóan más közéleti stílust képviselt, mint a visszafojtottan és ekkoriban még leplezve, de alapvetően mégis proletárdiktatúrára törő

\footnotetext{
${ }^{980}$ Kiss Ernő szociáldemokrata jelölt esetén a baloldali meggyőződés teljesen egyértelmű volt, több évtizedes munkásmozgalmi múlt állt már ekkor, 1945-ben a veterán közéleti szereplő mögött, aki 1911-től volt az MSZDP tagja. A Horthy-rendszerben munkásmozgalmi aktivitása miatt több évet töltött börtönben. 1944-ben az Ideiglenes Nemzetgyülés szociáldemokrata delegáltja. Nála a baloldali meggyőződés mellett a jogállami demokrácia melletti elkötelezettség is markáns tényező. Kiss Ernő számára a diktatúra mint államberendezkedés elfogadhatatlan volt, a társadalmi változásokat jogállami keretek között képzelte el. (Kiss Ernőröl: TóTH Ferenc: Makó igézetében. Cikkek, tanulmányok. Tóth Ferenc, Makó, 2014. 331-332. p.)

${ }^{981}$ Kiss Imre 1906-ban Makón született Makón. 1944 októberétől az MKP makói csoportjának titkára, az Ideiglenes Nemzetgyűlés képviselője. 1945. május 24-étől Makó város polgármestere. 1945 novemberétől Csongrád-Csanád vármegye nemzetgyülési képviselöje. 1950-ben a Csongrád Megyei Tanács elnökhelyettese, 1952-1956-os években a Veszprém Megyei Tanács elnöke.

${ }_{982}^{983}$ Makói Népújság. 1945. május 26. 1. p.; TAMASI Mihály: A népi demokratikus fejlődés Makón. 177. p.

${ }^{983}$ Az MKP délkerületi járási titkárainak üléséről készült jegyzőkönyv, 1945. június 22. Magyar Nemzeti Levéltár Csongrád Megyei Levéltára. MSZMP Csongrád Megyei Bizottság Archívuma. /A továbbiakban CSML MSZMP CSMBA/ 20. f. 3. öe.

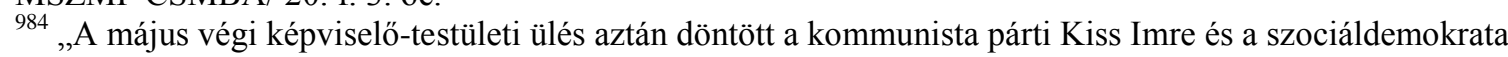
Kiss Ernő között. A testület 61:45 arányban a kommunista jelöltet választotta meg a felszabadulás utáni első polgármesternek. Ez nemcsak annak volt az elismerése, hogy a kommunisták szolgálták legodaadóbban az élet újraindítását, hanem azt is jelezte, hogy továbbra is az övéké volt a politikai kezdeményezés az elsőként felszabadított magyar városban" - írta a 45-ös makói polgármester-választás körülményeiről 1977-ben Balázs György történész. (BALÁzs György: Makó, 1944-45. A közigazgatás újjáéledése az első felszabadult magyar városban. Élet és Tudomány, XXXII. évf. (1977) március 25. 358-359. p.)

${ }_{985}$ Az MKP délkerületi járási titkárainak üléséröl készült jegyzőkönyv, 1945. június 22. CSML MSZMP CSMBA 20. f. 3. öe.

${ }^{986}$ Uo.
} 
helyi kommunisták, ezért bélyegezték meg a polgármester-választás előtti időkben a kommunisták hatalmi érdekből „reakciósnak.” E konkrét lokális szituációból is kitetszik, hogy miként használták már 1945-ben is a reakciós kifejezést a kommunisták a más nézetet vallókkal szembeni megbélyegzésre.

„A reakció elleni harcot legjobban egy kötélhúzáshoz hasonlíthatjuk. A kötél egyik végén áll a demokrácia, és húzza balfelé, a másik végén a reakció, ez szintén magafelé, jobbfelé húzza"987 - ezek Kovács Istvánnak, az MKP KV szervezési osztályvezetőjének a párt 1946. február 9-10-én megrendezett Csanád megyei belső tanácskozásán elhangzott gondolatai. Kovács az országos pártvezetés képviselőjeként vett részt a megbeszélésen, szavai az MKP hivatalos álláspontjának tekinthetőek, amelyeket a helyi kommunisták átvettek. E gondolat által ismét tetten érhető a korszak kommunista kommunikációs stratégiájának a lényege: eszerint országosan és helyben is vannak a demokrácia erői - ők a kommunista világlátással szimpatizáló csoportosulások - és velük szemben áll a reakció bázisa. A „reakció” és a „demokrácia” között nincs közéleti szellemi átjárás, csak kötélhúzás van, vagyis állandó küzdelem, állandó pozícióharc, a konszenzuális megoldások lehetetlenek, hiszen „a reakcióval” szemben csakis a „kötélhúzás” lehet legitim.

1946 első hónapjaiban az MKP makói szervezetén belül egyre türelmetlenebbül viselték, hogy a helyi kommunista akaratot még számos tényező korlátozza. Mindez a korlát, a jogállami demokrácia létével együtt járó hatalommegosztási mechanizmus - a helyi demokráciák müködési szempontjából - természetes jelenség, de a kommunisták az akaratkorlátozási folyamatot a „reakció” ármánykodásaival magyarázták, amely ármánykodással szemben lokálisan és országosan is fel kell lépni. „A demokrácia lassú fejlődése miatti elégedetlenség türelmetlenséggé vált" "988 - írta 1946 márciusában az országos pártvezetés számára készített belső jelentésében az MKP Csanád Megyei Pártbizottsága nevében Rudas Ede megyei titkár.

1946 tavaszától a Makói Népújságban már egyre inkább csak a kommunista stratégiai iránynak megfelelő publicisztikák, demokrácia-értelmezések jelenhettek meg. ${ }^{989}$ Az 1946.

\footnotetext{
${ }^{987}$ Jegyzőkönyv a Csanád megyei konferenciáról. 1946. február 9-10. PIL. 274. f. 16. cs. 152. őe.

${ }^{988}$ Az MKP Csanád Megyei Pártbizottsága jelentése, 1946. március 22. PIL 274. f. 16. cs. 152. őe.

${ }^{989} \mathrm{Ez}$ azzal is összefüggésbe hozható, hogy ekkortól válik egyértelműen az MKP helyi szócsövévé a lap, s 1946tól megjelenhetett a helyi közéletben a kisgazda szellemiségü Délvidéki Független Hirlap és a szociáldemokrata Makó és Vidéke. (BUZÁs László: Makói hírlapok és folyóiratok bibliográfiája 1870-1970. A Makói Múzeum Füzetei 10. Makó, 1972. 10-11. p.; 14. p.) 1945-ben még formailag a demokratikus összefogás lapja volt a Makói Népújság; a szerkesztőség munkáját a koalíciós pártok képviselőiből, illetve a szakszervezet és a MADISZ delegáltjaiból álló úgynevezett sajtóbizottság felügyelte. Az erről szóló dokumentumot közli: TóTH Ferenc: Farkas Imre munkásmozgalmi tevékenysége dokumentumok tükrében. A Makói Múzeum Füzetei 34. Makói Múzeumi Baráti Kör, Makó, 1983. 37.p.
} 
március 30-án napvilágot látott $A$ köztársaság védelmében című cikk szerint az új demokrácia addig „nagyon is elnéző, megbocsátó”,990 volt, de a demokratikus államrend védelméről szóló törvény hatálybalépése után végre eljött az idő, hogy fellépjenek a „rosszhiszemü” erőkkel szemben. „A szabadság híveinek demokráciát kell biztosítanunk, de a demokrácia ellenségeinek nincs jussuk szabadságra"991 - szól az országos kommunista kommunikációból ismert panel.

Kiss Imre kommunista polgármester is hasonló szellemiségü írást publikált a „felszabadulás” első évfordulójára. A polgármester úgy vélte: egy esztendő után visszatekintve, megállapítható, hogy sok még a teendő a demokrácia építésében is, ahogy Kiss Imre fogalmaz: „Sok a kipusztítani való dudva, ami a demokráciánk sarjadó vetését fenyegeti.”" "992 Kiss szerint „őszintébb” demokráciára és „feltételnélküli” őszinte szabadságra van szükség, mert ezzel az őszinte hozzáállással a reakció erői leleplezhetőek.

\section{A kisvárosi demokrata ideáltípusa: Könyves-Kolonics József jogász, városvezetö és} publicista

„Nehéz volt a végnapjait élő és innen már elüzött népgyilkos rendszerben bátor hazafinak, meg nem alkuvó demokratának és egyáltalán helytálló férfinak lenni. Nehéz volt, de nem lehetetlen. Mégis fehér holló az ilyen s úgy kell rámutatnunk ezekre, mint ritka szálfákra a meglapuló bozót közt. [...] Könyves-Kolonics József [...] Makó közéletében volt ilyen ritka szálfa a legsötétebb években"993 - e mondatokat még 1944 novemberében írta Erdei Ferenc Könyves-Kolonics Józsefröl, aki ekkoriban Makó város polgármesteri jogköröket gyakorló úgynevezett polgári városparancsnoka volt.

Könyves-Kolonics József - ahogy egykori pártfogoltja, Erdei fogalmazott - valóban „meg nem alkuvó demokrata” volt. A koalíciós években is. Könyves-Kolonics az 1944 utáni esztendőkben igazi demokrácia-hitvalló tevékenységet folytatott, ezért is kívánunk lokális demokrata szerepvállalásának önálló alfejezetet szánni.

„Könyves-Kolonics [...] Kossuth politikai hitvallását, Justh Gyula függetlenségi eszméit éppúgy magáévá tette, mint Jászi Oszkár polgári radikalizmusát. József Attila plebejusi verseinek egyik ihletője, Erdei Ferenc principálisa. A két világháború közötti Makó

\footnotetext{
${ }^{990}$ A köztársaság védelmében. Makói Népújság, 1946. március 30. 2. p

${ }^{991}$ Uo.

992 KISS Imre: Az első felszabadulási ünnepre! Makói Népújság, 1946. április 4. 1. p.

${ }^{993}$ ERDEI Ferenc: Voltak férfiak. Délmagyarország, 1944. november 29. 3. p.
} 
közjogi harcainak legfőbb irányítója, a népfrontos összefogás fáradhatatlan szervezője. Erdei Ferenc ritka szálfának, hü strázsának nevezte. Politikai nézetei szilárd erkölcsi alapon nyugodtak, ezért ellenfelei is elismerően nyilatkoztak róla"994 - írja Könyves-Kolonics József életútjának ${ }^{995}$ feldolgozója, Tóth Ferenc helytörténész.

Tóth Ferenc egy másik írásában így fogalmaz Könyves-Kolonicsról: „Ízig-vérig politikai alkat volt, nézeteit szilárd meggyőződés, morális szemlélet és elvhűség jellemezte. Kossuth függetlenségi eszméi hatották át gondolkodását, amely párosult a nincstelen kisegzisztenciák sorsának átérzésével; így 48-as szellemiségű nézete plebejusi szellemmel párosult. Közéleti tevékenységét az etikai morál, a meggyőződés melletti kiállás jellemezte. Nem ismerte a megalkuvást, meggyőződéséből jottányit sem volt hajlandó engedni. A magának teremtett, filozófiailag megalapozott eszményi tiszta demokratikus szellemiségben

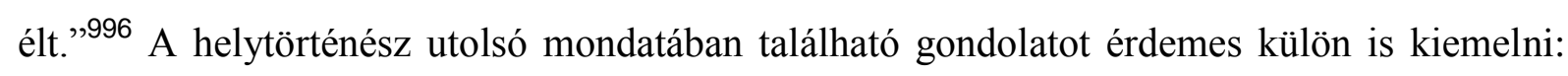
Könyves-Kolonics József a makói politikában az „eszményi tiszta demokratikus szellemiséget” képviselte, a tiszta demokrata karakterének megtestesítője a koalíciós évek diktatúra irányába forduló helyi közéletében.

A köztiszteletben álló demokrata, Könyves-Kolonics József a Horthy-korszakban Makón a jogállami demokrácia gondolatának jelképerejü személyisége volt, ezért is már szeptember 26-án, a város felszabadításának, megszállásának első napján a Vörös Hadsereg helyi parancsnoksága Könyves-Kolonicsot nevezte ki a polgármesteri jogok gyakorlásával megbízott polgári városparancsnoknak. ${ }^{997}$ Ő mielőtt elvállalta volna a feladatot, megbeszéléseket folytatott a parancsnokság tisztjeivel, akik arról biztosították a helyi politikust, hogy az ország demokratikus körülmények között fog majd dönteni ,államformája és belső igazgatása mikéntjéről”, 998 és egyáltalán az egész tanácskozás arra utalt, hogy a

\footnotetext{
994 TóTH Ferenc: Könyves-Kolonics József politikai pályája. A makói múzeum füzetei 42. Makói Múzeumi Baráti Kör. Makó, 1984.. 3. p.

${ }^{995}$ Könyves-Kolonics József 1912-ben köztársasági programmal az országban először jutott be a Csanád megyei közgyülésbe. A jogász végzettségü Könyves-Kolonics 1920-tól Makó város közjogi küzdelmének vezéralakja. Ahogy Tóth Ferenc fogalmaz: a Horthy-korszakban a demokratikus összefogás szervezője. Erdei Ferenc Futóhomok című művét e szavakkal dedikálta: „Kolonics Jóska Bátyámnak, a hű strázsának ajánlom. Makó, 1937. okt. 6." Tóth Ferenc szerint Erdei magát Könyves-Kolonics tanítványának tekintette. (TóTH Ferenc: Könyves-Kolonics József politikai pályája.) Könyves-Kolonics a Horthy-korszakban a makói illetőségü Függetlenségi és 48-as Kossuth Párt; 1945-ben a a Polgári Demokrata Párt tagja.

996 TÓтH Ferenc: Könyves-Kolonics József. Elérhető:

http://www.sulinet.hu/oroksegtar/data/egyhaztortenet/mako_igezeteben/pages/011_eletutak.htm (A letöltés időpontja: 2015. december 5.)

997 Könyves-Kolonics polgári városparancsnoki tevékenységéről: RUSZOLY József: Nemzeti bizottságok és önkormányzatok. Csanád-Arad-Torontál közigazgatásilag egyelöre egyesített vármegyék intézménytörténetéhez. (1944. szeptember-1945. május). In: RuSZOLY József: „és így is a mi korunk.” Írások és források Magyarország alkotmánytörténetéhez. 1944-1949. Püski Kiadó, Budapest, 2006. 32-97. p.

998 KoROM Mihály: Népi demokráciánk születése. Népi bizottságok és nemzeti összefogás KeletMagyarországon 1944 őszén. Hajdú-Bihar Megyei Tanács, Debrecen, 1981. 65. p.
} 
szovjetek valóban a demokratikus körülmények létrehozásában érintettek; annyit kértek Könyves-Kolonicstól, hogy a szélsőjobboldali erőket leszámítva minden demokratikus erővel működjön együtt polgári városparancsnoki munkájában.

Könyves-Kolonics József 1944. szeptember 26-tól az új polgármester megválasztásáig, 1945. május 25-ig látta el a polgármesteri jogköröket gyakorló polgári városparancsnoki tisztséget. Az Ideiglenes Nemzetgyülésben nem a pártok, hanem az egész város képviseletében vett részt. Életrajzírója, Tóth Ferenc szerint csalódottan jött haza Debrecenből. „Nem erről álmodoztunk”999 - jegyezte meg. Polgári városparancsnoki munkáját a demokrácia elveinek tiszteletben tartásával, közmegbecsüléssel végezte. „Könyves-Kolonics József személyét mindenki elfogadja, bármilyen politikai nézetet is vall. Neve a kifüggesztett plakátokon Makó szerte megnyugvást eredményez"1000 - írtja Tóth Ferenc.

Még városvezetőként így tett hitet az új rend, a demokrácia ethosza, a „népuralom” mellett 1945 januárjában: „Jöjjön az új rendszer, a politikai népuralom, a dolgozók gazdasági boldogulása, a széles néprétegek kiművelése. Jöjjenek az új emberek, akik a régi hatalommal harciasan és áldozatosan szemben állottak. Jöjjenek a munkásság, parasztság, a többi kispolgárság, a haladó szellemü értelmiségek vezetésre méltó és arra képes igaz képviselői. Nincs megalkuvás! Mi, akik soha semmit el nem alkudtunk, most sem alkuszunk."1001 Szintén még polgári városparancsnokként, ideiglenes polgármesterként írta a Húsvéti gondolatok címü filozofikus hangvételü publicisztikáját. Az írás hangvételén már érződik, hogy a demokrata Könyves-Kolonicsban kezd kialakulni a kétely, az aggódás, a szkepszis: a cikkben a tömegek jogos forradalma mellett a minőség forradalmának a szükségességre is felhívja a figyelmet. Ahogy írja: „Megbecsülöm a fiatalság képzeletét és akarat világát, gyakorlom az öregek bölcsességét és megnyugvását. A tömegek történelmileg jogos forradalma szükségképpen megvet mindent, ami nem őszinte és nem nyers, az egyéniségek azonban még ilyenkor is megbecsülik a magasabb erkölcsiség és a magasabb szellemiség úgynevezett minőség forradalmát is" ${ }^{1002}$ - írta a leköszönő városvezető, aki ekkor még óvatosan utal a jogállami demokráciát a kommunisták részéről ért sérelmekre.

Az ideiglenes polgármesteri munka után egyre több publicisztikával jelentkezik a helyi közéletben. 1945. június 3-án Köszöntöm az újságolvasót című cikkében már a címadással is

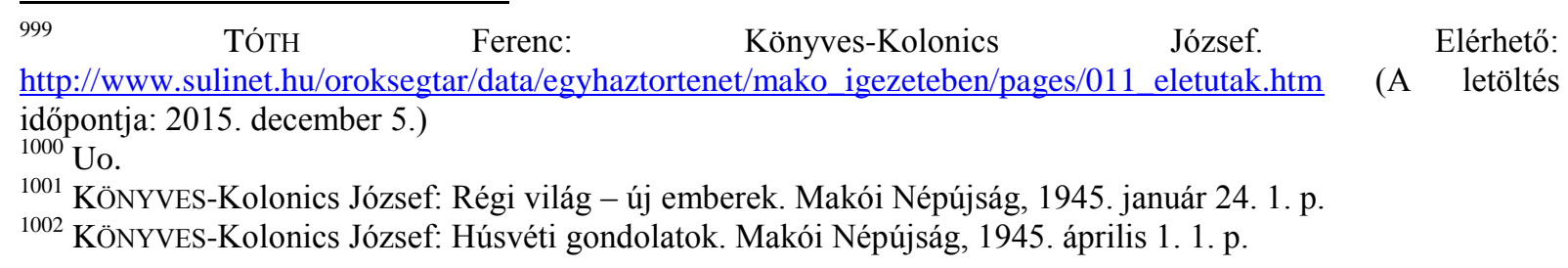


jelzi, hogy a városi közigazgatás irányítását követően ismét helyi közíróként a demokrácia elvi kérdései felé fordul. Ebben az írásban a korábbiakhoz képest sokkal nyíltabban fogalmazza meg bírálatát a demokratikus közállapotok védelme érdekében és fejezi ki aggodalmát a diktatórikus törekvésekkel szemben: „A tiszta erkölcs, az igazságos törvények és a szakértelem uralmát követelem, hogy legyen rend és fegyelem. Aki mást tesz, minden önkényeskedésével most már a demokrácia törvényét szegi meg. Aki pedig cinikusan az erkölcsi szabályokat szem elől téveszti, az az anarchia szálláscsinálója, már pedig minden jogi és erkölcsi zűrzavar végül is egyik zsarnokságból a másikba fajul.”1003

Az hogy bírálata egyre inkább a kommunisták stílusával szemben fogalmazódik meg a helyi nyilvánosság számára az alábbi idézettel válhatott teljesen egyértelművé: „A gyakorlati politikában azonban senkinek, nekem sem lehet annyira igazam, hogy másoknak ne lehessen soha, semmiben sem igazuk. Megmondom nyíltan, nyersen, hogy nemcsak dolgozó munkások, hanem dolgozó kispolgárok is vannak." ${ }^{1004}$ Az elkeseredettség hangja érzékelhető a cikk utolsó soraiból is: „A bünt nem lehet bünnel gyógyítani, a bün akkor is bủn, ha azt nem ugyanazok, akik régen, hanem történetesen mi követnénk is el."1005

Még nyíltabban fogalmaz bő két héttel később a Meggyözö erôt címü cikkében. Az írás legkomolyabb indulatokat kiváltó része így hangzott: „Unalomig hirdetjük a demokráciát, a népuralmat s ehelyett sok téren paprikajancsi diktatúrákat tapasztalunk." ${ }^{1006}$ A publicisztika végén arról ír Könyves-Kolonics, hogy ő most „,vigyázzt!” kiált, de „,nehogy »Megállj«-t vezényeljen a jövő.",1007

A nem sokkal korábban polgármesterré választott Kiss Imre a cikk tartalmát magára vette és úgy értelmezte, hogy ő lehet a paprikajancsi diktátor. Könyves-Kolonics többé nem publikálhatott a Makói Népújságban. Erről személyesen hozott döntést Kiss Imre. ${ }^{1008}$

„Keserü szájízzel tudomásul vettük Kolonics különös és egyáltalán nem időszerü eszmefuttatásait és igyekeztünk őt lebeszélni káros tevékenységéről, de ő senkire nem hallgatva tovább folytatva írásaiban (rendszerellenes) nyilatkozatait, [...] Türhetetlen volt már, amit Kolonics írásaiban megismételve még jobban kihangsúlyozta azt, hogy [...] a népnek már elege van a paprikajancsi diktátorokból, akik pusztulásba viszik a város életét. [...] Dr. Kolonics a szükséges és erélyes intézkedéseket rosszindulatú önkényeskedésnek

\footnotetext{
${ }^{1003}$ KÖNYVES-Kolonics József: Köszöntöm az újságolvasót. Makói Népújság, 1945. június 3. 1. p.

1004 Uo.

1005 Uo.

${ }^{1006}$ KÖNYVES-Kolonics József: Meggyőző erőt. Makói Népújság, 1945. június 19. 1. p.

1007 Uo.

${ }^{1008}$ KISS Imre: Egy munkásháztól a városházáig (Önéletírás). Szerzői kiadás, Makó, 1989. 206-207. p
} 
nevezte, amely szerinte paprikajancsi-féle diktatúra és újfajta zsarnokság"1009 - olvasható Kiss Imre kommunista polgármester több, mint négy évtizeddel később, 1986-1988-ban megírt visszaemlékezéseiben.

Tóth Ferenc helytörténész írja: „A város polgármestere, a kommunista Kiss Imre haláláig magára vonatkoztatta Könyves-Kolonics József jogos megállapítását: »unalomig hirdetjük a demokráciát, a népuralmat, s ehelyett sok téren paprikajancsi diktatúrákat tapasztalunk «. ${ }^{1010}$ A helytörténész 2014-ben a következőkröl számolt be: amikor kiadták Könyves-Kolonics József összegyüjtött írásait, a fenti mondat közlése miatt 1985-ben Kiss Imre tizenegy oldalas beadványával fegyelmit akart indítani ellene mint a kötetet kiadó múzeumigazgató ellen. Tóth Ferenctől azt is megtudhatjuk, az ügyet végül Apró Antal, az országgyűlés akkori elnöke állította le, mondván: „Kiss Imre nem ért a népfrontpolitikához.",1011

Visszatérve Könyves-Kolonics demokrácia-hitvalló publicisztikai tevékenységének ismertetéshez, onnan kell folytatnunk, hogy miután a Makói Népújságban nem publikálhatott többet, nem maradt más lehetősége csak az, hogy a Független Kisgazdapárt 1946 szeptemberében indult lapjában közölje írásait. „Akadt volna még mondanivalóm a makóiak számára azután is, amikor ötnegyed évvel ezelött avatatlan kezek kiütötték kezemből a tollat"1012 - írta '46 öszén Könyves-Kolonics.

A Kétértelmüségek címü 1946 őszi cikkében már egy „kisebbségi rút zsarnokságról” beszél. „A demokrácia és szabadság örve, ürügye alatt elképzelhető egy kisebbségi rút zsarnokság, a szocializmus örve és ürügye alatt pedig elképzelhető a vad egyéni profitéhség is. Tehát más az elv, más a párt. Az én elképzelésemben az anarchia nem demokrácia, a munkanélküli vagyon vagy meg nem érdemelt pozíció szervezés pedig nem szocializmus. Az ilyesmi nem népuralom és nem szegény dolgozó, kisemberek ügyének a szolgálata, hanem puszta hatalomvágy és vagyonéhség kóros tünete"1013 - írta a kommunista hatalomátvétel előtt hosszú hónapokkal higgadt hangú elemzőként a makói jogász, Könyves-Kolonics József. És hogy milyen nyugodt lelkülettel állt a közélet - számára ugyanakkor elborzasztó jelenségeivel szemben, példa a következő írás, amit az előbb idézett publicisztika után négy nappal közölt a Délvidéki Független Hírlapban: „Mi magyarok ne tegyünk törvényt Kelet és

\footnotetext{
${ }_{1010}^{1009}$ Uo.

TóTH

Ferenc:

Könyves-Kolonics

József.

Elérhető:

http://www.sulinet.hu/oroksegtar/data/egyhaztortenet/mako_igezeteben/pages/011_eletutak.htm (A letöltés időpontja: 2015. december 5.)

${ }^{1011}$ Uo

1012 KÖNYVES-Kolonics József: Pedig. Délvidéki Független Hírlap, 1946. szeptember 21. 1. p.

${ }^{1013}$ KÖNYVES-Kolonics József: Kétértelmüségek. Délvidéki Független Hírlap, 1946. szeptember 17. 2. p
} 
Nyugat között. Fogadjuk el Kelet hatalmát, de ugyanakkor tartsuk tiszteletben Nyugat szellemét is. Köttessük be Kelet társadalmi törvénykönyvét, a szocializmust, Nyugat díszes aranyozott könyvtábláiba. Elválasztó falnak gyengék vagyunk, mi csak keskeny összekötő hidacskát képezhetünk. A híd egyik pillére elkerülhetetlen, a másik pillére pedig nélkülözhetetlen. Ne ütközzünk belé egyikbe sem, ez a józan ész parancsa."1014 Szintén a Pedig című cikkében szögezte le örökérvényünek is tekinthető gondolatait: „Az igazi demokráciában a mások véleményét is tiszteletben tartják. Így fest a demokrácia, amúgy pedig csak erőszakról és a vele elkerülhetetlenül együtt járó korrupcióról lehetne csupán szó."1015

A '47-es kékcédulás választások előtt több mint nyolc hónappal írja e sorokat: „Csak a diktatúrák nem türik az olyan alkotmányos népítéletet, amelyik őket el is marasztalhatja. [...] Mostanában - nem tudom igaz-e - hasonló törekvésekről hallok.”1016

Könyves-Kolonics mint a jogállami demokrácia követője 1946 végére önmagát „magányos remetének” látja, aki tovább zsolozsmázza „a demokrácia Miatyánkjait.”1017 Ekkorra már a Horthy-rendszer helyi ellenzékének a vezére, a két világháború közötti helyi demokratikus összefogás markáns alakja is megkapta a reakciósság bélyegét. KönyvesKolonics - ahogy még 1944-ben Erdei Ferenc írta róla - bátor demokrataként viszont úgy gondolja, inkább vállalni kell a reakciósság bélyegét, mintsem feladni a jogokra alapozott demokrácia alapvető elveit: „Az unos untalan hangoztatott demokrácia a nép többségének uralma a kisebbségek ellenőrzése mellett. Ne hagyjuk elsikkasztani ezt az elvet semmiféle sanda ürügyek alatt, még akkor sem, ha politikai latrok közé feszítenének is egyesünket. Még akkor sem, ha szemben állásunkért akármilyen reakciósnak neveznének is."

Tamasi Mihály 1985-ben a makói „népi demokratikus” átmenetről írott tanulmányában úgy vélte, hogy a polgári demokrácia kontra népi demokrácia kérdése, illetve az ezek közötti összeütközés Könyves-Kolonics „,nézeteiben jelentkezett." ${ }^{1019}$ Tamasi szerint Könyves-Kolonics önmagát becsületes és feltétlenül elvhü demokratának tartotta, aki „tántoríthatatlanul ragaszkodott a demokrácia »általános«, vagyis polgári, kispolgári elveihez s nézeteit még bizonyos erkölcsi emelkedettség is színezte." ${ }^{1020}$ Tamasi Mihály arról ír, hogy Könyves-Kolonics érzékeny demokrácia-felfogása mögött személyes sértődés is állhat, mert a

\footnotetext{
${ }^{1014}$ KÖNYVES-Kolonics József: Pedig. Délvidéki Független Hírlap, 1946. szeptember 21. 1. p. ${ }^{1015}$ Uo.

${ }^{1016}$ KÖNYVES-Kolonics József: Általános, titkos választójog. Délvidéki Független Hírlap, 1946. december 8. 1. ${ }_{1017}^{\text {. Uo. }}$

${ }^{1018}$ Uo.

1019 TAMASI Mihály: A népi demokratikus fejlődés Makón. 177. p. ${ }^{1020}$ Uo.
} 
kommunista helyi vezetők „,nem mindig megfelelő hangot használtak vele szemben”, ${ }^{1021}$ és emiatt történhetett meg az, hogy a veterán helyi közéleti szereplö „a valóban létező hibákat” felnagyította. „Könyves-Kolonics a Makón erőteljesen érvényesülő kispolgári törekvések és érdekek tudatos képviselője volt, s tragédiája abban keresendő, hogy a felszabadulás utáni társadalmi átalakulás útjának kérdésével az országos fejlődést megelőzve, korán szembekerült és így nem volt ideje a népi demokratikus követelményeinek felismerésére"1022 - írja Tamasi Mihály.

Tóth Ferenc helytörténész és Szentpéteri István alkotmányjogász véleménye szerint Könyves-Kolonics demokrácia-felfogása, jogértelmezése hasonlítható Bibó István nézeteihez. „Könyves-Kolonics József századik születésnapján rendezett tudományos emlékülésen Szentpéteri István egy olyan jelenségre hívta fel a figyelmet, amely Bibó Istvánt is foglalkoztatta, nevezetesen a legalitás, a törvényesség rendszerének kérdése"1023 - olvasható Tóth Ferenc írásában. Szentpéteri István úgy véli, Könyves-Kolonics a legalitásnak, a törvényességnek új koncepcióját akarta kialakítani 1944 után, „ezt ő finom intuíciójával már a legelső csatározások alkalmával védeni próbálta, azt kívánta, hogy legyen szabálya a politikai harcnak."1024

Meglátásunk szerint a legalitás, a törvényesség rendjének tisztelete és a politikai harcok szabályozottságának követelménye mint alkotmányos elvárás szempontjából valóban lehetnek hasonlóságok Bibó István és Könyves-Kolonics József nézeteiben, ugyanakkor azt is meg kell állapítanunk, hogy Könyves-Kolonics már 1946 őszétől pontosan érzékelte a jogállami demokrácia létére törő kommunista párttaktika mögötti valós szándékokat, míg Bibó azt még - ahogy azt korábbi fejezetünkben elemeztük - 1947-ben sem. Ezzel a megállapítással nem Bibó helyzetelemzését kívánjuk bírálni, hanem inkább azt szeretnénk demonstrálni, hogy Könyves-Kolonics József Makóról, egy kisvárosi közéleti és szellemi közegből szemlélve az ország és a világ jelenségeit, képes volt érzékelni a jogállami demokráciára veszélyes tendenciákat és azokkal szemben fel is emelte a szavát, s ezáltal demokrácia-hitvalló szerepet tudott betölteni a koalíciós évek makói közéletében.

\footnotetext{
${ }^{1021}$ TAMASI: Uo. 178. p.

1022 TAMASI: Uo. 179. p.

1023 TÓTH Ferenc: Könyves-Kolonics József politikai pályája. 15. p.

${ }^{1024}$ Uo.
} 
3. A helyi demokrácia eröpróbája: a makói Pfeiffer-ügy-válság, botrány, megbélyegzés

1946-1947-ben az úgynevezett Pfeiffer-afférral és annak következményeivel a helyi demokrácia valódi próbája zajlott Makón. A botrány maga és az utána következő eseménysorozat jelképesen mutatta meg a makói közélet szereplői szempontjából a különböző demokrácia-értelmezéseket, a lokális demokrácia ethoszához való eltérő hozzáállást.

1946. július 21-én egy sok tucat főből álló, igen harsány kommunista párti tömeg nem engedte szóhoz jutni makói nagygyülésén Pfeiffer Zoltán igazságügyi államtitkárt, a Független Kisgazdapárt egyik vezető politikusát. Az államtitkár így nem tudta elmondani beszédét. Az eset annyiban nem egyedi a koalíciós évek Magyarországán, hogy a Magyar Kommunista Párt és a Baloldali Blokk számára 1946-tól kezdve bevált harci eszközzé vált a rivális politikai csoportosulások rendezvényeinek megzavarása. Az ügy két ok miatt fontos és történeti értelemben érdekes. Egyrészt ez az első olyan Pfeiffer-gyülés, amelyet botrányba fullasztanak. (A későbbiekben mindez mindennapossá válik, s végül odáig fajult, hogy 1947. augusztus 25-én csongrádi választási összejövetelén Pfeiffer Zoltánt a felheccelt kommunista aktivisták biciklilánccal - életveszélyes sérüléseket okozva a politikusnak - majdnem agyonverik.) Másrészt a gyülés megzavarása után az FKGP helyi szervezete arról döntött, hogy a párt városházi frakciója nem vesz részt a makói képviselőtestület munkájában. Vagyis a makói kisgazdák kvázi felmondták a helyi koalíciót a baloldallal és kivonultak a helyi demokrácia legfontosabb fórumának számító grémiumból. Ez mindenképpen unikálisnak tekinthető az országban - noha hasonló csörték előfordultak más településeken is. ${ }^{1025}$

A kisgazda városatyák hosszú hónapokig bojkottálták a „városi parlament” üléseit. Erőteljes és hosszú ideig tartó, több hónapos nyomásgyakorlást követően - az összeesküvési ügy árnyékában, Kovács Béla elrablása után néhány héttel és Pfeiffer Zoltánnak a Független Kisgazdapártból való kilépését, kiszorítását követő napokban - 1947. március 19-én tértek vissza a testületbe. Mindezen történéssel összefüggésben akár azt is mondhatnánk, hogy ismét teljesebbé válhatott a helyi demokrácia, de ismerve az országos kontextust, illetve a visszatérés érdekében a baloldal által végzett nyomás metódusát, kijelenthető: ezzel a helyi demokrácia ereje tovább gyengült, hiszen intézményesen, képviselőcsoporti szinten már nem

\footnotetext{
1025 A Makóhoz alig harminc kilométerre fekvő Hódmezővásárhelyen is zajlott hasonló jelenség. A témáról bővebben: BENCSIK Péter: Hódmezővásárhely politikai élete 1944-1950 között. Elérhető: http://allamszocializmus.lapunk.hu/tarhely/allamszocializmus/dokumentumok/hodmezo.pdf (A letöltés időpontja: 2015. november 27); illetve BENCSIK Péter: Politikai viszonyok Hódmezővásárhelyen 1947-ben a kékcédulás választások előtt. Belvedere Meridionale, XIX. évf. (2007) 5-8. 40-63. p.
} 
maradt lehetőség a baloldali aktoroktól független strukturális közéleti akaratképzésre.

A szervezők 1946. július 21., vasárnap délután 4 órára hirdették meg a kisgazda nagygyülést. Szónokként Pfeiffer Zoltán államtitkárt, Parragi György és Pártay Tivadar FKGP-s nemzetgyülési képviselőket jelölték meg. ${ }^{1026}$

Az összejövetel helyszíne a városháza elötti tér volt. A tömeg nagyságáról egymásnak ellentmondó adatainak vannak. A korszak kommunista polgármestere, Kiss Imre visszaemlékezésében „500 fónyi hallgatóságról”1027 beszélt. A kisgazda szellemiségű Igazság című országos hetilap szerint „többezer ember gyült össze.”1028 Az akkoriban egyetlen helyi napilap, a baloldali Makói Népújság publicisztikájában arról írt, hogy „nem sokkal többen”1029 lehettek, mint 500 fö. (A résztvevők számáról az eseményről szóló tudósításban nem közölt a lap információt.) A kisgazda napilap, a Kis Újság két, egymástól eltérő létszámról adott hírt a különböző lapszámaiban. Az affért követő napokban, 1946. július 25-én „többezres”1030 tömegről tájékoztatott, míg három héttel később, augusztus 18-án úgy fogalmazott, hogy „,néhány száz ember” ${ }^{1031}$ volt jelen az eseményen. ${ }^{1032}$

A gyülést Szőnyi Imre ${ }^{1033}$ nemzetgyülési képviselő, az FKGP makói vezetője nyitotta

\footnotetext{
${ }^{1026}$ Pfeiffer, Pártay és Parragi politikai szövetségesként jöttek Makóra, a támadásokkal szemben is együtt igyekeztek megküzdeni. Tanulságos XX. századi történet e három ember későbbi közéleti pályája. Parragi 1947ben egyik alapítója lesz a Független Magyar Demokrata Pártnak, Pfeiffer pedig a Magyar Függetlenségi Pártnak, Pártay az 1947-es választásokon az anyapárt, a Független Kisgazdapárt jelöltjeként indult. Pfeiffer '47 öszén emigrációba kényszerül, Pártay itthon marad és a recski munkatábor rabja lesz, míg Parragit az ötvenes években az Elnöki Tanács tagjának választják. Pfeiffer sohasem térhetett haza, 1981-ben egy New York-i kórházban hunyt el, Parragi 1963-ban távozott az élök sorából, hármójuk közül egyedül Pártay Tivadar érte meg a kommunista rendszer bukását, aki csalódva a rendszerváltó kor közéletében 1999-ben halt meg.

${ }^{1027}$ KIss Imre: Egy munkásháztól a városházáig. 231. p.

${ }^{1028}$ Igazság, 1946. augusztus 2. 5. p.

${ }^{1029}$ Makói Népújság, 1946. augusztus 6. 3. p.

${ }^{1030}$ Kis Újság, 1946. július 25. 2. p.

${ }^{1031}$ Kis Újság, 1946. augusztus 18. 3. p.

${ }^{1032}$ „Rekkenő hőségben a régi városháza járdája közelében tartózkodtam, így hozzávetőlegesen szemben álltam a résztvevőkkel. A közelemben állt Császtvay István, a hatodik osztályos gimnazista osztálytárs és Gajdi István végzös tanítóképzős barát, az ifjú költőtitán. A résztvevők számát utólag nem merném megbecsülni, de népes volt a Fötérnek ez a része. Az erkélyen négyen-öten is lehettek, név szerint Pfeiffer Zoltánra, Pártay Tivadarra és Szőnyi Imrére emlékszem. Szőnyi Imre bácsi bevezető előadása csendben zajlott. Pfeiffer Zoltán szavaiba viszont előbb rövid, inkább tömondatos bekiabálások történtek. Egyre emlékszem: »Le a lakk-cipős kisgazdákkal!« Erre Pártay Tivadar - miközben a fokozódó hangzavarban valamit mondott is - fölemelte az erkély korlátjára egyik csizmás lábát. Ezt a szimpatizáns részvevők derültséggel és tapssal viszonozták. A bekiáltások olyan ordítozó hangzavarrá fokozódtak, hogy Pfeiffer kénytelen volt beszédét megszakítani." (Dr. Tóth Ferenc helytörténész ifjú gimnazistaként ott volt a gyülésen, kérésemre írta le emlékeit az eseményröl)

${ }^{1033}$ Szőnyi Imre makói középbirtokos gazdálkodó, aki még a II. világháború elött kapcsolódott be a helyi közéletbe, a Kisgazdapártban vállalt szerepet. Kapcsolatot ápolt a makói származású Eckhardt Tiborral, a párt korábbi első számú politikusával. A háborút követően Szőnyi Imre az egyik megszervezöje a Független Kisgazdapárt makói csoportjának. A párt makói vezetője lett. Az 1945-ös választásokkor bekerült a nemzetgyülésbe, majd 1947-ben az országgyülésbe is, ugyanakkor tagja volt a helyi képviselőtestületnek. Szőny Imre életrajza: Az 1945-1947-es Nemzetgyülés Almanachja. 587-588. p. Elektronikusan elérhető: http://www.ogyk.hu/e-konyvt/mpgy/alm/almanach_1945-47/1945_ngy_a t587.htm (A letöltés időpontja: 2015.
} 
meg, majd átadta a szót Pfeiffer Zoltánnak. Az államtitkár rövid bevezetőjét követően a „kisgazdapárt többségi jogairól szólott.” ${ }^{1034}$ A beszámolók szerint ekkor „,tört ki a vihar, s az egész gyülés tartama alatt nem lankadó erővel tartott, egyre fokozódott." 1035

Az államtitkár egy ideig szócsatát vívott a közbeszólásokkal, majd abbahagyta a beszédet. Szőnyi megpróbálta a rendet helyreállítani, ez azonban nem sikerült.

Kiss Imre polgármester szerint a kisgazda politikus „olyan becsmérlően nyilatkozott a kommunistákról, hogy a gyülésen részt vevő párttagok és jobb érzésű emberek mind többen közbekiáltoztak és amikor erre Pfeiffer még dühödtebben ocsmány szavakkal válaszolt, olyan hangzavar keletkezett,"

A Makói Népújság baloldali elkötelezettségü publicistája - kissé cinikusan - úgy vélte: „egy népgyülés sikere mindig a szónokokon múlik," ${ }^{1037}$ majd a következőket írta: „Pfeiffer már szinte az első szavaival olyan hangot ütött meg, mely mélyen sértette a megjelent nem kisgazdapárti hallgatóságot. Mikor pedig az első közbeszólásokra rögtön le söpredékezte a tömeget, természetes csak azt bizonyította be a tömegnek, hogy okkal támadják őt." ${ }^{1038}$ A kommunisták részéről a vád, hogy Pfeifferék „söpredéknek, csőcseléknek, részegeknek" nevezték a hangoskodókat, többször is megjelenik. ${ }^{1039}$ Pfeiffer Zoltán életrajzírói, Földesi Margit és Szerencsés Károly megítélése szerint a politikus „igen robbanékony volt, az ellentétek elsimításához nem igazán értett." ${ }^{1040}$ Nem kizárt tehát annak lehetősége, hogy a kommunista provokátorok közbekiabálása valóban felbosszantotta az államtitkárt, aki visszaszólt a botrányt keltő csoportosulásnak. Ráadásul, mivel ekkor érte először ilyesfajta erőteljes inzultus, bizonyára még nem ismerte a módját, miként lehet kezelni az efféle kellemetlen szituációkat.

Hogy pontosan mit mondott Pfeiffer Zoltán, és föként, hogy mit szeretett volna elmondani, rekonstruálhatatlan. Segítséget jelenthet azonban a délelőtti kiskunhalasi szónoklata, hiszen tartalmilag valószínüleg nem készült két, teljesen eltérő hangvételü

december 13.) Egy 1948. május 13-i keltezésű kommunista párti jelentés a következőképpen jellemezte Szőnyi Imrét: „Az 1945-ös választások utáni időben minden igyekezetével a munkáspártokat, de főleg az MKP-t támadta, hol nyílt, hol burkolt formában, s jobboldali gondolkodásával és magatartásával annyira ment, hogy a gyüléseken több esetben nyíltan támadta a MKP-t és általában a demokráciát. 1946. év december hó 2-án Földeák községben az FKP gyülésén, mint előadó a következő kijelentést tette: Magyarországon demokráciát hirdetünk, hol van itt demokrácia, amikor a kisebbségben lévő nép, köztük az MKP ráerőszakolja akaratát a nagyobb számban lévő népre.” (CSML MSZMP CSMBA/ 26. f. 35 őe.)

${ }^{1034}$ Makói Népújság, 1946. július 23. 2. p.

${ }^{1035}$ Uo.

${ }^{1036}$ Kiss Imre: Uo. 231. p.

${ }^{1037}$ Makói Népújság, 1946. augusztus 6. 3.p.

${ }^{1038}$ Uo.

1039 TAMASI Mihály: A népi demokratikus forradalom győzelme. 86. p.

1040 FÖLDESI Margit-SZERENCSÉS Károly: A megbélyegzés hatalma. Pfeiffer Zoltán (1900-1981). Kairosz Kiadó, Szentendre, 2003. 251. p. 
megnyilatkozással. Kiskunhalason Pfeiffer kijelentette: „a demokráciában a parasztság nélkül nem lehet politikát csinálni, mint ahogyan nem lehet olyan politikai akciókat sem, melyek ellenkeznének az ország nagy többségét kitevő parasztság felfogásával.”1041 Minden bizonnyal e kérdéskörről kívánt beszélni a makói hallgatóság előtt is. Feltételezhetjük, Pfeiffer Makón is a kisgazda demokrácia-értelmezés szerint kívánt szónokolni és itt is el akarta mondani, hogy „demokráciában” a parasztságot képviselő erőknek döntő szavuk kell, hogy legyen a közéleti meghatározó kéréseiben.

Miután Pfeiffernek nem sikerült elmondani a beszédét, Pártay Tivadar nemzetgyülési képviselő próbált szóhoz jutni. Beszélt a „demokrácia eszményéről”, sürgette a helyhatósági választások megtartását, ${ }^{1042}$ tiltakozott azon beállítás ellen, miszerint a kisgazdapárt reakciós lenne, ${ }^{1043}$ és elismeréssel nyilatkozott a Szovjetuniónak az ország felszabadítása érdekében kifejtett erőfeszítéseiről. ${ }^{1044}$ E Vörös Hadseregnek szóló gesztus kettős célt szolgálhatott. Pártay igyekezett legalább minimálisan elnyerni a kommunista szimpatizáns kiabálók bizalmát, továbbá ezt követően kritikaként fogalmazhatta meg, hogy az MKP tagok hozzátartozói nagyobb segítséget kapnak hadifoglyaik hazahozatalához, mint azok, akik nem töltöttek ki kommunista párti belépési nyilatkozatot. „Természetes, hogy egy ilyen rágalmat a tömeg nem türte szó nélkül és nem volt kíváncsi a többi mondanivalóra"1045 - írta szerkesztőségi véleményként a Makói Népújság.

Eltérő számok állnak rendelkezésünkre arra nézve, hogy hányan lehettek a rendbontók. ${ }^{1046} \mathrm{Az}$ 1946. július 25-én megjelent Kis Újság tájékoztatása szerint „mintegy 200 főnyi csoport igyekezett megzavarni" ${ }^{1047}$ az összejövetelt. Július 28-án így írt a kisgazda napilap: „gyülésen részt vevő törpe kisebbség szenvedélytől fütött botrányt rendezett és sürün szakította félbe a szónokokat." ${ }^{1048}$ A Kis Újság augusztus 18-i számában viszont a következőket olvashatjuk: „néhány száz ember van jelen, kétharmaduk kommunista." kisgazda szellemiségű hetilap, az Igazság a gyülés megzavarásáról szóló tudósítás elején „egy

\footnotetext{
${ }^{1041}$ Kis Újság. 1946. július 25. 2. p.

1042 A kisgazdák elsőrendü politikai követelése volt, hogy tartsák meg szerte az országban a helyhatósági választásokat. Egy ilyen megmérettetésen ugyanis az FKGP földcsuszamlásszerü győzelmet arathatott volna, eltávolítva ezáltal a Baloldali Blokk helyi kádereit. Nem véletlen, hogy az MKP vezette baloldal ellenállt a helyhatósági választások megtartására irányuló tervnek. (BALOGH Sándor: Parlamenti és pártharcok Magyarországon 1945-1947. Kossuth Könyvkiadó, Budapest, 1975. 220. p., 233-236. p., 308. p.)

${ }^{1043}$ A Pártay által elmondottakról: Makói Népújság, 1946. július 23. 2. p.

${ }^{1044}$ A beszéd e részéről a Makói Népújság 1946. augusztus 6-i száma írt (3. p.). ${ }^{1045}$ Uo.

1046 „A kiabálók az első sorokban álltak, bizonyára ide valók lehettek, de idegeneknek, ágról szakadtaknak tűntek. Nem volt hangszóró és erősítő, így képesek voltak a szónokokat túlkiabálni." (Dr. Tóth Ferenc feljegyzéséből)

${ }^{1047}$ Kis Újság, 1946. július 25. 2. p.

${ }^{1048}$ Kis Újság, 1946. július 28. 2. p.

${ }^{1049}$ Kis Újság, 1946. augusztus 18. 3. p.
} 
szokatlanul nagy" ${ }^{1050}$ társaságról beszélt, majd ötszáz provokátorról tett említést.

Az Igazság beszámolójából arról értesülünk, hogy a kommunista pártiak „két részre oszlottak, körbefogva a hallgatóságot. Amikor a szónokok beszélni akartak a jól megszervezett rendbontók szavalókórusokat létesítettek és különféle munkáspárti jelszavak kiabálásával lehetetlenné tették a szónokok további beszédét."1051 A Makói Népújság baloldali újságírója azonban úgy vélte: „a két részre oszló közbefogás is csak a cikkíró fantáziájában létezett." 1052

A kisgazdák biztosak voltak benne, hogy a rendbontás tudatosan kigondolt akció lehetett. A Kis Újság arról írt, hogy a provokátorok „szervezetten lépnek fel.”1053 Az Igazság pedig „előre megszervezett suhanc-társaságról” ${ }^{1054}$ szólt. A Makói Népújság szerint „,valótlan, hogy a gyűlést előre megszervezett suhanc társaság zavarta volna meg. A Kommunista Párt tömegei a maguk lábán állnak, a maguk fejével gondolkodnak."1055

Az MKP makói vezetőségének üléseiről készült jegyzőkönyvek alapján nem lehet egyértelmüen megállapítani, hogy volt-e előzetes forgatókönyv a Pfeiffer-gyülés megzavarására. A július 21-i kisgazda rendezvény előtt alig egy héttel, július 16-án tartott az MKP helyi szervezete vezetőségi ülést. A jegyzőkönyv tanúsága szerint nem került szóba a téma. (Ez persze nem jelenti azt, hogy jegyzőkönyvön kívül nem tettek lépéseket az ügyben.) A július 23-i összejövetelen, tehát a botrányba fullasztott tömegrendezvény után két nappal Rátky György vezetőségi tag kijelentette, „,nekünk is van egy olyan tömegünk, amelyre mindenkor számíthatunk”, majd hozzátette: „láthattuk, hogy az elvtársak fegyelmezettek.”1056 E megjegyzést figyelembe véve, hajlamosak lehetünk elfogadni ,az előre eltervezett rendzavarás" variációját. Szintén e megbeszélésen kisebb vita alakult ki arról, hogy szükséges lett volna-e a kommunista befolyás alatt álló helyi sajtóban előzetesen cikket íratni Pfeifferről, hogy megfelelően ,jellemezzék” a kisgazda politikust a makóiak előtt. Kiss Imre polgármester úgy vélekedett, ,,helyes az, hogy nem mutattuk be előzőleg [...], mert így nem mondhatják legalább, hogy régen készültünk erre. Így spontán jött."1057

Csepregi Imre prelátus, a Makó-Belvárosi Katolikus Egyházközség plébánosa 1944től 1953-ig naplót vezetett. A megzavart kisgazda gyüléssel kapcsolatosan - noha az eseményen maga nem vett rész, másoktól értesült a történtekröl - érdekes bejegyzést találunk

\footnotetext{
${ }^{1050}$ Igazság, 1946. augusztus 2. 5. p.

1051 Uo.

1052 Makói Népújság, 1946. augusztus 6. 3.p.

1053 Kis Újság, 1946. augusztus 18. 3. p.

${ }^{1054}$ Igazság, 1946. augusztus 2. 5. p

${ }^{1055}$ Makói Népújság, 1946. augusztus 6. 3.p.

${ }^{1056}$ CSML MSZMP CSMBA 27. f. 4. őe.

${ }^{1057}$ Uo.
} 
a dokumentumban: „Mint mondják, a párthelyiségben volt a polgármester is és a háttérből irányította a rendzavarást." ${ }^{1058}$ A városban tehát elterjedt az, hogy Kiss Imre, Makó kommunista párti polgármestere személyesen vezényelte le a provokációt. ${ }^{1059}$ Ennek fényében lehet tanulságos a július 23-i MKP makói vezetőségi ülésén hozott határozat, miszerint „hívjuk fel az elvtársak figyelmét a suttogó propaganda elleni harcra."

Kiss Imre polgármester néhány nappal később a Makói Népújság hasábjain értékelte a július 21-én történteket. „Tárgyilagosan meg kell állapítanunk, hogy azon a sérelmezett népgyülésen, amelyen a hallgatók egy része valóban nem tudott parancsolni érzelmeinek és véleményét megmutatta a gyülés szónokaival szemben - és ezt különös mértékben szeretném kihangsúlyozni -, a demokrácián nem esett semmi sérelem. Nem párt ellen tüntetett és nyilvánított véleményt senki sem. Ismétlem, nem párt ellen, hanem egyes személyek ellen, akiket a Kisgazdapárt szónoknak hívott meg - szerencsésen vagy szerencsétlenül, nem vitatom, hiszen ez a párt belügye - de le kell szögeznem azt, hogy úgy Parragi, mint Pfeiffer államtitkár személye a gyűlést megelőző hetekben, sőt hónapokban egyöntetű céltáblája volt a demokratikus sajtónak, amely kifogásolta, sőt nem egy esetben elítélte azokat a megnyilatkozásokat, amelyek e két szónok részéről az ország különböző részein elhangzottak. Ebben a sajtóvisszhangban részt vett nemcsak a kommunista sajtó, de a Baloldali Blokk valamennyi sajtóorgánuma is. Ilyen előzmények után nem is olyan csodálatos, ha kirobban az, ami kirobbant azon a sérelmezett nagygyülésen. Újra hangoztatom, hogy az, ami azon a vasárnap délután történt - meggyőződésem szerint - nem a Kisgazdapárt ellen hangzott el, hanem azok ellen, akik ott a hallgatók elé álltak és szólni kívántak"1061 - hangsúlyozta a kommunista párti polgármester.

Figyelemre méltó, hogy Kiss Imre a gyülés megzavarását kiváltó okként a „demokratikus sajtó” Pfeiffer-ellenes írásait nevezte meg. A baloldali elkötelezettségű Makói Népújság szintén e vonal mentén érvelt: „A kommunista párt tömegei [...] eljöttek a nagygyülésre meghallgatni azokat a szónokokat, akiket a Szabad Nép ellenük vitatkozó cikkeiből már ismertek. Maguk akarták leellenőrizni a szónokok demokrata mivoltát."1062 Külön kiemelnénk azt a nyelvi panelt, miszerint a helyi kommunisták a kisgazda politikusok „demokrata mivoltát” kívánták úgymond megvizsgálni.

\footnotetext{
1058 CSEPREGI Imre: Napló. 1-2. 1944-1946. Makó város önkormányzata, Makó, 2011. 543. p.

1059 „Még ott voltunk a helyszínen, amikor feltünt, hogy Pfeiffer fölháborodottan, igen energikus léptekkel átvágott a Főtéren, és bement az MKP Posta utcai (Szőllősi-ház) székházába. A közelemben lévők ilyesmit mondtak: Most majd az igazságügyi államtitkár kioktatja a kommunistákat a demokráciára.” (Dr. Tóth Ferenc feljegyzéséből)

${ }^{1060}$ CSML MSZMP CSMBA 27. f. 4 öe.

${ }^{1061}$ Makói Népújság, 1946. július 28. 1. p.

${ }^{1062}$ Makói Népújság, 1946. augusztus 6. 3. p.
} 
A július 21-i makói nagygyülés előtti hónapban Pfeiffer Zoltán valóban a baloldal céltáblájává vált. Érdemes ezért felvázolni, milyen támadásokban volt része akkoriban az igazságügyi államtitkárnak. Ezáltal könnyebben megérthetjük, miféle érzések, indulatok bujkálhattak a botrányokozók lelkében.

Pfeiffer Zoltán a Bilkey-Papp Zoltán-ügyben vállalt jogvédő magatartása miatt már 1946 márciusában a kommunista sajtó támadásainak kereszttüzébe került. Bilkey-Papp Zoltánnal és társaival szemben demokrácia-ellenes összeesküvés volt a vád, de Pfeiffer igazságügyi államtitkárként igyekezett az ügy jogállami normákkal ellentétes vadhajtásait visszametszeni - ettől kezdve illesztették a kommunisták Pfeiffer neve elé a „fasisztamentő” nem túl hízelgő jelzőjét. ${ }^{1063}$

1946 májusában a kommunisták iránt lojális Ries István igazságügyi miniszter hosszabb időre Angliába utazott, s így Pfeiffer Zoltán államtitkár lett a tárca tényleges irányítója. Pfeiffer igyekezett gátat szabni az igazságszolgáltatás terén az MKP diktatórikus törekvéseinek. Rákosiék a népbíróságokat politikai eszközként használták, Pfeiffer államtitkárnak a jogállami eszméket értéknek tekintő világfelfogásába viszont nem fért bele, hogy ártatlanokat hurcoljanak meg mesterségesen kreált vádak („fasisztabarát”, ,reakciós”) alapján, így - egykori ügyvédként is - határozottan fellépett a törvénytelenségekkel szemben. Zolnay Kálmán, az igazságügyi minisztérium büntetőjogi osztályának vezetője, aki meggyőződéses kommunistaként rendszeresen küldte az MKP vezetői számára a jelentéseket Pfeifferről és a tárcáról - ebben az időszakban a következőket írta az államtitkárral kapcsolatosan egy bizalmas összefoglalóban: „Mindent tüvé teszünk, hogy a reá kompromittáló aktákat felszínre hozzuk." 1064 Mivel semmi érdemi tényt nem találtak, ezért maradt a megbélyegezés eszköztára.

A Szabad Nép 1946. június 29-i számában jelent meg Révai József, a kommunista párt ideológusának vezércikke. „Mit ér a harc a fasizmus ellen, ha az igazságügyminisztérium államtitkári székében Pfeiffer Zoltán ül, aki jobb ügyhöz méltó buzgalommal, módszeresen és rendszeresen, nem hanyagságból, hanem elöre megfontolt szándékkal akadályozta a köztársaság védelméről szóló törvény alkalmazását"1065 - adta meg az alaphangot Révai, majd ekképpen folytatta: „Ha a demokrácia megérdemelné nevét, akkor a [...] Pfeiffer Zoltánokon

\footnotetext{
1063 Az ügyről bővebben: FÖLDESI Margit-SZERENCSÉS Károly: Uo. 78-84. p.

${ }^{1064}$ FÖLDESI Margit-SZERENCSÉS Károly: Uo. 106. p.

1065 Szabad Nép, 1946. június 29. 1. p.
} 
kezdené el az erély alkalmazását." ${ }^{1066}$ Szintén e lapszámban napvilágot látott egy hosszú, több hasábos cikk Pfeiffer Zoltánról. Az írás címe: A legnagyobb fasisztamentö. Pfeiffer államtitkár úr, a demokrácia ellenségeinek védelmezője. Bevezetésként, a nyomaték kedvéért a szerkesztők idézték Szviridov tábornoknak, a Szövetséges Ellenőrző Bizottság elnökhelyettesének a Teréz körúti gyilkosság ${ }^{1067}$ után a szovjet katonák temetésen elmondott szavait. („Fasiszták, fasisztabarátok és különböző reakciósok vérrokonai egymásnak. Ha nem folytatunk ellenük erélyes harcot; tönkre tehetik a magyar népet. A magyar kormánynak a legerélyesebben le kell törnie a fasizmus és reakció védelmezőinek ellenállását.") ${ }^{1068}$ Majd jönnek sorba a Pfeiffert ostorozó mondatok. „Az államtitkár úr legfőbb gondja, hogy megmentse azokat, akik ha nem folytatunk ellenük erélyes harcot; tönkre tehetik a magyar népet. Egész tevékenysége azt igazolja, hogy fasiszták, fasisztabarátok és különböző reakciósok vérrokonai egymásnak. Ha pedig az államtitkár úr idekint tettekkel bizonyítja be, hogy tartja az odabent ülő fasisztákkal és reakciósokkal a rokonságot, akkor a magyar demokráciának - hogy letörhesse a fasizmus és reakció védelmezőinek ellenállását haladéktalanul gondoskodnia kell arról: Pfeiffer Zoltán ne államtitkárkodhasson tovább a magyar igazság ügyében, hanem odakerüljön, ahová a magyar köztársaság törvényeit megsértőknek, a fasisztáknak és a reakciósmentőknek kerülniök kell."1069

A Kommunista Párt hivatalosan is követelni kezdte az FKGP-től Pfeiffer Zoltán visszahívását az Igazságügyi Minisztérium államtitkári posztjáról. 1946. július 7-én pedig Szviridov tábornok jegyzéket adott át Nagy Ferenc miniszterelnöknek, melyben többek között

\footnotetext{
1066 Uo.

1067 A Teréz körúti gyilkosságról: az Oktogon téri kávéházában az egyik pincérnőnek két férfi udvarolt egyszerre, egy szovjet tiszt és egy magyar diák. Mikor a budapesti fiatal megtudta, hogy kedvese számára nem ő az egyedüli férfi az életében, bosszút forralt. Egy közeli romos ház padlásáról megleste, hogy a szovjet katona és bajtársa megérkezik a kávéházhoz, majd a magasból rálött az oroszokra. Ez a lövés azonban célt tévesztett. A diák erről mit sem tudva a padláson öngyilkos lett. Eközben — egyfajta fatális véletlen folytán — a két részeg szovjet katona hangos szóváltásba keveredett egymással, s utána tüzharcot vívtak. Az egyik a helyszínen, a másik a kórházba szállítást követően halt meg. (SZAKÁCS Sándor-ZINNER Tibor: A háború „megváltozott természete". Adatok és adalékok, tények és összefüggések. 1944-1948. 278. p. 282. p.; illetve FöLDESI Margit: A szabadság megszállása. A megszállók szabadsága. Kairosz Kiadó, Budapest, 2002. 281-282. p.) Visszaemlékezéseiben Mindszenty bíboros így írt az esetről: „A nyár közepén a rádió és az összes lapok nagybetűs címek alatt feltűnően terjedelmes beszámolókat adtak arról, hogy Budapesten a Teréz-körúton megöltek egy szovjet katonát és a merénylet után a színhely közelében egy romház padlásán megtalálták egy fiatalember hulláját. Az ifjú a KALOT egyenruháját viselte s így tudta a nyomozás kideríteni, hogy a gyilkos az egyik katolikus ifjúsági egyesületnek a tagja. A halálost lövést, amellyel a derék szovjet katona életét kioltotta így szóltak a közlemények —, a romház ablakából adta le s elvetemült tette után a ház padlására menekült, de a rendőrség utolérte. Ekkor szorult helyzetében ott a romház padlásán öngyilkosságot követett el. Ezt a kitalált rémdrámát azért szőtték meg, hogy megtorlásul ifjúsági egyesületeink feloszlatását követelhessék. Egyetlen lap sem tehetett említést arról, hogy a népes körúton, a járókelők szeme láttára, egy feldühödött szovjet katona szóváltás közben lötte agyon a társát." (MINDSZENTY József: Emlékirataim. Az Apostoli Szentszék Könyvkiadója, Budapest, 1989. 134. p.)

1068 Szabad Nép, 1946. június 29. 7. p.

${ }^{1069}$ Uo.
} 
felszólította a magyar kormányt, hogy mentse fel állásából az igazságügyi államtitkárt. Nagy Ferenc így emlékezett később a Szviridov-féle nyomásgyakorlás Pfeiffer személyét érintő vonatkozásaira: „A következő követelés, hogy mondassam le hivataláról Pfeiffer Zoltán igazságügyi államtitkárt, miután hivatalában akadályozza a demokráciaellenes bűncselekmények gyors kivizsgálását és a bünösök megbüntetését. [...] Hogy Pfeiffer Zoltán államtitkárt hivataláról mondassam le, a leghatározottabban visszautasítottam. Pfeiffer Zoltán ezután még több mint fél évig államtitkára volt az Igazságügy-minisztériumnak." 1070

Nagy Ferenc miniszterelnök dolgát megkönnyítette - vagyis maradt mozgástere, így például kiállhatott Pfeiffer mellett -, hogy a Szövetséges Ellenőrző Bizottság angol és amerikai tagjai tiltakoztak amiatt, hogy Szviridov egyoldalúan avatkozott be a magyar belpolitikába, s ennek következtében a szovjetek felfüggesztették a jegyzék hatályát. ${ }^{1071} \mathrm{~A}$ július 16-i pártközi megegyezés következtében pedig Pfeiffer Zoltán megmaradhatott a posztján, és mindez reményt jelentett arra, hogy a személyét érő kommunista párti támadások egy időre megszünnek.

Az időleges belpolitikai békét hozó július 16-i kompromisszumot követő napokban történt tehát Makón a Pfeiffer Zoltánt ért incidens.

A helyi kommunista párti vezetők, akik a baloldali országos sajtóból (fóként a már idézett Szabad Népből) és alkalmi parlamenti pletykákból, bennfentesnek gondolt pártapparátusbéli személyektől értesültek a politikai történésekröl, úgy érezhették: a „fasisztamentő” Pfeiffer üldözött vaddá vált (június közepétől egy hónapon át valóban az is volt), ellene bármi megengedhető. Ilyen megfontolások és lélektani összetevők állhattak a gyűlés megzavarása mögött. A makói MKP-s politikusok olvasták a Szabad Népnek az igazságügyi államtitkárra zúdított vádjait, ez meg is maradt bennük. (Láthattuk, Kiss Imre is a Szabad Nép Pfeiffert ostorozó írásaira utalt, mikor a makói botrány összefüggéseit igyekezett megmagyarázni.) Bizonyára nem értesültek viszont a Szviridov-levél felfüggesztéséről és a színfalak mögött zajló pártközi tárgyalások eredményéről. Így, amikor hírét vették Pfeiffer Zoltán makói látogatásának, azt gondolhatták, eljött az idő a cselekvésre, ahogyan a Makói Népújság publicistája írta: a kommunista tömeg maga akarta „leellenőrizni a szónokok demokrata mivoltát."1072

„A kommunista pártszervezet makói vezetői is belátták azt, hogy olyan eszközökkel

\footnotetext{
${ }^{1070}$ NAGY Ferenc: Küzdelem a vasfüggöny mögött. I. Európa - História, Budapest, 1990. 319-321. p.

${ }^{1071}$ VIDA István: Koalíció és pártharcok. 1944-1948. Magvető Kiadó, Budapest, 1986. 199. p.

1072 Makói Népújság, 1946. augusztus 6. 3. p.
} 
nem lehet gyengíteni a mind jobbra tolódó Kisgazdapárt előretörését"1073 — értékelt visszaemlékezéseiben a korszak első számú makói MKP-s politikusa, Kiss Imre.

A későbbiekben lehet, hogy a helyi kommunisták elismerték maguk között - amint ezt Kiss Imre közölte -, miszerint az effajta módszerek az akkor még demokratikusnak tekinthető lokális politikai kultúrában nem vezetnek eredményre; a gyülés megzavarását követő napokban viszont az önkritikának nyoma sem volt. Minderre és a korszakra jellemző arrogáns politikai stílusra jó példa Rozsnyai Mihály, kommunista párti városi titkárnak a Makói Népújságban megjelent írása. („Mi már eddig is nagyon sokszor és minden alkalommal megmondtuk: nem a Kisgazdapárt ellen van kifogásunk, hanem a Kisgazdapártban meghúzódott, reakciós és félfasiszta elemek ellen. Ezekkel az elemekkel minden jóindulatunk és jószándékunk ellenére, mivel demokrácia-ellenes cselekedetekről ismételten tanúbizonyságot tesznek, nem vagyunk képesek együtt dolgozni. [...] A demokratikus kisgazdák nem azonosítják magukat ezekkel az urakkal. Úgy látszik, Szőnyi Imre úgy látja biztosítottnak nemzetgyülési képviselői mandátumát, hogy átállt a jobboldali képviselő Pfeiffer és Parragi úrék oldalára. [...] A mi tömegeink jól ismerik Parragi és Pfeiffer urakat. [...] Azt tudjuk, hogy a Kisgazdapárt demokratikus parasztjai torkig vannak ezzel a demokráciával.”)

Rozsnyai Mihály imént idézett szavai - amelyek a július 28-i Makói Népújságban jelentek meg - a legnagyobb magabiztosságra és határozottságra utalnak. A cikk nyomdába adása után történt, hogy az MKP megyei és országos vezetése megállj parancsolt a helyi pártvezetésnek, és kritikával illette a gyülés megzavarását. Mindennek hatására Rozsnyai lemondott városi titkári posztjáról. A makói kommunisták pedig úgy értelmezték a felsőbb pártvezetés döntését, miszerint „letiltották a forradalmi gondolatot a tagságnál."1074

A Magyar Kommunista Párt Csanád Megyei Bizottságának 1946. augusztusi ülésén állapították meg, hogy helyben „fennáll még mindig a kissé baloldalra való elhajlás, túlzott radikalizmus, türelmetlenség." ${ }^{1075}$ Apró Antal, a MKP KV tömegszervezeti osztályvezetője a párt Csanád megyei szervezetének helyzetéről szóló 1946. augusztus 13-i keltezésű jelentésében is utal rá, személyi ellentétek vannak a makói vezetésben, és egyes kommunista funkcionáriusok részéről „a Párt irányvonalának kérdésében is állandó kritika és támadás hangzik el.”1076 (A dokumentum Farkas Mihály asztalára került, aki a következő megjegyzést írta a lapra: „Szükségesnek tartom, hogy a szervezési és káderosztály egy-egy jó, értelmes

\footnotetext{
${ }^{1073}$ KISS Imre: Uo. 232. p.

${ }^{1074}$ Makó az első felszabadult magyar város. II. kötet. 88-89. p.

1075 CSML MSZMP CSMBA 26. f. 3. öe

${ }^{1076}$ PIL 274. f. 16. cs. 152. őe.
} 
instruktorja [sic] lemenjen Makóra és megvizsgálja a pártszervezet belső helyzetét." ${ }^{1077} \mathrm{E}$ kritikus csoport túl puhának tartotta az MKP politikai stílusát, azt hogy a kommunisták formálisan elfogadják a parlamentáris demokrácia világát, szellemiségét, ezért is igyekezett önálló kezdeményezésekkel élni, ennek volt egyik megnyilvánulása a Pfeiffer-gyülés megzavarása.

A kisgazda összejövetel botrányba fullasztása miatt Makón azonban az MKP még a Baloldali Blokkon belül is elszigetelödött, ugyanis - a normasértés súlyossága folytán - a helyi szociáldemokraták és a Nemzeti Parasztpárt makói képviselői is elhatárolódtak a július 21-én történtektöl. („Az SZDP sajnos ellenünk fordult és ugyancsak ez a helyzet az NPP-vel is"1078 - olvasható a kommunista pártszervezet július 23-i vezetőségi ülésén készült jegyzőkönyvben.) A helyzet komolyságát mutatja, hogy a kisgazda összejövetel megzavarása miatti tiltakozás jeleként két személy kilépett a makói MKP-szervezetből. Erről Sárvári György, a vezetőség tagja számolt be: „A MÁV-nál két párttag arra hivatkozással, hogy a vasárnapi tüntetéssel nem azonosítja magát, kilépett."1079

A makói gyülés megzavarása belpolitikai téren is hangos botrányt okozott. Pfeiffer Zoltán szerint „,a demokrácia szégyene,"1080 ami történt.

Az országos kisgazda sajtó pedig nem mulasztotta el a lehetőséget, hogy az eset kapcsán is rávilágítson a kommunistáknak a demokratikus politikai kultúrát sértő közéleti stílusára.

„A népgyülés nem akadémiai ülés s épp a demokráciában nem szabad könnyelműen szordínót szereltetni a tömegek nyelvére. Kiváltképpen egy nagy párt nagygyülésén. Más azonban az, amikor kifejezett szavak, mondatok mellett vagy ellen tüntet a tömeg és más az, amikor szónokok egyáltalában nem szólhatnak. Sem tetszetősen, sem ellentmondást érdemlően, mert csak a hallgatóság beszél vagy a hallgató tömeg egy része vaklármázik. A demokrácia illemtanába sehogyan sem fér meg a szónémító vaklárma s nem a demokrácia ügyeit szolgálják azok a pártok, amelyek termékeny vita helyett politikai gyülések megzavarása terén vitézkednek" ${ }^{\prime 1081}$ - fogalmazott a Kis Újság. A kisgazda szellemiségü hetilap, az Igazság radikálisabb hangot ütött meg: „A makói kisgazdák kemény öklei nem sújtottak le a már nem is felelőtlen, hanem jó előre megszervezett és betanított rendbontókra,

\footnotetext{
1077 Uo.

1078 CSML MSZMP CSMBA 27. f. 4. őe.

${ }^{1079}$ Uo.

${ }^{1080}$ Kis Újság, 1946. július 28. 2. p.

${ }^{1081}$ Kis Újság, 1946. július 25. 2. p.
} 
mert a makói és az ország minden parasztja tudtában van a politizálás, a koalíció fontosságának."1082

„Ami pedig a provokációt és az önfegyelmet illeti, itt is valótlanságot állít a cikkíró. Éppen a munkáspárti tömegek nem hagyták magukat provokálni a szónokoktól. [...] Mert a gyülésen bizony a szónokok provokálták a tömeget, amikor söpredéknek nevezték, részeg, zöldinges, nyilas, SS sapkás, ${ }^{1083}$ és mit tudom én még minden provokáló jelzővel nem illették őket, pofonokat ígértek, karhatalmat követeltek és kimondottan azt szerették volna elérni, hogy verekedésbe, népítélet-be fúljon a gyülés. A megjelent nagygazda gentry Kalot ifjúsági kisgazda tömegek demokratikus mivoltára pedig jellemző az, hogy mihez tapsoltak. Mikor a szónokok becsmérelték, gyalázták a megjelent más pártállásúakat, karhatalmat emlegettek, akkor hangosak voltak, tüntetően tapsoltak" ${ }^{1084}$ - replikázott az Igazság írására a Makói Népújság publicistája.

A megzavart gyülést követően az FKGP helyi irányítói nem elégedtek meg önmagában azzal, hogy felháborodnak és tiltakoznak, hanem határozott politikai cselekvésre szánták el magukat. A helyi demokrácia struktúráját érintő döntést hoztak arról, hogy válaszként a Kisgazdapárt képviselőtestületi tagjai bojkottálni fogják a „városi parlament” üléseit.

A makói képviselőtestület a július 21-i incidens másnapján ült össze. Rendkívüli ülést kellett ugyanis tartani - a B-listára került tisztviselök és alkalmazottak ügyében. A közgyülés megnyitását követően Erdei Imre, a Független Kisgazdapárt delegáltja kért napirend előtti felszólalásra lehetőséget. Az akkor hatályos müködési szabályzat - vagyis a helyi demokrácia szabályrendszere - alapján rendkívüli ülésen nem lehetett napirend elött felszólalni. Ezt Kiss Imre kommunista párti polgármester is közölte a jelenlévőkkel, de egyben kérte a testületet,

\footnotetext{
${ }_{1082}$ Igazság, 1946. augusztus 2. 5. p.

${ }^{1083}$ A Makói Népújság újságírója szerint a kisgazda vezetők a tömeget „zöldingesnek” és „nyilasnak” nevezték. A valóságban bizonyára eleve csak a provokátorok egy részére vonatkozóan hangoztathatták az FKGP-sek mindezt. A II. világháború után szerte az országban, így Makón is gyakori jelenség volt, hogy az egykori kisnyilasok sebtében az új korszak hajnalán az MKP tagjaivá váltak. Még a hivatalos helyi párttörténetírás is elismeri, hogy így bekerültek a mozgalomba „nem oda való elemek”. (TAMASI Mihály: A népi demokratikus forradalom győzelme. 72. p.) A kisnyilasok körében ekkoriban követett taktika volt, hogy beléptek a Kommunista Pártba, ezáltal próbálták elkerülni az internálást. Ebből kiindulva nem lehetetlen, hogy most éppen kommunista „mezben” volt kisnyilasok is részét képezték a botrányt keltő csoportosulásnak. Ezt történeti eszközökkel bizonyítani immáron képtelenség, hiszen erre nézve nincsenek további forrásaink. Valószínüleg nem véletlen azonban, hogy a kisgazdák ,nyilast” kiállítottak. E következtetések alapján ismét egy XX. századi paradoxonra bukkanhatunk: hitehagyott korábbi szélsőjobboldaliak is közremüködtek a német megszállás után kibontakozott nemzeti ellenállás egyik szereplőjének, Pfeiffer Zoltánnak, Bajcsy-Zsilinszky Endre barátjának a kifütyülésében, akit 1946-ra — mint már láthattuk — a baloldali sajtóban pusztán fasisztamentőként, fasisztabarátként emlegettek.

${ }^{1084}$ Makói Népújság, 1946. augusztus 6. 3. p.
} 
hogy a „rendkívüli viszonyokra való tekintettel”1085 adjon engedélyt a kisgazda képviselőnek beszéde elmondására. A közgyülés szavazott, és az engedélyt megadta. Ezt a kommunisták részéről mindenképpen demokratikus gesztusnak tekinthetjük.

Erdei Imre a következő deklarációt - ami valóságos manifesztuma a helyi demokráciasérelmeknek - olvasta fel: „A Függetlenségi Frontba, majd pedig a koalícióba tömörült demokratikus pártok - köztük a Független Kisgazda, Földmunkás és Polgári Párt is együttesen vállalkoztak az ország újjáépítésére és az önkormányzatokban, addig is, amíg az önkormányzati választások megtarthatók lesznek, az ügyek intézésre. A Független Kisgazda, Földmunkás és Polgári Párt ezt a vállalkozást komolyan vette és veszi most is annak ellenére, hogy a lakosság között a többsége nyilvánvaló, vállalta még azt is, hogy a most meglevő paritásos alapon intézményesen kisebbségbe szorítkozzék. Tette ezt a kitüzött nagy cél érdekében, hogy a viszonyok mielőbb konszolidálódjanak és az újjáépítés haladhasson, feltételezve, hogy a többi pártoknak is ugyanez a céljuk [...] De kétségbe kell vonni azt, hogy a pártok egyike méltányolja ezt az áldozatkészséget és hajlandó a maga részéről is, ha nem is áldozatot hozni, de legalább belátni, hogy az együttmüködés érdekében bizonyos lojalitásokkal kell lenniök a pártoknak egymással szemben, mert különben együttmúködés el nem képzelhető, nem hogy megvalósítható volna. A Kommunista Párt által követett magatartás az együttműködést már eddig is sokszor és nagy mértékben megnehezítette a közelmúltban történt képviselőtestületi gyüléseken, különösen pedig a tegnapi napon a kisgazdapárt által rendezett gyülésen tanúsított magatartásával pedig teljes joggal hiheti a Független Kisgazdapárt, hogy az együttmüködési szándék nem őszinte, sőt e miatt minden közös munka lehetetlenné válik és ezért a maga részéröl levonja a következtetéseket és mindennemü közös tárgyalásról, így a városi képviselőtestületi gyülésekről is, távol tartja magát mindaddig, amíg ez a magatartás ilyen irányú lesz, vagy míg a[z önkormányzati MK.] választások meg nem történnek."1086 A memorandum elhangzása után a kisgazdapárti városatyák elhagyták a képviselőtestületi ülést.

Kiss Imrét valóban meglepte a kisgazdák lépése. Az MKP makói vezetőségének másnapi ülésén mondta: „Nem gondoltam, hogy ezért [ti. a gyülés megzavarása miatt - MK.] minden népi szervből ki fognak vonulni.”

A képviselőtestületen belül a koalíciós pártok paritásos alapon delegáltak képviselöket, ezért a többség biztosított volt a polgármester számára. Kiss Imre viszont hamar beláthatta, a helyi FKGP-sek e döntésükkel lényegében a képviselőtestület, illetve a város első

\footnotetext{
${ }^{1085}$ Uo.

${ }^{1086}$ Makó Város Levéltára (a továbbiakban: MVL) 290 kgy 15.706/1946.
} 
emberének legitimitását támadják.

Az 1945. november 4-i nemzetgyülési választásokon Makón a Független Kisgazdapárt a szavazatok 52\%-át szerezte meg, így egyértelmü lehetett, a közgyülésről való kivonulással messze a legnagyobb politikai tömörülés vonul passzív ellenállásba.

Ha arra keressük a választ, hogy valóban „csak” a július 21-i gyülés botrányba fullasztása okán robbantotta-e fel az FKGP a helyi koalíciót, akkor a válasz egyértelmúen nem. A memorandumban is szó esett róla, hogy kisgazdák szerint a Kommunista Párt magatartása már korábban is „sokszor és nagy mértékben megnehezítette” az együttmüködést. 1946 tavaszán-nyarán a különböző világlátásból fakadó általános ellentéteken túlmenően négy - kisebb-nagyobb - ügy terhelte meg a makói MKP és a Kisgazdapárt közös munkálkodását, a helyi demokrácia müködését.

Az 1946. március 11-i közgyülésen a képviselök arról hallgattak meg tájékoztatást, hogy a kommunista polgármester miért küldött el a hivatalból 11 köztisztviselőt - a „népakaratra” hivatkozva. Erdei Imre kisgazda városatya azt próbálta megtudakolni, „melyek azok az okok, amelyek a felfüggesztett tisztviselők ellen felmerültek?"1087 E kérdésfeltevés általában a képviselői munka természetes velejárója, az MKP-sok viszont igen indulatosan reagáltak, azzal kezdték vádolni a Kisgazdapártot, miszerint „ők hagyják, hogy minden a régi mederben menjen”. ${ }^{1088}$ A korabeli szóhasználat alapján mindez arra utalt, hogy a reakciósság bélyegét igyekeztek a makói FKGP-re sütni. Tudjuk, abban az időszakban a fogalom, „reakciós”, a legsúlyosabb elmarasztalást jelentette, és egyúttal szalonképtelenné tette azon erőt, melyre sikeresen ragasztották rá e jelzőt. Ez az önmagában jelentéktelen epizód persze kevés volt ahhoz, hogy politikai következményekkel járjon, de a helyi kisgazdákban bizonyosan nem erősítette a kommunisták iránti bizalmat.

A következő ütköző szintén nem egy kifejezetten nagy horderejü téma körül bontakozott ki; jelentősége abban állott, hogy a baloldal ismét átlépett a helyi demokrácia szempontjából egy szimbolikus határt. Az történt, hogy Kiss Imre polgármester mindenféle képviselőtestületi felhatalmazás és pályázat nélkül nevezte ki a városi iskola fogorvosát. A fő célkitűzéssel, hogy a diákok fogazata ép maradjon, mindenki egyetértett. A kisgazdák álláspontját az 1946. május 13i közgyülésen Szőnyi Imre ismertette: „Úgy látom, befejezett tény elé állított a polgármester úr. Tudom, hogy szükség van az orvosra, de miért nem tettek előbb előterjesztést, pályázatot hirdettünk volna." ${ }^{1089}$ A kommunista képviselők a vita során arra törekedtek, hogy megkerüljék

\footnotetext{
${ }^{1087}$ MVL 107 kgy. 5399 ikt./1946.

${ }^{1088}$ Uo.

${ }^{1089}$ MVL 211 kgy. 9183 ikt./1946.
} 
a kérdés lényegét, miért nem szabályosan, a jogszabályok szellemében intézték ezt a valóban nemes ügyet. A polgármester pedig megint a megbélyegzés eszközével élt. („Nem látszik semmi felelősségérzet azok részéről, akik tiltakoztak.") ${ }^{1090}$ Később, ha elszólásként is, de elismerte, hogy nem volt az eljárással minden rendben: „Ez[ért] a kis szabálytalanságnak látszó valamiért sütötték rám, hogy diktátor vagyok."1091

Ugyancsak a május 13-i képviselőtestületi ülés napirendjén szerepelt az úgynevezett házhelykiosztások ügye. ${ }^{1092}$ A probléma témánk szempontjából azért fontos, mert az e tárgyban született hivatalos előterjesztés azt a társadalmi csoportot, a paraszt-polgárságot érintette igencsak kedvezőtlenül, amely az FKGP fő bázisául szolgált - az MKP politikai eszközt látva az ügyben tudatosan épített erre. Az elképzelés szerint - némiképpen leegyszerüsítve - a nagyobb belterületi telkek egy részét elveszik, a tulajdonos jó esetben külterületi szántót vagy legelőt kap kárpótlásul; az újonnan létrehozandó telkek pedig az inkább a kommunistákat támogató szegényebb rétegek kezébe kerülnek. A felszólaló kisgazdák amellett érveltek, hogy a városon belüli ingatlanok közül eleve csak azok kerüljenek a rendelkezés hatálya alá, amelyek üresen állnak.

A paritásos - nem választás alapján létrejött - közgyülésben azonban a Baloldali Blokk többsége biztosított volt, így az eredeti előterjesztést fogadták el. Ez a fajta önmagában demokratikus, a sima többségi modellre építő - döntéshozatal erősíthette a kisgazdákban a gondolatot, miszerint a legnagyobb közéleti tényezőként minek ülnek a közgyülésben, ha ennyit ér a szavuk.

A legsúlyosabb történés 1946. május végére tehető. Május 31-e éjjelén felgyújtották a makói zsinagógát. Éppen azon az estén tartották a középiskolások ballagását. A tűzeset után a rendőrség egymás után vitte be a Független Ifjúsághoz ${ }^{1093}$ tartozó diákokat a rendőrségre. Megindult a híresztelés, hogy „,a szálak a Kisgazdapárthoz vezetnek.”1094

Valójában az esemény hátterében a helyi kommunista párti politikai nyomozók provokációja állt. ${ }^{1095} \mathrm{Az}$ előre eltervezett koncepció alapján a gyújtogatással a kisgazdákat gyanúsították, és egy nagyszabású, a „reakció” és azon belül az FKGP ellen irányuló perben gondolkodtak. Az akciót azonban a makói MKP-s nyomozók „dilettáns módon”"1096 hajtották végre, így nem tudták felhasználni az ügyet a Kisgazdapárt helyi szervezetével szemben.

\footnotetext{
${ }^{1090}$ Uo.

1091 Uo.

1092 MVL 255 kgy. 12152 ikt./1946.

${ }^{1093}$ A Független Ifjúság az FKGP ifjúsági szervezte.

${ }^{1094}$ Kis Újság, 1946. augusztus 6. 2. p.

${ }^{1095}$ A makói zsinagóga felgyújtásáról: SZAKÁCS Sándor-ZINNER Tibor: Uo. 239-241. p. ${ }^{1096}$ Uo.
} 
Az előbbiek során megfigyelhettük a viszonyok elmérgesedését. 1946 nyarára a makói FKGP számára már majdnem tele volt az a bizonyos pohár. E közéleti szituációban történt a július 21-i gyülés megzavarása, mely után a korábbi hetekben halmozódó feszültség kitört. Innen már ismerjük a történetet, a Kisgazdapárt bojkottot hirdetett a kommunisták ellen és kivonult a képviselőtestület munkájából.

Az MKP helyi vezetői felismerték a kisgazdák kivonulásával együtt járó politikai kockázatokat. Ennek megfelelően azonnal cselekedtek. Egyrészt erőteljes sajtókampánnyal, nyilatkozatokkal, publicisztikákkal arra törekedtek, hogy megbélyegezzék a kisgazdák e „felelötlen” magatartását, s ezzel az FKGP ellen fordítsák a közvéleményt. Másrészt megpróbálták megosztani a makói kisgazdákat, vagyis leválasztani a tagság egy részét a vezetőségről.

„A Népújság vasárnapi számában olvastam a kisgazdapárti képviselőtestületi tagok magatartásáról. Megdöbbenve vettem tudomásul, hogy az állítólag megzavart gyülés miatt felbontották a koalíciót és kivonták magukat a város ügyeinek intézéséből. Csak annyit akarok kérdezni a képviselő uraktól: Kiknek az érdekeit képviselik a városi képviselő testületben? Parragi és Pfeiffer urak érdekeit, vagy a makói nép érdekeit? Érdemesnek tartják Parragi és Pfeiffer urak miatt sutba dobni a város közigazgatásának felelősségét? Ha így van, akkor mondják meg nyíltan, hogy Parragi és Pfeiffer urak nekik többet érnek, mint Makó jövője. Akkor azután végleg kivonulhatnak a tanácsteremből”1097 - érkeztek az ilyen és ehhez hasonló jellegű nyomásgyakorlási kísérletek az FKGP helyi politikusai felé, ezúttal egy olvasói levél formájában.

Rozsnyai Mihály, helyi MKP titkár a Makói Népújságban megjelent cikkében szintén nem kímélte a kisgazda döntéshozókat: „Ezzel a lépéssel a makói Kisgazdapárt képviselői [...] eljátszották azt a jogukat, hogy valaha is arra hivatkozzanak, hogy ők ott álltak a város élén a legnehezebb időkben is. [...] Azok a kisgazdapárti képviselők, akik hétfön kivonultak a közgyülésről, megfutamodtak a nehézségektől. Ilyen munkát végeztek Parragi, Pfeiffer úr és makói híveik." 1098

Kiss Imre polgármester szerint az FKGP-s képviselők ,azzal, hogy a legsorsdöntőbb órákban ${ }^{1099}$ vonultak ki a képviselőtestületből, cselekedetükkel mintegy elhárították az elkövetkező események felelősségét magukról és áthárították azokra, akik helyükön maradtak.

\footnotetext{
${ }^{1097}$ Makói Népújság, 1946. július 30. 4. p.

${ }^{1098}$ Makói Népújság, 1946. július 28. 2. p.

${ }^{1099}$ Kiss Imre ezzel arra utalt, hogy e napokban folyt az országban a forint bevezetésének elökészítése.
} 
Megérdemli-e ezt az eljárást ennek a városnak a népe?"1100 - tette fel a kérdést Kiss Imre.

A másik kommunista párti csapásirány a helyi FKGP megosztása volt. A képviselőtestületből történő kivonulást követő napon tartott MKP helyi vezetőségi ülésen megfogalmazódott a cél: a „baloldali kisgazdákkal fel kell vennünk a kapcsolatot.”"1101 A kapcsolatfelvétel személyesen és a Makói Népújság hasábjain keresztül történt meg. „Nem hiszem el, hogy a Kisgazdapárt valamennyi tagjának tetszésével találkozott volna ez a büntetőexpedíció játék. Nem hiszem el, hogy helyeselték ezt a kivonulást, mert nem hiszem el, hogy jóváhagynának egy olyan elhatározást, amely szentesítené a város lakosságának cserbenhagyását. Ezért őhozzájuk fordulok. Hassanak oda, hogy orvoslást találjon ez a kérdés"1102 - írta az akkor még egyetlen helyi lapban a kommunista polgármester.

A Baloldali Blokk makói pártjai külön nyilatkozatot bocsátottak ki az ügyben: „A mögöttünk álló dolgozók nevében kéréssel fordulunk a demokratikusan gondolkodó, dolgozó, józan makói kisgazdákhoz, hassanak oda, hogy a Kisgazdapárt haladéktalanul bekapcsolódjék városunk ügyeinek intézésébe. A passzív rezisztencia korszaka lejárt. [...] Ma már nem úri passzió, időtöltés a politika, hanem dolgozó osztályunkkal szembeni kötelesség. Nem engedhetjük meg magunknak, hogy ideig-óráig is kikapcsolódjunk a közös munkából. Csak akkor tudunk talpraállani, ha a demokratikus erőket összefogjuk s együtt dolgozunk. Aki ezt nem teszi az a reakció malmára hajtja a vizet”1103 - áll a baloldali pártoknak a „demokratikus” kisgazdákhoz szóló felhívásában.

Mint láttuk, a vezetőségi ülésen a „baloldali” FKGP-sek megszólítását célozták meg. A nyilvánosság előtt persze már nem így nevezték őket, hanem „demokratikusan gondolkodó, dolgozó, józan” kisgazdáknak. E kis nyelvi játéktól függetlenül, hiába keresték, egyelöre nem találták a „demokratikus” kisgazdapártiakat. Hiába volt rendkívül intenzív az MKP ellentámadása, egy ideig még nem vezetett eredményre. A kisgazda városatyák kitartottak döntésük, a kisgazda bázis pedig a vezetés mellett.

A megzavart 1946. július 21-i rendezvény után Pfeiffer Zoltán azonnal jelezte; nem adják fel, néhány hét múlva visszatérnek és megtartják újra a gyülést. Makón széltébenhosszában terjedt a híresztelés, a budapesti politikusok ismételt látogatásakor a fóvárosból szállítanak majd le karhatalmat az összejövetel biztosítása érdekében. ${ }^{1104} \mathrm{E}$ pletykaelem

\footnotetext{
${ }^{1100}$ Makói Népújság, 1946. július 28. 1.p.

1101 CSML MSZMP CSMBA 27. f. 4. őe.

1102 Makói Népújság, 1946. július 28. 1. p.

1103 Uo.

${ }^{1104}$ Kis Újság, 1946. augusztus 18. 3. p.
} 
Csepregi Imre esperes-prelátus már idézett naplójában is előkerült. Az esperes feljegyezte a szájról-szájra terjedő vélekedést, miszerint az újabb gyülésre Pfeifferék „,hoznak magukkal rendört is az itteniek ellen."1105

A megismételt rendezvényre augusztus 11-én került sor. ${ }^{1106}$ Rendőrök természetesen nem jöttek Budapestről. Pfeiffer Zoltán államtitkárt ezúttal Bajcsy-Zsilinszky Endre özvegye kísérte el a csanádi megyeszékhelyre. Az esemény lázban tartotta a város közélet iránt érdeklődő lakosságát. Olyanok is elmentek kíváncsiságból a gyülésre, akik egyébként nem jártak politikai rendezvényekre. Akadtak, akik valamelyik közeli ingatlanból figyelték a történéseket. Csepregi prelátus például - többekkel együtt - ügyvéd ismerősének lakásából hallgatta végig a beszédeket. Már az is tanulságos, hogy ez a kis társaság milyen miliőben töltötte ott az időt. Az egyik vendég fia kommunista párti agitátor volt, így egymást figyelmeztették a jelen lévők, hogy az illetővel „óvatosan beszéljenek, "1107 nehogy tovább adja a férfi az elhangzottakat.

A gyülés ezúttal rendben zajlott. (Az MKP makói vezetősége augusztus 4-i ülésén „mindenféle provokációt” megtiltott, sőt arról rendelkezett, hogy „a kommunisták ne menjenek"1108 el a rendezvényre. Azok a párttagok, akik ezzel ellentétesen cselekszenek, pártfegyelmire számíthatnak, szólt a verdikt.) ${ }^{1109}$ Csak egy kisebbfajta incidens történt, amiről a tömeg ${ }^{110}$ nem is értesült. Az eseményt biztosító ügyeletes rendőrtiszt tanácsokat próbált „adni, hogy hogyan beszéljenek és hogyan ne beszéljenek”"1111 a szónokok. Pfeiffer azonban felszólította a rendőrt, ezzel „ne törődjék.”1112

A megismételt gyülésre a kisgazdák meghívták a város polgármesterét, Kiss Imrét. Milyen okok vezérelhették az FKGP makói irányítóit e lépésükkel? Pusztán az udvariasság vagy lehetett benne akár egy kis provokatív szándék is? A polgármester mindenesetre elment a rendezvényre. Kiss Imre úgy vélte, e gesztusával segítheti visszacsábítani a

\footnotetext{
1105 Dr. CSEPREGI Imre: Napló. 1. 543. p..

1106 „Hetek múlva a kisgazdák Pfeiffer részvételével újabb nagygyülést tartottak. Ekkor a Főtérnek a Gazdasági Egyesület elötti részén és a mai József Attila szobor környékén zajlott a rendezvény. Osztálytársaim közül Császtvay Istvánon kívül Lator László is részt vett. A jelen levők száma többszöröse volt az előbbinek. Úgy hírlett, hogy Szolnok megyéből is ide sereglettek. Pfeiffer azzal kezdte beszédét, a múltkor nem engedtek szóhoz jutni, ha ma is megzavarnak, még akár a nógrádiakat is idehozzuk. Semmi incidens nem történt. Ezt ezzel a megjegyzéssel érzékeltették: Összel minden légy elhullik.” (Dr. Tóth Ferenc feljegyzéséből)

${ }^{1107}$ Dr. CSEPREGI Imre: Napló. 1. 556. p.

1108 CSML MSZMP CSMBA 27. f. 4. őe.

${ }^{1109}$ Erröl a helyi napilap közölt információkat. (Makói Népújság, 1946. augusztus 13. 3. p.)

${ }^{1110}$ A Kis Újság (1946. augusztus 18. 3. p.) azt írta, hogy „tizenkétezer ember” vett részt az eseményen, Kiss Imre polgármester visszaemlékezésében úgy fogalmazott, hogy a gyülésen „több mint kétezren jelentek meg.” (KISS Imre: Uo. 233. p.) Apró Antalnak az MKP KV számára készített jelentésében a következő tájékoztatást adta a tömeg nagyságáról: „,becslésem szerint több mint hatezer ember volt.” (PIL 274. f. 16. cs. 152. őe.)

${ }^{1111}$ Kis Újság, 1946. augusztus 18. 3. p.

1112 Uo.
} 
képviselőtestületbe a kisgazdapárti városatyákat. Az eseményen szerzett benyomásairól visszaemlékezéseiben is szólt: „Pfeiffer Zoltán hasonlóan ocsmány hangon beszélt, mint az előző megzavart gyülésen, de ebben most már senki sem zavarta meg."1113

Cseperegi prelátus naplójában természetesen egészen más megközelítéssel elemezte a Pfeiffer-beszédet. („Okosan és ügyesen vágta a kommunistákat, múltkori példátlan viselkedésüket.") ${ }^{1114}$

A Makói Népújság tudósítása szerint Pfeiffer Zoltán beszédét „a munkáspártok elleni éles, gúnyos kritika jellemezte, mivel a három hét előtti gyülés megzavarását a Magyar Kommunista Párt makói szervezete előre megfontolt szándékának tulajdonította."1115 A megszólalás többi részében részletesen beszélt ,a magyar demokrácia eredményeiről,"1116 hangoztatva, hogy ezekben a sikerekben Kisgazdapárt segítsége is ott van. „A stabilizációval kapcsolatosan hangoztatta, hogy meg kell teremteni a lelkek stabilizációját is és az ősszel meg kell tartani a községi választásokat."

Az augusztus 11-i megismételt makói Pfeiffer-gyülés az MKP országos vezetőinek

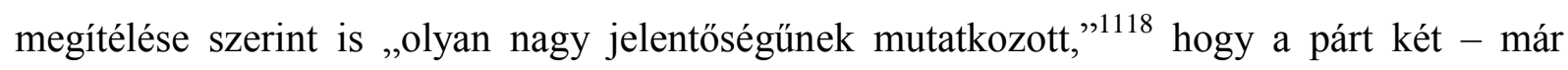
akkor sem névtelen, de a későbbiekben valóban széles ismertségre szert tevő - politikusát, Apró Antalt és Piros Lászlót küldték le Makóra az események megfigyelése végett. Mindketten nemzetgyülési képviselők voltak 1946-ban, emellett Piros a Szakszervezeti Tanács főtitkár-helyetteseként tevékenykedett, Apró ${ }^{1119}$ pedig - a tömegszervezeti kérdésekért felelős - osztályvezetőként dolgozott a központi apparátusban. Délután - a polgármester ${ }^{1120}$ hivatali szobájának ablakából - hallgatták meg Pfeiffer Zoltán beszédét. ${ }^{1121}$

Apró hivatalos jelentésében értékelte az MKP-nak a helyi közéletben betöltött szerepét, mozgásterét és e téma részeként a makói Pfeiffer-gyülések kísérőjelenségeit: „Politikai befolyásunk erősen gyengült az utóbbi időben. Ezt a megállapításom arra is építem, hogy eddig a kisgazdapárt Makón nem tudott erős gyökereket verni, de az utóbbi másfél hónap alatt, de különösen az utóbbi három hétben ezen a téren lényeges változás észlelhető a

\footnotetext{
1113 KISS Imre: Uo. 233. p.

${ }^{1114}$ Dr. CSEPREGI Imre: Napló. 1.556. p.

1115 Makói Népújság, 1946. augusztus 13. 2. p.

${ }^{1116}$ Uo.

1117 Uo.

1118 KISS Imre: Uo. 232. p.

1119 Apró Antal számára nem lehetett ismeretlen a környék, hiszen ifjú korában élt Makón.

${ }^{1120}$ Eközben - amint erről már szó esett - Kiss Imre polgármester meghívott vendégként az egyik fő helyen ült a kisgazda gyülésen.

${ }_{1121}$ „Apró elvtárs mindent jegyzetelt és fönt a központban ismerteti.” (Az MKP makói szervezet vezetőségi ülésén készült jegyzőkönyvből, CSML MSZMP CSMBA 27. f. 4. őe.)
} 
kisgazdapárt javára. Három héttel ezelőtt Makón a két munkáspárt tagjai megzavarták ${ }^{1122}$ Pfeiffer gyengén előkészített gyülését és akkor Pfeiffer azt mondotta, hogy három hét múlva visszajön, de a gyülést minden körülmények között meg fogja tartani. Most 11-én tényleg megtartotta gyülését és azon becslésem szerint több mint hatezer ember volt. A mi elvtársaink nem tettek semmi előkészületet, passzívak maradtak, úgy gondolták, hogy Pfeiffer úr gyülése nem sikerül, de a tények azt bizonyítják, de a kisgazdapárt megszervezte ezt a gyülést, a mi elvtársaink pedig megijedtek a nagy tömeg láttára. Pfeiffer közel három órás beszédet tartott és igen élénken éljeneztek, helyeseltek neki a megjelent munkások és parasztok" ${ }^{\text {"1123 }}$ - áll az Apró-jelentésben.

Kiss Imre kommunista párti polgármester „erős bírálatot” kapott Apróéktól amiatt, hogy miért nem hagyta ott az eseményt, „amikor a szónok a kommunista pártot olyan szigorúan elítélte és rágalmazta a beszédében." ${ }^{1124}$ Kiss Imre részben azzal védekezett, hogy tüntető távozásával nem akarta megsérteni a mellette helyet foglaló özvegy Bajcsy Zsilinszky Endrénét. („Nagy tiszteletlenségnek tartottam volna, hogy szó nélkül ott hagyjam őket.”) ${ }^{1125}$ Ez a fajta érvelés a legkevésbé sem hatott a pártközpont embereire. Szintén hatástalan maradt a polgármester másik megjegyzése: „Folyamatban volt az a párt által is szorgalmazott feladatom, hogy a városi képviselőtestületből tüntetően kivonuló kisgazdapárti képviselőket meggyőzzem, hogy térjenek vissza és vegyenek részt továbbra is a nagyon fontos városi ügyek intézésében."1126 Vagyis Kiss Imre taktikai szempontból sem látta jónak egy újabb front megnyitását azzal, hogy tiltakozása jeléül elhagyja a gyülést. „Persze, az akkori hangulatban egyik magyarázatomat sem fogadták el kellő megértéssel"1127 — írja visszaemlékezésben Piros és Apró reakciójáról a polgármester.

Kiss Imre „,büne” kompenzálásaként a kisgazda rendezvényt követő héten a Makói Népújság címlapján megjelent publicisztikájában ostorozta Pfeiffer Zoltánt. Azt nyilván nem bírálhatta, amit Pfeiffer mondott a szónoklatában, hiszen a polgármester ott ült az első sorban és csendben hallgatta az elhangzottakat - emiatt kapta a pártbírálatot. Így ügyes húzással azért kritizálta az államtitkárt, amiről nem beszélt. „Valamiről elfelejtett szólni Pfeiffer államtitkár úr a legutóbbi kisgazda nagygyülésen. Ez a valami a beszolgáltatás. Az a beszolgáltatás, amely végeredményben a stabilizációs alapja és elengedhetetlen létfeltétele a közellátásnak.

\footnotetext{
${ }^{1122}$ Apró ebben tévedett, hiszen mint már korábban láthattuk, a helyi szociáldemokraták elhatárolódtak a gyülés megzavarásától.

${ }^{1123}$ PIL 274. f. 16. cs. 152. őe.

${ }^{1124}$ KISS Imre: Uo. 232. p.

${ }^{1125}$ Uo. 233. p.

1126 Uo.

${ }^{1127}$ Uo.
} 
Azok a kisemberek és kétkezi dolgozók, akik az elmúlt inflációs világban, a szertemálló fizetésből élő tisztviselőkkel egyetemben, belefulladtak a bankjegytömegek áradatába és nem jutottak semmihez, akik az éhségtől szédelegve, rongyos ruhában és cipőben végezték munkájukat a magyar közösségért, ezek a névtelen hösök szerettek volna valamit hallani az államtitkár úrtól a beszolgáltatással kapcsolatosan" ${ }^{\text {1128 }}$ - igyekezett fogást keresni Pfeifferen Kiss Imre.

A sikeres Pfeiffer-gyülés „ellensúlyozására"1129 a makói kommunisták egy másik nagyszabású rendezvénnyel igyekeztek válaszolni. Augusztus 20-ra hívták össze híveiket. A szónok: Pfeiffer régi kritikusa, Révai József, a Magyar Kommunista Párt legfőbb ideológusa volt. Az MKP augusztus 13-i Csanád megyei pártbizottsági ülésén részletesen meghatározták a feladatokat. Döntést hoztak arról, hogy 5000 röpcédulát szórnak szét, 7 kocsi járja majd a környező településeket a gyülést megelőző napokban („,községenként 3-5 elvtárs fog kimenni Makóról háziagitálni.” ${ }^{1130}$ Mozgósították a megyei $\mathrm{R}$ gárdát is. „Mindenképpen azon leszünk, hogy a FgKFPP ${ }^{1131}$ 11-i gyülésénél népesebb és impozánsabb gyülést rendezzünk”1132 - áll a megyei pártbizottsági ülés jegyzőkönyvében. „Meg akarod tudni, mit fog válaszolni Révai József nemzetgyülési képviselő a múlt heti Kisgazdapárt gyülésén elhangzottakra? Jöjj el augusztus 20-án de. 10 órára a városháza elé”1133 - ilyen újsághirdetésekben invitálták az érdeklődőket a kommunista párti összejövetelre.

Révai József beszédében - a várakozásoknak megfelelően - szólt a Pfeiffer-féle rendezvényről is. „Egy népgyülés volt itt Makón, egy magasállású kormányférfi volt a szónok. Nem akarok vele vitatkozni. Arról beszélt, hogy ki a súlyosabb és nem arról, hogy mi a baja-gondja a magyar parasztságnak és hogyan lehet a bajon segíteni. [...] Legközelebb ha Makóra jön ez az úr, több figyelmet szenteljen a dolgozó parasztság igazi bajaira. És kevesebbet kötekedjen velünk kommunistákkal. És jegyezze meg, hogy az észt nem kilóval mérik" $" 1134$ - mondotta Révai.

A Makói Népújság tudósítója szerint „többezer főnyi tömeg”,1135 vett részt az eseményen. „A gyülés hangulatára is rányomta bélyegét azonban a kisgazdapárti térhódítás. A városi pártvezetőség kénytelen volt beismerni, hogy a 20-i népgyülés nem sikerült" ${ }^{\text {1136 }}$

\footnotetext{
${ }^{1128}$ Makói Népújság, 1946. augusztus 18. 1. p.

${ }^{1129}$ Az ,ellensúlyozás” megfogalmazás Kiss Imrétől származik. (KISS Imre: Uo. 233. p.)

${ }^{1130}$ CSML MSZMP CSMBA 26. f. 3. őe.

${ }_{1131}$ Az FKGP hosszabb megnevezése: Független Kisgazda- Földműves- és Polgári Párt (FKgFPP)

${ }^{1132}$ CSML MSZMP CSMBA 26. f. 3. őe.

1133 Makói Népújság, 1946. augusztus 18. 2. p.

${ }^{1134}$ Makói Népújság, 1946. augusztus 22. 1. p.

1135 Uo.

${ }^{1136}$ KISS Imre: Uo. 233. p.
} 
emlékezett később Kiss Imre kommunista párti polgármester.

Az augusztusi Pfeiffer- és Révai-gyülés után Kiss Imre polgármester - érzékelve a kommunisták számára e szempontból kedvezőtlen helyi közéleti klímát - egy időre letett arról, hogy visszacsábítsa a kisgazdapártiakat a képviselőtestületbe. Szeptember 25-én azonban újra kezdeményezést tett az ügyben, levelet írt a makói kisgazdáknak. (,Sajnálattal állapítom meg, hogy a kisgazdapárt képviselőtestületi tagjai a képviselőtestület közgyülésein hónapok óta nem jelennek meg. Tekintettel arra, hogy a magyar kormány és az ország összes közületei a koalíció alapján, demokratikus pártok együttmüködésével folytatják a magyar nemzet újjáépítésének nagy munkáját, nagyon fontosnak tartom, hogy a város egyetemes érdekeinek megfelelően a kisgazdapárt képviselő tagjai újból részt vállaljanak városunk felelősségteljes irányításában.") ${ }^{1137}$

Az MKP makói vezetőségének ülésén Kiss Imre tájékoztatást adott e lépéséről. Szóba került, hogy a Makói Népújságban közöljék-e a levelet vagy sem. Úgy határoztak, ne. ${ }^{1138}$ Ezáltal a kommunisták egyelőre megelégedtek a színfalak mögötti nyomásgyakorlással.

A Kisgazdapárt illetékesei, Szőnyi Imre városi elnök, Molnár Mihály, Csorba György és Diós Imre helyi politikai bizottsági tagok október 6-án tájékoztatták a polgármestert arról, miszerint nem térnek vissza a képviselőtestületbe a kisgazda városatyák. (Figyelemre méltó maga az indokolás is, amely szintén markáns módon fogalmazza meg a kisgazdákat ért demokráciasérelmeket: „Nyilvánvaló volt, hogy nem is annyira csupán a kommunista, hanem az úgynevezett Baloldali Blokk képviselő tagjai olyan magatartást tanúsítottak velünk szemben a [képviselőtestületi - MK.] gyüléseken, amely eleve kizárta az együttmüködhetés lehetőségét. Akármilyen ésszerü, vagy a város és a lakosság érdekeit szem előtt tartó javaslattal jöttünk, azt pusztán csak azért, mert mi hoztuk, elvetették. Az ő részükről hozott javaslatokkal szemben a mi tárgyilagos kritikánkat legtöbbször semmibe sem vették, de mindenesetre sohasem méltányolták, sőt gúnyos hangon kiabálták a nyílt gyülésen, hogy a többség úgyis megszavazza. Érthető ennek folytán, tekintve, hogy a képviselőtestület mostani összetétele semmi módon nem képviseli a lakosság tényleges és valóságos érzelmeit és pártállását, vagyis egyszóval a lakosság többségét képviselő párt intézményesen kisebbségre van szorítva, ahol a többségben lévők nem értelmezik a demokráciát valóban azon az eszmei alapon, hogy a többség tartozna a kisebbség jogos és ésszerű véleményét is tiszteletben tartani és mivel ez még máig is így van, az egyik ok ez, amiért továbbra is távol maradunk a

\footnotetext{
${ }^{1137}$ Makói Népújság, 1946. október 20. 3. p.

${ }^{1138}$ CSML MSZMP CSMBA 27. f. 4. őe.
} 
gyülésekröl."”) $)^{1139}$

A kisgazda választ követően a kommunisták felülvizsgálták korábbi határozatukat, most már úgy vélték, szükséges a sajtóbéli fellépés is. Kiss Imre polgármester október 20-án nyilatkozott a Makói Népújságnak, melyben a kisgazdák panaszait természetesen nem demokráciasérelemnek, hanem pusztán érzelmi alapú véleménykifejtésnek tekintette és így bélyegezte meg: „Sajnálom, és nem értem a kisgazdapárt érzékenységét. Nem tudom elhinni, hogy a kisgazdapártban ennyire félreértelmeznék a demokratikus közéletet és ne lennének tisztában azzal, hogy egy olyan testületben, ahol különböző pártok képviselöi ülnek együtt, elő ne fordulnának olyan események bírálatok és hasonlók, amelyek természetszerủen ellentétesek egyik vagy másik párt felfogásával. Előfordulhatnak a jövőben is, hogy egyes pártok indítványait vagy felszólalásait ellenszenvvel fogadják. De minden közéleti szereplőnek bírni kell annyi önkritikával, hogy az ilyen természetü bírálatot elviselje."1140

A Makói Népújság ${ }^{1141}$ is besegített a kommunista álláspont népszerüsítésébe. A kisgazdák magatartására utalva jegyezte meg az újság munkatársa: „Mi is hisszük, hogy a haragszomrád [sic] problémáit megoldják és nem játsszák tovább egy város közösségének és gondjainak, bajainak rovására." ${ }^{1142}$ A sajtókampány folytatódott. Novemberben a Makói Népújság ismét visszatért a témára. Ennek részeként a szerkesztőség a következő kérdéseket tette fel a kisgazdák felé: „Nem akarják tudomásul venni a baloldali munkásság és parasztság létjogosultságát a politikai életben? Vajon sérelemnek tekinthető-e, hogy ezek is megmondják véleményüket? Ez a tény kizárja az együttmüködést?"1143 Ebben az érvelésben mintha egyfajta fordított demokrácia-sérelmet vélhetnénk felfedezni - a baloldal azt próbálja artikulálni, mintha a demokrácia ethoszán azért esne sérelem, mert a kisgazdák azt nem tudják elviselni, hogy a baloldaliak is elmondhatják a véleményüket.

A kisgazdák a megtörési kísérletek ellenére továbbra is kitartottak elhatározásuk mellett. Nem tértek vissza a képviselőtestületbe. Elszántságuk mögött valószínűleg egyetlen ok állott: a makói FKGP töretlenül bízott abban, hogy az 1946. július 16-i országos pártközi megállapodásban foglaltakat a felek betartják; vagyis az év folyamán valóban megtartják a helyhatósági választásokat. Úgy gondolhatták a helyi kisgazdák, hogy ezt a kicsi időt már valahogyan csak kibírják - az esetleges győztes voksolás után pedig úgyis ők alkotják majd a többséget a képviselőtestületben és ők lesznek a helyi demokrácia formálói.

\footnotetext{
${ }^{1139}$ Makói Népújság, 1946. november 17. 3. p.

${ }^{1140}$ Makói Népújság, 1946. október 20. 3. p.

1141 Makói Népújság ekkor már nem egyedüli lapja a városnak, ugyanis szeptember folyamán megjelent a kisgazdák újságja, a Délvidéki Független Hírlap és a szociáldemokraták orgánuma, a Makó és Vidéke.

1142 Makói Népújság, 1946. október 20. 3. p.

${ }^{1143}$ Makói Népújság, 1946. november 17. 3. p.
} 
1947 elejére teljességgel nyilvánvalóvá vált, a közeljövőben nem lesznek helyhatósági választások. Január elején pedig ,kirobbant” a magyar közösségi összeesküvési-ügy, ${ }^{1144}$ ami által defenzívába szorították a Független Kisgazdapártot. Mindez a helyi küzdelmekben is éreztette a hatását.

1947. január 19-én a baloldali pártok szervezésében nagygyülést szerveztek Makón az „összeesküvés ellen.” Az összejövetelen elítélték és „halálbüntetést követeltek a demokrácia ellenségeire."1145 A rendezvény szónokai között találjuk Kiss Imre polgármestert is, aki mondandójában a makói kisgazdának a képviselőtestületből való kivonulását sem felejtette el megbélyegezni. „Az ellentétek mesterséges szításának a szelleme volt az, amely a helyi Kisgazdapárt vezetőségét is arra késztette, hogy kivonják magukat a város ügyeinek intézéséből. A jövőben valamennyi demokratikus pártnak a demokrácia megerősítéséért össze kell fognia és minden becsületes magyar embernek gyülölettel kell gondolnia a fasiszta összeesküvőkre" 1146 - hangsúlyozta Kiss Imre, vagyis a polgármester egyik legfőbb érve az volt, hogy a „demokrácia megerősítése” érdekében kell visszatérniük a kisgazdáknak a helyi koalícióba.

Érdekes nyelvpolitikai játékra adott lehetőséget Kiss Imre számára az „összefogás” fogalmának használata, eszerint össze kell fogni a demokrácia érdekében, de ebben az esetben az „összefogás” követelése éppen a demokratikus politika lényegét adó vitákat, véleményartikulálásokat zárja ki, teszi lehetetlenné. A kommunista polgármester érvelésének lényege, hogy a „,demokrácia” érdeke az „összefogás”, de valójában az „összefogás” fogalmát nyelvi fegyverként használja annak érdekében, hogy a kisgazdák ne képviseljenek a baloldaltól eltérő álláspontot.

A képviselőtestületből kivonuló kisgazda városatyák számára nyilvánvaló lehetett, a testületi bojkottal kapcsolatos küzdelemben immáron az utóvédharc következik. 1947 februárjában előterjesztés született arról, hogy amennyiben a Kisgazdapárt városatyái nem térnek vissza a közgyülésbe, akkor lényegében megfosztják őket képviselői helyüktől. Az antidemokratikus, a lokális demokrácia formális szabályait zárójelbe tevő, fenyegető hangvételü javaslatot jegyző Nemzeti Parasztpárti Erdei Sándor a következő tartalmú indítványt tette a képviselőtestületet asztalára: „Sajnálattal kell tapasztalnunk, hogy a

\footnotetext{
1144 „A magyar közösségi összeesküvési ügyröl”: A kommunista befolyás alatt álló politikai rendőrség által kidolgozott koncepciós eljárás, mely fóként a Kisgazdapárt szétzilálásának, megsemmisítésének célját szolgálta. (SZAKÁCS - ZINNER: Uo. 283-294. p., illetve FÖLDESI Margit: Uo. 315-323. p., CSICSERY-RÓNAY István CSERENYEY Géza: Koncepciós per a Független Kisgazdapárt szétzúzására 1947. 1956-os Intézet, Budapest, 1998.)

${ }^{1145}$ Makói Népújság, 1947. január 21. 1. p.

${ }^{1146}$ Uo.
} 
Kisgazda, Földmunkás és Polgári Párt makói tagozata hosszú hónapok óta nem vesz részt a város közgyülésének intézésében. Az utóbbi hetek eseményei megmutatták, hogy a Kisgazdapártba befurakodott reakciós erők nem nyugszanak s azok a feltevések, melyek a baloldali pártokban gyanúként éltek, nem voltak alaptalanok. Az összeesküvés nyomán megnyilatkozó államföi és pártvezetői beszédek különös nyomatékkal emelték ki a tényleges demokratikus erők egyesítését. Olyan kívánságok is felmerültek, hogy most már a Kisgazdapárt végre tényleg szabaduljon meg reakciós elemeitől s az ily módon megtisztult Kisgazdapárt kapcsolódjék be a baloldali blokk együttmüködésébe $s$ müködjék közre új demokratikus blokk létrehozására. Fel kell tennünk a kérdést: a Kisgazdapárt makói tagozata részt akar-e venni Makó város demokratikus gazdasági és szellemi újjáépítésében? Ha igen, azonnal kapcsolódjék be a képviselőtestületi munkába. Ha nem, le kell vonni ennek tanulságát. Tisztelettel javaslom: 1; keresse meg a város képviselőtestülete a Kisgazdapárt makói vezetőségét, 15 napon belül nyilatkozzék, hogy hajlandó-e azonnal bekapcsolódni a várost irányító képviselőtestületi munkába? 2; amennyiben a Kisgazdapárt nem nyilatkozik 15 napon belül illetve kijelenti, hogy továbbra is távol marad a munkától, utasítsa a képviselőtestület a polgármestert, hogy nevükben tegyen előterjesztést a Belügyminiszternek az iránt, hogy azon időre, amíg a Kisgazdapárt 20 képviselőtagja távol tartja magát a városi munkától a 3 másik párt saját kebeléből pótolhassa a 20 képviselőt, mégpedig kizárólag földműveléssel foglalkozó tagjai sorából, az alábbiak szerint: A Nemzeti Parasztpárt, mint a másik agrárpárt küld 10 tagot, a Szociáldemokrata Párt és a Magyar Kommunista Párt küld 55 tagot." 1147

A képviselőtestület 1947. február 10-i ülésén egyhangúlag fogadta el a javaslatot. Határozatot hoztak arról, utasítják a polgármestert, hogy amennyiben a kisgazdák nem válaszolnak vagy elutasítják a megkeresést, „hívja össze rendkívüli ülésre a város képviselőtestületét a további intézkedések megtétele céljából."1148

Az ultimátumban megszabott 15 napos határidő február 25-én járt le. Éppen azon a napon, amikor Kovács Bélát, a Kisgazdapárt korábbi országos fötitkárát a szovjet hatóságok semmibe véve a magyar jogrendet és a demokratikus szabályokat - letartóztatták. ${ }^{1149}$ A makói kisgazdák számára is egyértelmü lehetett Kovács Béla elrablásának üzenete: aki szemben áll a kommunista hatalmi törekvésekkel, az arra a sorsra juthat, mint az egykori FKGP fötitkár.

\footnotetext{
${ }^{1147}$ MVL 87. kgy. 2692 ikt./1947.

1148 Uo.

${ }^{1149}$ Kovács Béla elrablásáról: FöLDESI-SZERENCSÉS: Uo. 143-147. p., FÖLDESI Margit: Uo. 323-334. p., illetve PALASIK Mária: A jogállam megteremtésének kísérlete és kudarca Magyarországon: 1944-1949. Napvilág Kiadó, Budapest, 2000. 211-224. p.
} 
A helyi kisgazdapártiak eltökéltségét mutatja, hogy még mindig ellenálltak - az ultimátumban foglaltak és a Kovács Béla-ügy ellenére is. ${ }^{1150}$ A végső csapás az országos politika felöl érkezett: március 12-én Pfeiffer Zoltánt kilépett a Független Kisgazdapártból. (Hasonló módon járt el a megzavart makói gyülés másik két szereplője, Parragi György és Pártay Tivadar is.)

„Ez a három ember volt annak a megzavart népgyülésnek díszszónoka és ezeket nem hagyták szóhoz jutni. Vajon most, amikor a történtek: az összeesküvésnek a demokrácia megdöntésére, a parasztságnak a régi sorsba való visszataszítására irányuló próbálkozásai igazolták a népgyülés megzavaróit, nem kellene-e megváltoztatni álláspontját a Kisgazdapárt vezetőinek és visszatérésükkel színt vallani, hitet tenni a demokrácia mellett?"1151 - írta a kommunista politika szócsöveként a Makói Népújság.

A totalitárius eszmékkel szembeni nemzeti ellenállás és a magyar polgári demokrácia históriájában a makói kisgazdák e passzív rezisztenciája egy apró, de mégis figyelemreméltó történet. Pfeifferéknek a pártból való kiebrudalását követően azonban már nem volt tartható az addig követett határozott irányvonal. Március 19-én az FKGP képviselői visszatértek a városi közgyülésbe.

Napirend előtt Gubacsi Mihály kisgazda városatya olvasta fel a párt deklarációját. A dokumentum utal a múltra, mely szerint 1946 nyarára az FKGP és a baloldal között az ellentétek „olyan mértékben kiéleződtek, hogy a Független Kisgazdapárt úgy látta, hogy ilyen körülmények között lehetetlenné válik a városi politikában további együttműködés." "1152 A kisgazdák kifejtették, „habár nem is kapott ugyan teljes elégtételt” a sérelmekért pártjuk, de mivel az FKGP „,nem kívánja folytonosan a múltra hivatkozva a helyzetet élesíteni," ${ }^{1153}$ ezért a jövőben részt vesz a városi parlament munkájában.

A kisgazda deklarációra adott válaszában Kiss Imre visszautasította, hogy az FKGP ne kapott volna „tökéletes elégtételt” az 1946 nyarán történtek miatt. Majd arról beszélt: „elégtétel a demokráciának”, hogy Pfeifferéket (,akik miatt kirobbant ez az áldatlan állapot”) ${ }^{1154}$ kiszorították a Kisgazdapártból.

Kiss Imre polgármester elérte, amit akart. Megszűnt az a szituáció (a kisgazdapártiak bojkottja), amely önmagában nyílt kihívást jelentett a baloldali városvezetés legitimitását

\footnotetext{
${ }^{1150}$ A hódmezővásárhelyi kisgazdák 1946 novemberében léptek ki a nemzeti bizottságból és 1947. július 25 -én tértek vissza a helyi testületbe. (BENCSIK Péter: Hódmezővásárhely politikai élete 1944-1950 között. Elérhető: http://allamszocializmus.lapunk.hu/tarhely/allamszocializmus/dokumentumok/hodmezo.pdf $\quad$ (A letöltés idöpontja: 2015. november 27.) 33-34. p., 53. p.)

${ }^{1151}$ Makói Népújság, 1947. március 13. 3. p.

${ }^{1152}$ MVL 155 kgy./1947.

1153 Uo.

1154 Uo.
} 
illetően.

Pfeiffer Zoltán - dél-alföldi kampánykörútja részeként - még egy alkalommal, 1947. augusztus 17-én, a választások elött két héttel, az általa alapított Magyar Függetlenségi Párt (MFP) első embereként járt Makón.

1946 júliusában - mint láthattuk - még félig spontán módon, a budapesti MKP központ támogatását nélkülözve zavarták meg kommunista párti provokátorok Pfeiffer gyülését. 1947 augusztusára viszont a helyzet annyiban is megváltozott, hogy immáron az számított hírértékünek, ha egy rendezvényt az MFP nyugodt körülmények között meg tudott tartani.

1947. augusztus 17-én Makón rendbontás nélkül volt képes megszólalni Pfeiffer. Mindez nem adatott meg neki e napokban a közeli Szegeden és Hódmezővásárhelyen. Mindkét gyülést megzavarták. Augusztus 25-én az MFP csongrádi választási rendezvényén pedig kis híján agyonverték a pártvezért. Makón viszont nem történt atrocitás. Az MKP irányítói talán úgy gondolhatták, egyszer már „megégették magukat” egy makói Pfeiffergyülés kapcsán. ${ }^{1155}$

Pfeiffer Zoltán e látogatása azonban alkalmat ad még egy emberi-közéleti motívum kibontására. Az emlékezetes, 1946. július 21-i gyülésre - amint arról már szó esett - az FKGP makói elnöke, Szőnyi Imre invitálta meg Pfeiffert és másik két politikustársát. A rendezvény megzavarását is együtt élték meg, majd 1946. augusztus 11-én szintén Szőnyi hívására jött Makóra a megismételt összejövetelre Pfeiffer. Mindketten a kisgazda nemzetgyülési frakcióban tevékenykedtek, politikai szövetségesek voltak. Útjaik a következő esztendő tavaszán viszont külön váltak. Szőnyi a Kisgazdapárt tagja marad, Pfeiffer távozni kénytelen pártjából, és megalakítja új szerveződését, az MFP-t, amely el is indul '47-es választásokon. E kampányban Szőnyi Imre az FKGP-t segíti, Pfeiffer Zoltán pedig nyilvánvalóan a Magyar Függetlenségi Pártot igyekszik sikerre vinni. Még ezzel a természetszerü érdekkülönbséggel sem magyarázhatóak azonban Szőnyinek - az 1947. augusztus 17-ei makói MFP gyülés napján - a Délvidéki Független Hírlapban megjelent Pfeifferre vonatkozó megjegyzései: „Amikor valaki az eddigi pártok valamelyikében aktív szerepet vállalt, sőt egészen a legutóbbi időig még aktívabb vezető szerepet szeretett volna kapni és midőn látta, hogy ez

\footnotetext{
${ }^{1155}$ Az 1947. augusztus 17-i Pfeiffer-gyülés után néhány nappal Révai József tartott beszédet a városban, amelyben többek között a következöket mondotta: „Szólanom kell még az ellenzéki pártokról. Kezdem mindjárt Makó régi ismerősével, Pfeiffer Zoltánnal és pártjával. Ezek a pártok mind függetlenségi pártnak mondják magukat és elnevezik magukat Kossuth utódjának, vagy makói viszonylatban szólva, Justh Gyula utódjának. Ne engedjük meg, hogy ezek az új pártok visszaéljenek azzal, ami minden magyar számára szent, a magyar függetlenség fogalmával.” (Makói Népújság, 1947. augusztus 26. 2. p.)
} 
nem sikerülhet, új pártalapításra gondol, természetesen óvatosan ügyelve arra, hogy amíg az új alakulásban nem biztos a vezető szerep, addig a régi kapcsolatokat se tépje el, tehát vagy az egyik vagy a másik, de biztos legyen! Mert fő a vezető szerep, még ha nem alkalmas is rá."1156

Az 1947. augusztus 17-én Makón elmondott Pfeiffer-beszédet értékelve így írt Szőnyi: „Pfeiffer Zoltán nem tagadta meg magát, nagyszerü jogászi és dialektikai felkészültséggel, a maga jellegzetes, szangvinikus modorában ostorozta a koalíciós pártokat, természetesen a Kisgazdapártot is, habár itt néminemü gátlásai mégis csak voltak, hiszen a párt érdekében ő maga is sok ideig fontos vezető szerepet vitt és olyan alapos tudású politikustól mégis csak különösen hangzanék, hogyha korlátlanul pálcát törne egy olyan müködés felett, melyben neki is sok tekintetben része volt, és mindenkinél jobban ismerhette azokat az okokat, amelyek miatt másforma müködés lehetetlennek látszott."

Ebből az idézetből is kitetszik, hogy Szőnyi bizonyára nem tudta megbocsátani Pfeiffernek az FKGP-ből való kiválását, és az új párt megalakulását. Szőnyi Imre úgy értelmezhette, egykori párttársa személyi ambícióktól fütve hagyta el az anyapártot.

A helyi kisgazda elnök az 1947. augusztus 31-i választások elött nem sokkal publikált cikkében kifejtette: „a józan, reális gondolkodású makói nép tudja és megértette, hogy forrófejü, a személyi szempontoktól irányított érzelmi politika a mai halálosan reális időben

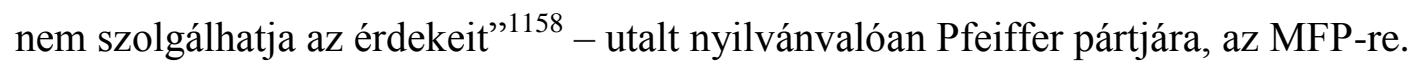

A „makói nép” azonban nem kis meglepetésre komoly bizalmat szavazott Pfeiffer Zoltánnak és pártjának. A választók 37\%-a voksolt a városban a Magyar Függetlenségi Párt listájára, ${ }^{1159}$ így az MFP messze megelőzte a 21\%-ot szerzett MKP-t és a 14,8\%-os arányt felmutató FKGP-t. ${ }^{160}$ Ebben a választási eredményben - a demokrácia biztosította keretek

\footnotetext{
${ }^{1156}$ Délvidéki Független Hírlap, 1947. augusztus 17. 1. p.

${ }^{1157}$ Délvidéki Független Hírlap, 1947. augusztus 20. 1. p.

1158 Uo.

1159 Az MFP országos eredménye 13,4\% volt.

1160 A 47-es választások makói eredményére Erdei Ferenc külön kitért a Város és vidéki címü városszociográfiájában. Erdei szerint annak, hogy a Pfeiffer-párt 37 \%-ot szerzett, „valami helyi oka” kellett, hogy legyen, ezért maradt el Makó az országos népi demokratikus fejlődéstől. (ERDEI Ferenc: Város és Vidéke. Akadémiai Kiadó, Budapest 1977. 269. p.) Az Erdei által emlegetett „valami helyi ok” lehetett maga a Pfeifferbotrány és annak következményei.

Tamasi Mihály helytörténész másként magyarázza a 47-es választások makói eredményeit. Szerinte a döntő ok a sajátos makói gazdasági-társadalmi viszonyokban keresendő. „Makón a felszabadulás előtt sem volt magán nagybirtok, a paraszti árutermelés - föleg a hagymatermelés révén - nagyobb arányokban kifejlödött, a polgári agrárfejlődés szabadabb utat tört magának és széles kisvállalkozói paraszti réteg jött létre a hagyományos értelemben vett birtokos parasztság mellett. A város társadalmában tehát döntő súlyra jutottak a birtokos paraszti, kistulajdonosi, kisvállalkozói, kisárutermelő rétegek - ideértve a városi kispolgárságot is. E rétegek a városban hagyományosan erős kispolgári demokrácia társadalmi bázisát alkották és egyben a polgári agrárfejlődésbe, a magánvállalkozás szabadabb kibontakozásába vetették reményeiket.” (TAMASI Mihály: A népi
} 
között - az 1946-os Pfeiffer-affér és közéleti következményei is szerepet játszhattak.

\section{A demokrácia szó mint fegyver a helyi közéleti küzdelmekben}

A következö alfejezetben azt a jelenséget igyekszünk körbejárni, hogy miként használták „fegyverként” a demokrácia kifejezést a koalíciós években a makói kommunisták.

„Makón egy demokráciaellenes cikk megírásába kergettük az egyik prominens reakcióst”"1161 - olvasható az MKP Csanád Megyei Bizottságának egy 1947. májusi belső jelentésében. A Puja Frigyes ${ }^{1162}$ megyei káderügyi titkár által jegyzet dokumentumból azt is megtudhatjuk, hogy ezen üggyel összefüggésben ,,a makói államvédelmi osztály a cikkírót és a főszerkesztőt a demokrácia védelméről szóló törvényjavaslat alapján letartóztatta. Ezt a munkát tovább folytatjuk és kíméletlen harcot hirdetünk ellenük."1163 (Puja Frigyes pongyolán fogalmazott, az általa említett ,a demokrácia védelméről szóló törvényjavaslat” az akkor már hatályos, elfogadott jogszabályt, a demokratikus államrend védelméről szóló 1946:VII. törvényt jelenti.)

A történet egyrészt a koalíciós évek helyi kommunista párttaktikájának módszertanát illusztrálja, másrészt érzékletesen demonstrálható a jelenség, aminek lényege, hogy a demokrácia kifejezést egyfajta fegyverként használták a lokális erőtérben is az MKP hivatalos képviselői.

Miről is szól ez a história, amelyben „demokráciaellenes cikk megírásába kergették az egyik prominens reakcióst”? Ifj. Puskás Antal volt az ominózus cikk írója. Puskás makói gazdálkodó, a jómódú hagymások képviselője, a helyi kisgazdák egyik vezéregyénisége. ${ }^{1164}$ 1947. május 11-i publicisztikájában alapvetően a kommunista polgármester fizetésének és

demokratikus fejlődés Makón. In: Tanulmányok Csongrád Megye Történetéből IX. Csongrád Megyei Levéltár, Szeged, 1985. 173-194. p. 193. p)

${ }^{1161}$ MKP Csanád Megyei Bizottságának káderügyi jelentése, 1947. május 13. CSML MSZMP CSMBA/ 26. f. 8. őe., ill. PIL 274. f. 16. cs. 153. őe

1162 Puja Frigyes a Csanád megyei Battonyán született 1921-ben. Betűszedőként dolgozott a második világháború végéig. A koalíciós években a Magyar Kommunista Párt battonyai járási titkára és az MKP Csanád Megyei Bizottságának káderügyi titkára, majd a párt megyei titkára. 1950-ben az MDP KV káderosztályának alosztályvezetője, a későbbiekben diplomata. 1973-tól 1983-ig külügyminiszterként irányította a magyar diplomáciát. 2008-ban hunyt el. Visszaemlékezéseit A szedőszekrénytől a miniszteri székig címmel írta meg. A visszaemlékezés szövegére a fejezetben még visszatérünk.

${ }^{1163}$ MKP Csanád Megyei Bizottságának káderügyi jelentése, 1947. május 13. CSML MSZMP CSMBA/ 26. f. 8. őe., ill. PIL 274. f. 16. cs. 153. őe

1164 Tamasi Mihály úgy vélte, 1947-re ifj. Puskás Antal „egyre inkább a helyi kisgazdapárti jobboldal szószólójaként lépett fel” és ,propagandahadjáratot” folytatott a kommunisták ellen. (TAMASI Mihály: A népi demokratikus forradalom győzelme. 120.p.) 
jövendőbeli nyugdíjának meghatározási módja kapcsán fogalmazott meg bírálatot, de ez pusztán egy partikuláris vitahelyzet volt. Mindemellett azonban - az akkorra már teljes mértékben a kommunisták befolyása alatt müködő - Makói Népújság írásainak stílusát kritizálta, s ezzel összefüggésben fejtett ki demokrácia-értelmező gondolatatokat. A cikkben Puskás fontosnak tartotta, hogy elhatárolódjon a korábbi korszaktól és „bünös, kizsákmányoló” ${ }^{1165}$ rendszernek titulálta a Horthy-rezsim időszakát, majd ezt követően „,rég vártnak" nevezte a demokrácia világát, s utal rá, hogy ő maga is baloldalinak volt tekinthető az előző kurzusban. Puskás kifejti, egy olyan demokráciát szeretne, „amelyben a tudás érvényesül, nem pedig a pártigazolvány!" ${ }^{1166}$ A makói kisgazda személyiség a demokrácia jegyében követelte az önkormányzati választások megtartását. „S hogy a pártok kit képviselnek? Erre majd a nép adja meg a választ. Csak addig jussunk, hogy megtarthassuk a községi választásokat. Nagy-Budapesten 1945-ben megtartott választások elég bizonyságul szolgálnak s ez megváltoztatta a pártok arculatát" ${ }^{1167}$ - írta Puskás, aki tisztában volt vele, az összeesküvők zászlóvivőjének és reakciósnak bélyegzik. Azt a helyzetet is illusztrálja a szerző, hogy aki nem a Makói Népújságban közöltek szerint foglal állást, azt egyből

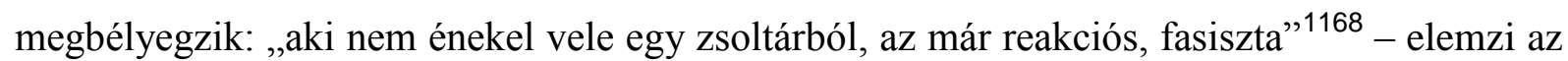
ismert jelenséget Puskás.

A cikk megjelenésének másnapján ifj. Puskás Antalt a makói rendőrség államvédelmi osztálya őrizetbe vette. ${ }^{1169}$ Szintén lefogták az írást publikáló felelős szerkesztőt, Vass Imrét is.

A Makó és Vidéke Puskás cikkéről így írt: „rosszindulatúan kritizálta a fennálló demokratikus államrendet."1170 A Makói Népújság vezércikkében ekképpen fogalmazott a kialakult helyzetről: „Valakik felelősek azért, hogy a Kisgazdapárt csanádmegyei szervezeteiben még mindig nem indult meg a várva-várt tisztogatás, amit a Kisgazdapárt országos vezetősége magára vállalt, hogy nem folyik harc a pártban a reakció ellen, hogy a párt a reakciót a keblén melengeti." 1171

E napokban letartóztatták a kisgazdák Csanád megyei vezetőjét, Csontos János gazdálkodót is, mert „izgatott a demokrácia ellen."1172 A szegedi népbíróság egy évre el is

\footnotetext{
${ }^{1165}$ Ifj. PUSKÁs Antal: Ez a válaszom Zs-úrnak. Délvidéki Független Hírlap, 1947. május 11. 3. p.

1166 Uo.

${ }^{1167}$ Uo.

1168 Uo.

${ }^{1169}$ Makó és Vidéke, 1947. május 18. 2. p.

${ }^{1170}$ Uo.

${ }^{1171}$ Egy ítélet margójára. Makói Népújság, 1947. május 18. 1. p.

${ }^{1172}$ Uo.
} 
ítélte a kisgazda pártvezetőt, de egy hónappal később felmentették a vádak alól. ${ }^{1173} \mathrm{~A}$ Csontossal szembeni fellépésben szerepet játszott a kisgazda helyi politikus Parasztkoalíciót! címmel írt cikke is, melyben a szerző hitet tett amellett, hogy a demokratikus Magyarországot „a magyar parasztságra kell építeni.” (Tamasi Mihály marxista helytörténész 1974-ben úgy vélte, Csontos írásának „tudatosan népi demokrácia-ellenes”1174 tartalma volt.) Kónya Lajos, az MKP Csanád megyei titkára 1947. június 15-én kijelentette, Csontos Jánosnak és ifj. Puskás Antalnak „nincs hely a demokrácia sáncain belül.”1175

Összegezve a Puskás-Csontos-ügy tanulságait: Puja Frigyes úgy vélte, Puskás demokrácia-ellenes cikket írt. A cikket elemezve láthattuk, a kisgazda helyi közéleti szereplő a polgári demokrácia, a jogállami demokrácia helyi szárnybontásában és megerősödésében bízott, s kétségtelenül szembeszállt a kommunista hatalmi törekvésekkel - mindez akkumulálódott úgy a helyi kommunista belső és külső véleményfórumokon, hogy Puskás demokrácia-ellenes írást publikált.

E lokális, döntő jelentőséggel nem bíró ügyböl is látható a fogalomhasználat mögött megbúvó antagonisztikus ellentét. A helyi kisgazdák „demokrácián” a mindenkire érvényes jogosultságokra épülő államjogi rendszert, a parlamentáris demokrácia és az önkormányzatiság elvén nyugvó államrendet képzeltek el; míg a makói kommunisták úgy gondolták, a demokrácia nem más, mint a kommunista világképből és nézőpontból fakadó állami struktúra. Szintén megállapítható, hogy a lokalitás szintjein is a „reakció” kifejezés mellett a „demokrácia” és a demokrácia-ellenes” fogalmak is fegyverként használtatnak a kommunista párt képviselői részéről a közéleti küzdőtéren a politikai ellenfelekkel szemben: aki más véleményt vallott, mint az aktuális kommunista párttaktikának megfelelő álláspont, az reakciósnak és demokrácia-ellenesnek minősült.

E gondolati struktúra rekonstruálható több koalíciós évekbeli Csanád megyei kommunista (nem a nyilvánosság számára készült) dokumentum segítségével.

„Amennyiben az adott körülmények megengedik, be kell épüljenek más pártokba is és a helyes demokratikus irányba kell terelnünk [a folyamatokat]"1176 - olvashatjuk a Csanád megyei járási titkároknak, vagyis a megyei pártelitnek szóló belső, titkos körlevélben. Két elemre érdemes külön kitérnünk. E forrás alátámasztja, a koalíciós évek demokratikus politikai kultúrájának közegében is a helyi-megyei közéleti küzdelmeknek része volt az, hogy

\footnotetext{
1173 Délvidéki Független Hírlap, 1947. június 19. 2. p.

${ }^{1174}$ TAMASI Mihály: A népi demokratikus forradalom győzelme. 120. p.

${ }^{1175}$ Makói Népújság, 1947. június 15. 1.p.

${ }^{1176}$ Fokozzuk a tömegmunkát címü belső körlevél a Csanád megyei járási és városi titkároknak. 1946. december. 6. p. CSML MSZMP CSMBA/ 26. f. 16. őe.
} 
a kommunisták saját embereket építettek be más pártokba. A belső dokumentum elvárásként fogalmazza meg, hogy be kell „épülni” a riválisok szervezeteibe. A másik megközelítés arról szól, hogy mindezt a konspiratív jellegü mechanizmust azért kell végigvinni, mert az a cél, hogy „demokratikus irányba” tereljék a konkurensek belső viszonyait. Megállapítható, a demokratikus irány ebben az esetben is azt jelenti, hogy az MKP törekvéseivel harmonizáló áramlatok legyenek jelen a többi pártban.

A sajátos fogalomhasználat kapcsán figyelemreméltó az MKP Csanád Megyei Bizottságának 1947. novemberi tömegszervezési munkaterve. A dokumentum külön feladatként határozza meg a különböző fórumokon megjelenő „demokrácia-ellenes hangok" ${ }^{1177}$ leleplezését.

„Az együttmüködés az NPP-vel ${ }^{1178}$ általánosságban megjavult. De eddig az NPP-ből még nem sikerült azokat a személyeket kiszorítani, akik a demokrácia részéről nem megbízhatók"1179 - e sorok már az MKP Csanád Megyei Bizottságának 1948. áprilisi jelentésében találhatóak. A Nemzeti Parasztpárt az országos és a helyi politikában is közeli szövetségese volt a kommunistáknak, az NPP társutasként szerepelt a koalíciós évek kommunista stratégiájában. Ennek ellenére - az előbb idézett forrás szerint - 1948 tavaszára már napirendre került azok kiszorítása a Nemzeti Parasztpártból, akik nem voltak feltétlen hívei a kommunista hatalmi elöretörésnek. Akik pedig kifogásaikat hangoztatták az MKP-s törekvésekkel szemben, azok voltak „a demokrácia részéről nem megbízhatók.” A „demokrácia” kifejezés ehelyütt is a kommunista politika összefoglaló fogalmát jelenti és nem a jogosultságokra építő parlamentáris demokrácia ideáját valószínűsíti.

Az MKP Csanád megyei káderesének jelentéséből tudjuk meg, hogy a megyei szociáldemokraták 1947 koratavaszán azt hangoztatták, hogy „aki fél a proletárdiktatúrától”, ${ }^{1180}$ az álljon a szociáldemokraták mellé. „Mi ezek a jelenségek ellen a legélesebb küzdelmet folytatjuk és kíméletlenül leleplezzük"1181 - olvasható a dokumentumban, amely egyértelmü üzenetet fogalmazott meg: helyi pártfeladatnak számított, hogy aki a szociáldemokraták közül olyan nézetet terjeszt, mely szerint a kommunisták proletárdiktatúrára törnek, reakciósnak kell bélyegezni.

\footnotetext{
${ }^{1177}$ MKP Csanád Megyei Bizottság tömegszervezési munkaterve, 1947. november. CSML MSZMP CSMBA/ 26. f. 16. őe.

${ }_{1178}^{117}$ Nemzeti Parasztpárt (NPP)

${ }^{1179}$ Az MKP Csanád Megyei Bizottságának jelentése, 1948. április hónapról. CSML MSZMP CSMBA/ 26. f. 8. őe.

${ }^{1180}$ MKP Csanád Megyei Bizottságának káderügyi jelentése, 1947. március 8. CSML MSZMP CSMBA/ 26. f. 8. öe. ${ }^{1181}$ Uo.
} 
Egy másik pártdokumentumból értesülhetünk arról, hogy Csanád megyében a szociáldemokraták kifejezetten elutasították az MKP embereinek diktatórikus törekvéseit, a jogállami demokrácia politikai kultúrájához nem illeszkedő stílust, agresszív magatartást. „A helyi szociáldemokraták felől hallatszanak olyan hangok, hogy a kommunisták a terror

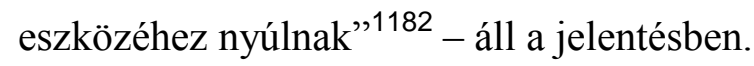

A makói SZDP-szervezet - feladva a kommunista nyomásgyakorlással szembeni ellenállást - 1948. február 29-én az MKP-vel való egyesítés mellett foglalt állást. A 300 fős taggyülésen hatvanan szavazták meg az egyesítéssel szimpatizáló határozatot, a túlnyomó többség tartózkodott ${ }^{1183}$ - a helyi szociáldemokratáknak már csak a tartózkodás maradt a kvázi ellenvélemény kinyilvánítására. E döntés következménye volt az is, hogy a következő hónapokban ötven ,jobboldali” párttagot zártak ki. A demokrácia-tematikával kapcsolatosan azért érinthető ez a kérdéskör, mert a kizárások gyakori indoka pusztán a következő volt: az illető demokrácia-ellenes.

Az egyik Csanád megyei szociáldemokrata párttag esetén azonban a szimpla demokrácia-ellenes indokláson túlmentek a döntéshozók. A kizárt tag kapcsán az indoklás a demokrácia-értelmezés tekintetében is hordoz tanulságokat: „A magyar demokráciáról illetékesek elött dicshimnuszokat zengedez, de a legalkalmasabb pillanatban minden lelkiismeret furdalás nélkül hátba szúrná a magyar demokráciát. Ma már bebizonyosodott tény az, hogy aki ellensége a kommunistáknak, az ellensége a magyar demokráciának és ezen keresztül a magyar népnek."1184 Az utóbbi mondat megvilágítja a kommunista demokráciaértelmezés lényegét: aki ellensége a kommunistáknak, az ellensége a magyar demokráciának.

Erre a fajta kirekesztő kommunista demokrácia felfogásra, a megbélyegzésre építő kulturális attitüdre reflektált még 1947 júliusában Szőnyi Imre kisgazda nemzetgyülési képviselő a Délvidéki Független Hírlapban a Rendkívüli közgyülés és egyebek címü vezércikkében. Az írásban Szőnyi főként Kiss Imre kommunista makói polgármestert támadta, szóvá tette, hogy „,a demokrácia örökös hangoztatásával”1185 magyaráz meg mindent a városvezető, ugyanakkor aki nem ért vele egyet, azt megbélyegzi. „A polgármester úr a közgyülésen, nem tudni milyen alapon, saját magában látja a demokrácia, vagy a magyar nép megtestesülését, szuverénül ítélve elevenek és holtak felett, egész természetesnek tartván, hogy ö támadjon, de ha még csak védekeznek is, az már személyeskedés és ha valaki csak nem helyesel is, nemhogy még ellent is mondjon, az persze reakciós, fasiszta, összeesküvő és

\footnotetext{
1182 Cserhát József vándornevelő jelentései, 1947. december 1. PIL 274. f. 21. cs. 29. őe

1183 TAMASI Mihály: A népi demokratikus forradalom győzelme. 147-160. p.

1184 „A Szociáldemokrata Párt által kizárt jobboldaliak névsora.” CSML MSZMP CSMBA/ 26. f. 11. őe.

1185 'SzŐNYI Imre: Rendkívüli közgyülés és egyebek. Délvidéki Független Hírlap, 1947. július 16. 1. p.
} 
ha tiltakozni mer az ítéletük vagy illetékességük ellen, fenyegetések özönét zúdítják rá”1186_ írta a kisgazda nemzetgyülési képviselö. Szőnyi azt is kifejtette, hogy Kiss Imre kommunista polgármester városirányítási stílusa nem különbözik az előző rendszer vezetőinek magatartásától, arroganciájától, s ő maga részéről nem tartja demokratikusnak Kiss polgármesteri karakterét, mert a demokráciát „,csak hangoztatja.”,1187

\section{A „demokrácia-ellenes” demokrácia-megnyilvánulás: a „Mindszenty-gyülés”}

A koalíciós évek Makóján az úgynevezett Marosmenti Mária-nap tömegrendezvénye (a „Mindszenty-gyülés”) volt a mindenkire érvényes jogosultságok rendszerére építkező jogállami/parlamentáris/polgári demokrácia utolsó megnyilvánulása. Az esemény 1948 májusában egyfajta végső demokrácia-megnyilvánulásnak tekinthető.

Az 1948. május 22-23-án, az országos Mária-év keretében a Csanádi Egyházmegye által megrendezett Marosmenti Mária-nap Makó történetének legnagyobb tömegdemonstrációja volt. Sem előtte, sem utána ennyi ember nem gyült össze a város területén egy adott cél érdekében. Egy tábori misét és körmenetet többnyire nem szoktunk tömegdemonstrációként emlegetni; akkor - 7 hónappal Mindszenty József letartóztatása előtt, a kommunista diktatúra kiépítésének árnyékában - azonban az eredetileg vallásos esemény is tüntetésnek, egyfajta demokrácia-megnyilvánulásnak számított.

A makói Mária-napra esettanulmányunkban olyan fontos eseményként tekintünk, amely rendezvénysorozat képes volt - a demokrácia adta keretek között - több tízezer ember akaratát, véleményét artikulálni. S képes volt arra, hogy - vallási-lelki dimenzióból ugyan, de - Csanád megyei, makói polgárok komoly tömegeinek véleményét kifejezze a sztalinizálódó magyarországi közállapotokkal szemben.

A jogállami demokrácia ethosza szempontjából egy több tízezres tömegrendezvény és az ott megfogalmazott nyilatkozatok egyértelmüen demokrácia-jelenségként értelmezhetőek, ugyanakkor a korabeli kommunista nézőpont szerint a „Mindszenty-gyülés” és a Mária-nap történései egyértelmüen „demokrácia-ellenes” megnyilvánulások voltak. A nyilvános kommunista megnyilatkozások és a belső fórumoknak szánt megfogalmazások abban azonosak, hogy mindkét kommunikációs felületen a baloldali aktorok a magyar demokrácia ellen ható cselekedetnek tartják a rendezvény megszervezését. 
1948. május 3-án Csepregi Imre plébános meglátogatta Kiss Imre kommunista polgármestert. Az egyházi személyiség célja az volt, hogy a néhány nappal később bérmálásra és a szerveződő Marosmenti Mária-napok előkészületeiről tájékozódni - Makóra érkező csanádi püspököt, Hamvas Endrét a városvezető a hagyományoknak megfelelően fogadja a település határában.

A Csepregi-naplóban e megbeszélésről a következő bejegyzést találjuk: „Kijelentette a polgármester úr, hogy a mai demokratikus világban a régi szerint ő nem fogadhatja a püspök urat és ő nem hódolhat előtte, mint régen tették, de ha a püspök úr eljön hozzá, szívesen beszélget vele, szeretne is sok mindenről szólni."1188

Az 1948. május 3-i naplórészlet a demokrácia-értelmezés mint téma szempontjából is felmutat egy érdekes aspektust. A polgármester e beszélgetésen arról szólt, hogy Mindszenty bíboros „bántóan viselkedik a demokráciával szemben." ${ }^{1189}$ Csepregi igyekezett feltárni, hogy mit ért ezalatt Kiss Imre. A polgármester azzal támasztotta alá kijelentését, miszerint Mindszenty „bántóan viselkedik” a demokráciával, hogy „nem érez a néppel.”1190 Csepregi Imre úgy gondolta, ez nem érv - a naplóba ezt írta: „ilyen érvelésre nem tartottam érdemesnek vele vitázni."1191 A polgármester és a püspök protokolláris jellegű találkozójára végül május 7-én került sor a makói városházán.

A Magyar Kommunista Párt és a Szociáldemokrata Párt május 17-én megtartott Csanád megyei egyesítő konferenciájának határozata megállapította: „,a nép ellenségei” most az egyház palástja mögül igyekeznek támadásba indulni. A konferencia elhatározta, a szerveződő közös párt „Csanád megyében mindenütt felveszi a harcot ez ellen a veszély ellen, miközben tiszteletben tartja és megköveteli a lelkiismereti és vallásszabadságot, de mindenütt megakadályozza azt, hogy bárki a vallást ellenforradalmi célkitüzéseinek fedezésére használja fel. [...] Kijelentjük, hogy erélyesen fellépünk az egyház palástja mögött jelentkező reakciós kísérletekkel szemben és kíméletlenül leleplezzük azokat."1192

Május 21-én este Csepregi prelátus látogatást tett a polgármesternél és meghívta a Mária-nap rendezvényeire. A plébános külön helyet kívánt biztosítani Kiss Imre és felesége

\footnotetext{
${ }^{1188}$ Dr. CSEPREGI Imre: Napló 2. 267. p.

1189 Uo.

${ }^{1190}$ Uo. 268. p.

1191 Uo.

1192 KOROM Mihály (szerk.): Makó az első felszabadult magyar város. II. kötet. Makó Városi Tanács, Makó, 1974. 265-266. p.
} 
számára. Kiss azonban kijelentette, oda, ahol Mindszenty jelen van, ő nem mehet, mert Mindszentynek más véleménye van a demokráciáról, mint neki. ${ }^{1193}$

Hamvas Endre csanádi püspök május 22-én este többezres tömeg jelenlétében köszöntötte a Makóra érkező Mindszenty József bíborost. „Mentül inkább támadják és ócsárolják Eminenciádat, annál inkább ragaszkodunk személyéhez és rendíthetetlenül állunk egy emberként mellette. [...] Hivatalos fogadtatás nem volt. De a demokratikus világban nem a hivatalos ${ }^{1194}$ a fontos, hanem a nép, mert ez jelenti a demokráciát, és amint látja Eminenciád, eljött a nép, hogy köszöntse, üdvözölje Magyarország bíboros hercegprímását" hangsúlyozta a demokráciát a hagyományos értelemben népuralomként felfogó Hamvas püspök.

Másnap hat órától kezdve voltak szentmisék bent a templomban és kint, a Szent István téren a szabadtéri oltárnál. 7 órától - hivatalosan az elektromos fővonal javítása, valójában a kommunista hatóságok tudatos zavarkeltése miatt - szünetelt Makón az áramszolgáltatás, ezért a megafonok müködtetését áramfejlesztő aggregátorok bevonásával oldották meg a szervezők. 9 órakor kezdődött a szabadtéri oltárnál a szentmise, melyet Mindszenty József bíboros mondott.

A később „demokráciát sértő” beszédnek nevezett megszólalás legtöbb kritikát kiváltott része - amely az egyházi iskolákat érintő államosítási törekvések ellen szóló érv kívánt lenni így hangzott: „Vannak alapok és alaptörvények, amelyeket félretolni az épület alól nem lehet. Amikor ez a szomorú tiszai árvíz volt és 1.000 ház összeomlott: mérnökök állapították meg hivatalos jelentésben, hogy azok a házak omlottak össze, amelyeknek nem volt tisztességes alapjuk, homokra építették őket. És azok a házak, még ha vályogból készültek is, de tisztességes talajon álltak, volt alapjuk és fundamentumuk, dacoltak a viharral, vésszel és mindennel és megmaradtak. /nagy taps/ A mi gyermekeink lelke fölséges építmény. Istennek temploma, a Szent Léleknek a lakása és ez alá az épület alá, hit és törvény elengedhetetlen. /taps/ Ha a két édesanyának, a Boldogságos Szüznek és az Anyaszentegyház[nak] az iskolába való bejárását, ajtaját szükítenék, amilyen mértékben ezt cselekednék, olyan arányban tágítsák [tágítanák] az iskolák felöl az átjárást a járásbíróságok, a törvényszékek, a bíróságok, a javítóintézet, a fogdák és a fegyházak felé. /Taps/”1195 - olvasható Mindszenty szentbeszédének legkonfliktusosabb

\footnotetext{
${ }^{1193}$ Dr. CSEPREGI Imre: Napló 2. 274. p.

${ }^{1194}$ Kiss Imre polgármester nem volt hajlandó a város határában fogadni a Makóra érkező Mindszenty József bíborost.

${ }^{1195}$ Kukucska János kommunista funkcionárius, megyei propagandista - amint már említettük - a Marosmenti Mária-napról írott jelentésében a Mindszenty-beszéd szövegét is közli. (CSML MSZMP CSMBA 40. f. 2 . cs. 48. ö. e. 20/4/8 - 1948) A szövegben gyakoriak a helyesírási hibák. Érezhető ugyanakkor, hogy Kukucska
} 
gondolatsora Kukucska János kommunista agitátor feljegyzésében.

A szentbeszéd elhangzása utáni napokban megfogalmazott támadások középpontjában az állt, hogy Mindszenty arról beszélt úgymond, hogy az állami iskolák tanulóinak egyenes útja vezet a fogdákba. Tény, a bíboros nem erről szólt, hanem abbéli aggodalmának adott hangot, miszerint az egyházi iskolák megszüntetésével csorbulhat az erkölcsi nevelés minősége, ugyanakkor az is leszögezhető: Mindszentytől nem állt távol a konfliktusorientált kommunikációs attitüd, ami az előbb idézet gondolatsort is jellemzi.

A szentmise után - tömegdemonstráció értékü és méretü - körmenetre sorakoztak fel a hívek. Végül a gyülés résztvevői - élve a demokrácia adta jogaikkal - elhatározták, az egyházi iskolák államosításáról szóló javaslat elleni tiltakozásul táviratot küldenek Ortutay Gyula kultuszminiszternek. A tiltakozó táviratban a rendezvény résztvevői hitet tettek az egyházi iskolák mellett.

Ellentmondásos adatok maradtak fenn a makói Mária-napok résztvevőinek számáról. Az előbb idézett távirat „több mint 30 ezer hívőről” szól. A Magyar Kurír 85 ezer embert említ. („Messze vidékről, 80 és 100 kilométeres távolságból, minden nehézség dacára 85 ezer hívő sereglett össze erre a két napra Makóra.”) ${ }^{1196}$ Az Új Ember így írt: „Pesszimisták szerint 70, mások szerint 80 ezer ember jött össze." ${ }^{„ 197}$ A Szív című újság tudósítója 50 ezer hívőről beszél. („Május 23-án vasárnap 9 órakor kezdődött a szabadtéri szentmise, melyet a Hercegprímás mondott körülbelül 50 ezer hívő jelenlétében.”) ${ }^{198}$ „Makón 85.000-en [...] gyűlnek össze a Nagyasszony tiszteletére.” - jegyzi fel emlékirataiban Mindszenty József. ${ }^{1199}$ Kukucska János megyei propagandista első jelentésében ez áll: „A gyülést [a Mindszenty által mondott szentmise - M.K.] 15-17 ezer ember hallgatta végig... A felvonuláson [a körmenet - M.K.] 12 ezer ember vett részt." ${ }^{, 1200}$ A második Kukucska jelentésben eredetileg „15 ezer” szerepelt, de azt valaki átjavította 11.136 -ra. ${ }^{1201}$

A kutatók, történészek álláspontja is eltér a résztvevők számáról. „A szervezők 50-60 ezer ember részvételére számítottak, de csak mintegy 15 ezren vettek részt.” - olvasható Tamasi Mihály tanulmányában. ${ }^{1202}$ „A mintegy 30.000 fönyi tömeg előtt Mindszenty bíboros, érsek hercegprímás elmondta az államosítás elleni érveit.” - közölte dolgozatában Vida

\footnotetext{
jelentésében a beszédet szó szerint kívánta közölni, nem szerkesztette a szöveget. Jellemzően az élőbeszéd fordulatait veszi át. Az idézett szövegrészben zárójelben a szerző javításai olvashatóak.

${ }^{1196}$ Magyar Kurír, 1948. május 25. III. kiadás. 1. p.

${ }^{1197}$ Új Ember, 1948. május 30. 3. p.

${ }^{1198}$ Szív, 1948. május 29. 2. p.

${ }^{1199}$ MINDSZENTY József: Emlékirataim, 198. p.

${ }^{1200}$ CSML MSZMP CSMBA. 40. f. 2. cs. 48. ő. e. 20/4/8 - 1948

${ }^{1201}$ CSML MSZMP CSMBA 40. f. 2. cs. 48. ö. e. 20/5/8 - 1948.

1202 TAMASI Mihály: A népi demokratikus forradalom győzelme. 158. p.
} 
Zoltán. ${ }^{1203}$ Tóth Ferenc ekképpen fogalmaz: „Minden korlátozás ellenére korabeli becslés szerint harmincezren vettek részt a Mária-napon." "1204 „Makón 80.000 hívő vette körül a Boldogasszony oltárát.” - írja Mészáros István. ${ }^{1205}$ Balogh Margit - Gergely Jenő kronológiájában ez szerepel: „Május 22-23. A Makón rendezett Marosmenti Mária-napon 57 községből 85 ezer hívő vett részt.”,1206

A Magyar Dolgozók Pártjának Csanád Megyei Bizottsága az 1948. május 23-tól július 1-jéig terjedő időszakra vonatkozó munkatervében kimondta: „Mindszenti (sic!) beszédében [ti. a május 23-i szentbeszéd] a pedagógusokat és állami iskolákat támadta, demokráciát sértő beszédét felhasználva lejárassuk [sic!] és egyúttal az ellen a beállítás ellen tiltakozást szervezzünk." 1207

Makó Város Nemzeti Bizottsága május 25-én azzal a kéréssel fordult Kiss Imre polgármesterhez, hogy a városi képviselőtestület május 28-i rendkívüli ülésén - Makó dolgozó népének nevében - hozzon tiltakozó határozatot a Mindszenty-beszéd ellen.

Eközben Bugár Jánostól, a szerveződő Magyar Dolgozók Pártja (MDP) Csanád megyei Bizottságának titkárától Farkas Mihály ${ }^{1208}$ titkársága is tájékoztatást kért a Mindszenty-gyülésről. ${ }^{1209}$ Bugár János május 26-án informálta Farkas Mihályt a május 23-i makói történésekröl.

A makói képviselőtestület május 28-i ülésén Kiss Imre polgármester előterjesztette határozati javaslatát, amely Mindszenty beszédét ,,a demokrácia ellen intézett támadásnak” nevezi. ${ }^{1210}$ Szőnyi Imre, a Független Kisgazdapárt képviselője „túl erős hangúnak” találta a javaslatot. „A város lakossága 36.000, ennek fele római katolikus. Ezzel számolnunk kell és nem elfelejtenünk, hogy Mindszenty bíboros érsek Makó város fele lakosságának az egyházi feje. A hithü katolikusok - mert feltételezem, hogy mind az - nem veszik jónéven, hogy az egyházuknak föpapjáról ilyen hangon mond véleményt a képviselőtestület.” - mondta Szőnyi. ${ }^{1211}$ B. Papp Mihály (Nemzeti Parasztpárt) pártja nevében elfogadta a határozat szövegét. „Nem tartom elég erősnek, még több erőt kell kifejteni benne. Nyilván, Szőnyi

\footnotetext{
${ }^{1203}$ VIDA Zoltán: Makó iskolatörténete a város felszabadulásától az államosításig (1944-1948). Makói Múzeum, Makó, 1973. 35. p.

${ }^{1204}$ Délvilág, 1990. május 19. 4. p.

${ }^{1205}$ MÉSZÁROS István: Boldogasszony Éve. Ecclesia, Budapest, 1994. 108. p.

1206 BALOGH Margit - GERGELY Jenő: Egyházak az újkori Magyarországon 1790-1992. História, Budapest, 1993. 273. p.

${ }^{1207}$ CSML MSZMP CSMBA 40. f. 1. cs. 10. ö. e. 20/35/1 - 1948.

${ }^{1208}$ Farkas Mihály ekkor az MKP KV titkára.

${ }^{1209}$ CSML MSZMP CSMBA 40. f. 2. cs. 48. ö. e. 20/11/8 - 1948.

${ }^{1210}$ Makó Város Levéltára (MVL) 277 kgy. 7747 ikt./1948.

${ }^{1211}$ Uo.
} 
képviselőtársam nem hallotta a hercegprímás előadását, melyben azt állította, hogy az állami iskolában ezután amennyire szükítik az egyházak befolyását, annyira bővítik a fegyházakat, fogházakat és börtönöket, s beszédében a demokráciát is támadta. Nyilvánvaló, hogy ha nem ő mondta volna ezeket, már rég nem is volna szabadon.” - hangoztatta a parasztpárti képviselö. ${ }^{1212}$

Kiss Imre polgármester a vita zárszavában elmondta, ő nem tartja erősnek a javaslat hangvételét: „Sokkal különb kifejezéseket el tudnék képzelni, amelyeket megérdemelne [ti. Mindszenty] azon beszédek miatt, melyet nemcsak Makón, hanem az ország különböző részein hónapok óta elmondott a magyar demokrácia ellen. Éppen ezért én a javaslatomat fenntartom és kérem a képviselőtestületet, hogy ennek megfelelő módon határozzon." ${ }^{1213} \mathrm{~A}$ képviselőtestület elfogadta a határozatot, amely kimondja: „Mindszenthy [sic!] bíboros érsek makói beszédével kapcsolatban a demokrácia ellen intézett támadásait a leghatározottabban visszautasítja." 1214

Révai József május 28-án a budapesti sportcsarnokban Letörjük a klerikális reakciót címmel szónokolt. Többek között arról beszélt, hogy „Hamvas Endre Makón május 23-án a módosítását rendelte el annak a gyönyörü egyházi éneknek, amely Magyarországról, édes hazánkról szól. Kiadta a rendelkezést, hogy ezután ezt az éneket ne így énekeljék, hogy »Magyarországról, édes hazánkról«, hanem így: »Magyarországról, romlott hazánkról.« Ez a »romlott hazánk« a magyar demokrácia - folytatta Révai -, amely visszaadta a magyar nép hitét önmagába, amely példátlan újjáépítési és munkalendületre, ezzel erkölcsi újjászületésre is vezette a magyar nép millióit. Arra a Magyarországra vonatkozik ez, amely három és félesztendős megfeszített munkával jóvátett rengeteget abból a bünből, amelybe a régi rendszer vitte az országot és felépítette oroszlánrészt azoknak a rombolásoknak, amelyeknek megakadályozásánál nem láttuk ugyanazokat, akik most romlottnak nevezik ezt a demokráciát." ${ }^{215}$ - hangoztatta Révai József.

A Csanádi Püspöki Hivatal közleményt adott ki Révai nyilatkozatával kapcsolatban, melyben megállapítja, Hamvas Endre nem rendelhetett el olyan módosítást a makói Márianapon, hogy a hívek „édes hazánk” helyett „romlott hazánk”-at énekeljenek a Boldogasszony anyánk kezdetű ősi egyházi ének szövegében, ugyanis „,minden egységes magyar egyházi énekeskönyvben, akár a legősibb, akár a 20-30 évvel ezelőtti kiadásokban, egyöntetüen a

\footnotetext{
1212 Uo.

1213 Uo.

${ }^{1214}$ Uo.

${ }^{1215}$ Délmagyarország, 1948. május 29. 1. p.
} 
következő szöveg olvasható: »Magyarországról, romlott hazánkról...« Következésképp a »romlott« kifejezés, mely rombadőltet jelent, - amint azt Makón az énekkel kapcsolatban ilyen értelemben nyilvánosan meg is magyaráztak - a történelem pusztító viharaiban sokat szenvedett országra vonatkozik. Hamvas püspök már jóval a makói Mária-nap előtt észrevételezte az ének kétféle szövegét, s ezért hívták fel a figyelmét az eredeti és minden hivatalos énekeskönyvben megtalálható ősi szövegre. Téves, és a makói szövegmagyarázatot nem ismerő megállapítás volt tehát Révai József beszédében levont következtetés"1216 _ fogalmaz az egyházmegyei közlemény. Hamvas hazatérését követően levélben válaszolt Révai Józsefnek. A püspök mellékelve elküldte Révainak a Magyar Kommunista Párt által a Tiszai Mária-napokra (1947. augusztus 15-17.) kiadott nyomtatott röplapját, amelyen szerepel a Boldogasszony anyánk kezdetű ének szövege és kottája, s e kiadványon is a „romlott hazánk” szövegrész olvasható.

Június elején Zakar András, Mindszenty titkára arra kérte Csepregit, hogy adjon tájékoztatást a május 23-át követő eseményekről. A prelátus június 16-i keltezésü levelében számolt be a hercegprímásnak arról, hogy milyen fejlemények történtek a Marosmenti Márianap után. „Az itteni pedagógusok szervezete szisszent fel először és a Nemzeti Bizottságot nekiugrasztva, sérelmeket vélt felfedezni abban, mintha az állami tanárok és tanítók nem nevelnének jellemeket! Ezt azonban senki sem veszi komolyan, ismerve a vezetőséget és a könnyü fajsúlyú előadókat, hangadó gárdát a kom[munista] pártból. Iskoláink ellen azonban rohamot intéztek és ezt minden meg nem engedett eszközzel folytatják. A terrornak nincs oly neme, melyhez ne folyamodnának"1217 - áll Csepregi Mindszentyhez írott levelében.

A makói Boldogasszony-ünnep után néhány héttel - hiába volt a több tízezer ember demokratikus akaratnyilvánítása - a június 16-án elfogadott 1948. évi XXXIII. törvény értelmében a Makó-belvárosi egyházközség iskoláját is államosították.

A makói Mária-napokon a több tízezres tömeg kiállt hite, elvei, meggyőződése mellett. Erre a demokratikus vélemény-kifejezésre láthattunk példát. Ez a fajta demokratikus kiállás azonban egyedi maradt. Az elkövetkezendő évtizedekben - a demokrácia hiányából is következően - nem volt lehetősége a makóiaknak arra, hogy ilyen szintü és nagyságú tömegdemonstrációkon álljanak ki a maguk álláspontja mellett.

\footnotetext{
${ }^{1216}$ Magyar Kurír, 1948. június 3. III. kiadás. 1. p.

1217 Szeged-Csanádi Egyházmegye Püspöki Levéltár I.1. a. 2929/47.
} 


\section{A demokrácia mint narratíva a helyi demokrácia közszereplöinek önéletírásaiban}

A koalíciós évek makói közszereplöi közül három személyről tudunk mint akik készítettek önéletírást. Csepregi Imre plébános naplót írt, Kiss Imre polgármester nem sokkal halála elött fejezte be visszaemlékezéseit. Memoárt írt Puja Frigyes, aki 1946 őszétől egy évig az MKP Csanád megyei kádertitkára, majd 1947 és 1949 között megyei párttitkár.

A közszereplők között már önmagában pozíciójuk tekintetében is különbözőségek lehetnek a demokrácia-kép szempontjából. Csepregi prelátus mélyen vallásos, konzervatív meggyőződésü ember volt, papként számára a kereszténység tanítása jelentette az élet lényegét. Kiss Imre és Puja Frigyes életük végéig hithű kommunisták voltak, mindez a szemlélet a memoárjaikban megjelenő demokrácia-fogalmat is alapvetően határozza meg.

Csepregi Imre 1944. szeptember 22-től 1953. június 8-ig írta minden egyes nap a vele történteket. A kézirat terjedelme 3363 oldal. „Nem magának, hanem az utókornak szánta munkáját, hogy a későbbi korok ismerjék meg az általa átélt diktatúra mindennapjait" írja a napló első kötetének bevezetőjében Tóth Ferenc helytörténész.

Csepregi a koalíciós évekbeli makói közélet elismert, tekintélyes alakja. Erdei Ferenc nemzetgyülési képviselőnek jelölte a debreceni Ideiglenes Nemzetgyülésbe, de a prelátus nem vállalta a pozíciót. ${ }^{1219}$ Képes volt szót érteni a helyi szociáldemokratákkal, hivatalos ügyekben kapcsolatban állt a kommunista Kiss Imre polgármesterrel és a Csanád Megyei Nemzeti Bizottság elnökével, az MKP-s Farkas Imrével és mindemellett a Kisgazdapárt tagja. $^{1220}$

„Különösen jól alakult a kapcsolat dr. Csepregi prelátussal, aki láthatóan kereste az alkalmat a társadalmi, főleg a szociális problémák megoldásában. [...] Hivatalos kapcsolatunkon túl, még bizonyos fokú enyhe barátság is kialakult közöttünk azáltal, hogy hasonló utónevünk miatt, minden évben kölcsönösen meglátogattuk egymást az Imre napokon és jó szívvel köszöntöttük egymást"1221 - írta Kiss Imre Csepregiröl.

Csepregi Imre naplóírási küldetéséről és demokrácia-képéről így fogalmaz Zombori István egyháztörténész: „Maga is látta, hogy az újonnan alakult átmeneti rendszer, majd az azt követő, úgynevezett »népi demokrácia« minden, csak nem demokrácia.”,1222

\footnotetext{
${ }_{1218}$ Dr. CSEPREGI Imre: Napló. 1. 5. p.

${ }^{1219}$ Uo. 7. p.

${ }^{1220}$ Uo. 110. p.

${ }^{1221}$ KISS Imre: Egy munkásháztól a városházáig. 239. p.

1222 Dr. CSEPREGI Imre: Napló. 1. 9-10. p.
} 
Ahogy már említettük, Csepregi Imre 1945 januárjában a Független Kisgazdapárt tagja, vagyis a prelátus - mondjuk így - demokrácia-felfogása leginkább a kisgazdákéhoz állhatott közel, tehát Csepregi a jogállami/parlamentáris demokrácia attitűdjét érezhette magához legközelebb. Hangsúlyozzuk, Csepregi papi személyként szolgálta közösségét, számára a demokrácia mint olyan csak másodlagos témakör, evilági szempontrendszer volt, amely tematika a hitbéli kérdéseket sohasem előzhette meg.

1945. február 13-án találjuk az első naplóbejegyzést Csepreginél, amely érinti a demokrácia tematikát. E nap kapott híreket a makói rendőrség atrocitásairól. Az információk szerint karácsonykor vittek be a rendőrségre és vallatták korbácsütésekkel az egyik ismerősét. A prelátus megütközik a jelenségen, hogy a formálódó demokrácia keretei között érdemi jogi kontroll nélkül három hétig fogva tarthatnak valakit. „Hát így fest a demokratikus igazságkeresés és szolgáltatás!"1223 - olvashatjuk a naplóban.

Az 1945-ös esztendő hangulatáról kapunk érdekes adalékot az 1945. október 13-i bejegyzésben. Köztörténeti tekintetben is érdekes és tanulságos információnak mondhatjuk az így nyert gondolatokat. Csepregi beszámol arról, találkozott a takarékpénztárban Szőnyi Imrével, a kisgazdapárt elnökével, aki elmondta a prelátusnak, hogy „a helyi orosz parancsnok gratulált neki a budapesti választási győzelem után, mert ő örül, bármely demokratikus párt sikert ér el, tehát ezzel is - úgymond Szőnyi - az orosz sem kizárólag a kommunista párt mellett áll."1224 A helyi szovjet parancsnok a szovjet kormány akkori hivatalos álláspontját képviselte, 1945-ben a Szovjetunió még tartotta magát a nyugati szövetségeseknek tett ígéretéhez a kelet-európai demokratikus állami struktúrák megteremtésével. Ezzel párhuzamosan abban Szőnyi Imre tévedett, miszerint a parlamentáris demokrácia berendezkedésének ideiglenes elfogadása azt jelentené, hogy „az orosz sem kizárólag a kommunista párt mellett áll."1225

1946. május 25-én azt jegyzi fel Csepregi, hogy az egyik makói kommunista rendőrtiszt arról beszélt, hogy aki majd a kisgazdák akkor még csak formálódó helyi lapját fogja járatni, „az mind reakciós és ki kellene azokat irttatni!” A prelátus kifakad: „Tehát szabad véleménynyilvánítás és szólásszabadság ez? Ilyen mélyen [sic] [mélyre] süllyedt a demokrácia?"1226

\footnotetext{
${ }^{1223}$ Uo. 133. p.

${ }^{1224}$ Uo. 348. p.

1225 Uo.

${ }^{1226}$ Uo. 508. p.
} 
„Üres az éléskamra, nincs tüzelő, rossz az élelmezés, nincs függelem, mindenki azt teszi, amit akar, mert mind mondják: demokrácia van!”1227 - ezt már a napló 1947. szeptember 20-i bejegyzésénél olvashatjuk.

Csepregi naplószövegeiben a demokráciát illetően egyfajta panaszkultúra jelenik meg. A prelátus témába vágó bejegyzéseiben több demokrácia-panaszra is bukkanhatunk mint nyelvi panelekre. („Hát így fest a demokratikus igazságkeresés és szolgáltatás!;”1228 „Tehát szabad véleménynyilvánítás és szólásszabadság ez? Ilyen mélyen süllyedt a demokrácia?"; ${ }^{1229}$ Üres az éléskamra, nincs tüzelő, rossz az élelmezés, nincs függelem, mindenki azt teszi, amit akar, mert mind mondják: demokrácia van!") ${ }^{1230}$

1947. június 5-én írja Csepregi Imre: az egyik makói kommunista ismerőse arról beszélt neki, hogy „mi nem akarunk proletárdiktatúrát, mint az 1919-ben volt, hanem demokratikus kormányzatot, hogy mindenki szóhoz juthasson."1231 Emlékeztetnénk, ez a gondolatsor Nagy Ferenc miniszterelnök lemondatása után néhány nappal hangozhatott el Makón.

A koalíciós évek időszakában az utolsó demokrácia-tematikát érintő bejegyzés a Mindszenty bíboros letartóztatása utáni napokban olvasható a Csepregi-naplóban. 1948. december 30-án arról számol be a prelátus, hogy folyamatosan küldöttségek jelennek meg nála, amely delegációk azt követelik, hogy „nyíltan” álljon a „demokrácia mellé.”1232

1948 végének nyelvi közegében a „demokrácia” melletti kiállás mint ,igény” már egyértelműen azt jelentette, azt várják el a követelést megfogalmazók, hogy az illető a formálódó kommunista diktatúra mellett foglaljon állást.

Kiss Imre, aki az MKP, majd az MDP politikusaként 1945 és 1950 között volt Makó város polgármestere, nyolcvanesztendősen, 1986-ban kezdte megírni visszaemlékezéseit, két évvel később, 1988-ban fejezte be a munkát. Az 1989-ben kiadott kötet elé előszót ír, Tamasi Mihály történész is utal rá, hogy a szövegben előfordulnak „egyoldalú”1233 vélemények. Tóth Ferenc helytörténész úgy fogalmaz: Kiss Imre írása „tendenciózus.”1234

\footnotetext{
${ }^{1227}$ Dr. CSEPREGI Imre: Napló 2. 145. p.

${ }^{1228}$ Dr. CSEPREGI Imre: Napló. 1. 133. p.

${ }^{1229}$ Uo. 508. p.

${ }^{1230}$ Dr. CSEPREGI Imre: Napló 2. 145. p.

${ }^{1231}$ Uo. 91. p.

${ }^{1232}$ Uo. 412. p.

1233 KISS Imre: Egy munkásháztól a városházáig. 7. p.

1234 TóTH Ferenc: Történeti kutatások Makón. Elérhető:

http://www.sulinet.hu/oroksegtar/data/telepulesek_ertekei/Mako_monografia_sorozat/pages/monografia_4/002_t orteneti.htm (A letöltés időpontja: 2015. december 15.)
} 
Puja Frigyes, aki az MKP Csanád megyei kádereseként és megyei titkárként vett részt a koalíciós évek makói közéletében 1988-ban írta meg memoárját.

Kiss Imre és Puja Frigyes is még a kommunista diktatúra időszakában készítették el visszaemlékezéseiket. Mindkettőjük szövegéből az derül ki, úgy érzik, életükben igaz ügyet szolgáltak. „Aki a kézbe veszi és elolvassa ezt a könyvet, bizonyára azzal az érzéssel teszi le, hogy ilyen és ennél merészebb ívü pályafutás csak a szocializmus körülményei között létezhet”"1235 - írja visszaemlékezése előszavában Puja.

Mikor Kiss Imre a visszaemlékezésben „demokráciáról” szól, akkor a koalíciós évek időszakához hasonlatosan negyven esztendővel később is, azon a kommunista világnézetnek megfelelő gondolati rendszert és állami struktúrát ért. A nyolcvan esztendős visszaemlékező demokrácia-képe semennyit sem változott 1945 és 1988 között. ${ }^{1236}$

Puja Frigyes visszaemlékezése koalíciós esztendőket érintő részének egyik leggyakrabban használt kifejezése a reakció. 1988-ban is a koalíciós évekbeli ellenség neve Pujánál: a reakciós. ${ }^{1237}$

Puja Csanád megyei küldöttként vett részt az MKP III. kongresszusán. A fiatal kommunista aktivista ekkor döbben rá, az addig hangoztatatott szövegek a demokráciáról egészen mást jelentenek mint ő azt korábban gondolta: „A parlament sok vihart látott üléstermeiben hallgatva pártunk vezetőinek beszédeit, a felszólalásokat, tudatosodott bennem, hogy a kongresszus után az ország fejlődésében valami új következik. Ott, a parlamenti padsorokban kezdtem behatolni jelszavaink értelmébe, s kezdett megvilágosodni elöttem, hogy [...] pártunk a népi demokrácia útján a szocializmus felé veszi az irányt. [...] Ott értettem meg, hogy a küzdelem java ezután következik. [...] Szilárdabban hittem, mint valaha, hogy ügyünk győzni fog."1238

1948-ban a koalíciós évek demokráciája Makón is véget ért. A „népi demokráciáról” mint sajátos kifejezésről, metanyelvi panelről a későbbi évtizedekben is sokat hallhattak a makóiak, de annak valós tartalmáról már nem vitatkozhattak, nem publikálhattak cikkeket. A népi demokrácia struktúrája Makó városában is a kommunista diktatúra hatalmi, jogi és világnézeti keretét hozta el.

\footnotetext{
${ }^{1235}$ Puja Frigyes: A szedőszekrénytől a miniszteri székig. Népszava, Budapest, 1988. 5. p.

${ }^{1236}$ KIsS Imre: Egy munkásháztól a városházáig. 152. p., 162.p., 184. p. 199. p.

${ }^{1237}$ PUJA Frigyes: A szedőszekrénytől a miniszteri székig. 94-127. p.

${ }^{1238}$ Uo. 97. p.
} 


\section{A kutatómunka során felhasznált források, irodalom}

Levéltári források

Politikatörténeti Intézet Levéltára

274. fond. A Magyar Kommunista Párt iratai (1944-1948)

Csongrád Megyei Levéltára. MSZMP Csongrád Megyei Bizottság Archívuma

Szeged-Csanádi Püspöki Levéltár

I. 1. a. Püspöki hivatal iratai. Egyházigazgatási iratok

Makó Város Levéltára

Közgyülési iratok (1946-1948)

\section{Publikált források}

A népi demokrácia útja. A Magyar Kommunista Párt III. kongresszusának jegyzőkönyve. A Magyar Kommunista Párt Budapesten 1946 szeptember 28., 29., 30. és október 1-én tartott III. kongresszusának jegyzőkönyve. Szikra Kiadó, Budapest, 1946.

A Szovjetunió Kommunista (Bolsevik) Pártjának története. Szerkesztette: A Szovjet

Kommunista (Bolsevik) Párt Központi Bizottságának Komissziója. Jóváhagyta az SZK(b)P KB 1938-ban. Szikra Kiadó, Budapest, 1945.

Demokrácia. A Pázmány Péter Tudományegyetem Bölcsészettudományi Karának kiadása.

Egyetemi Nyomda, Budapest, 1945.

Kereszténység és demokrácia. A Szent István Társulat kiadása, Budapest, 1946.

Központi Statisztikai Hivatal 1949. évi népszámlálás. 1. Előzetes adatok. Állami Nyomda, Budapest, 1949.

Schematismus Cleri Dioecesis Csanadiensis Pro Anno Domini 1947. Editio Ordinariatus

Csanadiensis, Szeged, 1947. (A Csanádi Egyházmegye 1947-es Sematizmusa) 


\section{Parlamenti naplók}

Az 1945. évi november hó 29-ére összehívott Nemzetgyülés naplója. Nemzetgyülési Napló, 1945-1947. I. kötet. Athenaeum Irodalmi és Nyomdai Részvénytársulat Könyvnyomdája, Budapest, 1946.

Az 1945. évi november hó 29-ére összehívott Nemzetgyülés naplója. Nemzetgyülési Napló, 1945-1947. V. kötet. Athenaeum, Budapest, 1952.

Az 1945. évi november hó 29-ére összehívott Nemzetgyülés naplója. Nemzetgyülési Napló, 1945-1947. VI. kötet. Athenaeum, Budapest, 1952.

Az 1945. évi november hó 29-ére összehívott Nemzetgyülés naplója. Nemzetgyülési Napló, 1945-1947. VII. kötet. Athenaeum, Budapest, 1952.

Az 1947. évi szeptember hó 16-ára összehívott Országgyülés naplója. Országgyülési Napló, 1947-1949. I. kötet. Athenaeum Irodalmi és Nyomdai Részvénytársulat Könyvnyomdája, Budapest, 1948.

\section{Korabeli sajtócikkek, irások}

ANTALLFy Gyula: Temessük be a lövészárkokat! Kis Újság, 1946. október 20. 1. p.

BALLA Antal: Ki a reakciós? Kis Újság, 1946. április 14. 1. p.

CSÉCSY Imre: Válasz egy förmedvényre. Huszadik Század, XXXV. évf. (1947) 2. 158-164. p.

DESSEWFFY Gyula: Új korszak küszöbén. Kis Újság, 1945. november 10. 1. p.

ERDEI Ferenc: Voltak férfiak. Délmagyarország, 1944. november 29. 3. p.

ERDEI Ferenc: A Válság vitájához. Fórum, I. évf. (1946) 3. 243-250. p.

ERDŐDY János: Magyar demokrácia. Szocializmus, XXX. évf. (1946) 3-4. 116-118. p.

FARAGÓ László: Öngyilkos demokrácia. Szocializmus, XXIX. évf. (1945) 2. 82. p.

FARAGÓ László: A demokrácia kilátásai. Szocializmus, XXX. évf. (1946) 3-4. 106-112. p.

FUTÓ Dezső: Az emberi szabadságjogok. Kis Újság, 1945. november 9. 1. p.

GAJDI István: Rólunk, kommunistákról! Makói Népújság, 1945. február 4. 1 p.

GIMES Miklós: Az elárult „Huszadik Század”. Szabad Nép, 1947. április 20.

GuLYÁs Gábor: A központi hatalom. Kis Újság, 1945. november 22. 1. p.

HÁM Tibor: Népi vagy polgári demokrácia. Kis Újság, 1946. szeptember 22. 1. p.

HoRvÁTH Márton: A III. kongresszus. Társadalmi Szemle, I. évf. (1946) 10. 693-701. p.

HoRvÁTH Márton: Tiszta demokrácia. Szabad Nép, 1947. augusztus 17. 1. p.

Justus Pál: Demokrácia és szocializmus. Szocializmus, XXX. évf. (1946) 3-4. 102-106. p. 
KÉTHLY Anna: Vita a demokrácia értelmezése körül. Szocializmus, XXX. évf. (1946) 3-4. 97-102. p.

KISS Imre: Az első felszabadulási ünnepre! Makói Népújság, 1946. április 4. 1. p.

KovÁCs Béla: Nélkülünk nincs demokrácia. Kis Újság, 1946. szeptember 28. 1. p.

KovÁCS Imre: A demokrácia útja Magyarországon. Válasz, II. évf. (1946) 11. 97-106. p.

KÖNYVES-KolONICS József: Régi világ - új emberek. Makói Népújság, 1945. január 24. 1. p.

KÖNYVES-KOLONICS József: Húsvéti gondolatok. Makói Népújság, 1945. április 1. 1. p.

KÖNYVES-KOLONICS József: Köszöntöm az újságolvasót. Makói Népújság, 1945. június 3. 1.

p.

KÖNYVES-KoLONICS József: Meggyőző erőt. Makói Népújság, 1945. június 19. 1. p.

KÖNYVES-KOLONICS József: Pedig. Délvidéki Független Hírlap, 1946. szeptember 21. 1. p.

KÖNYVES-KOLONICS József: Kétértelmüségek. Délvidéki Független Hírlap, 1946. szeptember 17. 2. p.

KÖNYVES-KolONICS József: Általános, titkos választójog. Délvidéki Független Hírlap, 1946. december 8 .

LuKÁCs György: Demokrácia és kultúra. Társadalmi Szemle, I. évf. (1946) 1. 31-40. p.

LUKÁCs György: Arisztokratikus és demokratikus világnézet. Fórum. I. évf. (1946) 3. $197-$ 216. p.

Ifj. PUSKÁs Antal: Ez a válaszom Zs-úrnak. Délvidéki Független Hírlap, 1947. május 11. 3. p.

RÁKosi Mátyás: Beszéd az MKP III. kongresszusán. Délmagyarország, 1946. október 1. 1. p.

RÁKOSI Mátyás: A népi demokrácia néhány problémájáról. Társadalmi Szemle, IV. évf.

(1949) 1. 1.p.

RÉVAI József: Harcos demokráciát! Délmagyarország, 1944. november 25. 3. p.

RÉVAI József: A demokrácia támadásban. Szabad Nép, 1945. július 22. 1. p.

RÉVAI József: A választások és a magyar demokrácia néhány alapkérdése. Társadalmi

Szemle, I. évf. (1946) 1. 6. p.

RÉVAI József: Összeesküvők és cinkosok. Szabad Nép, 1947. január 5. 1. p.

RÉVAI József: Amiben nincs alku. Szabad Nép, 1947. február 16. 1. p.

RÉVAI József: A Magyar Kommunista Párt Központi Bizottságának tevékenysége. In: A tartós békéért, a népi demokráciáért. Szikra Kiadó, Budapest, 1947. 179-195. p.

RÉVAI József: Marxizmus és népiesség. In: RÉVAI József: Marxizmus, népiesség, magyarság.

Szika Kiadó, Budapest, 1948.

RÉVAI József: Népi demokráciánk jellegéről. Társadalmi Szemle, IV. évf. (1949) 2. 161. p.

SULYOK Dezső: Ellenzékiség vagy ellenzékieskedés? Haladás, 1946. augusztus 1. 1. p. 
SULYOK Dezső: Mivégre vagyunk a Földön? A Holnap, I. évfolyam. 1947. március 15. 1.p

SZEKFÜ Gyula: Egy pünkösdi pártnap. Világ, 1945. május 29. 1. p.

SzEKFÜ Gyula: Értelemhiány. Világ, 1945. június 3. 3. p.

SzEKFÜ Gyula: A „klasszikus demokrácia”. Világ, 1945. július 22. 1. p.

SZEKFÜ Gyula: A két történeti erő. Világ, 1945. július 29. 1. p.

SzEKFÜ Gyula: Tavasz óta. Világ, 1945. augusztus 12. 3. p.

SzEKFÜ Gyula: A szabadság hívei. Világ, 1945. augusztus 26. 1. p.

SzEKFÜ Gyula: Az egyenlőség hívei. Világ, 1945. szeptember 2. 1. p.

SzEKFÜ Gyula: A választás után. Világ, 1945. október 21. 3. p.

SzŐNYI Imre: Rendkívüli közgyülés és egyebek. Délvidéki Független Hírlap, 1947. július 16. 1. p.

TILDY Zoltán: Magyar kérdések. Kis Újság, 1945. július 11. 1. p.

Z. NAGY Ferenc: A koalíció válsága és a kivezető út. Kis Újság, 1947. február 7. 1. p.

Zsolt Béla: Levél dr. Sulyok Dezsőhöz. Haladás, 1946. július 25. 1. p.

\section{Sajtóforrások}

Délmagyarország (1944-1948)

Délvidéki Független Hírlap (1946-1948)

Fórum (1946-1948)

Igazság (1946-1947)

Haladás (1945-1949)

Holnap (1947)

Kis Újság (1945-1948)

Magyar Kurír (1948)

Makó és Vidéke (1947)

Makói Népújság (1945-1947)

Népszava (1945-1948)

Szabad Nép (1945-1948)

Szocializmus (1945-1948)

Új Ember (1947-1948)

Válasz (1946-1948)

Valóság (1945-1948)

Világ (1945-1948) 


\section{Önéletírások}

A Nemzetgyülés elnöke volt. Varga Béla vallomásai életútjáról. Írta és összeállította:

KAPRONCZAY Károly. Mundus Magyar Egyetemi Kiadó, Budapest, 1998.

ARANY Bálint: Koronatanú. Emlékirat 1945-57. Püski, Budapest, 2006.

BOGNÁR József: „Én azt gondolom...”. Kritika, XVI. évf. (1987) 8. 19-35. p.

BöHM Vilmos: Másodszor emigrációban... Progresszió Kiadó, Budapest, 1990.

CSÉCSY Imre: Napló. 1940-1949. (Részletek) Kritika, XIII. évf. (1983) 8. 13-27. p.

CSEPREGI Imre: Napló. 1-2. 1944-1946. Makó város önkormányzata, Makó, 2011.

CSICSERY-RÓNAY István (szerk.): NAGY Ferenc miniszterelnök: Visszaemlékezések, tanulmányok, cikkek. Ezerkilencszáznegyvenöt Alapítvány - Occidental, Budapest, 1995.

CSICSERY-RÓNAY István (szerk.): Saláta Kálmán, az ifjú szürkeeminenciás. Fejezetek a

Független Kisgazdapárt 1945-ös küzdelméből. Occidental Press, Budapest, 2004.

CSICSERY-RÓNAY István: A demokrácia fellegvárának építői. Századvég, Budapest, 2002.

CSICSERY-RÓNAY István: Az 1946. évi I. törvénycikk történelmi perspektívában. In:

HORVÁTH János (szerk.): Tiltott történelmünk. Századvég Kiadó, Budapest, 2006. 141146. p.

DANCS József: Utak és állomások. Kossuth Könyvkiadó, Budapest, 1978.

DESSEWFY Gyula: Tanúvallomás. Agroinform Kiadó, Budapest, 1997.

DLuSZTus Imre: Barcs Sándor. Délmagyarország Kft., Szeged, 1997.

DOBI István: Vallomás és történelem. II. kötet. Kossuth Könyvkiadó, Budapest, 1962.

DONÁTH Ferenc: Bibó István és a magyar demokrácia alapkérdése. In uő: A Márciusi Fronttól

Monorig. MTA Közgazdaságtudományi Intézet-Századvég, Budapest, 1992. 237-254. p.

Elérhetö: http://www.rev.hu/sulinet45/szerviz/szakirod/donath.htm (A letöltés időpontja:

2015. szeptember 15.)

DrOzDY Győző: Elvett illúziók. Drozdy Győző emlékiratai. Kossuth Kiadó, Budapest, 2007.

FARKAS Vladimír: Nincs mentség. Az ÁVH alezredes voltam. Interart Stúdió, Budapest, 1990.

FiALA Ferenc: Zavaros évek. Gede Testvérek BT., Budapest, 2003.

FöldES Anita: Átéltem egy évszázadot. Utolsó interjúk Fejtő Ferenccel. Scolar Kiadó,

Budapest, 2014.

FöLDES László: A második vonalban. Kossuth Könyvkiadó, Budapest, 1984.

FuTó Dezső: Önéletírás. Világlátás. Országos Eckhardt Tibor Alapítvány, Budapest, 1995. 
GRŐsz József: Grősz József kalocsai érsek naplója. Szent István Társulat, Budapest, 1995.

HALAS Lajos: Az R Gárdától a Munkásőrségig. Zrínyi Katonai Kiadó, Budapest, 1986.

HÁM Tibor: A Magyar Köztársaság megalakulása. In: Nagy Ferenc miniszterelnök.

Visszaemlékezések, tanulmányok, cikkek. Ezerkilencszáznegyvenöt Alapítvány -

Occidentál Press, Budapest, 1995. 70-78. p.

HARASZTI Sándor: Befejezetlen számvetés. Magvető Kiadó, Budapest, 1986.

HÁY Gyula: Született 1900-ban. Emlékezések. Interart Kiadó, Budapest, 1990.

HEGEDÜs András: A történelem és a hatalom igézetében. Életrajzi elemzések. Kossuth Kiadó, Budapest, 1988.

HEGEDŰs B. András: Hegedűs B. András 1985-ös életút-interjúja Göncz Árpáddal. Elérhető:

http://server2001.rev.hu/oha/oha_document.asp?id=239\&order=1 A letöltés időpontja:

2015. október 17.

HORVÁTH János: Élő történelem. Horváth Jánossal, a parlamenti képviselők doyenével beszélget Spangel Péter. Kairosz Kiadó, Budapest, 2012.

HuszÁR Tibor: Beszélgetések Nyers Rezsővel. Kossuth Könyvkiadó, Budapest, 2004.

ILLYÉS Gyula: Naplójegyzetek 1946-1960. Digitális Irodalmi Akadémia - Petőfi Irodalmi

Múzeum, Budapest, 2011.

KÁDÁR János: Végakarat. Hírlapkiadó Vállalat, Budapest, 1989. Az interjút készítette és a dokumentumokat válogatta: Kanyó András.

KÁLLAI Gyula: Két világ határán. Magvető Könyvkiadó, Budapest, 1984.

KÁRÁSZ Artúr: 80 év alatt a Föld körül. Bethlen Gábor Könyvkiadó - Irodalmi Újság, Budapest - Párizs, 1990.

KÁROLYI Mihály: Hit, illúziók nélkül. Európa Könyvkiadó, Budapest, 1982.

KÁROLYI Mihály: Hit, illúziók nélkül. Európa Könyvkiadó, Budapest, 2013.

KÁROLYI Mihályné: Együtt a számüzetésben. Európa Könyvkiadó, Budapest, 2011.

KERTÉSz István: Magyar békeillúziók 1945-1947. Oroszország és a Nyugat között. História -

Európa Könyvkiadó, Budapest, 1995.

KISS Imre: Egy munkásháztól a városházáig (Önéletírás). Szerzői kiadás, Makó, 1989.

KISS Sándor: A magyar demokráciáért. Magyar Öregdiák Szövetség - Bessenyei György Kör, New Brunswick NY, 1983.

KoRNIS Pál: Tanúként jelentkezem. Zrínyi Katonai Kiadó, Budapest, 1988.

KovÁCs Imre: Magyarország megszállása. Katalizátor Iroda, Budapest, 1990.

KoVÁCS István: Élet egy eszme szolgálatában. 1911-2011. Visszaemlékezések és

dokumentumok. Válogatta, szerkesztette és a bevezetőt írta: MoRVA Tamás. Budapest, 
2014. Elérhető: http://vilagszabadsag.hu/index.php?f=1935 (A letöltés időpontja: 2016. január 9.)

KőVÁGÓ József: Az 1945-ben tartott budapesti és országos választások lefolyása és jelentősége. Történelmi dokumentum. Vetés Kiadó, Budapest, 1994.

MÁRAI Sándor: Napló. 1945-1957. Helikon Kiadó, Budapest, 1990.

MÁRAI Sándor: Ami a naplóból kimaradt 1945-1946. Vörösváry Publishing. Toronto, 1991.

MÁrAI Sándor: Föld, föld”... Helikon, Budapest, 2014.

MAROSÁN György: Az úton végig kell menni. Magvető Kiadó, Budapest, 1982.

MESTER Miklós: Arcképek. Két tragikus kor árnyékában. Visszapillantás a katasztrofális magyarországi 1944. esztendőre, részint annak előzményeire és követlen következményeire is, 24 év távlatából. Tarsoly Kiadó, Budapest, 2012.

MiHÁLYI Gábor: Két apa között. A magyar baloldal tragédiája 1899-1990. Kaligram, 2012.

MindSZENTY József: Emlékirataim. Az Apostoli Szentszék Könyvkiadója, Budapest, 1989.

MizSEI Béla: Életpályám. Kossuth Kiadó, Budapest, 2006.

MÜNNICH Ferenc: Viharos út. Kossuth Könyvkiadó, Budapest, 1986.

NAGY Ferenc: Küzdelem a vasfüggöny mögött. I-II. Európa - História, Budapest, 1990.

NAGY Imre: Snagovi jegyzetek. Gondolatok, emlékezések 1956-1957. Felelős szerkesztő:

VIDA István. Gondolat Kiadó-Nagy Imre Alapítvány, Budapest, 2006.

NAGY Vince: Októbertől októberig. Európa - História, Budapest, 1991.

NóGRÁDI Sándor: Új történet kezdődött. Kossuth Könyvkiadó, Budapest, 1966.

Osskó Judit: ANTALL József. Kései memoár. Publikálatlan interjúk. Corvina, Budapest, 2013.

OROSZ István: Emlékfoszlányok az 1945. évi választásokról. In: HORVÁTH János (szerk.):

Tiltott történelmünk. Századvég Kiadó, Budapest, 2006. 121-124. p.

ORtUTAY Gyula: Napló I. 1938-1954. Alexandra Kiadó, Budapest, 2009.

ORTUTAY Gyula: Napló II. 1955-1966. Alexandra Kiadó, Budapest, 2009.

PUjA Frigyes: A szedőszekrénytől a miniszteri székig. Népszava, Budapest, 1988.

RÁKOSI Mátyás: Visszaemlékezések 1940-1956. 1. kötet. Napvilág Kiadó, Budapest, 1997.

SCHIFFERNÉ SZAKASITS Klára: Fent és lent. 1945-1950. Magvető Könyvkiadó, Budapest, 1985.

ScHÖPFLIN Gyula: Szélkiáltó (Visszaemlékezés). Magvető Kiadó - Pontus Kiadó, Budapest, 1991.

SULYOK Dezső: Két éjszaka nappal nélkül. Éghajlat Kiadó, Budapest, 2004.

SzABÓ Lőrinc: Bírákhoz és barátokhoz (Napló és védőbeszédek 1945-ből). Magvető Kiadó, Budapest, 1990. 
SZÉCHÉNYI György: Harcom a szabadságért. Tizenkét év fogságban 1944-1956. Timp Kiadó, Budapest, 2006.

SZENT-IVÁNYI Domokos: Visszatekintés 1941-1972. Magyar Szemle Könyvek, Budapest, 2016.

VAS Zoltán: Akkori önmagunkról. Önéletírás II. Magvető Kiadó, Budapest, 1982.

VAS Zoltán: Betiltott könyvem. Életem III. Szabad Tér Kiadó, Budapest, 1990.

VAS Zoltán: Viszontagságos életem. Magvető Kiadó, Budapest, 1980.

VÁSÁRHELYI Miklós: Ellenzékben. Federigo Argentieri interjúja Vásárhelyi Miklóssal.

Szerkesztő: TóBIÁs Áron. Szabad Tér Kiadó, Budapest, 1989.

VERES Péter: Az ország útján. In: VERES Péter: Veres Péter válogatott müvei. Szépirodalmi

Könyvkiadó, Budapest, 1973.

VÖRÖS Vince: Politikai utam. Magyar Történelmi Társulat Dél-Dunántúli Csoportja - Pannon História Alapítvány, Pécs, 1995.

Z. NAGY Ferenc: Ahogy én láttam. Gondolat Kiadó, Budapest, 1965.

\section{Forrásközlések}

BIBÓ István: Válogatott tanulmányok. Első-második kötet. Szerkesztette: HuszÁR Tibor,

VIDA István, NAGY Endre. Magvető Kiadó, Budapest, 1986.

BIBÓ István: Életút dokumentumokban. Szerkesztő: LITVÁN György, S. VARGA Katalin.

1956-os Intézet - Osiris - Századvég, Budapest, 1995

BIHARI Mihály-GAZSÓ Ferenc-VIDA István (szerk.): Magyarországi pártprogramok 19441988. ELTE-Eötvös Kiadó, Budapest, 2004.

ERDEI Ferenc: Demokrácia, népi demokrácia, szocializmus. In: ERDEI Ferenc: Politikai írások.

2. kötet. Válogatás. Szerkesztette: TAMASI Mihály. Bába Kiadó, Szeged, 2003. 9-16. p

FARAGÓ László (1896-1967). A demokrácia kilátásai. Egy politikus írástudó gondolataiból.

Összeállította, jegyzetekkel ellátta és szerkesztette: JEMNITZ János - SzÉKELY Gábor.

Magyar Lajos Alapítvány, Budapest, 1998.

IZSÁK Lajos-Kun Miklós (szerk.): Moszkvának jelentjük... Titkos dokumentumok 1944-

1948. Századvég Kiadó, Budapest, 1994.

HAJDÚ Tibor (szerk.): Károlyi Mihály levelezése V. 1945-1949. Napvilág Kiadó, Budapest, 2003.

HORVÁTH Julianna et al. (szerk.): Pártközi értekezletek. Politikai érdekegyeztetés, politikai konfrontáció. 1944-1948. Napvilág Kiadó, Budapest, 2003. 
KARSAI Elek-SOMLYAI Magda (szerk.): Sorsforduló. Iratok Magyarország felszabadulásának történetéhez. 1944 szeptember - 1945 április. I-II. kötet. Levéltári Igazgatóság, Budapest, 1970.

KovÁCs Imre: Népiség, radikalizmus, demokrácia. Publicisztikai írások. Gondolat Nyilvánosság Klub - Századvég, Budapest, 1992.

LITVÁN György-VARGA F. János (szerk.): Jászi Oszkár publicisztikája. Magvető Könyvkiadó, Budapest, 1982. Elérhető: http://mek.oszk.hu/09800/09871/pdf/ (A letöltés időpontja: 2015. szeptember 15.)

MAJSZKIJ, Ivan M.: A jövendő világ kívánatos alapelveiről (1944). Fordította és közreadja: Baráth Magdolna. In: Külpolitika, II. évf. (1996) 3-4. 154-184. p.

NAGY Imre: Egy évtized. Válogatott beszédek és írások. (1945-1947) I. Szikra Kiadó, Budapest, 1954.

NAGY Imre: „A magyar nép védelmében”. Vitairatok és beszédek 1955-1956. A Magyar Füzetek kiadása, Párizs, 1984.

RÁKOSI Sándor-SzABÓ Bálint (szerk.): A Magyar Kommunista Párt és a Szociáldemokrata Párt határozatai 1944-1948. Kossuth Kiadó, Budapest, 1967.

RÉVAI József: Élni tudtunk a szabadsággal. Válogatott cikkek és beszédek 1945-1949. Szikra, Budapest, 1949.

STRASSENREITER Erzsébet (szerk.): Kéthly Anna válogatott levelei (1921-1976). Napvilág Kiadó, Budapest, 2011.

SzALAI Pál: Barankovics István utolsó beszéde. Beszélö, I. évf. (1985) 2. Elérhető:

http://beszelo.c3.hu/cikkek/barankovics-istvan-utolso-beszede (A letöltés idöpontja: 2015. szeptember 15.)

SzEKFÜ Gyula: Forradalom után. Hasonmás kiadás. Sajtó alá rendezte, a jegyzeteket és a bevezető tanulmányt írta: GLATz Ferenc. Gondolat Kiadó, Budapest, 1983.

SzÜCS László (szerk.): Nagy Ferenc első kormányának minisztertanácsi jegyzőkönyvei. A. kötet. 1946. február 5. - 1946. július 19. Magyar Országos Levéltár, Budapest, 2003. Zsolt Béla: A végzetes toll. Publicisztikai írások. Nyilvánosság Klub - Századvég, Budapest, 1992. 


\section{Szakirodalom, feldolgozások}

AGÁRDI Péter: Nemzeti értékviták és kultúrafelfogások. 1847-2014. Napvilág Kiadó, Budapest, 2015.

ÁGH Attila: Vita a népi demokratikus forradalom jellegéről. Magyar Filozófiai Szemle, VIII. évf. (1964) 2. 381-386. p.

ÁGH Attila: Népi demokratikus forradalmunk néhány kérdése. Magyar Filozófiai Szemle, IX. évf. (1965) 2. 298-307. p.

ANDICS Erzsébet: Demokrácia és szocializmus 1918-19-ben. Szikra Kiadó, Budapest, 1950.

APOR Péter: Az elképzelt köztársaság. A Magyarországi Tanácsköztársaság utóélete. 19451989. MTA Bölcsészettudományi Kutatóközpont Történettudományi Intézet, Budapest, 2014.

APPLEBAuM, Anne: Vasfüggöny. Kelet-Európa megtörése 1944-1956. Európa Könyvkiadó, Budapest, 2014.

ARON, Raymond: Demokrácia és totalitarizmus. L'Harmattan Kiadó - Szegedi Tudományegyetem Filozófia Tanszék, Budapest, 2005.

Az 1945-1947-es Nemzetgyülés Almanachja. Elektronikusan elérhető: http://www.ogyk.hu/ekonyvt/mpgy/alm/almanach_1945-47/1945_ngy_a_t587.htm (A letöltés időpontja: 2015. december 13.)

BALÁZs Béla: Népmozgalom és a nemzeti bizottságok 1945-1946. Kossuth Könyvkiadó, Budapest, 1961.

BALÁzS György: Makó, 1944-45. A közigazgatás újjáéledése az első felszabadult magyar városban. Élet és Tudomány, XXXII. évf. (1977) március 25. 358-359. p.

BALOG Iván: Politikai hisztériák Közép- és Kelet-Európában. Bibó István fasizmusról, nacionalizmusról, antiszemitizmusról. Argumentum Kiadó-Bibó István Szellemi Műhely, Budapest, 2004.

BALOG Iván: Bibó István recepciója. Politikai átértelmezések. Argumentum Kiadó, Bibó István Szellemi Mühely. Budapest, 2010.

BALOGH Margit - GERGELY Jenő: Egyházak az újkori Magyarországon 1790-1992. História, Budapest, 1993.

BALOGH Sándor - SÁGVÁRI Ágnes: A népi demokratikus forradalom magyarországi győzelmének történetéhez. Századok, XCVII. évf. (1963) 6. 1322-1340. p.

BALOGH Sándor: A népi demokratikus forradalom néhány kérdéséről. Magyar Tudomány, LXIX. évf. (1964) 11. 687-698. p. 
BALOGH Sándor: A Magyar Kommunista Párt értelmiségi politikájának felszabadulás utáni történetéből. Századok, XCIX. évf. (1965) 3. 458-483. p.

BALOGH Sándor: A demokrácia kérdései a magyarországi politikai pártok szervezeti felépítésében a felszabadulás után. Történelmi Szemle, XVIII. évf. (1975) 1. 50-67. p.

BALOGH Sándor: Parlamenti és pártharcok Magyarországon 1945-1947. Kossuth Könyvkiadó, Budapest, 1975.

BALOGH Sándor (szerk.): Földet, köztársaságot, állami iskolát! Viták a magyar parlamentben 1944-1948. Gondolat Kiadó, Budapest, 1980.

BALOGH Sándor: A demokrácia kérdései Magyarországon a felszabadulás után. In: Ideológia és demokrácia. A Magyar Politikatudományi Társaság évkönyve. Magyar Politikatudományi Társaság, Budapest, 1984. 162-175. p.

BALOGH Sándor: A magyar népi demokrácia demokratizmusáról (1944-1946). Történelmi Szemle, XXVII. évf. (1984) 1-2. 279-291. p.

BALOGH Sándor: Népi demokratikus örökségünk: parlamentáris és közvetlen demokrácia Magyarországon, 1944-1948. Századok, CXIX. évf. (1985) 2. 385-422. p.

BALOGH Sándor: Nagy Imre a népi demokráciáról és a magyarországi demokratikus fejlődésről. Múltunk - politikatörténeti folyóirat. XXXVII. évf. (1992) 4. 33-39. p. BALOGH Sándor et al: Miért alakult ki az államszocializmus? I-II. In: Eszmélet, VII. évf. (1995) 25. 4-66. p. Elektronikusan elérhető:

http://epa.oszk.hu/01700/01739/00010/eszmelet_EPA01739_25.item918.htm (A letöltés időpontja: 2015. október 31.)

BALOGH Sándor: Népi demokrácia vagy „népidemokrácia”? In: FEITL István, IzsÁK Lajos, SzÉKELY Gábor (szerk.): Fordulat a világban és Magyarországon 1947-1949. Napvilág Kiadó, Budapest, 2000. 381-389. p.

BALOGH Sándor: Szabad és demokratikus választás - 1945. In: FöLDES György - HUBAI László (szerk.): Parlamenti választások Magyarországon. 1920-2010. Napvilág Kiadó, Budapest, 2010. 216-242. p.

BAŃCZEROWSKI, Janusz: Metanyelvi struktúrák szerepe a jelentés módosításában. Elérhető: http://www.c3.hu/ nyelvor/period/1241/124101.htm\#002. (A letöltés időpontja: 2015. szeptember 15.)

BARÁTH Magdolna: Magyar-szovjet kapcsolatok 1944-1953 között. In: SzVÁK Gyula (szerk.): A magyar-orosz kapcsolatok tizenkét évszázada. Az ELTE Russzisztikai Központ 2005. május 26-i ünnepi konferenciájának előadása. ELTE Russzisztikai Központ, Budapest, 2005. 67-72. p. Elérhetö: 
http://www.russtudies.hu/php/upload/File/11Barath-M.pdf (A letöltés időpontja: 2015. október 21.)

BARTHA Eszter: Történetírás és ideológia: vita a totalitarizmusról. Múltunk, LVIII. évf. (2013) 3. 8-38. p.

BECK, Carl: Leadership Attributes in Eastern Europe : The Effect of Country and Time. In: Carl BECK et al. (szerk.): Comparative Communist Political Leadership. David McKay Company Inc., New York, 1973.

BÉKÉs Csaba: A hidegháború eredete. In: Évkönyv 1999. VII. Magyarország a jelenkorban. 1956-os Intézet, Budapest, 1999. 217-226. p.

BÉKÉS Csaba: Lopakodó forradalom. Kelet-Közép-Európa szovjetizálása. Rubicon, XXVI. évf. (2015) 9. 78-79. p.

BENCE György - KIS János: Határolt forradalom, megszorított többpártrendszer, feltételes szuverenitás. In: Bibó-emlékkönyv I. Század-vég. Budapest -Európai Protestáns Magyar Szabadegyetem, Bern, 1991. 386-403. p.

BENCSIK Péter: Politikai viszonyok Hódmezővásárhelyen 1947-ben a kékcédulás választások előtt. Belvedere Meridionale, XIX. évf. (2007) 5-8. 40-63. p.

BENCSIK Péter: „A történész... szükségszerűen a szereplők és a nézőközönség közt foglal helyet”. Beszélgetés Papp Gyulával. Aetas, XXIV. évf. (2009) 2. 145-158. p.

BENCSIK Péter: A Rákosi-rendszer állama 1945-1956. In: SzABÓ Pál Csaba (szerk.): A magyar állam története 1711-2006. JATE Press, Szeged, 2010. 223-254. p.

BENCSIK Péter: Az európai népi demokratikus és szocialista országok alkotmányainak összehasonlító vizsgálata. Múltunk, LVII. évf. (2012) 3. 153-205. p.

BENCSIK Péter: Hódmezővásárhely politikai élete 1944-1950 között. Elérhető: http://allamszocializmus.lapunk.hu/tarhely/allamszocializmus/dokumentumok/hodmezo.p df (A letöltés időpontja: 2015. november 27.)

BENCSIK Péter: Csehszlovákia története dokumentumokban. Napvilág Kiadó, Budapest, 2016.

BÉNDEK Péter: A „demokrácia” értelme: szóbeszéd egy banalitásról. In: SzABÓ Márton (szerk.): Szövegvalóság. Írások a szimbolikus és diszkurziv politikáról. Scientia Humana, Budapest, 1997. 159-169. p.

BENKÖ Péter: A Nemzeti Parasztpárt és a szocializmus 1947-1948. Kossuth Kiadó, Budapest, 1988.

BEREND T. Iván - SzAKÁCS Sándor: Hozzászólás a népi demokratikus forradalom jellegéről folyó vitához. Párttörténeti Közlemények, X. évf. (1964) 3. 207-233. p. 
BERÉNYI Sándor: A magyar népi demokratikus állam közigazgatása. 1944-1945. Kossuth Könyvkiadó, Budapest, 1987.

BIHARI Mihály: Magyar politika 1944-2004. Politikai és hatalmi viszonyok. Osiris, Budapest, 2005 .

BODA Zsolt: Narratív közpolitika elemzés. In: SzABÓ Márton (szerk.): Szövegvalóság. Írások a szimbolikus és diszkurziv politikáról. Scientia Humana, Budapest, 1997. 113-131. p.

BÓDY Zsombor: Két totalitarizmus között? Az 1945-48-as évek értelmezéséröl. Kommentár, III. évf. (2008) 3. 61-69. p.

BÓKAY Antal: Önéletrajz és szelf-fogalom a dekonstrukció és pszichoanalízis határán. In:

MEKIS D. János - Z. VARGA Zoltán (szerk.): Írott és olvasott identitás - Az önéletrajzi müfajok kontextusai. L'Harmattan Kiadó, Budapest, 2008. 33-65. p.

BOKOR Péter: Kovács Béla elhurcoltatása. Dokumentumdráma a magyar demokrácia elleni merényletről - 1947. Mozgó Világ, XVIII. évf. (1992) 11. 93-102. p.

BORBÁNDI Gyula: A magyar emigráció életrajza. 1945-1985. Európai Protestáns Magyar Szabadegyetem, Bern, 1985. Elérhetö: http://mek.oszk.hu/03400/03472/html/ A letöltés időpontja: 2015. április 15.

BORHI László: Magyarország a hidegháborúban: A Szovjetunió és az Egyesült Államok között, 1945-1956. Corvina, Budapest, 2005.

BORHI László: Nagyhatalmi érdekek hálójában. Az Egyesült Államok és Magyarország kapcsolata a második világháborútól a rendszerváltozásig. Osiris Kiadó - MTA Bölcsészettudományi Kutatóközpont Történettudományi Intézet, Budapest, 2015.

BotTONI, Stefano: A várva várt Nyugat: Kelet-Európa története 1944-től napjainkig. MTA BTK Történettudományi Intézet, Budapest, 2015.

Brown, J. F.: Bulgaria Under Communist Rule. Pall Mall Press, London, 1970.

BRUNNER, Otto - CONZE, Werner - KoSELLECK, Reinhart (szerk.): A demokrácia. Jószöveg Mühely, Budapest, 1999.

BRZEZINSKI, Zbigniew Kazimierz: Ideology and Power in Soviet Politics. Frederick A. Praeger, New York, 1962.

BRZEZINSKI, Zbigniew Kazimierz: The Soviet Bloc. Unity and Conflict. Mass Harvard Univ. Press, Cambridge, 1969.

BrZEZINSKI, Zbigniew Kazimierz: Between two Ages. America's Role in the Technetronic Era. The Viking Press, New York, 1970.

BuJDosó Anna: Vélemények, viták a demokráciáról 1944 novembere és 1945 áprilisa között. In: KISS Endre - TÜTŐ László (szerk.): A magyar gondolkodás: 1944 és 1948 között. 
Eötvös Loránd Tudományegyetem Bölcsészettudományi Kar-Tankönyvkiadó, Budapest, 1990.

BuZÁs László: Makói hírlapok és folyóiratok bibliográfiája 1870-1970. A Makói Múzeum

Füzetei 10. Makó Város, Makó, 1972. 10-11. p.

CARL J., Friedrich - BRZEZINSKI, Zbigniew K.: Totalitarian Dictatorship and Autocracy.

Harvard University Press, Cambridge, 1965.

CARVER, Terell: Diskurzuselemzés és a „nyelvi fordulat”. Politikatudományi Szemle, XIII. évf. (2004) 4. Elérhető:

http://www.poltudszemle.hu/szamok/2004_4szam/2004_4_carver.pdf (A letöltés időpontja: 2016. szeptember 2.)

CSAPODY Miklós: „A világban helyt állani...” Bálint Sándor élete és politikai működése 1904-1980. Korona Kiadó, Budapest, 2004.

CSAPODY Miklós: Bálint Sándor (1904-1980). Életrajz. Akadémiai Kiadó, Budapest, 2013. CSEPELI György: A maffiaállam használt ruhája. Mozgó Világ, XXXIX. évf. (2013) 9.

Elérhetö: http://www.mozgovilag.hu/csepeli-gyorgy-a-maffiaallam-hasznalt-ruhaja/ (A letöltés időpontja: 2016. január 31.)

CSICSERY- RÓNAY István - CSERENYEY Géza: Koncepciós per a Független Kisgazdapárt szétzúzására 1947. 1956-os Intézet, Budapest, 1998.

CsIzMADIA Andor: A nemzeti bizottságok állami tevékenysége 1944-1949. Közgazdasági és Jogi Könyvkiadó, Budapest, 1968.

CSIZMADIA Ervin: Diskurzus és diktatúra. A magyar értelmiség vitái Nyugat-Európáról a késő Kádár-rendszerben. Századvég Kiadó, Budapest, 2001.

DAHL, A. Robert: Forradalom után. Autoritás a jó társadalomban. Osiris Kiadó - Readers International, Budapest, 1995. 55-90. p.

DANIELS, Robert V.: The State and Revolution: A Case Study in the Genesis and Transformation of Communist Ideology. The American Slavic and East European Review, XII. évf. (1953) 1. 22-43. p.

DANIELS, Robert V.: Így értik az oroszok. In: Szabadság/Harcosok. Hidegháborús írások.

Válogatás a Commentary antikommunista írásaiból. Közép- és Kelet-Európai Történelem és Társadalom Kutatásáért Közalapítvány, Budapest, 2015. 66-80. p.

DEÁK István: Ötventől a száz százalékig - Magyarország a nagyhatalmi érdekszférák kialakulása és megszilárdulása korában, 1943-1947. Új Látóhatár, XXXII. évf. (1981) 2. 207-219. p. 
DÉNES Iván Zoltán: Egy igazságtalanság két értelmezése. Szekfü Gyula és Bibó István a párizsi békeszerződésről. Magyar Tudomány, CX. évf. (2003) 6. Elektronikusan elérhető: http://www.matud.iif.hu/03jun/denes.html (A letöltés időpontja: 2016. február 6.)

DÉNES Iván Zoltán: A történelmi Magyarország eszménye. Szekfü Gyula a történetíró és ideológus. Kalligram Kiadó, Pozsony, 2015.

Deutscher, Isaac: Sztálin. Politikai életrajz. Európa Kiadó, Budapest, 1990.

DiECKMAnN, Walther: A politikai szavak tartalma. In: SZABÓ Márton - KISS Balázs - BODA

Zsolt (szerk): Szövegváltozatok a politikára. Nyelv, szimbólum, retorika, diskurzus. Nemzeti Tankönyvkiadó - Universitas, Budapest, 2000. 28-52. p.

DILAS, Milovan: Találkozások Sztálinnal. Magvető Kiadó, Budapest, 1989.

DonÁTH Ferenc: A Márciusi Fronttól Monorig. Tanulmányok, vázlatok, emlékezések.

Válogatta: VALUCH Tibor. MTA Közgazdaságtudományi Intézet - Századvég Kiadó, Budapest, 1992.

E. FeHÉR Pál: A Bibó-probléma. Kritika, VIII. évf. (1979) 9. 25-27. p.

Edelman, Murray: Politikai ellenségek konstruálása. In. Szabó Márton (szerk.): Az ellenség neve. Jószöveg könyvek, Budapest, 1998. 88-123. p.

EDUARD, Mark: Revolution by Degrees. Stalin's National-Front Strategy for Europe, 19411947. Cold War International History Project. Working Paper No. 31 Washington, D.C., 2001. Elérhető: http://www.wilsoncenter.org/sites/default/files/ACFB11.pdf (A letöltés időpontja: 2015. április 15.)

EÖRSI István: Tünődések egy régi vitáról. In: Bibó-emlékkönyv. Századvég Kiadó - Európai Protestáns Magyar Szabadegyetem, Budapest-Bern, 1991. 300-312.

ERDEI Ferenc: Város és Vidéke. Akadémiai Kiadó, Budapest 1977.

ERDÉSZ Ádám: A történelem tanúja - Kovács Imre visszaemlékezéseiről. In. Kovács Imre centenáriuma. Tudományos emlékülés a Politikatörténeti Intézetben. Napvilág Kiadó, Budapest, 2013. 249-269. p.

ERÉNYI Tibor: Többpárti választások és parlamentarizmus Magyarországon 1920-1947. In:

FöLDES György - HuBAI László (szerk.): Parlamenti választások Magyarországon. 19202010. Napvilág Kiadó, Budapest, 2010. 266-282. p

ESTI Béla: A magyar munkásosztály politikai-szervezeti egységének megvalósulása. In:

LACKÓ Miklós (szerk.): Tanulmányok a magyar népi demokrácia történetéből. Akadémiai Kiadó, Budapest, 1955. 499-542. p. 
FAZAKAS Gergely - MIRU György - VELKEY Ferenc (szerk.): „Politica philosophiai okoskodás" Politikai nyelvek és történeti kontextusok a középkortól a 20. századig. Debreceni Egyetem, Debrecen, 2013. Elérhető:

https://www.academia.edu/11159587/_Politica_philosophiai_okoskod\%C3\%A1s_Politik ai_nyelvek_\%C3\%A9s_t\%C3\%B6rt\%C3\%A9neti_kontextusok_a_k\%C3\%B6z\%C3\%A 9pkort\%C3\%B31_a_20._sz\%C3\%A1zadig (A letöltés időpontja: 2016. szeptember 20.)

FEITL István - IZSÁK Lajos - SzÉKELY Gábor (szerk.): Fordulat a világban és Magyarországon (1947-1949). Napvilág Kiadó, Budapest, 2000.

FEITL István (szerk.): Köztársaság a modern kori történelem fényében. Napvilág Kiadó, Budapest, 2007.

FEITL István: Az ideiglenesség időszaka: Magyarország 1944-1945-ben. Eszmélet, XXVII. évf. (2015) nyár. 5-41. p. Elérhető: http://eszmelet.hu/wpcontent/uploads/2015/10/eszmelet106nyomdai.pdf (A letöltés idöpontja: 2015. november 15.)

FEITL István: Rákosi Mátyás - Visszaemlékezések 1940-1956. Elérhető: http://napvilagkiado.eu/webaruhaz/shop.product_details/11forraskiadvanyok/flypage.tpl/113-rakosi-matyas-visszaemlekezesek-1940-1956/ (A letöltés időpontja: 2015. október 1.)

FEJTŐ Ferenc: A népi demokráciák története. 1-2. kötet. Magvető-Magyar Füzetek, Budapest- Párizs, 1991.

FELKAI Dénes: Mozgalmas élet. Zrínyi Katonai Kiadó, Budapest, 1979.

FERRERO, Guglielmo: A hatalom. A legitimitás elvei a történelemben. Kairosz Kiadó, Budapest, 2001.

FIALA Ferenc: Zavaros évek. Gede Testvérek BT., Budapest, 2003.

FISCHER-GALATI, Stephen: The New Rumania: From People's Democracy to Socialist Republic. The M.I.T. Press, Cambridge - London, 1967.

FEISCHMIDT Margit - KovÁCs Éva (szerk.): Kvalitatív módszerek az empirikus társadalomés kultúrakutatásban. Digitális tankönyv, PTE-BTK Kommunikációs Tanszék, udapest/Debrecen, 2006. Elérhetö: http://commonline.hu/content/feischmidt-margitkov\%C3\%A1cs-\%C3\%A9va-szerk-kvalitat\%C3\%ADv-m\%C3\%B3dszerek-azempirikus-t\%C3\%A1rsadalom-\%C3\%A9s-kult\%C3\%BAraku (A letöltés időpontja: 2016. szeptember 3.) 
FOGARASI Béla: Társadalmi lét és társadalmi tudat az átmeneti korszakban. A Magyar

Tudományos Akadémia II. Társadalmi-Történeti Tudományok Osztályának

Közleményei. I. kötet 1. szám. Magyar Tudományos Akadémia. Budapest, 1950.

FoucAult, Michel: A diskurzus rendje. Holmi, III. évf. (1991) 7. Elérhető: http://www.holmi.org/1991/07/michel-foucault-a-diskurzus-rendje-torok-gabor-forditasa (A letöltés időpontja: 2016. szeptember 2.)

FÖGLEIN Gizella: A magyar népi demokrácia születésnapja. In: BALOGH Sándor (szerk.): A felszabadulás utáni történetünkröl. I. kötet. Kossuth Könyvkiadó, Budapest, 1987. 31-36. p.

FÖGLEIN Gizella: Államforma és államfői jogkör Magyarországon 1944-1949. Osiris Kiadó, Budapest, 2001.

FÖLDES György - HuBAI László (szerk.): Parlamenti választások Magyarországon. 1920_ 2010. Napvilág Kiadó, Budapest, 2010.

FÖLDESI Margit: A Szövetséges Ellenőrző Bizottság Magyarországon: visszaemlékezések, diplomáciai jelentések tükrében 1945-1947. Ikva, Budapest, 1995.

FöLDESI Margit: A szabadság megszállása. A megszállók szabadsága. Kairosz Kiadó, Budapest, 2002.

FÖLDESI Margit-SzERENCSÉS Károly: Halványkék választás. Kairosz Kiadó, Budapest, 2001. FÖLDESI Margit-SZERENCSÉS Károly: A megbélyegzés hatalma. Pfeiffer Zoltán (1900-1981). Kairosz Kiadó, Szentendre, 2003.

FÖLDESI Tamás: Néhány gondolat a népi demokrácia fogalmáról. Magyar Filozófiai Szemle, VI. évf. (1962) 1. 80-111. p.

G. FAZEKAS Erzsébet: Magyarország felszabadítása és a népi demokratikus forradalmunk érlelődésének néhány kérdése. In: LACKÓ Miklós (szerk.): Tanulmányok a magyar népi demokrácia történetéből. Akadémiai Kiadó, Budapest, 1955. 7-87. p.

GÁBOR Kálmán - VÁGVÖLGYI András: A kisvárosi fejlődés sajátos útja. Adalékok Makó demográfiai helyzetéhez. A Makói Múzeum Füzetei 12. Makó Város, Makó, 1974.

GANTNER Péter: Egy elfelejtett államfő. Zsedényi Béla életpályája. I.A.T. Kiadó, Budapest, 2008.

GANTNER Péter: Valentiny Ágoston, az elfelejtett államférfi. I.A.T. Kiadó, Budapest, 2010. GAREAU, Frederick H.: The Cold War 1947 to 1967: A Quantitative Study. University of Denver, Denver, 1969.

GATI, Charles: Hungary and the Soviet Bloc. Duke Univ. Press, Durham, 1986. GATI, Charles: Magyarország a Kreml árnyékában. Századvég, Budapest, 1990. 
GLATZ Ferenc: Balogh Sándor. Elérhető:

http://www.historia.hu/archivum/2005/0509glatz2.htm (A letöltés időpontja: 2015. október 30.)

GLÓZER Rita: A diskurzuselemzés a társadalomtudományokban. In: FEISCHMIDT Margit KovÁcs Éva (szerk.): Kvalitatív módszerek az empirikus társadalom- és kultúrakutatásban. Digitális tankönyv, PTE-BTK Kommunikációs Tanszék, Budapest/Debrecen, $2006 . \quad$ Elérhető:

http://mmi.elte.hu/szabadbolcseszet/mmi.elte.hu/szabadbolcseszet/index92e1.html?option =com tanelem\&id tanelem=831\&tip=0 (A letöltés időpontja: 2016. szeptember 3.)

GLÓZER Rita: Diskurzusok a civil társadalomról. Egy fogalom transzformációi a rendszerváltó évek értelmiségi közbeszédében. L’Harmattan Kiadó, Budapest, 2008.

GYÁNI Gábor: A napló mint társadalomtörténeti forrás. In: Uő: Emlékezés, emlékezet és a történelem elbeszélése. Napvilág, Budapest, 2000. 148-152. p. Elérhető:

http://www.szabarchiv.hu/drupal/sites/default/files/27-35.pdf (A letöltés időpontja: 2015. október 22.)

GYÁNI Gábor: Narrativitás és jelentésgeneráló retorikai elemek a történetírói diskurzusban.

In: RÁKAI Orsolya -Z. KovÁCs Zoltán (szerk.): A narratív identitás kérdései a társadalomtudományokban. Gondolat Kiadói Kör - Pompeji, Budapest, 2003. 78-95. p.

GYÁNI Gábor: Esemény és narratíva: A múlt és jelen mint nézőpont. In: Esemény és narratíva. Történetiség - elbeszélés(ek) - interpretáció. Bibliotheca Nationalis Hungariae - Gondolat Kiadó, Budapest, 2013.

GYÁNI Gábor: Valóban korszakhatár 1945? Levéltári közlemények, 2015. (86. évf.) 1-2. sz. 513. p.

GYARMATI György: Történetírásunk a felszabadulás utáni korszakról. Századok, CXIV. sz. (1980) 3. 466-507.p.

GYARMATI György: A diktatúra intézményrendszerének kiépítése Magyarországon (19481950). In: Jelenkor, XXXIV. évf. (1991) 2. 138-147. p.

GYARMATI György: Harc a közigazgatás birtoklásáért. A koalíción belüli pártküzdelmek az 1946. évi hatalmi dualizmus időszakában. Századok, CXXX: évf. (1996) 3. 497-570. p. GYARMATI György: A társadalom közérzete a fordulat évében. In: FEITL István, IzSÁK Lajos, SzÉKELY Gábor (szerk.): Fordulat a világban és Magyarországon 1947-1949. Napvilág Kiadó, Budapest, 2000. 118-137. p.)

GYARMATI György: Magyarország története: Demokráciából a diktatúrába 1945-1956.

Kossuth Kiadó, Budapest, 2010. 
GYARMATI György: A Rákosi-korszak: rendszerváltó fordulatok évtizede Magyarországon, 1945-1956. Állambiztonsági Szolgálatok Történeti Levéltára - Rubicon, Budapest, 2011.

GYURGYÁK János: Ezzé lett magyar hazátok. A magyar nemzeteszme és a nacionalizmus története. Osiris Kiadó, Budapest, 2007.

GYURKÓ László: Arcképvázlat történelmi háttérrel. Magvető Kiadó, Budapest, 1982.

H. HARASZTI Éva: Anglia és Magyarország párhuzamos története. 1945-1951. Scolar Kiadó, Budapest, 2002.

HAAS György: Dessewffy Gyula, egy magyar girondista. Magyar Szemle, XIX. évf. (2010) 34. 38-52. p. Elérhetö:

http://www.magyarszemle.hu/cikk/20100519_dessewffy_gyula_egy_magyar_girondista (A letöltés időpontja: 2016. január 31.)

HAAS György: Egy elfeledett szabadsághős - Kővágó József munkássága. Magyar Szemle, XXIII. évf. (2014) 3-4. Elérhető:

http://www.magyarszemle.hu/cikk/egy_elfeledett_szabadsaghos_kovago_jozsef_munkas saga (A letöltés időpontja: 2016. január 31.)

HABERMAS, Jürgen: A demokrácia három normatív modellje. In: HABERMAS, Jürgen:

Inklúzió, bevonás vagy bezárás. A nemzet, a jogállam és a demokrácia viszonyáról. http://epa.oszk.hu/02100/02121/00003/pdf/EPA02121_Fordulat_2009_5_10-87.pdf (A letöltés időpontja: 2017. április 29.)

HAHNER Péter: Nincs mentség. In: Élet és Irodalom, LVI. évf. (2012) 9. Elérhető: http://www.es.hu/hahner_peter;nincs_mentseg;2012-02-29.html (A letöltés időpontja: 2015. május 26.)

HAJDU Tibor: A koalíció titkai: 1945-1947 - Pártközi értekezletek. Politikai érdekegyeztetés, politikai konfrontáció 1944-1948. Mozgó Világ, XXX. évf. (2004) 5. 124-127. p.

HAJDU Tibor: Ki volt Károlyi Mihály? Napvilág Kiadó, Budapest, 2012.

HALMÁGYi Pál: A Makó és környékéért vívott harcok 1944 őszén. A Makói Múzeum Füzetei 65. Makó, 1989.

Hatos Pál: Az öreg Szekfü Gyula (1945-1955). Kommentár, VI. évf. (2011) 2.

Elektronikusan elérhető:

http://kommentar.info.hu/iras/2011_2/az_oreg_szekfu_gyula_1945_1955_\#foot14 (A letöltés időpontja: 2016. január 31.)

HATos Pál: Nyugatról Keletre? A köztes lét bukásai Szekfü Gyula történeti narratíváiban. Kommentár, X. évf. (2015) 6. 73-89. p. 
HEGEDÜS Géza: A magyar irodalom arcképcsarnoka. Elérhető:

http://mek.oszk.hu/01100/01149/html/index.htm A letöltés időpontja: 2016. január 16.

Heimann, Mary: Czechoslovakia: The State That Failed. Yale University Press, New Haven London, 2009.

HeINRICH, Hans-Georg: Hungary: Politics, Economics and Society. Frances Pinter, London, 1986.

HeLlER Ágnes: Az önéletrajzi emlékezés filozófiája. Múlt és Jövő Kiadó, Budapest, 2015.

HYMES, Dell: A nyelv és a társadalmi élet kölcsönhatásának vizsgálata. In: PLÉH Csaba-

SíKLAKI István-TERESTYÉNI Tamás (szerk.): Nyelv-kommunikáció-cselekvés. 458-495. p.

HoENSCH, Jörg Konrad: A History of Modern Hungary: 1867-1986. Longman, London - New

York, 1988.

Holmes, Leslie: Politics In The Communist World. Clarendon Press, Oxford, 1986.

HORÁNYI Károly: Vád és emlékezet. Lezáratlan eljárások Szabó Lőrinc ügyében. Kortárs,

LIV. évf. (2010) 1. Elérhető: http://epa.oszk.hu/00300/00381/00144/horanyi.htm (A letöltés időpontja: 2016. január 5.)

HoRVÁTH Attila - RÉVÉSz T. Mihály: Diktatórikus berendezkedések a 20. századi magyar alkotmánytörténetben. In: MEZEY Barna (szerk.): Magyar alkotmánytörténet. Osiris Kiadó, Budapest, 2003. 445-485. p.

HoRVÁTH Attila: A magyar sajtó története a szovjet típusú diktatúra idején. Médiatudományi Intézet, Budapest, 2013. Elérhető: http://mek.oszk.hu/13400/13447/13447.pdf (A letöltés időpontja: 2015. április 20.)

HoRvÁTH Dóra - Mitev Ariel: Alternatív kvalitatív kutatási kézikönyv. Alinea Kiadó, Budapest, 2015.

HORVÁTH János (szerk.): Tiltott történelmünk. Századvég Kiadó, Budapest, 2006.

HÖGYE Mihály: Állomások egy életpályán. In: NAGY Ferenc: Küzdelem a vasfüggöny mögött. 2. Európa - História, Budapest, 1990. 223-243. p.

HUBAI László: Viták és álláspontok a II. Magyar Köztársaságról. Múltunk, L. évf. (2005) 2. 203-220. p.

HUSZÁR Tibor: Bibó István - a gondolkodó, a politikus. In: BIBÓ István: Válogatott tanulmányok. Harmadik kötet. Szerkesztette: Huszár Tibor, Vida István, Nagy Endre. Magvető Kiadó, Budapest, 1986.

HuSzÁR Tibor: Erdei Ferenc. Politikai életrajz 1910-1971. Corvina Kiadó, Budapest, 2012. IGNÁCZ Károly: Hogyan vált kommunistává egy jómódú vidéki család sarja? Donáth Ferenc indulása. Múltunk, LIX. évf. (2014) 4. 4-11.p. 
IONESCU, Ghita: The Politics of The European Communist States. Weidenfeld \& Nicolson. London, 1967.

IzSÁK Lajos: Polgári ellenzéki pártok Magyarországon 1944-1949. Kossuth Kiadó. Budapest, 1983.

IzsÁK Lajos: A koalíció évei Magyarországon 1944-1948. Kozmosz Kiadó, Budapest, 1986.

IzSÁK Lajos: Az egypártrendszer létrehozása Magyarországon. Történelmi Szemle, XXXIV. évf. (1992) 1-2. 61-93. p.

IZSÁK Lajos: A parlamentarizmus veszett csatája - 1947. In: FöLDES György - HuBAI László (szerk.): Parlamenti választások Magyarországon. 1920-2010. Napvilág Kiadó, Budapest, 2010. 243-265. p.

IzSÁK Lajos: Barankovics István. In. IzSÁK Lajos: Pártok és politikusok Magyarországon 1944-1994. Napvilág Kiadó, Budapest, 2010. 294-300. p.

IzSÁK Lajos: „Két fordulat” jelenkori történelmükben: 1944-1945 és 1947-1949. In: IzSÁK Lajos: Pártok és politikusok Magyarországon 1944-1994. Napvilág Kiadó, Budapest, 2010. 178-187.p.

JANOS, Andrew C.: Haladás, hanyatlás, hegemónia Kelet-Közép-Európában. Helikon Kiadó, Budapest, 2003.

JÁszi Oszkár: A kommunizmus kilátástalansága és a szocializmus reformációja. Válogatás politikaelméleti írásaiból. Hét Torony Könyvkiadó, Budapest, 1989.

JUDT, Tony: A háború után. 1. Európa története 1945 óta. Európa Kiadó, Budapest, 2007. JUHÁSz Gyula: Gondolatok az 1945-1948 közötti társadalmi változások és társadalmi közérzet történetéhez Magyarországon. In: TóTH Miklós (szerk.): Önarcképünk sorsunk tükrében. 1945-1949. Sine ira et ratio. Hollandiai Mikes Kelemen Kör, Bleyerheide, 1984. 56-67.p.

K. HORVÁTH Zsolt: Önarcképcsarnok. A személyes emlékezés mint történeti probléma. In: SzEKERES András (szerk.): A történész szerszámosládája. A jelenkori történeti gondolkodás néhány aspektusa. L’Harmattan - Atelier, Budapest, 2002. 81-103. p. KABDEBÓ Lóránt: Szabó Lőrinc műhelyében. In: SzABÓ Lőrinc: Napló, levelek, cikkek. Szépirodalmi Könyvkiadó, Budapest, 1974. 5-9. p.

KABDEBÓ Lóránt: Egy eszmélet története. In: SzABÓ Lörinc: Bírákhoz és barátokhoz (Napló és védőbeszédek 1945-ből). Magvető Kiadó, Budapest, 1990. 253-334. p.

KALLA Zsuzsa: „Mivé egykor talán lehetni álmodoztam.” A naplóíró Bártfay László. Doktori disszertáció. Eötvös Loránd Tudományegyetem Bölcsészettudományi Kar, Budapest, 
2006. Elérhető: http://doktori.btk.elte.hu/lit/kalla/diss.pdf (A letöltés időpontja: 2015. október 22.)

KALMÁR Melinda: Ennivaló és hozomány. A kora kádárizmus ideológiája. Magvető Kiadó, Budapest, 1998.

KALMÁR Melinda: Az optimalizálás kísérlete. Reformmodell a kultúrában 1965-1973. In: RAINER M. János (szerk.): „Hatvanas évek” Magyarországon. Tanulmányok. 1956-os Intézet, Budapest, 2004. 161-197. p.

KALMÁR Melinda: Történelmi galaxisok vonzásában. Magyarország és a szovjetrendszer, 1945-1990. Osiris Kiadó, Budapest, 2014.

KÁRPÁTI Sándor: A szocialista forradalom hazánkban mint a népi demokratikus forradalmak egyik formája. In: Magyar Filozófiai Szemle, VII. évf. (1963) 3. 361-378 p.

KEEP, John L. H.: Last of the Empires: A History of the Soviet Union. Oxford University Press, New York, 1995.

KENDE Péter: A Károlyi-önéletrajz. A megcsonkított üzenet. Irodalmi Újság. 1978. márciusáprilis.

KENDE Péter: Budapest 1947 - Prága 1948. Hasonlóságok és különbségek. In: Az 1956-os Magyar Forradalom Történetének Dokumentációs és Kutatóintézete - Közalapítvány Évkönyv VI. 1998. 1956-os Intézet, Budapest, 1998. 187-192. p. Elérhető:

http://www.rev.hu/rev/htdocs/hu/kiadvanyok/evkonyv_1998.pdf (A letöltés időpontja: 2015. május 26.)

KENDE Péter: Hogyan vált 1945 reményből megosztó erővé? In: RAINER M. János STANDEISKY Éva (szerk.): A demokrácia reménye - Magyarország, 1945. 1956-os Intézet, Budapest, 2005. 176-182. p.

KENDE Péter: A kommunizmus és a magyar társadalom. Kalligram, Pozsony, 2013.

KENEDI János: A hajthatatlan és a megalkuvó. In: Bibó-emlékkönyv. Századvég KiadóEurópai Protestáns Magyar Szabadegyetem, Budapest-Bern, 1991. 194-230. p.

KERÉKGYÁRTÓ Béla: Egy kelet-európai demokrata viszontagságai. In: KISS Endre - TÜTŐ László (szerk.): A magyar gondolkodás 1944 és 1948 között. Eötvös Loránd Tudományegyetem Bölcsészettudományi Kar - Tankönyvkiadó, Budapest, 1990. 273333. p.

KIS András: A Magyar Közösségtől a Földalatti Fővezérségig. Zrínyi Katonai Kiadó, Budapest, 1969.

KISS Andor: „Megtalálni a szabadság rendjét.” Bibó István életművéről. Forrás, XXXIV. évf. (2002) 10. 98-103. p. 
KoRBEL, Josef: The Communist Subversion Of Czechoslovakia 1938-1948 : The Failure of Coexistence. Princeton University Press, Princeton, 1959.

KORNAI János: A szocialista rendszer. Kritikai politikai gazdaságtan. Heti Világgazdaság Kiadó, Budapest, 1993.

KoROM Mihály (szerk.): Makó az első felszabadult magyar város. II. kötet. Makó Városi Tanács, Makó, 1974.

KOROM Mihály: Magyarország ideiglenes nemzeti kormánya és a fegyverszünet, 1944-45.

Akadémiai Kiadó, Budapest, 1981.

KoROM Mihály: Népi demokráciánk születése. Népi bizottságok és nemzeti összefogás KeletMagyarországon 1944 őszén. Hajdú-Bihar Megyei Tanács, Debrecen, 1981.

KoROM Mihály: Makó felszabadulása. In: Makó negyven éve szabad. Várospolitikai füzetek 6. Makó Város, Makó, 1985.

KOSELLECK, Reinhart: Az asszimetrikus ellenfogalmak történeti-politikai szemantikája. Jószöveg tankönyvek, Budapest, 1997.

KosEllecK, Reinhart: Ellenségfogalmak. In. Szabó Márton (szerk.): Az ellenség neve. Jószöveg könyvek, Budapest, 1998. 12-23. p.

KOSELLECK, Reinhart: Elmúlt jövő: a történeti idők szemantikája. Atlantisz, Budapest, 2003. KovÁCs Gábor: Guglielmo Ferrero és Bibó István legitimitáskoncepciója. In: Bibó István és a XX. század magyar történelme. Nemzetközi tudományos konferencia. 2001. október 2627. Trento. Elektronikusan elérhetö: http://mek.oszk.hu/02200/02224/02224.pdf (A letöltés időpontja: 2016. február 6.)

KovÁCs Gábor: Az európai egyensúlytól a kölcsönös szolgáltatások társadalmáig. Bibó István, a politikai gondolkodó. Argumentum Kiadó - Bibó István Szellemi Mühely, Budapest, 2004.

KovÁCs Gábor: Forradalom, életmód, hatalom, kultúra. A politikai gondolkodás jellemzői a hatvanas években. In. RAINER M. János (szerk.): „Hatvanas évek” Magyarországon. Tanulmányok. 1956-os Intézet, Budapest, 2004. 198-236. p. /216. p./

KovÁCs Gábor: Politikai gyakorlat és politikai teória. Néhány gondolat Bibó István halálának 25. évfordulóján. Politikatudományi Szemle, XIII. évf. (2004) 1-2. 298-299. p.

KovÁCs Gábor: Tervezés és/vagy demokrácia? Demokráciafelfogások a második világháború alatt és után - nemzetközi eszmetörténeti körkép. In: RAINER M. János - STANDEISKY Éva (szerk.): A demokrácia reménye: Magyarország, 1945. 1956-os Intézet, Budapest, 2005. 9-28. p. 
KovÁCs Imre: Népiség, radikalizmus, demokrácia. Publicisztikai írások. Gondolat -

Nyilvánosság Klub - Századvég, Budapest, 1992.

KovRIG, Benneth: Communism in Hungary: From Kun to Kádár. Hoover Institution Press, Stanford, 1979.

KozÁK Gyula: Az identitás nélküli ember. Országos Széchenyi Könyvtár. Budapest, 2006.

Elérhetö: http://www.rev.hu/portal/page/portal/rev/kiadvanyok/evkonyv03/kozak (A letöltés időpontja: 2015. október 21.)

KÖPECZI Béla: Erdei Ferenc, a politikai gondolkodó. A Makói Múzeum Füzetei 39. Makó Város, Makó, 1985.

KÖVÉR György: Losonczy Géza. 1917-1958. 1956-os Intézet, Budapest, 1998.

KÖVÉR György: Biográfia és társadalomtörténet. Osiris Kiadó, Budapest, 2014.

KUBINYI Ferenc: A Katonapolitika regénye. Malomfalvi Kiadó, California, 1994.

L. BALOGH Béni (szerk.): „Törvényes megszállás.” Szovjet csapatok Magyarországon 1944 és 1947 között. Magyar Nemzeti Levéltár, Budapest, 2015.

LÁNCZI András: Demokrácia és politikatudomány. Aula, Budapest, 2000. 193-204. p.

LENIN, Vlagyimir Iljics: A szociáldemokrácia két taktikája a demokratikus forradalomban 1905. Szikra Kiadó, Budapest, 1948.

LEVI, Giovanni: Az életrajz használatáról. Korall, I. évf. (2000) 2. 81-91. p.

LiCHTHEIM, George: Social Democracy and Communism: 1918-1968. Studies in Comparative Communism, III. évf. (1970) 1. 5-30. p.

LILLY, Carol S.: Problems of Persuasion: Communist Agitation and Propaganda in Post-war Yugoslavia, 1944-1948. Slavic Review, LIII. évf. (1994) 2. 395-413. p.

LITVÁN György: Koalíciós közjáték, 1945-1948. Rubicon, VII. évf. (1996) 1-2. sz. 40-46. p. Elektronikusan elérhető:

http://www.rubicon.hu/magyar/oldalak/koalicios_kozjatak_1945_1948/ (A letöltés időpontja: 2015. április 26.)

LITVÁN György: A magyar polgárság citoyen lelkiismerete. Csécsy Imre (1893-1961).

Holmi, XIII. évf. (2001) 6. 736-740. p.

LuKACS, John: A History of The Cold War. Garden City, Doubleday, 1962.

LUKACS, John: 1945. A nulla év. Európa Könyvkiadó, Budapest, 1996.

LUKACS, John: A huszadik század rövid története. Európa Könyvkiadó, Budapest, 2014.

LUKACS, John: A magyar forradalom tanulságai. Az új proletár. In: Szabadság/Harcosok.

Hidegháborús írások. Válogatás a Commentary antikommunista írásaiból. Közép- és 
Kelet-Európai Történelem és Társadalom Kutatásáért Közalapítvány, Budapest, 2015. 52-64. p.

M. KISS Sándor: Bevezető. In: SzEKÉR Nóra: A Magyar Testvéri Közösség története. „Norma” Nyomdász Kft., Hódmezővásárhely, 2010. 7-11. p.

MÉREI Gyula: A magyar népi demokrácia története. Felsőoktatási Jegyzetellátó Vállalat, Budapest, 1959.

MÉSZÁROS István: Boldogasszony Éve. Ecclesia, Budapest, 1994.

Mevius, Martin: Agents of Moscow. The Hungarian Cummunist Party and Origins of Socialism Patriotism 1941-1953. Oxford Press, Oxford, 2005.

MEZEI Géza: Befolyás vagy hegemónia? A háború utáni rendezés Kelet-Közép-Európában. Új Mandátum Könyvkiadó, Budapest, 2001.

Mezei Géza (szerk.): Európa és a hidegháború a dokumentumok tükrében. Európa kettészakítása és a kétpólusú nemzetközi rend születése (1945-1949). Új Mandátum, Budapest, 2001.

Miklós Péter: A koalíciós évek állama. In: SzABÓ Pál Csaba (szerk.): A magyar állam története 1711-2006. JATE Press, Szeged, 2010. 205-222. p.

MóD Aladár: Egyház és demokrácia. In: Társadalmi Szemle, II. évf. (1947) 12. 836-848. p.

MóD Aladár: A népi demokratikus forradalom és a magyar népi demokrácia elvi és történelmi kérdései. Valóság, II. évf. (1965) 3. 1-16. p.

MoLNÁR Attila Károly: A tanácskozó demokrácia és a megváltó csevegés. Nemzeti

Közszolgálati Egyetem - Molnár Tamás Kutató Központ, Budapest, 2014. 22-45. p.

MOLNÁR Erik: A magyar történetírás fejlödése az elmúlt évtizedben. Századok, XCIV. évf. (1960) 1-3. 45-58. p.

MOLNÁR János: A munkás- és paraszttömegek harca a Kommunista Párt vezetésével a reakció ellen. (1945. október - 1946. március) In: LACKÓ Miklós (szerk.): Tanulmányok a magyar népi demokrácia történetéből. Akadémiai Kiadó, Budapest, 1955. 291-372. p.

MOLNÁR János: A Szociáldemokrata Párt demokrácia-felfogásának fő vonásai 1944 után. In: A Magyar Politikatudományi Társaság évkönyve. Magyar Politikatudományi Társaság, Budapest, 1984. 168-175. p.

MURAY, Leslie A.: Bibó István politikai gondolkozása. Magyar Filozófiai Szemle, XXXVIII. évf. (1994) 3-4. 521-528. p.

MURI György: Az alkotmányozás politikai nyelve 1848-49-ben. L’Harmattan Kiadó-TIT Kossuth Klub, Budapest, 2015. 
MyANT, M.R.: Socialism and Democracy in Czechoslovakia 1945-1948. Cambridge University Pres, Cambridge, 1981.

NAGY Ágnes: A hétköznapi érdekérvényesítés politikai eszköztára: a mikroközösségek konfliktusai és a pártállami logikák. Múltunk, LIII. évf. (2008) 4. 281-287. p. Elérhető: http://epa.oszk.hu/00900/00995/00016/pdf/egykonyv08-4.pdf\#page=6 (A letöltés időpontja: 2015. április 26.)

NAGY Endre: A népfrontos népi demokrácia két alternatívája. (Lukács és Bibó vitája 1946ban a demokráciáról). In: Ideológia és demokrácia. A Magyar Politikatudományi Társaság évkönyve. Magyar Politikatudományi Társaság, 1984. 176-188.p.

NAGY Endre: Kovács Imre 2. Kritika, XLIII. évf. (2014) 3-4. 27-29. p. Elérhető:

http://www.kritikaonline.hu/kritika_14marc-aprilis_nagyendre.html (A letöltés időpontja: 2016. február 7.)

NEMES Dezső: A népi Magyarország fejlődése 1945-1960. Századok, XCIV. évf. (1960) 1-3. 1-44. p.

NEMES Dezső: Magyarország felszabadulása. Magyarország fejlődése a felszabadulás után. Kossuth Könyvkiadó, Budapest, 1960.

ORBÁN László: Vita a népi demokratikus korszak története feldolgozásának helyzetéröl. Századok, CXVI. évf. (1962) 3-4. 611-626. p.

ORMOS Mária: Politikai eszmék, politikai gyakorlatok a 20-21. században. Napvilág Kiadó, Budapest, 2009.

Orzoff, Andrea: Battle for the Castle. The Myth of Czechoslovakia in Europe,1914-1948. Oxford University Press, New York, 2009.

Ö. KovÁCs József: A paraszti társadalom felszámolása a kommunista diktatúrában. A vidéki Magyarország politikai társadalomtörténete 1945-1965. Korall, Budapest, 2012.

PALASIK Mária: A jogállam csapdái Magyarországon. (A Magyar Közösség pere mint eszköz a kisgazdapárt hatalomból történő kiszorításához). Századok, CXXIX. évf. (1995) 6. 1305-1330. p.

PALASIK Mária: A jogállam megteremtésének kísérlete és kudarca Magyarországon: 19441949. Napvilág Kiadó, Budapest, 2000.

PALASIK Mária: Chess Game for Democracy. Hungary Between East and West 1944-1947. McGill-Queen's University Press, Montreal \& Kingston, 2011.

PALASIK Mária: Kovács Béla 1908-1959. Occidental Press - Ezerkilencszáznegyvenöt Alapítvány - Századvég Kiadó, Budapest, 2002.

PÁNDI Ilona: A haladó magyar értelmiség útja. 1848-1948. Kossuth Kiadó, Budapest, 1977. 
PAPP Gyula: Az igazoló eljárások és a háborús bünök megtorlása 1945 után Magyarországon. Aetas, XXIV. évf. (2009) 2. 162-179. p.

PAPP István: Az elveszett reformkor. Kommentár, I. évf. (2006) 2. 46-54. p.

PAPP István: Az „ismeretlen” Bibó István. A népi mozgalom ideológusa. Kommentár, VI. évf.

(2011) 6. Elérhetö: http://kommentar.info.hu/iras/2011_6/az_ismeretlen_bibo_istvan (A letöltés időpontja: 2016. február 7.)

PAPP István: A magyar népi mozgalom története. 1920-1990. Jaffa Kiadó, 2012.

PAPP István: Donáth Ferenc és a közvetlen demokrácia. Múltunk, LIX. évf. (2014) 4. 23-38.

p.

PELLE János: Jászi Oszkár. Életrajzi, eszme- és kortörténeti esszé. XX. század Intézet, Budapest, 2001.

PERECZ László: Kimért időben. Bibó István koalíciós válságelemzése. In: DÉNES Iván Zoltán (szerk.): Bibó 100. Recepciók, értelmezések, alkalmazási kísérletek. Argumentum Kiadó - Bibó István Szellemi Mühely, Budapest, 2012.98-114. p.

PÉTER László: Miért éppen az Elbánál hasadt szét Európa? A népi demokratikus rendszer társadalmi gyökerei. In: Önarcképünk sorsunk tükrében 1945-1949. Sine ira et ratio. Hollandiai Mikes Kelemen Kör, Bleyerheide, 1984. 20-43. p.

PETRÁs Éva: Barankovics István és pártja az 1945-ös demokráciában és annak utóvédharcában. Múltunk, 2016/1 90-107.p.

PITTAWAY, Mark: The Politics of Legitimacy and Hungary's Postwar Transition.

Contemporary European History, XIII. évf. (2004) 4. 453-475. p.

PóK Attila: A javíthatatlan girondisták. A radikális demokrácia alternatívája 1945 után. Világosság, XL. évf. (1999) 3. 47-54. p.

PÜSKI Levente: Az államtól az államosított társadalomig. In: Korall, XIII. évf. (2012) 49. 132-136. p.

PÜSKI Levente: Ellenségből bűnbak. Az MKP arisztokráciaképe 1945 után. In: GYARMATI György - LENGVÁRI István - PÓK Attila - VONYÓ József (szerk.): Bűnbak minden időben - Bűnbakok a magyar és az egyetemes történelemben. Kronosz Kiadó, Budapest, 2013. 433-443. p.

R. HuTÁs Magdolna: A demokrácia szó jelentésfejlődése. In: Magyar Nyelvőr, XCVII. évf. (1973) 4. 476-483. p.

RAINER M. János: Nagy Imre politikai életrajz. Első kötet. 1896-1953. 1956-os Intézet, Budapest, 1996. 
RAINER M. János: A magyarországi fordulatok és a szovjet politika, 1944-48. In: Rubicon, IX. évf. (1998) 4-5. sz. 50-57. p.

RAINER M. János: Az eszmék útja, előzmények és események. In: KIRÁLY Béla - Lee W. CONGDON (szerk.): A magyar forradalom eszméi. Eltiprásuk és győzelmük (1956-1999). Atlanti Kutató és Kiadó - Társulat Alapítvány, Budapest, 2001. 21-45. p. Elérhető: http://www.rev.hu/portal/page/portal/rev/kiadvanyok/forradalom/eszmekutja (A letöltés időpontja: 2015. május 20.)

RAINER M. János: Demokrácia volt-e Magyarországon 1945 után? A „koalíciós időszak” és a Rákosi-korszak átmenetének kérdése. In: LŐRINC László (szerk.): Egyezzünk ki a múlttal! Mühelybeszélgetések történelmi mítoszainkról, tévhiteinkröl. Történelemtanárok Egylete, Budapest, 2010. 85-90. p.

RAINER M. János: A magyarországi sztálinizmusok - diskurzusok. In: RAINER M. János: Bevezetés a kádárizmusba. 1956-os Intézet - L’Harmattan, Budapest, 2011. 41-78. p. RAINER M. János: Bevezetés a kádárizmusba. 1956-os Intézet - L’Harmattan, Budapest, 2011.

RATHMANNÉ TÚRY Mária: A Kisgazdapárt demokrácia-koncepciója. 1945-1947. Oktatási Minisztérium Marxizmus-Leninizmus Oktatási Főosztály, Budapest, 1977.

RÉV István: Miért győzhetett oly elviselhetetlenül könnyen a kommunizmus Magyarországon? Rubicon, IV. évf. (1993) 7. 4-6. p.

RÉVÉSZ Béla: A proletárdiktatúra ideológiai funkciójának kriminalizálása. Elérhető: http://mek.oszk.hu/01900/01981/01981.htm\#b75 (A letöltés időpontja: 2016. január 31.) RÉVÉSZ Sándor: Szabó Zoltán, az antiteoretikus. Mozgó Világ, XXXVIII. évf. (2012) 3. Elérhetö: http://www.mozgovilag.hu/revesz-sandor-szabo-zoltan-az-antiteoretikus/ (A letöltés időpontja: 2016. január 31.)

RICEOUR, Paul: Erőszak és nyelv. In. Szabó Márton (szerk.): Az ellenség neve. Jószöveg könyvek, Budapest, 1998. 122-136. p.

RICOEUR, Paul: A szöveg mint modell: a hermeneutikai megértés. Lettre, VIII. évf. (2001) 42. sz. Elérhető: http://epa.oszk.hu/00000/00012/00026/ricoeur.htm (A letöltés időpontja: 2016. szeptember 2.)

RoMSICS Ignác: Az 1945 és 1948 közötti magyar történelem a magyar historiográfiában. In: IzSÁK Lajos - STEMLER Gyulas (szerk.): Vissza a történelemhez... Emlékkönyv Balogh Sándor 70. születésnapjára. Napvilág Kiadó, Budapest, 1996. 293-299. p. RoMSICS Ignác: Magyarország története a XX. században. Osiris, Budapest, 1999. 
RoMSICS Ignác: Huszadik századi magyar politikai rendszerek. In: KovÁCs KISS Gyöngyi RoMSICS Ignác (szerk.): A mi 20. századunk. Komp-Press Kiadó, Kolozsvár, 2011. 27. p. RoMSICS Ignác: Magyar sorsfordulók. Osiris, Budapest, 2012.

RUSZOLY József: „És így is a mi korunk.” Írások és források Magyarország alkotmánytörténetéhez 1944-1949. Püski Kiadó, Budapest, 2006.

RUSZOLY József: Nemzeti bizottságok és önkormányzatok. Csanád-Arad-Torontál közigazgatásilag egyelőre egyesített vármegyék intézménytörténetéhez. (1944. szeptember-1945. május). In: RuSzOLY József: „és így is a mi korunk.” Írások és források Magyarország alkotmánytörténetéhez. 1944-1949. Püski Kiadó, Budapest, 2006. 32-97. p.

SÁGVÁRI Ágnes: Tömegmozgalmak és politikai küzdelmek Budapesten 1945-1947. Kossuth Könyvkiadó, Budapest, 1964.

SÁGVÁRI Ágnes: A demokratizmus formái és tartalma Magyarországon (1944-1948). In:

Marx Károly Közgazdaságtudományi Egyetem 1965. évi ünnepi ülésszaka. Közgazdasági és Jogi Könyvkiadó, Budapest, 1966. 121-132. p.

SCHEIBNER Tamás: A magyar irodalomtudomány szovjetizálása. A szocialista realista kritika és intézményei, 1945-1953. Ráció Kiadó, Budapest, 2014.

SCHIFFERNÉ SZAKASITS Klára: Fent és lent. 1945-1950. Magvető Könyvkiadó, Budapest, 1985.

SCHMIDT Mária: „Most majd mindent úgy csinálnak, mint az oroszoknál.” A kommunizmus kiépülése Magyarországon. In: LÖRINC László (szerk.): Egyezzünk ki a múlttal! Mühelybeszélgetések történelmi mítoszainkról, tévhiteinkröl. Történelemtanárok Egylete, Budapest, 2010, 90-101. p.

SCHÖPFLIN György: A politikai intézmények szerkezete 1944-1948. Új Látóhatár, XXXII. évf. (1981) 2. 220-227. p.

SCHÖPFLIN Gyula: A magyar kommunista párt útja 1945-50. Új Látóhatár, VI. évf. (1955) 4 5. 238-252. p.

Seton-Watson, Hugh: The East European Revolution. Methuen, London,1950.

SIBA Balázs: Isten és élettörténet. A narratív identitással kapcsolatos kutatási eredmények gyakorlati teológiai jelentősége. Doktori disszertáció. Elérhető:

http://193.224.191.196:8080/phd/siba_disszertacio.pdf (A letöltés időpontja: 2015. szeptember 28.) 
SíKLAKI István: A diskurzus szerepe a társadalmi befolyásolásban. In: SZABÓ Márton (szerk.):

Szövegvalóság. Írások a szimbolikus és diszkurziv politikáról. Scientia Humana, Budapest, 1997. 99-112. p.

SIPOS Balázs: „Az igazi történelmi élmény”.A naplóíró Márai Sándor és az 1945-1948-as évek ábrázolásai. Múltunk. 2017/1. 159-186. p.

SIPOS János: A népi demokratikus forradalom magyarországi sajátosságaihoz. Hozzászólás néhány vitás kérdéshez. Magyar Filozófiai Szemle, VIII. évf. (1964) 1. 16-74. p.

SIPOS Levente: Az 1945 utáni Rákosi Mátyás. In: ABLONCZY et al. (szerk): A magyar történelem vitatott személyiségei. Kossuth Könyvkiadó, Budapest, 2008. 346-354. p.

SIPOS Levente: Nagy Imre és a demokrácia. In. SIPOS Levente (szerk.): Nagy Imre és kora. Tanulmányok, forrásközlések VI. Nagy Imre Alapítvány, Budapest, 2012. 223-237. p

SIPOS Levente: Kovács Imre demokráciafelfogása. In: SIPOS Levente (szerk.): Kovács Imre centenáriuma. Tudományos emlékülés a Politikatörténeti Intézetben. Napvilág Kiadó, Budapest, 2013. 108-128. p.

STANDEISKY Éva-KozÁK Gyula-PATAKI Gábor-RAINER M. János (szerk.): A fordulat évei: politika; képzőművészet; építészet: 1947-1949. 1956-os Intézet, Budapest, 1998.

STANDEISKY Éva: Bomlás. A hatalom és a kulturális elit. In. RAINER M. János (szerk.):

„Hatvanas évek” Magyarországon. Tanulmányok. 1956-os Intézet, Budapest, 2004. 227-317. p.

STANDEISKY Éva: Gúzsba kötve. A kulturális elit és a hatalom. 1956-os Intézet Állambiztonsági Szolgálatok Történeti Levéltára, Budapest, 2005.

STANDEISKY Éva: Remény és szorongás. Demokrácia-elképzelések és demokráciaértelmezések. In: RAINER M. János - STANDEISKY Éva (szerk.): A demokrácia reménye: Magyarország, 1945. 1956-os Intézet, Budapest, 2005. 54-91. p.

STANDEISKY Éva: Népuralom ötvenhatban. Kalligram - 1956-os Intézet, Pozsony-Budapest, 2010.

STANDEISKY Éva: Kudarcos demokratizálódás: Magyarország a második világháború utáni években. In: GoMBÁR Csaba (szerk.): A konszolidációról: elméleti és történeti elemzések. Kalligram Kiadó, Pozsony, 2012.45-73. p.

STANDEISKY Éva: Tétova újraértelmezések. Magyarország második világháborút követő évei a rendszerváltozás utáni történetírásban. In: ERDŐs Vilmos - TAKÁCS Ádám (szerk.): Tudomány és ideológia között. Tanulmányok az 1945 utáni magyar történetírásról. ELTE Eötvös Kiadó, Budapest, 2012. 134-150. p. 
STANDEISKY Éva: Emigránscsapda. Sulyok Dezső Amerikában. Élet és Irodalom, LVIII. évfolyam, 2014. február 28.

STANDEISKY Éva: Demokrácia negyvenötben. Napvilág Kiadó, Budapest, 2015.

STANDEISKY Éva: Egy demokrata ellenzéki. Élet és Irodalom, LX. évfolyam, 2016. január 8.

STOKES, Jane: A média- és kultúrakutatás gyakorlata. Gondolat Kiadó - PTE Kommunikációés Médiatudományi Tanszék, Budapest - Pécs, 2008.

SUGAR, Peter F.: A History of Hungary. Indiana University, Bloomington - Indianapolis, 1990.

SuPPAN, Arnold: Austria and its Neighbors in the East 1945-1989. In: Arnold SuPPAN Wolfgang MuELLER (szerk.): „Peaceful coexistence” or „Iron Curtain”? : Austria, Neutrality, and Eastern Europe in the Cold War and Détente, 1955-1989. Lit Verlag, Bécs, 2009. 30-65. p.

SwAIN, Nigel: Hungary: The Rise and Fall of Feasible Socialism. Verso, London - New York, 1992.

SwAIN, Geoffrey -SwAIN, Nigel: Eastern Europe since 1945. Macmillan Press Ltd., Houndmills - Basingstoke - Hampshire - London, 1998.

SZABADFALVI József: „A demokrácia örvényei” - Moór Gyula demokráciafelfogása (19451947). Valóság, XXXIV. évf. (1991) 7. 28-40.

SzABADFALVI József: Moór Gyula (Egy XX. századi magyar jogfilozófus pályaképe). Kandidátusi értekezés tézisei. Miskolc, 1992.

SzABADFALVI József: Moór Gyula. Egy XX. századi magyar jogfilozófus pályaképe. Osiris Századvég, Budapest, 1994.

SzABADFALVi József (szerk.): Moór Gyula. Magyar Panteon sorozat. Új Mandátum Könyvkiadó, Budapest, 2001.

SzABÓ A. Ferenc: Kovács Imre és a politikatudomány. Politikatudományi Szemle, II. évf. (1993) 4. 72-83.p.

SzABÓ A. Ferenc: Társadalomismeret és önreflexió. In: Kovács Imre válogatott írásai. Szabó

A. Ferenc válogatása. Magyar Napló, Budapest, 2011. 277-293. p.

SzABÓ Bálint: Népi demokráciánk történetének néhány vitatott problémájáról. Párttörténeti Közlemények, X. évf. (1964) 2. 128-148. p.

SzABÓ Bálint: Népi demokrácia és forradalom-elmélet. A marxista forradalom-elmélet fejlődésének néhány kérdése Magyarországon 1935-1949. Kossuth Könyvkiadó, Budapest, 1974. 
SzABÓ Ferenc: Makó története 1849-töl 1920-ig. Makó Monográfiája 5. Makó Város, Makó, 2002.

SZABÓ Imre: A népi demokratikus államhatalom fejlődése hazánkban. In: LACKÓ Miklós (szerk.): Tanulmányok a magyar népi demokrácia történetéből. Akadémiai Kiadó, Budapest, 1955. 585-625. p.

SzABÓ István: Német alkotmányfejlődés 1806-1945. Szent István Társulat, Budapest, 2002. 195-219. p

SzABÓ János: Csanád vármegye a népi demokratikus forradalom időszakában 1944-1948.

Bölcsészdoktori disszertáció. 1983.

SzABÓ Márton (szerk.): Szövegvalóság. Írások a szimbolikus és diszkurziv politikáról. Scientia Humana, Budapest, 1997.

SzABÓ Márton: Politikai tudáselméletek. Szemantikai, szimbolikus, retorikai és kommunikatív-diszkurzív értelmezések a politikáról. Nemzeti Tankönyvkiadó Universitas, Budapest, 1998.

SzABÓ Márton (szerk.): Az ellenség neve. Jószöveg könyvek, Budapest, 1998.

SZABÓ Márton - KISS Balázs - BODA Zsolt (szerk.): Szövegváltozatok a politikára. Nyelv, szimbólum, retorika, diskurzus. Nemzeti Tankönyvkiadó - Universitas, Budapest, 2000.

SzABÓ Márton: Az összehasonlító politikai fogalomtörténet-írás lehetőségei. In: SzEKERES András (szerk.): A történész szerszámosládája. A jelenkori történeti gondolkodás néhány aspektusa. L'Harmattan - Atelier, Budapest, 2002. 159-171. p.

SzABÓ Márton: A diszkurzív politikatudomány alapjai. Elméletek és elemzések L’Harmattan Kiadó, Budapest, 2003.

SzABÓ Márton: Politikai idegen. A politika diszkurzív szereplőinek elméleti értelmezése.

L'Harmattan Kiadó, Budapest, 2006.

SZABÓ Márton - SzÜCS Zoltán Gábor: Fogalomtörténeti perspektívák. Múltunk, LVI. évf. (2011) 2.4-19. p.

SzABÓ Márton: Diszkurzív politikatudomány. Bevezetés a politika interpretatív szemléletébe és kutatásába. Osiris Kiadó, Budapest, 2016.

SZABÓ Miklós: 1945-1947 és 1989-1991: Két átmenet. In: LENKEI Júlia (szerk.): Csendes? Forradalom? Volt? Az ELTE Jogszociológiai Tanszék, az ELTE Szociológiai Intézet és a Bibó István Szakkollégium 1991. június 5-6-i konferenciájának előadásai és vitája. TTwins Kiadói és Tipográfiai Kft., Budapest, 1991. 18-21.p. 
SzABÓ Miklós: A jó kommunista szilárdan együtt ingadozik a Párttal : Előadások a

kommunista pártok történetéről és a fekete-piros-fehér-zöld színre festett sztálinizmusról. JATEPress, Szeged, 2013.

SzABÓ Tibor: Politikai Realizmus és illúziók. Bibó és Lukács vitája a demokráciáról.

Világosság, XXXIX. évf. (1998) 3. 72-82. p.

SZABÓ Zoltán: Bevezetés. (1960 és 1979) Elérhető:

http://epa.oszk.hu/02200/02201/00005/pdf/EPA02201_Magyar_Fuzetek_1979_04_006-

043.pdf (A letöltés időpontja: 2015. szeptember 30.)

SzAJDA Szilárd: A Rákosi korszak (Gyarmati György: A Rákosi-korszak). In: Múltunk, LIX. évf. (2014) 1. 74-83. Elérhető:

http://epa.oszk.hu/00900/00995/00037/pdf/EPA00995_multunk_2014_01_074-083.pdf (A letöltés időpontja: 2015. május 26.)

SZAKÁCS Sándor-ZINNER Tibor: A háború „megváltozott természete”. Adatok és adalékok, tények és összefüggések. 1944-1948. Genius Gold Rt. - Batthyány Társaság, Budapest, 1997.

SZALAI Pál: Zsolt Béla politikai publicisztikája. In: Zsolt Béla: A végzetes toll. Publicisztikai írások. Nyilvánosság Klub - Századvég, Budapest, 1992. 380-394. p.

SzÁLE László: Az omnipotencia igézete és kudarca. Élet és Irodalom, LVI. évf. (2012) 9. 21. p.

SZEKÉR Endre: Márai, a naplóíró. Kalligram. 2000. május. Elérhető:

http://www.kalligram.eu/Kalligram/Archivum/2000/IX.-evf.-2000.-majus-100-eveszueletett-Marai-Sandor/Marai-a-naploiro (A letöltés időpontja: 2015. október 22.)

SzEKÉR Nóra: A Magyar Testvéri Közösség története. „Norma” Nyomdász Kft., Hódmezővásárhely, 2010.

SzEREDI Pál: Szárszó vesztese. A népi mozgalom perifériáján - Kovács Imre. In: SIPOS

Levente - TóTH Péter Pál (szerk.): A népi mozgalom és a magyar társadalom.

Tudományos tanácskozás a szárszói találkozó 50. évfordulója alkalmából. Napvilág Kiadó, Budapest, 1997. 252-259. p.

SzERENCSÉS Károly: A nemzeti demokráciáért. Sulyok Dezső 1897-1997. Pápa Város Önkormányzata, Pápa, 1997.

SZERENCSÉS Károly: Hová tünt a demokrácia? Magyarország gleichschaltolása, 1945-1949.

Rubicon, XXI. évf. (2010) 2. 4-19. p.

SzIKLAI László: Demokrácia és realizmus. Világosság, XXII. évf. (1981) 1. 41-44. p. 
SZILÁGYI Sándor (szerk.) : Magyar Panteon. Bibó István. Új Mandátum Könyvkiadó, Budapest, 2001.

SzŐKE Domonkos: 1945 szabad választás - szabad választás? In: HORVÁTH János (szerk.):

Tiltott történelmünk. Századvég Kiadó, Budapest, 2006. 15-43. p.

SzÜCS Zoltán Gábor: A diszkurzív politikatudomány mint polittikai diskurzustörténet.

Tudományszemléleti és módszertani esszé. Mühelytanulmányok 2. Digitális archívum.

Miskolci Egyetem Politikatudományi Intézet, Miskolc, 2008. Elérhető: http://mek.oszk.hu/06200/06225/06225.pdf (A letöltés időpontja: 2016. szeptember 3.)

SzÜCS Zoltán Gábor: Az antalli pillanat. A nemzeti történelem szerepe a magyar politikai diskurzusban. 1989-1993. L’Harmattan, Budapest, 2010.

TAKÁCS Tibor: Besúgók a besúgásról. Ügynök-visszaemlékezések a Kádár-korszakról.

L'Harmattan Kiadó - TIT Kossuth Klub, Budapest, 2013.

TAKÁTS József: Modern magyar politikai eszmetörténet. Osiris Kiadó, Budapest, 2007.

TAMASI Mihály: Makó felszabadulása. Harc a népi demokratikus fejlődésért. In: TAMASI

Mihály (szerk.): Makó az első felszabadult magyar város. Makó Városi Tanács - Kossuth Könyvkiadó, Makó - Budapest, 1969. 244-279. p.

TAMASI Mihály: A népi demokratikus forradalom győzelme. In: KorOM Mihály (szerk.):

Makó az első felszabadult magyar város. II. kötet. Makó Városi Tanács, Makó, 1974.

TAMASI Mihály: A népi demokratikus fejlődés Makón. In: Tanulmányok Csongrád Megye

Történetéből IX. Csongrád Megyei Levéltár, Szeged, 1985. 173-194. p.

TIERSKY, Ronald: Ordinary Stalinism. Allen \& Unwin, Winchester, 1985.

TISCHLER János: Közép-Európa sztalinizálása, 1944-1949. Rubicon, XIII. évf. (2002) 9-10.

35-39. p. Elérhetö:

http://www.rev.hu/portal/page/portal/rev/tanulmanyok/1945_56/sztalinizalas (A letöltés időpontja: 2015. április 24.)

TOMKA Béla: A Harmadik Birodalom. A kutatás új útjai. JATEPress, Szeged, 1999. 9-29. p.

TóTH Ferenc: A makói hagyma történetéhez. A Makói Múzeum Füzetei 4. Makó Város, Makó, 1969.

Tо́тн Ferenc: Farkas Imre munkásmozgalmi tevékenysége dokumentumok tükrében. A

Makói Múzeum Füzetei 34. Makói Múzeumi Baráti Kör, Makó, 1983.

TóTH Ferenc: Könyves-Kolonics József politikai pályája. A makói múzeum füzetei 42. Makói Múzeumi Baráti Kör, Makó, 1984.

TóTH Ferenc: A makói hagyma. Makó Város Önkormányzati Képviselőtestülete. Makó Város, Makó, 1998. 
TóTH Ferenc (szerk.): Makó története 1920-tól 1944-ig. Makó Monográfiája 6. Makó Város Önkormányzati Képviselőtestülete, Makó, 2004.

TóTH Ferenc: Makó igézetében. Cikkek, tanulmányok. Tóth Ferenc, Makó, 2014.

TÓTH Ferenc: Könyves-Kolonics József. Elérhető:

http://www.sulinet.hu/oroksegtar/data/egyhaztortenet/mako_igezeteben/pages/011_eletut ak.htm (A letöltés időpontja: 2015. december 5.)

TóTH Ferenc: Történeti kutatások Makón. Tóth Ferenc, (é.n.) Elérhetö:

http://www.sulinet.hu/oroksegtar/data/telepulesek_ertekei/Mako_monografia_sorozat/pag es/monografia_4/002_torteneti.htm (A letöltés időpontja: 2015. december 15.)

Tóтн István: A Nemzeti Parasztpárt története, 1944-1948. Kossuth Kiadó, Budapest, 1972.

TÓTH István: Két fordulat a Nemzeti Parasztpártban. In. FEITL-IZSÁK-SzÉKELY: Fordulat a világban és Magyarországon 1947-1949. Napvilág, Budapest, 2000. 281-290. p.

TóTH István: A Nemzeti Parasztpárt demokráciafelfogása (1945-1946). In: FEITL István (szerk.): Köztársaság a modern kori történelem fényében. Napvilág Kiadó, Budapest, 2007. 310-323. p.

TóTH István: Kovács Imre, a parasztpárti vezető 1939-1947. In: SIPOS Levente (szerk.): Kovács Imre centenáriuma. Tudományos emlékülés a Politikatörténeti Intézetben. Napvilág Kiadó, Budapest, 2013.129-152. p.

Tóтн M. László: Bibó István vitája Lukács Györggyel. Magyar Szemle, I. évf. (1992) 2. Elérhető: http://www.magyarszemle.hu/volume/1992_2 (A letöltés időpontja: 2015. szeptember 15.)

TÖRÖK Bálint: Mégis szabad választások 1945-47-ben. In: HORVÁTH János (szerk.): Tiltott történelmünk. Századvég Kiadó, Budapest, 2006. 128-132. p.

UNGVÁRY Krisztián: Gyötrő illúziók. Bibó és 1945 eseményei. Beszélő, V. évf. (2000) 1. Elérhető: http://www.rev.hu/portal/page/portal/rev/tanulmanyok/1945_56/bibo (A letöltés időpontja: 2015. június 15.)

UNGVÁRY Krisztián: Magyarország szovjetizálásának kérdései. A tervek: szovjet koncepciók és Magyarország. Rubicon, XII. évf. (2001) 10.- XIII. évf. (2002) 1. 51-55. p. Elérhető: http://www.rev.hu/portal/page/portal/rev/tanulmanyok/1945_56/szovjetizalas (A letöltés időpontja: 2015. április 15.)

UNGVÁRY Krisztián: Magyarország szovjetizálásának kérdései. In: ROMSICS Ignác (szerk.):

Mítoszok, legendák, tévhitek a 20. századi magyar történelemröl. Osiris Kiadó, Budapest, 2002. 279-308. p. 
UNGVÁRY Krisztián: A Horthy-rendszer mérlege. Diszkrimináció, szociálpolitika és antiszemitizmus Magyarországon 1919-1944. Jelenkor Kiadó - OSZK, Pécs - Budapest, 2013.

UNGVÁRY Krisztián: Kisgazda politikusok és az állambiztonság. In: UNGVÁRY Krisztián (szerk.): Búvópatakok. A jobboldal és az állambiztonság 1945-1989. 1956-os Intézet Alapítvány - Jaffa Kiadó, Budapest, 2013. 81-142. p.

UNGVÁRY Krisztián: Palackposta. Kommentár, X. évf. (2015) 6. 112-121.

VALUCH Tibor: Irodalom és politika határán. Jegyzetek Kovács Imréröl. In: KovÁCs Imre: Népiség, radikalizmus, demokrácia. Publicisztikai írások. Gondolat - Nyilvánosság Klub -Századvég, Budapest, 1992.363-373.p.

VALUCH Tibor (szerk.): Radikalizmus és demokrácia. Csécsy Imre válogatott írása. JATE, Szeged, 1988.

VALUCH Tibor: Magyarország társadalomtörténete a XX. század második felében. Osiris Kiadó, Budapest, 2005.

VALUCH Tibor: Egy demokrata magyar közíró a XX. században. Vonások Kovács Imre portréjához. In: SIPOS Levente (szerk.): Kovács Imre centenáriuma. Tudományos emlékülés a Politikatörténeti Intézetben. Napvilág Kiadó, Budapest, 2013. 269-282. p.

VARGA László: Reflexiók. In: PÜSKI Levente - Valuch Tibor (szerk.): Mérlegen a XX. századi magyar történelem - értelmezések és értékelések. 1956-os Intézet, Budapest, 2002. 331.p.

VARGA Zoltán: Önéletrajzi töredék, talált szöveg, illetéktelen olvasó. Doktori értekezés (tézisek). Elérhető:

http://modernirodalom.btk.pte.hu/files/tiny_mce/File/tezisek/tezisekvargazoltan.pdf (A letöltés időpontja: 2015. szeptember 27.)

VASS Henrik - ZALAI K. László: A tájékoztatás intézményrendszere és munkásmozgalmi elitje (1944-1948). Triffer Kiadó, Budapest, 1991.

VIDA István: A Független Kisgazdapárt politikája, 1944-1947. Akadémiai Kiadó, Budapest, 1976.

VIDA István: A magyar népi demokrácia pártpolitikai struktúrája 1944-48. Történelmi Szemle, XXVIII. évf. (1985) 1. 26-53. p.

VIDA István: Koalíció és pártharcok. 1944-1948. Magvető Kiadó, Budapest, 1986.

VIDA István (szerk.): A Nemzetgyülés Almanachja 1945-1947. Magyar Országgyülés, Budapest, 1994. 
VIDA Zoltán: Makó iskolatörténete a város felszabadulásától az államosításig (1944-1948).

Makói Múzeum, Makó, 1973.

VIDALI, Anna: Trauma és történelem. Múltunk, LI. évf. (2006) 2. 258-275. p.

VIRÁG Attila: Diskurzuselemzés a politika- és vezetéstudományban. Vezetéstudomány, XLV.

évf. (2014) 3. Elérhető: http://unipub.lib.uni-corvinus.hu/1491/1/vt_2014n3p30.pdf (A letöltés időpontja: 2016. szeptember 2.)

WYDRA, Harald: Communism and the Emergence of Democracy. Cambridge University Press, Cambridge, 2006.

Z. KARVALICS László - ANDREIDES Gábor: A Magyar Távirati Iroda története 1945-1949. Napvilág Kiadó - Magyar Távirati Iroda, Budapest, 2006.

ZINNER, Paul E.: Communist Strategy and Tactics in Czechoslovakia, 1918-48. Frederick A. Praeger, New York, 1963. 